


$$
07 \frac{2}{3}=
$$






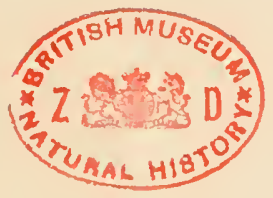

CATALOGUE

OF THE

\section{TERTIARY MOLLUSCA}

IN IHE

\section{DEPARTUENT OF GEOLOGY.}

PART I.

AUSTRALASIA. 


\section{A T A LOG UE}

oF

\section{TERTIARY MOLLUSCA}

IN THE

DEPARTMENT OF GEOLOGY

B R I T ISH MUSE U M

(NATURAL HISTORY).

PART I.

THE AUSTRALASIAN TERTIARY MOLLUSCA.

BY

GEORGE F. HARRIS, F.G.S., MEMB. SOC. OÉOL. FHANCE; MEMB. SOC. BELGE GÉOL.; TREAS. MALACOL. SOC. LOND.

L O N D O N :

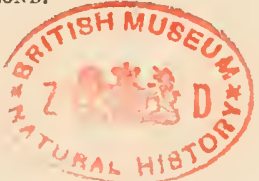

PRINTED BY ORDER OF TIIE TRUSTEES.

$$
\text { SOLD BY }
$$

LONGMANS AND CO., 39, PATERNOSTER ROW.

B. QUARITCH, 15, PICCADILLY. DUlaU AND CO., 37, SOHO SQUARF, W. KEGAN PAUL AND CO, CHARING CROSS ROAD, W.C. AND AT THE

BRITISH MUSEUJ (NATURAL HISTURT), CROMWELL ROAD, S.W.

$$
1897 .
$$


HERTFORD :

PRINIED BY STEPHEN AUSTIN AND SONS. 


\section{PREFACE.}

T're Catalogue of the Cephalopodous Mollusca by Dr. A. H. Foord, commenced in 1888 (two parts of which are issued, the third part being now in the press), together with the Systematic List of British Oligocene and Eocene Mollusca by Mr. R. Bullen Newton, in 1891, are the only volumes already published on the fossil Mollusca in this Department.

The present work by Mr. G. F. Harris, on Tertiary Mollusca, commences a new Catalogue; the first part being devoted to descriptions and figures of the shells of Australasia (exclusive of the Cephalopoda), to be followed by other geographical series in the collection, of equal interest.

Although thirteen volumes on Fossil Vertebrata, eight volumes on Fossil Invertebrata, and three upon Fossil Plants, have already been published by the Trustees, the larger part of the Mollusea and Bryozoa, and the whole of the Brachiopoda, Annelida, Arthropoda, Echinoderma, and Colentera, remain to be recorded, as well as the greater portion of the fossil plants, so that probably not less than thirty volumes will be needed to contain even a brief account of these very raried and extensive collections.

\section{HENRY WOODWARD.}

British Museum (Natural History),

Deliartuext of Geologr.

Nurch 25, 1897. 


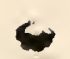




\section{INTRODUCTION.}

Tine Tertiary Mollusca of Australasia present many features of special interest, both to geologists and zoologists. The remarkable abundanee and perfect state of preservation of the Gasteropoda, especially of Victoria, enable us to shed much light on eertain questions relating to phylogeny, which cannot fail to assist the zoologist as indicating the origin of many of the prineipal groups of that divisiou of the Mollusca, and as imparting some idea of the past history of the moderu molluscan fauna of Australasia generally. The larral shells, especially, lave proved to be of great interest, and I renture to think that many of the details conceruing them as recorded in this Catalogue will prove serviceable, not only from the phylogenetic standpoint, and in regard to the early history of the individual, but as a contribution to the systematic classification of the Gasteropona. The phenomenil of growth in this division of the mollusea have nerer been studied, except in regard to restricted groups; and I have oceasionally criticized modern methods that give undue inportance (as it woukl secm) to the number and disposition of plications on the columella, the absence or presence of liræ within the outer margin of the aperture, the relative length of the anterior canal when present, aud modifications in detail of external sculpture. These and kindred phenomena ase frequently utilized by the systematist for purposes of specific and eren of generic classification, whereas in many iustances a careful study of ontogeny would show that they were mere peculiarities either of the individual or as characterizing a distinct stage of growth. I do not inteud to imply that the features of growth just mentioned are never of importance for purposes of classifieation; but until each ease is studied on its own merits, in other words until the ontogeny of each has bcen carefully worked out, it is impossible to say 
whether any particular phenomenon observed is of value to the systematist, or not. A phenomenon may be of the highest importance in the classification of eertain genera, and be of little value from that point of view in referenee to others. The stuly of the development of the Gastropoda would show better than anything else what value is to be ascribed to any particular structural feature in the shell, in that sense; but little has bitherto been attempted in that direction.

An exhaustive study of anxology cannot, obviously, be chronicled in a Catalogue like the present; but I have seized this opportunity of selecting the most pronising species and genera of Australasian Tertiary Gasteropodir from the material in the Museum, and, as far as is consistent with the plan of the book, have detailed certain structures of general interest which may hereafter prove of service to workers in elaborating the genesis of the modern Gasteropod fauna of the antipodes.

To the geologist, also, particulars concerning the growth of these Tertiary shells are not without their significance. It is very difficult for palæontologists, by the methods now commonly adopted in elassifying the Mollusea, to say how much of a variation from a normal type shall constitute a species: the personal equation is always with us. And seeiug that Tertiary beds are commonly elassified according to the relative percentage of extinct species of mollusea found in them, and that for the reason just giren it is almost impossible to arrive satisfactorily at such percentages, it seems to me that, rightly understood, the phylogeny of that division of the animal lingdom is a broader and surer basis for elassification of the various horizons, and might be made to run pari passu with the Lyellian method. Its most useful application, no doubt, would be in reference to homotaxis. This suggestion is to a large extent prompted by the great difficulty which geologists experience in working out the synchrony of the Tertiary beds of Anstralia, to this day a source of much controversy between them.

As instanees of the application of phylogeny in matters of this kind let me refer to $\mathrm{pp}, 17,18$, where in reference to the so-called Preropoda it will be noted that the assemblage of genera found in certain rocks elassified by competent authorities as Eocene is not such as might hare been expected in rocks of that age, when the known history and origin of the PrEROPODA are taken into 
consideration. As a further illustration I may refer to p. 96, where, after giving some aceount of the larval shells of the Volutid e (p. 92 et sqq.) and the light they throw on the origin and evolution of that family, I state that the development of these larral Volutes in the majority of instances in specimens found at the loealities mentioned . . . . is much more advanced thau one would have expected to find in beds as old as the Eocene-that is, on comparison with what is found in the true Eocene in other parts of the world. And it would not be diffienlt to give other evidence of the same nature. No doubt some families make more rapicl strides in one area than in another; but it is surprising to find in the Gasteropoda how uniform over large areas the rate of progression has been in regard to many of the widely distributed families. 'There is, for example, the genus that has survired from early Mesozoic times, with but little modification in the later stages of its journey; it has had its day, and has settled down as a more or less fixel form. Such a genus is of little use for homotaxial purposes, though eminently interesting from a purely phylogenetic point of riew. What we want to stucly specially for the purposes of Tertiary homotaxis are those families, quite numerous enough, the chief members of which, haring parted from the main stock in late Jurassic or Cretaceons times, arrive in the Eocene, with strong tendencies to variation, and, at the same time, are rapid travellers and become ubiquitous, as is the case with many prominent genera of the Australasian Tertiary Gasteropoda. But this is not the place to enlarge on the value of phylogeny to the geologist, and the subject is introduced here only as in some measure the outcome of a study of the Tertiary Mollusea from the Antipodes now catalogued.

In the foregoing observations special stress has been laid on the study of Gasteropona, but it must not be understood that the fossil Lamelibraxcmita are one whit inferior in point of interest from the phylogenetic or the geological standpoint. The want of sufficient suitable material in the MIuseum for the study of the auxology of the Australasian Tertiary I.hambibraxcimata, is the sole cause for the omission. It should, howerer, be adled that in many specimens the prodissoconeh is excellently preserved.

The names employed to designate stages of growth of the individnal, and the sense in which they are applied in this work, 
are, as nearly as may be, those of Professor Alpheus Hyatt, ${ }^{1}$ as amended by Messrs. S. S. Buckman and F. A. Bather. ${ }^{2}$ The terminology altuded to is as follows :-

1. Embryonic. "This stage includes all individnal history from the orrmm up to the time when the organism can be referred definitely to its class." In the fossil state we can only hare left for investigation the hard part of the organism, which in the case of the Gasteropoda is here called the Protoconch, and in the Lanellibanchiata the Prodissogonch.

2. Brephio. This stage immediately succeeds the Embryonic, and it is generally understood that during it no specific characters can be distinguished; but this point will be disenssed presently.

3. Neanic. "During this stage specific charaeters and all other morphological features present in the adult, appear and undergo development."

4. Ephebic. That stage denoting "the period of full development of the individual, when all specific characters are clearly recognizable."

5. Gerontic. "During this stage ehanges take place which are due to graciual failure of powers." It is subdicided into: "a, Catabatic stage, in which the individnaI loses its ephebic characters; and $b$, Iypostrophic stage, in which the continued loss of eharacters causes pronounced reversion."

In view of the fact that so little is known concerning the phylogeny of the Gasteropoda, I have found it somewhat diffienlt in certain cases to apply this terminology satisfactorily. For instance, in the case of shells that are quite smooth it is hard to say where the protoconch ends and the brephic stage begins; but in very many instances a characteristic rarix is present, denoting the termination of the former. The brephic stage, as a rule, in reference to these fossils, was a short one, the growth having been very rigorous immediately on the animal's escape from the capsule, and conchological specific characters consequently make their appearance at a very early stage.

Some of the more prominent results obtained from this study of Australasian shells may now be referred to.

1 Proc. Boston Soc. Nat. Hist, vol. xxiii. 1888, p. 396.

2 Zoologischen Anzeiger, Nos. 405-6, 1892, pp. 420, 429. 
It will be noticed (p. 7) that $I$ have retained Actcon in its usual place, amongst the Opistnobranciriata; but it must be confessed that this is done with some nisgiring. It is generally concluded, ${ }^{1}$ judging from the structure of its slell and its persistent operculum, that that genus should be placed amongst the lower Opisthobranchs; but it should be observed that the earlier portion of the protoconch is distiuctly sinistral, and has all the essential characteristics of the Prramidellide. On that ground alone one might feel inclined to classify Actcon, and possibly some of its associated genera, amongst the Prosobraxcinata. We should be strongly fortified in so doing by the important discovery by Bourier, ${ }^{2}$ in a careful anatomical investigation, that Actcon has a twist in its risceral nerve-loop, and is, consequently, streptonenrous. In riew of what is known of the general organization of the genus, eren in spite of the evidence afforded by the protoconch and the study of the nerrous system, we are hardly warranted, however, in remoring it from the Opisthobranchs; and for the present it will be safe to conclude that we are here dealing with inherited streptoneury. ${ }^{1}$

The value of the elevation of the spire in the elassification of the Covine is discounted by what we find in the ontogeny of Conus cuspidatus (p. 32), where the amount of eleration is shown to be merely a peculiarity of the individual.

The impossibility of satisfactorily differentiating surcula from Pleurotoma when dealing with fossil specimens, is insisted upon (p. 37); and, incidentall 5 , the position of the sinus as a prime element in the classification of the Plevrotomide is criticized. Although the majority of protoconclis in species of the Gasteropoda appear to be smooth and without sculpture, many exceptions are noted. In particular, Pleurotoma wanganuiensis (p. 46) is remarkable in that respect. The initial turu of the protoconch is smooth and obsoletely striated, and this is followed by an obtuse augulation, which rapidly develops into a bold, acute, median spiral carina, with accompanying lineation. See also Columbarium acanthostephes (p. 52), Teleochilus gracillimam (p. 65), Harpa abbreviata

1 Ilotres, Proc. Malac. Soc. London, rol. ii. 1896, p. 68.

2 Bull. Soc. Philom. Paris, t. r. 1893, p. 61. 
(p. 81), Latirus tatei (p. 147), Leucozonia staminea (p. 151), Pseudovaricia mirabilis (p. 160), and Murex otwayensis (p. 177).

Although we occasionally find that the main features of the sculpture of the adult are foreshadowed even in the protoconch, that is by no means a general rule. The protoconch of Pleurotoma alta (p. 45), for instance, is perfectly smooth, yet in the brephic stage a most pronounced peripheral carina makes its appearance; on the other hand, in P. wanganuiensis (p. 46) the strong spiral ornament obtains from the protoconch to the ephebic stage, though profuse additional ornament was suddenly produced in the brephic stage. On this evidence, and seeing how closely allied the two species are in some other respects, one would assume that the latter species most probably descended from an earlier stock of the former.

By way of contrast we find in Bathytoma angustifrons (p. 49) and Morio gradata (p. 201) that but few of the main features of the ornament in the adult were foreshadowed even in the brephic stage, and that ornament is not of a permanent character, but was modified at the caprice of the individual. That, and similar eridence given in this Catalogue, points pretty conclusively to a general rule that may be established (at least, so far as these Australasian fossils are concerned, and it is possibly of much wider application), namely: that when the main features of the ornament are foreshadowed in the early brephic stage, and especially when they obtain even in the protoconch, that ornament may be regarded as of ralue in the determination of species; but when, on the contrary, the ornament does not make its appearance until the late neanic stage, and is not, eren in an elementary sense, completed until what may be regarded, by analogy, as the early ephebic, that ornament merely characterizes the indiridual, and is only of negatire use for the p'irposes of classification.

The size of the protoconch is very variable (e.g. Cancellaria wannonensis, p. 66), as is well known, eren in the offspring of a single indiridual; that difference being commonly attributed to carnirorous proclivities on the part of the larger specimens when in the embryonic stage. In this connection it is noteworthy that the size of the protoconch does not seem to hare much influence in determining the size of the shell in the adult. The larger protoconch is not very frequently, it would seem, accompanied by the production of a larger adult shell than comes from a much smaller protoconch, that is, in the same species. There are, 
howerer, exceptions to this, and correlatively it may be noted that the shape of the protoconeh occasionally determincs the general shape of the shell. In Bathytoma angustifions (p. 49), for instance, the Muscum specimens show that the elevation or depression (as the case may be) of the turns of the protoconeh to a large extent determines the relative clongation of the growth of the whole shell, in that particular species.

Evidence is given (pp. 95, 96, and description of the species of Scaphella) that some of the Australasian Tertiary Voldtides possessed horny protoconchs; and the elassification of that family as deduced from a study of the larval shells, together with some account of the origin and development of the groups they represent, will be found (p. 92 et sqq.). Cf. Fusus hexagonalis (p. 131) in this connection.

The ontogeny of Mitra multisulcata (p. 120) forms an interesting study. As a result of the details of growth, it is shown that the number of columeliar plications is not neeessarily of ralue in classifieation in such a genus as Mitra; for in the brephie stage there were only two plaits, and the suspicion of a third, whilst in the ephebic no fewer than five are observable.

A very remarkable mode of growth is recorded in referenee to Tylospira coronata (p. 222); whilst Cerithium apheles (p. 224) is full of interest. The shell in the latter exhibits longitudinal costre in the brephic stage, which are lost in the neanic, but reappear strongly in the ephebic, only to die out again in the gerontic stage. There is thus a high possibility of this speeies having descended from a well-marked longitudinally costate stock, with a tendeney for its descendants to assume a mueh plainer type of ornament.

I hare stated in an carlier part of this Introdnction that, although it is gencrally understood that during the brephic stage of growth no specific eharacters can be distinguished, it was desirable to discuss the matter. Some of the obserrations just made prove that the shell is often highly sculptured in that stage, and many other cxamples are recorded in the text. It is by no means rare to find that the chief ornament relied upon for the classification of the speeies (in regard to individuals) suddenly makes its appearance in the brephic stage, and, not infrequently, starts abruptly from the termination of the protoconeh. A glance through the plates accompanying this work will, perhaps, help to make this obserration 
clearer. Dr. Jackson's investigations ${ }^{1}$ led him to the conclusion that characters almost inseparable from those of the adult frequently make their appearance in the brephic stage of the mollusca. In view of these facts it seems desirable to modify the geueral statement that during the brephic stage no specific characters can be distinguished. As a rule, no doubt, that statement is perfectly accurate, and the brephic stage is unquestionably well defined iu the Gasteropoda as a whole; but a little qualification seems necessary. I have found that the greatest difficulty in defining the brephic stage is in those cases where a strong rarix has been thrown up at the conclusion of the embryonic stage, and it seems right that that should be so. For the varix certainly indicates a pause in the growth of the shell, and it is reasonable to assume that during that pause the animal was passing throngh the brephic stage, but did not continue to make the normal shell of that period, except partially, it may be, in some instances. I have even doubted whether in certain instances the varix alluded to was not, in fact, the only manifestation of the growth of the shell during the brephic stage.

Turning now to some other points brought out in this Catalogue, it may be noted that it introduces frequent changes in nomenclature, especially in regard to genera and subgenera. Many well-known names, I am sorry to say, have disappeared as the result of bibliographic research. But I am not proud of haring made these changes-they were inevitable if the rule of priority must be applied.

In particular, I have been at some pains to discover the names of the type species of both genera and subgenera, in consequence of which a new interpretation has, occasionally, had to be placed on a well-known group. Some new genera and species are proposed; and species hitherto described have been considerably revised in regard to their generic position. In the description of species my general plan has been to gire only the salient features, usually in the nature of a short diagnosis, where the species had formerly been fully treated of; but where the material in the Mruseum collection permitted, and the species had hitherto received but scanty notice, it has been dealt with at greater length,

1 "Phylogeny of the Pelecypoda": Mem. Boston Soc. Nat. Hist. vol. iv. No. 8, 1890 , p. 290. 
Some dificulty has occasionally been experienced in assigning species to their correct geological position in the Tertiary. In regard to the Australian "Eocene" and Miocene I have, where possille, followed the classification of Professor Tate in his various works quoted, although, as will already have been noticed, I have considerable doubt whether the "Eocene" of that continent is really homotaxial with that of North-Western Europe. Again, in certain localities where two formations occur, as at Muddy Creek, Trelissick, etc., it has sometimes been doubtful from which horizon the particular specimens being catalogued came. In such cases I have been much assisted by the useful list of Muddy Creek fossils drawn up in Mr. John Dennant's memoir ${ }^{1}$ on the beds in that locality, which has been quoted from time to time. Again, Sir James Hector's list ${ }^{2}$ of New Zealand localities with their geological horizons have proved valuable in the same connection; whilst Professor Hutton's Catalogue ${ }^{3}$ has of necessity been referred to on many occasions. Nevertheless, there are a few specimens from that colong, the exact provenance of which I have not been able to fix, as will be observed; such specimens have, for the most part, been in the Mruseum for many years, and the name of the locality, which they bear, may possibly represent a place where a camp was temporurily made. The collection from Parimoa appears to come from two horizons, the Miocene and Pliocene, and in the case of a new record for that locality it has been fonnd impossible to give the geological age with certainty. At Wanganui, again, both Pliocene and l'ost-Pliocene beds are found; in general it has not been difficult to assigu a particular species from this locality to its correct horizon, but there are exceptions. These, and similar points, I must leare to Colonial geologists, who alone, by study on the spot, can satisfactorily clear them up. The locality of Limestone Creek, Glenelg river, Victoria, is here called Post-Pliocene, instead of Newer Pliocene; I beliere it will ultimately be found to be younger than the true Pliocene.

It should be explained that by "Australasia" throughout this work is meant, the Australian continent, Tasmania, New Zealand, and the Chatham Islands.

1 Trans. Roy. Soc. South Aust. rol. xi. 1889, p. 30.

2 Rep. Geol. Exp. 1890-91, p. 121 (and other Reports in the same Series).

3 Catalogue Tert. Moll, and Echin. X.Z. 1873. 
This work will not embrace the description of the Tertiary Cerinalopoda in the British Museum, as they are being catalogued by Dr. A. H. Foord and Mr. G. C. Crick ${ }^{1}$; but it may be mentioned that so far as Australasia is concerned only two Tertiary species, viz., Aturia aturi, Basterot, var. australis, M['Coy, and Nautilus geelongensis, Foord, are found in the collection, and they have already been dealt with. ${ }^{2}$

Finally, I must express my indebtedness to several friends who have assisted me, from time to time, during the preparation of this Catalogue. Foremost stands Mr. Edgar A. Smith, whose courtesy in permitting me frequently to consult the modern mollusca in the Zoological Department of the MIuseum, and for much advice in regard to matters of nomenclature, I most thankfully acknowledge; Mr. R. Bullen Newton has also rendered me assistance in regard to nomenclature, for which I tender him my best thauks; Mr. B. B. Woodward has on sereral occasions gireu me the advantage of his extensire knowledge of bibliography, which has been of signal service, and for which I am greatly indebted to him; MIr. C. D. Sherborn has kindly permitted me to refer to the MS. of his Index Animalium. Professor Tate, of the University of Adelaide, kindly sent me a collection of specimens and copies of his publications on the Tertiary mollusca of Australia, which have been of much use; whilst I am indebted to my friend MIr. H. W. Burrows for his ready assistance in reference to the classification of mollusea. To Miss G. M. Woodward I must also tender mF thanks for the preparation of the beautiful drawings which adorn this Catalogue.

GEO. F. HARRIS.

25th March, 1897.

1 Catalogue of Fossil Cephalopoda, British Museum.

2 1d. Part II. 1891, pp. 332, 354. 


\section{TABLE}

of

\section{FAMILIES, GENERA, AND SUBGENERA.}

\section{Class GASTEROPODA.}

Order Pulmonata.

Family HeLicIDe: PAGE

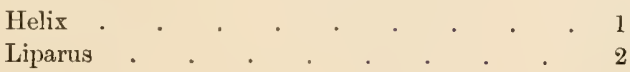

Family Bulimulide:

Placostylus . . . . . . . . 4

Family Limáme: :

Limnæa . . . . . . . . 4

Family Aмphibolide:

Amphibola . . . . . . . . 5

Order Opisthobranchiata.

Family AстæONID :

Actron . . . . . . . 7

Solidula . . . . . . . 8

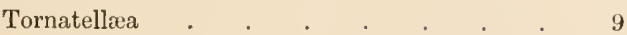

Triploca . . . . . . . 9

Adelactæon . . . . . . . 10

Family SCAPHANDRIDE:

Scaphander . . . . . . . . 12

Family Bullide: :

Bulla . . . . . . . . . 13

Bullinella . . . . . . . 13

Family Ringiculide:

Ringicula . . . . . . . . 15 
Family LIMACINIDE :

Family Cavolinidde:

Clio . $\cdot{ }^{\circ} \cdot{ }^{\circ} \cdot 20$

Vaginella .

Family UMBRACULIDÆ:

Umbraculum

Order Prosobranchiata.

Family Terebride :

Family CoNIDA:

Family Pleurotomide :

Pleurotoma . . 38

Bathytoma $\quad 48$

Columbarium . . 51

Drillia . . . . 55

Drillia . 57

Mangilia $\cdot \cdot \cdot \cdot \cdot \cdot 58$

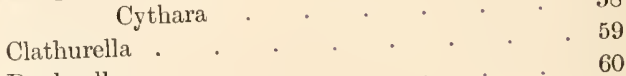

Daphnella $\cdot . \cdot \cdot{ }^{\circ} \cdot{ }^{\circ} \cdot 64$

Family Cancellaritde :

Cancellaria $\cdot \cdot \cdot \cdot{ }^{\cdot} \cdot 67$

Narona . $\cdot{ }^{\circ} \cdot{ }^{\cdot} \cdot 68$

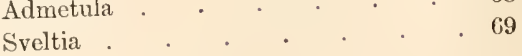

Family Olivide:

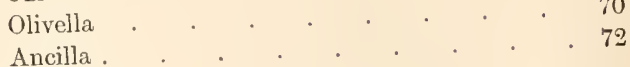

Family HARPIDE:

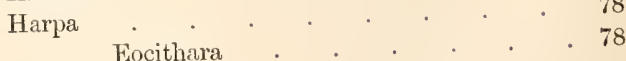

Family Marginelitide:

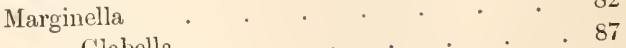

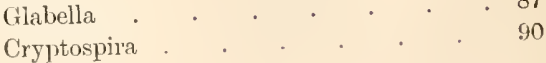


Family VOLUTIDE :

Volutilithes

Lyria

Voluta

Pterospira. . . . . 100

Aulica . . . . . . 101

Volutoconus . . . . . 107

Amoria. . . . . . 108

Scaphella. . . . . . . 110

Eopsephia . . . . 115

Family Mrtride :

Mitra

Cancilla

Uromitra

Conomitra

Family Fasciolaridide :

Fusus

Latirofusus .

Streptochetus

Fasciolaria .

Latirus

Lencozonia .

Family Buccnide :

Tritonofusus

Siphonalia

Pseudovaricia

Cantharus

Euthria

Dennantia . . . . 162

Phos

Zemira

Family NAsside :

Nassa

Family MURICIDE:

Typhis

Mulex 
Family MURICIDe (continued) :

Family Lotorinde :

Lotorium

Colubraria

Apollo

Family CASSIDIDE :

Cassis

Semicassis

Morio

\section{Casmaria}

Family CyPRAIDE :

Cypræa

\section{Bernayia}

Trivia

Family Strombide :

Strombus

Seraphs . 218

Family Struthrolarinde:

Struthiolaria

Tylospira

Family Cerithinde :

Cerithium

Colina.

Batillaria

Newtoniella . . . . . . . . . 229

Triforis . . . . . . . 231

Diastoma . . . . . . . 231

Family Trichotropide:

Trichotropis 233

Family VERMETIDE:

Tenagodes

Family Turritellide:

Turritella

Family SolaridDe:

Solarium .

Heliacus 
Family HipPONYCIDæ:

Hipponyx . . . . . . 246

Family CAPULIDE :

Crepidula . . . . . . . . 246

Ianacus . . . . . . 248

Family Calyptraide :

Calyptrea . . . . . . . . 249

Calyptropsis . . . . . 251

Family Xenophoride :

Xenophora . . . . . . . 253

Tugurium . . . . . 254

Family NATICIDE :

Natica

Lunatia . . . . . . 260

Stigmaulax . . . . . . 262

Sigaretopsis . . . . . 263

Euspira . . . . . . . . 264

Ampullospira . . . . . 265

Family Sequenzidde :

Sequenzia . . . . . . . . 266

Family SCALID E :

Cirsotrema . . . . . . 267

Crosseia . . . . . . . . 269

Eglisia . . . . . . . . 270

Family EULIMIDE:

Eulima . . . . . . . . 271

Niso . . . . . . 272

Family Turbinide :

Turbo . . . . . . . . 272

Phasianella . . . . . . . 275

Collonia . . . . . . 276

Family Trochide :

Trochus . . . . . . . 276

Anthora . . . . . . 277

Cœlotrochus . . . . . 278

Clanculus . . . . . . . . 279

Thalotia . . . . . . 279

Bankivia . . . . . . 280

Liopyrga . . . . . . . 281

Ethalia . . . . . . . 282

Solariella . . . . . . . 283 
Family Delphindlide :

Liotia. . . . . . . . 283

Family HaLiotida:

Haliotis. . . . . . . . 281

Family Pleurotomaridd: :

Pleurotomaria . . . . . . . 286

Family Fissureluid :

Fissurellidea . . . . . . $24 \overline{7}$

Emarginula . . . . . . . 288

Subemarginula $\quad . \quad$. $\quad . \quad$. $\quad . \quad . \quad 289$

Tugalia . . . . . . 289

Class SCAPHOPODA.

Family Dentalid e:

Dentalium . . . . . . . 290

Cadulus . . . . . . . 297

Class LAMELLIBRANCHIATA.

Order TETRABRANCHIA.

Family OsTreid :

Ostrea . . . . . . . 298

Gryphra . . . . . . 302

Family Anomide:

Placunanomia. . . . . . 303

Family Dimyids:

Dimya . . . . . . . . 305

Family SPONDYLIDE:

Spondylus . . . . . . 307

Family Limide:

Lima . . . . . . . . 309

Limatula . . . . . 311

Limea . . . . . . . 312

Family Pectinide:

Pecten . . . . . . . 313

Pseudamussium . . . . . . 322

Amussium . . . . . . . 324

Family Aviculine:

Margaritifera . . . . . . 325

Vulsella . . . . . . . 326

Pinuz . . . . . 326 
Family Mrtulde:

PAGE

Mytilus

327

Septifer . . . . . . . . 328

Modiola . . . . . . . . 329

Crenella . . . . . . . . 329

Family ArCIDE :

Area

\section{Barbatia}

331

\section{Plagiarca}

335

Fossularca . . . . 335

Cucullæa .

Pectunculus . . . . . . . 339

Limarca . . . . . . 343

Limopsis . . . . . . . . 344

Family NuCULID E :

Nucula . . . . . . . . 347

Family Nuculanide:

Nuculana

Family Trigonude:

Trigonia . . . . . . . . 352

Family UNIONID.e :

Unio . . . . . . . . . 355

Anodonta $. \quad . \quad . \quad . \quad . \quad . \quad . \quad 356$

Family CARDITIDE :

Cardita . . . . . . 357

Carditella . . . . . . . 362

Family Crassatellitida:

Crassatellites . . . . . . . 363

Family CARDIIDE :

Cardium . . . . . . . 366

Prutocardium . . . . . . . 368

Family CHAMID :

Chama . . . . . . . . $\quad .369$

Family VENERID.E :

Meretrix . . . . . . . . 370

Sunetta . . . . . . . 372

Chione . . . . . . . . 372

Family UxGULINID.E :

Diplodonta

Family Donacida :

Dollax 
Family GARIID : $\quad$ PAGE

Gari . . . . . . . . 377

Family Mesodeshatide:

Mesodesma . . . . . . . 378

Family MACTRID玉:

Mactra . . . . . . . 379

Zenatiopsis . . . . . . . 380

Family MrID $\approx$ :

Corbula . . . . . . . . 381

Family SAxICAVIdE :

Capistrocardia . . . . . . . . 383

Family Pholadid :

Barnea . . . . . . . . 384

Order Dibranchia.

Family LUCINID E :

Lucina . . . . . . . . . 385

Family Tellinide :

Tellina , . . . . , 386

Family SCROBICULARIIDE :

Semele . . . . . . . . . 388

Family Cuspidaridd :

Cuspidaria . . . . . . . . 389

Family PANDORID $\approx$ :

Myadora . . . . . . . . 390 


\section{LIST OF COLLECTIONS.}

The following are the principal sources whence the Collections catalogued in this work were obtained:-

1. A series of mollusca from the Miocene and Pliocene of $\mathrm{New}$ Zealand, chiefly from Parimoa and Onekakara. Presented by the Hon. W. B. D. Mlantell, about the year 1860 .

2. From various horizons of the Tertiary in South Australia. Presented by the Governors of Adelaide Museum, in 1861.

3. A few specimens from the Tertiary of Adelaide, South Australia. Presented by M. Marshall, Esq., in 1861.

4. From the Tertiary of the River Murray, South Australia. Presented by Commodore Goodenough, R.N., in 1876.

5. From the Pliocene and Post-Pliocene of New Zealand. Pre. sented by Lisut.-Col. L. W. Wilmer, late 12th Regiment, in 1882.

6. Several specimens from the Tertiary of Bairnsdale, Victoria. Presented by $W . H$. Grigson, Esq., in 1882 .

7. A large and important series from the Eocene and Mfiocene of Muddy Creek, Hamilton, Victoria. Presented by John Dennant, Esq., F.G.S., in 1886.

8. A large series from various horizons of the Tertiary of South Australia, and a few specimens from Western Australia. Presented by II. Y. L. Brown, Esq., F.G.S., in 1887.

9. Many spccimens from the Tertiary of Gippsland, Victoria. Presented by the Rev. J. S. II. Royce, in 1887.

10. From the Rirer Murray cliffs, South Australia. Presented by $W^{\prime} m$. Ecans, Esq., in 1887. 
11. Sereral specimens from the Eocene and Miocene of Muddy Creek, Victoria. Presented by Professor T. Rupert Jones, F.R.S., in 1887 .

12. From the Tertiary of Border Town, South Australia. Presented by R. Litton, Esq., in 1888.

13. From a raised beach at Opua, near Russell, New Zealand. Presented by F. A. Bather, Esq., M.A., F.G.S., in 1894.

In addition to the above donations:-

14. A rery large and raluable collection from rarious horizons of the Tertiary of New Zealand, obtained in exchange from Sir James Hector, K.C.M.G., F.R.S., in 1875.

15. Many specimens from the later Tertiary of New Zealand. Transferred from the Museum of Practical Geology, in 1880.

16. By purchase on several occasions, chiefly in 1876 (Strzelecki Collection), 1879, 1881, 1890, and 1896. 


\section{Class Gasteropoda.}

\section{Order PULMONATA.}

Family HELICID死.

\section{Genus HELIX, Linnæus (em. Müller).}

[Linn. Syst. Nat. ed. 10, 1758, p. 768; Müller, Verm. Terr. Fluv. vol. ii. 1774 . p. 12.]

Sereral recent writers have referred to $I I$. pomatia, Linnæus, as the type of Helix; there seems to be no reason, however, for departing from the emendation of Müller, as recognized by authors such as Pfeiffer, ${ }^{1}$ who made an exhaustive study of the genus.

Type.-Helix lampas, Mrüller.

Helix tasmaniensis, G. B. Sowerby.

1845. Helix tasmaniensis, G. B. Sowerby, in Strzelecki, Phys. Desc. N.S.W. p. 298, pl. xix. fig. 5 .

1878. Helix tasmaniensis, R. Etheridge, jun., Cat. Aust. Foss. p. 178. 1880. Helix tasmaniensis, Johnston, Pap. Roy. Soc. Tas. 1879, p. 88.

188s. Helix tasmaniensis, Johnston, Geol. Tasmania, pl, xxxiv. fig. 9.

The description by Sowerby being based on very imperfect materials, the following amplification may be quoted:-" Shell thin, globosely conical, umbilicated; whorls $4 \frac{1}{2}$, rapidly increasing, ornamented with fine obliquely-arcuate striæ, crossed by fine spiral lines . . . , flatly conrex above, conrex below, last whorl tumid and slightly descending in front; suture somewhat impressed, spire depressly conical; umbilicus deep, narrow, scarcely one-sixth of the diameter; aperture oblique, orately lunate; 
peristome simple; margins slightly approximating, basal margiu slightly dilated and reflexed."-Johnston, 1880.

Only one fragmentary specimen of the numerous examples in the Museum bears any trace of shell structure; the remainder are internal casts. The ornamentation of the shell fully bears out Mr. Johnston's description, except that no spiral lines are to be seen on the fragment alluded to. The casts present considerable variation in the elevation of the spire, occasionally, indeed, being somewhat depressed, when they closely resemble the living Helix confusa, Pfr., of Queensland, North Australia, etc. In the last-mentioned shell, however, certain adult forms attain to considerable spiral elevation, especially in the specimens in the Museum from North Australia. Judging from the sculpturing and general aspect of the casts, it is highly probable that H. tasmaniensis should be classed in the subgenus Rhytida, but the materials are not perfect enough to enable one to be quite certain on this point.

Mr. Johnston (op. cit. 1880, p. 89) describes two new species of Helix from the same locality as the Museum specimens come from: one of these, $I$. huxleyana, is very minute; and the other, II. geilstonensis, is described as orbicularly depressed, the whorls being markedly convex below; a variety of $I I$. sinclairi is also created which has, inter alia, a narrow umbilicus. Neither of these is represented in the British Museum Collection.

Dimensions (of the type specimen).-Height $22 \frac{1}{2} \mathrm{~mm}$.; breadth $34 \mathrm{~mm}$.

Form. and Loc.-Yellow Limestone (Travertine), probably of Pliocene age: all from the neighbourhood of Hobart Town, Tasmania.

96906. The type specimen figured by Sowerby. Purchased. 46592-3. Two specimens. Presented by Norton Allport, Esq. 98217. Two casts; from Geilston Quarry. Purchased.

G. 71. Several casts of adult specimens. Purchased.

\section{Genus LIP ARUS, Albers.}

[Die Heliceen, 1850, p. 172.]

Test ovately conical, with an obtusely conical spire, whorls to the number of 6 or 7 , aperture ovate, peristome simple, acute, 
columella twisted so as to form an obscure but somewhat callous plication, the slight callosity almost covering the very minutely perforated umbilicus, and extending more or less over the bodywhorl towards the posterior portion of the aperture.

Type.-Bulimus atomatus, Gray.

\section{Liparus gunni, G. B. Sby. (sp.).}

1845. Bulinus gunnii, G. B. Sowerby, in Strzelecki, Phys. Desc. N.S.W., ete., p. 298, pl. xix. fig. 6 .

1878. Bulimus gunnii, R. Etheridge, jun., Cat. Aust. Foss. p. 177.

1880. Bulimus gunnii, Johnston, Pap. Roy. Soc. Tas. 1879, p. 90.

1888. Bulimus gunnii, Johnston, Geol. Tasmania, pl. xxiv. fig. 7 .

This species is represented by one example only in the British Museum-the type figured by Mr. Sowerby. It is a cast of the interior, and no vestige of the shell itself appears thereon. $\mathrm{Mr}$. Johnston was only acquainted with fragments of the cast. Nevertheless the present writer is of opinion that the structure of the shell may, to some extent, be inferred from a careful examination of the type specimen. From the deepness and gencral aspect of the sutures it is certain that the test must have been rory thin, and, as in certain other representatives of the genus Liparus, the lines of growth no doubt existed both interiorly and exteriorly. These latter are strongly reflected in the cast under consideration, from which it is legitimate to conclude that the shell was by no means smooth, although Mr. Sowerby says "lavigatis?"

Unfortnnately, a large part of the cast is imbedded in the hard calcareous matrix in such a manner as to mask the phenomena of the aperture, so that the reference of the species to the genus Liparus is not altogether without doubt. When the specimen is compared with the living Liparus leeuwinensis, E. A. Smith, ${ }^{1}$ of N.W. Anstralia, however, the doubt almost decreases to the ranishing point, for, as far as can be judged from an internal cast, the two must be of the same genus, and, indeed, they are closely allied specifically. The chief specific difference is the more conical and tumid shape of the fossil. On comparing the latter with the living $L$. kingi, Gray, from King George's Sound, which

1 J'roc. Malac. Soc. Lond. vol. i. 1894, p. 94, pl. vii. fig. 27. 
it also resembles in some respects, it is found not to be so elongate, and the lines of growth are more oblique.

Dimensions.-Height $26 \mathrm{~mm}$; ; breadth $14 \frac{1}{2} \mathrm{~mm}$.

Form. and Loc.-Yellow Limestone (Travertine), probably of Pliocene age: Hobart Town, Tasmania.

96907. The type specimen figured by Sowerby. Purchased.

\section{Genus PLACOSTYLUS, Albers.}

[Die Heliceen, 1850, p. 147.]

Placostylus, Beck (MS.), Index Molluscorum, 1837, p. 57 (list name only).

Test imperforate, oblong, conical, rugosely striated; whorls to the number of 7 or 8 ; columella twisted, plicated; aperture irregular but mostly ovate, or oblong; peristome thick, haring an expanded and reflected callous margin, tuberculated near the anterior extremity of the aperture.

Type.-Bulimus fibratus, Martyn.

\section{Placostylus, sp.}

An imperfect specimen in the Museum collection presents the generie characters of Placostylus, but its condition precludes the possibility of referring it accurately to any known species. It nearest resembles the living $P$. bovinus, Brug., of New Zealand, and its close ally the variable $P$. fibratus, Martyn.

Form, and Loc.-Post-Pliocene: King's Creek, Darling Downs, Queensland.

75373. One specimen. Prescnted by Richard Daintree, Esq.

Family LINN EID E.

Genus LIMN 无A, Lamarck (em. Rang).

[Lamk., MÉm. Soc. Hist. Nat. Paris, 1799, p. 75; Sander Rang, Man. Hist.

Nat. Moll. 1829, p. 176.] 


\section{Limnæa, sp.}

Two indeterminate specimens of this genus exist in the collection from South Australia; one an imperfect internal cast from Tertiary beds in Fowler's Bay district, the other a monstrosity from Willunga.

H. Y. L. Brown Coll.

\section{Family AMPHIBOLID E.}

\section{Genus AMPHIBOLA, Schumacher.}

[Essai Nouv. Syst. Habit. Testacés, 1817, pp. 58, 190.]

Ampullacera, Quoy and Gaimard, Voy. de l'Astrolabe, Zool. t. ii. 1832, p. 196, pl. xv. figs. 1-9.

Thallicera, Swainson, Malacology, 1840, p. 196.

The test of this genus is not unlike an Ampullaria, though it differs in many essential particulars. It is thick, subglobose, and rugose; spire somewhat depressed; outer margin of the aperture with a deep sinus posteriorly; inner margin callous and expanded; columella broad and reflected at the base; umbilicus large.

Type.-Amphibola australis, Schumacher.

\section{Amphibola avellana, Bruguière (sp.).}

1775. Spengler, Beschäftigungen d. Natur. Freunde, Berlin, Bd. i. p. 395, pl, ix. figs. 4,5 .

1781. Nerita nux avellana merito, etc., Chemnitz, Conch. Cab. Bd.. p. 262, pl. clxxxviii. figs. 1919-20.

1784. Limax crenata, Martyn, Univ. Conch. pl. Ixix.

1789. Bulimus avellana, Bruguière, Ency. Meth. [Vers] t. i. p. 297.

1790. Helix avellana, Gmelin, Linn. Syst. Nat. ed. 13, p. 3640.

1790. Helix crenata, Gmelin, Linn. Syst. Nat. ed. 13, p. 3623.

1802. Helix avcllana, Bose. Hist. Nat. des Coq. Paris, t. iv. an. x. (1801-2) p. 38.

1802. Bulimus avellana, Bosc. Hist. Nat. des Coq. Paris, t. iv. an. x. (1801-2) p. 92 .

1817. Amphibola australis, Schumacher, Essai Nour. Syst. Habit. Testacés, p. 190.

1832. Ampullacera avellana, Quoy and Gaimard, Toy. de l'Astrolabe, Zool.

t. ii. p. 196, pl. xv. figs. 1-9.

1833. Ampullaria avellana, Deshayes and Milne Edwarls, Lamk. IIist. Ampullacera avellana $\}$ Nat. Anim. sans Vert. 1838, pp. 537-1I.

1840. Thallicera avellana, Srainson, Malacology, p. 196. 
1873. Amphibola avellana, Von Martens, List Moll. N.Z. p. 40.

1873. Amphibola avellana, Hutton, Cat. Marine Moll. N.Z. p. 58.

1873. Amphibola avellana, Hutton, Cat. Tert. Moll. N.Z. p. 17.

1879. Amphibola avellana, Hutton, Ann. Mag. Nat. Hist. vol. iii. 5th ser. p. 181, pl. xxii.

1880. Amphibola avellana, Hutton, Man. N.Z. Moll. p. 35.

1893. Amphibola avellana, Iutton, Linn. Soc. N.S.W., Macleay Mem. Vol. p. 36 .

The inner margin of the aperture, in certain individuals, is extremely callous and folded into a rough plication in the vicinity of the umbilicus; the latter is broad and keeled outwardly.

The species is frequently quoted as $A$. nux-avellana, Chemnitz; but as that author's designation of it is not binomial it cannot be accepted, and the description as a whole must be ignored. Martyn in 1784 figured the species under the name of Limax crenata, without description. The first author to regularly describe it was Bruguière, and he included it under Bulimus, a circumstance which Schumacher overlooked, apparently, in creating the generic name. Deshayes and Milne Edwards express their willingness to acquiesce in the genus Ampullacera proposed by Quoy and Gaimard, but, as in other cases, adhere to the description giren by Lamarck.

It inhabits salt marshes near the sea, or lives in brackish water. Professor Hutton, in 1879, published particulars concerning its anatomy, amplifying those previously given by Quoy and Gaimard, in which he remarks that "The animal lives between tide-marks in salt or brackish water on mud flats in sheltered bays. When found at all, it is always found in large quantities. It is very sluggish in its habits, and feeds on the regetable matter contained in the mud, passing large quantities through its alimentary canal. Although air-breathing, it will live for a week or ten days in fresh water, and for more than a fortnight in salt water, without being exposed to the air."

Dimensions.-Height $23 \mathrm{~mm}$.; breadth $23 \frac{1}{2} \mathrm{~mm}$.

Form. and Loc.-Post-Pliocene: Wanganui; Opua, near Russell, New Zealand.

G. 466. Two specimens. Presented by Lieut.-Col. WV. Wilmer.

G. 8281. Several specimens from a raised beach at Opua, $60 \mathrm{ft}$. to $100 \mathrm{ft}$. above sea-level.

Presented by F. A. Bather, Esq., Mr.A., F.G.S. 


\title{
Order OPISTHOBRANCHIATA.
}

\author{
Family ACT IEONID无.
}

\section{Genus ACT ÆON, Montfort.}

[Conch. Syst. t. ii. 1810, p. 315.]

"Tornatelle," Lamarck, Cours Zool. 1812, p. 117.

Tornatella, Lamarck, Hist. Nat. Anim. sans Vert. t. ri. pt. 2, 1822 , p. 219.

Speo, Risso, Hist. Nat. Eur. Mérid. t. iv. 1826, p. 235.

Myosota, Gray, Proc. Zool. Soc. Lond. 1847, p. 160.

Characterized by a not very prominent protoconch with sinistral nucleus; thick columella with one strong spiral, slightly oblique plication.

Type.-Voluta tornatilis, Linn.

Actæon scrobiculatus, Tenison-Woods.

[Plate I. Figs. 1a-c.]

1877. Actacon scrobiculatus, Tenison-Woods, Pap. Roy. Soc. Tas. 1876, p. 102.

1589. Tornatella scrobiculata, Dennant, Trans. Roy. Soe. South Aust. vol. xi. p. 48.

1893. Tornatella scrobiculata, Tate and Dennant, Trans. Roy. Soc. South Aust. vol. xvii. p. 223.

This species is described as follows by Mr. Tenison-Woods :"Shell oblong, ovate, solid, apex acute, smooth only at the extreme summit; whorls seren, cancellate with very distinct spiral liræ, much finer longitudinal striæ; interstices rounded or punctate, liræ on the last whorl broad and subdivided by a fine groove, longitudinal striæ subdistant (so that the interstices are transrersely oblong) and passing occasionally orer the liræ, so as to make them subgranular, especially at the anterior margin; aperture subauriform, posteriorly acutely attenuate; peristome anteriorly everted and recurred, plait conspicuous, solid, obtuse."

The species is compared with $A$. pinguis, D'Orbigns, of the European Yiocene, from which it may be distinguished in being nurrower, and in the disposition of the columellar plication. The 
size of the plication, its situation, and the excavated columella behind it, recall the genus Solidula to some extent, though it materially differs in only possessing one plication, which is not bifurcate. Mr. Tenison-Woods does not give a figure of this species, but from his description the identification appears certain; it is now figured.

Dineensions (of the figured specimen).-Length $9 \frac{1}{2} \mathrm{~mm}$; breadth $4 \frac{1}{2} \mathrm{~mm}$.; length of aperture $6 \mathrm{~mm}$.

Form. and Loc.-Eocene: Muddy Creek, Victoria.

G. 4296. One specimen. Presented by John Dennant, Esq.

Genus SOLIDULA, Fischer de Waldheim.

[Muséum Demidoff (Moscow), t. iii. 1807, p. 226.]

Dactylus, Schumacher, Essai Nouv. Syst. Habit. Testacés, 1817, pp. $70,234$.

Buccinulus (Plancus), H. and A. Adams, Gen. Rec. Moll. vol. ii. (1854) p. 5.

The columella of this genus carries two plications, the anterior prominent and bifid, the posterior comparatively inconspicuous when the shell is entire; between them the columella is spirally excavated. These, amongst other characters, distinguish Solidula from Actcon.

Type.-Voluta solidula, Linn.

\section{Solidula alba, Hutton (sp.).}

1873. Buccinulus albus, Hutton, Cat. Marine Moll. N.Z. p. 51.

1873. Buccinulus albus, Hutton, Cat. Tert. Moll. N.Z. p. 16.

1880. Buccinulus albus, Hutton, Man. N.Z. Moll. p. 119.

1893. Tornatella alba, Hutton, Linn. Soc. N.S.W., Macleay Mem. Vol. p. 37 , pl, vi. fig. 2 .

This is a typical example of the genus. It is spirally and closely sulcated, and longitudinal strix are distinctly seen in the grooves. On one of the British Yuseum specimens several flat ridges between the sulci bear a minor sulcation. The sutures are not deep; the outer margin of the aperture is extremely thin, and is not sinuous anteriorly. 
Dimensions. - Length $14 \mathrm{~mm}$.; breadth $7 \mathrm{~mm}$.; length of aperture $9 \mathrm{~mm}$.

Form. and Loc.-Pliocene: "Lower beds" at Wanganui, N.Z.

G. 464. Two specimens. Presented by Lieut.-Col. W. Wilmer.

\section{Genus TORNATELLÆA, Conrad.}

[Journ. Acad. Nat. Sci. Philad. (N.s.) vol. iv. p. 294.]

Several authors have confounded Tornatellaa with Solidula, but it may be readily distinguished from the latter by the marked depression on the anterior portion of the aperture; by the difference in disposition of the columellar plications, which are brought more prominently forward, the foremost anterior plication being situated relatively nearer the anterior extremity of the shell; and by the greater thickness of the shell in the neighbourhood of the outer border of the aperture, which is frequently crenulated. These characters suffice, also, to justify separation from Actcon, sensi6 stricto. It may be remarked, that the fossil usually known as Actcon simulatus, from the Barton beds, is undoubtedly a representative of this American genus in England. Tornatellaa, moreover, has sometimes been confused with Tornatella, Lamarck, which is a synonym of Actaon.

Type.-Turnatellaa bella, Conrad.

\section{Subgenus TRIPLOCA, Tate.}

[Journ. Roy. Soc. N.S. W. vol. xxvii. 1894, p. 186.]

The principal difference between this and Tornatellea, sensu stricto, consists in the former haring three columellar plications instead of two, the two anterior of which are situated close together; the spire is longer, and the outer border of the aperture is not crenulated.

Type.-Triploca ligata, Tate.

\section{Tornatellæa (Triploca) ligata, Tate (sp.).}

1894. Triploca ligata, Tate, Journ. Roy. Soc. N.S.W. vol. xxrii. p. 186, pl. xi. fig. 7 .

1895. Tornatellaa (Triploca) ligata, Cossmann, Ess. Paléoconch. Comp. p. 50 . 
Shell thick, spirally linear sulcate; sulci not punctated, close together and varying in promineuce, sometimes obliterated.

M. Cossmann states that this species possesses minute punctations in the spiral sulei, but neither of the specimens in the Museum exhibit that peculiarity, though when seen under the microscope slight irregularities exist where the faint lines of growth intersect the sulci. The shells are slightly more tumid than that represented by the figure given by Professor Tate; the other specific characters, however, are identical in the main, and the present writer hesitates to make a specific distinction on such unimportant differences. The species is evidently very variable; even the deep sulcation bordering the suture (so prominent in the specimens selected for description by the last-mentioned author) is occasionally reduced to such dimensions that it barely surpasses in size the ordinary spiral sulcations. The latter, too, are by no means always persistent over the whole of the whorls, one of the Museum specimens showing the body-whorl sulcated over twothirds of the surface only. It would seem that when ornamented in the manner lastly described, the sulcation bordering the suture is stronger, as though the missing sulci had gathered together at that point. On the other hand, when sulcated throughout, the sutural sulcus is relatively smaller-a phenomenon observable also in certain European forms of ACTEONIDE, where it seems to be merely an individual characteristic. The visible portion of the protoconch (Plate I. Figs. $2 a-b$ ) consists of about $1 \frac{1}{2}$ turns, and is remarkably small, hiding the sinistral nucleus-at least in the Museum specimens.

Dimensions. - Length $5.5 \mathrm{~mm}$.; breadth $3 \mathrm{~mm}$.; length of aperture $3 \mathrm{~mm}$.

Form. and Loc.-Eocene: Adelaide.

G. 9305. Three specimens.

Purchased.

\section{Genus ADELACT EON, Cossmann.}

[Ess. Paléoconch. Comp. 1er liv. 1895, p. 54.]

Myonia, A. Adams, Ann. Mag. Nat. Hist. 3rd ser. vol. v. 1860, p. 406 (non Dana, 1847).

Protoconch with sinistral nucleus; not very large. Sutures of the shell canaliculated, or impressed; whorls decussated by fine 
striæ, lines of growth inconspicuous; columella slightly excavated and carrying a small but well-marked plication; columellar border expanded and frequently covering the small umbilicus.

'This genus resembles Actcon in its general characters, but may be readily distinguished when the earlier portion of the protoconch can be satisfactorily determined; the protoconch, as a whole, is not so well developed as in Actron.

In proposing this new name for Myonia, M. Cossmann remarks that the fossil forms slightly differ from the living, and he bases a new description and diagnosis on a Miocene species, Actcon papyraceus, Basterot, from the neighbourhood of Bordeaux, quoting that species as the type of the genus. But, in substituting a generic name for one preoccupied, it is desirable to conform to usage by quoting as the type of the genus that appertaining to the genus displaced; therefore the type species proposed by the French anthor alluded to should be superseded by that referring to Myonia.

Type.-Myonia japonica, A. Adams.

\section{Adelactæon olivellæformis, Tate (sp.).}

1894. Actcopyramis olivelleformis, Tate, Journ. Roy. Soc. N.S.W. vol. xxvii. p. 181 , pl. xi. fig. 2 .

1895. Adelacteon alivellaformis, Cossmann, Annuaire Géol. Univ. t. x. p. 756 .

Protoconch (Plate I. Figs. $3 a-b$ ) small, earlier portion hidden by later turns in many specimens, but comparatively free in the one now figured. It is smooth and polished; more elevated than in $A$. papyraceus, and is implanted obliquely on succeeding whorls. Shell as a whole elongate; aperture less than half the total length of the shell; whorls slightly turriculate, smooth, with minute spiral strix, which become more prominent on the anterior portion of the body-whorl.

T'he classification of this species, as remarked by M. Cossmann (op. cit. supra), is a matter of cloubt; the embracing character of the last whorl is distinctly that of the AстжоміDж, but the earlier part of the protoconch is different to that of Adelacteon, which, sensu stricto, is obtuse, and is implanted in such a manner as to render its sinistral character hardly perceptible. 
Dimensions. - Length $10 \mathrm{~mm}$.; breadth $3 \mathrm{~mm}$.; length of aperture $4 \mathrm{~mm}$.

Form. and Loc.-Eocene: Muddy Creek, Victoria.

G. 9307. Two specimens.

Purchased.

\section{Family SCAPHANDRID无.}

\section{Genus SCAPHANDER, Montfort.}

[Conch. Syst. t. ii. 1810, p. 335.]

This genus may be readily distinguished from Bulla and Bullinella by the enormous capacity of the body-whorl, which is much dilated anteriorly; there exists no columella properly so-called, the whorls not being in contact with each other.

Type.-Bulla lignaria, Linn.

\section{Scaphander tenuis, sp. nov.}

[Plate I. Figs. 4a-c.]

Shell with small but deep apical umbilicus; spirally striated, the striæ frequently being regular and equidistant over part of the surface and closing in antero-posteriorly, farthest apart in the median portion of the whorl, closest together towards the apex; lines of growth conspicuous on the smooth exterior and in the thin spiral grooves, causing the latter to assume a minutely punctated appearance; aperture extending the whole length of the shell, constricted posteriorly, expanded, curved, and produced anteriorly; inner margin furnished with a conspicuous and slightly reflected smooth band; in consequence of the thinness of the shell, both strix and lines of growth are seen in the polished interior of the aperture.

Mr. John Dennant, in giving ${ }^{1}$ a list of species of mollusca found in the Muddy Creek beds, alludes to a MIS. species of Professor Tate as Scaphander fragilis. As that has, apparently, neither been figured nor described, the present writer is unable to state in what was it may be related to this species.

1 Trans. Roy. Soe. South Aust. vol. xi. 1889, p. 48. 
Dimensions. - The largest specimen is not perfect, but attained at least to the following dimensions: length $21 \mathrm{~mm}$; breadth $12 \mathrm{~mm}$. Form, and Loo.-Eocene: Muddy Creek, Victoria.

G. 4171. Four specimens. Presented by John Dennant, Esq.

\section{Family BULLID 玉.}

\section{Genus BULLA, Linnæus.}

\section{[Syst. Nat. ed. 10, vol. i. 1758, p. 725.]}

\section{Bulla australis, Gray.}

1825. Bulla australis, Gray, Ann. Phil. vol. xxv. p. 408.

1850. Bulla oblonga, A. Adams, Thes. Conch. vol. ii. p. 577, pl. cxxiii. fig. 74 .

Two fragments, and an internal cast, referable apparently to this species, are in the Museum collection. One is rather more eylindrical than the typical form of the species, but is too imperfect for description.

Dimensions.-Length $53 \mathrm{~mm}$; ; breadth $32 \mathrm{~mm}$.

Form. and Loc.-Post-Pliocene (?): South and West Australia.

97721. Two specimens, from Logues, Champion Bay, Western Australia.

Presented by R. Etheridge, Esq., jun., and H. Y. L. Brown, Esq.

42691. An internal compressed cast, from "Tertiary beds," South Australia. Presented by the Governors of Adelaide Musenm.

Genus BULLINELLA, R. B. Newton.

[Syst. List Edwards Coll. B.MI. 1891, p. 265.]

Bullina, Risso, Hist. Nat. Eur. Mérid. t. is. 1826, p. 51 (non Férussac, 1822).

Cylichna, Lorén, Öfr. K. Vet. Akad. Förhandl. 1847, p. 142 (non Burmeister, 1844).

Form eylindrical; spire deeply perforated at the summit; last whorl corcring all the others; surface generally ornamented by spiral strix especially marked at the auterior portion of the whorl; 
outer margin longer than the axis of the shell; columella having near its anterior extremity a small plication; often umbilicated.

This genus may be distinguished from Bulla, with which it is often confounded, by being more cylindrical in form and by the possession of the columellar plication alluded to.

Type.-Bulla cylindracea, Pennant.

\section{Bullinella exigua, Tenison-Woods (sp.).}

1880. Cylichna exigua, Tenison-Woods, Proc. Linn. Soc. N.S.W. vol. iv. p. 19, pl. ii. fig. 6 .

1893. Cylichna exigua, Tate and Dennant, Trans. Roy. Soc. South Aust. vol. xvii. p. 223.

This species appears to play the same róle in the Australian Eocene as does B. uniplicata, J. de C. Sby. (=B. bruguièrei, Deshayes), in the Eocene of North-western Europe, and $B$. galba, Conrad, and B. saint-hilairei, Lea, of homotaxial beds at Claiborne, Alabama, in the United States. It is a long, cylindrical shell; the aperture is dilated anteriorly; columellar border flattened in the ricinity of the rather deep umbilicus and carrying a well-marked, twisted plication; spiral strix on the body-whorl most conspicuous towards the anterior portion, and on and in the deep apical depression; rugosities of growth strongly developed.

Dimensions.-Length $17 \mathrm{~mm}$.; breadth $7 \mathrm{~mm}$.

Form. and Loc.-Eocene: Muddy Creek, Victoria.

G. 4297. Several specimens. Presented by John Dennant, Esq.

G. 4748. One specimen. Pres. by Prof. T. Rupert Jones, F.R.S.

\section{Bullinella arachis, Quoy and Gaimard (sp.).}

1832. Sulla arachis, Quoy and Gaimard, Voy. de l'Astrolabe, Zool. t. ii. p. 361, Atlas, pl. xxvi. figs. 28-30.

1850. Bulla (Cylichna) arachis, A. Adams, Thes. Conch. vol. ii. p. 590, pl. cxxv. figs. 133-4.

1873. Cylichna striata, Hutton, Cat. Marine Moll. N.Z. p. 52.

1873. Cylichne striata, Hutton, Cat. Tert. Moll. N.Z. p. 16.

1880. Cylichna striata, Hutton, Man. N.Z. Moll. p. 120.

1887. Cylichna arachis, Dennant, Trans. Roy. Soc. Vict. vol. xxiii. p. 240.

1893. Cylichne arachis, Hutton, Linn. Soc. N.S.W., Macleay Mem. Vol. p. 37.

non Cylichna arachis, Tenison-Woods, Pap. Roy. Soc. Tas. 1876, p. 102 (=Cylichna woodsi, Tite). 
The specimens in the Museum are larger than the average of the living $B$. arachis; also, they are relatively broader in proportion to their length and are not quite as cylindrical. In all other characters, however, they are essentially similar, and the differences indicated merely constitute a local variation of the species.

Dimensions.-Length $22 \mathrm{~mm}$; breadth $10 \mathrm{~mm}$.

Form. and Loc. - Post-Pliocene: Limestone Creek, Glenelg rirer, Victoria.

G. 55\%9. T'wo specimens.

Purchased.

\section{Bullinella, sp.}

A mutilated cast of what is evidently a very large example of this genus, probably allied specifically to $B$. arachis, forms part of the Museum collection. It is cylindrical, the sides being renarkably parallel to each other; the apical perforation is relatirely small, and there is a trace of a prominent denticle on the anterior portion of the columella.

Dimensions. -Length $30 \mathrm{~mm}$.; breadth $15 \mathrm{~mm}$.

Form. and Loc._-"Tertiary": Nullarbor Plains, South Australia.

G. 9303. Internal cast, mutilated. H. Y. L. Brown Coll.

Family RINGICULID Æ.

Genus RINGICULA, Deshajes.

[Hist. Nat. Anim. sans Vert. t. viii. éd. 2, 1\$38, p. 342.]

Shell small, mamillated protoconch; aperture canaliculated posteriorly, excavated anteriorly; outer margin usually rery thick, occasionally denticulated within; columellar border thick and callous, the callus extcnding from the anterior extremity to the postcrior canaliculation: columella arched and furnished with from two to four plications. M. Morlet has grouped ${ }^{1}$ the species

1 Journ. de Conchỵl. $3^{e}$ sér. t. xviii. 1878, p. 113 et sqq.; id. 3e sér. t. xx. 1850 , p. 150 ; id. $3^{\text {e }}$ sér. t. xxii. 1892, p. 200. 
according to the presence or absence of denticulations on the outer margin of the aperture, and with reference to the number and disposition of the columellar plications.

Type.-Auricula ringens, Lamarck.

\section{Ringicula lactea, Johnston.}

[Plate I. Figs. $5 a-d$.

1880. Ringicula lactea, Johnston, Pap. Roy. Soc. Tas. 1879, p. 34.

1888. Ringicula lactea, Johnston, Geol. Tasmania, p. 239.

1893. Ringicula lactea, Tate and Dennant, Trans. Roy. Soc. South Aust. vol. xvii. p. 223.

Mr. Johnston describes this species as follows:-" Shell white, shining, minute, conical, sub-turreted, of about 6 rapidly increasing whorls; whorls convex, ornamented by regular, distant, punctate, spiral sulci, about 12 on last whorl; under lens broad, distant, obsolete, transverse liræ may be traced; suture deeply impressed; columella abbreviate, with two thick, tortuous folds, the lower being the larger; aperture roundly notched posteriorly and anteriorly; outer margin thick and reflexed, forming a broad varix continuous with the last tortuous fold of columella." $\mathrm{He}$ does not gire a figure of the shell, but the description agrees generally with specimens in the Mnseum. It may be added that beyond the two columellar folds alluded to, a third one exists posteriorly, the direction of which is approximately at right angles to the others, and, as seen in perfect specimens, it resembles a " tooth."

Some specimens from Muddy Creek are but very faintly striated, the columellar callosity being thick and partly spread over the body-whorl, from which it is sharply defined. The protoconch of those from the locality mentioned is rery small, composed of a turn and a half, smooth and somewhat obtuse.

$R$. lactea may be distinguished from the living $R$. denticulata, Gould, of Port Jackson and elsewhere in Australia, in that the latter is more tumid, the anterior canal is more deeply cut, the columellar eallosity being much drawn out, whilst the spiral lineations are closer together.

Dimensions.—Length $3 \frac{1}{2} \mathrm{~mm}$.; breadth $2 \mathrm{~mm}$.

Form. and Loc.-Eocene: Muddy Creek, Victoria.

G. 9304. Three specimens.

Purchased. 


\section{Family LIMACINID无.}

The anatomy of the soft parts of PTERopods has led Dr. Paul Pelsencer to the conclusion ${ }^{1}$ that pteropods are not entitled to be regarded as a class of mollusca of the same value as the Cephalopoda, Gasteropoda, Scaphopoda, and Lamelibranchiata. Pteropods, he belieres, are not primitive mollusca, but are a derived and recent group, and he completely abstracts certain Primary fossils usually referred to the PTERopoda from that group, as represented by living forms. Boas had arrived $^{2}$ at a similar conclusion, though not on such abundant material. Dr. Pelseneer discusses the matter at some length (op. cit. p. 90), and expresses the opinion that real pteropods had no existence as such until the commencement of the Tertiary epoch. He bases his arguments on comparative anatomy, embryology, and palæontology, in that section dealing with the origin and phylogeny of the whole group.

He finds that the pteropods are GaSTEROPODA in which the adaptation to pelagic life has so modified their external characters as to give them an apparent synmetry; that they do not constitute a distinct subclass, nor eren an order. They belong to the Tectibranchiate Opisthobranchs, and they differ less from Tectibranchs than these differ from the other Opisthobranchs. And, he is of opinion that the Thecosomsta to which the Australiau fossils presently to be described may be referred, hare descended from the Bullomea (=Cephalaspidea).

The general classification of the PTEROPODA amongst Opisthobranchiate mollusca is here adopted, but without prejudice as to the disposal of pre-Tertiary fossils usually relegated to the group, the consideration of which does not fall within the scope of the present work.

It is not a little remarkable as a phase in the evolution of the Preropoda, that immediately the Trecosonsta as a group was well established, members of it became extremely numerous in the Lower Tertiaries of Anstralia. But the assemblage of genera is not such as might hare been expected in rocks as old as the Eocene, and it is highly probable that, regarded

1 "Challenger" Reports-Zoologr, vol. xxiii.: Pteropoda, part 3: Anatomy, p. 96 .

2 Spolia Atlantica, pp. 94, 95. 
from the evolutionary standpoint of the PTEropoda alone, the Australian "Eocene," as exemplified by the Lower beds of MIuddy Creek, Schnapper Point, etc., is younger than the Eocene of typical districts like the London, Hampshire, and Paris basins. A very common genus, for instance, in the Australian beds mentioned is Vaginella, which, as will be seen hereafter, has a distinct Miocene facies, and it is found in typical beds of that age in Europe and America. Styliola, again (when rightly interpreted), is rather a Miocene than an Eocene subgenus; as for Spirialis, its range in time, from the Middle Eocene to the present day, imparts no evidence of homotaxial value.

It will be observed that Styliola is here included as a subgenus of Clio; neither its embryonic nor its structural differences entitie it to rank as a genus. Its structural features go to show that Styliola is much more nearly related to Clio (sensu stricto) than to Creseis; the forms included under the latter designation have retained some of the more archaic characters of the Lriacinide.

\section{Genus LIMACIN A, Lamarck.}

[Anim. sans Vert. t. vi. pars 1, 1819, p. 291.]

Heterofusus, Fleming, Mem. Wernerian Soc. Edin. vol. iv. 1822, p. 498.

Spiratella, Blainville, Dict. Sci. Nat. t. xxxii. 1824, p. 284.

Heliconoides, D’Orbigny, Voy. Amérique Méridionale, t. v. 1836, p. 174.

Spirialis, Eydoux and Souleyet, Rerue Zoologique, t. iii. 1840, p. 235.

Helicophora, Gray, Synopsis of the Contents of the Brit. Mus. 1842, p. 59.

Scca, Philippi, Fauna Moll. Siciliæ, 1844, p. 164.

Protomedea, G. O. Costa, Microdoride Mediterranea, 1861, p. 73.

Embolus, Jeffreys, British Conchology, vol. v. 1869, p. 114.

"Shell umbilicate, with turns gradually increasing; with a fairly large aperture; and with a columella not prolonged into a rostrum; surface smooth or striated. The height of the spire, the form of the surface and that of the aperture, and the size of the umbiliens, vary according to the species."-Pelseneer.

Limacina is universally regarded as a genus established by 
Cuvier, but on reference to the French savant's work' it will be noticed that he refers merely to "Les Limacines"; the author who really established the genus was Lamarck, as above quoted. The last-mentioned author, however, did not give the name of the species correctly.

Type._Limacina helicialis (= Clio helicina, Phipps).

\section{Limacina tertiaria, Tate (sp.).}

1887. Spiralis tertiaria, Tate, Trans. Roy. Soe. South Aust. vol. ix. p. 196, pl. xx. figs. 12a-c.

1889. Spiralis tertiaria, Dennant, id. vol. xi. p. 48.

Shell umbilicated, thin, and shining; spire depressed to the level of the body-whorl, which is greatly expauded; the last whorl rapidly enlarges, is regularly curved, except near the suture, where it is rapidly descending; umbilicus small, but deep; the peristome is slightly reflected in its vicinity; surface of shell ornamented with fine lines.

Australian authors include this species in a genus Spiralis; it is presumed that Spirialis is intended. Dr. Pelsenecr dirides ${ }^{2}$ Spirialis, Eydoux and Souleyet, into two groups, according to the presence or absence of an umbilicus, and other characters. The species above described, following that classification, falls into the genus Limacina.

Dimensions.-Diameter about $1 \mathrm{~mm}$.

Form. and Loc.-Eocene: Muddy Creek, Victoria.

G. 9308. Three specimens.

Purchased.

\section{Family CAVOLINIID E.}

\section{Genus CLIO, Linnæus.}

[Syst. Nat. ed. 12, 1767, vol. i. pt. 2, p. 1094; non O. F. Müller, 1776.]

Cleodora, Péron and Lesueur, Ann. Mus. Hist. Nat. Paris, t. xr. 1810, p. 66.

Balantium, Benson, Journ. Asiat. Soc. Bengal, vol. vi. 1837, p. 151. 
Shell somewhat angular, compressed dorso-ventrally, with lateral keels. An anterior transverse section is thus always angular laterally. A crest or rib generally extends longitudinally along the back, and usually projects. The embryonic shell is variable in form, but may always be distinctly separated.

Type.-Clio pyramidata, Linn.

\section{Subgenus STYLIOLA, Lesueur.}

[In Blainville, Manuel de Malacologie, 1825, p. 655.]

Shell conical, straight, elongated; surface smooth or faintly striated; dorsal groore not parallel to axis of shell, but slightly oblique, with only the anterior extremity (which ends in a rostrum) in the median line; embryonic portion ends in a pointed apex.

Type.-Styliola recta, Lesueur (MS.) = Cleodora subula, Quoy and Gaimard.

\section{Clio (Styliola) rangiana, Tate (sp.).}

1887. Styliola rangiana, Tate, Trans. Roy. Soc. South Aust. vol. ix. p. 194, pl. xx. fig. 2.

1859. Styliola rangiana, Denuant, id. vol. xi. p. 48.

Its rounded sides and dorsal groove serve to distinguish this species from $C$. bicarinata, Tate, found in the same beds. Near the summit of the shell is a conspicuous inflation, whilst the apex is much swollen and abruptly tapers to a fine point. Professor Tate's figure barely does justice to this structure, and it is interesting enough to demand another figure, which is now given (Plate I. Figs. $6 a-b$ ) as seen under a microseope with a oue-iuch objective.

The phenomena in the neighbourhood of the apex recall the genus Euchilotheca, Fischer, to some extent, but many fundamental differences exist. In particular, C. rangiana has no reversed or collareted border round the aperture; whilst its pronounced longitudinal sulcus, extending from the aperture almost to the apex, is very distinctive. The whole shell is somewhat compressed dorso-ventrally, and its almost smooth and polished surface is ornamented with oblique transverse striations.

Professor Tate remarks that, compared with shells of the living 
Cleodora subula, this species is distinguished by its elliptical apcrture, proportionately greater breadth, and by its abruptly tapcring apex.

Dimensions.-Length $5 \mathrm{~mm}$; diameter of aperture about $1 \mathrm{~mm}$. Form. and Loc.-Eocene: Muddy Creek, Victoria.

G. 9306. Three specimens. Purchased.

\section{Genus VAGINELLA, Daudin.}

[Bull. des Sciences (Soc. Philom.) Paris, t. ii. No. 43, 1800, p. 145 , pl. xi. fig. 1.]

Shell long, rentricose, depressed ; apex sharp-pointed, constricted in front; aperture slightly canaliculated and compressed laterally.

The occurrence of this genus in Australia is rery remarkable, the more so that it is found in berls of Eocene age, whereas in Europe it is characteristic of the Upper Tertiaries, especially the Langhian division of the Miocene.

Type.-Vaginella depressa, Daudiu.

\section{Vaginella eligmostoma, Tate.}

1887. Vaginella eligmostoma, Tate, Trans. Roy. Soc. South Aust. vol. ix. p. 195 , pl. xx. fig. 7 .

1S59. Taginella eligmostoma, Dennant, id. vol. xi. p. 48.

1893. Vaginella eligmostoma, Tate and Demnant, id. vol, xvii. p. 223.

This species, which is very common in beds near the base of the section at Muddly Creek, has been aptly compared by Professor Tate to $V$. depressa, Basterot. The present writer, who has found large numbers of the latter species at Moulin de Lagus, the Coquillière at Léognan, and other localities near Saucats, south of Bordeaux, is enabled to state from comparison of abundant material of both the Australian and European species mentioned, that $V$. eligmostoma is narrower, longer, more depressed in proportion to its size, and more prominently constricted beneath the expansions of the aperture. The representation of $V$. depressa as haring simple margins mecting at an angle on either side of the aperture is not borne out by the facts, though the margins are not sinuated to the same extent as in the Australian species. The 
author of the latter remarks that the shell is angulated at the sides and sculptured by very fine arched striæ desceuding to the lateral angulations. "The aperture is narrowly oval-oblong, with truncatedly rounded ends; each lip has a median curvature bounded on each side by a broad insinuation." The apex is in nearly all cases well preserved. The shell is very variable in length, some specimens being much narrower in proportion than others; such differences may be adjusted, however, in reviewing a large number, and are not of specific value.

Dimensions.—Length $7 \mathrm{~mm}$; breadth about $1 \frac{1}{2} \mathrm{~mm}$. Form. and Loc.-Eocene: Muddy Creek, Victoria.

G. 9310. Several specimens.

Purchased.

Family UMBRACULID A.

Genus UIMBRACULUIM, Schumacher.

[Essai Nour. Syst. Habit. Testacés, 1817, p. 177.]

"Ombrelle," Lamarck, Cours Zool. 1812, p. 114.

Umbrella, Lamarck, Anim. sans Vert. t. vi. 1819, p. 339.

Gastroplax, Blainville, Dict. Sci. Nat. t. xviii. 1820, p. 176.

Ombrella, Blainville, Dict. Sci. Nat. t. xxxii. 1824, p. 267.

Umbella, D’Orbigny, Moll. Cuba, t. i. 1841, p. 115.

Opcrculatum, H. and A. Adams, Gen. Rec. Moll. vol. ii. 1854, p. 41.

Shell orbicular, broad, patelliform, apex very small; ornamented exteriorly with concentric lines of growth; internal surface with concentrically undulating striæ radiating from the centre to the circumference of the shell, but more prominent towards the centre.

The genus is generally called Uimbrella, but, as the synonymic references above indicate, Umbraculum has priority. The designation "Ombrelle," if it were not a mere list name, could not stand, in consequence of its being French, and not Latin. The term Operculatum created by Linnæus ${ }^{1}$ and brought on by the brothers Adams cannot be accepted, first because it was not made in a binomial sense, and secondly as it was proposed prior to the date

1 Mus. Tess. 1753, p. 116. 
of the tenth edition of Linnæus' "Systema Naturæ." Acardo," commonly quoted as being synonymous with Umbraculum, is said by its author to be a bivalve; from the figure given it might be the epiphysis of a whale's vertebra.

M. Cossmann ${ }^{2}$ states that $U$ mbrella has priority over Umbraculum, as it was proposed by Chemnitz in 1788 , whereas the latter dates from 1817. On referring to the joint work of Martini and Chemnitz that observation is hardly borne out. Martini ${ }^{3}$ alludes to "Umbella," but in his description ${ }^{4}$ he is clearly not binomial, and did not intend to name a genus Umbella; he rather calls it Lepas, as "Lepas vertice et limbo," etc. And a few pages farther on ${ }^{5}$ the same kind of thing is described as "Lepas Indioa vertice," etc. Subsequently Chemnitz" refers to "Umbella Chinensis, testa integra," etc.; though in the explanation of the plates the term is abbreviated to "Umbella Chinensis." As these authors were not binomial, their work must be ignored; and Umbraculum should be adopted.

Type.-Umbella chinensis, Schumacher (ex Martini).

\section{Umbraculum australe, sp. nov.}

[Plate I. Figs. 7a-c.]

? Uimbrella austrina, Tate, IIS. (list name).

Shell broad, moderately elevated; small but prominent protoconch, which is slightly oblique; lines of growth well marked on both the outer and inner surfaces; two inconspicuous sulcations diverge from the protoconch anteriorly at an angle of about $35^{\circ}$; inner surface of the shell smooth and shining, radially striated, orbicular muscle marks large and rather depressed, causing corrugations; margin thin and rough.

1 Commerçon MS., Bruguière, Ency. Meth. (Yers) t. i. 1789, p. 1 ; $c f$. also Lamarck, Mém. Soc. Hist. Nat. Paris, 1798, p. 81 ; id. Syst. Anim. sans Vert. 1801, p. 130.

2 Ess. Paléoconch. Comp. 1895, p. 131.

3 Conch. Cab. Bd. i. 1769 , p. 90 , pl. vii. fig. 49 ; also pl. vi. fig. 44.

4 Op. cit. p. 103.

6 op. cit. p. 106.

6 Op. cit. Bd. x. 1788 , p. 341 , pl. clxix. figs. $1645-6$. 
It is interesting to find this genus in the fossil state. Compared with the living $U$. mediterranea, Lamarck, the Australian shell is rather more elevated, is not so elliptical, and the inner radiating strix are not as well pronounced in the neighbourhood of the muscular impressions.

Dimensions. - Height $10 \mathrm{~mm}$; maximum breadth $33 \mathrm{~mm}$. ; minimum breadth $29 \mathrm{~mm}$.

Form. and Loc.-Eocene: Muddy Creek, Victoria.

G. 4183. One specimen. Presented by John Dennant, Esq.

\section{Order PROSOBRANCHIATA.}

\section{Family TEREBRID 玉.}

\section{Genus TEREBRA, Lamarek.}

[Mém. Soc. Hist. Nat. Paris, 1799, p. 71.]

Shell subulate, many-whorled, with a short anterior canal and smooth columella.

This genus has been divided into many sections, but the writer agrees with Tryon ${ }^{1}$ that it cannot be advantageously dealt with in that manner, though an exception may be permitted in the case of the subgenus Euryta.

Type.-Buccinum subulatum, Linnæus.

\section{Terebra catenifera, Tate.}

1886. Terebra catenifera, Tate, Southern Science Record, January, p. 5.

1889. Terebra catcnifera, Tate, Trans. Roy. Soc. South Aust. vol, xi. p. 160, pl. viii. fig. 14 .

Shell pyramidal, whorls flattened convexly; "slightly overlapping; double-banded and nodulose in front of the suture, the posterior band rather the broader, and separated by a shallow sulcus, in the centre of which winds a subangular ridge defined by linear grooves; about 20 pairs of nodulations on the penultimate whorl; anterior half of each whorl distantly and superficially 
spirally ridged; the whole surface areuately striated by lines of growth; base spirally ridged and transversely wrinkled." - Tate.

It may be compared with the living $T$. mariesi, E. A. Smith, of Japan.

Dimensions.-Length $43 \mathrm{~mm}$; ; breadth $7 \mathrm{~mm}$.

Form. and Loc.-Miocene: Muddy Creek, Victoria.

G. 4229. Fire specimens. Presented by John Dennant, Esq.

Terebra platyspira, Tate.

1886. Terebra platyspira, Tate, Southern Science Record, January, p. 6.

1889. Terebra platyspira, Tate, Trans. Roy. Soc. South Aust. rol. xi. p. 159, pl. viii. fig. 12.

1893. Terebra platyspira, Tate and Dennant, id. vol. xvii. pt. 1, p. 221.

Neither of the specimens in the Nuseum presents a perfect protoconch, but Professor Tate remarks that it consists of "a relatively large papillary pullus of two turns; the first turn of the pullus subglobose, with the tip reverted and immersed, much broader than the next two or three whorls." The sutures of the shell are slightly canaliculated and distantly bordered by a linear sulcation; the whorls are ornamented with transverse curvilinear ridges and a few indistinct spiral striæ most conspicuously developed in adult specimens.

This species has considerable analogy with eertain European Miocene forms of Terebra - in particular $T$. pertusa, Lamarek, from the Langhian beds south of Bordeaux. It is narrower than that species, however, and the whorls are flatter and more turriculate. It is allied also to the living $T$. cingulifera, Lamarck, from the Philippines, China, etc.

Dimensions.-Length $40 \mathrm{~mm}$; ; breadth $5.5 \mathrm{~mm}$. Professor Tate states that the largest examples attain to $60 \mathrm{~mm}$. in length.

Form. and Loc.-Eocene: Muddy Creek, Victoria.

G. 4230. Two specimens. Presented by John Dennant, Esq.

Terebra additoides, Tenison-Woods.

1877. Terebra additoides, Tenison-Woods, Pap. Roy. Soc. Tas. 1876, p. 95.

1889. Terebra additoides, Tate, Trans, Roy. Soc. South Lust. vol, xi. p. 163.

1893. Terebr a additoides, Tate and Dennant, id. rol. xvii. pt. 1, p. 221. 
The specimen in the Museum is too mutilated for minute description. The posterior portion of the later whorls have a narrow ante-sutural band; the plications are narrow, slightly bent, and subnodose, and between them are very fine and close reticulations.

Dimensions.-Length about $9 \mathrm{~mm}$. ; breadth $3 \mathrm{~mm}$.

Form. and Loc.-Eocene: Table Cape, Tasmania.

83991. One specimen.

Purchased.

\section{Terebra ustulata, Deshajes.}

1857. Terebra ustulata, Deshayes, Journ. Conchyl. p. 97, pl. iii. fig. 12.

1859. Tercbra ustulata, Deshayes, Proc. Zool. Soc. p. 294.

The sutural band is not so deeply impressed as in typical specimens in the Museum from 'Tasmania, as found living, whilst the body-whorl is more convex; these differences may constitute a variety from which the living forms may have descended, but they are not worthy of specific rank.

Dimensions._Length $33 \mathrm{~mm}$; breadth $9 \mathrm{~mm}$.

Form. and Loc.-Post-Pliocene: Limestone Creek, Glenelg river, Victoria.

G. 5555. Three specimens.

Purchased.

\section{Terebra geniculata, Tate.}

1886. Terebra geniculata, Tate, Southern Science Record, January, p. 6.

1889. Terebra geniculata, Tate, Trans. Roy. Soc. South Aust. vol xi. p. 161, pl. ix. fig. 8 .

The protoconch (Plate II. Figs. $1 a-b$ ) of this species is subacute and composed of three convex turns. The whorls of the shell are much constricted posteriorly, and between the constriction and the suture there is a row of tubercles; the remainder of the surface of the whorls has distant rugose ribs which are angulate, and the whole presents rather the aspect of certain forms of Drillia than of Terebra. That it ought not to be classified with the Pledrotomide, however, is clear from the general phenomena of the aperture.

It differs from $T$. mutica, Tate, from the same locality but of 
Eoeene age, in the whorls being more angulate, the anterior canal being more excavated, and in other minor features.

Dimensions.-Length $9 \mathrm{~mm}$; breadth $3 \mathrm{~mm}$.

Form. and Loc.-Miocene: Muddy Creek, Victoria.

G. 9309. Two specimens.

Purchased.

Family CONIDE.

Genus CONUS, Linnæus.

[Syst. Nat. ed. 10, 1758, p. 712.]

Shell convolute, turbinate; aperture narrow and long, edentulous; columella smooth.

An attempt to divide the Eocene fossils of this genus into subgeneric groups based on observations made on living examples of Conus, must always, the writer believes, be attended with great uncertainty: for the genus itself had only just been established; and although in a very unstable condition, it had not yet had full opportunity of modifying, with development in different directions. No doubt, to a large extent, certain features of modern groups of Cones were conceired in Eocene times, but they were not sufficiently well differentiated to enable the species to be allocated clearly to the subgenera as established on living species. Conus was pregnant with evolutionary possibilities in the early Eocene. Nerertheless, the writer has essayed a subdirision in spite of the difficulties and uncertainties existing.

Type.-Conus marmoreus, Linnæus.

\section{Subgenus LEPTOCONUS, Swainson.}

[Malacology, 1810, p. 312.]

The author describes Leptocomus as follows:- "Shell light, conic, sometimes striated; spire elerated, acute, concare; the basal whorl earinated, detaehed, and sinuated abore, and contracted near the suture." Other characters which seem to be fairly persistent in this group are the deeply-cut canal bordering the suture and the more or less staged convolutions.

Type.-Conus grandis, G. B. Sowerby. 


\section{Conus (Leptoconus) ligatus, Tate.}

1890. Conus ligatres, Tate, Trans. Roy. Soc. South Aust. vol. xiii. pt, 2, p. 196 , pl. vii. figs. $4,4 a-b$; pl. viii. fig. 9 .

1893. Conus ligatus, Tate and Dennant, id. vol. xvii. pt. 1, p. 221.

Protoconch (Plate II. Figs. 2a-b) composed of two smooth volutions, the earlier of which is somewhat oblique and inflated. The spire of the shell proper is of variable height, in some specimens being comparatively depressed and in others so elongated as to be one-third the length of the shell. Spire-whorls with an obtuse, thick shoulder and ornamented with closely-set, spiral striæ, which persist over the whole surface of the body-whorl also, being especially accentuated on the anterior half. The body-whorl varies in shape from prriform to elongate ovate, the peripheral keel defined anteriorly by a linear constriction, posterior to which there are one or two threads on the peripheral band. The aperture is narrow, with a comparatively shallow anal sinus.

The range of variation in this species is so great that innumerable "varieties" could be established. One of them, as pointed out by Professor Tate, closely resembles $C$. deperditus, Bruguière, of the Eocene of North-western Europe.

This species partakes of the characters of both Leptoconus and Lithoconus; it has been assigned to the former subgenus on account of its elevated and staged spire and striated surface.

Dimensions. -Length $40 \mathrm{~mm}$.; breadth $21.5 \mathrm{~mm}$.

Form. and Loc.-Eocene: Victoria.

48052. Several specimens, in various stages of growth; from Schnapper Point.

Purchased.

70424. Four specimens; from Meribee Plains. Purchased.

G. 4242. Two specimens; from Muddy Creek.

Presented by John Dennant, Esq.

G. 5490. One specimen; from Muddy Creek.

Purchased.

\section{Conus (Leptoconus) heterospira, Tate.}

1890. Conus heterospira, Tate, Trans. Roy. Soc. South Aust. vol. xiii. pt. 2, p. 197 , pl. vii. figs. $5,5 a$.

1893. Comes heterospira, Tate and Dennant, id. vol. xvii. pt. 1, p. 221. 
This species differs from $C$. ligatus in being more elongate, whilst it is minus the rim-like keel of that species, and the lineations on the whorls of the spire are not conspicnous. The staging of the whorls is a peculiar feature; when in the brephic and neanic periods of growth there is little or no attempt at staging, but in the adult, and especially in senile forms, the anterior whorls drop very sharply. It is highly probable that this catabatic phenomenon is the precursor of the establishment of an elevated spire in its descendants; but that is a point which cannot be definitely settled until the phylogeny of the Gasteropoda has been worked out.

Dimensions.-Length $31 \mathrm{~mm}$; ; breadth $15 \mathrm{~mm}$.

Form. and Loc.-Eocene: Victoria.

48052. A series of ten specimens ranging from the neanic to the catabatic stages; from Schnapper Point.

Purchased.

70423. Four specimens; from Meribee Plains. Purchased.

\section{Conus (Leptoconus) newtoni, sp. nov.}

[Plate II. Figs. $3 a-d$.

Protoconch small, composed of two and a half smooth turns, indistinctly striated with growth-lines anteriorly; posterior portion slightly oblique with reference to the axis of the shell.

Spire elevated, acute, conrex, about one-sixth the total length of the shell; spire-whorls seven in number, staged, excavated, spiral lineations bold and continuous, growth-lines prominent, sinuated. Keel sharp and plain, not being crenulated even in the brephic stage. Bolly-whorl elongate, ornamented throughout its length by distant spiral sulcations which are punctated where crossed by the lines of growth. Aperture long and narrow; outer margin thin and arched; posterior sinus very deep; anteriorly the aperture is somewhat dilated and the columella is slightly twisted.

The elongation and narrowness of the body-whorl are distinctire features. Its nearest ally in the Australian Tertiaries is C. extemuatus, Tate, which, however, is broader, whilst its body-whorl is not so long, its periphery is not so sharply keeled, the earlier whorls are crenulated, and the ormamentation of the spire differs. C. newtoni closely resembles C. sieboldi, Reere, 
liring in the seas round the coasts of China and Japan, but in the modern form the whorls are not so much staged and the spiral lineations are not so well marked; the principal point of difference, howerer, is the shape and shallowness of the posterior sinus.

Dimensions. - Length $62 \mathrm{~mm}$; ) breadth $26 \mathrm{~mm}$; length of aperture $52 \mathrm{~mm}$.

Form. and Loc.-Eocene (?): Muddy Creek, Victoria.

G. 4239. One example.

Presented by John Dennant, Esq.

G. 5494. One example.

Purchased.

\section{Conus (Leptoconus) murravianus, Tate.}

1890. Conus murravianus, Tate, Trans. Roy. Soc. South Aust. rol. xiii. pt. 2, p. 200, pl. vii. fig. 2.

Protoconch (Plate II. Figs. 4a-b) composed of three smooth turns implanted obliquely with reference to the axis of succeeding whorls; the initial portion is exceedingly small in comparison with the anterior turns. These latter are depressed and deeply canaliculated. The shell proper has an elevated spire with six whorls, which are somewhat staged, slightly excavated; and spiral lineations are not prominent, except towards the anterior half of the body-whorl. It is noteworthy that in the brephic stage the periphery of the body-whorl was obscurely crenulated, a character which disappeared, however, as the neanic period was reached. Aperture narrow, slightly expanded in front; outer margin thin; with a shallow posterior sinus.

This species presents characters of no less than three subgenera: by its very elevated spire and the obscure crenulations it recalls Conospirus, which does not appear to stand on a very firm basis; its protoconch presents the features of Lithoconus as represented in the Australian Tertiary by $C$. dennanti and $C$. pullulescens; but the general contour of the shell and the staged whorls reflect Leptoconus, to which subgenus the species is here referred. Specifically it has a near ally in $C$. brocchii, Bronn, of the Italian Pliocene.

Dimensions.-Length $41 \mathrm{~mm}$; ; breadth $16 \mathrm{~mm}$. Professor Tate records a length of $61 \mathrm{~mm}$.

Form, and Loc.-Eocene: River Murray cliffs.

G. 9136. One specimen. Presented by Tilliam Evans, Esq. 


\section{Conus (Leptoconus) convexus, sp. nor.}

[Plate II. Figs. $5 a-d$.

Protoconch composed of two smooth turns, the initial portion of which is lateral and immersed; much elevated above the remainder of the shell. The whorls of the spire, five in number, are slightly conrex, and are thus not excarated as in other species mentioned; they are ornamented by fire or six deeply-cut sulci, somewhat irregular in places owing to the intersection of growth marks; these latter, however, do not approach tessellation. The whorls are not staged, but the suture is distinctly canaliculated, especially as the growth approaches the ephebic stage. The body-whorl has an elerated band at its periphery, which is rugosely lineated; its whole surface is corered by small, undulating, irregular sulci, which broaden anteriorly and are interrupted by sinuous growthlines. Aperture long, narrow, its two margins parallel with each other; outer margin thin, curved, and distinctly crenulated within; anal sinus broad and comparatively shallow, inner margin straight.

Its protoconch is very different to that of C.pullulescens; and the conrexity of the whorls, deep sulci, canaliculate suture, and crenulated margin of the aperture, are highly distinctire. On comparison with $C$. complicatus, Tate, in addition to the characters just mentioned, it will be observed that $C$. convexus is broader, and the spire less elerated, whilst the ornament is peculiar to it; moreorer, the whorls are not staged, neither is the sinus deeply, arcuately notched.

Dimensions (of the type specimen).-Length $17 \mathrm{~mm}$; breadth $9 \mathrm{~mm}$.

Form. and Loc.-Eocene: Meribee Plains, Victoria.

70424. Two specimens.

Purchased.

\section{Subgenus LITHOCONUS, MIörch.}

[Cat. Yoldi, Fasc. i. 1852, p. 66.]

Shell conical, spire more or less elcrated, but often depressed, not coronate nor staged; body-whorl sharply carinate; aperture dilated in front, with a rather deep posterior sinus.

Type.-Conus millepunctatus, Linnxus. 


\section{Conus (Lithoconus) cuspidatus, Tate.}

1890. Comes cuspidatus, Tate, Trans. Roy. Soc. South Aust. vol. xiii. pt. 2, p. 194, pl. vii. fig. 1.

1893. Conus cuspidatus, Tate and Dennant, id. vol. xvii. pt. 1, p. 221.

Protoconch (Plate II. Figs. $6 a-b$ ) conspicuously elevated, rising to a sharp point, composed of four to five slowly and regularly increasing turns, forming a very distinctive feature. Spire of the shell proper with seven to eight volutions, slightly coneave and deeply lineated spirally.

In the brephic stage the spire is much elevated in all the specimens examined, and this eharacter may be perpetuated to the gerontic stage, or the whorls may become flatter and less elevated during the neanic, and absolutely depressed during the later stages of growth. Such a wide range in eleration of the spire is not ofteu observable in Conus; the amount of elevation is merely an individual peculiarity. This may be noted by those who seize upon this unstable property as a subgeneric character and often allow it to influence them in defining a species.

Body-whorl either obtusely or acutely angulate at the periphery, depending on the elevation of the spire; lines of growth well marked, spiral striæ plainly developed anteriorly. Aperture narrow, dilated in front, channelled behind; columella twisted, bordered by an elevated ridge in young specimens, and very pronounced in the catabatic stage where the anterior portion is usually much fractured, owing apparently to difficulties of growth. The columellar twist leads to a slight constriction of the body-whorl.

Dimensions.-Length $49 \mathrm{~mm}$.; breadth $25 \mathrm{~mm}$.

Form. and Loc.-Eocene: Muddy Creek, Victoria.

G. 5489. Three specimens.

Purchased.

Conus (Lithoconus) pullulescens, Tenison-Woods.

1880. Conus pullulescens, Tenison-Woods, Proc. Linn. Soc. N.S. W. vol. iv. p. 3, pl. i. fig. 4 (non fig. 3).

1890. Conus pullulescens, Tate, Trans. Roy. Soc. South Aust. vol. xiii. pt. 2, p. 196, pl. xi. fig. 9 .

1893. Conus pullulescens, Tate and Dennant, id. vol. xvii. pt. 1, p. 221.

This species may be distinguished from C. cuspidatus, amongst other things by its extremely characteristic and prominent protoconch (Plate II. Figs. $7 a-b$ ). This is very large, composed of 
three turns, somewhat turbinate, with deeply canaliculate sutures. The protoconch is oblique with reference to the axis of the shell. The spire of the shell proper is not much elevated, its whorls are narrow, separated by a linear suture, ornamented with a few spiral threads and closely-set sinuous lines of growth. Bodywhorl sharply keeled at the periphery, and corered with flat spiral threads which become obsolete with age, except anteriorly.

The figure accompanying Mr. Tenison-Wood's memoir abore cited refers to a young shell, and is practically unrecognizable. The interpretation placed upon it by Professor Tate is here adopted.

Dimensions.--Length $39 \mathrm{~mm}$; ; breadth $21 \mathrm{~mm}$.

Form. and Loc.-Eocene: Tictoria.

70423. Tro specimens; from Mreribee Plains.

Purchased.

73220. Three specimens; from Schnapper Point. Purchased.

G. 4240. One specimen; from Muddy Creek.

Presented by John Dennant, Esq.

G. 5491. One specimen; from Muddy Creek.

Purchased.

G. 4745. Two specimens; from Muddy Creek.

Presented by Prof. T. Rupert Jones, F.R.S.

\section{Conus (Lithoconus) dennanti, Tate.}

1890. Conus dennanti, Tate, Trans. Roy. Soc. South Aust. vol. xiii. pt. 2, pl. xi. fig. 7 (plate issued July, 1892).

1893. Comes dennanti, Tate and Dennant, id. vol. xvii. pt. 1, p. 221 (list name).

This species does not appear to be described, except in the explanation of the plate abore cited, where the following words occur: "Conus dennanti, sp. nor. (C. pullulescens, var., Tate)."

The protoconch (Plate II. Figs. $8 a-b$ ) differs from that of C. pullulescens in not being angulate, or turbinate; it is composed of three smooth, conrex turns, imbedded in the crown of the shell, being in fact the only part which stands abore the flat surface produced by the convolution of the shell-whorls proper. This upper surface is much depressed, has linear sutures, and is boldly, spirally striated. The periphery of the body-whorl is more sharply keeled than any other Australian Tertiary Conus; the surface of the whorl is corered by rather closely-set spiral lineations and sinuous growth-lines. Aperture rery narrow, outer 
border parallel with the inner, but slightly dilated anteriorly; columella twisted in front.

Dimensions.-Length $33 \mathrm{~mm}$; ; breadth $20 \mathrm{~mm}$.

Form. and Loo.-Eocene: Victoria.

70423. One specimen; from Meribee Plains.

Purchased.

G. 5493. Two specimens; from Muddy Creek.

Purchased.

\section{Conus (Lithoconus) ptychodermis, Tate.}

1890. Comus ptychodermis, Tate, Trans. Roy. Soc. South Aust. vol. xiii. pt. 2, p. 195, pl. vii. fig. 3 .

This species may be readily distinguished from all other A ustralian Tertiary Conus, by the peculiar, rugged aspect of the body-whorl caused by the inter-crossing of growth folds and the irregular character of the distant spiral lineations and ridges. The spire is much depressed, with canaliculated sutures; the periphery of the body-whorl is sharply keeled; the anterior portion of the columella is twisted and prominently lineated. The protoconch is not well preserved in the Musenm specimen, but it evidently had the general features of that of $C$. pullulescens, though more depressed.

Dimensions. - Length $20 \mathrm{~mm}$.; breadth $9 \mathrm{~mm}$.; length of aperture $17 \mathrm{~mm}$.

Form. and Loc.-Eocene: Muddy Creek, Victoria.

G. 5489. One specimen.

Purchased.

\section{Subgenus CHELYCONUS, Mörch.}

[Cat. Yoldi, Fasc. i. 1852, p. 69.]

Spire elevated, last whorl convex near suture, rounded at the shoulder, posterior sinus not very deep.

Type.-Conus testudinarius, Gmelin (ex Martini).

Conus (Chelyconus) ralphi, Tenison-Woods.

1879. Conus ralphii, Tenison-Woods, Proc. Linn. Soc. N.S.W. vol. iii. p. 228 , pl. xxi. fig. 14 .

1890. Conus ralphii, Tate, Trans. Roy. Soc. South Aust. vol. xiii. pt. 2, p. 198, pl. vii. fig. 6 . 
Protoconch (Plate II. Figs. 9a-b) conical, moderately elevated and composed of two smooth turns, somewhat similar to that of C. heterospira. In the brephic stage, and, possibly, to the commencement of the neanic, the whorls of the spire are coronate, but as the adult form is reached these disappear and the shoulders become rounded. Mr. Tenison-Woods was only acquainted, apparently, with young forms of the species, and the figure in his memoir cited above does not convey a correct idea of the shell, as each whorl is represented as being carinate and nodosely crennlated. Professor Tate has traced the young forms to the adult and firmly established the species. The spire is elevated, composed of eight whorls striated spirally above. The body-whorl is also spirally striated, the striæ bcing most conspicuous on the anterior half. Aperture narrow, posterior sinus shallow and following growthlines; columella slightly twisted anteriorly.

Dimensions -Length $43 \mathrm{~mm}$.; breadth $23 \mathrm{~mm}$.

Form. and Loc.-Eocene: Mruddy Creek, Victoria.

G. 5492. One specimen.

Purchased.

G. 4241. One specimen.

Presented by John Dennant, Esq.

\section{Conus (Chelyconus) catus, Hwass.}

1792. Conus catus, Hwass, Ency. Meth. (Vers) t. i. pt. 2, p. 707.

Shell bulbous, spire conrex, striated above; body-whorl fiuely striated on the posterior half, and haring deep spiral sulcations anteriorly. Aperture narrow, but widening in front and somewhat dilated; posterior sinus conspicuons; columella twisted anteriorly where a well-marked ridge or fold is produced.

The species differs from the earlier $C$. ralphi, with which it is closely related, in being much broader anteriorly and by the prominent columellar fold. The specimens in the Museum are not well enough preserved to show the protoconch or the condition of the shell in the brephic stage.

This species has living representatives over a large geographical area, including the Red Sea, Mauritius, Jara, China, New Caledonia, and Polynesia generally, and it is interesting to find it as a fossil.

Dimensions.-Length $44 \mathrm{~mm}$; brealth $24 \mathrm{~mm}$. 
Form. and Loc.-Pliocene: obtained from a well-digging 10 feet in depth, Chatham Islands.

G. 9502. Two specimens.

Transferred from the Mluseum of Practical Geology.

\section{Conus, sp.}

The following specimens, for the most part casts, are indeterminable specifically, but are interesting to record as establishing the marine character of Tertiary deposits in certain parts of Australia, and are worthy of notice also on other grounds :-

G. 9499. Five casts of a species allied to C. pullulescens, but larger, the body-whorl being more convex; the columella is distinctly twisted. From Nullarbor Plains, South Australia.

\section{H. Y. L. Brown Coll.}

G. 9500. Cast of a species which may be specifically identical with the preceding. From Fowler's Bay District, South Australia. II. Y. L. Brown Coll.

G. 9152. Cast imbedded in a mass of fragments of Bryozoa. From near Border Town, South Australia.

Presented by R. Littow, Esq., F.G.S.

G. 353. Cast of a species allied to C. murrarianus in having an elongated spire; but it is relatively broad, and the inner border of the aperture is curved. From Bairnsdale, Victoria.

Presented by W. H. Grigson, Esq.

G. 9501. Cast imbedded in ferruginous sandstone. From Flemington, near Melbourne.

Transferred from the Mruseum of Practical Geology.

G. 9493. Two casts, from the Miocene "Conus-beds" of Mokihinui river, New Zealand. Sir James Mector Coll.

G. 9494. Fragment of a species composed of six elerated whorls, having a protoconch composed of three smooth turns implanted obliquely on the spire. It is closely allied to and nay be specifically identical with $C$. trailli, Hutton. From A wamoa, New Zealand.

Sir Janes Hector Coll.

G. 4237. A new species of Conus, too imperfect for detailed description. It is $60 \mathrm{~mm}$. in length, with a rather elevated spire and elongate body-whorl; anterior of the columella twisted; 
aperture dilated in front. It may doubtless be referred to the subgenus Leptoconus. From the Tertiary of Muddy Creek, Victoria.

Presented by John Dennant, Esq.

\section{Family PLEURO'TOMID E.}

In assigning the species here described to their systematic positions in the Pleurotomide, it may be remarked that in view of the present unsatisfactory condition of the classification of many of the so-called genera and subgenera in the family, some of the conclusions arrived at must, of necessity, be of a tentative character. The group has been divided into subfamilies according to the presence or absence of an operculum, and the nature of that when present. The systematic position of many of the species is dependent on the situation of the sinus, its depth, and so forth. The length of the anterior canal, details of ornament, peculiarities of the radula, and the like, have also been permitted to rank high - even as generic characters.

The family as a whole is not of very great antiquity, its main features having been carved out in the Eocene; whilst many of its broad characteristics were not evolved until the Miocene, or early Pliocene. Possibly, no group of the mollusca has been so prolific in yielding so many diversified forms in such a short space of geological time. The variation of individuals in the living as well as in the fossil state is often so wide as to render it impossible to satisfactorily define the limits of range permissible in species. That difficulty, combined with the latitude of the personal equation, has led to the establishment of innumerable so-called species of the Plednotonidx, which appear to the writer to be founded merely on ontogenetic characters. The problem, already difficult with the living forms, is intensified when the fossils are considered. Here we hare no operculum to assist, and many other points utilized in the classification of modern Pleurotomide are missing. Shorn of the characters of their opercula, the chief difference between Pleurotoma and Sureula, for example, lies in the form and position of the sinus; in the former genus it is deeper, and is placed farther away from the suture than in the latter. If these characters were in any way constant they might be rendered useful; but, as it is, we are 
left without any material conchological differences between the two genera mentioned, and the assignment of any but typical species to either of them must remain doubtful. It is highly probable, however, that a special study of the protoconchs, and the mode of growth of the shells as found in the fossil condition, will assist in clearing up many difficulties.

Very few of the Australian Tertiary species of Pledrotonid.e hare been described; of these some have nerer been figured, and the descriptions of the remainder are often so imperfect as to render identification impossible. Several forms new to science are now recorded.

\section{Genus PLEUROTOMA, Lamarck.}

[Mém. Soc. Hist. Nat. Paris, 1799, p. 73.]

Shell turriculated, spire long; collumellar margin smooth; outer margin of the aperture with a narrow, deep sinus, situated sorne distance from the suture; canal long and straight.

Type.-Hurex babylonius, Linnæus.

Pleurotoma murndaliana, Tenison-Woods.

1879. Pleurotoma murndaliana, Tenison-Woods, Proc. Linn. Soc. N.S.W. vol. iii. p. 226 , pl. $\mathrm{xx}$. fig. 5 .

1889. Pleurotoma murndaliana, Dennant, Trans. Roy. Soc. South Aust. vol. xi. p. 44.

1893. Pleurotoma murndaliana, Tate and Dennant, $i d$. vol. xvii. pt. 1, p. 221.

Protocouch composed of three elongate turns, the initial portion being slightly inflated, whilst the anterior turns are obtusely carinate. Shell narrow, elongate; whorls ten in number, slightly courex, and having several bold, irregular, spiral threads or ridges, rather rugose where crossed by growth-lines, and somewhat granulated in the neighbourhood of the sinus. Canal long, slender, and twisted; outer margin serrate, sinus large and deep, and situated some distance from the suture.

Dimensions. - Length $47 \mathrm{~mm}$; breadth $13.5 \mathrm{~mm}$.; length of aperture $20 \mathrm{~mm}$.

Form. and Loc.-Eocene: Victoria.

73232. A variation in which the whorls of the spire carry three acute spiral ridges, or keels, the posterior of which has dereloped a median sulcus, and is granulose. From Brighton. Purchased. 
G. 4232. Two specimens; from Muddy Creek.

Presented by John Dennant, Esq.

G. 5502. A very elongate example, from Muddy Creek.

Purchased.

\section{Pleurotoma septemlirata, sp. nor.}

[Plate II. Figs. 10a-d.]

Shell large, fusiform, tumid; protoconch small, smooth, deroid of ornament, terminating abruptly at its junction with the shell in the brephic stage; whorls eleven in number, suture canaliculate and bimarginate, rugosely spirally lirate; there are seven principal spirally striated liræ on the penultimate whorl in the adult, but at sounger stages of growth they are fewer in number, decreasing gradually to four; the body-whorl is irregularly lirate throughout. Between the large compound liration on the margin of the suture anteriorly, and the elevated ridge denoting the position of the sinus, is a broad, deep sulcation, which, like the sulci between the liræ, is finely spirally striated and interrupted by lines of growth. Aperture large, broad, ovate, contracted anteriorly; outer margin thin, sulcate within, crenulated or serrated, arcuate; sinus broad, deep, situated distantly from the suture; columellar margin smooth, curred, slightly callous in senile individuals; canal rery short and broad.

Typically this species has some analogy with $P$. murndaliana, but is larger, more tumid, has a shorter canal, and is not subgranose, whilst the deep, broad sulcation in front of the suture is characteristic. Its great range of variation is remarkable, and might at first sight lead to the establishment of sereral new species. The type specimens, as above indicated, are strongly lirate, but with sufficient material these may be traced almost to the ranishing point, some individuals, indeed, being only rery faintly striated, and to all intents and purposes smooth. Pari passu the shell is shorter and more tumid, presenting the aspect of Pusionella, though it could not be classified with that genus, on account of its deep sinus, amongst other things.

Dimensions.-Length $60 \mathrm{~mm}$.; breadth $22 \mathrm{~mm}$.; length of aperture $25.5 \mathrm{~mm}$.

Form. and Loc.-Eocene: Muddy Creek, Victoria. 
G. 4231. Typical adult and senile specimens, and an example in which the liræ are not so bold, and the shell is relatively more tumid.

Presented by John Dennant, Esq.

G. 4233. Four specimens, in which the ornamentation is much reduced in importance, and numbers of additional spiral lineations are introduced.

Presented by John Dennant, Esq.

G. 5501. Two specimens, strongly lirate, but more elongate than typical examples.

Purchased.

G. 5499. A smooth specimen, in which the liræ have disappeared, or are only represented by obsolete lineations, whilst the growth-lines are more prominent.

Purchased.

\section{Pleurotoma trilirata, sp. nov.}

[Plate III. Figs. $1 a-d$.

Shell small, elongate. Protoconch large, composed of two and a half smooth turns; the earlier portion is much depressed, and even in the initial part the suture is canaliculate and marginate; at a later stage the protoconch is longitudinally costate and subnodose at the periphery, and this continues up to the brephic stage, where it gives way to the bold spiral liræ which form the sole ornamentation of the whorls in subsequent stages of growth. Whorls six, flat, suture canaliculate and marginate; spiral liræ three in number on the penultimate whorl, with a smaller lineation between the posterior two, which becomes more accentuated on the body-whorl. The latter is boldly lirated throughout; lines of growth inconspicuous. Aperture small, pyriform; outer margin arcuate; sinus shallow, situated not far from the suture; columellar margin smooth, not callous, slightly twisted in front; anterior canal very short.

The most interesting feature of this species is the highly sculptured protoconch, which differs from that of any other Australian form here described. The longitudinal costæ, however, precede the spiral liræ as in some other species of Pleurotoma. Dimensions. - Length $10.5 \mathrm{~mm}$.; breadth $4 \mathrm{~mm}$.; length of aperture $3.5 \mathrm{~mm}$.

Form. and Loc.-Eocene: Hobson's Bay, Victoria.

48052. The type specimen.

Purchased. 


\section{Pleurotoma consutilis, Tenison-Toods.}

1880. Plourotoma consutilis, Tenison-Woods, Proc. Linn. Soc. N.S.W. rol, ir. p. 9, pl. ii. fig. 5.

1889. Pleurotoma consucilis, Dennant, Trans. Roj. Soc. South Aust. vol. xi. p. 44.

1893. Pleurotoma consutilis, Tate and Dennant, id. vol. xvii. pt. 1, p. 221.

Protoconch composed of one and a half smooth, shining whorls, the anterior portion of which is obtusely keeled medially; this keel derelops into a strong feature in the brephic and neanic stages, but on approaching the adult is not so clearly marked. Shell small, fusiform; whorls obliquely cancellate, the transverse and longitudinal lines being regularly spaced; aperture broad, outer margin much produced towards the middle, sinus broad, deep, and some distance from the suture; columella distinctly twisted; anterior canal short.

Dimensions. - Length $12 \mathrm{~mm}$.; breadth $5 \mathrm{~mm}$.; length of aperture $5 \mathrm{~mm}$.

Form. and Loc.-Eocene: Muddy Creek, Victoria.

G. 9328. Three specimens.

Purchased.

\section{Pleurotoma subconcava, sp. nor.}

[Plate III. Figs. 2a-b.]

Shell large, elongated; from 11 to 12 whorls; the later portion of the protoconch (the only part preserved in the type specimen) is distinctly longitudinally ribbed; beyond the sinuous fracture denoting the commencement of the brephic stage these costæ suddenly cease and gire way to spiral lineations, with a prominent median sulcation indicating the position of the sinus. The whorls throughout the brephic and neanic stages are flat, with a deeply impressed suture, but in the adult stage they become convex, and hare a postero-median subaugulation at the periphery. Between this and the suture is a well-marked concare depression. The ornament consists of closely-set spiral lineations, which are nearest together in the depression alluded to; the suture is margined by one or two lineations bolder than the rest. The lines of growth are fairly conspicuous, producing rough, irregular corrugations here and there; these are most noticeable in the neighbourhood of the 
peripheral subangulation, and on the anterior portion of the bodywhorl. Aperture small, being about one-third the length of the whole shell, pyriform and produced in front; outer lip thin, sinus broad, arcuate, situated on the periphery; columella covered by a thin deposit of shell enamel, not callous posteriorly, slightly twisted in the middle; anterior canal rather long and deep.

Dimensions.-Length $58 \mathrm{~mm}$.; breadth $16 \mathrm{~mm}$.; length of aperture with canal $23 \mathrm{~mm}$.

Form. and Loc.-Eocene: Meribee river, Victoria.

70421. The type specimen.

Purchased.

\section{Pleurotoma salebrosa, sp. nov.}

\section{[Plate III. Figs. $3 a-d$.]}

Shell fusiform; whorls eight in number, in the young growth flat; in the neanic and ephebic stages subangulately convex, rapidly increasing in size; protoconch two smooth turns, globose, the later turn being wider than the succeeding whorl. Ornament consisting of from 13 to 14 deep, undulating sulcations on each whorl of the spire, the body-whorl being sulcated throughout in a similar manner; lines of growth not very conspicuous, but the surface of the shell is peculiarly, distantly corrugated, the corrugations being five in number on the peuultimate whorl, and rising into indistinct, broad, oblique ribs. Aperture pyriform, much contracted in front; outer lip thin, slightly sulcated within; sinus situated about half-way between the peripheral subangulation and the suture, broad and shallow; columella smooth, striated vertically, but not callous, twisted in front; anterior canal long, broad at its extremity.

This shell differs from $P$. subconcava in being relatively more tumid, having a larger aperture and fewer whorls; by the oblique broad, corrugated costæ; and by the position of the sinus, which in this case is indicative of Surcula of authors. The protoconch, also, is widely different, as will have been noticed.

Dimensions. - Length $33.5 \mathrm{~mm}$. ; breadth $12 \mathrm{~mm}$; length of aperture $17 \mathrm{~mm}$.

Form. and Loc.-Eocene: Hobson's Bay, Victoria.

48052. The type specimen.

Purchased. 


\section{Pleurotoma claræ, Tenison-Woods.}

18s0. Pleurotoma clare, Tenison-Woods, Proc. Linn. Soc. N.S.W. vol. iv. p. 11, pl. iii. fig. 11.

1893. Pleurotome clare, Tate and Dennant, Trans. Roy. Soc. South Aust. vol. xvii. pt. 1, p. 221.

1895. Pleurotoma (Sureula) elarce, Tate and Deunant, id. vol. xix. pt. 1, p. 111.

Shell elongate, fusiform, and thin; posterior part of the spire ribbed, anteriorly the ribs become obsolete; shoulder of last whorl obtusely angulate; entire external surface of whorls eovered with small, elosely-set spiral liræ; aperture broad, the broad sinus being situated near the suture.

From the position of the sinus this species might be classed with Surcula; but in view of the difficulties of making use of that variable eharacteristic (which in the ease of the present species ranges between the shoulder and the suture, but is nearest to the latter), as already stated, no attempt is here made to separate Surcula from Pleurotoma.

Dimensions. - Length $17.5 \mathrm{~mm}$.; breadth $6 \mathrm{~mm}$.; length of aperture $9 \mathrm{~mm}$.

Form. and Loc.-Eocene: Muddy Creek, Victoria.

G. 4235 and G. 4236. Several specimens, showing range of rariation. Presented by John Dennant, Esq.

Pleurotoma samueli, Tenison-Woods.

[Plate III. Figs. 5a-b.]

1879. Pleurotoma samueli, Tenison-Woods, Proc. Linn. Soc. N.S.W. vol. iii. p. 226, pl. xx. fig. 3 .

1893. Pleurotoma samueli, Tate and Dennant, Trans. Roy. Soc. South Aust. vol. xvii. pt. 1, p. 221 .

Shell fusiform, elongate; protoconch turbinate, composed of three smooth turns, the suture of which is marginate. In the brephic stage the margination is much accentuated, and at a later period of growth gires was to a row of small, distant granules. In the same manner, the median, tuberculated carina of the adult commences in the brephie stage by large obtuse nodulations. The shell is thus deseribed by Mr. Tenison-Woods:- "It is a polished shell, with whorls angular in the middle, supporting 
a single, somewhat distant series of coarse, blunt, somewhat square tubercles. These are exactly on the line of the sinus, and at each side the lines of growth curve away from it. The sinus itself is deep, broad, and somewhat quadrate. The aperture is long and round, rather square posteriorly, and the canal is long and only slightly curved."

The marginate character of the protoconch is noteworthy; from its metamorphosis in later stages of growth, it would appear that the species has descended from a stock in which the suture was accompanied by a large flat keel, though no shell of that character has been recorded as occurring in the Australian Tertiaries.

Another point of interest in this species is its compound character: it possesses the tubercular sutural coronation and produced spire characteristic of Clavatula, and shows what value is to be placed on that feature; the special nature of the peripheral carina and the arcuate, long canal somewhat resemble Surcula; whilst the position of the suture and other general features of the shell recall Pleurotoma. Clearly it was pregnant with evolutionary possibilities.

Dimensions. - Length $12 \mathrm{~mm}$.; breadth $4 \mathrm{~mm}$. ; length of aperture $7 \mathrm{~mm}$.

Form. and Loc.-Eocene: Muddy Creek, Victoria.

G. 9329. 'Three specimens.

Purchiased.

\section{Pleurotoma optata, sp. nov.}

[Plate III. Figs. 4a-b.]

Shell fusiform; aperture (with anterior canal) more than onehalf the length of the whole shell; whorls seven in number, slightly convex, keeled above and below the suture, which is near the centre of the whorls, the anterior keel being the most prominent; the other ornament consists of several closely-set small spiral lineations, crossed by rather conspicuous growth-lines, and accompanied by a peculiar damascened structure. Protoconch composed of two smooth turns, the anterior being subangulate and vertically striated; terminating abruptly agaiust the shell of the brephic stage, which is longitudinally, obliquely costated and marginate. Aperture elongately pyriform, much constricted 
anteriorly; outer margin thin, undulating; sinus broad and shallow; columella corered by a thin deposit of vertically striated callus, twisted anteriorly; canal long, curved, broad in front.

This shell agrees with others here described in being longitudinally costated in the earlier stages of growth, which costæ disappear in the adult. It has the aspect of what is generally included under Surcula, but the sinus is far remored from the suture, as in typical Pleurotoma.

Dimensions. - Length $16.5 \mathrm{~mm}$.; breadth $6 \mathrm{~mm}$.; length of aperture $9.5 \mathrm{~mm}$.

Form. and Loc.-Eocene: Hobson's Bay, Victoria.

48052. The type specimen.

Purchased.

\section{Pleurotoma alta, nom. mut.}

1873. Pleurotoma pagoda, Hutton, Cat. Tert. Moll. N.Z. p. 5 (non Reere). 1593. Pleurotoma pagoda, Hutton, Linn. Soc. N.S.W., Macleay Mem. Vol. p. 48 , pl. ri. fig. 21 .

Protoconch composed of two elevated smooth turns; whorls six in number, smooth, or only marked with growth-lines, very strongly and acutely keeled at the periphery, and with one or two inconspicuous spiral lineations, as an individual characteristic, above or below the keel; body-whorl subangulate in front, denoting the position of growth as the suture became developed; aperture orate, contracted anteriorly, and terminating in a rather long canal; sinus deep, situated between the keel and the suture, but nearer the former; columella twisted, covered with a smooth, thin deposit of shelly enamel.

On conchological grounds this species might be relegated to Surcula, but, as preriously remarked, any such reference must always be exceedingly doubtful with fossil specimens. An intercsting point is that, whilst many strongly keeled species of Pledrotomide bear traces of angulation in the protoconch which lead up to the keel in subsequent stages of growth, $P$. alta is without this in spite of the fact that the carina is most strongly developed in the brephic stage. This species has considerable analogy with Surcula jani, Bellardi, from the Upper Miocene of the Piedmont basin. The specific name alta is here proposed in substitution for pagoda, preoccupied, as indicated. 
Dimensions.-Length $18 \mathrm{~mm}$. ; breadth $7.5 \mathrm{~mm}$.; length of aperture $10 \mathrm{~mm}$.

Form. and Loc.-Miocene: New Zealand.

G. 9498. Several specimens, from Parimoa, Middle Island. W. B. D. Mantell Coll.

G.9495. A tumid variety, from Awamoa. Sir James Ilector Coll.

\section{Pleurotoma wanganuiensis, Hutton.}

1873. Pleurotoma wanganuiensis, Hutton, Cat. Tert. Moll. N.Z. p. 4. 1893. Pleurotoma wanganuiensis, Hutton, Linn. Soc. N.S.W., Macleay Mem. Vol. p. 50, pl. vi. fig. 28.

Professor Hutton describes this as follows:- "Shell fusiform, the spire longer than the body-whorl. Whorls strongly spirally ribbed, and obliquely longitudinally ribbed in the centre. From 13 to 16 longitudinal ribs in a whorl. Suture very finely obliquely striated, and with a spiral rib. Aperture oval, canal short and recurved."

Specimens in the British Musenm agree very well with this description, but the figure given in the memoir above cited represents a more tumid variety. The protoconch (Plate II. Figs. $11 a-b)$ is most remarkable, and merits detailed description. Of the four specimens in the collection, two exhibit the characteristic fracture or undulation at the termination of growth of the protoconch. As thus defined, the latter is composed of from two and a half to three turns; the initial turn is smooth and obsoletely striated, and this is followed by an obtuse angulation which rapidly develops into a bold, acute, median spiral carina, with a conspicuous lineation both above and below it, and another bordering the suture. Up to this point, no longitudinal costæ or other ornamentation are developed, and if the growth had continued in the same manner a shell somewhat resembling $P$. alla would have resulted. Instead of that, however, the brephic stage is characterized from its commencement by the profuse ornamentation, suddenly introduced, which obtains in the adult. This should prove of material value in working out the genetic relationships of the group. 
By the short canal and longitudinal costæ this shell presents some analogy with Drillia, but it differs in the position of the sinus, which is distant from the suture, and in the absence of a posterior callosity on the columellar border. The length of the anterior canal is not of much value in systematics, and in some species of Pleurotoma may only indicate sexual differences. The ribs and position of the sinus are characteristics recalling Surcula.

Dimensions. - Length $14 \mathrm{~mm}$.; breadth $5 \mathrm{~mm}$.; length of aperture $6 \mathrm{~mm}$.

Form. and Loc.-Pliocene: New Zealand.

G. 1618. Two adult examples, from Wanganui.

G. 9497. An exceptional form, from Shakespeare Cliff.

Sir James Hector Coll.

\section{Pleurotoma buchanani, Hutton.}

1873. Pleurotoma buchanani, Hutton, Cat. Tert. Moll. N.Z. p. 4.

1893. Pleurotoma buchanani, Hutton, Linn. Soc. N.S.W., Macleay Mem. Vol. p. 50, pl. vi. fig. 26.

"Shell elongato-fusiform. Whorls obliquely longitudinally plaited, and with fine spiral ribs below the sinus area; above the sinus area smooth, concave, with a slight ridge at the suture. Between 11 and 15 longitudinal plications on a whorl. Aperture oral, canal produced, rather bent."-IIutton.

Protoconch composed of two oblique smooth turns, the anterior portion haring four decp spiral sulci, cutting through the small longitudinal costre of the brephic stage, into which the protoconch imperceptibly passes.

This species might be classified with Surcula; the sinus is situated half-way between the suture and the periphery, and is not deep; the development of longitudinal costre removes it from Pleurotoma, sensu stricto.

Dimensions. - Length $20 \mathrm{~mm}$. ; brcadth $7.5 \mathrm{~mm}$.; length of aperture $10.5 \mathrm{~mm}$.

Form. and Loc.-Pliocene: New Zealand.

G. 1617. Adult and jurcnile specimens, from Wanganui.

G. 9496. Three specimens, from Shakespeare Cliff.

Sir James Mector Coll. 
Pleurotoma, sp. indet.

Impression, in compact white limestone, of a large species, probably one of the Pleurotoninz. It is furnished with large equidistant tubercles at the periphery of the whorls, and has a marginate suture, but the specimen is not well enough preserved to warrant specific description. From the Tertiary of Nullarbor Plains, South Australia.

II. Y. L. Brown Coll.

\section{Genus BATHYTOMA, Harris and Burrows.}

[Eoc. and Oligo, Paris Basin, 1891, p. 113.]

Dolichotoma, Bellardi, Bull. Malac. Ital. t. i. 1875, p. 21 (non Hope, 1839).

Tryon, ${ }^{1}$ in reviewing the genera of Pleurotomide, follows Fischer ${ }^{2}$ in including Dolichotoma as a subgenus of Genotia, and remarks that in common with Pseudotoma, Oligotoma (=Asthenotoma), Rouaultia, and Cryptoconus its characters are not important. The American author alluded to does not monograph the fossil species, nor does he explain the matter further, so that it is impossible to arrive at his precise meaning. Professor Tate ${ }^{3}$ remarks that he was not satisfied that Dolichotoma is clearly definable from Genotia, and therefore describes the Australian species which follow as Genotia.

Now the type of Genotia is Murex mitriformis, Wood, which is an elongate shell with oblique suture, narrow aperture, straight columella, and wide and shallow sinus situated some distance in front of the suture. The type of Bathytoma (olim Dolichotoma) is more solid and turbinate, it has a wider and relatively shorter aperture, a very deep sinus situated near the shoulder of the whorl, its outer margin is highly arcuate, and its columella is distinctly twisted. These are differences enabling the two genera to be distinguished at sight.

M. Cossmann, ${ }^{4}$ whilst drawing attention to the fact that the Australian Tertiary species are, perhaps, examples of Bathytoma,

\footnotetext{
1 Manual of Conch. vol. vi. 1884, p. 154.

2 Manuel de Conchyl. 1883, p. 589.

3 Journ. Roy. Soc. N.S.W. vol. xxvii. 1894, p. 174.

* Ann. Géol. Universel, t. x. 189o, p. 706.
} 
states that they have not a twisted columella. As the possession of this is a typical generic factor, it may be observed that the French author's statement is not correct; and though, it is true, the figures accompanying Professor Tate's memoir ${ }^{1}$ do not exlitit a twist or plication, that author expressly states ${ }^{2}$ that the specimens have a slightly twisted columella.

Pleurotoma atractoides, Watson, dredged by the "Challenger" off the Philippines in 375 fathoms of water, should be relegated to this genus.

Type.-Murex cataphractus, Brocchi.

\section{Bathytoma angustifrons, Tate (sp.).}

1893. Dolichotoma angustifrons, Tate and Dennant, Trans. Roy. Soc. South Aust. vol. xvii. pt. 1, p. 221 (list name).

1894. Genotia angustifrons, Tate, Journ. Roy. Soc. N.S.W. p. 175, pl. x. figs. $7,7 a-b($ non $7 c)$.

Protoconch composed of two turns, somewhat oblique and slightly longitudinally striated anteriorly. The elevation or depression of these turns to a large extent determines the relative elongation in the growth of the whole shell. Where it is depressed, the whorls tend to become broad and strongly keeled; where, on the other hand, it is much elerated, the carinations are not so sharp and the shell becomes very long. It is intercsting to observe also that but few of the main features of the ornament were foreshadowed in the brephic stage, and the extremely diversified character of that ornament as the animal became adult is merely an individual characteristic, of no value for systematic purposes. If the shells of a number of rery young specimens be compared, no one would have anj difficulty in relegating them to a single species; but as they get larger the ornament tends to become so variable that many malacologists would feel inclined to admit the extreme types of variation as of specific rank. Professor Tate's description and figure refer to a commonly prevailing form.

The sinus in this species is unusually deep, though not more so than in some forms of the type species from the Pliocene of

1 Journ. Roy. Soc. X.S.W. rol. xxrii. 1894, pl. x. fig. T, ete.

2 Op. cil. p. 174 . 
the Mediterranean area. Comparing the shell with that of B. cataphracta of the Uppor Tertiary of Italy, the latter will be found to be relatively more elongate and not so rich in ornament, whilst the body-whorl is, in the majority of specimens, more tumid. The aperture of the Australian shell is somewhat narrower. But it is unquestionably a near ally of the European species mentioned; and bearing in mind the great range of variation in both shells, it would even be desirable on many grounds to unite the two species.

The living $B$. atractoides, Watson, of the Philippines is, perhaps, synonymous in its general characters, though in that case the name proposed by $\mathrm{Mr}$. Watson would take precedence. The present writer hesitates to deal with the matter, however, as only one specimen of $B$. atractoides is at his disposal, and that has a much broader, though shallower sinus than any of the fossil examples here quoted. This species may also be compared with B. viabrunnea, Dall (sp.), living in the West Indies.

Dimensions. - Length $37 \mathrm{~mm}$; breadth $16 \mathrm{~mm}$.; length of aperture $19 \mathrm{~mm}$.

Form. and Loc.-Eocene: Victoria and South Australia.

48052. Several specimens, from Hobson's Bay.

Purchased.

70422. Screral specimens, from Meribee river. Purchased.

73224. Four examples, from Brighton. Purchased.

G. 4234. Several specimens, from Muddy Creek.

Presented by John Dennant, Esq.

G. 5500 and G. 5503. Two specimens, from Muddy Creek.

Purchased.

G. 9134. One specimen, from Murray river, near Adelaide. Presented by William Evans, Esq.

G. 9330. Three examples, from Mornington. Purchased.

Bathytoma decomposita, Tate (sp.).

1893. Dolichotoma decomposita, Tate and Dennant, Trans. Roy. Soc. South Aust. vol. xrii. pt. 1, p. 221 (list name).

1894. Genotia decomposita, Tate, Journ. Roy. Soc. N.S.W. vol. xxvii. p. 175 , pl. $x$. fig. $7 e$.

Protoconch similar to that of the last-named species. The transverse ornament is not of such a rugged character as in 
B. angustifrons, but the essential points of difference are the more turbinate character of its spire, and its relatively longer aperture. The body-whorl in typical specimens is rather inflated, and the transverse fold on the columella is very conspicuous.

It is closely allied to $B$. engonia, Watson.

Dimensions. - Length $25 \mathrm{~mm}$.; breadth $13 \mathrm{~mm}$. ; length of aperture $16.5 \mathrm{~mm}$.

Form. and Loc.-Eocene: Gellibrand river, Victoria.

G. 9326. Two specimens.

Purchased.

\section{Bathytoma fontinalis, Tate (sp.).}

1893. Dolichotoma fontinalis, Tate and Dennant, Trans. Roy. Soc. South Aust. vol. xrii. pt. 1, p. 221 (list name).

1894. Genotia fontinalis, Tate, Journ. Roy. Soc. N.S.W. vol. xxvii. p. 175, pl. $x$. fig. 4.

Protoconch slightly more oblique, but is, otherwise, similar to that of the other two species mentioned. The shell may be readily distinguished by its more fusiform character; the spirewhorls carry a rough angulation, between which and the suture posteriorly is an excarated area with a number of spiral lineations. The lines of growth being rather prominent, a species of oblique reticulation is set up, and where these pass over the peripheral angulation, rudimentary compressed tubercles result. The spiral lineations of the body-whorl are prominent, and occasionally granulose. The sinus is not quite as deeply cut as in the other species mentioned; aperture pyriform, constricted posteriorly; columella erect and bearing a well-marked fold.

Dimensions.-Length $20 \mathrm{~mm}$.; brealth $18.5 \mathrm{~mm}$.; length of aperture $11 \mathrm{~mm}$.

Form. and Loc.-Eocene: Muddy Creek, Victoria.

G. 9327. Two specimens.

Purchased.

Genus COLUMBARIOM, E. ron Martens.

[Conch. Mittheil. Bd. ii. 1881, p. 105.]

Fusus, in part, of authors.

Protoconch bulbous; shell with a comparatively short bodywhorl, and long, straight, narrow, nearly closed canal, similar 
to that of the genus Fusus; margin of the shoulder slightly curved, but there is no sinus, properly so-called.

Tryon, ${ }^{1}$ although including Columbarium amongst the Plevroтомпє, remarks that he feels "pretty well satisfied" that he was correct in placing the typical species of the genus in Fusus. It may be remarked, however, that regarding Murex colus, Linn., as the type of Fusus, the type of the present genus does not, even conchologically, resemble it very closely.

The inclusion of this genus in the PLEURoromide rests almost exclusively on the character of the radula, which is distinctly tosoglossate. The passage can be understood, conchologically, if Ancistrosyrinx, Dall, be studied in that connection. If we exclude Pleurotoma cedonulli, Reeve, which, as Professor Dall shows, ${ }^{2}$ should be classed in the genus last mentioned, then the living examples of Columbarium would appear to belong exclusively to the seas of Australia and Japan.

Type.-Pleurotoma spinicincta, E. von Martens.

\section{Columbarium acanthostephes, Tate (sp.).}

1888. Fusus acanthostephes, Tate, Trans. Roy. Soc. South Aust. vol. x. p. 133 , pl. vii. fig. 7 .

1889. Fusus acanthostephes, Dennant, id. vol. xi. p. 41.

1893. Fusus acanthostephes, Tate and Dennant, id. vol. xvii. pt. 1, p. 219.

1895. Fusus acanthostephes, Tate aud Dennant, id. vol. xix. pt. 1, p. 111.

This is a rery typical example of the genus. Its protoconch (Plate III. Figs. $6 a-b$ ) is composed of two smooth turns, the earlier of which is bulbous and the later carinate medially. This carination in the brephic stage is developed to an abnormal extent, and is even spinose, as in adult individuals.

The spire is turreted; the whorls, six in number, are "excessively angulated, and coronated at the keel with large erect or radially extended, compressed, hollow spikes. Last and penultimate whorls with three rounded serrated ridges on the posterior slope, reduced to one on the middle whorls, and entirely absent on the earlier ones. Base of last whorl very contracted and precipitous, ornamented with four or five angular keels, the

I Nanual of Conchology, vol. vi. 1884, p. 175.

2 Bull. Museum Comp. Zool. Harvard, vol. sviii. 1889, p. 78. 
third from the coronal fringe serrated, the others carrying short, crowded, recurred prickles. Beak encircled with prickly ridges."-Tate. Inner margin of the aperture covered with a leaf-like expansive callosity, extending into the anterior canal, which is rery long.

This species has considerable analogy with the living $C$. pagoda var. spinicincta, Von Martens, of West Australian seas, and it is highly probable that $C$. acanthostephes is merely a synonym of that; in the absence of an example of a shell of the living species alluded to, the present writer hesitates to further deal with the matter, however.

Dimensions. - Length $38 \mathrm{~mm}$.; breadth $13 \mathrm{~mm}$.; length of aperture $7 \mathrm{~mm}$.; length of anterior canal $21 \mathrm{~mm}$.

Form. and Loc.-Eocene: Victoria.

70416. Three specimens, from Port Jackson.

Purchased.

73229. Sereral specimens, from Schnapper Point. Purchased.

G. 4274. One example, from Muddy Creek.

Presented by John Dennant, Esq.

Columbarium foliaceum, Tate (sp.).

1888. Fusus foliaceus, Tate, Trans. Roy. Soc. South Aust. vol. x. p. 132, pl. vii. fig. 10 .

1889. Fusus foliaceus, Dennant, id. vol. xi. p. 41.

1893. Fusus foliaceus, Tate and Dennant, id. vol. xvii. pt. 1, p. 219.

Protoconch of the same general character as in $C$. acanthostephes, but not so bulbous and relatively much smaller. A remarkable feature is, that in the brephic stage, and immediately after the animal emerged from the capsule, bold longitudinal ribs make their appcarance; but as the neanic stage is approached these disappear, and are not resuscitated in the adult. These costæ, which seem to be connected with longitudinal strix on the protoconch (seen when the latter is well preserred), are nodosely angulate medially. The growth of the shell from the neanic stage onwards exhibits no variation worthy of record.

The shell differs from $C$. acanthostephes in haring what Professor Tate calls the "coronal fringe" well dereloped by the absence of "prickles," and the plain character of the area from the peripheral angulation to the suture. The shell as a whole is 
not so ornate; and the protoconch differs, as already described. It is elosely allied to $C$. pagodoides, Watson, obtained by the "Challenger" expedition off Sydney in 410 fathoms of water; from which it differs in having a much smaller protoconch and a non-spinose anterior canal.

Fusus craspedotus, Tate, ${ }^{1}$ is stated by its author to belong to the same group as his F. foliaceus (= Columbarium foliaceum). Several examples of that species are in the Museum collection; and the present writer, from a careful examination of that and other material, believes that the differences in the respective protoconchs, and the general phenomena of the aperture and ornament, are sufficient to warrant generic separation. At the same time it must be remembered that as the status of this genus largely depends on the character of the radula, and as that part of the animal is not found in fossil specimens, the classification of fossil species which conchologically resemble the recent forms, must always remain doubtful.

Dimensions.-Length $45 \mathrm{~mm}$.; breadth $13.5 \mathrm{~mm}$.; length of aperture $9 \mathrm{~mm}$.; length of anterior canal $23 \mathrm{~mm}$.

Form. and Loc.-Eocene: Victoria.

73228. A series exhibiting stages of growth from the very joung to the adult, from Schnapper Point.

Purchased.

G. 4287. One specimen, from Muddy Creek.

Presented by John Dennant, Esq.

\section{Columbarium spiniferum, Tate (sp.).}

1888. Fusus spiniferus, Tate, Trans. Roy. Soc. South Aust. vol. x. p. 124, pl. vii. fig. 1.

Similar to C.acanthostephes, but with shorter spire; the posterior slope of the whorls has no spiral ornament; angular ridge spinose, the spines being irregularly developed in regard to size; in front of this, and coinciding with the posterior angle of the aperture, is a slender, crenulated, spiral carina, and minor spiral threads are developed anteriorly; aperture subquadrate, contracted in front; outer margin dentate; anterior canal long and spinose.

1 Trans. Roy. Soc. South Aust. vol. x. 1888, p. 134. 
Dimensions. - Length $30 \mathrm{~mm}$; breadth $10 \mathrm{~mm}$.; length of aperture $7 \mathrm{~mm}$.; length of anterior canal $17 \mathrm{~mm}$.

Form. and Loc.-Eocene: River MIurray cliffs, near Morgan.

G. 9334. Three specimens.

Purchased.

\section{Genus DRILLIA, Gray.}

[Ann. Nat. Hist. vol. i. 1838, p. 28.]

This differs from Pleurotoma in having longitudinal ribs; the last whorl is, typically, short; and the columella is furnished with a posterior callosity. The outer lip is thick, flexuous, and a deeply-cut sinus is situated near the suture; whilst the columella is curred and frequently umbilicate.

Type.-Drillia umbilicata, Gray.

Drillia trevori, Tenison-Woods.

1879. Drillia trevori, Tenison-Woods, Proc. Linn. Soc. N.S.W. vol. iii. p. 227, pl. $x x$. fig. 4 .

1889. Drillia trevori, Dennant, Trans. Roy. Soc. South Aust. vol. xi. p. 44.

Protoconch composed of two tumid, shining turns, the posterior portion being laterally immersed. The longitudinal costæ, which become so well developed at later stages of growth, commence in the brephic by prominent tubercles. Shell regularly and spirally grooved; suture hidden by an elevated prolongation of the posterior part of the whorls, between which and the ribs referred to is a rather broad and flat space. Aperture very small; outer margin greatly curved, sinus deep and near the suture; columella corered by a leaf-like expansion and having a tuberculose callus posteriorls; anterior canal short and somewhat twisted.

This species is said to occur both in the Eocene and Miocene beds of Muddy Creek. Mr. Tenison-Woods states (op. cit. p. 228) that it considerably resembles $D$. beraudii of the south-cast coast of Tasmania.

Dimensions. - Length $13 \mathrm{~mm}$; breadth $6 \mathrm{~mm}$.; length of aperture $5 \mathrm{~mm}$.

Form. and Loc.-Eocene: Muddy Creek, Victoria.

G. 4220. Three young and one adult specimens.

Presented by John Dennant, E'sq. 


\title{
Drillia oblongula, sp. nov.
}

\author{
[Plate III. Figs. $7 a-b$.
}

Shell small, turreted, fusiform; protoconch with two smooth subangulate turns, elosely resembling that of $D$. trevori. Whorls six in number, longitudinally obliquely costated in the brephic and neanic stages, closely spirally lineate, the lineations being irregularly granular at the points of intersection of the growthlines; typically the costated whorls are deeply sulcated spirally, and in later stages of growth a lineation is developed in each sulcus. On arrival at the adult stage this lineation becomes more conspicnous, but never attains to the same proportions as the originally-formed lineations. These latter persist over the whole body-whorl down to the tip of the anterior canal. Suture marginate and accompanied, anteriorly, by a broad band, medially sulcated, denoting the former positions of the sinus. Aperture narrow, but inflated towards the middle; outer margin arcuate, the deep, broad sinus being situated near the suture; inner margin covered by a thin coating of enamel; columella slightly twisted; anterior eanal very short.

This differs from $D$. integra, Tenison-Woods, in not being conspicuously ribbed, and by the absence of costre in the adult, though the shell is somewhat corrugated longitudinally at that stage. It differs also in not being broadly suleate abore, nor regularly spirally lirate; whilst the outer margin is not thickened to an appreciable extent. A form from the same locality has smoother whorls.

Dimensions. - Length $13.5 \mathrm{~mm}$.; breadth $5 \mathrm{~mm}$.; length of aperture $6 \mathrm{~mm}$.

Form. and Loc.-Eocene: Muddy Creek, Victoria.

G. 4219. Adult and young examples.

Presented by John Dennant, Esq.

\section{Drillia vixumbilicata, sp. nov.}

[Plate III. Figs. $8 a-b$.

Protoconch composed of two smooth elongated turns, the anterior of which is faintly spirally striated. Shell lanceolate, having seren subangulate convex whorls; the earlier of these are distinctly 
costate; the whole surface of the whorls is spirally striated, but not so conspicuously between the angulation and the suture; the latter is marginate. Aperture small and narrow; inflated towards the middle; outer margin produced, areuate; deep, broad sinus in the proximity of the suture; inner margin curred, enamelled, with a posterior callosity; umbilicus rery small; anterior canal small, almost truncate.

Dimensions. - Length $15.5 \mathrm{~mm}$; breadth $4.5 \mathrm{~mm}$.; length of aperture $5.5 \mathrm{~mm}$.

Form. and Loc.-Eocene: Muddy Creek, Victoria.

G. 4221. Au adult specimen. Presented by John Dennant, Evq.

\section{Genus MANGILIA (Leach MS.), Risso (em.).}

[Hist. Nat. Eur. Mérid. t. iv. 1826, p. 219.]

Bula (Leach MS.), Gray, Proc. Zool. Soc. 1847, p. 134.

Shell fusiform, not perforated; aperture commonly narrow, with a short truncated canal; inner margin raricose; sinus near the suture. Typically the shell is longitudinally costate. It is usual to include species with a well-marked, deep sinus; the type of the genus, howerer, has a mere currature as a sinus. In regard to Bela, see p. 60.

Type.-Mangelia costulata, Risso.

\section{Mangilia obsoleta, sp. nor.}

\section{[Pl. III, Figs. $9 a-b$.}

Shell small; protoconch composed of two smooth turns, deeply umbilicated; whorls four and a half to fire in number, spire-whorls short, subangulate not far from the suture, oblique costæ not very prominent and becoming obsolete on the anterior portion of the body-whorl; the latter is very large in proportion to the size of the shell; spiral strix not prominent, equidistant, more numerous between the peripheral subangulation and the suture. Aperture elongate; outer margin curved, slightly raricose, with an elevated docp sinus, also varicose, near the suture; columellar margin covered with a thin deposit of smooth callus; caual short.

This is by no means a trpical Mangilia; but for the absence 
of denticulations within the outer margin of the aperture and the comparatively inconspicuous longitudinal costæ, it might have been included in the subgenus Cythara.

Dimensions. - Length $10 \mathrm{~mm}$.; breadth $4.5 \mathrm{~mm}$.; length of aperture $6 \mathrm{~mm}$.

Form. and Loc.-Eocene (?): Muddy Creek, Victoria.

G. 4222. One specimen. Presented by John Dennant, Esq.

Subgenus CYTHARA, Schumacher.

[Essai Nouv. Syst. Habit. Testacés, 1817, p. 245.]

Shell elongate; longitudinally costate; aperture narrow; outer margin more or less denticulated within; columellar border striated. Typically the shell is columbelliform.

Type.-Cythara striata, Schumacher.

Mangilia (Cythara) glabra, sp. nov.

[Plate III. Figs. 10a-b.]

Shell solid, narrow, elongate; whorls four in number, obliquely costellated, the costæ being large, rounded, curved (especially near the suture), equidistant, and extending orer the suture, which is much hidden in consequence; between the ribs are several spiral lineations. Aperture narrow, widening somewhat in the middle; outer margin thick, callous, obscurely denticulated within; sinus deep, oblique, near the suture and bordered by a thick callosity; columellar border covered, the callus being thick posteriorly; columella excarated; anterior canal short and truncated.

It is closely allied to Mr. bicolor, Reere, living in the seas of Northern Australia and the Philippines, but is narrower, whilst the columella is excarated instead of being convex or sinuate. More distantly it is related also to $\boldsymbol{M}$. capillacea, Reere, of the same geographical regions.

Dimensions. - Length $11.5 \mathrm{~mm}$.; breadth $5 \mathrm{~mm}$.; length of aperture $6 \mathrm{~mm}$.

Form. and Loc.-Miocene (?): Muddy Creek, Victoria.

G. 4201. Slightly rolled specimens.

Presented by John Dennant, Esq. 


\section{Genus CLATHURELLA, Carpenter.}

[Mazatlan Cat. 1857, p. 399.]

Differs principally from MIangilia in its whorls being more rounded and cancellate; sinus varicose and sutural; inner margin of the aperture denticulate posteriorly. It is closely allied to that genus, however.

Type.-Pleurotoma purpurea, Montagu.

\section{Clathurella bidens, Tenison-Woods (sp.).}

1879. Mangelia bidens, Tenison-Woods, Proc. Linn. Soc. N.S.W. vol. iii. p. 227 , pl. xx. fig. 2 .

1895. Mangilia bidens, Tate and Dennant, Trans. Roy. Soc. South Aust. vol. xix. pt. 1, p. 111.

Protoconch composed of two smooth, angulate, elevated turns. Shell fusiform, tumid; whorls six in number, obliquely costate and distinctly lirate; between the subangular periphery and the deeply-cut suture the liræ are smaller and more numerous. Aperture rather broad; outer margin raricose, produced, and thin at the edge, dentate within; sinus large, broad, and situated near the suture; inner margin curved, with a callous dentiele posteriorly; columella slightly twisted; canal broad and short.

Dimensions. - Length $15 \mathrm{~mm}$; ; breadth $7 \mathrm{~mm}$; ; length of aperture $8 \mathrm{~mm}$.

Form. and Loc.-Eocene: Muddy Creek, Victoria.

G. 4202. Four examples. Presented by John Dennant, Esq.

\section{Clathurella obdita, sp. nor.}

[Plate III. Figs. 11 $a-b$. .]

Shell fusiform, elongate, solid; protoconch composed of one and a half smooth, conrex turns terminating abruptly against the shell proper, which, even in the brephic stage, is distinetly angulate, and possesses the general characteristics of the ornamentation of the adult. Whorls fire in number, spirally lirate throughout, the liræe being larger and farther apart in front of the peripheral subangulation. The growth-lines develop into equidistant, oblique, incouspicuous costr, best seen in the early stages of growth; and 
where they cross the larger spiral lirr, and especially at the periphery, teeth-like tubercles result. Aperture narrow; outer margin thick, dentate within, raricose, produced, the anterior portion bent and partly encircling the short canal; sinus sutural, very conspicuous, deep and bordered by the posterior extension of the outer margin, which covers the suture in that region, and is reflected towards the thin enamel of the inner margin; a prominent denticle is placed on the latter near the sinus; columella somewhat excarated, sharply twisted anteriorly.

This species differs from $M$. bidens in being more elongate, the spire is much longer in proportion to the aperture, is narrower, the columella is more sharply twisted; the longitudinal costæ are not so conspicuous, the subangulation at the periphery is more towards the centre of the whorls, and the surface of the shell between that and the suture is more sloping. The shell as a whole is not so rugged.

Dimensions.-Length $9 \mathrm{~mm}$.; breadth $4 \mathrm{~mm}$.; length of aperture $4.5 \mathrm{~mm}$.

Form. and Loc.-Eocene (?): Muddy Creek, Victoria.

G. 4204. Two specimens. Presented by John Dennant, Esq.

\section{Genus DAPHNELLA, Hinds.}

[In Belcher, Voy. "Sulphur," Mollusca, vol. ii. 1844, p. 25.]

Shell thin, fusiform; whorls convex; body-whorl usually elongate, surface finely cancellated; outer margin slightly curved, broad shallow sinus near the suture; columella excarated; canal short, truncate.

None of the species here described are typical examples of the genus; they appear to be intermediate between Daphnella (sensu stricto) and its subgenus Pleurotomella, Verrill. They are not included in the latter, by reason of the sinus not being deep enough, and from the absence of the "smooth concave surface" between the shoulder of the whorls and the suture. By some authors they would possibly be classified with Bela; that genus, however, appears to be much misunderstood. It does not seem to be recognized that the type of Bela (Leach MS.), Gray, ${ }^{1}$ is Murex

1 Proc. Zool. Soc. 1847, p. 134. 
nebula, Montagu, which is practically synonymous with Mangelia costulata, Risso, the type of the genus Mangilia (em.). None of the Australian Tertiary forms now figured and described bear the slightest resemblance to "Murex nebula," which Tryon" classifics with Raphitoma, Bellardi, a subgenus of Daphnella.

Type.-Pleurotoma lymnaiformis, Kiener.

\section{Daphnella sculptilis, Tate (sp.).}

[Plate IV. Figs, $1 a-b$.]

1888. Bela sculptilis, Tate, Trans. Roy. Soc. South Aust. vol. x. p. 173, pl. iv. fig. 1.

1859. Bela sculptilis, Dennant, $i d$. vol, xi. p. 45 (list name).

Protoconch composed of one and a half smooth, depressed, obtuse turns, the earlier portion of which is laterally disposed, and the later longitudinally striated. Whorls tumid, six in number, subangulate at the periphery and somewhat excavated between that and the suture. The latter is canaliculate and margined. Surface covered by closely-set spiral lineations, remarkably regular from the brephic stage onwards, and crossed by conspicuous growthlines, which occasionally produce minute granulations at their points of intersection, but are for the most part more clearly defined in the sulci between the lineations referred to. Aperture nearly one-half the length of the shell, narrow, obliquely terminated posteriorly and curred anteriorly where a short broad canal exists; outer margin thin, moderately curred, sinus broad but shallow, and occupying the whole of the sutural depression; inner margin corered by a rery thin deposit of enamel, best dereloped anteriorly; columella twisted.

This species, although figured, has not, apparently, been previously described.

Dimensions. - Length $47 \mathrm{~mm}$.; breadth $18 \mathrm{~mm}$.; length of aperture $21 \mathrm{~mm}$.

Form. and Loc.-Eocene: Muddly Creek, Victoria.

G. 4194. Thrce specimens. Presented by John Dennant, Esq.

1 Manual of Conchology, vol. ri. 1881, p. 307. 


\section{Daphnella crassilirata, Tate (sp.).}

[Plate 1V. Figs. 2a-b.]

18s8. Bela crassitivata, Tate, Trans. Roy. Soc. South Aust. vol. x. p. 173, pl. iv, fig. 7.

1889. Bela crassilirata, Dennant, id. vol. xi. p. 45 (list name).

Protoconch similar to that of $D$. sculptilis, but somewhat eanaliculate, and the anterior portion is more strongly striated spirally. Shell tumid; whorls five to six in number, angulate at the periphery, between which and the suture is a deep depression; suture canaliculate and marginate; surface of the whorls uniformly and deeply sulcated spirally, and crossed by regular growth-lines which produce a cancellation especially well dereloped in the neighbourhood of the suture. Aperture rather broad, pyriform, obtuse posteriorly; outer margin rery thin, sinus broad, but shallow between the suture and the periphery; inner margin corered by thin deposit of callus, through which the spiral sulcations are visible posteriorly; columella excavated, twisted anteriorly.

This species, though figured, does not appear to have been hitherto described. It differs essentially from $D$. sculptitis in being shorter, having the peripheral angulation placed nearer the suture, in being much more deeply excarated between; the surface of the shell is more deeply sulcated, and the aperture is wider.

Dimensions.-Length $25 \mathrm{~mm}$; breadth $11.5 \mathrm{~mm}$; length of aperture $13.5 \mathrm{~mm}$.

Form. and Loc.-Eocene: Muddy Creek, Victoria.

G. 4193. Two specimens. Presented by John Dennant, Esq.

G. 5496. One example.

Purchased.

\section{Daphnella pulchra, Tate (sp.).}

1888. Bela pulchra, Tate, Trans. Roy. Soc. South Aust. vol. x. p. 173, pl. iv. fig. 2.

1889. Bela pulchra, Dennant, in. vol. xi. p. 45 (list name).

Protoconch composed of one and a half smooth, polished turns, turbinate, depressed, and canaliculate. Shell as a whole short and 
tumid; whorls fire in number, conrex; suture slightly canaliculate and bordered by a shallow excaration. Surface corered by spiral striæ, the penultimate whorl carrying six prominent striations, between each of which are three or four minor ones. Growth-lines regular, producing a species of cancellation, the points of interseetion of the larger with the revolring strix being crowned by a small tubercle. These growth-lines, also, are of two orders, three or four minor ones being situated between the more prominent of them. Aperture broad, rounded posteriorly and truncated anteriorly; outer margin thin, curved, the sinus being marked by a mere sinuosity in the neighbourhood of the suture; columella excarated.

This species does not appear to have been described before, though figured by Professor Tate, as abore indicated. It may be readily distinguished from the two species of Daphnella already deseribed, by the granulated aspect of the whorls, as seen under a lens, by the comparatirely shallow excavation bordering the suture, and by the special character of the sinus.

Dimensions. - Length $18 \mathrm{~mm}$; breadth $9 \mathrm{~mm}$.; length of aperture $9 \mathrm{~mm}$.

Form. and Loc.--Eocene: Muddy Creek, Victoria.

G. 4157. Two examples. Presented by John Dennant, Esq.

\section{Daphnella striata, Hutton.}

1873. Bela striata, Hutton, Cat. Tert. Moll. N.Z. p. 5.

1893. Daphnella striata, Hutton, Linn. Soc. N.S.W., Macleay Mem. Vol. p. 52 , pl. vii. fig. 33 .

Shell cominelliform, body-whorl longer than the spire; whorls convex, six in number, finely spirally striated; aperture oratoelongate, wide anteriorly; outer margin sinuous, but there is no sinus properly so-called, reflected; columellar margin corered by a leaf-like expansion of smooth shell enamel, which is continuous with the outer margin, near the suture is a small callosity; columella twisted; canal short, recurved.

Dimensions. - Length $20 \mathrm{~mm}$.; breadth $9 \mathrm{~mm}$.; length of aperture $10 \mathrm{~mm}$.

Form. and Loc.-Pliocenc: Shakespeare Cliff, Wanganui, New Zealand.

G. 9509. Two specimens.

Sir James Hector Coll. 
TELEOCHILUS, ${ }^{1}$ nor. gen.

Protoconch (Plate III. Figs. 12c-d) large, from one to one and a half depressed turns, spirally and longitudinally striated from the initial portion onwards, the spiral striæ developing into welldefined sulcations as the shell passes from the brephic to the neanic stages of growth. Shell as a whole elongate, the aperture being much longer relatively than the spire; whorls slightly convex and spirally sulcated throughout, lines of growth well marked; suture typically canaliculate; aperture with thin, erect, outer margin, constricted posteriorly, and broad towards the anterior; columella plain, with a thin deposit of callus through which the sulci appear.

It is difficult to satisfactorily classify this genus. By its general' configuration it has considerable analogy with Daphnella; but may be easily differentiated by the unique characteristics of the protoconch, and the absence of a posterior sinus. The lastmentioned circumstance might be taken adrantage of to remove Teleochilus from the Pledrotomide, did we not know that the possession of a sinus is not an absolutely necessary qualification for inclusion in that family.

In some respects Teleochilus recalls certain forms of Mitra, but it has no columellar plications, nor eren the semblance of a fold; whilst its protoconch is distinctive. At the same time, it approaches the genus Dibaplus, Philippi, which, although deprived of folds on the pillar, is classified with the Mrтride, chiefly on anatomical grounds. Dibaphus differs only from Mitroidea, Pease, by the absence of plaits. The soft parts of the animal were first described by Mr. A. Garrett, ${ }^{2}$ who was unable to detect any difference between them and those of Cylindra, Schumacher. Unfortunately, it is not possible to ascertain the relationships of Teleochilus in the same manner, as its soft parts are denied to us; on conchological considerations alone it is included in Pledrotomide, and may be assigned a position in the neighbourhood of Daphnella.

Type.-Daphnella gracillima, Tenison-Woods.

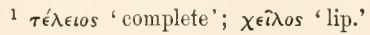

2 Proc. Zool. Soc. 1872, p. 843 . 
Teleochilus gracillimum, Tenisou-Toods (sp.).

1876. Daphnella graeillima, Tenison-Woods, Pap. Roy. Soc. Tas. 1876, p. 106.

1879. Daphnella graeillima, Tenison-Woods, Proc. Linn. Soc. N.S.W. rol. iii. p. 226 , pl. xx. fig. 10 .

Mr. Tenison-Wood's description of this species is as follows: "Shell fusiform, thin, fragile, shining, whorls six, gracefully sloping, last longer than the spire, finely striate lengthwise with irregular ridges of growth which become fine, elose, and rounded at the lip; regularly and somewhat distantly groored with rather broad, flat, shallow, conspicuously striate grooves, one of which is much broader just below the suture, which is distinctly canaliculate; apex obtuse and Natica-like; mouth narrow, finely rounded at the suture; outer lip thin; eanal short, base of the pillar finely and obliquely decussate behind."

The general characteristics of the protoconch have been alluded to in the generic description. The figure of the species giren by its author is a representation of a much worn specimen; it is deemed adrisable, therefore, to refigure it (Plate III. Figs. 12a-d).

Dimensions. - Length $25 \mathrm{~mm}$.; breadth $10 \mathrm{~mm}$.; length of aperture $16 \mathrm{~mm}$.

Form. and Loc.-Eocene: Muddy Creek, Tictoria.

G. 4161. Four examples, shell of the adult.

Presented by John Dennant, Esq.

G. 4162. Two examples, exhibiting the neanic stage of growth. Presented by John Dennant, Esq.

\section{Family CANCELLARIID王.}

Genus CANCELLARIA, Lamarck.

[Mém. Soc. Hist. Nat. Paris, 1799, p. 71.]

Shell oral, fusiform; aperture slightly caualiculated; columella strongly plicated; onter margin not reflected, creuulated.

Type._Voluta reticulata, Linnæus. 


\section{Cancellaria wannonensis, Tate.}

1889. Cancellaria wannonensis, Tate, Trans. Roy. Soc. South Aust. vol. xi. p. 156 , pl. viii. fig. 11 .

Shell solid, ventricose; protoconch elerated, more vigorously developed in some individuals than others, typically composed of two and a half turns, but occasionally two and sometimes three turns, faintly longitudinally ridged anteriorly; whorls strongly ribbed and spirally lirate; aperture wide, outer border arcuate, inner border callous, especially in the adult stage; columella imperforate, having three prominent plications, the posterior of which is the largest, frequently with a smaller ridge between the central and the posterior plications, and some rugosities on the flat portion of the callus in the umbilical region.

It has considerable affinities with the living $C$. semperiana, Crosse, from New Caledonia, but the aperture of the latter is much more dilated, the longitudinal costæ are bolder, and the shell as a whole not so solid.

Dimensions. - Length $32 \mathrm{~mm}$.; breadth $21 \mathrm{~mm}$; length of aperture $21 \mathrm{~mm}$.

Form. and Loc.-Miocene: Muddy Creek, Victoria.

G. 4259. A senile example. Presented by John Dennant, Esq.

G. 5524. One specimen. Purchased.

G. 93\%4. A series exhibiting stages of growth. Purchased.

\section{Cancellaria gradata, Tate.}

1889. Cancellaria gradata, Tate, Trans. Roy. Soc. South Aust. vol. xi. p. $155, \mathrm{pl}$. $\mathrm{x}, \mathrm{fig} .12$.

1889. Bivetia gradata, Cossmann, Ann. Géol. Univ. t. v. p. 1091.

This species is very different to any other Cancellaria from Australasia in the British Museum. The shell is thin, cancellate, sharply carinate, with a broad spiral platform at the suture; the spire in consequence is staged; the protoconch is composed of one and a half turns, the early portion of which is implanted obliquely and is somewhat inflated, the remainder being decidedly convex with deeply-cut suture; aperture quadrately oval, outer border crenulated, lirate within; columella slightly callous, furnished with three prominent plications. 
This is by no means a typical Cancellaria. MI. Cossmann remarks (op. cit. supra) that it should be classified with Biretia; but the type of that subgenus has a posterior canal, varices, and other characteristics absent in $C$. gradata. For the present it may remain with Cancellaria proper, the present writer having no inclination to increase the number of subgenera with which this group is burdened.

Dimensions. - Length $12 \mathrm{~mm}$. ; brealth $6.5 \mathrm{~mm}$.; length of aperture $6 \mathrm{~mm}$.

Form. and Loc.-Eocene: Muddly Creek, Victoria.

G. 4262. One specimen. Presented by John Dennant, Esq.

G. 9372. An adult example with well-preserred protoconch.

Purchased.

\section{Cancellaria, sp.}

G. 5580. Two imperfect, rolled specimens; from the postPliocene beds of Limestone Creek, Glenelg river, Victoria.

Purchased.

Subgenus NARONA, H. and A. Adams.

[Genera Recent Moll. vol. i. 1854, p. 277.]

Shell not umbilicated, oblong, costulated, or cancellated; whorls depressed near the suture; columellar border with two oblique plications.

Type-Cancellaria clavatula, Sowerby.

\section{Cancellaria (Narona) capillata, Tate.}

1589. Cancellavia capillata, Tate, Trans. Roy. Soc. South Aust. rol. xi. p. 158 , pl. x. fig. 10.

1889. Narona capillata, Cossmann, Ann. Géol. Univ. t. v. p. 1091.

1893. Cancellaria capillate, Tate and Dennant, Trans. Roy. Soc. South Aust. rol. xvii. pt. 1, p. 221.

Shell small, solid; protoconch smooth, except anteriorly, where it is longitudinally costated, composed of one and a half convex turns, the earlicr portion being somewhat oblique with reference to the axis of the shell; whorls convex, lirate, and sleuderly 
costated; the spiral liræ produce small nodose crenulations on the costr. The external ornament is much interrupted by inflated variciform ridges on several individuals in the Museum. Aperture oblong, outer border lirate within; columella with two small trausverse plications; umbilicus partly covered over by the columellar border.

Dimensions. - Length $5 \mathrm{~mm}$.; breadth $2.75 \mathrm{~mm}$.; length of aperture $2.5 \mathrm{~mm}$.

Form. and Loc.-Eocene: Muddy Creek, Victoria.

G. 9369. Four adult examples.

Purchased.

\section{Cancellaria (Narona) etheridgei, Johnston.}

1880. Cancellaria etheridgei, Johnston, Proe. Roy. Soc. Tas. 1879, p. 32.

1889. Cancellaria etheridgei, Tate, Trans. Roy. Soc. South Aust. vol. xi. p. 157 , pl. ix. fig. 6 .

1889. Narona etheridgei, Cossmann, Ann. Géol. Univ. t. v. p. 1091.

1893. Cancellaria etheridgei, Tate and Dennant, 'Trans. Roy. Soc. South Aust. vol. x vii. pt. 1, p. 221.

This species is closely allied to $C$. capillata, but the longitudinal costæ are relatively larger and oblique; columella with two plications situated posteriorly. The specimen in the Museum is not sufficiently well preserved to enable the protoconch, or minute ornament, to be described. The general character of the embryonic shell was, evidently, similar to the last-mentioned species, however.

Dimensions.-Length $5 \mathrm{~mm}$.; breadth $3 \mathrm{~mm}$. ; length of aperture $2 \cdot 5 \mathrm{~mm}$.

Form. and Loc._Eocene: Spring Creek, Victoria.

G. 9373. Two worn specimens.

Purchased.

\section{Subgenus ADMETULA, Cossmann.}

[Ann. Soc. Roy. Malac. Belg. t. xxiv. 1888, p. 224.]

This subgenus differs from Admete, Möller, in the possession of varices and by the thickuess of the test.

Type.-Buccinum evulsum, Solander. 


\section{Cancellaria (Admetula) varicifera, Ten.- Toods.}

1879. Cancellaria varicifera, Ten.-Woods, Proc. Linn. Soc. X.S. W. rol. iii. p. 231, pl. xxi. fig. 12 .

1889. Cancellaria varicifern, Tate, Trans. Roy. Soc. South Aust. vol. xi. p. 155.

1893. Cancellaria varicifera, Tate and Dennant, Trans. Roy. Soc. South Aust. vol. xvii. pt. 1, p. 221.

Professor Tate remarks that this is the antipodean analogue of C. evulsa, Solander, from Barton, and that it differs "only by its much finer ornament, and by the liræ within the outer lip." No doubt there is a close resemblance between the two species, but a study of the protoconch is sufficient to separate them immediately. The Australian shell commences with a relatively large protoconch, the earlier portion of which is obtuse and even slightly inflated, and is composed of only one and a half turns; the Bartonian shell, on the other hand, has a somewhat pyramidal protoconch composed of from two and a half to three turns, the earlier portion is not oblique, and the whole is regularly coiled. There must be some error respecting the liræ alluded to: both the Australian and European shells possess these within the outer lip, t5pical examples of $C$. exulsa from Barton haring them especially prominent opposite the varices. The Australian shell is thinner.

Dimensions. - Length $14 \mathrm{~mm}$.; breadth $8 \mathrm{~mm}$.; length of aperture $5.5 \mathrm{~mm}$.

Form. and Loc.-Eocene: Victoria.

48052. Specimens much more tumid than the type; this has considerable analogy with $C$. evulsa; from Schnapper Point.

Purchased.

G. 4260. An elongate specimen; from Muddy Creek.

Presented by John Dennant, Esq.

G. 9371. A series exhibiting stages of growth.

Purchused.

\section{Subgenus SVELTIA, Jousseaume.}

[Le Naturaliste, t. i. sér. 2, 1887, p. 214.]

Shell not umbilicated, long, turriculated; suture deep; aperture ovate; posterior canal hardly perceptible; anterior canal large and cutting into the peristome; columella with two uncqual, rather salient plications.

Type.-Cancellaria varicosa, Brocchi. 


\section{Cancellaria (Sveltia) epidromiformis, Tate.}

1889. Cancellaria epidromiformis, Tate, Trans. Roy. Soc. South Aust. vol. xi. p. 154 , pl. viii. fig. 9 .

1889. Stcltia epidromiformis, Cossmann, Ann. Géol. Univ. t. v. p. 1091.

Shell long, thick with sub-turreted spire; protoconch obtuse, composed of one and a half turns, the earlier portion being planted obliquely with reference to the axis of the shell, smooth, except anteriorly, where frequent, microseopie, Iongitudinal lineations appear; whorls deeply excavated at the suture, where an inwardsloping spiral platform occurs; spirally and longitudinally ribbed, granulated at the points of intersection, the former being the more prominent; interrupted here and there by varices; aperture relatively small, ovate; outer border plieate within; eolumella imperforate, with three plieations; anterior eanal truneate.

This is a typical example of the subgenus Sveltia, except that it has three columellar plications instead of two. In the young these are even more marked than in the adult.

Dimensions. - Length $20 \mathrm{~mm}$.; breadth $10 \mathrm{~mm}$.; length of aperture $9 \mathrm{~mm}$.

Form. and Loc.-Eocene: Muddy Creek, Victoria.

G. 4260. An adult example. Presented by John Dennant, Esq.

G. 9370. Two specimens, one of which is a well-preserved example of the neanie stage of growth.

Purchased.

\section{Family OLIVID王.}

Genus OLIVELLA, Swainson.

[Malacology, 1840, p. 34.]

Olivina, D’Orbigny, Voy. Amérique Méridionale, t. v. 1841, p. 417 (non Mörch).

A comparison of the soft parts of Olivella and Oliva exhibits many features of interest, fully sustaining the generic separation of the two. The head of Oliva, for instance, is furnished with slender tentacles and eyes, the median tooth of its radula is 
tricuspidate; on the other hand, a typical Olirella has neitler tentacles nor eyes, and the median tooth of the radula carries a great number of small denticles, in addition to which the radula has accessory lateral plates. In spite of these important anatomical differences, the shells of certain species of both genera closely resemble each other, and it is, therefore, almost impossible to classify them with any degree of accuracy from an examination of the test alone. Fortunately, howerer, the more extreme forms of the shells are not difficult to determine generically, and the Australasian Tcrtiary fossils about to be described are allocated to the genus Olivella without much doubt.

In general, the shells may externally be distinguished from those of Oliva by the columella not being plicate (or lirate) throughout its entire length, whilst the columellar border is more obliquely inclined with reference to the axis, aud is sometimes slightly excarated (as in $O$. nymphalis, Tate); the spire is more elerated, though this last character is by no means constant.

Type.-Oliva biplicata, G. B. Sowerby.

\section{Olivella angustata, Tate (sp.).}

1859. Oliva angustata, Tate, Trans. Roy. Soc. South Aust. vol. xi. p. 144, pl. viii. figs. $\tau a-b$.

1859. Olive angustata, Dennant, id. vol. xi. p. 43.

The spire in this species is long, in adult specimens being more than one-third the cntire length of the shell; suture deep; aperture narrow, wider where the columella is slightly excarated; plications rariable in number, situated on the anterior half of the columellar border only.

Compared with 0 . nitidula, Desh., of the Parisiau Eocene, it is found to be longer, its aperture is narrower and straighter, and its columella is less excarated; in other respects it presents considerable analogy with the shell of that species.

Dimensions. - Length $26 \mathrm{~mm}$.; breadth $8.5 \mathrm{~mm}$.; length of aperture $15.5 \mathrm{~mm}$.
Form, and Loc.-Eocene: MLuddy Creek, Victoria.
G. 4170. Three specimens. Presented by John Dennant, E*q.
G. 9367. Examples showiug stuges of growth. Purchased. 


\section{Olivella nymphalis, Tate (sp.).}

1889. Oliva nymphalis, Tate, Trans. Roy. Soc. South Aust. vol. xi. p. 145, pl. vii. fig. 7 .

1859. Oliva nymphalis, Dennant, id. vol. xi. p. 43.

1889. Olivella nymphalis, Cossmann, Ann. Géol. Univ. t. v. p. 1090.

This is a more stunted form than $O$. angustata, whilst the plications are only two or three in number, being confined to the anterior portion of the columella. The whorls have a tendency to become invaginate, and the spiral sulcation near the middle of the body-whorl is prominent.

A close European ally is 0 . mitreola, Lamarck, a more elongate shell, from the Eocene of the Cotentin and Paris Basin.

Dimensions. - Length $8.5 \mathrm{~mm}$. ; breadth $4 \mathrm{~mm}$. ; length of aperture $4 \mathrm{~mm}$.

Form. and Loc.-Miocene: Muddy Creek, Victoria.

G. 9368. Two specimens.

Purchased.

\section{Olivella, sp.}

G. 9511-2. Two pieces of argillaceous limestone containing casts of several shells, including a species of Otivella closely allied to O. angustata; from the Lower Miocene (Mangapakeha beds) of Akuakua, east coast of Auckland, N.Z. Sir James Hector Coll.

\section{Genus ANCILLA, Lamarck.}

[Mém. Soc. Hist. Nat. Paris, 1799, p. 70; also Syst. des Anim. sans Vert. 1801, p. 73.]

Ancillaria, Lamarck, Ann. Mus. 1810, t. xvi. p. 302.

Sparella, Gray, Guide Moll. Brit. Mus. pt. 1, 1857, p. 26.

Shell oblong, occasionally acuminate; suture sometimes canaliculate, but more frequently covered over by callus; columella excavated, twisted, and carrying several plications anteriorly, which are not hidden by callous growth, whereas the posterior portion of the columella is thick, callous, or gibbose. A depression, or groove, usually separates the callosity of the spire from what is commonly termed the "smooth zone," though this zone is often not as smooth as the callous spire, especially when strongly exhibiting the lines of growth as in certain fossil species. The 
relative size of this zone is of specific value taken in conjunction with cognate characters; aperture groored posteriorly, and truncate and deeply sinuous in front.

Ancilla may be distinguished from Olivancillaria, with which it is frequently confounded, in that the latter, sensu stricto, has the columella callous throughout its entire length, the spire is usually much more acuminate, and the sutures are deeply canaliculate. The columella of the section Agaronia, however, is not callous, except to a feeble extent posteriorly. Ancilla is readily distinguished from that subgenus, as the latter has such welldereloped sutures, and the comparative absence of callosity on the spire and body-whorl is well marked.

The subgenus Sparella, almost universally adopted by modern anthors, must disappear in synonymy, for the following reasons:The type of Ancilla is A. cimnamomea, Lamarck, and the type of Sparella is A. albisulcata, Sby.; but these two species are synonymous with each other, the only distinguishing feature between them being that the impressed groove of the latter is white-a charicter without constancy. It is generally stated that a more or less prominent denticle on the outer margin of the apcrture characterizes Sparella, but that is found also in the type species of Ancilla; the spread of the callosity orer the spire is usually regarded as a special feature, but what value that may possess from a morphological point of view does not in any way affect the synonymity of the type species mentioned.

Type.-Ancilla cinnamomea, Lamarck.

\section{Ancilla pseudaustralis, Tate (sp.).}

1859. Ancillaria pseudaustralis, Tate, Trans. Roy. Soc. South Aust. vol. xi. p. 148, pl. vi. fig. 13 ; pl. vii. fig. 1.

1893. Aneillavia pseudaustralis, Tate and Dennant, id. vol. svii. pt. 1, p. 220 .

This is the largest Australian Ancilla in the Museum. Professor 'Tate compares it with the European Eocene A. buccinoides, Lamk., but it differs markedly from the latter: the broad band trespassing anteriorly on the smooth zone of the body-whorl, terminating at the inner margin of the aperture by a pronounced denticle forming a slight posterior prolougation of the band, or of the groore which borders it posteriorly, at once distinguishes this species from 
A. buccinoides. The granulations on the callus, the manner in which a portion of the latter is spread over the whorls of the spire from the columellar border nearly to the protoconch, and the relatively smaller size of the twisted anterior of the columella, are also distinctive features.

Dimensions. - Length $46 \mathrm{~mm}$.; breadth $20 \mathrm{~mm}$; length of aperture $26.5 \mathrm{~mm}$.

Form. and Loc.-Eocene: Muddy Creek, Victoria.

G. 419\%. Two adult specimens. Presented by John Dennant, Esq.

G. 5507. Two younger examples. Purchased.

G. 9331. A series exhibiting stages of growth. Purchased.

\section{Ancilla semilævis, Tenison-Woods (sp.).}

1879. Ancillaria semilavis, T. Woods, Proc. Linn. Soe. N.S.IV. rol. iii. p. 229 , pl. xx. fig. 7 .

1889. Ancillaria semilavis, Tate, Trans. Roy. Soc. Sonth Aust. vol. xi. p. 148.

1893. Ancillaria semilcevis, Tate and Dennant, $i d$. vol. xvii. pt. 1, p. 220.

This shell has an acuminate spire, the callus is not strongly developed, and the sutures are bordered by a slight angulation producing a spiral ridge on the surface. The smooth zone is rather narrow, and the spiral band and denticle are well pronounced. It presents some analogy with $A$, arenaria, Cossmann, from the Eocene of the Paris basin; the latter, however, is a smaller species, whilst the aperture of the shell is not so large relatively, and its columella is not excavated so deeply.

Dimensions. - Length $18 \mathrm{~mm}$; breadth $7.5 \mathrm{~mm}$.; length of aperture $9 \mathrm{~mm}$.

Form. and Loc.-Eocene: Muddy Creek, Victoria.

G. 4224. Three specimens. Presented by John Dennant, Esq.

G. 9333. Several examples showing stages of growth. Purchased.

\section{Ancilla lanceolata, Tate (sp.).}

1889. Ancillaria lanceolata, Tate, Trans. Roy. Soc. South Aust. vol. xi. p. 147 , pl. vii. fig. 2 .

The callus of this species presents some analogy with that of $A$. hebera, but the spire is contracted slightly at the apex; the shell is not so eylindrical, and is much more elongated. None of the specimens in the Museum exhibit the denticle; its existence, 
however, may be inferred from the feeble groore running round the anterior portion of the body-whorl. The columella is excavated, and for the size of the slell its plicated anterior extremity is not very large. Professor Tate remarks that this species is intermediate in character between $A$. hebera and Apseudaustralis.

Dimensions. - Length $32 \mathrm{~mm}$. ; breadth $10 \mathrm{~mm}$.; length of aperture $17.5 \mathrm{~mm}$.

Form. and Loc.-Eocene: Muddy Creek, Victoria.

G. 4199. An example of the senile stage of growth.

Presented by Jolnn Dennant, Esq.

G. 5509. One specimen, with columella abnormally excavated.

Purchased.

G. 9332. Tro forms in which the spire is very callous.

Purchased.

Ancilla papillata, Tate (sp.).

1889. Ancillaria papillata, Tate, Trans. Roy. Soc. South Aust. vol. xi. p. 146, pl. vii. fig. 4 .

This may be readily distinguished from all other Australian Tertiary Ancilla by the peculiar aspect of the callous growth around the spire, which is sculptured with narrow, sharply rounded, spiral ridges of unequal size, the larger with two or three smaller ones interposed. The spiral band, though deep, is very narrow, and terminates with a sulcated denticle. The shell is almost eylindrical.

Dimensions.—Length $29 \mathrm{~mm}$; breadth $12.5 \mathrm{~mm}$; length of aperture $17 \mathrm{~mm}$.

Form. and Loc.-Miocene: Miuddy Creek, Victoria.

G. 4194. Two specimens. Presented by John Dennant, Esq.

G. 5508. Two adult examples. Purchased.

G. 9324. A series exhibiting stages of growth. Purchased.

\section{Ancilla ligata, Tate (sp.).}

1889. Ancillaria ligata, Tate, Trans. Roy. Soc. South Aust. rol. xi. p. 147, pl. rii. fig. 6 .

This small shell resembles $A$. semilavis, but it has a more obtuse apex, and is strongly angulate at the suture; callus comparatirely thin, deuticle not prominent. 
Dimensions.-Length $17 \mathrm{~mm}$.; breadth nearly $6 \mathrm{~mm}$.; length of aperture $8 \mathrm{~mm}$.

Form. and Loc.-Eocene: Aldinga, South Australia.

G. 9325. A series exhibiting stages of growth. Purchased.

\section{Ancilla hebera, Hutton (sp.).}

1573. Ancillaria hebera, IIutton, Cat. Tert. MIoll. N.Z. p. 6.

1880. Ancillaria mucronata, Johnston, Geol. Tasmania, pl. xxxi. fig. 12 (non Sowerby).

1889. Ancillaria hebera, Tate, Trans. Roy. Soc. Sonth Aust. vol. xi. p. 147, pl. vii. fig. 5 .

Although differing in several important particulars, this species is not unlike $A$. papillata. It lacks the solidity of the latter, however, whilst the spire is not sculptured in the same manner, the shell is not so cylindrical in shape, and the aperture is wider and proportionately larger. Professor Tate compares it with A. olivula, Lamarck, of the Paris basin, which it closely resembles, though, as he remarks, the callosity is larger, more gibbous and granulated in the Australasian fossil. The twisted anterior portion of the columella is relatively much smaller than in the European form.

Dimensions. - Length $38 \mathrm{~mm}$.; breadth $13.5 \mathrm{~mm}$.; length of aperture $22 \mathrm{~mm}$.

Form. and Loc.-Eocene: Tasmania and Victoria.

83979. A tumid example, from Table Cape.

Purchased.

G. 4198. An elongate form, from Muddy Creek.

Presented by John Dennant, Esq.

G. 9376. Sereral examples, showing stages of growth; from River Murray cliffs.

Purchased.

\section{Ancilla australis, G. B. Sby. (sp.).}

1830. Ancillaria australis, G. B. Sowerby, Spec. Conchyl. p. 7, figs. 44-6.

1S34. Aneilleria albisuleata, Quoy and Gaimard, Voy. de l'Astrolabe, Zool.

t. iii. p. 19, pl. xlix. figs. 5-12 (non Sowerby).

1834. Aneillaria australis, Quoy and Gaimard, id. p. 20, pl. xlix. figs. 13-17.

18t4. Ancillaria austratis, Deshayes, in Lamarck, Hist. Nat. Anim. sans Yert. éd. 2, t. x. p. 592. 
1850. Ancillaria albisulcata, Gray, Fig. Moll. vol. iv. p. 4, pl. xix. figs. 1-3 (non Sowerby).

1850. Ancillaria australis, Gray, id. rol. iv. p. 4, pl. xix. fig. 5.

1859. Ancilluria australis, Sowerby, Thes. Conch. vol. iii. p. 63, pl. cexi. figs. $1,2$.

1864. Ancillaria australis, Reeve, Conch. Icon. rol. xv. pl. iii. figs. $7 a-b$.

1873. Ancillaria australis, Vou Martens, Crit. List. Moll. N.Z. p. 23.

1873. Ancillaria (Anaulax) australis, IIutton, Cat. Marine MIoll. N.Z. p. 17.

1873. Ancillaria australis, Hutton, Cat. Tert. Moll. N.Z. p. 6.

1880. Ancillaria australis, IIutton, Man. N.Z. Moll. p. 58.

1893. Ancillaria australis, Hutton, Linn. Soc. N.S.W., Macleay Mem. Vol. p. 44.

The rariable proportion of the callus on the spire, even in specimens from the same locality, causes this shell to assume a variety of forms. Sometimes it renders it mucronate, the eallus being finely granular and extending over the posterior half of the columella, in which case it is impossible to observe the actual shape and number of the whorls. In other specimens, owing to the comparative absence of callus, the spire is almost acuminate, the suture being distinctly eut in, but in any case the protoconch is entirely covered up. The examples from Parimoa have the greatest thickness of callus on the spire above the body-whorl, and it is so disposed as to render the shell somewhat eylindrical with an angulate ridge above the anterior suture. In the two specimens from Glenelg river the callus is closely corrugater, leading to the formation of a number of spiral ridges; an accidental mutilation of the spire of one of them reveals the protoconch, which, as far as ean be seen, is composed of two turns, the earlicr portion being vers minute and the later somewhat inflated.

The denticle on the outer margin of the aperture is practically a prolongation of a deeply-cut sulcus; the anterior canal is broad and deep ; columella exearated and carrying several small plications anteriorly. In well-preserved specimens with but little eallus, what is commonly termed the "varnished zone" of the body-whorl is light-brown in colour, in front of which is a band of the same tint, but darker. The whorl is finely striated, both longitudinally and spirally.

Compared with the older A. pseudaustralis, the latter is more elongate, and its spire is more acuminate. Living examples of the species are found in Australia, New Zealand, and Tasmania. Some of the specimens of $A$. australis in the Museum very elosely 
resemble $A$. mucronata, Sowerby, and it is possible that the latter is a local variation of the former.

Dimensions.—Length $41 \mathrm{~mm}$.; breadth $19.5 \mathrm{~mm}$.; length of aperture $25 \mathrm{~mm}$.

Form. and Loc._Pliocene and post-Pliocene: New Zealand and Victoria.

G. 5563. Two specimens of stunted growth, with callus spirally corrugated; from Limestone Creek, Glenelg river. Purchased.

G. 9521. Several fragments of the spire, exhibiting subangulate mucronation; from Parimoa, Middle Island. W. B. D. Mantell Coll.

G. 9514. A number of specimens showing wide range of variation, the spires of some being acuminate, of others mucronate; from Wanganui.

Sir James Ilector Coll.

G. 9520. An example of the adult, from Onekakara.

Transferred from the Museum of Practical Geology.

\section{Family HARPID E.}

Genus HARPA, Lamarek.

[Mém. Soc. Hist. Nat. Paris, 1799, p. 71.]

Shell orate, ventricose; last whorl very large, ornamented with regularly spaced longitudinal ribs, prolonged over the suture and joined to preceding whorl; spire short; aperture wide, channelled anteriorly, columellar border callous, the callosity extending over part of the whorls, occasionally up to the protoconch; columella twisted.

Type.-Buccinum harpa, Linnæus.

Subgenus EOCITHARA, Fischer.

[Man. Conchyl. 1883, p. 601.]

Columellar callosity more sharply defined and elerated than in Harpa (sensu stricto); posterior prolongations of the transverse ribs frequently flattened against and practically covering the suture. This, together with the subgenus Silia, Mayer, includes almost all fossil forms of the genus.

Type.-II arpa mutica, Lamarck. 


\section{Harpa (Eocithara) lamellifera, Tate.}

1859. Harpa lamellifera, Tate, Trans. Roy. Soc. South Aust. vol. xi. p. 149, pl. vi. fig. 2 .

The protoconch of this species (Plate IV. Figs. $3 a-b$ ) is very different to that of either II. sulcosa or $I$. tenuis, descriptions of which follow. It is more depressed than that of the type of the genus, from which it differs also in being striated. It recalls the protoconch of the Pliocene and living Voluta musica, Linn., though it is not quite as large. Compared with the protoconch of specimens of H. mutica, Lamk. (the subgeneric type), of the Parisian Eocene, it is relatively much larger and is more depressed, though of the same general eharacter.

The ornamentation of the whorls consists of thin, elerated, curred lamellæ close together, the anterior portions of which are tristed so as to obscure the suture; between each of these are three or four fine longitudinal lineations and many spiral striæ closely set, the latter being continued up the posterior side of the lamellæ. The columellar border is covered with callus; the anterior portion, howerer, is comparatively free therefrom, being sharply defined and elevated. The successive stages of growth of the anterior canal have left a well-marked, broad, rounded ridge, between which and the elerated columellar border is a decp rugose sulcus.

Dimensions.—Length $34.5 \mathrm{~mm}$.; breadth $23 \mathrm{~mm}$; length of aperture $27 \mathrm{~mm}$.

Form. and Loc.-Eocene: Muddy Creek, Victoria.

G. 4215. Two examples of the adult.

Presented by John Dennant, Esq.

G. 9336. Two specimens of the neanic stage of growth.

Purchased.

Harpa (Eocithara) sulcosa, Tate.

1889. IIarpa suleosa, Tate, Trans. Roy. Soc. South Aust. vol. xi. p. 150, pl. ri. fig. 10.

It is noteworthy that the subgeneric distinction previously observed should be emphasized also in the protoconchs of this 
and its congener $I I$. tenuis. The embryo of $I I$. sulcosa has only two and a half turns visible, the nucleus appears to be covered over, and is slightly oblique, as exemplified by weathered specimens; the last turn is longitudinally lineated, the earlier portion being smooth and shining.

This species is readily distinguished from any other IIarpa of the Australian Eocene by the flat area bordering the suture; the transverse lamellæ are very close together, and are exceedingly thin over the area alluded to. The columellar callosity is thin, but sharply defined, with the formation of a deep sulcation and perforation anteriorly.

Dimensions. - Length $2.5 \mathrm{~mm}$.; breadth $16 \mathrm{~mm}$.; length of aperture $17 \mathrm{~mm}$.

Form. and Loc.-Eocene: Muddy Creek, Victoria.

G. 4218. Specimen having protoconch abnormally developed. Presented by John Dennant, Esq.

G. 9337. Two examples. Purchased.

\section{Harpa (Eocithara) tenuis, Tate.}

1S89. Harpa temis, Tate, Trans. Roy. Soc. South Aust. rol. xi. p. 151, pl. vi. fig. 1 .

The anterior of the protoconch (Plate IV. Figs. $4 a-b$ ) is slightly oblique, and almost entirely hidden by subsequent turns; there are two and a half of these latter, and the whole are microscopically granulated, the later turus being also transversely and longitudinally lineated. This is a larger species than II. lamellifera, and it has fewer longitudinal lamellæ; the interlamellar striæ, both Iongitudinal and transverse, are not so prominent, except towards the anterior portion of the body-whorl, where a species of corrugation results; the shoulder of the last whorl is roughly angulate, and this is accentuated by scaly projections from the lamellæ in that region.

There seems to be a great deal in common between this and II. pulligera, from the blue clays at Schnapper Point; judging from Professor Tate's figure (op. cit. pl. ri. fig. 9) it may, perhaps, be regarded as an extreme form of this species.

Dimensions. - Length $36 \mathrm{~mm}$.; breadth $22 \mathrm{~mm}$.; length of aperture $28.5 \mathrm{~mm}$. 
Form. and Loc.-Eocene: Muddy Creek, Victoria.

G. 5511. An adult specimen, longitudinal costæe distantly separated.

Purchased.

G. 9335. Two examples, one of which illustrates the senile stage.

Purchased.

\section{Harpa (Eocithara) abbreviata, Tate.}

1889. Marpa abbreviata, Tate, Trans. Ro5. Soc. South Aust. rol. zi. p. 150, pl. vi. fig. 7 .

Protoconch (Plate IV. Figs. $5 a-b$ ) composed of two turns; it has the general features of that of $H$. tenuis, but differs in that the initial portion is much inflated and is sharply defined from the remainder. The anterior portion of the turns may be divided into two parts, the earlier of which (like the first turn) is smooth, and the later is obscurely ribbed. The last-mentioned character is of much ralue in working out the phylogeny of the Gasteropoda; the more pronounced generic characters were imparted to the shell whilst yet in the embryonic stage, prior to the escape of the animal from the capsule. In the brephic stage the incised suture is initially accompanied by an elerated border, which becomes modified as the animal approaches the neanic stage, and altogether disappears in the adult. The shell in the brephic stage also has some rather bold spiral elerations on the whorl, which, iu conjunction with the closely-set longitudinal ribs, cause cancellation, but this is wanting in the adult form.

A cursory examination might lead one to think that this species was merely a rariation of $I I$. tenuis, with which it could not possibly be confounded, howerer, when the protoconch and shell in the brephic stage are compared. The ordinary spire-whorls are subangulated medially, and ornamented by rather distant, slightly elevated lamellæ.

Dimensions. - Length $24 \mathrm{~mm}$.; breadth $14.5 \mathrm{~mm}$.; leugth of aperture $18.5 \mathrm{~mm}$.

Form. and Loc.-Eocene: Jruddy Creek, Victoria.

G. 4216. Two specimens. Presented by John Dennant, Esq. 


\section{Family TARGINELLID A.}

\section{Genus MARGINELLA, Lamarck.}

[Mém. Soc. IIist. Nat. Paris, 1799, p. 70.]

Shell oral or oblong; smooth; spire short, sometimes inconspicuous; outer margin frequently thickened and dentate; columella plicate; aperture slightly canaliculate anteriorly.

Type.-Voluta glabella, Linnæus.

\section{Marginella wentworthi, Tenison-Woods.}

1877. Irarginella wentworthii, Tenison-Woods, Pap. Roy. Soc. Tas. 1876, p. 109.

1878. Marginella wentworthii, R. Etheridge, jun., Cat. Aust. Foss. p. 165.

1S78. Marginella wentworthi, Tate, Trans. Phil. Soc. Adelaide, 1877-8, p. 92.

1888. Marginella wentworthii, Johnston, Geol. Tasmania, pl. xxxi. figs. 5, 5a.

1859. Marginella wentworthi, Denuant, Trans. Roy. Soc. South Aust. vol. xi. p. 43.

1895. Marginella wentworthi, Tate and Dennant, $i d$. vol. xix. pt.1, p. 111.

Protoconch composed of a globose, obtuse, smooth turn, barely distinguishable from the succeeding whorl. Shell small; elongate, and polished; spire moderately elevated; whorls five in number in adult specimens, convex, body-whorl obtusely angulate at the periphery, surface longitudinally striated by lines of growth, and obscurely spirally lineated, suture accompanied by an anterior spiral depression; aperture elongate, somewhat inflated towards the middle; outer margin thickened, furnished with a number of small crenulations terminated posteriorly by a rather large denticle, or tubercle, behind which is a broad, slightly canaliculate depression; inner margin with four prominent plications; anterior portion of the aperture widely channelled.

This species resembles $M I$. contabulata, Deshayes, from the Middle Eocene of the Paris Basin; but the latter is more lanceo. late, is minus crenulations on the inner side of the outer margin, and has bifid and divergent plications.

Dimensions.-Length $7 \mathrm{~mm}$.; breadth $4 \mathrm{~mm}$.; length of aperture $4 \mathrm{~mm}$. 
Form. and Loc._Eocene: M[uddy Creek, Victoria.

G. 4213. A series exhibiting stages of growth.

Presented by John Dennant, Esq.

G. 9341. Sereral specimens of the adult stage.

Purcleased.

\section{Marginella muscarioides, Tate.}

1878. Marginella muscarioides, Tate, Trans. Phil. Soc. Adelaide, 1877-8, p. 91 .

1889. Marginella muscaroides, Dennant, Trans. Roy. Soc. South Must. rol. xi. p. 43 .

This species is characterized by its broad aperture, which opens out anteriorly and is deeply channelled; the body-whorl is gibbose, and well-preserred specimens exhibit inconspicuous, narrow, longitudinal bands of brownish tint.

It differs from $\boldsymbol{M}$. wentworthi in the characters abore notel, as well as by the absence of crenulations on the outer margin. The latter in M. muscarioides is much thickened, especially torards the middle, where an obscure denticle is obserrable in some specimens; the inner margin is somewhat callous, and carries four conspicuous plications. Professor Tate remarks that in a broad sense this species is a diminutive $\boldsymbol{M}$. muscaria, Lamarck, from which, howerer, it differs, amongst other things, in that the callous outer margin of the latter species is extended "on to the penultimate whorl, thence spreading over the base of the shell, and giving rise to a flattened appearance raricosely margined on the left side." The sutural region in $\boldsymbol{I}$. muscarioides is somewhat depressed.

Mr. Dennant quotes this species as occurring in the younger beds at Mínddy Creek.

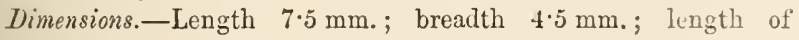
aperture $5 \mathrm{~mm}$.

Form. and Loc.-Miocene: Muddy Creek, Victoria.

G. 4212. Sereral specimens. Presented by John Dennant, Esq.

G. 9338. Examples illustrating stages of growth. Purchasul. 


\section{Marginella winteri, Tate.}

1878. Marginclla winteri, Tate, Trans. Phil. Soc. Adelaide, 1877-8, p. 94. 1880. Witra coarctata, Tenison-Woods, Proc. Linn. Soc. N.S.W. vol. iv. p. 8, pl. ii. fig. 10 .

1859. Irarginella wintcri, Dennant, Trans. Roy. Soc. South Aust. vol. xi. p. 43.

Shell elongate, subcylindrical, smooth; protoconch obtuse, composed of two smooth turns, the anterior being disproportionately large; spire elevated, three-whorled, body-whorl comprehensice, ornamented by longitudinal curred growth-lines, suture conspicuous; aperture elongate, tapering posteriorly, the sinus being very small, broad anteriorly, and channelled; outer margiu moderately thickened, but variable in individuals, closely crenulated withiu; columella callous, especially towards the anterior, where five plications occur in the adult: these latter are close together, aud only four are well dereloped, the fifth one, posteriorly, being very small, and altogether absent in young specimens.

This is by no means a typical Marginella, but it does not fall conreniently into any of the recognized sections of the genus. The writer does not, howerer, feel inclined to add to these latter, already too numerous for systematic purposes. It differs from Marginella (sensu stricto) in its cylindrical shape and exsert spire, and $b y$ the possession in the adult of fire columellar plaits. It has certain affinities with Volvarina, Hinds, ${ }^{1}$ which, howerer, has ouly four plications on the columella, whilst its outer margiu is not crenulated, at least in the type species, $M$. avena, Valenciemnes.

Specifically it closely resembles the lising $M$. gracilis, C. B. Adams ( $=M$. bibalteata, Reeve), from the West Indies, which is much smaller, more lanceolate, and is only quadriplicate.

Dimensions. - Length $15.5 \mathrm{~mm}$.; breadth $7 \mathrm{~mm}$.; length of aperture $10.5 \mathrm{~mm}$.

Form. and Loc.-Eocene: Muddy Creek, Victoria. 
G. 4211. A large series of specimens showing stages of gromth. Presented by John Dennant, Esq.

G. 9340. Four examples of the adult.

Purchesed.

\section{Marginella propinqua, Tate.}

1878. Marginella propinqua, Tate, Trans. Phil. Soc. Adelaide, IS:-i-S, p. 94 .

1952. Marginella propinqua, Kirk, Trans. N.Z. Inst. vol. xir. p. 409.

1859. Mrarginella propinqua, Dennant, Trans. Roy. Soc. South Aust. vol. xi. p. 43 .

1595. Marginella propinqua, Tate and Dennant, id. vol. xix. pt. 1, p. 111.

This species differs from $\boldsymbol{M}$. winteri in being broader, and in haring a much shorter spire. In studying the stages of growth, which are illustrated by an excellent series of specimens in the Museum, the following particulars concerning the columellar plications may be noted. In the neanic stage of some indiriduals four equal-sized, well-dereloped plaits occur, whilst in others the two posterior plaits are much smaller than the anterior. As the ephebic stage is attained a fifth, posterior plication appears, which is placed farther within the aperture of the shell, and is rery small. In many indiriduals, however, only four plaits occur, eren towards the gerontic stage, and one specimen in the collection possesses three large anterior plaits and one very small posterior. Another point of interest is the development of the crenulations ou the outer margin. In the majority of specimens these are fuund from the neanic stage on rards; but it is clear from others that crenulations were not dercloped, even up to the early portion of the ephebic stage, although the thickening of the outer margin took place under both conditions.

The foregoing observations, in the opinion of the writer, are calculated to shed some light on the systematic value of the columellar plications and the crenulations on the outer margin, in this group. It is customary with authors, dealing with Hurginella, to lay especial stress on both these characters, in assigning species to subordinate divisions of the genus. Yet in $M$. propinqu these features are very unstable, and certainly ought not to rauk higher than ontogenetic characters. Some anthors might be disposed to ereate another specific name for the non-creuulate forms; but in carefully examining a series of the shells, it is 
impossible not to recognize the phenomena alluded to as mere rariations of individuals of one species. The protoconch, the shape of the shell, form of aperture, the suture-in fact, every other characteristic except the number of plications and the occurrence of marginal crenulations-are identical in the forms here retained in $\boldsymbol{M I}$. propinqua.

Dimensions. - Length $12 \mathrm{~mm}$.; breadth $5.5 \mathrm{~mm}$.; length of aperture $9.5 \mathrm{~mm}$.

Form, and Loc.-Eocene: Muddy Creek, Victoria.

G. 9339. A series exhibiting stages of growth. Purchased.

Marginella inermis, Tate.

1878. Marginella inermis, Tate, Trans. Phil. Soc. Adelaide, 1877-8, p. 93.

1889. Marginella inermis, Dennant, Trans. Roy. Soc. South Aust. vol. xi. p. 43.

1895. Marginella inermis, Tate and Dennant, id. vol. xix. pt. 1, p. 111.

Shell pyriform, attenuating anteriorly, smooth; spire rery short, composed of from two to three whorls, body-whorl comprehensive, extending almost the whole length of the shell, longitudinal growthlines conspicnous, suture well defined, polished; aperture elongate, broally rounded posteriorly and slightly produced anteriorly where it is widely channelled; outer margin thickened and crenulated, though comparatively smooth towards the posterior extremity; columellar margin furnished with four plications in the majority of individuals, though one adult specimen in the MIuseum has only three, and another three with the trace of a fourth.

Its shape, the elongation of the aperture, and its rounded form in the neighbourhood of the posterior sinus, serve to readily distinguish M. inermis from all other Australasian Marginella. Except for the dentated outer margin, this species might perhaps be included in the subgenus Prunum.

Dimensions. - Length $12 \mathrm{~mm}$.; breadth $6.5 \mathrm{~mm}$.; length of aperture $10.5 \mathrm{~mm}$.

Form, and Loc.-Eocene: Minddy Creek, Victoria.

G. 4207. Several examples of the adult. 


\section{Subgenus GLABELLA, Swainson.}

[Malacology, 1840, p. 324.]

The principal distinguishing features of this subgenus are the more or less conical form of the spire, which is well dereloped, and the longitudinal plaits on the peripheral subangulation of the body-whorl present in the majority of the species. The first species mentioned bJ $\mathrm{S}$ wainson is quoted as "P. ruffina, $\mathrm{Sw}$."; as it is not clear what he intended by that specific name, II. bifasciata, Lamarck (one of the typical species mentioned by Swainson), is here adopted as the type of this subgenus.

In reference to $M$. ovata and $M$. conica, two new species here described from the Tertiary of New Zealand, it may be noted that certain kinds of Marginella have been recognized in the newer beds of that colony; but for the most part these have neither been figured nor described, unless, indeed, two or three lines of remarks can be called a description. The present writer has not been able to identify either of the species abore mentioned with the meagre descriptions alluded to, and is of opinion that these latter ought to be suppressed as being of no real value to systematists.

Type.-Marginella bifusciata, Lamarck.

\section{Marginella (Glabella) turbinata, G. B. Sowerby.}

1846. Marginella turbinata, G. B. Sowerby, Thes. Conch. rol. i. p. 3S5, pl. 1xxv. figs. 70-1.

1865. Marginella turbinata, Reeve, Conch. Icon. vol. sv. pl. xxii. fig. 122.

1867. Marginella turbinata, Angas, Proc. Zool. Soc. Lond. p. 196.

1S78. Marginella turbinata, Tate, Trans. Phil. Soc. Adelaide, 1S77-8, p. 86. 1879. Marginella turbinata, Weinkauff, Conch. Cab. (ed. Küster), p. 86, sp. 115, pl. rvi, figs. 9, 12.

1883. Marginella (Glabella) turbinata, Tryon, Manual of Conchology, rol. r. p. 23 , pl. vii. figs. 4,5 .

18\$6. Marginella (Glabella) turbinata, Watson, Foy. "Challenger," Zool. (Gasteropoda), vol. sv. p. 265.

Shell volutiform; spire very short, from two to three whorls, body-whorl comprehensire, subangulate, and longitudinally plicated on the shoulder; apcrture nearly as long as the shell, rather wide, roundly contracted posteriorly, wider and broadly channelled anteriorl5; outer margin much thickened, callous, the callosity extending nearly to the apex of the whorls, and returning corcring 
the columellar region, columella with four distinct plaits, the three anterior ones close together, the remaining (posterior) plait usually being smaller and less oblique.

This fossil form is more solid than are typical examples of the species in the living state from Australia, as represented in the Mnsenm.

Dimensions. - Length $11 \mathrm{~mm}$; breadth $7 \mathrm{~mm}$; length of aperture $9 \mathrm{~mm}$.

Form. and Loc.-Post-Pliocene: Limestone Creek, Glenelg river, Victoria.

G. 5559. Several epecimens illustrating later stages of growth. Purchased.

Marginella (Glabella) ovata, sp. nov.

[Plate IV. Figs. 6a-b.]

Shell small, solid, ovate; protoconch smooth, obtuse; spire short, conical, composed of two slightly convex whorls; bodywhorl large, ornamented by obscure, irregular, longitudinal folds, especially well dereloped at the periphery; suture obseurely marginate; aperture narrow, elongate, posterior sinus small, curved, anterior broad, deep, and oblique; outer margin thickened, not crenulated; columellar margin with four conspicuous plaits, the most anterior of which borders the channel.

This species differs from all other Australasian Marginelle here described, by its solidity, ovate form, and truncated anterior sinus, together with its very short and conical spire.

Diinensions. - Length $7 \mathrm{~mm}$.; breadth $4.5 \mathrm{~mm}$.; length of aperture $5.5 \mathrm{~mm}$.

Form. and Loc.-Miocene: Parimoa, New Zealand.

G. 9522. A number of examples of the adult.

W. B. D. Mantell Coll.

Marginella (Glabella) conica, sp. nov.

[Plate IV. Figs. 7a-b.]

Shell small, solid, volutiform, smooth; spire short, conical; protoconch obtuse, semi-transparent, with one and a half turns; 
whorls convex, subangulate, body-whorl large, obscurely, irregularly plicate at the periphery; lines of growth inconspicuous, except where the outer enamel is rery thin; suture well marked, and between it and the peripheral subangulation is a broad, smooth conearity; aperture elongate, abruptly terminated at the posterior end, somewhat inflated in the middle, and truncated anteriorly, where there is a broad, oblique channel; outer margin thickencd, bent over towards the aperture, crenulated throughout its length except near the posterior extremity; inner margin callous, and bearing four large columellar plaits, the most anterior of which borders the channel.

In its general shape $\boldsymbol{M}$. conica somewhat resembles $\boldsymbol{M}$. goodalli, Sby., though the former is much smaller. It has a near ally in 11. micula, Tate, from the Eocene of Mruddy Creek, which, however, is a much smaller and broader form, with a less elevated spire.

Dimensions. - Length $7 \mathrm{~mm}$.; brearlth $4.5 \mathrm{~mm}$.; length of aperture $5 \mathrm{~mm}$.

Form. and Loc.-Miocene: Parimoa, New Zealand.

G. 9522. Sereral examples.

W. B. D. IFantell Coll.

\section{Marginella (Glabella) micula, Tate.}

1878. Marginella micula, Tate, Trans. Phil. Soc. Adelaide, 1877-8, p. 93.

1889. Marginclla micula, Dennant, Trans. Roy. Soc. South Aust. vol, xi. p. 43 .

Shell minute, smooth, conically ovate; spire rery short, composed of one and a half whorls; bolly-whorl comprehensive, subangulate at the periphery and slightly concave between the shoulder and the suture, which is covered over, growth-lines conspicuous with the aid of a lens; aperture elongate, abruptly terminating posteriorly and deeply channelled anteriorly; outer margin minutely crenulated, much thickened, the callosity bounding the posterior sinus and extending over a great part of the surface of the body-whorl in the vicinity of the columella; inner margin callous, furnished with four rather distant plications, the most anterior of which borders part of the anterior channel.

This species is allied to $\boldsymbol{M}$. conica from the Tertiary of New Zealand, as previously described. It has relationships, also, with 11. vitica, Hinds, from the west coast of Africa, as meutioned 
by Professor Tate; but it has a smaller and shorter spire, and is more gibbose.

Dimensions. - Length $3.5 \mathrm{sm}$.; breadth $2.75 \mathrm{~mm}$.; length of aperture $3 \mathrm{~mm}$.

Form. and Loc.-Eocene: Muddy Creek, Victoria.

G. 4209. A series exhibiting stages of growth.

Presented by John Dennant, Esq.

\section{Marginella (Glabella) cassidiformis, Tate.}

1878. Marginella cassidiformis, Tate, Trans. Phil. Soc. Adelaide, 1877-8, p. 91.

1859. Marginella cassidiformis, Dennant, Trans. Roy. Soc. South Aust. vol. xi. p. 43.

Shell small, tumid, conical, solid; spire of medium height, two to three whorls, ornamented by bold, obtuse, distant, longitudinal plications, nodose at the subangnlar periphery; suture distinct; aperture narrow, attenuated posteriorly, truncated anteriorly; onter margin abnormally thickened and slightly reflected, not crenulated; columella quadriplicate.

The bold longitudinal plications on the whorls, and stunted, solid form, serve to distinguish this from any other Australasian Marginella. It differs from $M$. aldinga, Tate, in its general shape and form of aperture; the species resemble each other, however, in being nodosely plicated on the periphery of the whorls.

Dimensions.-Leugth $4 \mathrm{~mm}$.; breadth $3 \mathrm{~mm}$.; length of aperture $2.75 \mathrm{~mm}$.

Form. and Loc.-Eocene: Aldinga, South Australia.

G. 9342. Several examples of the adult.

Purchased.

\section{Subgenus CRYPTOSPIRA, Hinds.}

[Proc. Zool. Soc. 1844, p. 76; Belcher, Voy. “Sulphur," Mollusca, vol. ii. 1844, p. 46.]

Shell ovate or globose; spire very short or completely hidden; columella with several plications; anterior extremity covered by a callosity passing from the outer margin round the canal, and extending over the front of the columellar border; outer margin thick, and often crenulated.

Type.-Marginella tricineta, Hinds. 


\section{Marginella (Cryptospira) septemplicata, Tate.}

1878. Marginella (Persicula) septemplicata, Tate, Trans. Phil. Soc. Adelaide, $1877-8, \mathrm{p} .95$.

1859. Marginella septemplicata, Dennant, Trans. Roy. Soc. South Aust. vol. xi. p. 43.

Shell solid, orately globose; spire hidden; aperture elongate, slightly curved, widest in front, auterior canal deep; outer margin crenulated within; inner margin callous, with from seren to eight plications, the two situated most anteriorly being the largest, and extending outwardly over the thick eallosity which spreads all round the aperture.

This is unlike any other speeies of Australasian Mlarginella. The spiral limb or callosity on the auterior of the columella, which passes underneath another growth of callus on the inner margin, is very distinetive, aud is one of the reasons why the species is here classified with Cryptospira. The number of plieations on the columella and the hidklen spire are also specially characteristie. Although not a typical Cryptospira, it is more elosely allied to that than to Persicula, which, typically, has an enormous callous tubercle situated on the auterior portion of the inner margin, and has not the limb referred to.

Dimensions. - Length $6.5 \mathrm{~mm}$.; breadth $4.5 \mathrm{~mm}$.; length of aperture $6.5 \mathrm{~mm}$.

Form. and Loc.-Eocene: Muddy Creek, Victoria.

G. 4214. Three speeimens. Presented by John Dennant, Esq.

\section{Marginella (Cryptospira) ventricosa, Hutton (sp.).}

1873. Mitra ventrieosa, Hutton, Cat. Tert. Moll. N.Z. p. 8.

1873. Marginella ventricosa, Hutton, id. p. 47 (index).

1S78. Marginella ventricosa, Tate, Trans. Phil. Soc. Adelaide, 1877-8, p. 94.

"Orato-rentricose; spire very short; smooth; outer lip thiekened, strongly dentate; columella plaited. Axis 0.65 ; breadth $0.5 . "$ Irutton. This short description appears to apply to some specimens in the Museum colleetion which are, howerer, too imperfect to enable all the eharacters to be identified.

Dimensions. - Length $23.5 \mathrm{~mm}$; breadth $16.5 \mathrm{~mm}$; length of aperture $21 \mathrm{~mm}$. 
Form. and Loc.-Eocene: Broken river, Trelissick (No. 5), South Island, New Zealand.

G. 9513. Two casts.

Sir James Ilector Coll.

G. 9515. An example of the scnile stage; outer margin extremely thick; the callosity communicating anteriorly with the widespread deposit on the columellar surface.

Sir James Hector Coll.

\section{Family VOLUTID无.}

The fine collection of larral shells appertaining to this family in the Mnseum collection of Australasian Tertiary mollusca, suggests a few words concerning the origin and evolution of the groups they represent, as deduced from the study of the protoconch, and early stages of growth of the shell generally.

The striking claracters presented by the protoconch in living forms of the family have long attracted attention, and were to a limited extent taken advantage of in describing genera and species. Amongst others who place a high value on the larval shells for systematic purposes is M. Crosse, of Paris, who reviewed ${ }^{\mathrm{I}}$ the living species referred to the family, and was willing to concede, in at least one instance, ${ }^{2}$ that the phenomena of the protoconch might be of generic importance. But it was reserved for Professor W. H. Dall, ${ }^{3}$ of Washington, who studied fossil as well as living representatives of the VouUtide to throw the greatest light on this matter. He stated his conviction that the family descended from the Mesozoic "Fusids." In the Mesozoic transition forms the larval covering was shelly and minute, its upper surface like a minute Conulus or Myalinia. This indicates, he believes, that those forms found their benefit in the production of a large number of small shell-bearing larræ, rather than in a small number of large ones. This holds good for all the Mesozoic forms, at least in America, and for all the exotic

1 Journ. de Conchyl, 3e sér. t. xi. 1871, p. 263 et sqq.

2 Op. cit. p. 275.

3 Bull. IIuseum Comp. Zool. Harvard, vol. xriii. 1889, p. 452; Proc. U.S. National Museum, vol. xii. 1890, p. 311; and especially Traus. Wagner Free Inst. Sci. Philad. vol. iii. 1890 , p. 57 et sqq. 
Mesozoic forms he has been able to examine. These small larval shells are persistent, and often of a different texture to the succeeding whorls of the adult. Professor Dall remarks ${ }^{1}$ that "When the Volutide first begin to appear, and branch off from Fusus, Fasciolaria, and Turbinella, the nucleus or larral shell in all these forms was small and shelly. . . . We may classify the larral shells broadly into two groups-those which were shelly from the beginning; and those which have succeeded to a horny or uncalcified protoconch, which is lost before the larral shell escapes from its oricapsule. . . . There are sereral forms of the shelly nucleus. It undoubtedly preceded the horny one in this group."

This is followed up by dividing the larval shells into two groups-(1) the Volutoid series, and (2) the Scaphelloid series. Representatives of both these groups occur amongst the Australasian Volutes presently to be described.

The Volutold Series.-This series is characterized by the possession of a shelly protoconch, the earliest form of which is called the "trochiform," and is met with in Liopeplum of Upper Cretaceous age, and in the earlier types of Volutilithes. This kind of protoconch is practically identical with that of the original stock from which those genera sprang. A variation from this, in which the earlier portion becomes flat, is termed "planorboid"; another, where the turns of the protoconch are more numerous and are considerably elerated, is known as "pupiform"; whilst another important step is taken when the larral shell becomes larger, one-sided, and much inflated, as in the type known as "bulbous." Finally, as a more recent development in the Volutoid series, there is the enormous protoconchin which the "trochiform" type has become greatly exaggerated -known as the "melo" type.

Turning to the Australasian species here catalogned, the writer recognizes amongst the Volutoid series, representatives of Volutilithes, Lyria, Pterospira (a new subgenus), Aulica, Volutoconus, and Amoria.

The protoconch of the Folutilithes represented, is not of the most archaic type; it is a modification in which the small trochoid

1 Trans. Wagner Free Inst. Sci. Philad. rol. iii. 1\$90, p. 66. 
original has giren way to a small inflated, asymmetrical form (see Plate IV. Figs. $8 a-b$ ). Neither Volutilithes antiscalaris nor $V$. anticingulatus can therefore be said to be examples of the real stock of the genus, which was of greater geological antiquity than they. This is important in view of the habit of moderu palrontologists to link the Australian species mentioned too closely to such typical European forms as $\bar{V}$. scalaris and $\bar{V}$. spinosus, from a consideration of the sculpture of the whorls and the character of the colnmellar plaits alone. It is quite a question whether the antipodean forms alluded to ought not, indeed, on the evidence afforded by the protoconchs, to be separated from Volutilithes (sensu stricto) and placed in a new subgenus.

In regard to Lyria, but little need be said; the larval shells (Plate IV. Figs. $9 a-b$ ) and adults are very similar to European Eocene types, and they do not differ materially from living representatives found in the Indian and Pacific oceans, China seas, etc. The genus appears to have separated from the Rostellites-Volutitithes stock in the Cretaceous. In common with the remainder of the VoLUTID 2 in existence in the early Eocene, it was then in a very unstable condition, as witness the variable character (within limits) of the protoconch of Lyria harpula, Lamarck, from the Calcaire Grossier of the Paris Basin. After haring provided Fulgoraria with its small bulbous protoconch (to be afterwards greatly enlarged as in the living $V$. rupestris, Gmelin), it seems to have settled down, and to have come on from late Eocene times to the present day without material modification. It succeeded, however, amongst other things, in giving rise to Voluta (sensu stricto) during the late Miocene or early Pliocene; and the liring Enata was separated from it in the post-Pliocene.

The only Pterospira here recorded has a Fulgoraria-like bulbous protoconch (Plate IV. Figs. 10a-b), and the subgenus was probably intimately connected with Fulgoraria, which is not represented in the collection.

In reference to Aulica, so little is known concerning its geological history, and the material for studying it in the fossil state is so limited, that it is impossible for one to say definitely by which line of descent it came from the early Volutilithes stock-whether along that of Volutilithes proper, or through the medium of Lyria.

The Australian Tertiary Voluta strophodon and $V$. weldi, very characteristic forms; appear to be the precursors of the modern 
species of Tespertilio, as well as of Aulica, and they are in a measure linked together by the Tertiary Voluta macdonaldi, as will be seen later on (see p. 106). There is nothing antagonistic in the riew that the protoconch (Plate IV. Figs. 11a-b) of either of the antipodean species mentioned is a gigantic representation of Tolutilithes far advanced in an evolutionary sense. Neither, on the other hand, can it be denied that there is much in common between it and typical examples of Voluta (as in the living $\Gamma$. musica, Linnæus). The spinose character of the whorls in $V$. strophodon and its congener-if such a property can be said to be of any ralue whatever for systematic purposes-certainly reminds one of true Tolutilithes also. In the present state of our knowledge, however, the writer prefers to leare the mode of descent of Aulica an open question; though the latter undoubtedly came from the RostellitesVolutilithes stock, and was evolved in late Eocene, or more probably in Oligocene, times.

The corrugations of the anterior part of the protoconch of Volutoconus (Plate IV. Figs. 13a-b) suggest affinities with Vespertilio (see p. 108); and the larral shell as a whole, at least in the fossil Foluta conoidea, betrays its origin in Aulica, of which Volutoconus may be regarded as a minor but persistent offshoot.

Amoria has a more pointed protoconch (Plate IV. Figs. 14a-b) than Aulica, and the anterior portion is more spread out; but it is obviously a modification of the Voluta strophodon type of larral shell, of late Tertiary origin. By the general configuration of the shell of the adult, both in fossil and living forms, Amoria appears to be sharply defined from all other groups of the Volutidx. It has been a characteristic of the Australian fauna since Upper Miocene times, if the upper beds at Muddy Creek are as old as that period.

The Scapueluoid Series.-In typical forms of this series the larra is clothed with a horny protoconch, the existence of which was first made known by Professor Dall,' with reference to the living Scaphella magellanica, Sowerby. That author remarks that the horny type was probably similar in form to that which, when sholly, results in the "bulbous nucleus" of the Volutoid line of descent. "Later on," he says, " but while still in the ovicapsule,

1 Bull. Ifuseum Comp. Zool. IIarvard, rol. xriii. 1889, p. 452. 
the deposition of limy matter begins as a slender cone or elerated point along the line of the axis of the protoconch, and as the larra grows the posterior part of the mantle secretes a shelly dome. Being thus cut off from the horny protoconch, the latter falls into shreds, and is lost. The nucleus of the larra, still in the oricapsule, then presents a slightly irregular dome, with a slender point rising from the apical part." The horny portion is never found in the fossil state; but its former presence, where it existed, may be inferred from the scars and irregular, often granulated, aspect of the shelly portion of the protoconch which remains. In those cases where the shell has been rolled, or (with reference to examples of living Volutes) where it has becn treated by acid to "clean" it, as with large numbers of shells in our museums, it is often impossible to detect the Scaphelloid type of protoconch, and thus to assign species to their proper systematic position in the VoLUtID王.

Without going into details, it may be observed that Professor Dall has detected three types of Scaphelloid protoconch. Those in which it is pointed he calls the "Caricella" type; the larger and pointless kind is termed the "Scaphella" type; and the dome-shaped form is named the "Cymba" type. That nomenclature, as well as the terms emplojed in reference to the Volutoid series, is here adopted.

The Scaphella type is represented in the Museum collection by several specics, of which S. polita (Plate IV. Figs. $15 a-b$ ) is a good example; and the Caricella type (Plate IV. Figs. 16a-b) is well illustrated by a number of species of Eopsephia (see p. 115).

'This is not the place to discuss the geological age of the beds in which the bulk of the Volutes occur; in deference to the authority of Professor Tate such beds, as at Muddy Creek, Schnapper Point, Cape Otway, etc., are here termed "Eocene." But the writer cannot help remarking that the development of the larval shells of the family now under discussion, in the majority of instances, in such specimens as occur in the beds at the localities mentioned (excluding the upper beds at Muddy Creek), is much more adranced than one would have expected to find in beds as old as the Eocene-that is, on comparison with what is found in the truc Eocene in other parts of the world. 


\section{Genus VOLUTILITHES, Swainson.}

[Malacology, 1840, p. 318.]

Shell fusiform; spire conical; protoconch small, rising to a more or less acute apex; whorls costate, typically spinose; columellar plications rariable, several in number, those towards the anterior generally being the most pronouncel.

The special character of the protoconch, and the peculiar disposition of the columellar plications, are highly distinctive features.

Type.-Conus spinosus, Linnæus (= Strombus spinosus, Linnæus).

\section{Volutilithes antiscalaris, Mr'Coy (sp.).}

1874. Toluta antiscalaris, M'Coy, Prod. Pal. Vict. dec. i. p. 26.

1878. Toluta antiscalaris, R. Etheridge, jun., Cat. Aust. Foss. p. 170.

1889. Voluta antiscalaris, Tate, Trans. Roy. Soc. South Aust. vol. xi. p. 133.

This species somewhat resembles $V$. scalaris, Sowerby, from Barton, in Hampshire; but, as Sir F. M'Coy points out, it may be distinguished by its slightly longer spire, less rentricose bodywhorl, and the costre are less twisted. 'The protoconch (Plate IV. Figs. $8 a-b)$ also in the Australian species is more obtuse, consisting of one and a half smooth, rounded turns. The columellar plications are remarkable; in the neanic stage they are commonly from three to four in number, but in the adult they range from six to twelve, and possibly more. In the ephebic and gerontic stages the whole of the plications are mounted on an elerated callosity. The anterior portion of the columella is slightly excarated, a feature especially noticeable in adult specimens.

Compared with $V$. depauperatus, Sowerby, of the European Upper Eocene, with which it presents considerable analogy, it is found to possess a relatirely longer aperture and a more obtuse protoconch.

Dimensions. - Length $53 \mathrm{~mm}$. ; breadth $29 \mathrm{~mm}$. ; length of aperture $41 \mathrm{~min}$.

Form. and Loc.-Eocene: Victoria and South Australia.

G. 4276. T'wo specimens; from Muddy Creek.

Presented by John Dennant, Esq. 
G. 5483. An example having several subsidiary columellar plications; from Muddy Creek.

Purchased.

G. 9130. A specimen possessing a rery much elevated spire; from Murray river, near Adelaide. Presented by William Evans, Esq.

G. 9354. A series showing stages of growth; from MIuddy Creek.

Purchased.

\section{Volutilithes anticingulatus, M[`Coy (sp.).}

1874. Toluta anticingulata, $\mathrm{M}{ }^{\prime} \mathrm{Coy}$, Prod. Pal. Vict. dec. i. p. 24, pl. vi. figs. 2-4.

1878. Voluta anticingulata, R. Etheridge, jun., Cat. Aust. Foss. p. 170.

1858. Voluta antiscalaris, Johnston, Geol. Tasmania, pl. xxx, figs. 5, $5 b$.

1889. Voluta anticingulata, Tate, Trans. Roy. Soc. South Aust. vol. xi. p. 133.

1895. Toluta anticingulata, Tate and Dennant, id. vol. xix. pt. 1, p. 111.

This differs from $V$. antiscalaris in not being so spinose, its spire is more elevated, and the comparatively obscure longitudinal ribs on the body-whorl are furnished with obtuse tuberculations forming a rough angulation on the shoulder, though the ribs are more pronounced in young specimens. The aperture is wider, and the outer margin not so thick as in the other Australian species alluded to; columellar plications generally fewer in number.

Dimensions. — Length $53 \mathrm{~mm}$.; breadth $26 \mathrm{~mm}$; l length of aperture $37 \mathrm{~mm}$.

Form. and Loc.-Eocene: Table Cape, Tasmania.

83997. A specimen having only three columellar plications.

G. 9358. Two examples. Purchased. Purchased.

\section{Genus LYRIA, Gray.}

[Proc. Zool. Soc. 1847, p. 141.]

Shell ovate; protoconch small, from one and a half to two elevated, canaliculate turns; whorls costate; aperture narrow, anterior channel broad; columella with several plications, two in front being much compressed and very large, the others decreasing in size antero-posteriorly; outer margin thickened. 
The disposition of the columellar plications and the strongly costate whorls are highly characteristic.

Type.—Voluta nucleus, Lamarck.

\section{Lyria harpularia, Tate.}

1888. Lyria harpularia, Tate, Traus. Roy. Soc. South Aust. vol. x. p. 176, pl. xii. fig. 12.

1889. Lyria harpularia, Tate, id. vol. xi. p. 118.

The protoconch of this species (Plate IV. Figs. $9 a-b$ ) is practically identical with that of Lyria harpula, Lamarck, of the Eocene of Europe. The shell as a whole, however, is larger, more rolutiform, and the transverse costa are more numerous. The latter terminate posteriorly in obtuse points leading to a flattening in the vicinity of the suture; spiral lines prominent on the body-whorl anteriorly. The outer margin of the aperture is not rery thick; whilst the columellar border is furnished towards the anterior canal with two plications more prominent than the remainder, which become very minute as they gradually disappear within the aperture posteriorly.

Dimensions. - Length $42 \mathrm{~mm}$. ; breadth $19 \mathrm{~mm}$.; length of aperture $22.5 \mathrm{~mm}$.

Form. and Loc.-Eocene: Victoria.

70426. An example of the adult; from Meribee Plains.

G. 4174. A series illustrating stages of growth; from $\mathrm{Mnd} d \mathrm{y}$ Creek. Presented by John Dennant, Esq.

G. 9359. A similar series; from Muddy Creek. Purchased.

Genus VOLUTA, Linnæus (em. Lamarck).

[Linn. Syst. Nat. ed. 10, 1758, p. 729 ; ed. 12, 1767, p. 1186 ; Lamarck, Mém. Soc. Hist. Nat. Paris, 1799, p. 70.]

Shell solid, broad, longitudinally plicate, the plications being elerated into obtuse tubercles on the periphery of the whorls; spire short; protoconch elevated, turbinate, smooth; aperture narrow, canaliculate behind and broad in front; inner margin often corered by thin callus; columella carrying many plaits, four or fire being prominent, the remainder much smaller.

Type.- Toluta musica, Linnæus. 


\section{Subgenus PTEROSPIRA, ${ }^{\circledR}$ nov. subgen.}

Shell broadly fusiform; protoconch bulbous, granular, much larger than succeeding whorls, initial portion lateral and hidden; whorls spirally striated, tuberculose at the periphery, body-whorl very large, outer margin in adults forming a wing-like expansion, with a broally rounded, auriculate posterior margin, rising nearly up to the suture of the penultimate whorl for attachment; inmer margin corered by a thin deposit of callus; columella excavated in the middle and furnished with three large, equal, prominent plications.

The wing-like expansion of the outer margin of the aperture and the enormous globose protoconch serve to distinguish Pterospira from all other groups of the Volurid $\approx$. The general character of the larval shell is that of Fulgoraria, as typified by Voluta rupestris, Gmelin.

Type.-Voluta hannafordi, Mr'Coy.

\section{Voluta (Pterospira) hannafordi, $\mathrm{M} \mathrm{I}^{\circ} \mathrm{Coy}$.}

1874. Toluta hannafordi, M`Coy, Prod. Pal. Viet. dec. i. p. 23, pl. vi. fig. 1.

1876. Toluta hannafordi, M'Coy, id. dec. iv. p. 25, pl. xxxvii. fig. 1.

1889. Toluta hannafordi, Tate, Trans. Roy. Soc. South Aust. vol, xi. p. 121.

Distinguished by its immense, inflated protoconch (Plate IV. Figs. $10(a-b)$, aud the wing-like expansion of the outer margin of the aperture. The whorls are obtusely angulate, crowned by nodose tubercles, which near the summit appear as rugose costæ. In the young of this species the last whorl is spirally lineate, the lines being close together in the neighbourhood of the suture and towards the anterior portion of the columella, and more distant between those two points; in the adult the anterior part of the whorl is smooth; the columella has three plications.

It differs from its congeners $V$. macroptera, $\mathrm{I}^{\prime} \mathrm{CoJ}$, and $\Gamma$. mortoni, Tate, in that the whorls of the latter are practically smooth, though all possess the wing-like expansion. The present writer is uuable to speak as to the precise character of the

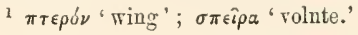


protoconchs of the two speeies last mentioned, no representatives of them being in the Museum.

Dimensions. - Length $50 \mathrm{~mm}$.; breadth $28 \mathrm{~mm}$.; length of aperture $30 \mathrm{~mm}$; protoconch, length $11 \mathrm{~mm}$., breadth $14 \mathrm{~mm}$. I'rofessor Tate describes a specimen exceeding $150 \mathrm{~mm}$. in length and $90 \mathrm{~mm}$. in breadth.

Form. and Loc.-Eocene: MIuddy Creek, Vietoria.

G. 9351. An example of the neanic stage of growth. Purchased.

\section{Subgenus AULICA, Gray (em. Crosse).}

[Proc. Zool. Soc. 1847, p. 141; H. and A. Adams, Genera Recent Moll. vol. i. 1853, p. 160 (partim) ; em. Jouru. de Conchyl. $3^{\text {e }}$ sér. t. xi. 1871, p. 2\$1.]

Shell oval-oblong, more or less ventricose; protoconch regularly coiled, turbinate or trochoid, elevated, smooth or obscurely lineated; whorls of the spire smooth, spinose at the periphery, the nodulations being distant and situated on broal, short costæ in the adult; columellar plications commonly four in number.

'This is very closely related to the subgenus Vespertilio, Klein $(e m$.$) , the principal differentiating character being the protoconeh,$ which in Aulica is, typically, smooth, whilst in Vespertitio it is crenulated. The fossil forms here described appear to be the common ancestors of the living forms of the two subgenera mentioned, and in general shape they approach also the earlier (stock) Volutilithes, from which they differ, however, very markedly in the characters of the larval shells.

Type._-Voluta aulica, Sowerby.

\section{Voluta (Aulica) strophodon, $\mathrm{I}^{\circ} \mathrm{Coy}$.}

1876. Toluta strophodon, M‘Coy, Prod. Pal. Vict. dec. iv. p. 25, pl. xxxrii. figs. 2-4c.

1878. Voluta strophodon, R. Etheridge, juu., Cat. Aust. Foss. p. 170.

15ss. Voluta weldii, Johnston, Geol. Tasmania, pl. xxx. fig. 7 (non figs. $6,6 b)$.

1589. Toluta strophodon, Tate, Trans. Roy. Soc. South Aust. vol. xi. p. 134.

Considerable analogy exists between this species and certain well-known forms of Volutilithes; the protoconch is the chief distinguishing feature. The form of $V$. strophodon raries considerably: 
some specimens hare a spire approaching that of $V$. spinosus, Lamarek, of the European Eocene, as remarked by Sir F. II'Coy; whilst others are conoidal and have been compared with $V$. athletus, Solander. A strong variety of $V$. athletus (perhaps a distinct species) found in the Sables Moyens (Upper Eocene) of Le Ruel, Paris Basin, which more nearly approaches the typical $V$. spinosus, is not unlike the Australian species now diagnosed; but the latter has not much in common with the typical $V$. athletus found at Barton, in Hampshire, which has a more depressed (and not conical) spire with enormous, obtuse spines. The columellar plaits of $V$. strophodon are four in number, sharp, of approximately equal size, and oblique; the first one anteriorly being directed so as to merge into the flat callosity bordering the deep, broad canal. The disposition of these plaits alone suffices to distinguish it from the European Eocene forms alluded to, which have one large anterior plait or fold, with sereral smaller ones behind it.

Certain forms of this variable species so closely resemble T. symmetricus, Conrad, of the Eocene of Jackson, Mississippi, that they are not easily separated from it at first sight. An examination of the protoconch (Plate IV. Figs. 11a-b), however, soon places all loubt at rest : this Australian species has a large, obtuse, turbinate, spirally striated protoconch, whilst the European and American species mentioned all have the sharp, small protoconch so characteristic of Volutilithes.

Dimensions. - Length $43 \mathrm{~mm}$. ; breadth $23 \mathrm{~mm}$. ; length of aperture $31 \mathrm{~mm}$.

Furm. and Loc.-Eocene: Muddy Creek, Victoria.

G. 4275. Three examples of the adult.

Presented by John Dennant, Esq.

G. 9350. A series illustrating stages of growth; one specimen in the neanic stage has a perfect protoconch, obscurely tuberculated towards the anterior extremity.

Purchased.

\section{Voluta (Aulica) weldi, Tenison-Woods.}

1876. Tolute weldii, Tenison-Woods, Proc. Roy. Soc. Tas. 1875, p. 24 pl. i. fig. 2.

1878. Toluta weldii, R. Etheridge, jun., Cat. Aust. Foss. p. 170.

18s8. Ioluta weldii, Johnston, Geol. Tasmania, pl. xxx. fig. 6.

1859. Toluta Weldii, Tate, Trans. Roy. Soc. South Aust. vol. xi. pp. 134-6. 
The present writer is almost inclined to regard this as a variation of $V$. strophodon (or vice versa) brought about by the extremely farourable conditions under which it lived. It has a thicker shell, the callus spread orer the columella extends some distance beyond on to the body-whorl, from which it is sharply defined; the coste are almost obsolete, but each has a pronounced pointed tuberele at the subangulate periphery of the whorls. One specimen in the Museum has five columellar plaits-four normal and one subsidiary, the latter becoming dereloped as the gerontic stage was attained.

Dimensions. - Length $35 \mathrm{~mm}$; breadth $18.5 \mathrm{~mm}$. ; length of aperture $25.5 \mathrm{~mm}$.

Form. and Loc.-Eocene: Victoria, South Australia, and Tasmania.

83983. One specimen; from Table Cape.

Purchased.

G. 9129. An example of the adult; from Murray river, near Adelaide. Presented by William Evans, Esq.

G. 9347. A series exhibiting growth from the brephic to the gerontic stages; from Muddy Creek.

Purchased.

\section{Voluta (Aulica) lirata, Johnston.}

[Plate IV. Fig. 12.]

1850. Toluta lirata, Johnston, Proc. Roy. Soc. Tas. 1879, p. 37.

18s8. Voluta allporti, Johnston, Geol. Tasmania, pl. xxx. fig. 10.

1889. Foluta lirata, Tate, Trans. Roy. Soc. South Aust. vol. xi. p. 130, pl. ii. fig. 4.

Shell fusiform, elongate; protoconch large, turbinate, or trochoid, composed of three and a half turns, inconspicuously spirally lineate and, anteriorly, longitudinally striated; whorls of the spire concare posteriorly in the neighbourhood of the suture, and conrex towards the middle, ornamented by undulating, unequal, closely-set liræ accentuated at the periphery, and absent on the anterior half of the body-whorl in the adult; aperture elongately oral, contracted behind and broad in front; columella curved towards the middle, furnished with four well-dereloped oblique plications.

Special attention may be directed to the restiges of coloration, which do not appear to hare been previously described in this species. As will be seen on reference to the figure nor gireu 
(Plate IV. Fig. 12), they consist of closely-set zigzag lines somewhat similar in character to those of the living $V$. undulata. They are preserved in conseyucnce of those portions of the shell where they are found being more durable than the remainder of the surface; the markings are slightly in relief.

This species is assigned to the subgenus Autica because the protoconch is identical with that of the other Australian forms here included therein, and agrees very closely with that of the type species. The general shape of the shell is more suggestive of Scaphella, howerer. It is minus tubercles, or spines, and lacks the solidity of $\Gamma$. aulica. In some respects it resembles $I$. bednalli, Brazier, living in North Australian seas.

The writer has rot seen an authenticated specimen of $V$. lirata as described (but not well figured) by Mr. R. M. Johnston; but accepts Professor Tate's interpretation of the species. It may be pointed out, however, that Mr. Jobnston describes the "pullus" of his species as having only one and a half turns, whilst the species as here accepted possesses three and a half. In all other respects the Muddy Creek examples appear to correspond with his description.

Dimensions. - Length $52 \mathrm{~mm}$. ; breadth $22 \mathrm{~mm}$.; length of aperture $33 \mathrm{~mm}$.

Form, and Loc.-Eocene: Victoria and South Australia.

G. 5485. Example of the adult, with colour-markings on the body-whorl; from Muddy Creek.

Purchased.

G. 9129. A specimen in which the liræ are very large and distant; from Murray river, near Adelaide.

Presented by Willian Evans, Esq.

G. 9346. Two examples of the neanic stage of growth; from Muddy Creek.

Purchased.

\section{Voluta (Aulica) pseudolirata, Tate.}

1888. Toluta pseudolirata, Tate, Trans. Roy. Soc. South Aust. vol. x. p. 176.

1889. Toluta psendolirata, Tate, id. vol. xi. p. 121.

Shell somewhat fusiform, narrow, thin; whorls slightly conrex or subangulate medially, costæ close together, inflated, and a little elevated on the periphery, but becoming almost obsolete 
anteriolly, where they are mingled with the numerous longitudinal strix more prononnced on that part of the shell; columella with four oblique, thin, and sharp plaits.

Professor Tate remarks that this is intermediate between $V$. lirata and (what is here called) Seaphella sarissa, though differing from the latter by its "pullus" and the absence of pronounced spiral sculpture. So far as general form is concerned, that obscrvation may be endorsed; but, if close genetic relationship with $S$. sarissa be implied, that view must be dissented from, as the species arose from another line of development in the VoLutide. There can be no question, howerer, of its immediate connection with $V$. lirata, from which it differs in shape and by the well-developed costæ.

Dimensions.-Length $43 \mathrm{~mm}$.; breadth $16.5 \mathrm{~mm}$.; length of aperture $24 \mathrm{~mm}$.

Form. and Loc.-Eocene: Mruddy Creek, Victoria.

G. 427\%. Three specimens, including a fine example of the neanic stage of growth.

Presented by John Dennant, Esq.

G. 9356. An example of the adult.

Purchased.

\section{Voluta (Aulica) ellipsoidea, Tate.}

1888. Voluta ellipsoidea, Tate, Trans. Roy. Soc. South Aust. vol. x. p. 176 (explanation of plate only), pl. xiii. fig. 4.

1889. Toluta ellipsoidea, Tate, id. vol. xi. p. 127.

The only example in the Museum is a young specimen, well prescrved, and exhibiting the characters of the elevated trochoid protoconch and brephic and neanic stages to perfection. From this it may be gleaned that the ornament first to appear, and just prior to the escape of the animal from its capsule, was the longitudinal ribbing; the ribs are small and close together, and, with the growth of the shell, gradually derelop into fine longitudinal strix. In the brephic stage, bold spiral lineations make their appearance, and these pcrsist to the neanic stage; at the sume rate of progression they should, however, become almost obsolete in the adult. The suture is slightly incised, and the whorls are somewhat constricted posteriorly in its vicinity. The columella is slightly callous, and has four distinct plaits.

The protoconch is rery similar to that of $r$. lirata and 
$V$. pseudolirata; but the shell differs from them in being devoid of longitudinal costæ and by the development of the spiral strix alluded to.

Dimensions.-Length $42 \mathrm{~mm}$.; breadth $17 \mathrm{~mm}$. Professor Tate describes a specimen $62 \mathrm{~mm}$. in length.

Form. and Loc.-Eocene: Muddy Creek, Victoria.

G. 4255. An example of the neanic stage of growth.

Presented by John Dennant, Esq.

\section{Voluta (Aulica) macdonaldi, Tate.}

1888. Toluta macdonaldi, Tate, Trans. Roy. Soc. South Aust. vol. x. p. 176, pl. xii. fig. 11.

1889. Voluta macdonaldi, Tate, id. vol. xi. p. 123, pl. iii. fig. 5.

The only specimen in the Museum is a very young example in which many interesting characters are not brought out, though the unique larval shell is well preserved. The following abstract of Professor Tate's description may therefore be given:--"Whorls three, excluding pullus; the two posterior whorls angulated in the posterior third, the front parallel with the axis and costated, the posterior area concavely sloping upwards; the costæ terminate at the shoulder in high-raulted spinous scales; on the first spirewhorl the spines are about twenty in number, and terminate each a pair of costæ. The body-whorl is somewhat ventricose, with a high shoulder, concavely sloping upwards to the suture; the angulation crowned with sixteen spinous scales, which terminate broad undulations, not ribs, rapidly becoming obsolete. Columella with four distant plaits . . . whole surface [of shell] is sculptured with strix and growth-lines; the only spiral sculpture is confined to the last whorl of the pullus. The pullus is not sharply separated from the ordinary spire-whorls, as there is a gradual change in the shape and ornament of the whorls; the actual junction being somewhat indicated by a slight eccentricity of the first spirewhorls."

The depression of the initial portion of the protoconch is not a point of much systematic value, and the species is here included in Aulica, though it is by no means a typical example of that subgenus, on account of the general agreement of the earlier part of the larval shell with eertain forms of Aulica. The first three 
or four whorls taken together remind one of $V$ espertilio, except that the protoconch is not lirate or tuberculate at the commencement. The larval characters indicate the influence of both of those branches of the VoLdTiD.e, and it appears to lie in an intermediate position between them.

In general form, except that the whorls of the spire are more elevated, $V$. macdonaldi is somewhat like the living $V$. rossiniana, Bernardi, of New Caledonia, a close ally of $V$. imperialis, Lamarck, of the seas in the neighbourhood of the Philippine Islands. The protoconch in the fossil species, however, is much larger.

Dimensions. - Length $36 \mathrm{~mm}$.; breadth $21 \mathrm{~mm}$.; length of aperture $21 \mathrm{~mm}$. Professor Tate describes a specimen $115 \mathrm{~mm}$. in length.

Form. and Loc.-Eocene: Muddy Creek, Victoria.

G. 9345. An example of the neanic stage of growth.

Purchased.

\section{Subgenus VOLUTOCONUS, Crosse.}

[Journ. de Conchyl. 3e sér. t. xi. 1871, p. 306.]

Shell oblong, subcylindrical ; spire short and obtuse; protoconch broad, depressed, planorboid; whorls ornamented by minute, closely-set spiral lineations crossed by rather conspicuous growthlines; outer margin of the aperture simple, slightly reflected towards the middle; columella with four plications, not well developed, anterior portion swollen and corrugated by former positions of the deep, wide anterior channel.

Type._Voluta coniformis, Cox.

\section{Voluta (Volutoconus) conoidea, Tate.}

1888. Toluta (Folutoconus) conoidea, Tate, Trans. Roy. Soc. South Aust. vol. x. p. 176, pl. xiii. fig. 9 .

1889. Toluta (Folutoconus) conoidea, Tate, id. vol. xi. p. 125.

Protoconch (Plate IV. Figs. 13a-b) broad, depressed, composed of three turns, the earliest being exceedingly small in comparison with the others, the whole being bordered at the periphery next the canaliculated suture by an elerated ridge; last turn irregularly 
spirally corrugated. It is difficult to define, from the specimen in the Museum, the exact limits between the protoconch and the shell in the brephic stage, but approximately at the junction between the two the larral shell is longitudinally corrugated, which suggests analogy with Vespertilio. The whorls of the spire proper enrelop the suture, the junction being uneven; they are sculptured with delicate, undulating, irregular growth-lineations, crossed by faintly discernible spiral striæ; body-whorl obscurely tuberculose at the periphery, the broad nodulations being far apart, and (judging from the figure given by Professor Tate ${ }^{1}$ ) more conspicuous in some specimens than in others. Outer margin of the aperture sharp, slightly inflected medially, inner border with four sharp, oblique plaits on the anterior half of the columella.

This species is narrower and more coniform than either $V$. strophodon or $V$. weldi.

Dimensions. - Length $32 \mathrm{~mm}$.; breadth $15 \mathrm{~mm}$.; length of aperture $23 \mathrm{~mm}$.

Form. and Loc.-Eocene: Muddy Creek, Victoria.

G. 9353. One example.

Purchased.

\section{Subgenus AMORIA, Gray.}

[Proc. Zool, Soc. 1855, p. 64.]

Shell fusiform, smooth, and polished; protoconch turbinate, elevated, canaliculate, smooth, whorls of the initial portion pointed, small, becoming slightly inflated with growth, and spirally and longitudinally striated towards the anterior extremity; shell ornamented with coloured bands, or more or less undulating longitudinal lineations; suture callous; columella with four or fire plications.

This subgenus is confined, in the living state, to Australasia, and it is interesting to note the occurrence of fossil forms. The coloured lineations are persistent, eren in many fossil examplesin all of those in the Museum collection.

Type.-Voluta turneri, Gray.

1 op. eit. pl. xiii. fig. 9. 


\section{Voluta (Amoria) undulata, Lamarck.}

1804. Toluta undulata, Lamarek, Ann. du Musée, t. v. p. 157, pl. xii. fig. 1.

1822. Troluta undulata, Lamarck, Auim. sans Vert. t. vii. p. 345.

1832. Toluta undulata, Quoy and Gaimard, Voy. de l'Astrolabe, Zool. t. ii. p. 623 , pl. xliv. figs. 1 and 2 .

1832. Toluta undulata, Deshayes, Ency. Méth. Vers. t. iii. p. 1142.

1810. Toluta undulata, Küster, Conch. Cab. (ed. Küster), Volutu, p. 163, pl. $x x r$. fig. 3 ; pl. xxr. figs. 3 and 4.

1849. Toluta undulata, Reeve, Conch. Icon. rol. ri. pl. xi. fig. 26.

1856. Foluta undulata, Wood and Hauley, Ind. Test. p. 109, pl. xxi. fig. 166.

1864. Toluta (Amoria) undulata, Angas, Proc. Zool. Soc. p. 52.

1865. Amoria undulata, Angas, id. p. 165.

1867. Toluta (Amoria) angasi (?), Angas, id. p. 193.

1871. Toluta (Amoria) undulata, Crosse, Journ. de Conchỵl. 3e sér. t. xi. p. 288.

1877. Toluta (Amoria) undulata, Kobelt, Jahrb. deutsch. malak. Gesellsch. p. 307.

18s2. Foluta (Amoria) undulata, Tryon, Manual of Conchology, rol. iv. p. 92 , pl. xxviii. figs. 87,88 .

1886. Foluta (Scaphella) undulata, Watson, Toy. "Challenger," Zool. vol. xv. (Gasteropoda), p. 257.

Shell with short spire, sutures covered orer; aperture broad and long; outer margin curred, solid, truncated anteriorly, and having a broad, slightly reverted canal; columella with four large plications rising from a rather thick deposit of callus. The surface of the body-whorl is covered by a number of distant zigzag bromn lines, which appear to be more durable than the uncoloured portions of the whorl, from which they stand out in relief, in one specimen in the Museum.

Dimensions. - Length $109 \mathrm{~mm}$.; breadth $55 \mathrm{~mm}$.; length of aperture $83 \mathrm{~mm}$.

Form. and Loc.-Post-Pliocene: Victoria.

G. 4787. One specimen; from Bairnsdale, Gippsland. Presented by the Rev. J. S. II. Royce.

G. 5542. Two examples of the adult, one of which, of rery large size, is much broader than typical forms of the species; from Limestone Creck, Glenclg river. 


\section{Voluta (Amoria) masoni, Tate.}

1589. Toluta masoni, Tate, 'i'rans. Roy. Soc. South Aust. vol, xi. p. 128, pl. iii. fig. 9 .

Shell fusiform, ovate, smooth; protoconch (Plate IV. Figs. 14a-b) turbinate, pointed, the anterior portion being larger than the succeeding whorl in the brephic stage in some individuals. Spire very short, solid, smooth, polished; the greater part of the shell enreloped by the body-whorl; aperture large, broad, channelled where it joins the preceding whorl, outer margin expanded in front; anterior noteh deep and broad; columella with four stout plications. The body-whorl is ornamented with transverse, closely-set, thin, undulating, chestnut-coloured lines-a very distinctive feature.

Compared with the living $V$. undulata, of which it appears to be a direct ancestor, the body-whorl is more rounded and inflated at the periphery, the posterior channel is deeper, and the coloured lineations are of a widely different pattern. It somewhat resembles the living $V$. zebra, Leach, from which, however, it may be readily distinguished by the character of the protoconch; the fossil shell is more inflated.

Dimensions.-Length $65 \mathrm{~mm}$; breadth $32.5 \mathrm{~mm}$.; length of aperture $51 \mathrm{~mm}$.

Form. and Loc.-Miocene: Muddy Creek, Victoria.

G. 4258. An example of the adult.

Presented by John Dennant, Esq.

G. 5482. A similar specimen.

Purchased.

\section{Genus SCAPHELLA, Swainson.}

[Zool. Illust. 2nd ser. 1832, pl. lxxxvii. (with description); Malacology, 1840, p. 318.]

Shell with somewhat elerated spire; smooth, earlier whorls generally faintly striated or longitudinally ribbed, which characters may be effaced in the adult or, on the other hand, become more accentuated; columella arched, prolonged anteriorly, covered with callus, plications three to six in number, commonly four; margin of the outer lip sometimes thickened and reflected outwardly. 
There seems to have been some difficulty in deciding what should be the typo species of Scaphella. On reviewing the subject, Professor Dall ${ }^{1}$ emends the genus and selects $S$. undulata, Lamarck; that species, howerer, clearly falls in Amoria, Gray, ${ }^{2}$ and is not, therefore, arailable for a typical Scaphella. In a subsequent work Professor Dall ${ }^{3}$ quotes Voluta junonia, Hwass, as the type, which species was included by Swainson in his genus, and that riew is accepted in this work.

Type.-Voluta junonia, Hwass.

\section{Scaphella maccoyi, Tenison-Woods (sp.).}

1877. Toluta $m^{\prime}$ coyi, Tenison-Woods, Pap. Roy. Soc. Tas. 1876, p. 95.

1878. Toluta $m^{6}$ coyi, R. Etheridge, jun., Cat. Aust. Foss. p. 170.

1888. Voluta agnewi, Johnston, Geol. Tasmania, pl. xxx. fig. 9 (non 1850. Pap. Roy. Soc. Tas. 1879, p. 37).

1859. Ioluta m'coyii, Tate, Trans. Roy. Soc. South Aust. vol. xi. p. 126, pl. ii. fig. 2.

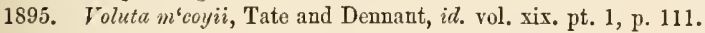

This, and S. polita are rery distinctive species, differing from all other Australian members of the family here described in being smooth and polished, and in possessing true Scaphelloid protoconchs. $S$. maccoyi has a thin shell, minutely striated by lines of growth and flatly depressed near the suture; columellar plications four in number in the brephic and neanic stages, but frequently fire in the ephebic, due to the derelopment of a small plication posteriorly; the plications are more oblique in the young than in the adult forms; outer margin thickened and reflected outwardly.

Dimensions. - Length $44 \mathrm{~mm}$.; breadth $18 \mathrm{~mm}$.; length of aperture $26 \mathrm{~mm}$.

Form. and Loc.-Eoccne: Victoria.

G. 4256. Three examples of the adult, one of which is extremely lanceolate and furnished with five stout columcllar plications; from Muddy Creek. Presented by John Dennant, Esq.

G. 5487. 'Ihree specimens; from Muddy Crcek. Purchased.

Bull. Museum Comp. Zool. Harvard, vol. xviii. 1889, pp. 147-8.

2 Proc. Zool. Soc. 1855 , p. 64.

${ }^{3}$ Trans. Wagner Free Inst. Sci. Philad, vol, iii. 1890, p. 79. 
73227. A series exhibiting stages of growth; from Schnapper Point. Purchased.

G. 9352. Three specimens showing rariation in development of columellar plications; from Muddy Creek.

Purchased.

\section{Scaphella polita, Tate (sp.).}

1889. Toluta polita, Tate, Trans. Roy. Soc. South Aust. vol. xi. p. 127, pl. ii. fig. 7 .

This is a close ally of $S$. maccoyi, from which it differs only in being proportionately broader, in having more rentricose whorls, and by the protoconch being larger; columellar plications typically fire, but sometimes six in number, the largest plait being placed anteriorly.

The protoconch (Plate IV. Figs. 15a-b) in general shape is turbinate, and is distinctly scaphelloid. It consists of two turns, the earlier portion of which is irregularly granular, and rises to an obtuse point, the later portion being regular, deeply canaliculate, and spirally and longitudinally lineate anteriorly.

Dimensions. - Length $30 \mathrm{~mm}$. ; breadth $14 \mathrm{~mm}$.; length of aperture $19.5 \mathrm{~mm}$.

Form. and Loc.-Eocene: Muddy Creek, Victoria.

G. 9355. Examples of the neanic and ephebic stages of growth. Purchased.

\section{Scaphella ancilloides, Tate (sp.).}

1889. Toluta ancilloides, Tate, Trans. Roy. Soc. South Aust. vol. xi. p. 126, pl. iii. fig. 7 .

Spire composed of four slightly convex whorls; in the young stage these are obliquely ridged and furnished with spiral lineations, both of which characters almost disappear as the ephebic stage is attained. Body-whorl in the adult closely longitudinally striated, and with obscure spiral lines; suture incised; aperture large, contracted posteriorly, expanded anteriorly where it is truncated and broadly channelled; outer margin thick and slightly sinuous, inner margin covered by effuse polished callus; columella with three plications which in the joung are much 
compressed, very thin, and more oblique than in the adult. A very noticeable feature in the shell is the arch-shaped, much produced columella.

It is unfortunate that the only specimen in the Museum is minus its protoconch; and the present writer is not able, in consequence, to assign the species to a systematic position without doubt. From Professor Tate's description, and from the figure accompanying it, the protoconch would appear to be bulbous, which is not a characteristic of Scaphella. It is possible, on that account, that the species should be assigned to Voluta, and placed somewhere in the neighbourhood of Fulgoraria, Schumacher ${ }^{1}$; but the other features of the shell are in close agreement with the genus in which it is here placed, and in the absence of direct evidence it may be provisionally retained as a Scaphella.

Dimensions.-Length $67 \mathrm{~mm}$.; breadth $30 \mathrm{~mm}$.; length of aperture $42 \mathrm{~mm}$.

Form. and Loc.-Eocene: Muddy Creek, Victoria.

G. 4254. An example of the adult, showing abundant callosity on the posterior half of the columella.

Presented by John Dennant, Esq.

\section{Scaphella pacifica, Lamarck (sp.).}

1822. Toluta pacifica, Lamarek, Anim. sans Vert. t. vii. p. 344, No. 35 .

1832. Toluta pacifica, Quoy and Gaimard, Toy. de l'Astrolabe, Zool. t ii, p. 625 , pl. xliv. fig. 6 .

1849. Toluta pacifica, Reeve, Conch. Icon. pl. xrii. figs. $35 a-b$.

1871. Toluta (Alcithoe) pacifica, Crosse, Journ. de Conchyl. $3^{e}$ sér. t. si. p. 293.

1873. Toluta pacifica, Hutton, Cat. Tert. Moll. N.Z. p. 7.

1873. Toluta pacifica, Ton Martens, List. Moll. N.Z. p. 22.

1873. Toluta (Aleithoc) pacifica, Ilutton, Cat. Marine Moll. N.Z. p. 18.

1880. Toluta pacifica, IIutton, Man. X.Z. Moll. p. 61.

1852. Voluta (Alcithoe) pacifica, Tryon, Mauual of Conclrology, rol. ir. p. 94, pl. xxviii. figs. 97-9.

1893. Toluta pacifica, IIutton, Linn. Soc. N.S. Tr., Macleay Mem. Tol. p. 46.

Shell elongate, fusiform; protoconch scaphelloid, composed of two and a half smooth turns; spire of fire whorls, the first two 
or three of which are plicated, the plications dying out as the adult stage is attained. Pari passu with this phenomenon we find in some individuals the incoming of tubercles at the periphery of the whorls; these are distantly situated, small at first and then becoming very large, the maximum size being reached with full growth of the shell. On the other hand, we find individuals in which these tubercles are not developed; after the plications on the earlier whorls had died ont the remainder of the whorls became perfectly smooth, as may be seen in examples of the species in the living state. Clothed with prominent, spinose tubercles, this species bears but little resemblance to typical forms of the genus Scaphella; but when smooth it is readily comparable with S. junonia. The last-mentioned characteristic, taken together with its distinctly scaphelloid protoconch, enables the writer to assign it to Scaphella, and it may be placed in the neighhourhood of Eopsephia. The outer margin of the aperture is thin and reflected outwardly; columella covered over by a thin deposit of callus, plications to the number of four.

Dimensions. - Length $132 \mathrm{~mm}$; breadth $54 \mathrm{~mm}$.; length of aperture $88 \mathrm{~mm}$.

Form. and Loc.-Pliocene: Wanganui, New Zealand.

G. 9504. Two specimens, with well-dereloped spines at the periphery of the whorls.

Sir James Ilector Coll.

\section{Scaphella gracilis, Swainson (sp.).}

1821. Voluta gracilis, Swainson, Exotic Conch. p. 20, pl. xlii.

1824. Voluta gracitus, Swainson, Quart. Journ. Sci. rol. xrii. p. 32.

1532. Voluta fusus, Quoy and Gaimard, Voy. de l'Astrolabe, Zool. t. ii. p. 627 , pl. xliv. figs. 7,8 .

1849. Toluta gracilis, Reeve, Conch. Icon. pl. xrii. fig. 40.

1864. Voluta (Scapha) gracilis, Augas, Proc. Zool. Soe. p. 52.

1871. Voluta (Alcithoe) gracilis, Crosse, Journ. de Conchyl. $3^{\mathrm{e}}$ sér. t. xi. p. 295.

1873. Voluta (Alcithoe) pacifica var, gracilis, Hutton, Cat. Marine Moll. N.Z. p. 18.

1873. Voluta gracilis, Von Martens, List Moll. N.Z. p. 22.

1877. Voluta (Alcithoe) gracilis, Kobelt, Jahrb. deutsch. malak. Gesellsch. p. 309 .

1880. Toluta gracilis, Hutton, Man. N.Z. Moll. p. 62.

1882. Toluta (Alcithoe) pacifica var. gracilis, Tryon, Manual of Conchology, vol. iv. p. 94. 
1856. Toluta (Aleithoe) gracilis, Watson, Toy. "Challenger," Zool. vol. xv. (Gasteropoda), p. 258.

1893. Voluta gracilis, Iutton, Linn. Soc. N.S.WV., Macleay Mem. Vol. p. 46.

This is a close ally of $S$. pacifica, of which it has been regarded as a mere variation in form by some authors. It is usually much smaller and more ventricose than that species, is plicated to a later stage of growth, the peripheral tubercles when present being comparatively inconspicuous. Outer margin of the aperture usually thickened and not reflected, inner margin corered by a thin deposit of callus; columella sinuous, slightly produced in front, and furnished with four plications; anterior channel broad and rather dcep.

Dimensions. - Length $50 \mathrm{~mm}$.; breadth $19.5 \mathrm{~mm}$.; length of aperture $31.5 \mathrm{~mm}$.

Form. and Loc.-Miocene and Pliocene: New Zealand.

G. 9510. Several specimens exhibiting variations in form of growth; from Wanganui.

sir James Hector Coll.

G. 9518. Example having an elongate spire and corrugated columella; from Parimoa, near Waitaki. W. B. D. Ilantell Coll.

G. 9519. Similar, but with larger nodulations at the periphery of the body-whorl; from Parimoa.

Transferred from the Museum of Practical Geology.

\section{Subgenus EOPSEPHIA, Fischer $(e m$.$) .$}

[Manuel Conchyl. 1883, p. 607.]

Shell long, fusiform; ornamented by longitudinal ribs commonly spinose at the periphery of the whorls; typically the columellir has seren plications, the anterior being the more salient. So far, it agrees in general with the subgenus Psephea, Crosse ${ }^{1}$ (type Voluta concinna, Broderip); bnt the protoconch is very distinctive. The latter is of the Scaphelloid-Caricella type, somewhat inflated and rising to a sharp point, laterally situated.

The Australian species here included in this subgenus differ from typical forms of Eopsephia in regard to the number and disposition of the columellar plications, and the shells as a whole 
are more elongate. Possibly they are entitled to rank as a separate subgeneric group; but the characters of the protoconchs present no serious differences from those of true Eopsephia as found in the Eocene of the Paris Basin, and the phenomeua connected with the columellar plications do not seem important enough to warrant етеn subgeneric separation.

Type.-Toluta muricina, Lamarck.

\section{Scaphella (Eopsephia) sarissa, Tate (sp.).}

1889. Toluta sarissa, Tate, Trans. Roy. Soc. South Aust. rol. xi. p. 129, pl. ii. figs. $1 a-b$.

Protoconch (Plate IV. Figs. 16a-b) composed of three turns, the earliest being small, somewhat granular, and rising to a sharp point in well-preserved specimens, later turns larger, flat, with a bordered and deeply canaliculate suture, anterior portion spirally lineate and longitudinally corrugated. Shell fusiform, turreted; whorls flatly convex, ornamented with spiral threads and angular costre, described by Professor Tate as follows:- "The rounded spiral threads (about twelve on the first whorl), which are about as wide as the interspaces, increase in number with the revolution of the spire. On the fourth and fifth whorls, adjacent to the anterior suture, the threads are reduced to strix; and on the body-whorl the anterior half is smooth, or nearly so. The costæ begin to appear on the front half of the second posterior whorl, and on the three anterior whorls have attained to stoutish, wedgeshaped, slightly curved, angular ridges, which are continued in subdued strength to the anterior suture, but do not reach the posterior one. Last whorl with about nine transversely elongate costre on the periphery, not much attenuated to the broadish opeu canal, which is bent to the right and slightly reverted." The columella carries five large, somewhat flattened plaits, the first and fifth being smallest; between these are occasional obscure folds, especially noticeable in adult specimens.

Dimensions. - Length $88 \mathrm{~mm}$.; breadth $21.5 \mathrm{~mm}$.; length of aperture $40 \mathrm{~mm}$.

Form. and Loc.-Eocene: Muddy Creek, Victoria.

G. 4246. Three examples of the adult.

Presented by John Dennant, Esq. 
G. 9349. Four specimens; one, of the neanic stage of growth, possessing a perfect protoconch; another, an example of the senile stage, having subsidiary folds on the columella. Purchased.

\section{Scaphella (Eopsephia) pagodoides, Tate (sp.).}

1888. Voluta pagodoides, Tate, Trans. Roy. Soc. South Aust. vol. x. p. 176, pl. xiii. fig. 7 .

1889. Voluta pagodoides, Tate, id. vol. xi. p. 132.

1895. Voluta pagodoides, Tate and Dennant, $i d$. rol. xix. pt. 1, p. 111.

Protoconch similar to, but smaller than, that of $S$. sarissa, though not perfect enough in the Nuseum specimens to enable details to be given. The shell in the brephic stage is strongly longitudinally ribbed. The aperture of this species is much longer in proportion to the length of the shell than in that species; the longitudinal costæ are recluced to pointer tuberenlations on the shoulder, in front of which the last whorl is depressed; longitudinal striæ conspicuous, irregular, and undulating. The author states that there are "four subequal, equidistant, rather slender plaits"; but all the specimens seen by the present writer have five, the first and fifth being smaller than the remainder, as in $S$. sarissa, the fifth (posterior) being smallest of all.

Dimensions.-Length $49 \mathrm{~mm}$. ; breadth $15.5 \mathrm{~mm}$.; length of aperture $28 \mathrm{~mm}$.

Form. and Loc.-Eocene: Cape Otway, Victoria.

G. 9357. Examples of the young and adult.

Purchased.

\section{Scaphella (Eopsephia) cathedralis, Tate (sp.).}

1888. Voluta cathedralis, Tate, Trans. Roy. Soc. South Aust. rol. x. p. 176, pl. xiii. fig. 10.

1889. Toluta cathedralis, Tate, id. vol. xi. p. 131.

Protoconch large, turbinate, granular at the commencement, composed of two and a half turns, not pointed, sharply coiled, longitudinally and spirally striated anteriorly, canaliculate; thus slightly differing from the protoconch of either $S$. sarissa or S. pagodoides. The shell is of the same general configuration as the last-mentioned species, but is narrower and the spinose 
tubercles are less prominent, in adult specimens often reduced to obscure nodulations; spiral lineations especially noticeable near the suture; columella with four oblique, thin plications.

Dimensions. - Length $44.5 \mathrm{~mm}$.; breadth $14 \mathrm{~mm}$.; length of aperture $22 \mathrm{~mm}$.

Form. and Loc.-Eocene: Muddy Creek, Victoria.

G. 9348. Two examples of the adult.

Purchased.

Voluta, sp. indet.

The following specimens of VoLutide, for the most part in the state of casts, are iudeterminable, and cannot be assigned to systematic positions in the family without considerable doubt, namely :-

From South Australia-

G. 9523, G. 9524, and G. 9525. Casts of Scaphelloid forms; from the Tertiary of Nullarbor Plains. H. Y. L. Brown Coll.

48803. Four casts, one of which is large and elongate, and has two prominent plications on the columella; it is probably referable to Scaphella. From the River Murray.

Presented by Commodore Goodenough, R.N.

G. 9528. Cast of a smooth species.-G. 9529. An elongate form, the internal cast showing four columellar plications and distant obtuse tubercles on the periphery of the body-whorl, allied to Volutiluthes anticingulatus.-G. 9530. Cast of Scaphella, aff. S. maccoyi.-G. 9682. Cast of an elongate Scaphella (?).-All from the Eocene of the River Murray, near Adelaide.

Transferred from the Museum of Practical Geology.

From Victoria-

G. 4786 and G. 4787. Casts of four rolutoid shells; from the Tertiary of Bairnsdale, Gippsland.

Presented by the Rev. J. S. II. Royce.

From Tasmania-

70403. Mutilated cast of volutoid shell, aff. $V$. stephensi, Johnston; from the Eocene of Brown's river. Purchased. 
From New Zealand-

G. 9505. Two mutilated shells of a species of Scaphella (?) aff. S. gracilis, imbedded in shelly argillaceous limestone.G. 9506. Two blocks of similar limestone with remains of Scaphella (?).-G. 9508. Cast of a volutoid shell in limestone. -All from the Lower Miocene of Akuakua, east coast of Auckland. Sir James Hector Coll.

70414. Mrutilated cast of shell having affinities with Scaphella gracilis; from the Tertiary of Mount Wellington.

Purchascd.

\section{Family MITRIDA.}

\section{Genus MITRA, Lamarck.}

[Mém. Soc. Hist. Nat. Paris, 1799, p. 70.]

Shell thick, mitriform, solid; aperture narrow, channelled anteriorly; columella obliquely plicated, the posterior plaits often being larger than the anterior; lip commonly thickened, and devoid of liræ or denticles within.

Type.-Voluta episcopalis, Linnæus.

\section{Mitra alokiza, Tenison-Woods.}

1Ss0. MLitra alokiza, Tenison-Woods, Proc. Linn. Soc. N.S.W. vol. ir. p. 9, pl. ii. fig. 12.

1889. Mitra (Eumitra) alokiza, Tate, Trans. Roy. Soc. South Aust. rol. xi. pp. 135-6, pl. iv. fig. 8 .

1893. Mitra alokiza, Tate and Dennant, id. vol. xvii. pt. 1, p. 220.

Protoconch, according to Professor Tate, with two small, narrow, rounded turns; whorls ten in number, slightly convex, last whorl subangulate medially; sutures margined, the whorls being somewhat staged; spiral groores regular and distant, elegantly and closely punctated, the anterior half of the body-whorl haring more numerous and closely-set groores; aperture narrow, elongate, truncated anteriorly, outer border very thin for such a solic shell; columella with four plications, the most anterior of which is much smaller than the others.

This species closely approximates 1 . scrobiculata, Brocchi, from 
the Pliocene of North Italy; the latter, however, is not so narrow, it is minus the subangulation of the last whorl, whilst the anterior half of the columella is twisted, and the plications are not so prominent. It is analogous, also, with $M$. melaniana, Lamarck, and $M$. digna, A. Adams, both of which are found living in Australian waters.

Dimensions. - Length $66 \mathrm{~mm}$. ; breadth $16 \mathrm{~mm}$.; length of aperture $28 \mathrm{~mm}$.

Form. and Loc.-Eocene: Muddy Creek, Victoria.

G. 4244. An example of the neanic stage.

Presented by Joln Dennant, Esq.

G. 9360. A series illustrating stages of growth; one specimen, of the late brephic stage, haring only two columellar plications.

Purchased.

Mitra multisulcata, sp. nov.

[Plate V. Figs. 1 $a-d$.

The protoconch of this species forms an interesting study; it is composed, typically, of six gradually increasing volutions, polished, slightly granulated, and the anterior turns are longitudinally striated. In the first two volutions the calcium carbonate assumes a wbite, rather pearly colour and lustre, the succeeding turns being light yellow and porcellaneous. The large number of volutions indicate a long intracapsular existence. The protoconch is clearly cut off from the shell proper. In some specimens examined there were only five volutions, and these were implanted obliquely with reference to the axis of the shell. Immediately the larval form escaped from the capsule it commenced to grow rigorously, and at once assumed the cancellate structure so well developed in succeeding whorls.

The formation of the columellar plaits at this (brephic) stage may be described as follows:- Shortly after the shell emerged from the capsule the anterior portion of the columella became slightly callous, and this was prolonged posteriorly into an inconspicnons ridge, which, as the animal grew, developed into a true columellar plication. That portion free from callus bears, even at this early stage, two small plications, which must not be confounded with the bold spiral lineations, seren in number, 
wound round the pillar. The posterior of these plications is, nominally, placed between the second and third (counting posteroantcriorly) lineations; whilst the anterior is practically conterminous with the fifth lineation.

At a later period of the brephic stage, when the normal shell had dereloped to the extent of a whorl and a half, the whole pillar became covered with a slight deposit of callus, with threc plications, the hindermost being decidedly the largest and the anterior the smallest. At two and a half rolutions the plications became still more accentuated, though not increased in number. But between that period, and nntil five normal shell-whorls were formed (neanic stage), a fourth columellar plication was dereloped anteriorly. Finally, with the production of seven normal whorls - the most adult example of the species in the MIuseum-yet another, the fifth, plication was formed.

From the foregoing it would appear, therefore, that the number of columellar plaits in the brephic stage was only two and the suspicion of a third, and that as the shell increased in size the number of plaits increased also, until in the adult there were no fewer than five of them. Whatever might be the true origin and function of the plaits, we find, in this case at any rate, that they were always dereloped anteriorly.

These facts ought effectually to dispose of the view that the number of plications in such a genus as Ifitra is per se of specifie importance. It is quite clear that in many instances the number dereloped depends on the stage of growth, and, when the animal of Mitra becomes senile, subsidiary plications are frequently formed between the normal plaits.

The ornament of the whorls of M. multisulcata consists, essentially, of closely-set small sulcations running spirally, interrupted by fairly equidistant, longitndinal strix or lines of growth, the whole assuming a minutely cancellated aspect. This ornament extends from the brephic stage, and persists with extreme regularity to the senile, only that, in the more adult individuals, the growth-lines are somewhat corrugated. The spiral suleations are multiplied us the shell increases in size, additional ones from the protoconch onwards being dereloped between those already formed. The sulcations become much broalcr on the anterior aspect of the body-whorl. The sutures are very slightly cut in, the whorls being a little convex, and not angulate. 
The aperture is rather more than one-third the length of the whole shell; it is elongately ovate, outer border arcuate, smooth within, acute at the suture posteriorly, broad and truncated auteriorly. The margin of the aperture is oblique with reference to the axis of the shell.

This species has hitherto been confounded apparently with its congener $\boldsymbol{M}$. alokiza, Tenison-Woods, from which it differs, however, in many important particulars. The protoconch of M. multisulerta, as will have been noticed, is more fully dereloped; its spiral sulcations are much closer together from the earliest stage; the body-whorl is minas a subangulation, the margin of the aperture is not parallel with the axis of the shell, and it is wider and more arcuate; finally, it is relatively more truncate anteriorly.

Dimensions. - Length $24.5 \mathrm{~mm}$.; breadth $8 \mathrm{~mm}$.; length of aperture $10 \mathrm{~mm}$.

Form. and Loc.-Eocene: Muddy Creek, Victoria.

G. 9361. A series illustrating stages of growth, from the brephic onwards.

Purchased.

Mitra uniplicata, Tate.

1889. Mitra (Eumitra) uniplicata, Tate, Trans. Roy. Soc. South Aust. vol.xi. pp. 135, 138, pl. iv. fig. 12.

This is distinguished from $M$. alokiza and $M$. multisuleata in that its nine whorls are much more convex, and the columella has only one, prominent plication, with the suspicion of a second. The surface of the shell is covered by almost imperceptible spiral striæ, which, however, become much more pronounced and developed into prominent spiral ridges on the anterior half of the bodywhorl. The sutures are deeply cut in, and peculiar iudentations, where spots of colour appear to have been, border the whorls in that region.

Professor Tate does not mention Muddy Creek as a locality for this species, but the specimen in the Museum undoubtedly came from there, and not from Schnapper Point. It is much larger, has more whorls than the figured type, and is more perfect, though the protoconch is wanting.

Dimensions. - Length $69 \mathrm{~mm}$.; brealth $18 \mathrm{~mm}$.; length of aperture $32 \mathrm{~mm}$. 
Form. and Loc.-Eocene: Muddy Crcek, Victoria.

G. 4244. An example of the adult stage.

Presented by John Dennant, Esq.

Subgenus CANCILLA, Swainson.

[Malacology, 18 10, p. 320.]

Spire elerated; whorls ornamented by spiral ridges; outer margin of the aperture thin.

The heterogeneous forms usually included in this subgenus sufficiently attest the absurdity of utilizing ornament of the whorls for systematic purposes-at least, so far as chief subdivisions are concerned. Cancilla mas, howerer, be provisionally retained in its present state, until the Mirride as a whole are classified according to more modern methods.

Type.-Mitra sulcata, Swainson.

\section{Mitra (Cancilla) atractoides, Tate.}

1889. Mitra (Cancilla) atractoides, Tate, Trans. Roy. Soc. South Aust. vol. xi. pp. 135, 139, pl. iv. fig. 11.

1893. Mitra atractoides, Tate and Dennant, $i d$. vol. xrii. pt. 1, p. 220.

The protoconch (Plate V. Figs. $2 a-b$ ) in this species is large, obtuse, and composed of four turns, the first three of which are implanted obliquely, in the majority of individuals; its suture is somewhat canaliculate, the surface of the shell being smooth and polished, but the fourth turn is spirally lineate, the lineations being in strict continuity with those, more plainly marked, on the whorls in the brephic stage.

The shell as a whole is somewhat fusiform, with a rather clerated spire of fire convex whorls; spiral ridges conspicuous and regular, erossed by sinuous growtli-lines. Aperture half the length of the shell, narrow, slightly dilated anteriorly; columella with four prominent plications in the ephebie stage; and sometimes with five in the gerontic, owing to a very small one being developed anteriorly.

The fusiform shape of the shell, the subcancellate aspect of the external ornament, and the size and general character of the protoconch, are rers distinctive. 
Dimensions. - Length $18 \mathrm{~mm}$; breadth $7 \mathrm{~mm}$.; length of aperture $9.5 \mathrm{~mm}$.

Form. and Loc.-Eocene: Muddy Creek, Victoria.

G. 4250. Three examples of the adult stage.

Presented by John Dennant, Esq.

G. 9363 . Two specimens.

Purchased.

\section{Genus UROMITRA, Bellardi.}

[Mem. Reale Accad. del. Sci. Torino, ser. ii. t. xxsviii. 1887, p. 277.]

Fusimitra, auct., non Conrad, Proc. Acad. Nat. Sci. Philad. rol. vii. 1855, p. 261.

IIuch confusion has arisen orer Conrad's Fusimitra, and it is commonly believed that that anthor never properly described it. Thus, Tryon" remarks that Fusimitra is "uncharacterized," and gives the date as 1865, from the "American Journal of Conchology, vol. i. p. 25"; he also quotes $M$. cellulifera, Conrad, in connection therewith. Dr. Paul Fischer ${ }^{2}$ gires the same date, and quotes Conrad's species mentioned as the type. II. Cossmann ${ }^{3}$ seems to have felt the necessity, under the circumstances, of putting Fusimitra on a firmer basis, and gives a complete diagnosis of it, also quoting M. cellulifera as the type. Professor Dall" states that Fusimitra "never had any value, and Conrad's original list contained the precursors of species as different as $M$. wandoensis and $M$. swainsoni, Brod.," from which it is clear that he also accepted the date as 1865; and Dr. Dall further states ${ }^{4}$ that " M. cellulifera, Conrad, was the first species" mentioned.

The modern authors quoted do not appear to have been aware that Conrad ${ }^{5}$ described Fusimitra ten years prior to 1865 , and that it is perfectly recognizable. In describing it Conrad says: "Elongate-fusiform, smooth and polished, with impressed revolving

1 Manual of Conchologr, vol. iv. 1882, pp. 109, 217.

2 Man. de Conchyl. 1884, p. 613.

3 Ann. Soc. Roy. Malac. Belg. t. xxiv. 1589, p. 184.

4 Trans. Wagner Free Inst. Sci. Philad. vol. iii. 1890, p. 94.

5 Proc. Acad. Nat. Sci. Philad. vol. vii. 1855, p. 261. 
lines; aperture narrow; plaits, two prominent and two obsolete, or much smaller than the others; beak elongated." The author then remarks: "To this subgenus belongs $\boldsymbol{M}$. conquisita, Con., and M. mississippiensis, Con., of the Vicksburg deposit," and describes in detail a new species called " $\mathbb{M}$. (Fusimitra) mellingtoni." And these three are all the speeies mentioned by Conrad on that occasion. Consequently we must take one of them as the type of Fusimitra; $M$. cellulifera is not admissible for that purpose.

This interpretation puts a different aspect on Fusimitra as usually understood; and that term must be reserved for long forms of Mitride like $\boldsymbol{M}$. mellingtoni, closely allied to Mitra (sensu stricto).

The shorter forms, contracted anteriorly and for the most part longitudinally costated (formerly called Fusimitra), must receire another name. Such forms bear considerable resemblance to Costellaria, Swainson, ${ }^{1}$ which, howerer, is typically not so much contracted in front, being thus devoid of a beak-like prolongation. They approaeh still nearer to the genus Uromitra, Bellardi, in which the Australian forms here deseribed are included. The protoconehs of typical species of Uromitra from the Piedmont Basin are more pointed and elerated than those of the Tertiaries of the Antipodes, otherwise the resemblance is rery close.

Type.-Uromitra antegressa, Bellardi.

\section{Uromitra leptalea, Tate (sp.).}

1S59. Mitra (Costellaria) leptalca, Tate, Trans. Roy. Soc. South Aust. pp. 135,140 , pl. v. fig. 3 .

1593. Mitra leptalea, Tate and Dennant, id. rol. xrii. pt. 1, p. 220.

Shell narrow, fusiform; protoeonch (Plate V. Figs. $3 a-b$ ) composed of two smooth turns, the earlier of which is much the smaller, the later one being considerably inflated; there is no sharp line of demarcation between the protoconch and the shell in the brephic stage, the smooth turn leadiug up to the shell proper, gradually assuming the longitudinal costate sculpture which 
characterizes the later whorls. These latter are nearly flat, with an impressed suture, ornamented with subacute, longitudinal ribs and small, closely-set striæ, crossed by uneven spiral threads. The body-whorl is subangulate, constricted anteriorly, and attenuated so as to form a rather long canal, which is encircled by prominent spiral ridges; aperture small, prolonged anteriorly; outer margin slightly sinuous, thin; columella with four plications, increasing in size antero-posteriorly.

Dimensions, - Length $16 \mathrm{~mm}$.; breadth $6 \mathrm{~mm}$.; length of aperture $6 \mathrm{~mm}$.

Form. and Loc.-Eocene: Muddy Creek, Victoria.

G. 4249. Two specimens. Presented by John Dennant, Esq.

G. 9362. A series illustrating stages of growth. Purchascd.

\section{Uromitra paucicostata, Tate (sp.).}

1889. Mitra (Costellaria) paucicostata, Tate, Trans. Roy. Soc. South Aust. vol. xi. pp. 136, 141, pl. v. fig. 2 .

1893. Mitra paucicostata, Tate and Demnant, id. vol. xvii. pt. 1, p. 220.

Protoconch as in $D$. leptalea. In the neanic stage the columella has three plications; but as the adult form is attained four make their appearance by the development of a fold anteriorly. The shell differs primarily from that of the species mentioned, in having the longitudinal costæ farther apart, more conrex and turriculate whorls, and in the body-whorl being biangulate. The aperture is lirate within.

Dimensions. - Length $12 \mathrm{~mm}$.; breadth $4 \mathrm{~mm}$.; length of aperture $4 \mathrm{~mm}$.

Form. and Loc.-Eocene: Muddy Creek, Victoria.

G. 9364. Two specimens.

Purchased.

\section{Uromitra exilis, Tate (sp.).}

1889. Mitra (Costellaria) exilis, Tate, Trans. Roy. Soc. South Aust. vol. xi. pp. 135,140, pl. viii. fig. 5 .

1893. Mitra exilis, Tate and Dennant, id. vol. xvii. pt. 1, p. 220.

Protoconch similar to that of $U$. leptalea. In the brephic stage it must be difficult to separate this species from young individuals of $U$. paucicostata, and they are unquestionably of common origin. 
The differenees between the two species, howerer, become more accentnated as the neanic stage is reached in each case, and with the adults the separatiou is well marked.

In general, it may be stated that the shell is small and turriculate; but the costæ are eloser together and more striate than in the last-mentioned species. Peeuliar characters are the comparaticely sharp angulation in the vicinity of the suture, and the absence of nodosities on the anterior portion of the body-whorl, which is oceupied by prominent transverse threads. 'The number of eolumellar plieations varies from three to four; but the material at the writer's disposal is not abundant enough to enable their development to be traced.

Dimensions. - Length $5.5 \mathrm{~mm}$.; breadth $1.75 \mathrm{~mm}$.; length of aperture $2 \mathrm{~mm}$.

Form. and Loc.-Eocene: Muddy Creek, Victoria.

G. 9375. Three specimens.

Purchased.

\section{Uromitra semilævis, Tate (sp.).}

1889. Mitva (Pusio) semilevis, Tate, Trans. Roy. Soc. South Aust. vol. xi. pp. 136, 143, pl. v. fig. 9.

1893. Mitra semilevis, Tate and Dennant, id. vol. xvii. pt. 1, p. 220.

Shell very small, fusiform, narrow; protoconeh similar to that of $J$. exilis and $U$. leptalea; whorls three in number, slightly convex, ornamented by obtuse longitudinal costæ on the earlier whorls, and these become eomparatively inconspieuous on the body-whorl of the adult, being reduced to mere undulating corrugations; the suture is slightly marginate. The last whorl is much attenuated and drawn out anteriorly; aperture elongate, outer margin lirate within, columella with four plieations, which hare the appearance of being eontinued as spiral ridges round the anterior portion of the body-whorl.

The obtuse, rather distant costæ on the earlier whorls, the comparatirely smooth body-whorl of the adult, and the peculiar anterior prolongation, are features enabling $U$. semilaris to be readily distinguished amongst its congeners.

Dimensions. - Length $5 \mathrm{~mm}$.; breadth $1.75 \mathrm{~mm}$.; length of aperture $2 \cdot 75 \mathrm{~mm}$.

Form. and Loc.-Eoeene: Muddy Creek, Vietoria.

G. 9344. Three examples of the adult.

Purchased. 


\section{Uromitra terebriformis, Tate (sp.).}

1859. Mitra terebreformis, Tate, Traus. Roy. Soc. South Aust. vol. xi. p. 141 , pl. v. fig. 5 .

The external configuration of this shell is that of a typical Terebra, but the protoconch is distinctive, and closely resembles that of the species of Uromitra already described, whilst the columella is furnished with four stout, oblique plaits, becoming progressively larger antero-posteriorly. The whorls are longitudinaliy custate, and a narrow band accompanies the well-marked suture. The anterior portion of the body-whorl is constricted, and is spirally corrugated. It has certain affinities with Pyramimitra, Conrad, which, however, is not much constricted anteriorly, and only carries two columellar plaits.

Dimensions.-Length $19 \mathrm{~mm}$.; brealth $6.5 \mathrm{~mm}$.; length of aperture $8 \mathrm{~mm}$.

Form. and Loc.-Miocene: Muddy Creek, Victoria.

G. 4251. A series, mostly examples of the adult. Presented by John Dennant, Esq.

\section{Uromitra clathurella, Tate (sp.).}

1889. Mitra clathurella, Tate, Trans. Roy. Soc. South Aust. vol, xi. p. 142 , pl. viii. fig. 8 .

1893. Mitra clathurella, Tate and Dennant, id. rol. xvii. pt. 1, p. 220.

None of the specimens in the Museum possess a well-preserved protoconch, which, however, appears to be small and obtuse. The ordinary whorls are four iu number, convex, depressed posteriorly in the neighbourhood of the suture, and marginated. T'hey are ornamented with oblique costæ, fine transverse striæ, and spiral threads in front of the antesutural depression. Professor Tate remarks (op. supra cit.) that the aperture is "narrow-oblong, contracted in front to a short broadish, bent, and slightly reverted beak. Outer lip slightly ascending on the penultimate whorl, slightly emarginate at the suture, smooth within; columella with four rather distant, transverse plaits."

The species appears to be very variable. The drawing accompanying Professor Tate's description is more grauose in aspect 
than are the actual specimens, and the costate character of the whorls is not very well brought out.

Dimensions. - Length $6 \mathrm{~mm}$.; breadth $2.75 \mathrm{~mm}$.; length of aperture $3 \mathrm{~mm}$.

Form. and Loe.-Eocene: Muddy Creek, Victoria.

G. 9365. Four specimens.

Purchased.

\section{Genus CONOMITRA, Conrad.}

[Amer. Journ. Conch. vol. i. 1865, p. 25.]

Shell biconical, smooth, finely longitudinally plicate, or netlike; aperture narrow; outer margin ereet, sharp, bent round in the neighbourhood of the rather broad anterior canal; columella with four or five plaits.

Type.-Mitra fusoides, Lea.

Conomitra othone, Tenison-Woods (sp.).

1880. Mitra othone, Tenison-Woods, Proc. Linn. Soc. N.S.W. vol. iv. p. 8 , pl. ii. fig. 4 .

1889. Mitra (Cancilla) othone, Tate, Trans. Roy. Soc. South Aust. vol. xi. pp. 135,139 , pl, iv. fig. 10 .

1893. JSitra othone, Tate and Dennant, id. vol. xvii. pt. 1, p. 220.

Shell biconical; protoconch composed of two and a half to three smooth turns; aperture more than half the length of the shell, elongate, acute posteriorly, and truncate anteriorly; columella somewhat twisted iu front, earrying four well-developed plaits, the smallest being the most anterior. The whorls are almost flat, ornamented with more or less granulose, closely-set, spiral threads, crossed by growth-lines; suture bordered by a slightly raised ridge or thread.

Conomitra othone has been compared with Mitra atractoides, but the biconical form and less obtuse protoconch of the former are very distinctive.

Dimensions. - Length $9.5 \mathrm{~mm}$. ; breadth $5 \mathrm{~mm}$.; length of aperture $5.5 \mathrm{~mm}$.

Form. and Loc.-Eocene: Mluddy Creek, Victoria.

G. 9366. 'Two specimens.

Purchased. 


\section{Conomitra dennanti, Tate (sp.).}

1889. Mitra (Eumitra) demanti, Tate, Trans. Roy. Soc. South Aust. vol. xi. pp. 135, 137, pl. iii. fig. 3 .

Shell biconical, spire short; protoconch (Plate V. Figs. $4 a-b$ ) composed of four smooth turns, minutely spirally striated anteriorly, the initial portion being very small and suddenly broadening out with growth; whorls slightly staged, rentricose, strongly spirally lineate and finely longitudinally striate, the striæ in the lineate sulcations causing a punctate appearance; body-whorl large, embracing, tapering anteriorly; aperture long, narrow; outer margin straight, very thin, the deep spiral sulcations on the body-whorl appearing within and forming pseudo-liræ; columellar margin covered by a thin deposit of callus throughout its length, and furnished with four medially-situated plications increasing in size antero-posteriorly; anterior channel broad and truncate.

In general shape Conomitra dennanti approaches the so-called Mitra florida, Gould, said to be living in the seas of Florida and the Philippine Islands.

Dimensions. - Length $36 \mathrm{~mm}$.; breadth $16 \mathrm{~mm}$.; length of aperture $23 \mathrm{~mm}$.

Form. and Loc.-Eocene: Muddy Creek, Victoria.

G. 4245. An example of the adult.

Presented by Joln Dennant, Esq.

\section{Conomitra ligata, Tate (sp.).}

1889. Mitra (Strigatella) ligata, Tate, Traus. Roy. Soc. South Aust. vol. xi. pp. 135, 139, pl. v. fig. 4.

1893. Mitra ligata, Tate and Dennant, id. vol. xvii. pt. 1, p. 220.

Distinguished from other species of Conomitra here described, in being smooth; the only ornament it possesses is a depressed spiral band in the region of the suture, causing the latter to assume a marginate aspect, also some extremely faint spiral strix on the body-whorl, which become accentuated near the anterior extremity of the shell. The aperture is narrow; outer margin thin, lirate within; columella with five plications in the adult, but only four in the brephic stage, judging from specimens in the Museum collection. 
C. ligata is not columbelliform, and cannot be included in Strigatella on other grounds also. Its protoconch is truly characteristic of Conomitra, and the shell is biconical as in typical examples of that genus. The species is comparable with the smooth Conomitra of the Paris Basin, as exemplified by C. marginata, Lamarck.

Dimensions. - Length $6.5 \mathrm{~mm}$.; breadth $3.5 \mathrm{~mm}$.; length of aperture $3.5 \mathrm{~mm}$.

Form. and Loc.-Eocene: Muddy Creek, Victoria.

G. 9343. Three specimens.

Purchased.

\section{Family FASCIOLARIID无.}

Genus FUSUS, Lamarck.

[Mém. Soc. Hist. Nat. Paris, 1799, p. 73.]

Shell narrow, clongate, spire acuminate; aperture orate; outer margin thin, sometimes crenulate, and often striate within; columella smooth, typically with a detached border; canal very long: straight, and open.

Type.-Inurex colus, Linnæus.

\section{Fusus hexagonalis, Tate.}

1888. Fusus hexagonalis, Tate, Trans. Roy. Soc. South Aust. vol. x. p. 139, pl. iii. figs. $15 a-b$.

1889. Latirofusus (?) hexagonalis, Cossmann, Ann. Géol. Univ. t. v. p. 1089.

1893. Fusus hexagonalis, Tate and Dennant, Trans. Roy. Soc. South Aust. vol. xrii. pt. 1, p. 219.

Shell lanceolate, fusiform, prismatic. Professor Tate describes the protoconch (Plate V. Figs. $5 a-b$ ) as follows: "Apex of two and a half whorls, medially angulated; the anterior unicostate and projecting beyond the succeeding whorl, the next narrower, smooth, and ending in an upturned lateral point." Whorls from six to seren in number, conrex, deeply spirally sulcated, and crossing the longitudinal costr; the latter are well elevated, sharp, and distantly spaced; those on the body-whorl are approximately in line with those on preceding whorls, producing a prismatic appearance, though this phenomenon is not so well 
marked in the younger stages of growth; aperture ovate, contracted in front; columella slightly twisted; anterior canal very long, sinuous, and almost closed.

The protoconch of this species is peculiar, and it may hereafter lead to the establishment of a new subgenus for the inclusion of this and kindred forms of Fusus. The sharp point at its commencement, the granulated character of the earlier portion generally, together with the irregular scar-like ridge (Plate V. Figs. $5 a-b)$, are suggestive of a pre-existing horny protoconch, similar to that found in living Scaphella.

MI. Cossmann ${ }^{1}$ doubtfully referred $F$. hexagonalis to Latirofusus, but although the columella is twisted it earries no plication, at least in any of the IIuseum specimens. A remarkable feature in this shell is that the growth-lines are raised into arched scales at the suture.

The figure accompanying Professor Tate's description indicates that the longitudinal costre are absent on the body-whorl. This appears to be merely an individual characteristic, as a specimen in the Museum, of older growth, apparently, than the type speeimen, still retains the angulate costæ to the eud; though, unfortunately, the anterior canal is broken off.

Dimensions (of a perfect specimen).-Length $19 \mathrm{~mm}$.; breadth $4 \mathrm{~mm}$.; length of aperture $3 \mathrm{~mm}$.; length of canal $7 \cdot 5 \mathrm{~mm}$.

Form. and Loc.-Eocene: Muddy Creek, Victoria.

G. 4744. Two specimens.

Presented by Professor T. Rupert Jones, F.R.S.

G. 9436. Examples of the neanic and adult stages. Purchased.

\section{Fusus dictyotis, Tate.}

1888. Fusus dictyotis, Tate, Trans. Roy. Soc. South Aust. vol. x. p. 135, pl. vii. figs. 2,6 .

1893. Fusus dictyotis, Tate and Dennant, id. vol. xrii. pt. 1, p. 219.

1895. Fusus dictyotis, Tate and Dennant, id. vol. xix. pt. 1, p. 111.

If we restrict Fusus to those forms having a perfectly straight columella and anterior canal, the species now uuder description would not fall therein; but there seems to be no necessity for

J Ann. Géol. Univ. t. v. 1889, p. 1089. 
drawing such a fine distinction, especially if we consider that slight curvature in the columella is due to the merely mechanical requirements of the animal. The protoconchs of the ouly two specimens in the Muscum collection are not well enough preserved for description; but they appear to be of the same general character as in $F$. hexagonalis. The shell is narrow, with an elcvated spire; whorls convex, angulate, with a median serrate kecl and subsidiary spiral lines elevated on the longitudinal ribbings, and crossed by fine growth-lines; aperture angularly orate; outer margin thin, striate within; columellar border excavated, covered by a thin deposit of callus; anterior canal very long aud sinuous.

Except for the excavated columella, the curred canal, and the longitudinal costæ, this shell resembles $F$. serratus, Deshayes, of the Middle Eocene of the Paris Basin.

Dimensions. - Length $51 \mathrm{~mm}$.; breadth $13.5 \mathrm{~mm}$.; length of aperture $11 \mathrm{~mm}$; length of anterior canal $21 \mathrm{~mm}$.

Form. and Loc.-Eocene: Muddy Creek, Victoria.

G. 9435. Examples of the neanic stage.

Purchased.

\section{Fusus senticosus, Tate.}

1888. Fusus senticosus, Tate, Trans. Roy. Soc. South Aust. vol. x. p. 135, pl. vii, fig. 3.

1893. Fusus senticosus, Tate and Dennant, id. vol. xrii. pt. 1, p. 219.

Shell small, elongate, fusiform, thin; protoconch similar to that in typical forms of the geuus, it is much elerated, composed of one and a half smooth turus longitudinally striated towards the anterior; the shell in the brephic stage suddenly derelops a strong median carina which rapidly becomes tubular at intervals and continues to increase in size to the body-whorl, imparting an angulose character throughout. In front of this in the brephic stige is dereloped a minor keel of a similar description, and at a slightly later period of growth a small one makes its appearance posteriorly between the median carina and the suture. Subsequently others are gradually interposed until the penultimate whorl in the adult earries five such keels. The mode of growth is thus of a different character to that of most species of the same group, in which the main features of the ornament are foreshadowed at a very early stage. 
Professor Tate, in describing the ornament, says:- "Whorls squarely rouuded, deeply impressed at the suture, with fire eucircling ribs covered with tubular hollow spines, or slender, vaulted, pointed scales; the middle rib on the angle of the whorl stouter than the rest, and furnished with long spines. Last whorl shouldered and subtabulated, with two or three threads rarely wanting on the posterior slope; the rounded base and canal with equidistant similar spiral liræ, one or two on the canal are stouter aud provided with larger spines. The transrerse ornament is rery peculiar, consisting of imbricating lamellæ, nore or less radially disposed around the bases of the spines, and the bundles of one row somewhat alternating with those of the next."

The aperture is pyriform; outer margin slender, erenulated; columellar border covered with a thin deposit of callus which is continuous with the outer margin ; columella slightly excarated, twisted anteriorly, and terminating in a very long anterior canal.

The special character of the ornament and mode of growth of the shell are not very typical of Fusus, but the protoconch certainly is, as previously remarked; and the differences mentioned are not sufficiently important to remore the species from Fisus, sensu stricto.

Dimensions.-Length $14 \mathrm{~mm}$; ; breadth $5 \mathrm{~mm}$.; length of aperture $3 \mathrm{~mm}$.; length of canal $6 \mathrm{~mm}$.

Form. and Loc.-Eocene: Muddy Creek, Victoria.

G. 9437. Two specimens.

Purchased.

\section{Fusus craspedotus, Tate.}

1888. Fusus craspedotus, Tate, Trans. Roy. Soc. South Aust. vol. x. p. 134, pl. vii. fig. 4.

1893. Fusus craspedotus, Tate and Dennant, id. rol. xvii. pt. 1, p. 219.

Shell very thin, fusiform; with an elevated spire; protoconch composed of two smooth rounded turns; whorls angular, compressed into a narrow keel, serrate on the margin. The other ornament is described by Professor Tate as follows:- "Last whorl with the posterior slope convex, depressed behind the keel, and much more so at the suture; the rounded and contracted base is produced into a long, rather broad, somewhat flexuous beak; ornamented on the posterior slope with numerous inconspicuous spiral threads, 
and towarls the middle by two or three prominent ones, crossed by growth-lines which are raised into minute scales on the larger liræ; bases of serrations with rounded ridges, conformable with their currature. Base of body-whorl encircled by a slender keel, which is coincident with the posterior angle of the aperture; the whole surface roughly cancellated by numerous unequal spiral threads and lamellæ of growth; beak encircled with spiral threads and two or three ridges carrying vaulted scales." The aperture is pyriform, opening widely anteriorly and angulate at the outer margin; columella slightly twisted; anterior canal long, open.

As mentioned on p. 54, this species bears considerable external resemblance to certain forms of Columbarium, and it would have been included in that genus only that the protoconch is different and more nearly resembles that of a Fusus. Further, the aperture is more open and the columella is not covered in the same manner. The species is by no means a typical Fusus, as exemplified, for instance, by $F$. colon. For further observations on its systematic position see ante, p. 54 .

Dimensions. - Length $44 \mathrm{~mm}$.; breadth $16 \mathrm{~mm}$.; length of aperture $9 \mathrm{~mm}$.; length of canal $21 \mathrm{~mm}$.

Form. and Loc.-Eocene: Victoria.

48052. Several examples illustrating stages of growth; from Schnapper Point.

Purchased.

G. 4284. Specimens with spire very much elongated; from Muddy Creek.

Presented by John Dennant, Esq.

G. 4747. An example of the adult; from Muddy Creek.

Presented by Professor T. Rupert Jones, F.R.S.

G. 5522. Two specimens of the adult; from Muddy Creek.

Purchased.

\section{Genus LATIROFUSUS, Cossmann.}

[Ann. Soc. Roy. Malac. Belg. t. xxiv. 1889, p. 175.]

Shell very narrow; protoconch smooth and globose, ornamented by spiral strixe and small longitudinal ribs; aperture small and rounded; auterior canal long, straight, almost closed, the external aspect merely presenting a narrow slit; columellar border ofteu detached and having one or two oblique plications anteriorly.

In general configuration Latirofusus is not unliko Fusus, but 
it may be readily distinguished from that genus by the unique, costated protoconch and the columellar plaits.

Type.-Fusus funiculosus, Lamarck.

\section{Latirofusus aciformis, Tate (sp.).}

1888. Fusus aciformis, Tate, Trans. Roy. Soc. South Aust. vol. x. p. 139, pl. vii. figs. $5 a-b$.

1889. Latirofusus aciformis, Cossmann, Ann. Géol. Univ. t. v. p. 1089.

1893. Latirofusus aciformis, Tate and Dennant, Trans. Roy. Soc. South Aust. vol. xvii. pt. 1, p. 219.

1894. Latirofusus aciformis, Tate, Journ. Roy. Soc. N.S.W. rol. xxvii. p. 171 .

Shell elongate with tapering spire; protoconch not well preserred in the Museum specimens, but evidently smooth or slightly pointed at the commencement and longitudinally costated anteriorly; whorls but slightly convex, costate, spiral ridges well pronounced, crossed by irregular lines of growth, and, in the brephic stage, slightly cancellate; body-whorl inflated, descending sharply in front to join the long anterior canal, spiral ridges very prominent and becoming oblique and undulating on the canal proper; aperture rounded, contracted in front; outer margin rather thick, lirate within; inner margin detached from the columella, carrying a small plication anteriorly and another on a slight callosity posteriorly; canal almost closed.

The species is variable in regard to its ornamentation, some individuals having hardly a trace of longitudinal costæ; the bolder spiral ridges commonly have a single lineation between them. Compared with L. funiculosus, Lamarck, with which M. Cossmann ${ }^{1}$ thought it might possibly be synonymous, we find that $L$. aciformis is proportionately narrower and does not possess the latiriform longitudinal costre so characteristic of the Paris Basin shell. The protoconch of the latter is, relatively, much smaller, and the shell as a whole is more solid.

Dimensions. - Length $30 \mathrm{~mm}$.; breadth $7.5 \mathrm{~mm}$.; length of aperture $5 \mathrm{~mm}$; length of anterior canal $11 \mathrm{~mm}$.

Form. and Loe.-Eocene: Muddy Creek, Victoria. 
G. 4288. A specimen having strong spiral ridges, longitudinal costre being suppressed.

Presented by John Dennant, Esq.

G. 9469. A series exhibiting stages of growth; the largest specimen is finely costate, and one of the others, apparently a monstrosity, is bent or twisted in its length and slightly cancellate.

Purchased.

\section{Genus STREPTOCHETUS, Cossmann.}

[Ann. Soc. Roy. Malac. Belg. t. xxiv. 1889, p. 170.]

Shell fusiform; with an obtuse protoconch; ornamented by nodose costr; apcrture shorter than the spire; canal twisted, rather long; columella cxcavated, inflected in front, often carrying oblique plications, one of which is more salient than the others; outer margin slightly sinuous, not crenulated.

It is distinguished from Latirus by its more simple ornamentation, by the columella, its outer margin not being crenulated, and by the protoconch, which is analogous to that of Clavella.

Type.-Fusus intortus, Lamarck.

\section{Streptochetus exilis, Tate (sp.).}

1888. Fasciolaria exilis, Tate, Trans. Roy. Soc. South Aust. vol. x. p. 149, pl. x. fig. 3 .

1893. Fasciolaria exilis, Tate and Dennant, id. rol. xvii. pt. 1, p. 219.

Shell fusiform, clongate; spire acuminate, protoconch composed of two smooth, elevated, conrex turns, faintly costate in front; whorls flatly convex, longitudinally obtusely plicate, and crossed spirally by bold thread-like lineations of rarying size; costre about eight in number on the penultimate whorl of the adult; bodywhorl gradually descending to the long tapering canal; aperture elongate, broadly opened in front; outer margin simple, except for the intersection of the spiral ornament, which renders it slightly sinuous; columella coneare, and with two or three small oblique plaits, only one of which is rery prominent.

Professor Tate describes the aperture as being lirate within, which may be characteristic of the adult, but the specimens in the IIuscum collection are quite smooth. The species is like 
a miniature $S$. incertus, Deshayes, of the Paris Basin, except for minor details of ornament on the whorls. The figure accompanying Professor Tate's memoir hardly does justice to the shell.

Dimensions.-Length $12 \mathrm{~mm}$.; breadth $3.75 \mathrm{~mm}$; length of aperture $3 \mathrm{~mm}$.

Form. and Loc.-Eocene: River Murray eliffs, near Morgan, South Australia.

G. 9439. Two specimens.

Purchased.

\section{Genus FASCIOLARIA, Lamarck.}

[Mém. Soc. Ilist. Nat. Paris, 1799, p. 73.]

The animal of Fusciolaria closely resembles that of Fusus, and the two genera are unquestionably of the same origin. It is difficult to satisfactorily separate the shells in the recent state, and increasingly difficult as we pass from recent through older deposits into the Eocene. In general, Fasciolaria may be dis. tinguished in having a shorter spire, more inflated body-whorl, a wider and more sinuous or flexuous canal; but the oblique plications on the anterior portion of the columella are the principal differentiating characters.

Type.-DIurex tulipa, Linnæus.

\section{Fasciolaria cristata, Tate.}

1888. Fasciolaria eristata, Tate, Trans. Roy. Soc. South Aust. vol. x. p. 151, pl. viii. fig. 4 .

1893. Fasciolaria cristata, Tate and Dennant, id. vol. xrii. pt. 1, p. 219.

Shell fusiform, broad; protoconch composed of two smooth, bulbous turns, the anterior part being longitudinally corrugated, though the rough costa are not immediately connected with the ornamentation of the whorls proper; spire elesated and tapering; whorls medially serrate, the serrations being flattened, their posterior surface leading by a sloping, undulating platform, np to the suture; this broad platform is spirally lineate, the lines being of unequal size; in front of the median serrate carina are three minor ones of similar character, between which are numerous undulating spiral lines; the anterior portion of the body-whorl is 
also eneireled by eyeles of lineations, and the whole are rendered slightly uneven by the passage of the elosely-set growth-lines; aperture orate, but eontracted and drawn out in front; outer margin thin, striate, and lirate within; columellar border smooth, with three conspicuous, drawn-out plaits, situated anteriorly; canal long and sinuous, especially in the adult.

One specimen in the Museum collection is larger than the type as measured by Professor Tate; its dimensions are given below. This speeies is of the same general character as the living $F$. papillosa, Sowerby, which Tryon ${ }^{1}$ says is the young of F. gigantea, Kiener; the former name, howerer, has priority. The spire of the fossil is relatirely shorter, the whorls are more serrate, and the anterior canal is longer.

Dimensions. - Length $73 \mathrm{~mm}$.; breadth $31 \mathrm{~mm}$.; length of aperture $20 \mathrm{~mm}$.; length of canal $24 \mathrm{~mm}$.

Form. and Loc.-Eocene: Victoria.

70420. A fine example of the senile stage; from Meribee river.

Purchased.

73231. Two specimens of the neanie stage; from Schnapper Point.

Purchased.

G. 4289. An example of the adult; from Muddy Creek.

Presented by John Dennant, Esq.

Fasciolaria rugata, Tate.

1888. Fasciolaria rugata, Tate, Trans. Roy. Soc. South Aust. rol. x. p. 152 , pl. viii. fig. 3 .

1893. Fasciolaria rugata, Tate and Dennant, id. vol. xrii. pt. 1, p. 219.

This speeies differs from $F$. cristata in having a less elerated spire, a shorter anterior eanal, and in being less spinose, though the gencral character of the ornament is somewhat similar. The protoconeh is composed of two smooth globose turus, the front portion being striate and obscurely eostate; its junction with the shell in the brephic stage is rery abrupt. The columella carries three plaits, the largest being situated anteriorly, and bordering a sharp twist leading to the eurred canal. 
Dimensions. - Length $36 \mathrm{~mm}$; breadth $17 \mathrm{~mm}$.; length of aperture $13 \mathrm{~mm}$.; length of canal $11 \mathrm{~mm}$.

Form. and Loc.-Eocene: Victoria.

48052. Two specimens; from Schnapper Point. Purchased.

G. 5525. An example in which the spiral lines are much reduced in size; from Muddy Creek.

Purchased.

G. 9438. Specimens having the rugose costæ more spinose; from Muddy Creek.

Purchased.

\section{Fasciolaria cryptoploca, Tate.}

1888. Fasciolaria cryptoploca, Tate, Trans. Roy. Soc. South Aust. vol. x. p. 151, pl. viii. fig. 2.

1893. Fasciolaria cryptoploca, Tate and Dennant, id. rol. xrii. pt. 1, p. 219.

Shell fusiform; spire moderately elevated; protoconch similar to that of $F$. cristata and $F$. rugata; earlier whorls flatly convex, and graduating to tabulated in the two anterior volutions. Professor Tate describes the ornament as follows:- "Anterior whorls with nine plications to each whorl; plicæ narrowly rounded, elevated into sharpish conical tubercles at the shoulder, separated by wide, shallow, and open furrows, dying out on the posterior slope and on the base of the body-whorl; the ornament consists of acute spiral ridges, alternately large and small (about twenty on the penultimate whorl), separated by rather wider augular furrows, roughened by transrerse lamellæ of growth." Aperture orate, contracted both in front and behind; outer margin crenulated, oblique, and having closely-set, interrupted liræ within; inner margiu detached from the columella in adult specimens, with a prominent fold at the posterior extremity near the suture, and a very oblique plication bordering the entrance to the canal from within, with two or three smaller ones behind; the detached inner border is continued to the extremity of the long, twisted, anterior canal, creating a pseudo-umbilicus.

This species has considerable analogy with $F$. rugata, and, indeed, they are barely worthy of separation specifically. The latter, however, has fewer and more rapidly enlarging whorls, which are about equally sloping from the periphery to the suture.

Dimensions.-Leugth $53 \mathrm{~mm}$.; breadth $24 \mathrm{~mm}$.; length of aperture $18 \mathrm{~mm}$.; length of canal $16 \mathrm{~mm}$. (anterior extremity broken off). 
Form. and Loc.-Eocene: Muddy Creek, Victoria.

G. 4253. An example of the senile stage, callous at the posterior extremity of the columellar border.

Presented by John Dennant, Esq.

G. 5526. An example of the adult stage with thick outer margin, and coarse granose liræ within.

Purchased.

Fasciolaria decipiens, Tate.

18s8. Fasciolaria decipiens, Tate, Trans. Roy. Soc. South Aust. rol. $x$. p. 150 , pl. viii. fig. 1.

1893. Fasciolaria decipiens, Tate and Dennant, id. vol. xvii. pt. 1, p. 219.

The spire of this shell is more elerated than in $F$. cryptoploca, it is more tapering and narrower; the ornament on the whorls is of the same general character; the aperture is narrower and dramu out; the columellar border is often detached, and carries two small plaits in front. In the adult the columellar plications are barely perceptible, being situated well within the aperture, so that the shell is somewhat like Aptyxis, Troschel, with which subgenus it is unquestionably closely allied. The passage from Fusus to Fasciolaria may be readily understood from a consideration of this species.

$F$. decipiens bears considerable external resemblance to Fusus nigrirostratus, E. A. Smith, living in the seas of Japan, south of Corca; but the latter species, though haring a twisted columella, possesses no plaits, and is a true Aptyxis.

Dimensions. - Length $48 \mathrm{~mm}$.; breadth $19 \mathrm{~mm}$.; length of aperture $16 \mathrm{~mm}$; ; length of canal $11 \mathrm{~mm}$.

Form. and Loc.-Eocene: Victoria and South Australia.

G. 4252. Examples of the adult; from Muddy Creek. Presented by John Dennant, Esq.

G. 4285. A specimen of the neanic stage; from M[uddy Creek. Presentcd by John Dennant, Esq.

G. 5523. A rery elongate form; from Muddy Creek. Purchased.

G. 9440. An example showing extreme rariation; the longitudinal coste are subnodose at the periphery, and the shell is broader than in typical specimens; from River IIurray cliffs. 
G. 9441. Mutilated specimens exhibiting columellar plaits; from Muddy Creek.

Purchased.

Fasciolaria johnstoni, Tenison-Woods (sp.).

1977. Fusus jolinstonii, Tenison-Woods, Pap. Roy. Soc. Tas. 1876, p. 94.

1878. Fusus johnstonii, R. Etheridge, jun., Cat. Aust. Foss. p. 164.

1888. (?) Fusus johnstoni, Johnston, Geol. Tasmania, pl. xxxi. figs. 7, 8, 10, 17 (indet.).

1S88. Fusus johnsioni, Tate, Trans. Roy. Soc. South Aust. vol. x. p. 136, pl. xii. figs. $4 a-b$.

1896. Fusus johnstoni, Pritchard, Proc. Roy. Soc. Vict. vol. viii. x.s. p. 83.

Shell fusiform; spire narrow, elevated; whorls convex, angulate at the periphery, longitudinally costate, and closely spirally lineate; costæ broad, rounded, from 8 to 10 on the penultimate whorl; aperture pyriform, opening in front to the broad, long, anterior canal; outer margin thin, simple, striate within; columella with two plications.

This species differs from $F$. decipiens in the mode of development of the longitudinal costæ, in minor details of ornament, and in having a comparatively straight colnmella and canal. It cannot be classified with Fusus, because of its columellar plications.

Dimensions. - Length $26 \mathrm{~mm}$.; breadth $11.5 \mathrm{~mm}$.; length of aperture $8.5 \mathrm{~mm}$.

Form. and Loc.-Eocene: Table Cape, Tasmania.

G. 9434. Three specimens, only one of which, with columellar plaits, is well preserved.

Purchased.

\section{Genus LATIRUS, Montfort.}

[Conch. Syst. t. ii. 1810, p. 531.]

Shell fusiform, turreted, spire costate; aperture oblong, outer margin thin by comparison with the general solidity of the shell, erenulate; columellar border slightly twisted, carrying two or three small oblique plaits anteriorly; sometimes umbilicate; anterior canal rather long.

Latirus differs from Peristernia (in which the majority of the species of Latirus here described have been included by Australian 
anthors) in haring a longer spire and canal, whilst the columellar plaits are more central. The presence of an umbilieus in Latirus has also been regarded as a differentiating character, but it is not constant. On the other hand, Peristernia is credited with haring a recurred canal, in which particular many of the Australian fossils here called Latirus agree with it, though their canals are long. It is questionable whether the slight and inconstant differences indicated warrant generic separation, the distinction between Latirus and Peristernia being entirely arbitrary. Howerer that may be, the Australian forms alluded to are, in the ensemble of their characters, more nearly related to the former than to the latter.

Type._Latirus aurantiacus, Montfort.

\section{Latirus approximans, Tate (sp.).}

188s. Peristernia approximans, Tate, Trans. Roy. Soc. South Aust. rol. x. p. 153 , pl. ix. fig. 2 .

Shell fusiform; spire elerated; whorls medially subangulate, spirally lineate, longitudinal costæ broad, distant, subacute at the peripheral subangulation; body-whorl sloped and constricted anteriorly, the costr becoming obsolete on the front half, though corrugated lines of growth persist, and the spiral lineations are rery conspicuous; aperture orate, deeply channelled in front; onter margin curved, lirate within; inner margin enamelled, the enamel continuing from the suture, in the neighbourhood of which is a small denticle; eolumella excarated, umbilicate, having a small oblique fold opposite the entranee to the canal; the latter is long, broad, eurred, and slightly turned up at its extremity.

The columellar fold can hardly be termed a plication, and is not so well pronounced as in the majority of characteristic species of Latirus. Professor Tate discusses its affinities at some length.

Dimensions. - Length $27 \mathrm{~mm}$. ; breadth $14 \mathrm{~mm}$. ; length of apcrture $9 \cdot 5 \mathrm{~mm}$. ; length of canal $8 \mathrm{~mm}$.

Form. and Loc.-Wiocene: Muddy Creek, Victoria.

G. 9459. An example of the adult, and two specimens illustrating the neanic stage.

Purchased. 


\section{Latirus murrayanus, Tate (sp.).}

1888. Peristernia murrayana, Tate, Trans. Roy. Soc. South Aust. vol. x. p. 155.

1889. Peristemia murrayane, Tate, $i d$. vol, xi. p. 117, pl. iv. fig. 4.

1893. Peristernia murayana, Tate and Dennant, id. vol. xvii. pt. 1, p. 219.

1896. Peresternia murrayana var. costata, Pritchard, Proc. Roy. Soc. Vict. vol. viii. N.s. p. 87 , pl. ii. fig. 4 .

Spire more elevated than in $L$. approximans; whorls obtusely costate, nodose at the periphery, and spirally lineate; aperture rounded; outer lip rather thick, faintly lirate within, and having a prominent denticle in front; columella concave, carrying a bold plait juxtaposed to the denticle referred to, and two or three smaller plaits or elongate tubercles behind; canal rather long and bent.

Its nearest ally is L. morundianus, Tate (not represented in the Mruseum collection), which, however, is much larger; whilst the whorls more rapidly increase in $L$. murrayanus, its tubercles are relatively smaller and are trisected. The protoconch of the present species (Plate V. Figs. $6 a-b$ ) is large, conrex, composed of two and a half turns, the earlier portion being oblique with reference to the axis of the shell, the later part bearing longitudinal strix; the shell in the brephic stage is boldly, longitudinally costate and spirally lineate.

Conchologically L. murrayanus resembles "Murex" afer, Gmelin, the type of the genus Afer, Conrad ${ }^{1}$; whilst it also has some affinities with "Tudicla" porphyrostoma, Adams and Reere, the type of the genus Streptosiphon, Gill, ${ }^{2}$ which the present writer believes to be synonymous with Afer. The claims of the term Streptosiphon to priority do not appear to rest on very secure grounds. Fiscleer ${ }^{3}$ admits that $A$ fer is synonymous, but retains the name Streptosiphon, as Conrad did not define Afer. As Tryon ${ }^{4}$ says, although Conrad did not describe his genus, he made Murex afer (or Fusus afer), Gmelin, the type of it; from which it is not

1 Jouru. Acad. Nat. Sci. Philad. v.s. vol. iii. 1858, p. 332.

2 Amer. Jonrn. Conch. vol. iii. 1867, p. 152.

3 Manuel de Conchyl. 1884, p. 619.

4 Manual of Couchology, 18s1, vol. iii. p. 69. 
difficult to see what Conrad meant. Whaterer views we may hold as to the propriety or otherwise of making genera in that fashion, Afer has as much right to stand as many other genera established in the same way.

L. murrayanus differs from both Afer afer and A. porphyrostoma in the character and derelopment of the protoconch, in which respect it more nearly resembles the Australian species here classed as Latirus. With this exception the separation of the species from Conrad's genus is purely arbitrary, and eonchologically it is intermediate between the two genera mentioned.

The form found at Table Cape, Tasmania, and described by Mr. G. B. Pritchard in the memoir above eited, is more costate, and the whorls are not so distinctly angulate as in typical examples of the species from the River Murray. The species appears to be very variable.

Dimensions. - Length $27 \mathrm{~mm}$; breadth $14 \mathrm{~mm}$.; length of aperture $9 \mathrm{~mm}$; length of canal $8.5 \mathrm{~mm}$.

Form. and Loc.-Eocene: River Murray cliffs, near Morgan, South Australia.

G. 9137. An example of the neanic stage of growth.

Presented by William Evans, Esq.

G. 9460. Three specimens of the adult.

Purchased.

\section{Latirus interlineatus, Tate (sp.).}

1888. Peristernia interlineata, Tate, Trans. Roy. Soc. South Aust. vol. x. p. 159 , pl. vi. fig. 1 .

1893. Peristernia interlineata, Tate and Dennant, id. vol. xvii. pt. 1, p. 219.

Shell fusiform, spire elerated, staged; protoconeh similar to that of L. murrayanus; whorls spirally ridged. Deseribed by Professor Tate as follows :- "Ridges angular, acute, three or four of which on the median portion of the spire-whorls forming keels; the broad concare furrows with a thread, crossed by straight distant strix. On the body-whorl the ridges are more serrately cut by the transverse striæ than those are on the spire." Aperture orate, broadened outwarlly; outer margin lirate within, with a large denticle at the entrance of the eanal; inner margin corered with a thin deposit of callus, sometimes partially detached, carrying 
an obscure tubercle posteriorly and a strong oblique plait (juxtaposed to the large denticle referred to), together with a few small, irregular tubereles, anteriorly ; canal very long, bent, and slightly twisted. It may be readily distinguished from the species of Lutirus already described by its bold spiral ridges and by the absenee of pronounced longitudinal costæ.

Dimensions. - Length $24 \mathrm{~mm}$.; breadth $12 \mathrm{~mm}$.; length of aperture $8 \mathrm{~mm}$.; length of canal $8 \mathrm{~mm}$.

Form. and Loc.-Eocene: Muddy Creek, Victoria.

G. 4264. Two examples of the adult.

Presented by Joln Dennant, Esq.

\section{Latirus succinctus, Tenison-Woods (sp.).}

1880. Trophon succinctus, Tenison-Woods, Proc. Linn. Soc. N.S.W. vol. iv. p. 16, pl. iv. figs. $6,6 a$.

1888. Peristernia succincta, Tate, Trans. Roy. Soc. South Aust. vol. x. p. 158.

1893. Peristernia succincta, Tate and Dennant, id. vol. xvii. pt. 1, p. 219.

Much more tumid than either L. interlineatus or L. subundulosus, though belonging to the same group. The shell is turbinate; protoconch similar to those of the two species mentioned; whorls substaged, strongly spirally ridged, the ridges being relatively far apart and unequal in size, interspaces roughly corrugated, especially on the body-whorl of senile examples, lines of growth oceasionally breaking through, obscurely longitudinally costate, this feature being most notieeable in the neanic stage of growth; aperture rounded; outer margin striate within; colnmella smooth, deeply excarated, and carrying a eonspicuous fold anteriorly bordering the entrance to the eanal, with a few very small dentieles belind; eanal bent and twisted, and rather deep.

Dimensions. - Length $28 \mathrm{~mm}$.; breadth $17 \mathrm{~mm}$. ; length of aperture $11 \mathrm{~mm}$; length of eanal $8.5 \mathrm{~mm}$.

Form. and Loc.-Eocene: Muddy Creek, Victoria.

G. 4189. An example of the neanic stage of growth, showing longitudinal corrugations.

Presented by John Dennant, Esq.

G. 5521. A specimen illustrating the adult stage, with anterior canal much twisted.

Purchased. 


\section{Latirus subundulosus, Tate (sp.).}

1858. Peristernia subundulosa, Tate, Trans. Roy. Soc. South Aust. vol. x. p. 159 , pl viii. fig. 12 .

1893. Peristernia subundulosa, Tate and Dennant, id. vol. xvii. pt. 1, p. 219.

This so elosely resembles $L$. interlineatus that it might almost be regarded as an extreme form of that species; the whorls are more regularly convex, the spiral ridges more flatly rounded, and there are other minor differences in the ornament which led its author to regard $L$. subundulosus as a distinet speeies.

Dimensions. - Length $23 \mathrm{~mm}$.; breadth $11.5 \mathrm{~mm}$.; length of aperture $8 \mathrm{~mm}$.; length of eanal $6.5 \mathrm{~mm}$.

Form. and Loc.-Eocene: Muddy Creek, Victoria.

G. 9461. Three speeimens illustrating stages of growth.

Purchased.

\section{Latirus tatei, sp. nov.}

[Plate V. Figs. $7 a-b$.

Shell small, fusiform; protoconch smooth, eomposed of two and a half turns, the earlier portion being lateral and very small, the suture is bordered by a slightly elerated keel seen only in well-presersed speeimens, surface microscopically granulate; the anterior portion of the protoconeh is at first somewhat inflated, and then becomes constricted and longitudinally striated as it passes into the brephic stage; spire moderately elevated, with nive short, conrex whorls; ornament eonsisting of widely distant, broad, obtuse costæ, extending from suture to suture, exeept orer the narrow, undulating, striated band bordering the suture posteriorly, regarded from above the whorls appear polygonal, commonly hexagonal; the body-whorl in the adult is frequently depriced of these, but is furnished with a thiek, almost varicose anterior margin; surface of the shell strongly spirally lineate, a thin lineation alternating with a bolder one in the later stages of growth, the interruptions of the lines of growth producing a semi-granulate and undulating appearmee; aperture ovate, broadly ehannelled in front; outer margin thick, lirate within, the eallosity being continued round the acute posterior channel and terminated 
on the inner border by a couspicuous denticle; colnmella excarated and carrying an acute fold anteriorly, with traces of accompanying granulations in the gerontic stage; canal moderately long and slightly bent.

Compared with L. nurrayanus, it is much smaller, though of the same general build; it is relatively more elongate, whilst the obtuse costæ, plain body-whorl, thickened outer margin, and the fewer number of plications on the columella in the present specics are very characteristic, readily serving to distinguish it from all the other species of Latirus.

Dimensions. - Length $12.5 \mathrm{~mm}$. ; breadth $6 \mathrm{~mm}$. ; length of aperture $4 \mathrm{~mm}$; length of canal $2.75 \mathrm{~mm}$.

Form. and Loc.-Eocene: Spring Creek, Victoria.

G. 9860. A series exhibiting stages of growth. Purchased.

\section{Genus LEUCOZONIA, Gray.}

[Proc. Zool. Soc. 1847, p. 136.]

This genus, closely allied to Latirus, is more globose, has a short, keeled spire, a very short anterior canal, excarated columella with three or four oblique plications, the outer margin being plicated internally and especially characterized in typical examples by a prominent and often very long denticle on the forepart, opposite the columellar plications.

Type.-Murcx nassa, Gmeliu.

Leucozonia nassa, Gmelin (sp.).

[Plate V. Figs. 11a-b.]

1790. Muvex nassa, Gmelin, Linn. Syst. Nat. tom. i. pars 6, Vermes, p. 3,551, No. 93.

1822. Turbinella eingulifere, Lamarck, Hist. Nat. Anim. sans Vert. t. vii. p. 107.

1851. Lencozonia cingulifera, Tryon, Manual of Conchology, vol. iii. p. 94.

Shell fusiform, solid; whorls angulate at the periphery, whore broad, undulating, longitudinal costæ are comprossed, producing serration in typical examples; body-whorl carrying one or more 
nodose, distant, spiral carinæ in front of the peripheral angulation, and sharply depressed half way botween the latter and the end of the caual; surface of the whorls bearing sereral more or less conspicuons, undulating spiral lineations; aperture orate, broad in front; outer margin thin, bearing a small tooth-like projection anteriorly, lirate within, grooved posteriorly; inner margiu furnished with one or two salient, elongate ridges bordering the posterior channel, excavated; columella umbilicate, smooth, and, typically, carrying four plications, the one in front being smallest; anterior canal short, broad, and slightly bent.

This species is exceedingly variable, but the specimens commonly found in the West Indies, and particularly from St. Vincent, are typical, and are almost identical with the specimen from the Pliocene beds of the Chatham Is., in the Museum collection. Living examples have been obtained from the west coast of Africa, Florida, and Brazil, as well as in the West Indies.

Compared with Latirus barclayi, Reere, the whorls of the spire are similarly ornamented, but the aperture of the last. mentioned species is narrower, the columellar plaits are smaller and more numerous, and are not in the same position, whilst the canal is very much longer.

This shell is commonly known as L. cingulifera, Lamarck, but the name here adopted has priority. This fact has been recognized by authors,' but $L$. nassa appears to have been ignored because Gmelin included other species in his description and references, a riew which cannot be entertained. Following usage, we consult the first reference given by Gmelin, ${ }^{2}$ which is undoubtedly the species under description, and which should therefore bear the name of nassa.

Dimensions. - Length $49 \mathrm{~mm}$. ; breadth $27 \mathrm{~mm}$. ; length of aperture and canal $27 \mathrm{~mm}$.

Form. and Loc.-Pliocene: obtained from a rell-digging ten feet in depth, Chatham Islands.

G. 9672. An example of the adult.

Transferred from the Ifuseum of Practical Geology.

E.g. Tryon, Manual of Conehology, rol. iii. 1881, p. 95.

2 Lister, Hist. Couch. lib. iv. 1688, No. 828, fig. 50; also ed. 1770 (same No. and fig.). 
Subgenus LATIROLAGENA, nom. mut.

Lagena, Schumacher, Essai Nouv. Syst. Habit. Testacés, 1817, p. 240; non Walker and Boys, 1784; non Bolten, 1798.

Distinguished from typical examples of Leucozonia by the absence of keels on the whorls, the latter being rounded; the shell is bucciniform and devoid of conspicuous ornament, whilst the denticle or tubercle (when present) on the outer margin is extremely rudimentary.

The name Lagena, Schumacher, commonly employed, is preoccupied by that given to the well-known genus of foraminifera by Walker and Boys, and it refers also to one of the Tritonidæ, if Bolten's work is to be accepted. Plicatella, Swainson ${ }^{1}$ (non Schmidt, 1870), is sometimes alluded to as being synonymous with Lagena, but the first species mentioned by that author as ascertained on reference to the work he quotes, ${ }^{2}$ is Fusus polygonus, Lamarck (erroneously given as "polyzono" by Swainson), and that has been selected by Dr. Gray ${ }^{3}$ as the type of Plicatella. Swainson substituted the last-mentioned name for Polygona, Schumacher, ${ }^{4}$ rejected on aceount of being preoccupied in Botany, which, however, is not a valid ground for exclusion following the rules of nomenclature as usually interpreted at the present day. If, therefore, we have recourse to Polygona, we find on reference to the type quoted by Schumacher that that gerreric name could not possibly apply to such forms as he included in the genus Lagena. The Lagena of Klein, ${ }^{5}$ being pre-Linnean, ought not to be recognized. Under these circumstances the present writer cannot, in suppressiug Lagena, Schumacher, utilize either Polygona or its synonym Plicatella, and now suggests the name Latirolagend iustead, as indicating its affinities with Latirus.

It is related to Mazzalina, Conrad, but the type of that genus (II. pyrula, Conrad) is strongly plicate, the several plaits being implauted obliquely on a profoundly excavated columella; that

1 Malacology, 1840, p. 304.

${ }^{2}$ Eney. Meth. pl. eccexxiï. fig. 1.

3 Proc. Zool. Soc. 1847, p. 136.

4 Essai Nouv. Syst. Habit. Testacés, 1817, p. 241.

5 Ostracologies, 1753 , p. 49 , tab. iii. No. 61 . 
genus is not umbilicate, and the outer margin is of a different character.

Type.-Buccinum smaragdulum, Linnæus.

\section{Leucozonia (Latirolagena) staminea, Tate.}

1888. Leucozonia staminea, Tate, Trans. Roy. Soc. South Aust. rol, х. p. 163, pl. ix. fig. 13.

1893. Lewcozonia staminea, Tate and Dennant, $i d$. rol. xvii. pt. 1, p. 219.

Shell bucciniform, globose, solid; protoconeh (Plate V. Figs. 8a-b) composed of one and a half turns, the earlier portion being exeeedingly small, subsequently becoming large, much inflated and oblique with reference to the axis of the shell, the later portion is distinetly longitudinally costated, whieh ornament obtains to the fraeture denoting the commeneement of the brephie stage of growth; whorls to the number of four, conrex, slightly concare in the neighbourhood of the sutnre posteriorly, and ornamented with closely-set spiral lines, some of which are regularly and distantly spaced and much more aecentuated on the anterior half of the body-whorl, smaller ones appearing between; lines of growth conspienous, cansing minute granulations at the points of interseetion with the spiral lineations; aperture orate, broad in front; onter margin sinuous, lirate within; columellar border smooth, exeavated, carrying three slightly oblique plaits anteriorly, each terminating with a compressed dentiele; canal short and broad.

The costæ on the anterior portion of the protoconch are very remarkable, this eharacteristic not being perpetuated in later stayes of growth, and seeming to indieate that Latirolagena had its origin in costate forms such as Latirus, or Fasciolaria. Turning to liring examples of the subgenus, we find in certain indiriduals of L. leucozonalis, Lamarck, a persistent attempt to preserve and eren to accentuate the costate character referred to, the coste remaining even in later stages of growth. Typieal examples of that species, now liring in the West Indies, and of its ally L. subrostrata, Gray, found in the Bay of Montija, West Columbia, closely resemble $L$. staminea. L. smaragduta, Linnaus, of the Philippines, is more globose, has a more profoundly excarated columella, a shorter canal, aud wider aperture than has the last-mentioned fossil species. 
Dimensions. - Length $15 \mathrm{~mm}$; breadth $9 \mathrm{~mm}$.; length of aperture and canal $9.5 \mathrm{~mm}$.

Form. and Loc.-Eocene: Gellibrand river, Victoria.

G. 9490. An example of the adult.

Purchased.

\section{Family BUCCINIDA.}

\section{Genus TRITONOFUSUS, Beck.}

[Amtl. Bericht 24ste Vers. dentsche Naturf., Kiel, 1847, p. 217 ; id. Vers.

Naturf. Samml. p. 114 (author's name not given): vide Herrmannsen, Indicis Generum Malac. vol. ii. 1847, p. 611.]

Sipho (Klein), Mörch, Cat. Yoldi, 1852, p. 104 (non O. Fabricius, 1823, nec T. Brown, 1827, 1833, 1844).

Shell thin, usually fusiform, whorls rounded, typically smooth and striated; spire elerated; columella plain; canal produced and often recurved.

The term Sipho, commonly employed for this genus, was first proposed by Klein, ${ }^{1}$ but that author's work, being pre-Linnean, cannot be accepted. The name was brought on by Mörch in 1852, as above indicated. But in 1847 Beck had already proposed Tritonofusus, which is synonymous with Sipho, Klein, as interpreted by Mörch, and must therefore take priority.

Even if that were not the case, Sipho (Klein), Nörch, could not be adopted, as T. Brown had employed the term in 1827.2 If that be objected to on the ground that the work in which it was suggested was merely a collection of plates without deseriptions, Sipho (Sypho), Brown, must fall in sjnonymy with Puncturella, Lowe, 1827, though Brown subsequently attempted ${ }^{3}$ to establish his term.

In reference to Sipho, O. Fabrieius, 1823 (not 1822, as commonly quoted), that name was proposed in an auction eatalogue, ${ }^{4}$ referring to the books, natural-history specimens, etc., whieh belonged to Bishop Fabricius. ${ }^{5}$ Murex infundibulum, Gmel., appears to be

1 Ostracologicæ, 1753, p. 53.

2 Illust. Conch. 1827 , tab. 36 .

3 Conch. Text Book, 1833, p. 100 ; Illust. Conch. 1814, p. 61.

4 Fortegnelse over afg. Biskop Fabricius' efterladte Naturalier, 1823, p. 83.

5 Information kindly supplied to the writer by Dr. G. Bruu, Director of the Royal Library at Copenhageu. 
the type of this Sipho, but that species is distinctly a Latirus, and if any value attaches to an auction catalogne, for systematic purposes, Sipho, Fabricius, must be quoted in synonjmy with Latirus, Montfort, 1810.

The name Tritonofusus was, according to Herrmaunsen (see abore), proposed by Beck in 1846, and was at that time apparently a MS. name attached to some specimens in the Royal Museum at Copenhagen. During the meeting at Kiel above referred to, the conchological section saw the specimens, and an account of them was published in the "Amtl. Bericht" quoted, where the name Tritonofusus, with its type, are set forth, but the reporter's name is not given. In all probability the writer of the account was Herrmannsen, who was present at the meeting. In any case, he, in 1847 (op. supra cit.), quotes Beck as the author of the genus.

Type.-Fusus islandicus, Chemnitz.

\section{Tritonofusus crebrigranosus, Tate (sp.).}

1888. Sipho crebrigranosus, Tate, Trans. Ror. Soc. South Aust. vol. x. p. 145 , pl. iii. fig. 8 .

1S59. Sipho crebrigranosus, Cossmann, Ann. Géol. Univ. t. v. p. 1089.

1593. Sipho crebrigranosus, Tate and Dennant, Trans. Roy. Soe. South Aust. vol. xvii. pt. 1, p. 219.

Shell narrow, clongate; protoconeh (Plate V. Figs. 9a-b) composed of two and a half smooth, but slightly convex turns, the earlicr portion being much smaller relatively than the later, which is faintly longitudinally ridged; and this characteristic is much more accentuated in the brephic stage, where spiral lineations become devcloped, producing a tubercle at the points of intersection, the ormament being bolder than in later stages of growth; whorls convex, rounded, with elosely-set longitudinal and spiral lineations; aperture pyriform; outer margin thin, lirate within, prolonged by a slight callosity orer on to the inner margin ; columelli smooth, twisted; canal long and curved.

Dimensions. - Length $15 \mathrm{~mm}$.; breadth $5.5 \mathrm{~mm}$; length of aperture $4.5 \mathrm{~mm}$.; length of eanal $4 \mathrm{~mm}$.

Form. and Loc.-Eocene: Muddy Creek, Tietoria.

G. 9444. Three specimens illustrating stages of growth.

Purchased. 


\section{Tritonofusus labrosus, Tate (sp.).}

1888. Sipho labrosus, Tate, Trans. Roy. Soc. South Aust. vol, x. p. 144, pl. iii. fig. 7.

1889. Sipho labrosus, Cossmann, Ann. Géol. Univ. t. v. p. 1089.

Shell thin, narrow, elongate; protoconch composed of one and a half smooth globose turns, terminating abruptly against the shell proper, the ornament of the whorls not being foreshadowed; whorls angulate at the periphery, and carrying prominent, elerated, distant, irregular spiral threads, broken up by longitndinal lineations and growth-lines; aperture rounded; outer margin having a tendency to become rarieose, peristome continued, detached from the columella; canal long and slightly curved.

This differs from $T$. crebrigranosus in having subangulate whorls, in the lineations not being so closely set, and in their irregularity, also in the special character of the protoconch and continued peristome.

Dimensions. - Length $6 \mathrm{~mm}$.; breadth $2.5 \mathrm{~mm}$.; length of aperture and canal $3 \mathrm{~mm}$.

Form, and Loc.-Eocene: Nuddy Creek, Victoria.

G. 9445. An example of the neanic stage of growth. Purchased.

\section{Genus SIPHONALIA, A. Adams.}

[Ann. Mag. Nat. Hist. ser. 3, vol. xi. 1863, p. 202.]

Shell ovately fusiform, rather thin; body-whorl rentricose, usually nodosely costate and spirally lineated; aperture oral, onter margin thin; columella smooth, excavated, not plicate; canal twisted, generally short.

Tiype-Buccimum cassidariaformis, Reeve.

\section{Siphonalia longirostris, Tate (sp.).}

1888. Siphonatia longirostris, Tate, Trans. Roy. Soc. South Aust. vol. x. p. 143 , pl. xi. fig. 8 .

1893. Siphonatia longorostris, Tate and Deuuant, id. vol. xvii. pt. 1, p. 219.

This species is rery variable in character, but in general the shell is elongate-fusiform, with a high scalariform spire; protoconeh composed of two smooth turns, the later being spirally subcarinate 
and faintly longitudinally striate; whorls axially costate, the costæ of the spire-whorls extending from suture to suture, and rounded; body-whorl in the adult prominently costate at the periphery only; the whole of the whorls are deeply spirally lineate, and are crossed by frilled growth-lines, rendering the shell somewhat rugose; aperture pyriform, drawn out in front; outer margin rery thin, sulcated, and sometimes slightly lirate within; eolumella deeply coneave, covered by a striated thin coating of enamel, not plicate; anterior eanal twisted and sinuous.

The great length of the canal is a special feature of this species, and it is abnormal for the genus. Its rugose and scalariform spire distinguishes it from all other Australian Tertiary forms of Siphanalio. S. maxima, Tryon, living in Tasmanian seas, is an analogous species.

Dimensions (of a mutilated specimen).-Length of spire and aperture $63 \mathrm{~mm}$; breadth $28 \mathrm{~mm}$.

Form. and Loc.-Eocene: Victoria.

48052. Three examples of the neanic stage of growth; from Sihnapper Point.

Purchased.

G. 9433. An example of the senile stage, minus anterior canal; more rugose than speeimens from the other localities; from Mornington .

Purchased.

G. 9442. Specimen of the adult, having the canal well preserved; from Muddy Creek.

Purchased.

\section{Siphonalia tatei, Cossmann, MS.}

1SS8. Sipho asperulus, Tate, Trans. Roy. Soc. South Aust. vol. x. p. 145, pl. vi. fig. 5 .

1893. Siphonalia tatci, Cossmann, in litt. ${ }^{1}$

1893. Siphonalia tatci, Tate and Dennant, Trans. Roy. Soc. South Aust. vol. $x$ vii. pt. 1, p. 219.

Shell elongate, narrow, fusiform; protoconeh composed of one and a half smooth whorls, elevaterl, the earlier portion oblique, the later longitulinally costate, varieose at its termination; spire long, whorls flat, or but slightly convex, polygenal; ormament consisting of irregularly spaeed spiral threads, the most promineut one of which is situated anteriorly in the neighbourhood of the

1 Information kindly supplied by Professor Tate, at the writer's request. 
suture, and which rises into compressed subacute projections on distant, longitudinal costæ; the spiral orvament is rendered grauulate by the crossing of the frequent, scaly lines of growth; aperture ovate, broad in front; outer margin thin, lirate within, peristome continued over to the columellar border, from which it is slightly detached; canal long, oblique, and twisted.

Dimensions. - Leugth $17 \mathrm{~mm}$.; breadth $6 \mathrm{~mm}$.; length of aperture $4 \mathrm{~mm}$; length of canal $5.5 \mathrm{~mm}$.

Form. and Loc.-Eocene: Mruddy Creek, Victoria.

G. 9443. Three examples of the adult.

Purchased.

Siphonalia styliformis, Tenison-Wools (sp.).

1880. Fusus styliformis, Tenison-Woods, Proc. Linn. Soc. N.S.W. vol iv. p. 12, pl. iii. fig. 6.

1888. Sipho styliformis, Tate, Trans. Roy. Soe. South Aust. vol. x. p. 145.

1889. Sipho styliformis, Dennant, id. vol. xi. p. 41.

Shell fusiform, spire elevated; whorls conrex, with broad, obtuse, distant, longitudinal costre extending from suture to suture, and twisted in series, lines of growth very small, except on the suture, where they rise into reverted scales, spiral lines fairly equal in size, distant, and having a flat area between each; aperture ovate; outer margin thin, lirate within, grooved posteriorly; columella excavated, smooth, sharply turned at the entrance of the long bent canal.

Professor Tate describes the protoconch as follows: "Apex of two smooth whorls, joined to the spire by a thick rarix, behind which, for about half a whorl, the surface is costated, thence rapidly enlarging into a globose whorl terminating in a narrow, subimmersed tip."

The shell is relatirely broader than in $S$. tatei, the canal is shorter and more oblique, the longitudinal costre are more conspicuous, and the whorls are not so markedly polygonal.

Dimensions. - Length $13 \mathrm{~mm}$.; breadth $5.5 \mathrm{~mm}$.; length of aperture and canal $7 \mathrm{~mm}$.

Furm. and Loc.-Eocene: Muddy Creek, Victoria.

G. 4286. An example of the adult. 


\section{Siphonalia mandarina, Duclos (sp.).}

1831. Fusus mandarimus, Duclos, Mag. Zool. classe v. pI. viii.

1832. Fitsus zealandicus, Quoy and Gaimard, Toy. de I'Astrolabe, Zool.

t. ii. p. 500, pl. xxxiv. figs. 4,5 .

1873. Fusus mandarinus, Yon Martens, List Moll. X.Z. p. 18.

1873. Fusus zcalandicus, Hutton, Cat. Marine Moll. N.Z. p. 8.

1873. Fusus mandarinus, Hutton, id. p. 8.

1873. Fusus zealandicus, Hutton, Cat. Tert. Moll. N.Z. p. 2.

1873. Fusus mandarinus, Hutton, id. p. 3.

18s0. Neptunca zealandica, Hutton, Man. N.Z. Moll. p. 50.

1880. Teptunea (Austrofusus) mandarinus, Kobelt, Conch. Cab. (ed. Küster), p. 137 , pl. xlir. figs. $2,3$.

1881. Siphonalia (Austrofusus) mandarina, Tryon, Manual of Conchology, vol. iii. p. 138 , pl. lvi. fig. 384 ; pl. lvii. fig. 385 .

1886. Fusus (Neptunea) mandarimus, Watson, Voy. "Challenger," Zool. rol. $\mathbf{x r . ~ ( G a s t e r o p o d a ) , ~ p . ~} 200$.

1893. Siphonalia mandarina, Hutton, Liun. Soc. N.S.W., Macleay Mem. Tol. p. 41.

The young of this species somewhat resembles $S$. longirostris, though the sculpturing on the whorls of the latter species is more rugose, and the dentate tubereles on the periphery are much more pronounced. The protoconch of S. mandarina is relatively larger, aud it is turbinate. The costate and tuberculate ornament is lost with advaneing age, and adult specimens possess bolder spiral ridges. The inner margin, smooth in the joung, beeomes covered with a detached plate in the adult and senile stages.

Fusus zealandicus, Quoy and Gaimard, is inseparable from the present species, as is now generally recognized.

Dimensions. - Length $114 \mathrm{~mm}$.; breadth $54 \mathrm{~mm}$.; length of aperture and eanal $70 \mathrm{~mm}$.

Form, and Loc,-Pliocene: New Zealand.

G. 9556. Specimen of the gerontic stage, in which the detached plate on the inner margin is granose; from Wanganui (?).

Sir James Hector Coll.

G. 9597. An example of the neanic stage, with long anterior canal; from Onekakara.

Sir James Hector Coll.

G. 9609. Haring protoconch in good preservation; from Wangauni (?).

Sir James Hector Coll. 


\section{Siphonalia nodosa, Martyn (sp.).}

1784. Buccinum nodosum, Martyn, Univ. Conch. pl. v.

1832. Buccinum raphanus, Quoy and Gaimard, Yoy. de l'Astrolabe, Zool. t. ii. p. 428 , pl. iii. figs. 3,6 .

1841. Buccinum triton, Lesson, Rev. Zool. p. 37.

1842. Buccinum triton, Lesson, id. p. 237.

1847. Fusus nodosus, Reeve, Conch. Icon. fig. 41.

1873. Fusus nodosus, Von Martens, List Moll. N.Z. p. 18.

1873. Fusus triton, Hutton, Cat. Marine Moll. N.Z. p. 11.

1873. Futsus nodosus, IIutton, id. p. 11.

1873. Fusus triton, Hutton, Cat. Tert. Moll. N.Z. p. 3.

1873. Fusus nodosus, Hutton, id. p. 3.

1880. Neptuncea nodosa, Hutton, Man. N.Z. Moll. p. 50.

1881. Siphonalia nodosa, Tryon, Manual of Conchology, rol. iii. p. 136.

1893. Siphonalia nodosa, Hutton, Linn. Soc. N.S.W., Macleay Mem. Vol. p. 41.

This is a shorter and smaller species than $S$. manderina; it is relatively broader, and the spinose tubercles on the periphery extend to the body-whorl eren in the adult; the columella is more deeply excavated, whilst the anterior canal is sharply twisted. But the most characteristic difference, perhaps, is the protoconch, which is conoidal, and composed of four and a half smooth turns, commencing as an extremely minute point, and regularly increasing in size, instead of being large, obtuse, and irregular, as in S. mandarina.

Dimensions (of a typical specimen).-Length $40 \mathrm{~mm}$.; breadth $21 \mathrm{~mm}$.; length of aperture and canal $21 \mathrm{~mm}$.

Form. and Loc.-Pliocene: New Zealand.

G. 9535. Three specimens of an elongate form, in which the spinose tubercles become obsolete on the body-whorl and small rugose costæ take their place; from Wanganui.

Sir James Hector Coll.

G. 9633. A series exhibiting stages of growth, and sereral variations in form; from Shakespeare Cliff. Sir James Hector Coll.

G. 9714. Two examples; from Parimoa, Middle Island. W. B. D. Mantell Coll.

G. 9724. Specimens of the neanic stage of growth; from Wanganui.

(Old Collection.) 


\section{Siphonalia, sp.}

Sereral casts and more or less imperfect specimens in the Sir James Hector Coll., from the Tertiary of New Zealand, appear to be referable to the genus Siphonalia, as follows:-

G. 9532. Block of impure limestone with cast and fragments of a very large speeies. Miocene: Awatere.

G. 9533. Grit, with two casts of a strongly eostate specics. Miocene: Port Hills, Nelson.

G. 9563. Dark limestone, having cast of a small speeies. Miocene: Mokihinui.

G. 9611. Cast of a small speeies resembling the young of S. mandarina. Miocene: Akuakua (upper beds), east eoast of Auckland.

G. 9632. Two blocks of shelly limestone, haring casts of eostate and angulate speeies, probably related to Siphonalia. Miocene: Akuakua (upper beds).

Also-

G. 9679. Cast of a large speeies possessing immense, distant tubereles on the periphery of the body-whorl. Eocene: River Murray, South Australia.

Transferred from the Mruseum of Practical Geology.

\section{Genus PSEUDOVARICIA, Tate.}

[Trans. Roy. Soc. South Aust. vol. x. 18s8, p. 146.]

The following deseription of this interesting genus is giren by its author :- "Shell eylindroid-fusiform, smooth, spire obtuse, whorls with a few remote and non-continuous imbricating varices; eanal rery short, wile, eolumella smooth, sligbtly arehed. The varices are not produeed as ordinarily by an outward thickening or bulging of the shell wall, but appear as abrupt step-like interruptions to the regularity of the spiral curre, and seem to indicate that each periodic mouth was slightly margined with enamel, and the new growth to hare been commenced from withiu, so that the sueeessive growths are not in the same plane." 
The phenomena connected with the columella, though roughly indicated in the figure accompanying Professor Tate's description, seem to need further explanation. Although the pillar is smooth, yet eren in the brephic stage it is seen to be slightly twisted, a character perpetuated through the neanic stage, though not prominent until the ephebic stage was attained, when a small, inconspicuous fold was developed with another just risible on the margin of the columella anteriorly. It was not until the extreme ephebic or, perhaps, the commencement of the catabatic stage, however, that these two folds or corrugations became well developed, and their accentuation, as seen in the largest specimen in the Museum (larger than that described by Professor Tate) appears to be due to senility. It somewhat resembles Andonia, Harris and Burrows, from the Upper Tertiary of Italy and the Eocene of North-Western Eirope, but the nature of the protoconch and the peculiar derelopment of the varices are highly distinctire.

Type.-Pseudovaricia mirabilis, Tate.

\section{Pseudovaricia mirabilis, Tate.}

1858. Pscudovaricia mirabilis, Tate, Trans. Roy. Soc. South Aust. vol. $x$. p. 146, pl. vii. figs. $9 a-\epsilon$.

Protoconch (Plate VI. Figs. $1 a-b$ ) composed of two and a half broad and narrow, slightly angulate turns flattened at the apex; smooth, but bearing microseopic spiral lineations and longitudinal striæ, best developed on nearing the shell proper. It is almost impossible to define the precise limits between the protoconch and the brephic stage; the longitudinal striæ run in sets divided by the varices, and the striations undoubtedly begin on the protoconch, though they are extremely minute to commence with. In that ricinity the "varices" are close together, and are mere stria larger than the others. As this is the only species hitherto describer as belonging to the genus, much of what has been said in the gencric reriew applies specifically also. In addition, it may be mentioned that the sliell is composed of seven slowly-increasing whorls, flatly convex, with a very narrow, high-sloping shoulder defined by a strong thread. The whole surface is finely transversely striated; the striæ become larger near the suture and prominent on the body-whorl anteriorly. 
Lines of growth close and conspicuous; where they cross the larger strixe near the suture subgranulation occurs. Aperture elliptical, smooth within; canal wide and short.

Dimensions. - Length $52 \mathrm{~mm}$.; breadth $16.5 \mathrm{~mm}$.; length of aperture and canal $25 \mathrm{~mm}$.

Form. and Loc.-Eocene: Muddy Creek, Victoria.

G. 4169. An example of the neanic stage of growth. Presented by John Dennant, Esq.

G. 9482. Senile specimen, spiral lineations accompanying the suture well pronounced.

Purchased.

Genus CANTHARUS (Bolten), H. and A. Adams.

[Gen. Rec. Moll. vol. i. 18533, p. 84 ; vol. iii. pl. ix. fig. 5.]

Shell thick, short, anterior canal large; outer margin thick, raricose; columella eallous, ridged, slightly twisted in front, often carrsing a denticle, or small sharp plication anteriorly.

Type.-Buccinum undosum, Linnæus.

\section{Cantharus semicostatus, Tate (sp.).}

18ss. Pisania semicostata, Tate, Trans. Roy. Soc. South Aust. rol. x. p. 164, pl. iv. fig. 9.

1859. Tritonidea semicostata, Cossmann, Ann. Géol. Univ. t. v. p. 1090.

1894. Cantharus semicostatus, Tate, Journ. Roy. Soc. N.S.W. rol. xxrii. p. 172 .

The examples of this species in the Museum collection are not in a good state of preserration. Professor Tate describes it as follows:- "Shell oblong-fusiform, similar to $P$ (isania) rostrata, with more rapidly increasing whorls, base less abruptly attenuated, canal shorter, costæ fewer and stouter. Whorls below the apex four, costæ slightly curved, rounded, about as wide as the interspaces, 16 on the penultimate whorl, obsolete or only faintly dereloped on the body-whorl."

M. Cossmann ${ }^{2}$ includes Cantharus as a section of Tritonidea, hence the above synonymic reference.

1 Ann. Soc. Roy. Malac. Belg. t. xxir. 1889, p. 137. 
Dimensions. - Length $16 \mathrm{~mm}$. ; breadth $7 \mathrm{~mm}$. ; length of aperture and canal $8 \mathrm{~mm}$.

Form. and Loc.-Miocene: Muddy Creek, Victoria.

G. 9382. Two specimens.

Purchased.

\section{Genus EUTHRIA, Gray.}

[Fig. Moll. An. vol. iv. 1850, p. 67.]

Shell bucciniform, smooth; aperture ovate, outer margin posteriorly sinuated, lirate within; inner margin excarated, smooth, callous in the neighbourhood of the posterior sinus and twisted, with an oblique fold at the entrance of the canal, the latter being rather long, bent, and recurved.

Type.-Fusus lignarius, Chiaje.

Subgenus DENNANTIA, Tate.

[Trans. Roy. Soc. South Aust. vol. x. 1888, p. 161.]

This differs from Euthria, sensu stricto, in being much more elongate, in having a relatively smaller aperture, by the possession of a more distinct and dentate plait on the anterior portion of the columella, and by a small denticle projecting from the outer margin anteriorly. At the same time it is not worthy of generic separation, and the present writer has some diffidence in regarding it otherwise than as an extreme form of Euthria. In this connection it is interesting to note that Euthria, sensu stricto, a common Mediterranean species, has recently been discorered in Australian seas.

Type.-Fusus ino, Tenison-Toods.

\section{Euthria (Dennantia) ino, Tenison-Woods (sp.).}

1880. Fusus ino, Tenison-Woods, Proc. Linn. Soc. N.S.W. vol. iv. p. 13, pl. iii. fig. 10 .

1888. Dennantia ino, Tate, Trans. Roy. Soc. South Aust. vol. x. p. 161, pl. xii. figs. $1 a-c$ and 3 .

1893. Dennantia ino, Tate and Dennant, id. vol. srii. pt. 1, p. 219. 
The figure accompanying Mr. Tenison-Woods' memoir abore referred to is very poor, representing a shell with the greater part of the body-whorl broken away. Professor Tate's interpretation is here accepted. Shell solid, turriculate; from 8 to 9 convex whorls, the suture being impressed; ornament consisting of distant, bold spiral ridges between which smaller spiral striæ occur, towards the base of the body-whorl is a couspicuous spiral carina; aperture small, orate, wide in front; outer margin thin, haring a small denticle as a prolongation of the carina; inner margin smooth, slightly callous and denticulate near the posterior channel, lirate in front; canal short, bent, and twisted.

Dimensions. - Length $32 \mathrm{~mm}$. ; breadth $13 \mathrm{~mm}$.; length of aperture and canal $15 \mathrm{~mm}$.

Form. and Loc.-Eocene: Victoria.

48052. A series illustrating stages of growth; from Schnapper Point.

Purchased.

G. 4294. Several specimens; from Muddy Creek.

Presented by John Dennant, Esq.

G. 5498. Three examples; from Muddy Creek. Putrchased.

\section{Euthria (Dennantia) cingulata, Tate (sp.).}

1888. Dennantia cingulata, Tate, Trans. Roy. Soc. South Aust. vol. $x$. p. 162 , pl. sï. figs. $2,5 a-b$.

1893. Dennantia eingulata, Tate and Dennant, id. vol. xvii. pt. 1, p. 219.

Closely allied to $E$. ino, of which it may be only a variation in form, but it is more slender and elongate, the sculpturing consists rather of small sulci than ridges. Protoconch (Plate VI. Figs. $2 a-b)$ identical with that of $E$. ino, consisting of two smonth, rapidly increasing whorIs, the later portion of which is inflated and terminates abruptly, the brephic stage commencing suddenly by having broad and deep spiral sulci.

Dimensions. - Length $28 \mathrm{~mm}$.; breadth $10 \mathrm{~mm}$. ; length of aperture $12 \mathrm{~mm}$.

Form. and Loc.-Eocene: Schnapper Point, Victoria.

73234. Four cxamples of the adult.

Purchused. 


\section{Genus PHOS, Mlontfort.}

[Conch. Syst. 1810, vol. ii. pp. 495.]

Shell elongate, bucciniform, turriculate; spire sharp, elerated, whorls ornamented with prominent longitudiual costæ, and less salient spiral threads and sulci, often varicose; aperture oblong; outer margin lirate within; columella excavated, plicate in front; canal short, slightly twisted.

Type.-Hurex senticosus, Linnæus.

\section{Phos liræcostatus, Tenison-Woods (sp.).}

1877. Cominella lyracostata, Tenison-Woods, Pap. Roy. Soc. Tas. 1876, p. 108.

1878. Cominella lyrecostata, R. Etheridge, jun., Cat. Aust. Foss. p. 160.

1888. Phos liracostatus, Tate, Trans. Roy. Soc. South Aust. vol. x. p. 167, pl. xi. fig. 12.

1896. Phos livecostatus, Pritehard, Proc. Roy. Soc. Vict. vol. viii. x.s. p. 90 .

Shell elongate, bucciniform, tapering; protoconch composed of two and a half subcylindrical, smooth turns; whorls elevated, slightly convex, longitudinally costate, the costæ being oblique, large and far apart, spirally lineate, the conspicuous threads rising over the costæe producing a characteristic roughness, the spiral ornament is irregular and interrupted in the neighbourhood of the suture, that on the anterior half of the body-whorl is more uniform; aperture small, quadrate, opening widely in front; outer margin thiu, striated within; inner margin comparatively smooth; columella sharply twisted and plicated in front, reverted; canal rery short, broad, oblique, and supported at the back by a strong spiral ridge.

Dimensions. - Length $16.5 \mathrm{~mm}$.; breadth $7 \mathrm{~mm}$.; length of aperture and canal $7.5 \mathrm{~mm}$.

Form. and Loc.-Eocene: Table Cape, Tasmania.

G. 9378. Examples of the neanic and ephebic stages of growth. 


\section{Phos gregsoni, Tate.}

1888. Phos gregsoni, Tate, Traus. Roy. Soc. South Aust. vol. x. p. 168.

1889. Phos gregsoni, Tate, id. vol. xi. p. 118, pl. iv. fig. 5.

This species, allied to $P$. liracostatus, differs from it in having more promineut and erect longitudinal costæ, in being angulate at the periphery, and the whorls are more tumid. Its aperture is relatively shorter and broader, and wider in front, whilst the columellar twist is even more pronounced, and the spiral ornament is comparatively regular. The protoconch is not preserved in either of the specimens in the Museum collection.

Dimensions. - Length $17 \mathrm{~mm}$. ; breadth $8 \mathrm{~mm}$. ; length of aperture and canal $8 \mathrm{~mm}$.

Form. and Loc.-Miocene: Gippsland, Victoria.

G. 9862. Two examples of the adult.

Purchased.

Subgenus LOXOTAPHRUS, ${ }^{\mathrm{I}}$ nov. subgen.

Shell narrow, elongate; protoconch smooth, obtuse; spire turriculate, whorls angulate, ornamented by longitudinal costæ and spiral threads; aperture narrow, acute at both ends, wider towards the middle, channelled in front; outer margin thin, slightly reflected outwardly, bordered by a strong varix, faintly lirate within, and continued round the posterior channel, or acute groove; inner margin continuous with the outer and consisting of a shining plate affixed to the body-whorl, and covering the whole colnmellar border from which it rises, and is often detached; this leaf-like corering is slightly corrugated, but in no sense plicate or tuberculate, it borders the twisted, oblique canal, and gires rise to a small umbilicus.

The entire peristome, and especially the disposition of the enamelled plate constituting the inner margin, with its raised edge, suggest affinities with Nassaria, Link (Hindsia, H. and A. Adams), but the latter has not the same contour, and is furnished with denticles on the columella. It differs from Phos, sensu stricto, which is of the same general configuration, in the phenomena of the aperture alrcady described; but the chief point

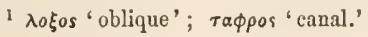


of difference, and which has more weight than any other in deciding the writer to suggest its separation from Phos, properly so called, is the character of the protoconch. In Phos the protoconch is, typically, turbinate, the turns gradually increasing in size from an exceedingly small beginning; moreover, the coils are regular, their axis being in alignment with the axis of the whole shell. In Loxotaphrus, on the other hand, the protoconch (Plate VI. Figs. $3 a-b$ ) has fewer turns (typically one and a half), and is by no means turbinate, it commences by an obtuse inflation, and quite one-half of it is oblique with reference to the axis of the shell.

Type - Phos variciferus, Tate.

\section{Phos (Loxotaphrus) variciferus, Tate.}

1888. Phos (?) variciferus, Tate, Trans. Roy. Soc. South Aust. vol. x. p. 169, pl. xi. fig. 3 .

1893. Phos variciferus, Tate and Dennant, id. vol. xvii. pt. 1, p. 219.

Shell turriculate, narrow, bucciniform; protoconch (Plate VI. Figs. $3 a-b$ ) composed of one and a half smooth tums, the earlier portion being inflated and implanted obliquely with reference to the axis of the shell, later portion finely striated longitudinally and ending abruptly; the main features of the ornament of the whorls suddeuly make their appearance in the brephic stage (a very unusual character), and do not appear to be foreshadowed in the protoconch. That ornament consists of promineut, slightly oblique, longitudinal costx, with smaller longitudinal lineations ruuning between and obliquely over them; and broad, irregular, spiral threads, considerably elevated ou the costre, especially at the angular periphery, where the points of intersection are surmounted by small tubercles, complete the sculpturing of this ornate shell. The plienomena of the aperture have been sufficiently described under the subgeneric heading.

Dimensions. - Length $26 \mathrm{~mm}$. ; breadth $11 \mathrm{~mm}$.; length of aperture and canal $12 \mathrm{~mm}$.

Form. and Loc._Eocene: Muddy Creek, Victoria.

G. 4160. An example of the gerontic stage.

Presented by John Dennant, Esq.

G. 9377 A series exhibiting stages of growth. Purchased. 


\section{Genus ZEMIRA, H. and A. Adams.}

[Gen. Rec. Moll. vol. i. 1853, p. 110.]

Related to Eburna, from which genus it may be distinguished by haviug a much smaller umbilicus, and by the possession of a prominent denticle towards the anterior of the outer margin. This projection is the continuation of the spiral chaunel on the forepart of the shell.

Type.-Pseudolica australis, Sowerby.

\section{Zemira præcursoria, Tate.}

1888. Zemira pracursoria, Tate, Trans. Roy. Soc. South Aust. vol. x. p. 163 , pl. xi. fig. 5 .

1893. Zemira preckrsoria, Tate and Dennant, id. vol. xvii. pt. 1, p. 219.

The only example of this species in the Museum collection is not well preserved. $Z$. pracursoria, according to l'rofessor Tate, differs from Z. australis, Sby., which inhabits the temperate seas of Eastern Australia, by possessing a longer spire and narrower body-whorl, narrower sutural sulcus, and in haring more pronounced spiral ridges.

Dimensions. - Length $14 \mathrm{~mm}$.; breadtl $9 \mathrm{~mm}$.; length of aperture $9 \mathrm{~mm}$.

Form. and Loc.-Eocene: Muddy Creek, Victoria.

G. 4163. One specimen. Presented by John Dennant, Esq.

\section{Buccinum, sp.}

The following indeterminate bucciniform shells occur in the Sir James Hector Coll.:-

G. 9557. Large east $48 \mathrm{~mm}$. in length, of a tumid specimen, hariug smooth courex whorls and canaliculate suture. Miocene: "Upper beds," Akuakua, east coast of Auckland, New Zealand.

G. 9558. Cast of a smaller form, having rery convex and longitudiually costate whorls. Miocene: Port Hills, Nelson, New Zealand.

G. 9606. Cast of small shell possessing enveloping body-whorl, 
upon which are traces of cancellate structure. Eocene: Broken river, Trelissick (No. 5), New Zealand.

G. 9622. Three blocks containing casts of shells with smooth, shouldered whorls and canaliculate suture. Miocene: "Conusbeds," Mokihinui, New Zealand.

Family NASSIDÆ.

\section{Genus NASSA, Lamarek.}

[Mém. Soc. Hist. Nat. Paris, 1799, p. 71.]

Shell solid, bucciniform, elongate or turriculate; spire generally acute; aperture oral; outer margin thick, often raricose, lirate, striate or denticulate within; inner margiu callous, the latter commonly spreading over a large portion of the ventral surface of the shell, becoming especially thick in front, and having a more or less salient denticle posteriorly; columella truncate and furnished with an oblique plication in front; canal very short aud twisted.

The writer does not attempt any subdivision of this genus.

Type.-Buccinum mutabile, Linuæus.

\section{Nassa crassigranosa, Tate.}

1888. Nassa (Phrontis) crassigranosa, Tate, Trans. Roy. Soc. South Aust. rol. x. pp. 169, 170, pl. xii. figs. $6 a-b$.

Distinguished by its varicose outer margin, which presents a thin edge, by the widespread callosity on the inuer margin and by the granose aspect of the whorls. Professor Tate remarks that "Senile examples occur which have added another whorl, aud by reason of the posterior varix have a somewhat distorted spire." He compares it with the living $N$. granifer, Kiener.

It also resembles $N$. vibex, Say, of the Atlautic coast of the United States, but the protoconch of the latter is more acute, the longitudinal costce on the whorls are more distaut and not so oblique, and granulate; further, the spire in the American shell is not so much elevated, and the borders of the aperture 
are more corrugate and callous. Dr. Dall ${ }^{1}$ recognizes $N$. vibex in the Plioeene beds of Florida, as well as in the living state.

Dimensions.-Length $15 \mathrm{~mm}$.; breadth $9 \mathrm{~mm}$.; length of aperture and eanal $8 \mathrm{~mm}$.

Form. and Loc.-Mioeene: Muddy Creek, Victoria.

G. 4187. A large series exhibiting stages of growth. Presented by John Dennant, Esq.

G. 9467. A number of examples of the brephic and gerontic stages.

Purchased.

\section{Nassa tatei, Tenison-Woods.}

1879. Nassa tatei, Tenison-Woods, Proc. Linn. Soc. N.S.W. rol. iii. p. 230 , pI. xxi. fig. 13.

1880. Nassa tatci, Tenison-Woods, id. vol. iv. pl. ii. fig. 2.

1888. Tassa (Hima) tatei, Tate, Trans. Roy. Soc. South Aust. vol. x. pp. 169, 170, pl. xii. fig. 9 .

1S93. Tassa tatei, Tate and Dennant, id. vol. xrii. pt. 1, p. 219.

This small speeies is extremely variable both in shape and ornament, but the series examined by the writer exhibits such gradual passages that no doubt exists that the divers forms all belong to one species. The protoconeh (Plate VI. Figs. 4a-b) is turbinate, eomposed of four smooth, gradually increasing turns, the anterior portion being faintly longitudinally striated; the shell in the brephic stage beeomes strongly longitudinally eostate, the ribs being eut up by spiral sulci and lineations. Professor Tate describes the ornament in some detail, and diseusses the affinities of the speeies. He fiuds that $N$. compacta, Angas, of Australian seas, is its nearest modern representatire.

Dimensions. - Length $9 \mathrm{~mm}$. ; breadth $4.5 \mathrm{~mm}$.; length of aperture $4 \mathrm{~mm}$.

Form. and Loc.-Eoeene: Victoria.

48052. Two speeimeus; from Schnapper Point. Purchased.

G. 4186. Examples of the adult; from Yuddy Creek.

Presented by John Dennant, Esq.

G. 9470. A series showing range of variation; from Muddy Creek.

Purchased.

1 Trans. Wagner Free Iust. Sci. Philad. vol. iii. 1890, p. 132. 


\section{Family MURICID A.}

\section{Genus TYPHIS, Montfort.}

[Conch. Syst. vol. ii. 1810, pp. 614, 615.]

Shell generally small, muriciform; spire elevated; rarices spinose or tubulose; between the varices on the posterior part of the whorls, in the neighbourhood of the suture, there is commonly a more or less salient tubule; aperture oval or circular, peristome continuous in typical species; canal short, closed.

Type.-Murex tubifer, Bruguière.

\section{Typhis maccoyi, Tenison-Woods.}

1876. Typhis maccoyii, Tenison-Woods, Pap. Roy. Soe. Tas. 1875, p. 22, pl. i. fig. 5.

1877. Typhis hebetatus, Hutton, Trans. N.Z. Inst. vol. ix. pl. xvi. fig. I.

1878. Typhis maccoyi, R. Etheridge, jun., Cat. Anst. Foss. p. 170.

1888. Typhis maccoyi, Tate, Trans. Roy. Soc. Sonth Aust. vol. х. pp. 91, 92.

1888. Typhis maccoyi, Johnston, Geol. Tasmania, p. 237, pl. xxix. fig. 11.

1893. Typhis maccoyi, Tate and Dennant, Trans, Roy. Soc. South Aust. vol. xvii. pt. 1, p. 218.

1896. Typhis maccoyi, Pritchard, Proc. Roy. Soc. Tiet. vol. viii. x.s. p. 79.

This species has considerable analogy with T. pungens, Solander, of the European Eocene, and young specimens are not readily differentiated at a cursory glance. The protoconch, however, is very different: in $T$. maccoyi it consists of two smooth turns, the earlier portion being implanted obliquely with reference to the axis of the shell; whereas in $T$. pungens the three smooth turns are elevated and rise to a sharp erect point. Further, the Australian species is relatively broader, and the spines and tubes are not curred in the wauner peculiar to the European species. Young specimens resemble $T$. tubifer, Bruguière, of the Middle Eacene of the Paris Basin, but that species is longer, less spinose, and the protoconch is much more erect.

Dimensions.-Length $18.5 \mathrm{~mm}$.; breadth $16 \mathrm{~mm}$.; length of aperture $6 \mathrm{~mm}$.

Form. and Loc.-Eocene: Spring Creek, Victoria.

G. 9379. Examples of the neanic and ephelic stages of growth. 


\section{Typhis laciniatus, Tate.}

1888. Typhis laciniatus, Tate, Trans. Roy. Soc. South Aust. vol. x. p. 93, pl. i. fig. 10.

1893. Typhis laciniatus, Tate and Dennant, id. vol. xvii. pt. 1, p. 218.

This species differs from T. maccoyi, Tenison-Woods, in being relatively narrower, the spire is much higher, it is not so prominently spinose, though the varices bear several minute frills which curl round, forming short tubules, leading up to which on the whorls are some oblique costæ. The intermediate tube is very near the suture, and is larger than any of the others. The aperture is ovate, and the plate affixed to the columella rises high, as in T. horridus, of the Italian Miocene.

Dimensions._Length $10 \mathrm{~mm}$.; brealth $5.5 \mathrm{~mm}$.; length of apcrture $2.5 \mathrm{~mm}$.

Furm. and Loc.-Eocene: Muddy Creek, Victoria.

G. 9380. Two specimens.

Purchased.

\section{Typhis evaricosus, Tate.}

18s8. Typhis evaricosus, Tate, Trans. Roy. Soe. South Aust. vol. x. p. 94, pl. i. fig. 6.

1893. Typhis cvaricosus, Tate and Denuant, id. vol. xrii. pt. 1, p. 218.

Much smaller than any of the preceding species of Typhis, from which it may readily be distinguished by the plainer character of the ornament on the whorls. It is solid, not distinctly varicose, though there are frequent breaks in the growth. Between each of these latter the whorls rise into a curved, obtuse, plain, longitudinal ridge, on the crown of which is a large, blunt, recurved, flattened tubule, completely covering the suture though detached from it. The suture may only be obserred between these large tubules, and then not very listinctly. The protoconch is of the same character as in $T$. maccoyi; aperture very suall, almost circular, canal quite covered in.

It is of the same general type as $T$. fistulosus, Brocchi, of the Italian Tertiary and of our own Barton Beds, but the spire in the Australiun species is more elevated, it is minus the leaf-like expansion on the outer margin of the aperture, and it has not the 
longitudinal ridge between the prominent tubules so characteristic of the European species mentioned.

Dimensions. -Length $8.5 \mathrm{~mm}$. ; breadth $4 \mathrm{~mm}$.; length of aperture $2 \mathrm{~mm}$.

Form. and Loc.-Eocene: Muddy Creek, Victoria.

G. 9381. Three examples of the adult.

Purchased.

\section{Genus MUREX, Linnæus.}

[Syst. Nat. ed. 10, 1758, p. 746.]

Shell rounded; spire prominent; whorls variced, commonly three on each whorl; aperture ovate; anterior canal much prolonged, partially closed, usually spinose.

Sereral of the Australian species are with difficulty allocated to the known subgenera. The passages between Murex, sensu stricto, Chicoreus, and Triplox are so gradual, that it is hard to say where one begins and the others end, though typical species of each group are easily differentiated.

Type.-MTurex haustellum, Linnæus.

\section{Subgenus TRIPLEX (Humphrey), Perry.}

[Mus. Calonnianum, 1797, p. 40 ; Perry, Conchology, 1811, pls. vi., vii. (with description).]

Pteronotus, Swainson, Malacolog5, 1840, p. 296 (non J. E. Gray, 1838).

Shell trigonal, spire elevated; canal long, partially closed; three foliaceous and typically spinose varices succeed each other at regular intervals, those on the body-whorl being in alignment with, and joined to, the correspouding varices on the preceding whorls, thus producing the trigonal shape.

It is impossible to distinguish Triplex from Cerastoma, Conrad, in the fossil state, the principal differential characters being in the operculum.

It is not without some hesitation that the writer admits the synonymity of Triplex with Pteronotus. ${ }^{1}$ Perry (see abore) includes

1 R. B. Newton, Syst. List Edwards Coll. Brit. Mus. 1891, p. 149. 
in Triplex species that undoubtedly fall within the earlier Chicoreus, Montfort, but there are others which are unquestionably like the later Ptronotus. Perry does not state the type of his genus, but in a footnote he allules to Mfurex frondosus, Linnæus, and to the fossil Murex tripteris, Lamarck (M. tripteroides), the former possessing the essentiul characters of Chicoreus and the latter of Pteronotus. If we take the first species mentioned as the type of the subgenus, Triplex must fall in synonymy with Chicoreus, that name having been proposed by Nontfort ${ }^{1}$ one year earlier; but if, on the other land, either $M$. tripteroides, II. Alexuosus, or II. pinnatus (which two last are both figured and described by Perry under his genus) be selected, we are enabled to retain Triplex. We are fortified, to some extent, in so doing by referring to Humphrey's work, which, although it cannot be accepted, as being a mere auctioneer's catalogue, enables us to see what directed Perry in his definition of the genus. The first recognizable species mentioned by Humphrey ${ }^{2}$ under Triplex is Murex triqueter, Born; that occurs, apparently, in Perry's ilescription as Triplex flexuosa, and is here selected as the type of the genus.

Type.-Tiiplex flexuosa, Perry.

\section{Murex (Triplex) velificus, Tate.}

1858. Murex (Pteronotus) velificus, Tate, Trans. Roy. Soc. South Aust. rol. x. p. 95 , pl. i. fig. 8 .

1893. MLurex velificus, Tate aud Dennant, id. vol. xrii. pt. 1, p. 218.

Shell very thin, elongate; protoconch composed of one and a half smooth turns, somewhat inflated at the commencement, and microscopically longitudinally striated in the ricinity of the first minute varix, which appears to denote the beginning of the brephic stage. The foliæ of the three rarices are extremely thin and much spread out; the posterior aspect of the projections are corered, like the surface of the shell between them, with rather large scaly punctures, and the irregular spiral ridges of the whorls are prolonged also on to the aliform expansions posteriorly;

1 Conch. Srst. t. ii. 1810 , pp. $610,611$.

2 Mus. Calounianum, 1797, p. 40. 
the fronts of the expansions are granose. Half-way between the varices an obscure longitudinal rib occurs, rising into a small tubercle at the point of iutersection with the prominent spiral ridge at the periphery. The aperture is elongately ovate, is lined with a thin plate of enamel, which is somewhat detached from the columella in adult specimens, and is slightly grooved posteriorly; outer margin crenulate, denticulate within; canal long, almost closed.

Except that the wing-like expansions are more fully developed, and the aperture is not spread out, it is like $M$. tripteroides, Lamarck, of the Eocene of the Paris Basin.

Dimensions.—Length $28 \mathrm{~mm}$. ; breadth $18 \mathrm{~mm}$. ; length of aperture $6 \mathrm{~mm}$; ; length of canal $12 \mathrm{~mm}$.

Form. and Loc.-Eocene: Muddy Creek, Victoria.

G. 4292. An example of the adult.

Presented by John Dennant, Esq.

G. 9448. A series illustrating stages of growth. Purchased.

\section{Murex (Triplex) calvus, Tate.}

1888. Mruvex (Pteronotus) calvus, Tate, Trans. Roy. Soc. South Aust. vol. x. p. 6, pl. i. fig. 11.

1895. Mfurex (Pteronotus) calvus, Tate and Dennant, id. vol. xix. pt. 1, p. 111.

1896. Murex (Pteronotus) calvus, Pritchard, Proc. Roy. Soc. Vict. vol. viii. N.s. p. 79 .

This species is closely allied to MI. velificus, from which it differs in not having the foliated varices so greatly expanded, a relatively shorter spire, the intervariceal nodulations, or short, tuberculate, longitudinal ribs, are much more prominent, whilst the plate lining the aperture is spread out all round, and is more deeply sinuated posteriorly.

It has considerable analogy, as Professor Tate remarks, with the living M. rubridentatus, Reere, in regard to shape and obliquity of varices, but has only one intervariceal longitudinal short rib. It differs primarily from the modern $\boldsymbol{M}$. pinnatus, Wood, in not having the aliform expansions interrupted, and its spire is shorter. It is more closely allied to the Paris Basin M. tripteroides, Lamarck, of which, indeed, it may only be a local variation. In the 
absence of better material, however, the writer hesitates to quote II. colvus in absolute synonymy with the French species mentioned.

Dimensions (of a mutilated specimen).-Length $27 \mathrm{~mm}$.; breadth $14 \mathrm{~mm}$; length of aperture $7 \mathrm{~mm}$.

Form. and Loc.-Eocene: Cape Otway, Victoria.

G. 9455. Two specimens.

Purchased.

\section{Murex (Triplex) bifrons, Tate.}

1858. Irurex (Pteronotus) bifrons, Tate, Trans. Roy. Soc. South Aust. vol. x. p. 97 , pl. i. fig. 12.

1895. Murex (Pteronotus) bifrons, Tate and Dennant, id. vol. xix. pt. 1, p. 111 .

Shell tumil, partly trigonal; protoconch composed of at least two obtuse, smooth whorls, the earlier portion commonly being turned round and buried horizontally in the succeeding turn, the sudden twisting interfering with the symmetry of the turns as a whole. In some cases the last turn of the protoconch enrelops the carlier portion of the apex. The shell is specially characterized by having a well-pronounced longitudinal rib on the earlier whorls between each varix; there are the usual three foliated varices on the bolly-whorl, but these latter are not broad, and they are discontinuous. The body-whorl is ornamented with abont twenty equidistant slender spiral threads, transversely striater.

Dimensions. - Length $17 \mathrm{~mm}$.; breadth $11 \mathrm{~mm}$.; length of aperture and canal $11 \mathrm{~mm}$.

Form. and Loc-Eocene: Cape Otway, Victoria.

G. 9456. Two examples of the adult.

Purchased.

\section{Murex (Triplex) amblyceras, Tate.}

1888. Murex (Chicoreus) amblyceras, Tate, Trans. Roy. Soc. South Aust. rol. x. p. 101 , pl. ii. fig. 12 .

1\$93. Murex amblyceras, Tate and Deunant, id. vol. xrii. pt. 1, p. 218.

Shell elongate, with elevated spire, rounded whorls, and rather long caual ; protoconch composed of one and a half smooth, obtuse 
turns, the anterior portion being spirally striated and terminated by a sharp varix; shell in the brephic stage strongly spirally lineated, and haring rudimentary spines; remainder of whorls cut up by three slightly foliated varices, crenulated at the edge, and each bearing a large, loug, hollow spine at the periphery; the spiral ornament consists of bold, thread-like lineations, with minor ones between and in the vieinity of the suture posteriorly; body-whorl contracted medially, and the prolongations of the varices learl to projecting, curved, hollow spines on the dorsal aspect of the columella; aperture large, ovate; outer margin slightly sulcatcd; inner margin covered by a thin plate of enamel, which is detached from the columella anteriorly and spread out, bordering the narrow, curved slit of the almost closcd canal.

Dimensions. - Length $29 \mathrm{~mm}$.; breadth $14.5 \mathrm{~mm}$.; length of aperture $7 \mathrm{~mm}$; ; length of canal $9 \mathrm{~mm}$.

Form. and Loc.--Eocene: Muddy Crcek, Victoria.

G. 4291. Example of the adult. Presented by John Dennant, Esq.

G. 9449. One specimen.

Purchased.

\section{Murex (Triplex) dennanti, Tate.}

1888. Murex (Chicoreus) dennanti, Tate, Trans. Roy. Soc. South Aust. vol. x. p. 98 , pl. ii. fig. 7 .

This species is so closely allied to $\boldsymbol{M}$. amblycercas that a large serics of speeimens would probably show that the two were synonymous. The principal point of difference is the less pronounced character of the ornanent, whereby the spire at the periphery of the whorls is much reduced in size, the varices are not so deeply foliated, nor the edges of the latter so markedly crenulate. $\boldsymbol{M}$. amblyceras has no intervariceal nodulations. MI. dennanti has a spiral carina, which becomes spinose on passing over the varices, on the anterior portion of the body-whorl, best developed in the earlier stages of growth; canal long.

Dimensions. - Length $25 \mathrm{~mm}$.; breadth $10.5 \mathrm{~mm}$.; length of aperture $6.5 \mathrm{~mm}$.; length of canal $8 \mathrm{~mm}$.

Form. and Loc.-Eocene: Muddy Creek, Victoria.

G. 5520. Example of the adult.

Purchased.

G. 9451. Specimens of the neanic and ephebic stages. Purchased. 


\title{
Murex (Triplex) otwayensis, sp. nor.
}

\author{
[Plate VI. Figs. 5a-d.]
}

Shell small, narrow, spire elerated; protoconch composed of one and a half smooth turns, invaded by scalariform longitudinal lamellæ, which appear to proceed from the brephic stage of growth, crossing the suture and affixing themselves to the preceding turns of the protoconch; varices three to each whorl in the neanic and ephebic stages, but more numerous on the carlier whorls, foliated, crenulated on the edges due to the prolongation of the spiral lineations, which are far apart, not more than four or five being developed on the penultimate whorl; the anterior aspect of the variceal folia exhibit the usual undulating scales of growth, whilst there is a prominent hollow spine of medium length projecting from each folium, situated posteriorly, in the neighbourhood of the suture; the interrariceal longitudinal costr are about six in number on the penultimate whorl, and their intersection with the spiral lines cause tessellation of a peculiar character, each point of junction being crowned by an obtuse nodulation; the anterior half of the bod 5 -whorl is comparatively denuded of ornament; aperture quadrate, open anteriorly, peristome continuous except at the entrance of the canal; outer margin slightly reflected; canal short, almost covered up.

This shell is more ornate than either of the preceding species of Triplex, and forms a link between that subgenus and Chicoreus through the medium of its rariceal spines. The protoconeh is highly distiuctive; it is doubtful whether part of the scalariform structure did not originate within the capsule, but the folia being longitudinally continuous and unbroken from the brephic stage across the suture, the point cannot be definitely resolved by the few specimens in the Museum eollection. Compared with II. contabulatus, Lamarck, of the Paris Basin, with which it presents some analogy, the latter is found to possess more convex whorls, is broader, larger, and is miuus the intervariceal tessellation.

Dimensions.-Length $11 \mathrm{~mm}$; breadth (including. spines) $5 \mathrm{~mm}$.; length of aperture $3 \cdot 25 \mathrm{~mm}$; length of canal $2 \cdot 75 \mathrm{~mm}$.

Furm. and Loc.-Eocene: Cape Otway, Victoria.

G. 9457. Three examples of the adult.

Purchased. 


\section{Murex (Triplex) trinodosus, Tate.}

1888. Muvex (Triplex) trinodosus, Tate, Trans. Roy. Soc. South Aust. vol. x. p. 96 , pl. i, fig. 4.

Readily distinguished from other Australasian species of Triplex by the elementary character of its ornamentation; it is solid, varices three in number, and continued obliquely from whorl to whorl, they are very narrowly foliated, and are furnished posteriorly with a short blunt spine or tubercle; between the varices are three stout, nodulous, short costæ; aperture ovate, channelled in front and having a deep notch posteriorly bordering the suture; eanal short, slightly curved, and almost closed.

The deep noteh on the after part of the outer margin is very distinctive. Professor Tate remarks (op. cit. p. 97) that $M$. trinodosus is separable from the living $\boldsymbol{M}$. angasi, Crosse, by "being broader across the posterior part of the body-whorl, by the variceal spine not being hooked, by the less angulated whorls, longer canal, and by haring three stout intervariceal nodulations instead of two inconspicuous ones."

Dimensions. - Length $16 \mathrm{~mm}$.; breadth $7 \mathrm{~mm}$.; length of aperture and canal $8 \mathrm{~mm}$.

Form. and Loc.-Miocene: Muddy Creck, Victoria.

G. 9458. Two examples of the adult.

Purchased.

\section{Subgenus CHICOREUS, Montfort.}

[Conch. Syst. t. ii. 1810 , pp. $610,611$.

The varices of the shells included in this subgenus are foliated, though not to the same extent as in Triplex, and a principal distinguishing feature is the elaborate character of the spinose varices or foliations. It differs also from Triplex in having a relatively larger aperture; eanal short, curved, and nearly closed.

Type-ILrex ramosus, Linnæus.

Murex (Chicoreus) lophœssus, Tate.

1888. Murex (Chicoreus) lophossus, Tate, Trans. Roy. Soc. South Aust. vol. x. p. 98 , pl. ii. fig. 5 .

1893. Mrurex (Chicoreus) lophoessus, Tate and Dennant, id. vol. svii. pt. 1, p. 218. 
Shell tumid, rounded, short eonical spire, and broad body-whorl; protoeonch eomposed of one and a half smooth turns, the earlier prtion rising high and is mueh inflated, a strong varix denotes its termination; shell in the brephie stage eancellate, but the rariees gridually become aecentuated in the neanie stage, and carry leaf-like expansions which increase in size as the adult eondition is approached; there are three variees to eaeh whorl, and these are rendered somewhat spinose at the edge by the prolongation of the elerated spiral ridges which form sueh a conspicuous part of the ornament; between eaeh ridge there is one prominent lineation, commonly aeeompanied by one or two smaller threads; and there are usually three interrarieeal eostæ, whieh are subspinose at the periphery on the later whorls; the lines of growth give rise to scales on intersecting the spiral ornament; aperture slightly oblique, orate, peristome eontinuous exeept for the narrow slit which communieates with the almost elosed canal; outer margin crenulate; inner margin lined with a thick, enamelled, refleeted plate; eanal short, eorrugated.

The comparatice simplieity of the spinose ornament remores this speeies from typieal examples of Chicoreus; but, on the other hand, the eonfiguration of the shell and the nature of the varices are not typieal of Triplex.

Dimensions. - Lengtl $25 \mathrm{~mm}$.; breadth (ineluding rarices) $19 \mathrm{~mm}$.; length of aperture $10 \mathrm{nın}$. ; length of eanal $16 \mathrm{~mm}$.

Form. and Loe._Eoeene: Muddy Creek, Vietoria.

G. 4274. Three specimens. Presented by John Demant, Esq.

G. 9446. Two examples of the adult. Purehasel.

\section{Subgenus MURICOPSIS, Buequoy and Dautzenberg.}

[Moll. Marins Roussillon, t. i. 1882, p. 19.]

Spire elerated; eamal short, open; umbilieate; rariees numerons; columella with dentieles in front; outer margin crenulated.

Typo.-Murex blainvillei, Payraudeau.

\section{Murex (Muricopsis) irregularis, Tate.}

1885. Nurex (Chicoreus) irregularis, Tate, Trans. Roy. Soc. South Aust. vol. x. p. 102 , pl. vi. fig. 3 .

Protoeonch eonsisting of one and a half smooth turns, terminated 
anteriorly by a small varix, beyond which the salient features of the ornament of the adult are foreshadowed; rarices irregular, not being in alignment from whorl to whorl, three on the bodywhorl, increasing in number posteriorly; they are not foliated, but rounded off, bold spiral threads passing over them, there are three varices on the last whorl in the adult, increasing to four or six on the preceding whorls; whorls eight in number, subangulated at the periphery, longitudinally lineate, scaly, and obscurely nodose at the points of intersection with the spiral threads; sutures deep; boily-whorl constricted, Fusus-like on the anterior half; aperture ovate, open in front; outer margin thin, curved, crenulate, lirate within; inner margin corered by a thin plate of enamel, bearing three or four denticles on the forepart of the columella; canal of medinm length, broad, open, nearly erect.

The canal is rather longer than in typical examples of Muricopsis, whilst the rarices are not quite as numerous; but the tubercles on the columella, the liræ within the outer margin, and the partial umbilicus are characteristic.

Dimensions. - Length $27 \mathrm{~mm}$.; breadth $12.5 \mathrm{~mm}$.; length of aperture $8 \mathrm{~mm}$.; length of canal $7 \mathrm{~mm}$.

Form. and Loc.-Eocene: Muddy Creek, Victoria.

G. 9454. Examples illustrating stages of growth. Purchased.

G. 4273 . An example of the senile stage.

Presented by John Dennant, Esq.

Murex (Muricopsis) graniformis, nom. mut.

188s. Murex (Ocinebra) alveolatus, Tate, Trans. Roy. Soc. South Aust. vol, x. p. 108, pl, iii. fig. 12 (non J. de C. Sowerby, 1823).

1889. Murex (Muricopsis) alveolatus, Cossmann, Ann. Géol. Univ. t. $\nabla$. p. 1088.

1894. Murex (Muricopsis) alvcolatus, Tate, Journ. Roy. Soc. N.S.W. rol. xxvii. p. 170.

This species resembles the joung of $\boldsymbol{M}$. irregularis, from which it chiefly differs, according to Professor Tate, in haring four varices on the last whorl and seren on the preceding two whorls, in the adult; the canal, also, is shorter, and the transverse ornament is more regular and closer. The vaulted scales 
of growth produce an irregular, granulated aspect between the distant spiral liræ.

The specific name of this fossil is now altered, as Mrurex alieolatus had already been utilized by J. de C. Sowerby ${ }^{1}$ for a different shell.

Dimensions.-Length $9 \mathrm{~mm}$; breadth $4 \mathrm{~mm}$; length of aperture and canal $4.5 \mathrm{~mm}$.

Form. and Loc.-Eocene: Muddy Creek, Victoria.

G. 9452. Example of the neanic stage of growtl. Purclused.

\section{Subgenus MURICIDEA, Swainson.}

[Malacology, 1S40, p. 296.]

Shell piriform; canal short; rarices more than three in number. The figure referred to by Swainson in his description of Mfuricidea is obviously not what that author intended, as the type of the subgenus and the particular reference are no doubt a clerical error, as he subsequently ${ }^{2}$ refers to the shell indicated as a true II urpa, in which geuus it should unquestionably be placed. Under these circumstances it is desirable to adopt the suggestion made by M. Cossmann, ${ }^{3}$ and select the following species as the type of the subgenus.

Type.-Murex hexagonus, Lamarck.

\section{Murex (Muricidea) eyrei, Tenison-Woods.}

1877. Mrurex eyrei, Tenison-Woods, Pap. Roy. Soc. Tas. 1876, p. 93.

1888. Murex (Phyllonotus) eyrei, Tate, Trans. Roy. Soc. South Aust. vol. $x$. p. 103 , pl. iv. fig. 8 .

1888. Nurex eyrei, Johnston, Geol. Tasmania, p. 237 (non pl. xxxi. figs. $3,3 a)$.

1893. Murex eyrei, Tate and Dennant, Trans. Roy. Soc. South Aust. rol. $\mathrm{x}$ vii. pt. 1, p. $21 \mathrm{~s}$.

1896. Wurex (Phyllonotus) eyrei, Pritchard, Proc. Roy. Soc. Viet. vol, viii. s.s. p. 79 .

1 Miu. Coneh. 1823, vol. v. tab. eceeri. fig. 2, p. 9.

2 Malacology, 18 40, p. 298.

${ }^{3}$ Ann. Soc. Roy. Malac. Belg. t. xxiv. 1889, p. 121. 
This well-known shell of the Australian and Tasmanian Tertiatry is eharacterized by its erect, staged spire, by the frequent, loug, hollow spines which crown and terminate obtuse longitudinal ribs at the periphery of the body-whorl, and by the free sloping area, but slightly spirally lineated, between these spines and the suture; in front of the spines are bold, undulating, spiral threads, passing over the broad longitudinal costre, and continuing over the whole of the anterior portion of the body-whorl. The aperture is large, ovate, well open in front; outer margin thin, curved; columella exeavated, covered by a thin plate of enamel, which is detached anteriorly and causes a pseudo-umbilicus; canal slightly oblique, broad, of moderate length.

The absence of conspicuous varices, the nature of the spiral ornament, the bold threads in front of the prominent peripheral spines, and their comparative absence behind them, are very distinctive.

Dimensions.-Length $27.5 \mathrm{~mm}$.; breadth $16 \mathrm{~mm}$.; length of aperture $10 \mathrm{~mm}$.; length of canal $7 \mathrm{~mm}$.

Form. and Loc.-Eocene: Muddy Creek, Victoria.

G. 426\%. Two specimens. Presented by John Dennant, Esq.

G. 5518. Specimen of the adult, having a much enlarged umbilicus, and broader whorls and wider aperture than in typical examples of the species.

Purchased.

G. 9453. Examples illustrating stages of growth. Purchased.

\section{Murex (Muricidea) zelandicus, Quoy and Gaimard.}

1832. MIurex zelandicus, Quoy and Gaimard, Voy. de l'Astrolabe, Zool. t. ii. p. 529, pl. xxxvi. figs. 5-7.

1845. Murex zelandicus, Reeve, Conch. Icon. iii. pl. צxxiv. fig. 177.

1873. Murex nove zcelandia, Von Martens, List Moll, N Z. p. 17.

1873. Mrurex zealaniicus, Hutton, Cat. Marine Moll. N.Z. p. 7.

1873. Murex zealandicus, Hutton, Cat. Tert. Moll. N Z. p. 2.

1880. Misrex zealandicus, Hutton, Man. N.Z. Moll. p. 46.

1880. Murex (Phyllonotus) zelandicus, Tryon, Manual of Conchology, vol. ii. p. 108, pl. xxix. fig. 268.

1893. Murex neozelanicus, Hutton, Linn. Soc. N.S.W., Macleay Mem. Vol. p. 37.

The canal and spines of this species are rather longer than in typical examples of the subgenus; but it is a close ally of $M$. eyrei, 
from which it differs not only in the characters just mentioned, but in having frondose varices, smaller umbilicus, and a thinner shell.

Dimensions.-Length $32 \mathrm{~mm}$; ; breadth (not including spines) $15 \mathrm{~mm}$.; length of aperture $10 \mathrm{~mm}$.; length of canal $10 \mathrm{~mm}$.

Form. and Loc.-Pliocene: Shakespeare Cliff, Wanganui, N.Z.

G. 9546. Several specimens illustrating stages of growth.

Sir James Hector Coll.

G. 9716. Example in which the frondose varices are much reduced in size.

(Old Collection.)

\section{Murex (Muricidea) asperulus, Tate.}

[Plate V. Figs. 10a-d.]

1885. Mrurex (Ocinebra) asperulus, Tate, Trans. Roy. Soc. South Aust. vol. x. p. 106 , pl. iii. fig. 1 .

1893. Murex asperulus, Tate and Demnant, id. vol. xvii. pt. 1, p. 218.

Shell fusiform, tumid, rugged; protoconch composed of one and a half smooth canaliculate turns, the earlier portion inflated and obtuse, the later slightly contracted and ending abruptly by a very prominent varix, or thickening; the shell in the brephic stage is cancellate, but at later stages of growth the prominent longitudinal lineations involved in the cancellate structure become developed into broad rugose varices or costæ, of which there are six on the body-whorl; the spiral lineations are bold, and there are about nine of these on the penultimate whorl; lines of growth close together, and producing minute vaulted scales in crossing orer the spiral lineations, which form the characteristic ruggedness on the exterior of the shell; suture cut in, the whorls at first sloping gently away from it and then becoming rounded; body-whorl constricted towards the anterior, but lineate and rugged throughout; aperture round, slightly opened in front; outer margin thin, the spiral ornament refleeted within; inner miargin smooth; columella covered by a thin plate of enanel detached near the twist at the entrance of the moderately long, curred canal; large vaulted seales appear in the front part of the columella bordering the canal.

This species is refigured, as the view given by Professor Tate hurdly does justice to it, showing but one side only, and that of not a rery typical example, apparently. It approaches the genus Urosalpinx in that it is fusiform, and that the rarices are not very 
distinct, resembling costæ. At the sane time, rarices are present, and II. asperulus may, conchologically, be regarded as intermediato hetween Buricidea and Urosalpinx.

Dimensions. - Length $18 \mathrm{~mm}$.; breadth $8 \mathrm{~mm}$.; length of aperture $5 \mathrm{~mm}$.; length of canal $5 \mathrm{~mm}$.

Form. and Loc.-Eocene: Muddy Creek, Victoria.

G. 9450. Three specimens.

Purchased.

G. 10068. The figured specimen. Presented by John Dennant, Esq.

\section{Murex (Muricidea) camplytropis, Tate.}

188s. Murex (Ocinebra) camplytropis, Tate, Trans. Roy. Soc. South Aust. vol. x. p. 105 , pl. iii. fig. 2.

1893. Murex camplytropis, Tate and Dennant, id. vol. xvii. pt. 1, p. 218.

1896. Murex camplytropis, Pritchard, Proc. Roy. Suc. Vict. vol. viii. N.s. p. 145.

This species is larger than $M$. asperulus, from which it differs, principally, in not being so elongate, in haring a relatively shorter cunal, by the varices being less erect, and in some minor details of ornament. The only specimens in the Museum collection are badly preserred, and full particulars of dimensions cannot be given. The dimensions as here stated, however, indicate a larger shell than that mentioned by Professor Tate.

Dimensions.-Length $29 \mathrm{~mm}$; breadth $16 \mathrm{~mm}$.

Form. and Loc.-Eocene: Mnddy Creek, Victoria.

G. 9447. Two examples, from the larger of which the columella is missing.

Purchased.

\section{Genus SISTRUM, Montfort.}

[Conch. Syst. t. ii. 1810, p. 595.]

"Ricinule," Lamarek, Cours Zool. 1812, p. 119.

Ricinula, Lamarck, Ency. Meth., Vers. Coq., Moll., etc. t. iii. 1816, pl. 395 , figs. $1 a-b$.

Shell ovate or subfusiform, solid; whorls tubercular, spinose, or longitudinally costate, aperture narrow, contracted by callous projections; canal short; outer margin strongly dentate within; inner margin wrinkled or plicated.

Type.-Sistrum a bum, Montfort (Buccinum echinatum, Lamar.k). 


\section{Sistrum purpuroides, Johnston (sp.).}

1880. Ricinula purpuroides, Johnston, Pap. Roy. Soc. Tas. 1879, p. 33.

1888. Risania purpuroudes, Tate, Trans. Roy. Soc. South Aust. vol. x. p. 165 , pl. xi. fig. 6 .

18s9. Latirus purpuroides, Cossmann, Ann. Géol. Univ. t. v. p. 1090.

1894. Ricinula purpuroides, Tate, Journ. Roy. Soc. N.S.W. vol. xxrii. p. 173.

1596. Ricimula purpuroides, Pritchard, Proc. Roy. Soc. Vict. vol, viii. x.s. p. 90.

The specimens in the Museum collection are not well preserved, the phenomena of the aperture (the most distinctive character of the genus) being incomplete. In reference to the latter, Professor Tate remarks": "Aperture narrowly ovate; outer lip varicosely dilated behind, slightly crenulated on the acute margin, and with seren tooth-like ridges within; inner lip spreading orer the columella and thinly continuous with the outer lip, with one elongated plication near the posterior angulation, and about eight small irregular callosities thence to the point of the pillar."

These features are not characteristic of Pisania or Latirus, but of Sistrum.

Dimensions.-Length $11 \mathrm{~mm}$; breadth $6 \mathrm{~mm}$.

Form. and Loc.-Eocene: Table Cape, Tasmania.

G. 9492. Two examples.

Purchased.

Family LOTORIID \&.

Genus LOTORIUIM, Montfort.

[Conch. Syst. t. ii. 1810 , p. 583.]

Tritonium, Link, Besch. Rostock, rol. iii. 1807, p. 121 (non M[üller, 1776).

Triton, Moutfort, Conch. Syst. t. ii. 1810, p. 587 (non Linnæus, 1767).

Jonoplex, Perry, Conchology, 1811, pl. iii. (in partem).

Lampusia, Schumacher, Essai Nour. Syst. Habit. Testacés, 1817, pp. 76, 250.

Luterium, Herrmannsen, Indicis Generum Malac. vol. i. 1846, pp. 625,626 .

1 Trans. Roy. Soc. South Aust. vol. x. 18ss, p. 165. 
The circumstance that Triton had been used in other departments of zoology, before it was proposed for the well-known group of molluses which for so many years has borne the name, ${ }^{1}$ has been known for a long time to students of mollusca, but it is only in recent years that the priority rule has been applied, when Mr. R. B. Newton ${ }^{2}$ suggested that Lampusia, Schumacher, should be adopted. That name, however, was not proposed until 1817, and we find that Montfort had already, in 1810, in the work above quoted, suggested Aquillus, Lotorium, and Apollon, all of which are regarderl by some writers ${ }^{3}$ as subgenera of Triton, though by others Apollon bas been placed under Ranella. It is obvious, therefore, that before accepting Lampusia, we must examine the claims of Nontfort's genera mentionet.

Commencing with Aquillus, the etymology of the word is uncertain, ${ }^{4}$ and in any case is hybrid. When it is emended, in the manner suggested by Agassiz $^{5}$ and others, we hare Aquilus, or Aquila, whieh is anticipated by the well-known Aquila, Brisson, ${ }^{\theta}$ in ornithology, and by several other authors prior to the appearance of Miontfort's work. Ta prevent difficulty, therefore, it is not advisable to select Aquillus, the more so that Montfort suggested another name at the same time, in the same work, which will do very well.

In reference to Apollon, although that has been included by authors as a subgenus of Triton, it has also been called a Ranella. It is certainly worthy of generic rank, and under the name of Argobuccinum has recently ${ }^{7}$ been restored to that status (see also p. 195), and is thus not available to take the place of Triton.

We are left with Lotorium, which we wouk now suggest should be adopted for the group hitherto denomiuated Triton, or Lampusia. In this view Mr. Edgar A. Smith fully concurs.

Type.-Murex lotorium, Linnæus.

1 E.g. Tryon, Manual of Conchology, vol. iii. 1881, p. 7.

2 Syst. List Edwards Coll. B.M. 1891, p. 145.

3 E.g. Fischer, Manuel de Conehyl. 1884, p. 655.

4 Herrmannsen, Indicis Generum Malac. vol. i. 1846, p. 71.

5 Nomenclator Zoologicus, 1846, p. 31, Moll. p. 7.

6 Ornithologie, vol. i. 1760 , p. 419.

7 Cossmann, Aun. Soc. Roy. Malac. Belg. t. xxxi. 1896, p. 82. 


\section{Lotorium radiale, Tate (sp.).}

1888. Triton radialis, Tate, Trans. Roy. Soc. South Aust. vol. x. p. 118, pl. v. fig. 8 .

Protoeonch (Plate VI. Figs. $6 a-b$ ) consisting of two and a half turns, the posterior portion is smooth and eommenees with a somewhat inflated, elevated, obtuse point, situated laterally, and in some instances orerlapping the anterior portion. The latter is irregularly lineated, the threads corresponding to the principal features subsequently developed in the shell in the brephie stage. One specimen in the Musenm collection, in which the protoconch is well preserved, shows the central lineation broken up into small granulations, homologous with the spinose tubereles afterwards so distinetly pronouneed in the ephebic stage.

The shell proper has fire whorls carinated medially, from which arise distant, compressed, tooth-like tubereles, the body-whorl carrying a similar bnt smaller row of tubereles anteriorly. The whorls are spirally and elosely lineated. Prominent variees oeenr at intervals, and it is noteworthy that just prior to putting on a new varix the spinose tubereles become smaller than others up to the preceding varix. The aperture is almost cireular, outer border lirate within, haring a dentiele where the deep, oblique, anterior eanal commences; iuner border thin, lirate, dentate in frout, and having a prominent callous plait posteriorly; columella umbilicate, exearated, and twisted.

Dimensions. - Length $39 \mathrm{~mm}$.; breadth $25 \mathrm{~mm}$.; length of aperture $12.5 \mathrm{~mm}$.; length of eanal $8.5 \mathrm{~mm}$.

Form. and Loc.-Eocene: River Murray cliffs, South Australia.

G. 9123. Example of the aduit.

G. 9400. Two specimens.

Presersted by William Eians, Esq.

P'urchased.

\section{Lotorium cyphus, Tate (sp.).}

1888. Triton cyphus, Tate, Trans. Roy. Soc. South Aust. vol. x. p. 119, pl. v. fig. 11 .

1893. Triton cyphus, Tate and Dennant, id. vol. xrii. pt. 1, p. 218.

This species is allied to $L$. radiale in many respects; but its protoconch, although laterul, is highly distinctive. It is composed 
of two turns, the posterior of which is smooth and slightly oblique, whilst the anterior is spirally lineate. In regard to ornament of the whorls, the compressed angulate tubereles are not relatively as large as in the species mentioned, and the spiral lineations ate stronger. But the principal distiuguishing features bejond the protoconch are the prolonged anterior canal, the thin outer border of the aperture, and the absence of pronounced liræ in the interior; a thin columellar callosity is observable in many indiriduals.

Dimensions. - Length $38.5 \mathrm{~mm}$. ; breadth $23 \mathrm{~mm}$.; length of aperture $15 \mathrm{~mm}$; length of canal $10 \mathrm{~mm}$.

Form. and Loc.-Eocene: M[uddy Creek, Victoria.

G. 9397. Examples of the neanic and ephebic stages of growth, the shell of the latter being extremely thin.

Purchased.

\section{Lotorium tumulosum, Tate (sp.).}

1888. Triton tumulosus, Tate, Trans. Roy. Soc. South Aust. vol. x. p. 122, pl. $\mathrm{v}$. fig. 2.

1893. Triton temulosus, Tate and Dennant, id. vol. xvii. pt. 1, p. 219.

The protoconch is not very well preserved in any of the specimens in the Museum collection; the author of the species describes it as follows: "Apex of two polished whorls; the anterior one is high, bicarinated, and transversely striated; the posterior one, encircling a shallow concavity, at first suddenly narrowed, then somewhat depressly dilated, and ending in a blunt appressed point." L. tumulosum is allied to L. cyphus, but the shape of the whorls is different, the latter species being much more angulate, and the peripheral tubercles being so flattened as to resemble serrations, whereas in $L$. tumulosum the tubercles at the periphery are norlose and eut up by small spiral sulci. Further, the spiral ornament of the latter species is different, the threads being markedly gramose, whilst the anterior canal is shorter.

Compared with the living $L$. fusiformis, Kiener, of Australian seas, the fossil has a longer canal, larger aperture, the denticles on the outer margin are not so large and they are more numerous, whilst the spiral ornament is more profuse. 
Dimensions. - Length $52 \mathrm{~mm}$. ; breadth $28 \mathrm{~mm}$. ; length of aperture $16 \mathrm{~mm}$. ; length of canal $14 \mathrm{~mm}$.

Form. and Loc.-Eocene: Victoria.

G. 352. A specimen in which the anterior spiral ornament is abuormally granulose; from Bairnsdale.

Presented by $I$. W. Grigson, Esq.

G. 4265. Example of the adult; from MLuddy Creek.

Presented by John Dennant, Esq.

G. 4272. A young specimen, in which the whorls are not as conrex and tubereulose as the type, whilst the shell is more solid; from AInddy Creek.

Presented by John Denuant, Esq.

G. 5513. Example of the adult, having a rery thin outer margin and sharply bent canal; from Nuddy Creek. Purchased.

G. 9398. A series exhibiting stages of growth of the joung; from Muddy Creek.

Purchased.

\section{Lotorium gibbum, Tate (sp.).}

188s. Triton gibbus, Tate, Trans. Roy. Soc. South Aust. vol. x. p. 118, pl. v. fig. 9 .

Shell remarkably distorted, of the same group as $L$. cyphus ; it is distinguished by its gibbose whorls, which are much compressed and angulated at the periphery, where immense projecting, acute, flattened scrrations are developed; the other ornament of the whorls consists of undulating spiral lineations, crossed by fine lines of growth; rarices prominent, about three in every two whorls in the adult; aperture broad, orate; outer margin slightly reflected, dentate within, denticles being mostly developed near the entrance to the canal; inner margin smooth, plated, and granulate; columella excarated, twisted in front, umbilicate; canal long, bent, and narrow.

Dimensions. - Length $31 \mathrm{~mm}$; breadth $19 \mathrm{~mm}$.; length of aperture $11 \mathrm{~mm}$; length of canal $9 \mathrm{~mm}$.

Form, and Loc.-Eocene: Victoria. 
48052. A series exhibiting various stages of growth; from Schnapper Point.

Purchased.

G. 4269. Three examples of the adult; from Muddy Creek.

Presented by John Dennant, Esq.

\section{Lotorium woodsi, Tate (sp.).}

1880. Triton woodsii, Tate, Proc. Linn. Soc. N.S.W. vol, iv. p. 15, pl. iii. figs. $1,2$.

1888. Triton uoodsii, Tate, Trans. Roy. Soc. South Aust. vol. x. p. 119, pl. v. figs. 4,6 .

1893. Triton woodsii, Tate and Denmant, id. vol. xvii. pt. 1, p. 218.

Nore elongated and less spinose than $L$. radiale or L. cyphus, though the surface of the shell is spirally lineate in a manner somewhat similar to the latter. The protoconch rises to an acute, erect point, but the remaining turns are depressed; whorls elevated, somewhat attenuated, six in number; rarices distant, broad and clearly defined, not spinose; angulation at the periphery compressly nodose, one or two spiral tuberculose and granose lineations (more or less accentuated following individuals) in front of the peripheral angulation, and three or four smaller rows of spiral granulations behind; aperture almost circular; outer margin thin, with a rudimentary posterior groove and a large obtuse tubercle near the narrow entrance of the anterior canal; inner margin corered by a thin, elevated, partially detached plate, bearing a large plait bordering the groove alluded to, and having three or four dentate elevations anteriorly, the largest being in front; columella excavated, umbilicate; anterior canal long, bent, and narrow.

Dimensions. - Length $42 \mathrm{~mm}$.; breadth $19.5 \mathrm{~mm}$.; length of aperture $11 \mathrm{~mm}$.; length of canal $12.5 \mathrm{~mm}$.

Form. and Loc.-Eocene: South Australia and Victoria.

G. 4266. Several examples of the adult; from Muddy Creek. Presented by John Dennant, Esq.

G. 9125. Examples having larger nodose tubercles than in typical specimens; from River Murray cliffs, near Adelaide.

Presented by William Evans, Esq.

G. 9402. Specimens illustrating stages of growth; from Gellibrand river.

Purchased. 


\section{Lotorium protensum, Tate (sp.).}

1888. Triton protensus, Tate, Trans. Roy. Soc. South Aust. vol. x. p. 124, pl. v. fig. 10.

The ornament of the whorls of this species is somewhat similar to that of $L$. woodsi; but the shell is much narrower.

Dimensions. - Length $32 \mathrm{~mm}$.; breadth $14.5 \mathrm{~mm}$.; length of aperture $9 \mathrm{~mm}$; length of eanal $8 \mathrm{~mm}$.

Form. and Loc. - Eocene: Muddy Creek, Victoria.

G. 4268. An example of the adult.

Presented by John Dennant, Esq.

Lotorium tortirostris, Tate (sp.).

1877. Triton minimum, Tenison-Woods, Pap. Roy. Soc. Tas. 1876, p. 107 (non Hutton).

1888. Triton tortirostr/s, Tate, Trans. Roy. Soc. South Aust. vol. x. p. 123, pl. v. fig. 7 .

1858. Tritonium minimum, Johnston, Geol. Tasmania, p. 237.

1893. Triton tortirostris, Tate and Dennaut, id. vol. xvii. pt. 1, p. 219.

1895. Triton tortirostris, Pritchard, Proc. Roy. Soc. Vict. rol. riii. x.s. p. $\$ 2$.

Of the same general character as $L$. voodsi, but readily distinguished in having a different type of protoconeh, which in this species is roundly turbinate, composed of three and a half turns, spirally striated, commencing in the centre and gradnally increasing in size, instead of being excentric, and commencing as an elerated point, as in $L$. woodsi; further, the anterior canal is much shorter, and there are three spiral rows of small, trifid nodulations on the body-whorl.

Dimensions. - Length $30 \mathrm{~mm}$.; breadth $16.5 \mathrm{~mm}$.; length of aperture $10 \mathrm{~mm}$; length of canal $8.5 \mathrm{~mm}$.

Form. and Loc. - Eocene: Tasmania, Victoria, and South Australia.

83987. An example of the adult; from Table Cape. Purchased.

G. 9124. A local rariation, in which the nodulations on the periphery of the body-whorl are more pronounced than in the type, and are arranged to form longitudinal costæ; from the liver Murray, near Adelaide.

Presented by William Eians, Esq.

G. 9399. Examples of stages of growth; from Muddy Creek. 


\section{Lotorium annectans, Tate (sp.).}

18s8. Triton annectans, Tate, Trans. Roy. Soc. South Aust. vol. x. p. 121, pl. v. fig. 3.

1893. Triton annectans, Tate and Dennant, id. vol. xvii. pt. 1, p. 219.

1895. Triton annectans, Tate and Dennant, id. vol. xix. pt. 1, p. 111.

The protoconch (Plate VI. Figs. $7 a-b$ ) of this species is similar to that of $L$. tortirostris in being somewhat elevated, roundly turbinate, and spirally striated; it is composed of three and a half to four whorls, and the strix, which are four in number, equidistant, and rery pronounced on the last turn, decrease in size on being traced backwards, the top of the larval shell is extremely minute and central. The ornament of the whorls is also much like that of the species just mentioned, but there are only two rows of tubercles, or nodulations, instead of three, on the bodywhorl, and seven interrariceal tubercles occur on the posterior peripheral angulation. The specimens from Cape Otway are more elongate than the type found at Muddy Creek, the body-whorl of which is subquadrate. Examples of the young stages of growth are almost inseparable from those of $L$. tortirostris, and the latter may only be an extreme form of this species.

Dimensions. - Length $35 \mathrm{~mm}$. ; breadth $18 \mathrm{~mm}$. ; length of aperture $13 \mathrm{~mm}$; length of canal $9 \mathrm{~mm}$.

Form. and Loc.-Eocene: Victoria.

48052. An example of the neanic stage of growth; from Schnapper Point.

Purchased.

G. 5514. Adult specimen, largely umbilicate; from Muddy Creek.

Purchased.

G. 9403. Examples of the neanic stage; from Cape Otway.

Puichased.

\section{Lotorium textile, Tate (sp.).}

1Ss8. Triton textilis, Tate, Trans. Roy. Soc. South Aust. vol. x. p. 120, pl. v. fig. 12.

Closely allied to L. gibbum, from which it differs in being less gibbose, in having a longer canal, and in the derelopment of distant, bold spiral liueations amongst smaller ones, more especially on the anterior slope of the body-whorl. It is more distorted in the growth than is $L$. woodsi, the whorls are more compressed 
and angulate at the periphery, and there is no distinct anterior carination on the body-whorl.

Dimensions. - Length $35 \mathrm{~mm}$. ; breadth $18 \mathrm{~mm}$.; length of aperture $10.5 \mathrm{~mm}$; length of canal $9.5 \mathrm{~mm}$.

Form. and Loc.-Eocene: Victoria.

48052. An example of the adult, in which the serrations on the angulation of the body-whorl are much reduced in size; from Schnapper Point.

Purchased.

70417. Two specimens; from Dandenony.

Purchased.

\section{Lotorium quoyi, Reeve (sp).}

1844. Triton quoyi, Reeve, Conch. Icon. vol, ii. fig. 93.

18sı. Triton quoyi, Tryon, Manual of Conchology, vol. iii. p. 24, pl. xiii. fig. 116.

18ss. Triton quoyi, Tate, Trans. Roy. Soc. South Aust. vol. x. p. 127.

The specimens in the collection are much rolled, but appear to be identical with the living $L$. quoyi, so common on the southern shores of Australia. The symmetrical cancellate ornament on the body-whorl, the smallness of the aperture, the armature of the latter, and the abbreriated canal, are distinctire.

Dimensions. - Length $18 \mathrm{~mm}$.; brealth $9 \mathrm{~mm}$.; length of aperture and canal $8.5 \mathrm{~mm}$.

Form. and Loc.-Niocene and post-Pliocene, Victoria.

G. 4271. Two examples of the neanic stage of growth. Miocene: from Muddy Creek. Presented by John Dennant, Esq.

G. 5545. Examples of the adult. Post-Pliocene: from Limestone Creek, Glenelg river.

Purchased.

G. 9396. Specimens of divers stages of growth; from Muddy Creek.

Purchased.

\section{Lotorium spengleri, Chemnitz (sn.).}

1795. Murex spengleri, Chemnitz, Conch. Cab. Bd. xi. p. 117, pl. cxei. figs. $1839, \mathbf{1 8 4 0 .}$

1843. Triton spengleri, Lamarck, Deshayes, Hist. Nat. Anim. sans Vert.

t. ix. p. 627 .

1844. Triton spengleri, Reeve, Conch. Icon. vol. ii. fig. 36 .

1873. Tritonium spengleri, Ton Martens, List Moll. N.Z. p. 24.

1873. Triton spengleri, Uutton, Cat. Marine Moll. X.Z. p. 13.

1873. Triton spengleri, Ilutton, Cat. Tert. Moll. X.Z. p. 5. 
1880. Tritonium spenglevi, Hutton, Man. N.Z. Moll. p. 64.

1881. Triton spengleri, Tryon, Manual of Conchology, vol. iii. p. 16, pl. ix. fig. 61 .

1893. Triton spengleri, Hutton, Linn. Soc. N.S.W., Macleay Mem. Vol. p. 53.

Characterized by its large, sulcated spiral carinæ, which are distinctly but regularly nodose; spiral sulci deep and broad, the whole ornament passing over the much elevated, compressed varices. Neither of the specimens in the Museum collection are in good preservation.

Dimensions (of a mutilated specimen).-Length $71 \mathrm{~mm}$; breadth $42 \mathrm{~mm}$. ; length of aperture aud canal $39 \mathrm{~mm}$.

Form. and Loc.-Pliocene and Miocene: New Zealand.

G. 9554. An example of the adult, in which the spiral carinæ are not so bold as in typical specimens; from Wanganui.

Sir James Hector Coll.

G. 9706. A typical example of the adult; from Parimoa.

W. B. D. Mantell Coll.

\section{Lotorium, sp.}

70415. Cast of a specimen having large nodosities at the periphery of the whorls; from the Tertiary of Mount Wellington, New Zealand.

Purchased.

G. 467. Crushed specimen, in which the spiral ornament is very conspicuous; from the Tertiary of Wellington, N.Z.

Presented by Lieut.-Col. Wilmer.

Genus COLUBRARIA, Schumacher.

[Essai Nouv. Syst. Habit. Testacés, 1817, pp. 76, 251.]

Spire elongate; ornament subdued, varices not obtrusive, rather distant; aperture small; outer margin lirate within, posterior sinus absent or rudimentary; inner margin plated; columella frequently granulate; anterior canal short.

Type.-Colubraria granulata, Schumacher.

Colubraria tenuicostata, Tenison-Woods (sp.).

1879. Pisania tenuicostate, Tenison-Woods, Proc. Iinn. Soc. N.S.W. vol. iii. p. 224 , pl. xx. fig. 6 .

1888. Epidromus tennicostatus, Tate, Trans. Roy. Soc. South Aust. vol. x. p. 38 , pl. vi. fig. 12 .

1893. Epidromus tenuicostatus, Tate and Dennant, id. vol. xvii. pt. 1, p. 219. 
Shell elongate; protoconch very small, composed of two smooth, shining turns, somewhat inflated, elevated and subcentral at the commencement; shell in the brephic stage strongly, longitudinally ribbed, interstitial ornament obsolete; the latter, however, becomes accentuated with growth, consisting of elosely-set spiral lineations, which, in conjunction with the flexuous and elosely-set longitudinal ribs, produce subeancellation, and granulation in the adult; varices broad, rounded, crossed by the spiral lineations; aperture suall, narrow, deeply channelled in front; outer margin typically raricose, dentate, lirate within, posterior sinus alusent; inner margin plated, smooth; columella slightly granulose, twisted; canal short.

Dimensions.-Length $16 \mathrm{~mm}$.; breadth $6 \mathrm{~mm}$.; length of aperture and canal $7 \mathrm{~mm}$.

Form. and Loc.-Eocene: MLuddy Creek, Tictoria.

G. 4165. Two specimens. Presented by John Dennant, Esq.

G. 9391. Examples of the adult. Purehased.

\section{Gemns APOLLO, Montfort (em.).}

[Conch. Syst. t. ii. 1810, p. 571.]

The principal distinctive features of this genus are the continuous or subcontinuous rarices by which it may be distinguished from Lotorium. Its general contour is that of Ranella, from which it differs, amongst other things, by the absence of a posterior groove, canal, or sinus.

Apollo is sometimes regarded ${ }^{1}$ as a section of Argobuccinum, Klein; but that cannot be admitted, the latter being the work of a pre-Linnean author and not brought on until Apollo had already been suggested. If Argobuccinum is not to be regarded as synonjmous with Apollo, the differences are certainly not of generic ralue, and it is here suggested that Apollo should be regarded as the genus, and Argobuccinum, Gyrina, Schumacher, Aspella, Mörch, etc., as subgenera.

Type.-Ilurex gyrinus, Linnæus. 


\section{Apollo pratti, Tenison-Woods (sp.).}

1879. Triton prattii, Tenison-Woods, Proc. Linn. Soc. N.S.W. vol. iii. p. 223 , pl. xxi. fig. 15.

1888. Ranella (Aigobucimum) prattii, Tate, Trans. Roy. Soc. South Aust. rol. x. p. 115 , pl. vi. fig. 6 .

1889. Argobuceimem pratti, Cossmann, Ann. Géol. Univ. t. v. 1888, p. 1089. 1893. Ranella (Argobuccinum) prattii, Tate and Dennant, Trans. Roy. Soc. South Anst. vol. xrii. pt. 1, p. 218.

1894. Argobuccinum pratti, Tate, Journ. Roy. Soc. N.S.W. vol. xxvii. p. 172.

This species is much flattened, rarices obliquely continuous; outer margin distautly grooved within; columella excavated, plated, twisted, granulose; canal short and bent. Professor Tate remarks, in his work of 1888 above cited, that it is related to the living Ranella bitubercularis, Lamarck, of the Indo-Pacific region, "from which it differs in being multicostated, and not bi- or trituberculated between the varices."

Dimensions. - Length $29 \mathrm{~mm}$. ; breadth $18 \mathrm{~mm}$.; length of aperture $9.5 \mathrm{~mm}$; length of canal $4.5 \mathrm{~mm}$.

Form. and Loc. - Eocene: Victoria and South Anstralia.

48052. Several specimens in which the longitudinal ribbings are much suppressed, and the spiral lineations bolder and more numerous; from Schnapper Point.

Purchased.

70417. An example of the neanic stage of growth; from Dandenony.

Purchascd.

G. 4290. Example of the adult; from Muddy Creek.

Presented by John Dennant, Esq.

G. 4298. Specimen of the neauic stage, with the ornament on the whorls much reduced; from Muddy Creek.

Presented by John Dennant, Esq.

G. 5527. Examples of the senile stage of growth; from Muddy Creek.

Purchased.

G. 912\%. Sereral examples in which the longitudinal ribs are rery conspicuous; from River Murray cliffs, near Adelaide.

Presented by William Evans, Esq.

G. 9401. Specimens of the same local variation as the preceding; from River Murray cliffs.

Purchased. 


\section{Family CASSIDIDA.}

\section{Genus CASSIS, Martini.}

[Conch. Cab. vol. ii. 1773, pls. xxxii., xli. p. 15; also Lamarck, Mém. Soc. IIist. Nat. Paris, 1799, p. 72.]

Cassidea, Bruguière, Ency. Meth. Vers. t. i. pars 2, 1792, p. 414.

Shell ovoid, ventricose, having irregular varices; spire short; aperture clongate; outer margin reflected outwardly, denticulate in the interior; columella callous, plicate, dentate or granulate; columellar callosity extending over a great portion of the ventral surface; canal very short, broad, reflected.

Type.-Buccinum cornutum, Linnæus.

\section{Cassis exigua, Tenison-Woods.}

1879. Cassis exigua, Tenison-Woods, Proc. Linn. Soc. N.S.W. vol. iv. p. 17, pl. ii. fig. 7.

1889. Cassis exigua, Tate, Trans. Roy. Soc. South Aust. vol. xi. p. 164, pl. vii. fig. 13.

The specimen figured by $\mathrm{Mr}$. Tenison-Woods refers evidently to a very young shell, and the interpretation placed upon it by Professor Tate (op. supra cit.) is here adopted, though the specimens in the Museum do not enable the present writer to control the matter.

The protoconch consists of one and a half oblique, smooth turus, abruptly joined to the succeeding whorl. The shell is solid, rentricose, with a short conical spire; suture in the later whorls hidden and surmounted by an undulating, granulose, and tuberculate ridgre; shoulder of the body-whorl coronate, with large, prominent, eompressed, tooth-like tubercles; smaller tubercles are developed in front of this on the body-whorl. Aperture narrow, outer margin flattened, inflected, and slightly reffected, dentate within; inner margin nuch expanded, projecting in front as a thin plate orer the umbilical region; columella twisted, and furnished with a number of irregularly disposed plications.

C. mamillaris, Grateloup, of the Upper Tertiary of Europe, is a close ally. 
Dimensions. - Length $45 \mathrm{~mm}$.; breadth $33 \mathrm{~mm}$.; length of aperture and canal $40 \mathrm{~mm}$.

Form. and Loc.-Eocene: Muddy Creek, Victoria.

G. 4178. Example of the neanic stage of growth.

Presented by Jukn Dennant, Esq.

G. 5504. An example of the adult.

Purchased.

\section{Cassis, sp.}

The following specimens in the Museum collection are indetermiuable specifically, and are all in the state of casts:-

G. 9646. A narrow form, nodose at the subangulation of the body-whorl near the suture; from the Tertiary of Willunga, South Australia.

II. Y. L. Brown Coll.

G. 9636. Cast of Cassis, or Dolium, having much depressed spire, and the whorls broadly sulcated; from the Eocene of Oamaru, New Zealand.

Sir James Hectur Coll.

G. 9640. Casts of a species allied to C. exigua, Tenison-Woods; from the Tertiary of Nullarbor Plain, South Australia.

H. Y. L. Broun Coll.

G. 9658. Cast of a large varicose species, with ventricose bodywhorl aud short spire; from the Tertiary of Nullarbor Plain (Price Maurice's well), South Australia.

II. Y. L. Brown Coll.

\section{Genns SEMICASSIS (Klein), Mörch.}

[Cat. Yoldi, fasc. i. 1852, p. 112.]

Spire prominent; whorls spirally sulcate and lineate; aperture large; outer margin reflected, dentate ; columella plicate and often granulate.

Type.-Cassis japonica, Reeve.

\section{Semicassis sufflata, Tenison-Woods (sp.).}

1877. Cassis sufflatus, Tenison-Woods, Pap. Roy. Soc. Tas. 1876, pp. 93, 94. 1889. Semicassis transenna, Tate, Trans. Roy. Soc. South Aust. vol. xi. P. 166, pl. viii. fig. 2 .

1896. Semicassis sufflatus, Pritchard, Proc. Roy. Soc. Tict. vol. viii. s.s. p. 106. 
Protoconeh of two and a half smooth, depressed turns, griulually increasing in size from the initial portion, abruptly separated from the succeeding whorl. The eancellate ornament, so well developed on the body-whorl of the adult, commenced to form in the earliest part of the brephic stage. Spire elevated, subangulate at the shoulder; suture accompanied by a small, acute ridge; aperture oral-oblong, obtuse posteriorly, and ronded in front; outer murgin thickened, refleeted, and dentate within; columellar expansion smooth, forming a thin plate anteriorly; columella twisted, and having several irregular plications, with here and there a tubercle anteriorly.

A characteristic feature of the shell is the fine cancellate ornament.

Mr. G. B. Pritchard has indicated that $S$. transenna, Tate, is a synonym of this species as abore shown. As Mr. Tenison-Woods did not give a figure of $S$. sufflata, the present writer eannot eontrol the matter; but the description given by its author certainly appears to bear out Mr. Pritehard's views.

Dimensions. - Length $29 \mathrm{~mm}$.; breadth $17 \mathrm{~mm}$.; length of aperture and canal $19 \mathrm{~mm}$.

Form. and Loc.-Eocene: Muddy Creek, Vietoria.

G. 4179. Several examples of the adult.

Presented by John Dennant, Esq.

G. 5505. An example of the adult.

Purchased.

\section{Semicassis muelleri, Tate.}

1889. Semicassis muelleri, Tate, Trans. Roy. Soc. South Aust. vol. xi. p. 167 , pl. vii. fig. 9 .

This species differs from the preceding principally in the absence of cancellate ornament, its aperture being broader and the whole shell more rentricose. The whorls have bold spiral bands of unequal size erossed by fine growth-liues which lead to eancellation accompanied by dentate elevations on the bands referred to. 'This ornament is almost entirely confined to the area between the subangulation of the shoulder of the body-whorl and the suture; the latter is bordered by a granulose lineation best dereloped in the soung state. The body-whorl has regularly-spaced growthlines with obsolete spiral lineations in front of the snbangulate 
shonlder, and sereral better-marked lineations near the anterior extremity. Columella twisted medially, furnished with a number of small, irregular plications.

It is, apparently, the precursor of the living S. nivea, Brazier, of the Australian seas.

Dimensions. - Length $29 \mathrm{~mm}$. ; brealth $20 \mathrm{~mm}$.; length of aperture and canal $21.5 \mathrm{~mm}$.

Form. and Loc.-Miocene: Muddy Creek, Victoria.

G. 5506. An example of the adult.

Purchased.

Subgenus CASMARIA, H. and A. Adams.

[Gen. Rec. Moll. vol. i. 1853, p. 216.]

Whorls almost smooth, or plicated longitudinally; outer margin smooth, or only slightly crenulated; columella smooth.

Type.-Buccinum vibex, Linnæus.

\section{Semicassis (Casmaria) pyrum, Lamarck (sp.).}

1822. Cassis pyrum, Lamarck, Anim. sans Vert. t. vii. p. 226.

1844. Cassis pyrum, Lamarck, id. 2nd ed. t. x. p. 33.

1848. Cassis pyrum, Reeve, Conch. Icon vol. v. pl. si. figs, $29 a-c$.

1873. Cassis pirum, Yon Martens, List Moll. N.Z. p. 24.

1873. Cassis pyrum, Hutton, Cat. Marine Moll. N.Z. p 20.

1873. Cassis pyrum, Hutton, Cat. Tert. Moll. N.Z. p. 8.

1873. Cassis striatus, Hutton, id. p. 8.

1880. Cassis pyrum, Hutton, Man. N.Z. Moll. p. 66.

1885. Cassis (Semicassis) achatina, Lamarck, var. pyrum, Tryon, Manual of Conchology, vol. vii. p. 278, pl. viii. figs. $6-8$; pl. ix. fig. 7 .

1893. Cassis pyrum, Hutton, Linn. Soc. N.S.W., Macleay Mem. Vol. p. 53.

Shell orate, ventricose; whorls obscurely angnlate posteriorlf, nodose on the angulations; whorls of the spire irregularly spirally sulcate, body-whorl of the adult spirally sulcate near the suture aud towards the anterior portion only, the middle being smooth; aperture dilated; columella smooth, having a large plait anteriorly; outer margin reflected, smooth.

Dimensions. - Length $42 \mathrm{~mm}$; ; breadth $31 \mathrm{~mm}$.; length of aperture and canal $29 \mathrm{~mm}$.

Form. and Loc.-Pliocene: Wanganui, New Zealand.

G. 9536. An example of the adult. Sir James Hector Coll. 


\section{Semicassis, sp.}

G. 5541. Mutilated example of what is possibly a new species of Semicassis. It is $43 \mathrm{~mm}$. in length; the whorls are conrex, those of the spirc have five to six prominent spiral lines broken up into granulations, and these are confined to the posterior portion of the borly-whorl, between the shoulder and the suture; the middle of the body-whorl is smooth, or only very faintly lineated, but the spiral sulci are well marked in the neighbourhood of the anterior canal. It is allied to S. subgranosa, Tate, but has no longitudinal costæ. From Muddy Creek, Victoria.

Purchased.

G. 9548. Cast of a species of Semicassis, allied to S. suffata, Tenison-Woods. From the Eocene of Wrapara, New Zealand.

Sir James Hector Coll.

Genus MORIO, Montfort.

[Conch. Syst. rol. ii. 1810, p. 479.]

Galeodea, Link, Besch. Rostock, Abth. iii. 1807, p. 113 (non Olivicr, 1791).

Cassidaria, Lamarck, Cours Zool. 1812, p. 119.

Echinora, Schmmacher, Essai Nouv. Syst. Habit. Testacés, 1817, pp. $75,249$.

Shell ventricose, not varicose; onter margin reflected, often crennlate; colnmellar border plicate; canal long, twisted.

Type.-Buccinum echinophorum, Linnæus.

\section{Morio gradata, Tate (sp.).}

1889. Cassidaria gradata, Tate, Trans. Roy. Soc. South Aust. vol. xi. p. 169 , pl. viii. fig. 1 .

Protoconch small, composed of one and a half turns implanted obliquely on the sncceeding whorl; it is sharply defined from the shell proper. The most interesting facts concerning the mode of growth are to be gleaned by obscrvation of the brephic stage. On escape from the eapsule the animal appears to hare been unilecided on eren the main lines of its subsequent ornament; and it is found at that period of growth to consist, first of all of 
a number of small closely-set spiral lines intersected here and there by obsolete growth-lines, and this in some individuals persisted for at least one whorl. Gradually the longitudinal lines develop into small ridges, which, after establishing small tubercles in the neanic stage, pass away into almost imperceptible striæ of growth. The tubercles on the shoulder of the whorl become divided into two parts spirally at a very early period, and as the animal arrived at maturity they are further subdivided in the same direction. The spiral cords in the young shell develop irregulariy, but in the neanic stage they are transformed into broad spiral ridges with concave sulci between. It is not until the ephebic stage is reached that these ridges are erowned with regularly spaced tubereles of similar character to those at the shoulder of the whorl. It is interesting also to trace the development of the broad area surrounding the suture. In the brephic stage no indication of this is apparent, at least in any of the specimens in the Museum; but immediately afterwards an oblique sulcus is gradually formed, which broadens and becomes flat with age.

It would not be difficult to trace the development of other details of the ornament in the same way, but enough has been said to show the absurdity of placing much reliance on the character of the ornament in such a genus as Morio as a criterion for differentiating species, or even so-called "varieties." The facts given suggest that if the growth of the shell in this and some allied genera be studied in detail, it will be seen that the difference observable in many so-called species are mere individual characters, brought about by the suppression of bold features, or the lack of accentuation in the adult of certain characters which made their appearance at a much earlier stage. In jucking the relative ralue of ornament in this connection, it would seem that the most reliable differentiations are to be made out in the younger stages of growth. Professor Tate is to be congratulated in the moderation displayed in estimating the number of species of Morio in the older Tertiary of Australia; contrast the work of Professor Sacco, ${ }^{1}$ of Turin, in describing the Cassidide of the Piedmont Tertiary.

1 Moll. Terz. Piedmont e Liguria. Torino, 1890, p. 11 et sqq. 
The species has a superficial resemblance to the common M. cchinophora, Linn., of the Upper Tertiary of the Mediterranean area.

Dimensions. - Length $29 \mathrm{~mm}$.; breadth $19 \mathrm{~mm}$.; length of aperture and canal $18 \mathrm{~mm}$.

Form. and Loc.-Eocene: Victoria.

73225. Specimens showing stages of growth; from Schnapper Point. Purchased.

G. 4180. An example of the neanic stage of growth; from MIuddy Creek.

Purchased.

\section{Morio, sp.}

G. 9559. Cast of a species of Morio allied to M. gradata, Tate; from the Hiocene of Port Hills, Nelson, New Zealand.

Sir Jumes Hector Coll.

\section{Family CYPR EID王.}

\section{Genus CYPR王A, Linnæus.}

[Syst. Nat. ed. I0, 1758, p. 718; id. ed. 12, vol. i. 1767, p. 1172.] Fulgusella, Jousseaume, Bull. Soc. Zool. France, t. ix. 1884, p. 90 .

Shell oroid, rentricose, enamelled; spire (except in joung stages of growth) enveloped by the body-whorl, or covered over by a thin coating; aperture narrow, extending the whole length of the shell, canaliculate at each extremity; both inner and outer margins crenulate.

The following was selected as the type of the genus by Lamarck: ${ }^{1}$ Type.-Cypraa mappa, Linnæus.

\section{Cypræa scalena, Tate.}

1890. Cypraa sculena, Tate, Trans. Roy. Soc. South Aust. vol. xiii. pt. 2, p. 203.

1892. Cypraa scalena, Tate, id. vol. xiii. supp. pl. v. figs. 2, $2 a$.

Shell oval-oblong, spire completely hidden; aperture and phenomena connected therewith rery similar to that of $C$. subsidua; 
but the spire of the last-mentioned species is well developed, and the shell generally is somewhat narrower.

Dimensions.-Length $28 \mathrm{~mm}$. ; breadth $18 \mathrm{~mm}$.

Form. and Loc.-Eocene: Mudily Creek, Victoria.

G. 9416. An example of the neanic stage of growth. Purchased.

\section{Cypræa parallela, Tate.}

1590. Cypraa parallela, Tate, Trans. Roy. Soc. South Aust. vol. xiii. pt. 2, p. 203.

1892. Cyprea parallele, Tate, id. vol. xiii. supp. pl. v. fig. 1.

Almost cylindrical, mnch narrower, and smaller than $C$. scalena; the outer border rises higher posteriorly, and restiges of the whorls of the spire are apparent. Its author compares it with dwarfed examples of $C$. isabella, Linnæus.

Dimensions.-Length $16 \mathrm{~mm}$.; breadth $8 \mathrm{~mm}$.

Form. and Loc.-Eocene: Muddy Creek, Victoria.

G. 9420. Two examples of the adult.

Purchased.

\section{Subgenus BERNAYIA, Jousseaume.}

[Bull. Soc. Zool. France, t. ix. 1884, p. 88.]

Spire visible, elerated; columella haring a large excavation in front; aperture deeply channelled at its two extremities, slightly turned or curved posteriorly.

Type.-Cyprea media, Deshayes.

\section{Cypræa (Bernayia) subsidua, Tate.}

1890. Cypraa subsidua, Tate, Trans. Roy. Soc. South Aust. vol. xiii. pt. 2, p. 204.

1892. Cyprca subsidza, Tate, id. supp. pl. v. fig. 3 .

Shell ovate, oblong, under-surface flattened; spire exsert, from three to four whorls partly visible; aperture narrow, curred, broadest in front; outer margin rising slightly above the level of the spire, crenulate throughout its length; inner margin and columella crenulate, the latter broadly concave anteriorly, bordered by a strong flattened callosity in the neighbourhood of the posterior and anterior channels. 
This species is allied to C. bartonensis, Edwards, of the English and Parisian Eocene, from which it differs in having a less prominent spire, and by the large posterior protuberance on the inner margin.

Dimensions.-Length $27.5 \mathrm{~mm}$. ; breadth $17 \mathrm{~mm}$.

Form. and Loc,-Eocene: Muddy Creek, Victoria.

G. 9417. An example having a conspicuous spire. Purchased.

\section{Cypræa (Bernayia) contusa, M'Coy.}

1877. Cyprea (Luponia) contusa, M'Coy, Prod. Pal. Vict. dec. v. pl. xlix. tigs. $3-3 c, 4,4 a$.

1890. Cyprea contusa, Tate, Trans, Roy. Soc. South Aust. vol. xiii. pt. 2, p. 206.

1893. Cyprea contusa, Tate and Denuant, id. rol. xrii. pt. 1, p. 221.

Very globose, with a narrow aperture extending the whole length of the shell, dentate on either side; the onter margin rises a little abore the level of the top of the spire; the anterior portion is but slightly drawn out; anterior canal very short and wide; posterior short, and curved towards the apex. The surface is "irregularly reticulated with small contusions, or irregular polygonal bruise-like depressions."-Tate. Rough spiral lines are clearly shown on the specimens from Muddy Creek.

Dimensions.-Length $31.5 \mathrm{~mm}$, ; breadth $24 \mathrm{~mm}$.

Form. and Lac.-Eocene: Victoria.

70408. An example of the neanic stage of growth, in which the spiral lineations and other surface ornament are not strongly dereloped; from Mount Martha.

Purchased.

G. 4306. Two examples; from Muddy Creek.

Presentcd by John Dennant, Esq.

G. 5479. Speeimen of the senile stage, with corrugated surface; from Muldy Creek.

Purchased.

G. 9419. Tזо specimens; from Muddy Creek.

Purchased.

Subgenus LUPONIA, Sowerby and Gray.

[Conch. Illust. and Desc. Cat. Shells, by G. B. Surrerby, jun., and J. E. Gray, 1832, p. 12.]

Spire barely risible through the corering of enamel, and sometimes quite hidden; columella but slightly excarated; outer 
margin extending above the level of the spire and of the inner margin, and frequently bent over towards the former.

Type.-Cyprea algoensis, Gray.

\section{Cypræa (Luponia) brachypyga, Tate.}

1890. Cyprea brachypyga, Tate, Trans. Roy. Soc. South Aust. vol. xiii. pt. 2, p. 206.

1892. Cypraa brachypyga, Tate, $i d$. supp. pl. vi. fig. 3.

1893. Cyprea brachypyga, Tate and Denuant, $i d$. vol. xvii. pt. 1, p. 221.

This species differs from $C$. subsidua in being pyriform, the anterior portion of the shell being attenuated, by not having such abundant callosity bordering the inner margin, and by the indistinct longitudinal and spiral lineations on the surface. The aperture is very narrow, both margins are crenulated, the outcr one rising somewhat above the exsert spire.

Dimensions.—Length $23 \mathrm{~mm}$.; breadth $12 \mathrm{~mm}$.

Form. and Loc.-Eocene: Victoria.

48052. Series showing stages of growth; from Schnapper Point. Purchased.

70409. An example of the neanic stage; from Meribee Plains. Purchased.

G. 9421. Specimens of earlier stages of growth; from Muddy Creek.

Purchased.

\section{Cypræa (Luponia) pyrulata, Tate.}

1890. Cyprea pyrulata, Tate, Trans. Roy. Soc. South Aust. vol. xiii. pt. 2, p. 207.

1892. Cypraa pyrulata, Tate, $i d$. supp. pl. vi. figs. $4 a-b$.

1893. Cyprea pyrulata, Tate and Deunant, id. vol. xvii. pt. 1, p. 221.

Broader, larger, and less attenuate anteriorly than C. brachypyga, whilst the spire is almost entirely hidden; the aperture is relatively more open, being broad and deeply grooved in front, and the crenulated outer margin rises much higher above the level of the spire, at which point the former is not canaliculate; inner margin crenulated, the ridges being divided medially by a plane surface concave in front; this margin is not produced posteriorly. 
Professor Tate records this species as occurring at Muddy Creek only; but from examination of specimens from other localities mentioned below, it seems clear that $C$. pyrulata has a wirler geographical range; it is impossible to distinguish those specimens from authenticated examples, except that they are slightly more inflated, and in that respect form a connecting link with C. murraviana, Tate.

Form. and Loc.-Eocene: Victoria.

70407. A specimeu rather more iuflated than in typical examples; from Nount Martha.

Purchased.

73223. A series illustrating stages of growth; from Brighton.

Purchased.

G. 5480. Example of the adult; from Muddy Creek, Purchased.

G. 9418. Three specimens, the largest of which is mueh drawn out anteriorly, and its caual is broad and reflected; from Muddy Creek.

Purchased.

\section{Cypræa (Luponia) leptorhyncha, M'Coy.}

1877. Cypraa (Luponia) leptorhyncha, M'Coy, Prod. Pal. Vict. dec. $\nabla$. pl. xlix. figs. $1-1 c$.

1890. Cypraa leptorhyncha, Tate, Trans. Roy. Soc. South Aust. vol. siii. pt. 2, p. 208.

1893. Cyprea leptorhyncha, Tate and Dennant, id. vol. xrii. pt. 1, p. 221.

Globose, attenuated anteriorly; spire usually traceable, depressed; aperture broad, slightly constricted medially, broadest in front; sharply curved posteriorly; outer margin strongly crenulate, flatly callous anteriorly, much produced posteriorly where it is bent or arched and fortified behind, the superior portion of the margin descending almost vertically to one side of the spire; inner margin crenulate, the ridges extending partly orer the ventral surface, furnished with a protuberant callosity at the margin of the rudimentary posterior eanal; columella flatly callous and exearater in front; anterior canal short, broad, truncate, reflected; a small tuberele appears on the dorsal aspect of the shell in which the canal is cut.

It may be compared with $C$. inflata, Lamarck, and C. globularis, Elwarls, of the European Eocene; it is more globose than either of them. 
Dimensions.-Length $63 \mathrm{~mm}$; breadth $39 \mathrm{~mm}$.

Form. and Loc.-Eocene: Muddy Creek, Victoria.

G. 5478. An example of the adult.

Purchased.

\section{Subgenus EROSARIA, Troschel.}

[Gebiss der Schnecken, Bd. i. 1863, p. 210.]

Aricia, Sowerby and Gray, Conch. Illust. and Desc. Cat. Shells, 1832 , p. 7 (non Sarigny, 1817).

Shell smooth on the dorsal surface; flattened underneath; columella not excarated in front; aperture crenulate, dentate or ridged on both the inner and outer margins.

Type.-Cypraa erosa, Linnæus.

\section{Cypræa (Erosaria) gigas, M‘Coy.}

1867. Cyprea gigas, M'Coy, Ann. Mag. Nat. Hist. 3rd ser. vol. xx. p. 438.

1875. Cyprea (Aricia) gigas, M·Coy, Prod. Pal. Vict. dec. ii. p. 19, pl.xr.; pl. svi. fig. 2 ; pls, xvii. and xviii. fig. 1.

1876. Cyprea (Aricia) gigas, M·Coy, id. dec. iii. p. 35, pls. xxviii. and xxix. fig. 1.

1890. Cyprea gigas, Tate, Trans. Roy. Soc. South Aust. vol. xïi. pt. 2, p. 212.

1893. Cyprea gigas, Tate and Dennant, id. vol. xrii. pt. 1, p. 221.

This is the largest known species of Cypraa, living or fossil. It is much inflated dorsally, base flattened; inner margin smooth within, flattened near the anterior canal, which is deep, narrow, elongate, and projects upwards; outer margin tumid, furnished with nine or ten obsolete obtuse teeth near the anterior end, and a few also near the posterior extremity; posterior canal obliquely truncate, bent upwards, and adherent to the spire.

This is by no means a typical Erosaria, the inner margin not being dentate or plicate; but Sir F. $\mathrm{I}{ }^{\circ}$ Coy states $^{1}$ that under certain circumstances, "faint indications of teeth may be detected"; in other respects, and in the broad sense, it conforms fairly well to that subgenus. It is allied to Gisortia, Jousseaume, which, however, is typically largely tuberculate or keeled on the surface.

Dimensions.-Length $8 \frac{3}{8}$ inches; breadth $5 \frac{6}{8}$ inches.

Form. and Loc.-Eocene: Muddy Creek, Victoria.

1 Prod. Pal. Vict. dec. ii. 1875, p. 19. 
G. 4304. Example of a fully-grown individual.

Presented by John Dennant, Esq.

\section{Cypræa (Erosaria) platypyga, M‘Coy.}

1876. Cyprea (Aricia) platypyga, $\mathbf{I}^{\circ} \mathrm{Coy}$, Prod. Pal. Fict. dec. iii. pl. xxx. figs, 1-1 $c$.

1890. Cyprea platypyga, Tate, Trans. Roy. Soc. South Aust. vol, xiii. pt. 2, p. 211.

1893. Cyprea platypyga, Tate and Dennant, id. vol. xvii. pt. 1, p. 221.

1896. Cyprea platypyga, Pritchard, Proc. Roy. Soc. Vict. vol. viii. x.s. p. 106.

This large species is characterized by its solidity, the narrowness of the aperture, grooved and ridged on either side, the grooves on the columellar border extending well over the surface outwardly. The shell is globose, smooth, furnished with solid, broad, flattened extensions posteriorly, through which the short posterior canal is cut; anterior canal sharply bent towards the dorsal surface, and flanged by thick, flattened callosities.

The short, very wide, truncate posterior extension, and the prolongation posteriorly of the inner margin of the aperture, which rises abore the lerel of the callosity on the opposite side, are distinctive. The enormous grooves on the columellar border are not characteristic of Erosaria, in which it is here placed, but in other respects it recalls that subgenus.

Dimensions.-Length $79 \mathrm{~mm}$.; breadth $46 \mathrm{~mm}$.

Furm. and Loc.-Eocene: Victoria.

70405. Example of the adult; from Mount Martha. Purchased.

G. 4305. Au example of the alult, having the inner border much prolonged anteriorly; from Muddy Creek.

Presented by John Demnant, Esq.

G. 5477. Specimen in which the anterior canal is bent almost at a right angle with reference to the axis of the shell; from Muldy Creek.

Purchased.

Subgenus UMBILIA, Jousseaume.

[Bull. Soc. Zool. France, t. ix. 1884, p. 90.]

Shell depressed anteriorly; spire umbilicated; extremities produced and beaked; aperture sintous, ridged on either side, or, 
rarely, sulcated on the inner margin and over a large portion of the rentral surface.

Type-Cypraa umbilicata, Sowerby.

\section{Cypræa (Umbilia) eximia, G. B. Sowerby.}

1815. Cypræa eximia, G. B. Sowerby, in Strzelecki, Phys. Desc. N.S.W. p. 296, pl. xix. figs. 1-3.

1876. Cyprea (Aricia) eximia, M'Coy, Prod. Pal. Tict. dec. iii. p. 35, pls. xxriii. and xxix. figs. 2-2b.

1878. Cyprea eximia, R. Etheridge, jun., Cat. Aust. Foss. p. 161.

1878. Cyprcoovula eximia, R. Etheridge, jun., id. p. 162.

1890. Cypraa eximia, Tate, Trans. Roy. Soc. South Aust. vol. xiii. pt. 2, p. 209.

1893. Cyprea eximia, Tate and Dennant, id. vol. xvii. pt. 1, p. 221.

This is one of the most striking shells found in the Australian Tertiary; it is prolonged, and channelled both anteriorly and posteriorly, and in these features bears a certain resemblance to Amphiperas, Gronorius. The form of the spire, which is depressed, is barely visible through the thin deposit of callous enamel with which it is covered; the anterior prolongation has two large irregular, obtuse tubercles of a compound character on the dorsal surface, and is bordered by broad callons extensions of the ventral surface. These features, together with long, deep sulcations cut in the ventral surface and extending over the inner margin, which take the place of crenulations (and, in fact, produce the effect of a number of bold ridges), serve to readily distinguish this species from its congeners. It has a general subgeneric resemblance to C. umbilicata, Sowerby, which, as Professor Tate ${ }^{1}$ points out, falls into Umbilia, Jousseaume, in which subgenus it is here included, though it is not typical, and may by some authors be regarded as furnishing material for a new section of Cypraa.

Dimensions.-Length $83 \mathrm{~mm}$. ; breadth $39 \mathrm{~mm}$.

Form. and Loc.-Eocene. "It was found in a muddy sand, in sinking a well to 140 feet in depth, at Franklin's Village, Van Diemen's Land."-Sowerby.

G. 9694. The type specimen figured by Sowerby. Purchased. 


\section{Cypræa (Umbilia) sphærodoma, Tate.}

1890. Cyprea spherodoma, Tate, Trans. Roy. Soc. South Aust. vol. xiii. pt. 2, p. 209.

1992. Cyprea spharodoma, Tate, $i d$. vol. xiii. supp. pl. viii. fig. 5.

1896. Cyprea sphcesodoma, Pritchard, Proc. Roy. Soc. Vict. vol. viii. x.s. p. 107.

This species is closely allied to C. eximia, but is not so elongate, the body-whorl being much more inflated, whilst the pasterior third of the aperture is strongly curved to the left. Another point of difference is the mode of development of the columellar liræ or sulcations: in $C$. eximia these are typically rery close together, and extend over a large portion of the ventral surface of the body-whorl, especially towards the anterior; whilst in $C$ spherodoma they are more like ridges, are shorter, broader, farther apart, fewer in number, and do not extend orer such a wide area.

This species forms a connecting link between $C$. eximia and the living C. umbilicata, Sowerby, as the author indicates.

Dimensions. -Length $95 \mathrm{~mm}$.; breadth $52 \mathrm{~mm}$.

Form. and Loc.-Eocene: Victoria.

70406. Example of a rery globose rariation, in which both anterior and posterior canals are short, the latter being sharply curred; from Mount Martha.

Purchased.

G. 4303. Example of the adult; from Nuddy Creck.

Presented by Joln Demant, Esq.

G. 5476. Specimen of the neanic stage of gromth; from Muddy Creek.

Purchased.

\section{Cypræa, sp.}

The following specimens of Tertiary Cyprea are wot determinable specifically; they are all in the state of casts.

From South Australia-

48803. Two examples of a very gibbose species allied to C. leptorhyncha; from the River Murray cliffs. 
G. 9128. Closely related to, if not identical with, C. murrariana; from the River Murray, near Adelaide.

Presented by William Evans, Esq.

G. 9151. Cast of an elongate subcylindrical species; from near Border Town. Presented by R. Littow, Esq., F.G.S.

G. 9637. Four easts, the largest, some $58 \mathrm{~mm}$. in length, is of a species related to C. spharodoma; from Nullarbor Plains.

H. Y. L. Brown Coll.

G. 9638. Two casts of a species not unlike C. subsidua, but larger; from Nullarbor Plains.

II. Y. L. Brown Coll.

G. 9683. Cast of a broad, depressed species; from the River Murray cliffs. Transferred from the Museum of Practical Geology.

From Victoria-

G. 4410. Two casts, one of which is $75 \mathrm{~mm}$. in length and $65 \mathrm{~mm}$. in breadth, of a species with a much expanded outer margin ; from Mount Eliza, Hobson's Bay.

Purchased.

G. 4784. Two casts of a large species, flattened by pressure; from Lake Tyers, Gippsland. Presented by the Rev. J. S. II. Royce.

G. 4786. Several casts; from Gippsland.

Presented by the Rev. J. S. II. Royce.

G. 9689. Casts, in ferruginous sandstone, of a species related to C. subsidua; from Flemington (?), near Melbourne.

Trunsferred from the Museum of Practical Geology.

Genus TRIVIA, Sowerby and Gray.

[Conch. Illust. and Desc. Cat. Sbells, by G. B. Sowerby, jun., and J. E. Gray, 1832, p. 13.] $]^{\mathrm{I}}$

Shell usually small, transrersely ridged and frequently marked by a depression running antero-posteriorly across the dorsal region; whorls of the spire submerged, but mas often be traced through

1 The title of this pampblet, which is often erroueously quoted as "Desc. Cat. Cyprea, 1832," is as follows: "The Conchological Illustrations or Coloured Figures of all the hitherto unfigured Recent Shells, by G. B. Sowerby, jun.; with the corresponding text of a Descriptive Catalogue of Shells, by J. E. Gray, Esq., F.R.S., etc. Loudon, 1832." The title-page is sometimes missing from copies of this work. 
their thin outside covering; anterior channel not prolonged, wide and sliglitly reverted.

Dr. Gray ${ }^{1}$ selected the following as the type of the genus:-

Type.-Cypraa europaa, Montagu.

\section{Trivia avellanoides, $\mathrm{M}^{\prime} \mathrm{C} \mathrm{Coy}$.}

1867. Cyprea (Trivia) avellanoides, M[Coy, Ann. Mag. Nat. Hist. 3rd ser. vol. xx. p. 436.

1876. Cyprea (Trivia) avellanoides, $\mathbf{Y}^{\circ} \mathrm{Coy}$, Prod. Pal. Vict. dec. iii. p. 36, pls. xxviii., xxix., figs. $3-3 e$.

1877. Trivia europcea, Tenison-Woods, Pap. Roy. Soc. Tas. 1876, p. 109.

1878. Trivin avellanoides, R. Etheridge, juu., Cat. Aust. Foss. p. 168.

1879. Trivia minima, Tenison-Woods, Proc. Linn. Soc. X.S.W. vol, iv. p. 4 , pl. i. fig. 8 .

1890. Trivia avellanoides, Tate, Trans. Roy. Soc. South Aust. vol. xiii. pt. 2, p. 213.

1893. Trivia avellanoides, Tate and Dennant, id. vol. xvii. pt. 1, p. 222.

1895. Trivia avellanoides, Tate and Denuant, id. vol. xix. pt. 1, p. 111.

1896. Trivia avellanoides, Pritehard, Proc. Roy. Soc. Vict. vol. viii. x.s. p. 146.

Distinguished by its immense size (for the genus), it is more globose, and has more distant ridges than has $T$. australis; the young closely resemble $T$. europaea, from which they can only be separated with difficulty, the principal differentiating characters being a more pronounced dorsal furrow, a prominently thickened lip, and obscurely traceable spire-whorls. Professor Tate states that dwarfed examples differ from $T$. europea by much the same characters as the species does from $T$. anstralis, but that is hardly borne out on comparison with a number of specimens of the European species referred to. T. minima, Professor Tate says, is an early stage of growth of $T$. avellanoides.

Dimensions.-Length $29 \mathrm{~mm}$; ; breadth $23 \mathrm{~mm}$.

Form. and Loc.-Eocene: Victoria.

73222. Series illustrating stages of growth; from Brighton.

P'urchased.

G. 4307. Examples of the neanic and gerontic stages; from Suddy Creek.

Presented by John Dennunt, Esq.

G. 9415. Four specimens; from Muddy Creek. Purchased.

1 Proc. Zool. Soc. 1847, p. 142, genus No. 104. 


\section{Trivia australis, Lamarck (sp.).}

1822. Cyprea australis, Lamarck, Hist. Nat. Anim. sans Vert. t. vii. p. 404. 1828. Trivia australis, Gray, Zool. Journ. vol. iii. p. 570, sp. 108.

1834. Cyprea australis, Quoy and Gaimard, Voy. de l'Astrolabe, Zool. t. iii. p. 48, pl. xlriii. figs, 19-26.

1846. Cypraa australis, Reeve, Conch. Icon. vol. iii. pl. xxiv. fig. 138.

1867. Trivia australis, Angas, Proc. Zool. Soc. p. 206.

1881. Cypreca australis, Weinkauff, Conch. Cab. (ed. Kuister), p. 142, pl. sxxix. figs. 14, 15.

1885. Cyprea (Trivia) australis, Roberts, in Tryon, Manual of Conchology, vol. vii. p. 206, pl. xxiii. figs. 53,54 .

1886. Cypraa (Trivia) australis, Watson, Voy. "Challenger," Zool. (Gasteropoda), vol. xष. p. 427.

Ovate, slightly narrowed in front, thin; costæ prominent near the aperture, nearly obsolete on the centre of the dorsal surface, or, in some specimens, the costæ are much reluced in size on that area; aperture narrow, curved at both extremities; columella flattened, deeply excavated in front; outer margin thickened.

Dimensions.-Length $13.5 \mathrm{~mm}$; ; breadth $10 \mathrm{~mm}$.

Form. and Loc.-Post-Pliocene : Limestone Creek, Glenelg river, Victoria.

G. 5564. Three examples of the adult.

Purchased.

\section{Genus ERATO, Risso.}

[Hist. Nat. Eur. Mérid. t. iv. 1826, p. 240.]

Shell oroid, or pyriform; spire conical; aperture narrow ; outer margin denticulate; columellar border with small plications anteriorly; canal notch-like, broad.

The similarity of the animal of Erato, including its radula, to Trivia precludes the possibility of classifying the genus with the Marginellide, as is frequently done by authors. As Dr. Paul Fischer ${ }^{1}$ obserres, it may readily be separated conchologically from Marginella from the method of development of the columellar plications.

Type-Cypraa cypraola, Brocchi. 


\section{Erato minor, Tate.}

1878. Erato minor, Tate, Trans. Phil. Soc. Adelaide, p. 96.

1890. Erato minor, Tate, Trans. Roy. Soc. South Aust. vol. xiii. pt. 2, p. 215.

1892. Erato minor, Tate, $i d$. vol. xiii. supp. pl. xiii. figs. 10, $10 a$.

1895. Erato minor, Tate and Dennant, id. vol. xix. pt. 1, p. 111.

1896. Erato minor (?), Pritchard, Proc. Roy. Soc. Vict. rol. viii. x.s. p. 146.

Shell small, pyriform, tumid, abruptly contracted, and slightly reverted in front; spire very short, later whorls partially enveloped by the callosity extending from the thick, dentate, outer margin, and corering a large portion of the ventral surface of the shell; aperture narrow, broadening posteriorly, notched in front; columella finely plicate anteriorly, where it is also spirally ridged.

It is broader than E. lavis, Donovan, of the Upper Tertiary and recent seas of Europe, with which it has considerable analogy, and its columella is more saliently and numerously plicated.

Dimensions.-Length $4 \mathrm{~mm}$; ; breadth $2.75 \mathrm{~mm}$.

Form. and Loc.-Eocene: Muddy Creek, Victoria.

G. 9475. Sereral examples of the adult.

Purchased.

\section{Erato australis, Tate.}

1878. Erato australis, Tate, Trans. Phil. Soc. Adelaide, p. 96.

1890. Erato australis, Tate, Trans. Roy. Soc. South Aust. vol. xiii. pt. 2, p. 216.

1892. Érato australis, Tate, $i d$. vol. xiii. supp. pl. xiii. fig. 9.

1893. Erato australis, Tate and Dennant, id. rol. xrii. pt. 1, p. 222.

1895. Erato australis, Tate and Denmant, id. rol. xix. pt. 1, p. 111.

Distinguished from $E$. minor in being orately fusiform instead of pyriform, but especially in having a much elerated spire and less callosity. The outer margin is moderately thickened, and the shelly deposit extends to the penultimate whorl, being dentated at the inner edge of the aperture; columella with four thread-like plications with a few denticles behind, though these latter are not al ways dereloped.

Dimensions.-Length $6.5 \mathrm{~mm}$. ; breadth $3.75 \mathrm{~mm}$.

Form. and Loc.-Eocene: Spring Creek, Victoria.

G. 9472. Three examples of the neanic stage of growth. 


\section{Erato pyrulata, Tate.}

1890. Erato pyrulata, Tate, Trans. Roy. Soc. South Aust. rol. xiii. pt. 2, p. 216.

1892. Erato pyrulata, Tate, id. vol. xiii. supp. pl, xiii. figs. 12, $12 a$.

1895. Erato pyrulata, Tate and Dennant, id. vol. xix. pt. 1, p. 111.

This species is characterized by its columella ending anteriorly in a strong spiral plait, in having a moderately wide aperture, and by the thickening of the outer margin being squarely shouldered behiud. In shape it is globose-pyriform, and the spire in the adult is so short that it does not rise abore the level of the curved posterior notch of the aperture.

As Professor Tate remarks (op. supra cit.), its "terminal spiral plait on the columella, running out to form the left margin of a slightly effuse canal," is not characteristic of the genus. "The deuticles on the two margins appear when the adult stage is reached, but the columella-plait belongs to all ages." Compared with Marginella edentula, Tate, it is less inflated, and has not such a convex columella.

Dimensions. - Length $6.5 \mathrm{~mm}$; ; breadth $4.5 \mathrm{~mm}$.

Form. and Loc.-Eocene: Aldinga, South Australia.

G. 9474. Examples illustrating stages of growth. Purchased.

\section{Family STROMBID疋.}

\section{Genus STROMBUS, Linneus.}

[Syst. Nat. ed. 10, 1758, p. 742.]

Shell ovoid, tuberculose or spinose, solid; spire with several whorls; aperture elongate, obliquely truncated and cliannelled anteriorly, canaliculate posteriorly; outer margiu dilated, usually thick, often produced behind, sinuate and sometimes channelled in front; columellar border simple, enamelled.

The following species is selected by Lamarck ${ }^{1}$ :-

Type.-Strombus pugilis, Linnæus.

1 Mém. Soc. Hist. Nat. Paris, 1799, p. 72. 


\title{
Strombus denticostatus, sp. nor.
}

\author{
[Plate VI. Fig. 8.]
}

Shell elongate; whorls eight in number, those of the spire lougitudinally costate in the earlier stages, the costre there being numerous, and extending almost from suture to suture; in subsequent stages these are modified, being much contracted, and becoming dentate at the periphery; on the body-whorl the costæ have shrunk, and are represented by immense, dentate, very distant tubereles; the other ornament of the spire eonsists essentially of elosely-set spiral lineations, which are broken up into wary undulations on the body-whorl of the adult by the crossing of the lines of growth; the outer margin is expanded and wing-like, extending as a broad wide lobe posteriorly, rounded at the extremity, and joining the spire at the posterior suture of the penultimate whorl; this aliform expansion tapers towards the frout by a graceful eurve, the shell in that region becoming much narrower in consequence; the exterior aspeet of the wing shows that the spiral lineations beeome bolder and spread out until they attain the margin; iu particular, a bold keel fortifies the prolonged lobe alluded to, whilst the growth-lines beeome prominent, almost rugose; anterior canal truneate.

It is unfortunate that the only example of this ornate species in the Museum collection is an impression in limestone of the back of the shell; but, as will be seen from the figure (Plate VI. Fig. 8), which is drawn from a plaster cast, the impressiou is very perfeet, and it seemed desirable to place this distinctire species on record.

Dimensions.-Length $43 \mathrm{~mm}$.; breadth (ineluding aliform expansion) $23.5 \mathrm{~mm}$.

Form. and Loc. - Tertiary: Tallowan Well, Fowler's Bay Distriet, South Australia.

G. 9654. Impression of the shell, apparently of the adult, in a block of shelly limestonc.

II. Y. L. Brown Coll. 


\section{Genus SERAPHS, Montfort.}

[Conch. Syst. t. ii. 1810, p. 375.]

Terebellum, Lamarck, Mém. Soc. Hist. Nat. Paris, 1799, p. 69 (non Linnæus, 1767).

Shell elongate, subcylindrical; spire short, summit obtuse; suture linear; aperture longitudinal, narrow posteriorly, and slightly dilated anteriorly; outer margin thin, simple, obliquely truncated in front, sometimes prolonged in the spire posteriorly by a callosity; columellar border smooth, straight.

Type.-Terebellum convolutum, Lamarck (Bulla sopita, Solander).

\section{Seraphs, sp.}

Casts of a narrow elongate species having a salient spire and oblique sutures; closely allied to the European Eacene S. fusiformis, Lamarck.

G. 9643. Three specimens; from the Tertiary of Nullarbor Plains, South Australia. H. Y. L. Brown Coll.

\section{Family STRUTHIOLARIID无.}

\section{Genus STRUTHIOLARIA, Lamarck.}

[Ency. Meth., Vers. Coq., Moll., etc. t. iii. 1816, pl. cccexxxi. figs. $1 a-b$ (sine descr.) ; Hist. Nat. Anim. sans Vert. t. vii. 1822, p. 147.]

Pelicaria, Gray, Guide Moll. Brit. M[us. pt. 1, 1857, p. 77.

Shell aval-oblong; spire turreted; aperture truncate in front; outer margin greatly thickened, partly reflected, sinuous, prominent in the middle; inner margin thickly callous, greatly expanded.

In proposing the name Pelicaria, Dr. Gray gives a rery brief description, and quotes only one species, which must, therefore, be regarded as the type of the genus. It is evident, however, that the description does not refer to that species, and the specific references serve to accentuate the fact. Now, the type species referred to is Pelicaria vermis (misquoted as P. vernis), which is admittedly a Struthiolaria. Pelicaria must, in consequence, fall in synonymy with that genus.

Type.-Struthiolaria nodulosa, Lamarck. 
Struthiolaria papulosa, Martyn (sp.).

1784. Buccinum papulosum, Martyn, Univ. Conch. pl. liv.

1790. Murcx stramineus, Gmelin, Linn. Syst. Nat. ed. 13, t. i. pt. 6, p. 3542.

1822. Struthiolaria nodulosa, Lamarck, Hist. Nat. Anim. sans Vert. t. vii. p. $1 \pm 7$.

1857. Struthiolaria papillaris, Gray, Guide Moll. Brit. Mus. p. 76.

1873. Struthiolaria papulosa, Von Martens, Iist Moll. N.Z. p. 25.

1873. Siruthiolaria nodulosa, Huttou, Cat. Mariue Moll. N.Z. p. 24.

1873. Struthiolaria nodulosn, Hutton, Cat. Tert. Moll. N.Z. p. 10.

1876. Struthiolaria papulosa, Paulucci, Bull. Soc. Malac. Ital. ser. 2, vol. ii. p. 225.

1880. Struthiolaria papulosa, Hutton, Man. N.Z. Moll. p. 67.

1855. Struthiolaria papulosa, Tryon, Manual of Conchology, vol. vii. p. 133, pl. xii. fig. 34 .

1893. Struthiolaria papulosa, Hutton, Iinn. Soc. X.S.W., Macleay Men. Vol. p. 60 .

The ornament of the whorls of this well-known species is very variable, though the contour is fairly constant; the spiral threads are sometimes very close and regularly spaced, more often at irregular interrals, and occasionally far apart in bands of two and three; the prominent angle at the shoulder may be faintly, distantly tuberculose, or the tubereles may attain to a great size. The extent of the callosity corering the inner margin of the aperture is also variable, but it is always thickest posteriorly, where it spreads over part of the penultimate whorl, aud anteriorly on the front half of the columella.

Dimensions. - Length $88 \mathrm{~mm}$; ; breadth $49 \mathrm{~mm}$.; length of aperture $42 \mathrm{~mm}$.

Form. and Loc.-Pliocene: Wanganui, New Zealand.

G. 9539, G. 9544. Two examples of the adult, with somewhat depressed spire, and strongly tuberculose at the periphery.

Sir James Hector Coll.

G. 9715. A large specimen, having an elongate spire, and tubcreles not strongly dereloped. $\quad W . R . D$. Mantell Coll.

\section{Struthiolaria vermis, Martyn (sp.).}

1784. Buccinum vermis, Martyn, Univ. Conch. pl. liii.

1790. Murex australis, Gmelin, Linn. Syst. Nat. ed. 13, t. i. pt. 6, p. 3542.

1822. Stmuthiolaria cremulata, Lamarck, Hist. Nat. Anim. sans Vert. t. vii. p. $1 \pm$ s. 
1842. Struthiolaria inermis, Sowerby, Thes. Conch. rol. i. p. 23, pl. v. figs. 12,13 , and 19 .

1873. Struthiolaria australis, Von Martens, List Moll. N.Z. p. 26.

1873. Struthiolaria rermis, Hutton, Cat. Marine Moll. N.Z. p. 24.

1873. Struthiolaria vernis, Hutton, Cat. Tert. Moll. N.Z. p. 10.

1876. Struthiolaria vermis, Paulucei, Bull. Soc. Malac. Ital. ser. 2, vol. ii. p. 229.

1880. Struthiolaria australis, Hutton, Man. N.Z. Moll. p. 68.

1850. Struthiolaria inermis, Hutton, id. p. 68.

1885. Struthiolavia rermis, Tryon, Manual of Conchology, vol. vii. p. 133, pl. xii. figs. 35,36 .

1893. Struthiolaria vermis, Hutton, Linn. Soc. N.S.W., Macleay Mem. Vol. p. 61.

This species is characterized by its smaller size, excavated suture, obtuse shoulder, which is more or less nodose, by the younger whorls being spirally bicarinate, and in being faintly spirally striate; the front part of the body-whorl is more strongly and distantly lineate, and the middle is flattened and somewhat depressed.

Dimensions. - Length $45 \mathrm{~mm}$. ; breadth $30 \mathrm{~mm}$.; length of aperture $23.5 \mathrm{~mm}$.

Form. and Loc.-Pliocene: Wanganui, New Zealandl.

G. 9543, G. 9551. Two examples of the adult.

Sir James Hector Coll.

\section{Struthiolaria frazeri (Hector MIS.), Hutton.}

[Plate VI. Figs. 10a-b.]

1885. Struthiolaria frazeri, Hutton, Trans. N.Z. Inst. vol. xvii. p. 329.

1886. Struthiolaria fraseri, Hector, Ontlines of Geol, of X.Z. (Ind. and Col. Exhib. New Zealaud Court, Cat. of Exhibits), p. 48, fig. 1.

1893. Struthiolaria fraseri, Hutton, Linn. Soc. N.S.W., Macleay Mem. Vol. p. 61.

This shell differs from S. papulosa in being strongly spirally grooved, the sulcations are very deep and wide; the whorls are elerated, keeled, flattened, and gradated, the area between the suture and the broad, distant tuberculose spiral band or keel at the shoulder posteriorly being almost flat, and also deeply spirally grooved, there are three or four groores behind the keel and four or five in front of it in the whorls of the spire; body-rrhorl similarly sulcated, subangulate, and broadly banded at the fourth or fifth sulcation in front of the peripheral keel, the whole being 
fuely spirally lineate; aperture broad, channelled in front; onter margin much thickened, sulcated within, the sulci corresponding with the elevated bands on the exterior of the body-whorl, callosity continuous and spreading over part of the penultimate whorl; inner margin thickly callous and spreading.

Dimensions. - Jength $75 \mathrm{~mm}$.; breadth $42 \mathrm{~mm}$.; length of aperture $36 \mathrm{~mm}$.

Form. and Loc.-Pliocene: MacLean's station, Napier, New Zealand.

G. 9545. An example of the adult. Sir James Hector Coll.

\section{Struthiolaria cincta, Hutton.}

1S73. Struthiolaria cincta, Hutton, Cat. Tert. Moll. N.Z. p. 11.

"Orate turreted; spire acute; whorls six, keeled; body-whorl hollowed in the middle; spirally ribbed, ribs thin, narrower than the intermediate grooves, smooth; keel subnodular; columella somewhat callous, slightly bent; outer lip not much thickened; axis $2 \cdot 1$; breadth $1 \cdot 4 . "-$ Hutton.

Sereral examples apparently referable to this species are found in the Museum collection; but they are not well preserved, and none are sufficiently perfect to allow of dimensions being accurately taken. The largest of them is about $1 \frac{3}{4}$ inches in length.

Form. and Loc.-Miocene: Akuakua, New Zealand.

G. 9542 , G. 9617 , G. 9623 , G. 9624 . Many specimens showing variation in the derelopment of the slightly tuberculate carinæ of the body-whorl, many having mere traces of tuberculations, others approaching S. tuberculata, Hutton. Sir James Hector Coll.

\section{Struthiolaria, sp.}

The following specimens from the Miocene of New Zealand, for the most part fragments imbedded in shelly limestone, form part of the Sir James Ilector Coll.:-

G. 9552. Whorls broadly tuberculate at the periphery; from Taipo, east coast of Wellington.

G. 9600. Globose species, probably referable to Tylospira, but not well preserved; from Waipara. 
G. 9628. Sereral fragments of a species allied to S. cincta, Hutton ; from the "Conus-beds," Mokihinui.

G. 9629. Broadly costate and tuberculate at the periphery of the body-whorl; from Port Hills, Nelson.

\section{Genus TYLOSPIRA, ${ }^{1}$ nom. nov.}

\section{Peticaria, auctorum.}

Spire elerated, conical, whorls partially or entirely corered by a deposit of enamel, in which last-mentioned character it differs, chiefly, from Struthiolaria. This enamel may be quite thin, so as to form a mere film, or it may consist of thick, eallous material corering the whole spire, rendering the shell almost spherical.

In reference to Pelicaria, see p. 218.

Type.-Buccinum scutulatum, Martyn.

\section{Tylospira coronata, Tate (sp.).}

[Plate VI. Figs. $9 a-b$.

1S59. Pelicaria coronata, Tate, Trans. Roy. Soc. South Aust. vol. xi. p. 171, pl. x. figs. 6,13 .

The mode of growth of the shell of this species is rery remarkable. Unfortunately the protoconch is not preserved in any of the specimens in the Museum collection; the whorls which immediately succeed, and which, presumably, constitute the brephic stage, are boldly spirally lineate, each of the small whorls haring from six to seven lineations; with growth, longitudinal striations make their appearance, and these erentually give rise to small nodulations on crossing the spiral lines, the surface of the shell at about the commencement of the neanic stage beiug cancellate, with the exception of a broad, slopiug area surrounding the suture posteriorly, which continues smooth and bears three or four spiral cords with smaller lineations between; the growth of the neanic stage was evidently very rigorons, longitudinal costæ are dereloped on the anterior half of the whorls, and the nodulations at the periphery become fewer iu number but progressively larger until

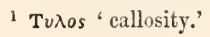


they form large dentate tubercles, the ornament towards the close of that stage being typieally fusoid. Then a revolution was effected by the commencement of the deposition of a thick coating of enamel, all ornament being corered up, the posterior prolongation of the enamel hiding the suture, and being flattened and fixed to the preceding whorl; with growth, the eallosity becomes broadly and deeply canaliculate, a feature which continues to the ephebic stage. The body-whorl of the adult is entirely covered with enamel, and it would appear that the large peripheral tubercles are no longer developed, as they are not traceable through the enamel, which is sinuously corrugated by growth-lines and bears a few spiral threads, in which last-mentioned feature we seem to see a recurrence to a former state. The callous enamel spreads orer the whole of the body-whorl and the anterior half of the penultimate whorl, in the adult. Columella thickly corered; outer margin sinuous.

Dimensions.-Length $38 \mathrm{~mm}$; breadth $28 \mathrm{~mm}$.

Form. and Loc.-Miocene: Victoria.

G. 4293. Two examples of the adult; from Mrudds Creek. Presented by John Dennant, Esq.

G. 4783. Specimen of the senile stage, having a more elerated spire and corrugated eallosity than the typical form; from Lake Tyers, Gippsland.

Presented by the Rev.J. S. H. Royce.

G. 5530. Example having a much elevated spire; from Muddy Cruek. Purchased.

Family CERITHIID正.

Genus CERITHIUM, Bruguière.

[Ency. Meth. Ters. t. i. pt. 2, 1792, p. 467.]

Shell imperforate, turriculate; whorls numerous, the last alwars shorter than the spire; aperture oblong, orate, prolonged into a short posterior canal; anterior canal short, oblique; columella coneare. In typical species a dentiform tubercle is dereloped on the inner margin in the rieinity of the posterior canal, the outer margin is dilated in front and the whorls are varicose. 
Lamarek, in his "Prodreme," selects the following species as typifying the genus:-

Type.-Murex aluco, Linnæus.

\section{Cerithium apheles, Tenison-Woods.}

\section{[Plate VII. Figs. 1, 2.]}

1879. Cerithium apheles, Tenison-Woods, Proc. Linn. Soc. N.S.W. vol. iii. p. 232 , pl. xx. fig. 15 .

1893. Cerithium apheles, Tate and Dennant, Trans. Roy. Soc. South Aust. vol. xvii. pt. 1, p. 222.

Shell tapering, about twenty-four narrow, convex whorls; protoconch composed of four smooth turns, the earliest portion slightly inflated, and the later turns being medially, spirally carinate; in the breplic stage the whorls are closely spirally sulcate, and these are broken up irregularly by the undulations of growth; the undulations, being of variable breadth, have, at first, the aspect of varices; beyond the brephic stage (and this is very remarkable) the irregular longitudinal ribs as a rule become almost obsolete, several whorls being practically smooth, or broadly longitudinally undulating, the spiral sulci being well developed with several smaller striæ between. Then, as the animal approached the ephebic stage, there was a recurrence to the longitudinally costate condition which characterized the brephic stage, aud these castre become very large and prominent at maturity. Subsequently the ornament undergoes rapid transformation. With declining powers, ushering in conditions of the gerontic stage, the conspicuous costre alluded to drop to insignificance and die ont, the surface of the whorls bearing only the spiral cords and lineations and the undulating lines of growth. As a final effort, an enormous variciform elevatiou was then thrown up, much larger and more prominent than any of the longitudinal ornament which preceded it; after which, permanent senile conditions having been attained, the surface of the body-whorl becomes smooth again, only being interrupted by the lines and slight corrugations of growth and the abnormal development of two or three spiral cords which persist to the end. The aperture

1 Mém. Soc. Hist. Nat. Paris, 1799, p. 73. 
in adults is ovate; the callosity of the posterior canal is deeply channelled, onter margiu smooth, slightly callous, and spread ontwardly; inner margin concave, callous, and columella twisted; anterior canal short, bent at an angle of about $45^{\circ}$ from the axial line.

The figure aecompanying Tenison-Woods' memoir above quoted refers to a mere fragment, and it seems adrisable to refigure the shell (see Plate VII. Figs. 1, 2).

Dimensions. - Length $103 \mathrm{~mm}$. ; breadth $22 \mathrm{~mm}$.; length of aperture $18 \mathrm{~mm}$.

Form. and Loc.-Eocene: MInddy Creek, Victoria.

G. 4154. Two examples of the adult.

Presented by John Dennant, Esg.

G. 5534. Several examples of a rariation in which the longitudinal costæe are more pronouneed, and extend from the carlier whorls to the body-whorl in the adult; the costre are eloser together, and the granulated threads accompanying the suture are bolder than in typieal examples, whilst the shell is relatively bronder.

Purchased.

\section{Cerithium pritchardi, nom. mut.}

[Plate VII. Fig. 3.]

1885. Potamides semicostatum, Tate, Pap. Roy. Soc. Tas. 1884, p. 226 (non Deshayes).

1896. Potamides scmicostatum, Pritchard, Proc. Roy. Soc. Vict. vol. viii. x.s. p. 116.

Shell large, solid; composed of about twelre flattened whorls; much widened towards the anterior aspect; suture undulating, slightly incised; ornament of the whorls consisting of immeuse distant, elevated, rather oblique, obtuse costre extending over the anterior half of the whorls only, 10-11 in number on the penultimate whorl, the whole surface of the whorls eovered by close, irregular, spiral striatious, interrupted by the slight corrugations of growth; suture in the adult borlered auteriorly by more or less obsolete tubereles; ornament of the last whorl abruptly ended by a large variciform ridge; inner margin of the aperture callous, carrying a prominent ridge posteriorly; columella excurated. 
The cireumstance that the aperture is not perfect in the specimens described by Professor Tate has, naturally, rendered it difficult to state the generic position of this species. The speeimens in the Museum collection are not perfect in that respect, but the present writer assigns the species to Cerithium rather than to Potamides on account of its close resemblance to C. semicostatum, Deshayes, of the Lower Eocene of North-West Europe. It is always difficult to discriminato between the two gonera mentioned in the fossil state, but, typically, Cerithium is a marine orgauism, whilst Potamides inhabits brackish and fresh waters. The beds at Table Cape are certainly of marine origin, and that lends support to the view that the present species is a Cerithium. As before mentioned, however, the circumstance that $C$. semicostatum, Deshayes, of the European Eocene is undoubtedly a Cerithium ${ }^{1}$ (of the subgenus Vulgocerithium $^{2}$ ), is one of the chief reasons for the present classification of the Tasmanian form.

On being assigned to Cerithium, the specific name proposed by Professor Tate is preoccupied by C. semicostatum, Deshayes; the species is now named in honour of Mr. G. B. Pritchard, a wellknown worker on the Table Cape beds.

Dimensions (of an imperfect specimen). - Length $75 \mathrm{~mm}$; breadth $24 \mathrm{~mm}$.

Form, and Loc.-Eocene: Table Cape, Tasmania.

G. 9491. Two examples.

Purchased.

\section{Cerithium flemingtonense, II'Coy.}

1876. Cerithium femingtonensis, M[C Coy, Prod. Pul. Vict. dec. iii. p. 28, pl. xxvi. figs. 3-9.

1878. Cerithium flemingtonensis, R. Etheridge, jun., Cat. Aust. Foss. p. 160.

Form. and Loc. - Lower Pliocene: Flemington, north of Melbourne, Victoria.

G. 9688. Cast of the adult in hard ferruginous sandstone; too imperfect for deseription.

Transferred from the Museum of Practical Geology.

1 See Cossmann, Ann. Soc. Roy. Malac. Belg. t. xxiv. 1889, p. 16.

2 Id. t. xxxi. 1896 (separate copy), p. 28. 


\section{Cerithium hectori, nom. mut.}

1873. Corithium nodulosum, Hutton, Cat. Tert. Foss. N.Z. p. 12 (non Bruguière).

Shell turreted; whorls flattened, ten to eleren in number, haring a spiral row of large dentate, subspinose tubereles, about cight per whorl, situated medially on the body-whorl, but more towards the suture anteriorly, in the whorls of the spire; bodywhorl short, keeled, with two spiral ridges in front of the tubercles; aperture quadrate; outer margin thin; columella excarated; anterior canal short, slightly oblique.

The specific name is now altered for the reason indicated in the synonymy.

Dimensions.-Length $46 \mathrm{~mm}$; breadth $15 \mathrm{~mm}$.

Form. and Loc.-Eocene: Broken River, New Zealand.

G. 9601. Two examples, one of which is evidently more perfect than Hutton was acquainted with, since, although not complete, the aperture is preserved.

Sir James Hector Coll.

Genus COLINA, H. and A. Adams.

[Gen. Rec. Moll. vol. i. 1854, p. 286.]

Aperture dilated; columella plicated; canal short, slightly twisted; inner margin detached.

Type-Cerithium macrostoma, Hinds.

\section{Colina huttoni, Cossmann.}

1873. Cerithium cancellatum, Hutton, Cat. Tert. Moll. X.Z. p. 12 (non Lamarck, nec Bronn, nec Lea).

1893. Cerithium cancellatum, Hutton, Linn. Soc. N.S.W., Macleay Mem. Vol. p. 59, pl. vii. fig. 55 .

1895. Colina huttoni, Cossuann, Feuille Jeunes Natur. No. 299, p. 174.

Shell small, turreted; protoconch smooth, minute; whorls in the brophic stage longitudinally ribbed at the beginning, and gradually becoming cancellate with growth; the cancellation obtains to the body-mhorl, the threads being regularly spaced; longitudiual threads to the number of twenty-three or twenty-four 
on the penultimate whorl; the spiral threads, which are sunken below the level of the longitudinal, are five in number on the spire-whorls, and thirteen on the body-whorl; the anterior half of the latter and around the pillar is spirally lineate only, the longitudinal threads not being continued over that part; suture cut in; aperture broad, subruadrate, abruptly contracted at the entrance of the anterior eanal; outer margin thin; dilated anteriorly; inner margin covered by a thin plate of enamel, faintly ridged posteriorly; columella slightly oblique, twisted; anterior canal short, oblique.

Dimensions._Length $14 \mathrm{~mm}$.; breadth $6.5 \mathrm{~mm}$.; length of aperture $4.5 \mathrm{~mm}$.

Form. and Loc.-Pliocene: Wanganui, New Zealand.

G. 9592. An example of the adult. Sir James Hector Coll.

\section{Cerithium, sp.}

70442. Cast of a large species of Cerithium, probably referable to the subgenus Campanile; from Kadina, South Australia.

Presented by the Trustees of the Adelaide Museum.

G. 9150. Cast of a species allied to C. femingtonensis, in a block of limestone; from the Tertiary of Border Town, South Australia. Presented by R. Litton, Esq.

G. 9655. Impression of a tumid species, in which the whorls are but slightly convex, and are ornamented by closely-set, small, longitudinal ribs; from the Tertiary of Crawford's Wells, Ooldea, Nullarbor Plains, South Australia.

II. Y. L. Brown Coll.

\section{Genus BATILLARIA, Benson.}

[Ann. Mag. Nat. Hist. vol. ix. 1842, p. 488.]

Lampania, Gray, Syn. Brit. Mus. 1840, ed. 42, p. 148 (list name); Proc. Zool. Soc. 1847, p. 153.

Shell turriculate, not raricose; canal straight, or but rery slightly turned; columella arched; outer margin sinuous.

Type.-Cerithium zonale, Lamarek. 


\section{Batillaria pomahakensis, nom. mut.}

[Plate VII. Fig. 4.]

1873. Cerithium rugatum, Hutton, Cat. Tert. Moll. N.Z. p. 11 (non Mart., nec Cpr., nec Desh.).

Shell turreted; whorls to the number of nine or ten, plicate and nodose at the periphery, spirally striated, bolly-whorl large and having two prominent spiral keels in front of the median row of tubercles, lines of growth well marked lcading to rugosities, sinuons and deeply cut in towards the middle; aperture suborbicular; outer margin slightly channelled posteriorly; inner margin reflected, corered by a thin plate of enamel, ridged posteriorly; columella straight, slightly arched; anterior caual very short.

The specific name rugatum having been used by several anthors for divers forms of Cerithium, which differ from the present species, as above indicated, a new name is here suggested.

Dimensions.-Length $45 \mathrm{~mm}$.; breadth $17.5 \mathrm{~mm}$.; length of apertnre $13 \mathrm{~mm}$.

Form. and Loc.-Miocene: Ponahaka, Otago, New Zealand.

G. 9634. Several examples of the adult. Sir James Ilector Coll.

\section{Genus NEWTONIELLA, Cossmann.}

[Mém. Soc. Roy, Malac. Belg. t. xxviii. 1893, p. 18.]

Lovenella, G. 0. Sars, Norges Arktiske Fauua, 1878, p. 187, pl. xiii. fig. 5 (non Hincks, 1868).

Cerithiella, Verrill, Trans. Connecticut Acad. vol. v. 1882, p. 522 (non Morris and Lycett, 1850).

Newtonia, Cossmann, Ann. Géol. Univ. t. viii. 1892, p. 721 (non Schlegel, 1866).

Shell subulate, cancellate; spire sharp; columella not plicate in the middle; canal strongly curred backwards, bordered by a conspicuous twist of the columella.

The columella is too much twisted, and the anterior canal is too long to enable Newtoniella to be confounded with Cerithiopsis, 
which has, typically, merely a rudimentary notch on the anterior margin of the aperture.

Type._Cerithium metula, Lorén.

Newtoniella cribarioides, Tenison-Woods (sp.).

1879. Cerithizm cribarioides, Tenison-Woods, Proc. Linn. Soc. N.S.W. vol. iii. p. 231, pl. xx. fig. 14 .

1893. Cerithium cribarioides, Tate and Dennant, Trans. Roy. Soc. South Aust. vol. xvii. pt. 1, p. 222.

Shell elegant, turreted, slender; whorls to the number of fourteen, typically convex, but frequently slightly angulate anteriorly, having bold spiral threads crossed by longitudinal threads, pro. ducing retiform ornament; spiral threads three or four in number, the most anterior being at the margin of the angulation when that is present; sutures much cut in; anterior of the body-whorl flattened, smooth, interrupted by growth-lines, keeled at the periphery, and having a single spiral thread inside; aperture subquadrate; onter margin thin; columella twisted; anterior canal long and slightly twisted.

The protoconch is not preserved in any of the examples in the Yuseum collection. $N$. cribarioides may be compared with the European Eocene $N$. accedens, Deshayes. It is an extremely variable species.

Dimensions.-Length $33.5 \mathrm{~mm}$; breadth $8 \mathrm{~mm}$.

Form. and Loc.-Eocene: Victoria.

48052. Several examples in which the anterior angulation of the whorls is well developed; from Hobson's Bay.

Purchased.

73226. Example of the adult; in the earlier stages of the growth of this shell the longitudinal threads are very close together, and persist with regularity until the ephebic stage, where they are much opened out. During that stage these threads gradually become still closer together, and smaller in size, producing granulation by crossing the spiral threads. From Brighton.

Purchased.

G. 4155. Specimen of the neanic stage of growth; from Muddy Creek. Presented by John Dennant, Esq. 
G. 5536. Example in which the whorls are regularly convex and not angulate; from Muddy Creek.

Purchased.

G. 9477. Sereral specimens; from Muddy Creek. Purchased.

\section{Genus TRIFORIS, Deshayes.}

[Coq. Foss. Paris, t. ii. 1833, p. 429.]

Shell small, turriculate, frequently attenuated at its anterior extremity; almost always sinistral; aperture small, terminated by a short anterior canal.

Type.-Triforis plicatus, Deshayes.

\section{Triforis planata, Tenison-Woods.}

1880. Triforis planata, Tenison-Woods, Proc. Linn. Soc. N.S.W. vol. ir. p. 6, pl. i. fig. 12 .

1893. Triforis plamulata, Tate and Dennant, Trans. Roy. Soc. South Aust. vol. xrii. pt. 1, p. 222.

This species is readily distinguished by the comparative smoothness of the whorls, which are spirally lineated anteriorly, and crossed by faint closely-set longitudinal costæ, the points of junction being granulate; aperture quadrate; columella twisted; anterior canal bent.

Dimensions.-Length $19.5 \mathrm{~mm}$; ; breadth $3.5 \mathrm{~mm}$.

Form. and Loc.-Eocene: Muddy Creek, Victoria.

G. 9464. Two examples of the neanic stage of growth, and one of the ephebic.

Purchased.

\section{Genus DIASTOMA, Deshayes.}

[Dese. anim. sans Vert. 1861, vol. ii. p. 411.]

Shell turriculate, varicose, with a sharp spire; aperture orate, oblique, canaliculate, and detached behind, sinuous but not canaliculate in front; columella slightly concave, covered by a thin, shining, and somewhat detached plate, or an affixed callosity, and carrying, towards the middle, an oblique plication not always well marked. 
In shape it resembles Melania, with which genus it has been commonly confounded; but the characteristic varicose whorls and the phenomena of the aperture indicate closer affinities with the Ceritnimde, in which family the late Dr. Paul Fischer ${ }^{1}$ and M. Cossmann ${ }^{2}$ have elassified it.

Type.-Melania costellata, Lamarek.

\section{Diastoma provisi, Tate.}

1894. Diastoma provisi, Tate, Journ. Roy. Soc. N.S.T. vol. xxvii. p. 177, pl. x. fig. 6 .

Shell solid, turriculate; whorls about ten in number, excluding protoconch (which is not preserved in the specimens in the Museum collection), the fine longitudinal and spiral ornament is deseribed in detail by its anthor; suture ent in; aperture oblique, ovate, angular behind, and slightly depressed in front; outer margin thin; inner margin callous, a thick, obtuse ridge bordering the posterior channel; columella with a single plication or fold, accentuated in the adult, the attendant callosity spreading over the anterior portion up to the sinuosity in the front of the aperture.

The costre of the whorls are more slender and numerous than in the living $D$. melanoides, Reere, and the callosity spreading behind the front of the columella is more sharply defined than in the recent shell, with which it presents many striking points of resemblance. Compared with $D$. costellatum, Lamarek, of the Hampshire and Paris basins, amongst other things it is more solid, broader, has less convex whorls, the longitudinal ribs are smaller and closer together, whilst the large ridge and thick callous inner margin are highly characteristic.

Dimensions.-Length $45 \mathrm{~mm}$.; breadth $14.5 \mathrm{~mm}$.; length of aperture $14 \mathrm{~mm}$.

Form. and Loc._Older Pliocene: near Adelaide, South Australia.

G. 9479. Examples illustrating stages of growth. Purchased.

1 Manuel de Conchyl. 1881, pp. 682-3.

2 Ann. Soc. Roy. Malac. Belg. t. xxiv. 1889, p. 30. 


\section{Family TRICHOTROPIDE.}

Genus TRICHOTROPIS, Broderip and Sowerby.

[Zool. Journ. vol. iv. 1829, p. 373.]

Shell umbilicate, turbinate, carinate, the carinæ bearing epidermal fringes in well-preserved specimens; spirc short or conical; aperture large, angulate or slightly caualiculate in front; outer margin simple, sharp; columellar border arched.

Type.-Turbo bicarinatus, Sowerby.

\section{Trichotropis clathrata, G. B. Sowerby.}

1873. Trichotropis inornata, Hutton, Cat. Marine Moll. N.Z. p. 26.

1873. Trichotropis inomata, Hutton, Cat. Tert. Moll. N.Z. p. 11.

1874. Trichotropis clathrata, G. B. Sowerby, Couch. Icon. vol. xix. pl. ii. fig. 10 .

1880. Trichotropis inornata, IIutton, Man. N.Z. Moll. p. 69.

1887. Trichotropis clathrata, Tryon, Manual of Conchology, rol. ix. p. 43, pl. vii. fig. 51 .

1893. Trichotropis inomata, Hutton, Linn. Soc. N.S.W., Macleay Mem. Tol. p. 59.

An easily recognized species; the whorls are cancellate, the spiral threads predominate; gramulate at the points of intersection; body-whorl enormous in size; aperture very large, channelled in frout; outer margin thin, spread out; columella narrowly umbilicate and twisted; inner margin reflected.

Dimensions. - Length $16 \mathrm{~mm}$.; breadth $10 \mathrm{~mm}$.; length of aperture $8.5 \mathrm{~mm}$.

Form. and Loc.-Pliocene: Shakespeare Cliff, New Zealand.

G. 9558. Two examples of the adult. Sir James Hector Coll.

\section{Family VERMETIDA.}

Genus TENAGODES, Guettard, $e m .^{1}$

[Mém. Sci. et Arts, t. iii. 1770 (or 1774), p. 128.]

Siliquaria, Bruguière, Ency. Meth. Ters. i. 1789, p. 15.

Shell tubular, cylindrical ; for the most part uncoiled, furnished with a long fissure extending from the aperture backwards; the 
"fissure" may be simple or consist of a series of perforations set close together in alignment; aperture circular; not septate within.

Type.-Serpula anguina, Linnæus.

\section{Tenagodes occlusus, Tenison-Woods.}

1S77. Tenagodus occlusus, Tenison-Woods, Pap. Roy. Soc. Tas. 1876, p. 100.

1878. Tenagadus occlusus, R. Etheridge, jun., Cat. Aust. Foss. p. 167.

1893. Tenagodus occlusus, Tate and Dennant, Trans. Roy. Soc. South Aust. vol. xrii. pt. 1, p. 222.

1896. Tenagodes occlusus, Pritchard, Proc. Roy. Soc. Vict. vol. viii. N.s. p. 116.

The first two or three whorls are slightly adherent, but the shell becomes rapidly uncoiled; the fissure is very long, prominent, wide, and the sides are irregularly cut; the lines of growth form corrugations and small cracks, and are soluewhat scaly; spiral lineations very faint except on the under-surface, where they are broken up into short lengths. The ornament is, therefore, of an exceedingly simple character

Dimensions. - Extreme length $34 \mathrm{~mm}$. ; breadth of aperture $6 \mathrm{~mm}$. Form. and Loc.-Eocene: Muddy Creek, Victoria.

G. 9484. Two examples.

Purchased.

\section{Family TURRITELLID无.}

\section{Genus TURRITELLA, Lamarek.}

[Mém. Soc. Hist. Nat. Paris, 1799, p. 74.]

Shell long, attenuated, many-whorled; whorls often ornamented by spiral ridges, lines of growth arched and sinuous; aperture eutire, subquadrangular, or ovate; outer margin thin, excavated behind and slightly produced in front; columella arched, commonly callous.

The protoconch is not preserved in many of the species in the Museum collection.

Type.-Turbo terebra, Linnæus. 


\section{Turritella murrayana, Tate (sp.).}

1885. Torcula murrayaxa, Tate, Pap. Roy. Soc. Tas. 188t, p. 227.

1893. Turritella murayana, Tate and Dennant, Trans. Roy. Soc. South Aust. rol. xvii. pt. 1, p. 222.

1893. Turvitella murrayana, Tate, $i d$. rol. xvii. pt. 2 , p. 340 , pl. viii. fig. 3.

1895. Turritella murrayana, Pritchard, Proc. Roy. Soc. Vict, vol. viii. x.s. p. 115.

This common species is liable to great rariation, each distant locality seeming to possess a dominant form. Professor Tate describes it as follows:- "Shell pyramidally turreted, apical angle about $15^{\circ}$. Whorls twelve to fourteen, flattish, medially depressed, and acutely elevated at about the anterior-fourth; suture threadlike, or somewhat grooved; apical whorls two, rery small, globulose; first spire-whorls rapidly enlarging, 1-3 carinate. Surface ornamented by about twenty-four spiral threads, with or without smaller internediary ones, crossed by close-set strix, the latter on the anterior whorls thinly squamose. Last whorl bluntly truncated on the periphery; base with spiral threads and trausverse strix on the upper part of the whorl. Aperture quadrately oval, continuous; outer lip with a deepish subtriangular median sinus. The sectional outline of the whorls varies from flat or slightly concare to somewliat quadrate, and correspondingly in the depth of the suture; the ante-medial keel is sometimes obsolcte, but the medial depression is always present."

The last-mentioned feature and the numerous spiral lineations are, perhaps, the chief differentiating characters.

Dimensions. - Length $55 \mathrm{~mm}$.; breadth $17 \mathrm{~mm}$.; length of aperture $11 \mathrm{~mm}$.

Form. and Loc.-Eocene: Victoria and South Australia.

G. 5535. A very narrow form in which the sutures are much eut in ; from Muddy Creek.

Purchased.

G. 9126. Several examples illustrating stages of growth; from River Murray eliffs. Presented by William Erans, Esg.

G. 9428. Three examples of the adult; from Rirer Murray cliffs.

Purchased. 


\section{Turritella septifraga, Tate.}

1893. Turvitella septifraga, Tate, Trans. Roy. Soc. South Aust. vol. xvii. pt. 2 , p. 336 , pl. viii. fig. 5.

A large species, distinguished by its rather concave whorls aud the absence of very conspicuous spiral ornament; there is, however, a slightly elevated bisected ridge bordering the suture on the anterior of the spire-whorls, behind which is a small but distinct spiral lineation, and there are a few obsolete spiral threads; the lines of growth are deeply sinuous and numerous, but are not very striking.

Dimensions.- None of the specimens in the Museum collection are perfect enough to enable the dimensions of the shell to be taken; the author states that its length (incomplete) is $100 \mathrm{~mm}$. and width $17 \mathrm{~mm}$.

Form. and Loc.-Eocene: Spring Creek, Victoria.

G. 9427. Sereral fragments.

Purchased.

Turritella platyspira, Tenison-Woods.

1879. Turritella platyspira, Tenison-Woods, Proc. Linn. Soc. X.S.W. vol. iii. p. 234, pl. xx. fig. 13.

1893. Turritella platyspira, Tate and Dennant, Trans. Roy. Soc. South Aust. vol. xvii. pt. 1, p. 222.

1893. Turritella platyspira, Tate, $i d$. vol. xvii. pt. 2 , p. 341.

Shell smoother and the ornament of the whorls less conspicuous than in any other Australian species of Turritella here described. Spire subulate and much attenuated; protoconch (Plate VII. Figs. $5 a-b)$ composed of two smooth, porcellanous, somewhat globose turns, the later portion being larger than the succeeding whorl; earlier whorls of the sliell proper flat, and but slowly increasing in size; in the neanic and ephebic stages the whorls become convex; a sulcation which develops into a broad groove occurs on the anterior portion of the whorls throughout; surface of whorls faintly spirally striated, and often bearing two or three more prominent spiral lineations, the anterior one lying between the sulcus alluded to and the suture; lines of growth deeply sinuous. 
Dimensions. - Length $14 \mathrm{~mm}$; breadth $4 \mathrm{~mm}$. ; length of aperture $3 \mathrm{~mm}$.

Furm. and Loc.-Eocene: Mnddy Creek, Victoria.

G. 4743. Specimen of the neanic stage of growth in which the protoconch is well preserved.

Presented by Professor T. Rupcrt Jones, F.R.S.

G. 9423. Sereral examples illustrating stages of growth.

Purchased.

\section{Turritella conspicabilis, Tate.}

1893. Turvitella conspicabilis, Tate, Trans. Roy. Soc. South Aust. vol. xvii. pt. 2 , p. 339 , pl. viii. fig. 7 ; pl. ix. fig. 6 .

1895. Turritclla conspicabilis, Pritchard, Proc. Roy. Soc. Vict, vol, viii. N.s. p. 115 .

Typical forms of this species possess but one prominent keel, whilst those of $T$. tristira, Tate, hare three which are equal in size; and that appears to be the chief point of difference between the two species. Occasionally, howerer, forms of T. conspicahilis are found possessing two minor keels, behind the prominent one, and as these derelop in size the shells elosely approximate T. tristira as haring three lieels, but they are of unequal size. Its author reluetantly eonsiderel $T$. conspicabilis as distinct. It might have been advisable to regard it as synonymous with $T$. tristira, but not haring seen actual specimens of the latter, the present writer hesitates to definitely make the alteration. Tariation in the number of spiral heels is well exhibited by the Miocene and Pliocene T. triplicata, Brocchi, of Europe, with which the Australian species mentioned hare considerable affinity. In the Tortonian beds of Stazzano, in Piedmont, for example, one can find $T$. triplicata with practically every rariation from one prominent spiral keel to three well-formed keels; and parallel cases could be eited from other localities in reference to other species. The number of keels is certainly not a good differentiating elaracter with Turvitella.

Dimensions.-Length $35 \mathrm{~mm}$.; breadth $10.5 \mathrm{~mm}$.; length of aperture $7 \mathrm{~mm}$.

Form. and Loc.-Miocene: Gippsland, Victoria.

G. 9430. Two examples of the adult.

Purchased. 


\section{Turritella acricula, Tate.}

1893. Turritclla acricula, Tate, Trans. Roy. Soc. South Aust. rol, xvii. pt. 2, p. 339 , pl. viii. fig. 4 ; pl. ix. figs. $4,7,12$.

This variable species may be distinguished by its slender lanceolate form, by the large number of whorls, amouuting to twenty in typical forms of the adult, and by their flatness. Commonly there are from fifteen to twenty spiral lines of unequal size, the larger ones forming liræ or carinæ, which latter may be from two to five in number, the largest bordering the suture anteriorly. The rariation consists principally in the mode of development of the spiral oruament and the consequent change in shape of the whorls.

It is closely related to $T$. acuta, Tenison-Woods (non Mayer), a species living in South Australia and Tasmania, but the fossil is relatively narrower, and the spiral lineations and carinæ are more numerous.

Dimensions.-Length $27 \mathrm{~mm}$; ; breadth $6 \mathrm{~mm}$.

Form. and Loc.-Eocene: River Murray cliffs, South Australia.

G. 9429. Examples illustrating stages of growth; one shell is narrower than the others, the usually prominent spiral carina being much reduced in size.

Purchased.

\section{Turritella aldingæ, Tate.}

1882. Turritella aldinge, Tate, Trans, Roy. Soc. South Aust, rol. v. p. 42.

1893. Turritella aldinga, Tate, $i d$. vol. xvii. pt. 2, p. 336 , pl. viii. fig. 1.

1895. Turvitella aldinge, Tate and Dennant, id. vol. xix. pt. 1, p. 112.

Shell pyramidal, spire acute; whorls flat, furnished with three prominent, unequal, spiral carinæ, and distant spiral striæ; lines of growth conspicuous, deeply sinnated, producing rugosity, and granulating the medial keel; suture incised; apcrture (according to the author of the species) subquadrate, margins united by a somewhat thick callus, which extends over much of the flattened forepart of the shell; columella arched; outer margin somewhat flatly compressed, and deeply and broadly sinuated. Its pyramidal shape, the graulose median keel, and the deep sinus, serve to readily distinguish this from $T$. warburtoni and $T$. conspicabilis. 
Dimensions. - Length $27 \mathrm{~mm}$. ; breadth $10 \mathrm{~mm}$.; length of aperture $6 \mathrm{~mm}$.

Form. and Loc.-Eocene: Aldinga, South Anstralia.

G. 9424. Four examples illustrating stages of growth. Purchased.

\section{Turritella warburtoni, Tenison-Woods.}

1877. Turritella warburtonii, Tenison-Woods, Pap. Roy. Suc. Tas. 1876, p. 99.

1877. Turritella sturtii, Tenison-Woods, id. p. 99.

1878. Turritella warburtonii, R. Etheridge, jun., Cat. Aust. Foss. p. 169.

1878. Turitella sturtii, R. Etheridge, jun., id. p. 169.

1893. Turritella wavbutoni, Tate, Trans. Roy. Soc. South Aust. vol. xvii. pt. 2, p. 337 , pl. viii. fig. 2.

1893. Turvitella sturtii, Tate, id. p. 338 , pl. viii. fig. 6.

1895. Tumitella warburtoni, Pritchard, Proc. Roy. Soc. Vict. vol. viii. x.s. p. 113.

Mr. Pritchard, in the work abore cited, has discussed the synonymity of $T$. sturtii with $T$. varburtoni at some length. The chief differences noticeable in the two so-called species are mere details of ornament of the whorls, which certainly are not important enough to warrant specific separation in such rariable forms as we are now dealing with.

Dimensions._Length $18 \mathrm{~mm}$; breadth $5.5 \mathrm{~mm}$.

Form. and Loc.-Eocene: Table Cape, Tasmania.

G. 9425. Three examples of the adult.

Purchased.

G. 9426. Examples of the neanic stage of growth. Purchased.

\section{Turritella gemmulata, Tate.}

1893. Turritella gemmulata, Tate, Trans. Roy. Soc. South Aust. vol. xrii. pt. 2, p. 33s, pl. riii. fig. 11 .

The distinct, rounded granulations on the four or fire spiral carinx, which occupy the greater part of the whorls, serve to distinguish this minute shell at a glance from amongst other Australian forms of the genus alluded to in this work.

Dimensions.-Length $7 \mathrm{~mm}$; breadth $2 \mathrm{~mm}$.

Form. and Loc._Eocene: Mruddy Creek, Victoria.

G. 9422. Sereral specimens.

Purchased. 


\section{Turritella pagodula, Tate.}

1893. Turritella pagodula, Tate, Trans. Roy. Soc. South Aust. vol. xvï. pt. 2, p. 336, pl. viii. fig. 10.

Shell small; characterized by a rery prominent obtuse spiral carina near the suture on the anterior portion of the spire-whorls, between which and the suture is a small spiral thread, the space between the two developing into a sulcus on the periphery of the body-whorl in the adult. Behind the carina are sereral more or less obsolete spiral strix, one of which, towards the middle of the whorls, is nsually more accentuated than the others; an obscure ridge borders the suture posteriorly. Several spiral lineations occur near the anterior extremity of the body-whorl. Lines of growth sinuous, cut in towards the middle of the whorls.

Professor Tate compares this species with the living $T$. exoleta, Linnæus, and with $T$. granulifera, Tenison- Woods.

Dimensions._Length $11 \mathrm{~mm}$.; breadth $4 \mathrm{~mm}$.

Form. and Loc.-Miocene: Gippsland, Victoria.

G. 9431. Three examples of the adult.

Purchased.

Turritella rosea, Quoy and Gaimard.

1S34. Turritella rosea, Quoy and Gaimard, Toy. de l'Astrolabe, Zool. t. iii. p. 136, pl. lv. figs. 24, 26.

1849. Turvitella rosea, Reeve, Conch. Icon. rol. v. pl. riii. fig. 41.

1873. Turritella rosea, Ton Martens, List Moll. N.Z. p. 27.

1873. Turritelln (Haustator) rosea, IIutton, Cat. Marine Moll. N.Z. p. 29.

1873. Turritella rosea, Hutton, Cat. Tert. Moll. N.Z. p. 12.

1880. Turritella (Haustator) rosea, Hutton, Man. N.Z. Moll. p. 83.

1s86. Turritella (Haustator) rosea, Tryon, Manual of Conchology, vol. viii. p. 199, pl. lxi. fig. 59 ; pl. lxii. figs. $67,68$.

1593. Turritella rosea, Hutton, Linu. Soc. N.S.W., Mac'eay Mem. Yol. p. 63 .

Distinguished by its flat whorls, the bod 5 -whorl in the majority of adult specimens being sharply hecled, and haring a broad, flat area anteriorly; a spirally striated keel borders the suture, and there are sereral undulating spiral threads of irregular sizes, some being rery prominent.

It recalls joung specimens of the common $T$. carinifera, Deshayes, of the European Eucene. A remarkable feature both 
in some living and extinct forms of the adult of this rariable species is the diminishing importance of the prominent spiral carina and the corresponding roundness of the periphery of the body-whorl, and slight convexity of the usually that area of the forepart of that whorl. These features may possibly be characteristic of the gerontic stage, but the adult specimens at the writer's disposal are not numerous enough to enable him to satisfactorily determine that point.

Dinensions.-Length $84 \mathrm{~mm}$; breadth $22 \mathrm{~mm}$.

Form. and Loc.-Miocene (?) and Pliocene: New Zealand.

G. 9588. Specimens in which the peripheral keel of the bodywhorl is rery acute, and the anterior area flat and even slightly concare; from Wanganui.

Sir James Hector Coll.

G. 9700, G. 9701. Examples of the neanic and gerontic stages, the periphery of the body-whorl in the last-mentioned being rounded; from Parimoa.

W. B. D. Mantell Coll.

G. 9723. Two examples of the adult; from Onekakara.

[old Collection.]

\section{Turritella kanieriensis, nom. mut.}

1850. Turritella rosea, Mantell, Quart. Journ. Geol. Soc. vol. vi. p. 331, pl. xxriii. fig. 16 (non Quoy and Gaimard, 1834).

1873. Turritella (Zaria) tricincta, Hutton, Cat. Tert. Moll. X.Z. p. 13 (non Borson et auct.).

1893. Turritella tricincta, Hutton, Linn. Soc. N.S.W., Macleay Mem. Tol. p. 63 , pl. riii, fig. 60 .

Distinguished by three subequal and equidistant strong spiral carinæ, the interstices being spirally striated; the forepart of the body-whorl is flattened, and covered by closely-set spiral strix; apcrture subquadrate.

It is closcly allied to $T$. triplicata, Brocchi, of European and North African Jiocene and Pliocene, and still living in the Jediterranean and in the Atlantie; but differs in regard to the sinuosity of the lines of growth and in not haring the spiral carinæ flattened. Further, in the New Zealand species the caringe are fairly equal in size, whilst in T. triplicata the middle one is the largest, the posterior one being suallest, and this latter is frequently duplicate. Hutton's specific name is here altered, 
as tricincta had been used to designate several kinds of Turritella prior to 1873 , as above indicated.

Dimensions.—Length $29 \mathrm{~mm}$; breadth $8.5 \mathrm{~mm}$.

Form. and Loc.-Miocene and Pliocene: New Zealand.

G. 9594. Several examples illustrating stages of growth ; from Shakespeare Cliff.

Sir James Ilector Coll.

G. 9599. A specimen of the adult; from Kanieri.

Sir James Hector Coll.

\section{Turritella cavershamensis, nom. mut.}

1873. Turritella gigantea, Hutton, Cat. Tert. Moll. N.Z. p. 12 (non Bellardi and Michelotti).

This large species has slightly concave whorls, elevated in the neighbourhood of the suture, and covered by unequal spiral strix; lincs of growth deeply sinuous. The specific name gigantea being preoccupied, as indicated, a new designation is here given.

Dimensions.-Hutton gives the dimensions of a specimen as 5 inches in length; the largest fragment in the Musenm collection is $3 \frac{1}{2}$ inches in length, and when perfect the shell must have been fully 6 inches.

Form. and Loc.-Eocene: New Zealand.

G. 9618. Fragment of the adult; from Oamaru.

Sir James Mector Coll.

G. 9635. Inperfect example of the adult; from Carersham.

Sir James Hector Coll.

\section{Turritella, sp.}

The following Australasian Tertiary Turritelle, although specifically indeterminable, are interesting on account of the localities represented:-

48803. Cast of a species of Turritella, aff. murrayana; from River Murray cliffs, South Australia.

Presented by Commodore Goodenough, R.N.

98221. Mutilated examples of a species imbedded in limestone; from Flinders I.

Purchased. 
G. 9649. Cast of a large species; from Forler's Bay distriet, South Australia. II. Y. L. Brown Coll.

G. 9659. Several casts of a species, aff. murrayana; obtained in McLaren Vale, 500 fect abore sea-level, near Willunga, south of Adelaille.

II. Y. L. Brown Coll.

G. 9660 , G. 9662 , G. 9666 . Blocks of earthy limestone containing several casts; from Ardrossan, Yorke's Peninsula, South Australia.

II. Y. L. Brown Coll.

G. 9668, G. 9669 . Blocks of argillaceous limestome containing many fragments of Turritella; from Willunga.

II. Y. L. Brown Coll.

G. 9674. Casts of a large species; from River MLurray cliffs, South Australia.

Transferred from the Iruseum of Practical Geology.

From New Zealand-

G. 9619. Turritella, sp., with Cucullea, in argillaceous sandstone. Miocene: from Akuakua, east coast of Auckland.

Sir James Ilector Coll.

G.9652. Fragment of Turritella imbedded in argillaceous sandstone. Miocene: from the "Conus-beds," IIokihinui.

Sir James Hector Coll.

G. 9690, G. 9691. Fragments of a small species, in argillaceous limestone; from Bank's Rirer. Presented by IIugh Cuming, Esq.

Family SOLARIIDE.

Genus SOLARIUM, Lamarek.

[Mém. Soc. Hist. Nat. Paris, 1799, p. 74.]

Shell orbicular, depressed, thin, angulate at the periphery; aperture subquadrangular, outer margin simple; umbilicus having crenulated margins, spiral and wide.

Type.-Trochus perspectivus, Linnæus. 
Solarium acutum, Tenison-Woods.

[Plate VII. Figs. $6 a-c$. ]

1879. Solarium acutum, Tenison-Woods, Proc. Linn. Soc. N.S.W. vol. iii. p. 236 , pl. xxi. fig. 11.

1893. Solarium acutum, Tate, Trans. Roy. Soc. Sonth Aust. vol. xrii. pt. 1, p. 222 .

Shell thin, discoidal; spire depressed, periphery acutely carinate, spiral lineations granulose; base depressed so as to form a broad gutter following the peripheral keel, with sereral simple, small lineations crossed by elosely-set undulating lines of growth; inside this plain depressed portion, towards the umbilicus, are seven rows of spiral granulations, the first one (outside) consisting of minute elongate ridge-like elevations, the longer axis pointing towards the centre; then follows the second row, in which the granulations or ridges are of the same shape but much larger; in the third row the granules are a little smaller and farther apart; in the fourth row the granules are much larger; the fifth row has very minute granules, the sixth and seventh progressively larger, the largest of all bordering the umbilicus; the umbilicus is fumnel-shaped, rery broad, spiral, each whorl being separated from the next by a deep channel; aperture broad.

The detail not being well expressed in the figure accompanying Mr. Tenisou-Woods' memoir alluded to, a new figure is here gireu.

Dimensions.-Height $9.5 \mathrm{~mm}$. ; breadth $22 \mathrm{~mm}$.

Form, and Loc.-Eocene: Victoria and South Australia.

G. 4295. Two examples; from Muddy Creek.

Presented by John Dennant, Esq.

G. 5533. An example of the adult; from Muddy Creek.

Purchased.

G. 9135. Specimen in which the detail surrounding the umbilicus is bolder than in the examples from Victoria; from River Murray cliffs. Presented by William Evans, Exq.

G. 9481. Examples of the neanic and ephebic stages of growth; from Iuddy Creek.

Purchased. 


\section{Genus HELIACUS, D'Orbigny.}

[Moll. Cuba, t. ii. 1842, p. 68.]

Torinia, Gray, Syn. Brit. Mus. 1840, p. 147 (list name); id. 1842 , pp. 60,90 (list name, not specified); vide Proc. Zool. Soc. 1847, p. 151.

This differs from Solarium principally in having rounded whorls instead of being sharply keeled at the periphery; the whorls are granulated and spirally lineate; aperture almost circular, lip simple, umbilicus large. Typically the spire is much elerated, and even turbinate; but several species have a depressed spire, and the shell is then planorboid. It would appear that, in some cases (e.g. the living $H$. variegata, Gmelin) the elevation or depression of the spire is only a rarietal character.

The term Torinia must fall in synonymy, as Heliacus was proposed before the forner was established on a firm basis, as above indicated.

Type.-Solurium heberti, Deshayes.

Heliacus wannonensis, Tenison-Woods (sp.).

1879. Solarium wannonensis, Tenison-Woods, Proc. Linn. Soc. N.S.W. vol, iii. p. $23 \pi$, pl, xxi. fig. 10 .

Shell small, discoid; spire depressed, spiral lineations granulated, the largest bordering the slightly canaliculate suture; whorls rounded at the periphery, where there is a row of rather large granulatious; base of the body-whorl spirally granulate, the two rows having the largest granules surrounding the umbilicus, which is wide and deep; the granulations are so arranged from row to row as to form broken radiating lines.

Dimensions.-Length $3.5 \mathrm{~mm}$; ; breadth $6.5 \mathrm{~mm}$.

Form. and Loc.-Eocene: Muddy Creek, Victoria.

G. 9463. Two examples.

Purchased. 


\section{Family HIPPONYCID A. \\ Genus HIPPONYX, Defrance.}

[Journ. Phys. Hist. Nat. vol. Ixxxviii. p. 215, figs. 1-4.]

Shell conical, thick; summit slightly arched, directed backwards, rarely curved; surface rough or longitudinally striated.

Type._Patella mitrata, Gmelin.

\section{Hipponyx, sp.}

G. 4300. A waterworn shell in an imperfect condition, probably referable to $I I$. antiquatus, Linnæus; from the Miocene of Muddy Creek, Victoria. Presented by John Dennant, Esq.

Family CAPULID Æ.

Genus CREPIDULA, Lamarck.

[Mém. Soc. Hist. Nat. Paris, 1799, p. 78.]

Shell ovate, elongate, patelliform; generally having a lateral spiral apex; interior with a lamina or shelf covering the posterior half of the aperture.

Type._Patella fornicata, Linnæus.

\section{Crepidula monoxyla, Lesson (sp.).}

1830. Calyptrcea (Crepidula) monoxyla, Lesson, Voy. Coquille, t. ii. pt. 1, p. 391.

1834. Crepidula contorta, Quoy and Gaimard, Voy. de l'Astrolabe, Zool. t. iii. p. 418, pl. Ixxii. figs. $15,16$.

1873. Crepidula contorta, Von Martens, List Moll. N.Z. p. 28.

1873. Crypta contorta, Hutton, Cat. Marine Moll. N.Z. p. 32.

1873. Crypta contorta, IIutton, Cat. Tert. Moll. N.Z. p. 14.

1873. Crypta profunda, Hutton, id. p. 14.

1880. Crypta monoxyla, Hutton, Man. N.Z. Moll. p. 87.

1886. Crepidula monoxyla, Tryon, Manual of Conchology, vol, viii. p. 128, pl. xxxvii. figs. 35,36 .

1893. Crepidula monoxyla, Hutton, Liun. Soc. N.S.W., Macleay Mem. Vol. p. 62. 
Shell elongate, dorsal aspect much elerated, high-conrex, contorted, frequently assuming the shape of the object it grows upon; internal lamina stout, extending over about one-half of the aperture.

Dimensions. - Height $16 \mathrm{~mm}$; length of aperture $33 \mathrm{~mm}$.; brealth $22.5 \mathrm{~mm}$.

Form. and Loc.-Miocene and Post-Pliocene: Victoria and New Zealand.

G. 5574. Two examples of the adult; Limestone Creek, Glenelg river.

Purchased.

G. 9621. Decomposed shells in coarse grit; from Port Hills, Nelson. Sir James Hector Coll.

G. 956\%. Two internal casts of the adult; from Awatere.

Sir James IIector Coll.

\section{Crepidula aculeata, Gmelin (sp.).}

1790. Patella aculeata, Gmelin, Linn. Syst. Nat. p. 3693.

1834. Crepidula costata, Quoy and Gaimard, Voy. de l'Astrolabe, Zool. t. iii. p. 414, pl. Ixxii. figs. 10, 12.

1836. Crepidula costata, Deshayes, Lamarck, Hist. Nat. Anim. sans Vert. t. vii. p. 644 .

1873. Crepidula costata, Von Martens, List Moll. N.Z. p. 28.

1873. Crypta costata, Hutton, Cat. Marine Moll. N.Z. p. 32.

1873. Crypta costata, Ifutton, Cat. Tert. Moll. N.Z. p. 14.

1880. Crypta costata, Hutton, Man. N.Z. Moll. p. 87.

1886. Crepidula (Crypta) aculeata, Tryon, Mauual of Conchology, vol. vï. p. 129, pl. xxxix. figs. 61-5.

1893. Crepidula aculeata, Hutton, Linn. Soc. N.S.W., Macleay Mem. Vol. p. 62 .

Shell orate, not so deeply conrex as $C$. monoxyla, apex lateral; surface covered with rarliating ridges of variable character, for the most part spinose or prickly in the examples now living, somewhat more simple in the fossil state, apparently. The subgenus Crypta of (Humphrey) Gray, Fischer, ete., was suggested for those Crepidula with a spinose surface-a rariable feature having but little importance, at any rate, from a sectional point of riew.

Dimensions. - Height $12 \mathrm{~mm}$; length of aperture $26 \mathrm{~mm}$.; breadth $16.5 \mathrm{~mm}$. 
Form. and Loc.-Pliocene: Parimoa, New Zealand.

G. 9705. Several examples illustrating stages of growth and variation in the derelopment of the surface ridges.

$$
\text { W. B. D. Mantell Coll. }
$$

\section{Crepidula incurva, Zittel.}

1865. Crepidula incurva, Zittel, Reise der Novara, Paläontologie, Bd. i. Abth. ii. p. 44 , taf. xv. figs. $9 a-b$.

1873. Crypta incurva, Hutton, Cat. Tert. Moll. N.Z. p. 14.

Shell elongate, extremely conrex; flattened on one side; apex incurved, not situated on the margin, thickened; "internal septum concave, or almost flat, extending to the middle of the shell." Ilutton. The growth-lines produce corrugations on the surface.

Dimensions. - Height $26 \mathrm{~mm}$; breadth $24 \mathrm{~mm}$.

Form. and Loc.-Hiocene (?): Motanau, Marlborough, New Zealand.

G. 9566. A large specimen affixed to a piece of argillaccons limestone, the upper surface of the shell only being visible; the surface is very irregular, owing to the development of corrugations of growth. Sir James Hector Coll.

\section{Subgenus IANACUS, Mörch.}

[Cat. Yoldi, 1852, p. 146.]

Shell depressed, frequently concave above, apex posterior, slightly lateral.

Type.-Crepidula plana, Say.

\section{Crepidula (Ianacus) unguiformis, Lamarck.}

1822. Crepidula unguiformis, Lamarek, Hist. Nat. Anim. sans Vert. t. vii. p. 642 .

1873. Crypta (Janacus) unquiformis, Hutton, Cat. Marine Moll. N.Z. p. 32.

1880. Crypta unguiformis, Hutton, Man. N.Z. Moll. p. 87.

1886. Crepidule (Janacus) unguiformis, Tryon, Manual of Conchology, vol. viii. p. 130, pl. xxxix. figs. $66-8$.

1893. Crepidula unguiformis, Hutton, Linn. Soc. N.S.W., Macleay Mem. Vol. p. 62 .

1893. Crepidula unguiformis, Tate, Trans, Roy. Soc. South Aust. vol. xvii. pt. 2 , p. 330 . 
Shell elongate, curved; upper surface flat, or slightly concare; apex marginal; smooth, externally concentrically striated; interior highly polished; plate small, convex.

Dimensions._Length $15.5 \mathrm{~mm}$; breadth $8.5 \mathrm{~mm}$.

Form. and Loc.-I'liocene: Wanganui, New Zealand.

G. 9725. An example of the neanic stage of growth.

[old Collection.]

\section{Crepidula, sp.}

The following species from the Sir James Hector Coll., from New Zealand, are indeterminable:-

G. 9565. Cast in micaceous sandstone of a highly convex species, angulate towards the apex, which is lateral. Miocene: Port Hills, Nelson.

G. 9579. Cast of a narrow, highly convex species, allied to C. incurra. Miocene (Upper Redeliffe beds): Red Cliff, Rakaia river, Canterbury.

G. 9630 . Cast of a species $42 \mathrm{~mm}$. in length, broad, flattened, apex curred aud lateral. Miocene: Akuakua.

\section{Family CALYPTRAIDE.}

Genus CALYPTR王A, Lamarck.

[Mém. Soc. IIist. Nat. Paris, 1799, p. 78; non Lamarck, 1801.]

Infundibulum, Sowerby, Min. Conch. vol. i. 1812, pl. xevii. (non Montfort, 1810).

Trochita, Schumacher, Essai Nouv. Syst. Habit. Testacés, 1817, p. 18 .

Galerus (Humphrey), H. and A. Adams, Gen. Rec. Moll. vol. i. 1854 , p. 367.

Shell conical, trochiform, protoconch central; aperture almost circular, the inferior aspect furnished with a spiral plate, the anterior border of which adheres to the periphery on the one side, and ends in at false columella on the other, in the neighbourhood of which it is deeply sinuous.

Type.-Patella chinensis, Linnæus. 


\section{Calyptræa corrugata, Tate.}

1893. Calyptraa corrugata, Tate, Trans. Roy. Soc. South Aust. vol. xvii. pt. 2 , p. 331 , pl. vii. fig. 9 .

Shell thin, depressed, orbicular; protoconch subcentral; surface of shell irregularly concentrically ridged; edge of internal plate slightly curved.

Comparing it with the living $C$. pellucida, Reeve, the author, states that it differs by interruptedly convex whorls and strong growth-folds.

Dimensions.-Height $3.75 \mathrm{~mm}$; breadth $10 \mathrm{~mm}$.

Form. and Lac.-Miocene: Muddy Creek, Victoria.

G. 9384. Three examples of the adult.

Purchased.

\section{Calyptræa crassa, Tate.}

1893. Calyptraa crassa, Tate, Trans. Roy. Soc. South Aust. vol. xrii. pt. 2, p. 332, pl. vii. figs. 2,7 .

Shell much larger than $C$. corrugata, solid; spire elerated; protoconch coiled, somewhat depressed, subcentral; whorls slightly inflated, suture clearly marked, growth-lines irregular and producing corrugations on the surface; edge of internal plate concave.

Dimensions._Height $11 \mathrm{~mm}$; breadth $27.5 \mathrm{~mm}$.

Form. and Loc.-Miocene: Gippsland, Victoria.

G. 9395. Examples of the neanic and ephebic stages of growth.

Purchased.

\section{Calyptræa subtabulata, Tate.}

1877. Trochita calyptraformis, Johnston, Pap. Roy. Soc. Tas. 1876, p. 86 (non Lamarck, 1822).

1888. Trochita calyptraformis, Johnston, Geol. Tasmania, pl. xxix. figs. $14,14 a$.

1893. Calyptica subtabulata, Tate, Trans. Roy. Soc. South Aust. vol. xvii. pt. 2, p. 332 , pl. vii. fig. 1.

1895. Calyptrea subtabulata, Pritchard, Proc. Roy. Soc. Vict. vol, viii. s.s. p. 113.

Closely allied to $C$. crassa, but the whorls increase more rapidly in size, they are less corrugated, and become flat in front of the 
suture; there are a few coarse spiral strix, whilst the internal plite has an almost straight edge. The spire raries considerably in height.

Dimensions.-Height $11 \mathrm{~mm}$; breadth $25 \mathrm{~mm}$.

Form. and Loc._Eocene: Table Cape, Tasmania.

83986. Example having an elerated spire and slightly inflated body-whorl.

Purchased.

G. 9394. Three specimens.

Purchased.

\section{Subgenus CALYPTROPSIS, Tate.}

[Trans. Roy. Soc. South Aust. rol. xrii. pt. 2, 1893, p. 333.]

"Shell like Calyptraa, but umbilicated, and with a columellainsinuosity at the umbilical border."-Tate.

In the work ahore quoted the author cites the Journ. Poy. Soc. X.S. Wales, vol. $\mathrm{xx}$ rii. 1893 , p. 181, as the publication in which he first established Calyptropsis; but the latter work was not, in reality, published until early in the year 1894 , whereas the Trans. lioy. Soc. South Aust. rol. xrii. pt. 2, above quoted, was published in Dec. 1893, thus taking priority. The following species is here selected as the type of the subgenus:-

Type.-Calyptraa arachnoidens, Tate.

Calyptræa (Calyptropsis) turbinata, Tenison-Woods (sp.).

1579. Trochita turbinata, Tenison-Woods, Proc. Linn. Soc. N.S.W. rol. iii. p. 238, pl. xxi. fig. 1 .

1893. Calyptrea (Calyptropsis) turbinata, Tate, Trans. Roy. Soc. South Aust. vol. xvii. pt. 2, p. 333.

1894. Calyptropsss turbinata, Tate, Journ. Roy. Soc. Y.S.W. rol. xxvii. p. 181 .

Shell thin, suborbicular, turbinate, depressed; protoconch small, coiled, leaning to one side; whorls two and a half, rapilly increasing, ornamented by slender radial and concentric threads; internal plate relatively small, striated, edge curved over towards the umbilicus, which is narrow. 
Dimensions.-Height $8.5 \mathrm{~mm}$.; breadth $15.5 \mathrm{~mm}$. Form. and Loc.-Eocene: Muddy Creek, Victoria.

G. 9392. Examples of the neanic and ephebic stages of growth. Purchased.

\section{Calyptræa (Calyptropsis) umbilicata, Johnston (sp.).}

1855. Crepidula umbilicata, Johnston, Pap. Roy. Soc. Tas. 1884, p. 232 (two figs.).

1858. Crepidula umbilicata, Johnston, Geol. Tasmania, pl. xxrii. fig. 10.

1893. Calyptrcea (Calyptropsis) umbilicata, Tate, Trans. Roy. Soc. South Aust. vol. xvii. pt. 2, p. 333.

1894. Calyptropsis umbilicata, Tate, Journ. Roy. Soc. N.S.W. vol. xsvii. p. 181 .

1895. Calyptropsis umbilicata, Pritchard, Proc. Roy. Soc. Vict. vol. viii. s.s. p. 146.

This differs from $C$. turbinata principall 5 , in that the protoconch is more laterally situated, the shell increases in size more rapidly; the surface is prominently ornamented by a few distant spiral ridges crossed by lamellæ of growth and fine striæ; internal plate small, surface covered by striæ radiating from the rather large umbilicus.

Dimensions.-Height $4.5 \mathrm{~mm}$.; breadth $14 \mathrm{~mm}$.

Form. and Loc.-Eocene: Table Cape, Tasmania.

G. 9393. An example of the neanic stage of growth. Purchased.

\section{Calyptræa (Calyptropsis) calyptræformis, Lamarck.}

1822. Calyptrea calyptraformis, Lamarck, Hist. Nat. Anim. sans Vert. t. vii. p. 12.

1834. Crepidula maculata, Quoy and Gaimard, Voy. de I'Astrolabe, Zool. t. iii. p. 422 , pl. lxxii. figs. 6,9 .

1859. Trochta maculata, Reeve, Conch. Icon. vol. xi. fig. 15.

1873. Trochita maculata, Von Martens, List. MoII. N.Z. p. 28.

1873. Calyptrce maculata, Hutton, Cat. Marine Moll. N.Z. p. 31.

1873. Calyptrea maculata, Hutton, Cat. Tert. Moll. N.Z. p. 13.

1880. Trochita nova zealandia, Hutton, Man. N.Z. Moll. p. 86.

18s6. Calyptraa (Sigapatella) calyptraformis, Tryon, Manual of Conchology, vol. viii. p. 122, pl, xxxv. figs. 96-9.

1893. Calyptrea calyptreformis, Hutton, Linn. Soc. N.S.W., Macleay Mem. Vol. p. 61. 
This common species is distinguished by its compressed form and lateral apex; the whorls rapidly enlarge, growth-lines corrugating the surfuee; internal plate moderately large, part of the edge slightly orerhanging the umbilicus.

Some of the specimens mentioned lereunder, which are in the state of casts only, are doubtfully referred to this species.

Dimensions.--Height $7 \mathrm{~mm}$; breadth $21 \mathrm{~mm}$.

Form. and Loc.-Pliocene and Niocene: New Zealand.

G. 9602. Specimens showing rariation in position of the apex; from Wanganui.

Sir James Hector Coll.

G. 9608. Casts in which the spire is much elevated; from Blind Bay.

Sir James Hector Coll.

G. 9620. Cast of a small specimen in a block of argillaceous limestone; from Akuakua, east coast of Auckland.

Sir James Hector Coll.

G. 9626, G. 9631. Casts of large specimens haring a depressed spire; from Akuakua.

Sir James Ilector Coll.

G. 962\%. Cast of a small example in which the earlier whorls increase rery rapidly; from the Upper liedeliffe beds, lied Cliff, Rakaia river, Canterbury.

Sir James Ilector Coll.

G 9698. Three examples of the arlult, in one of which the body-whorl is much iufluted; from Parimoa. W.B.D. Mantell Coll.

\section{Family XENOPHORID A.}

\section{Genus XENOPHORA, G. Fischer (Ton Waldheim).}

[Museum Demidoff, rol. iii. 1807, p. 213.]

Phorus, Montfort, Conch. Syst. t. ii. 1810, pp. 158-9.

Shell trochiform, concave or flattened below; whorls broad, commonly carrying pices of stone, shells, or other objects which are agglutinated to, or imbedded in, the upper surface of the shell, sometimes completely hiding it from riew; last whorl compressed, keeled at the periphery; aperture large, oblique; outer margin rery oblique and sharp; umbilicate, or narrowly rimate.

Type--Tenophora lavigata, G. Fiseher (Trochus conchyliophorus, Guclin). 


\section{Subgenus TUGURIUM, P. Fischer.}

[Kiener and Fischer, Coq. Viv. Trochidæ, 1880, p. 450.]

Shell umbilicate, foreign substances being agglutinated only in the neighbourhood of the suture; periphery of the last whorl much prolonged, trectiform.

Type.-Tenophora indica, Gmelin.

\section{Xenophora (Tugurium) tatei, sp. nov.}

[Plate VII. Figs. $7 a-b$.

Shell trochiform, with moderately elevated spire; whorls broad, seven in number, Fery small to commence with, but rapidly increasing in size; the surface of the whorls, as seen between the foreign fragments adhering (mostly in the vicinity of the suture), is irregularly, obliquely undulating and ornamented by closely-set wavy, roughly spiral lineations, which are crossed by more or less conspicuons growth-lines; the keel at the periphery of the last whorl is sharp and undulating; the under surface is concave, the depression being most marked near the keel, curved lines of growth are conspicuous; aperture subquadrate; outer margin thin, strongly curved, deeply concave, and wuch produced at the margin owing to the prolongation of the last whorl in that region; iuner margin slightly thickened, the thin callosity spreading over as a plate or lining on the inner posterior surface of the aperture; umbilicus funnel-shaped, small.

Compared with the European Tertiary $\Gamma$. agglutinans, Lamarek, with which it is allied, the Australian species has a relatively higher spire, the whorls are not so flat, and the under surface is narrower; $X$. agglutinans has a much larger umbilicus, whilst its outer margin is not so deeply concave, nor so greatly produced; the ornament of the whorls is different. On the other hand, T. tatei is broader than the European Eocene $X$. confusa, Deshayes, whilst the latter is not umbilicate.

Dimensions.-Height $25 \mathrm{~mm}$; ; breadth $44 \mathrm{~mm}$.

Form. and Loc.-Eocene: Victoria and South Australia.

G. 4156. Example of the neanie stage of growth, the foreign substances adhering being, for the most part, bryozoa; from Muddy Creek.

Presented by John Dennant, Esq. 
G. 5538. The type specimen, figured; from Nuddy Creek.

Purchased.

G. 9404. Specimen having small pieces of stone, bryozoa, and shell fragments adheriug; from Mudds Creek.

Purchased.

G. 9650. Cast of an umbilicated species, probably referable to X. tatei; from the Tertiary of Fowler's Bay I)istrict.

II. Y. L. Brown Coll.

Family NATICIDA.

\section{Genus N A T I C A, Scopoli.}

[Introd. Hist. Nat. 1777, p. 392.]

Shell orate, globose, shining, solid, usuall 5 smooth; umbilicate; spire short; aperture entire; columellar border thick, subvertical; outer margin thin, not sinuons.

Kecent authors, ${ }^{1}$ following Lamarck, ${ }^{2}$ regard $N$. canrena, Linnæus, as the type of Natica. Adanson ${ }^{3}$ was the first to propose Natica, but his work must be ignored, according to the usual rules of nomenclature adopted in this country. In introducing Adanson's name into binomial nomenclature Scopoli cited four examples, neither of which includes $N$. canrena, which cannot, therefore, be cited as the type. Another reason (if one were required) for not accepting that species is, that $N$. camrena of Linnsus was a compound of sereral species, as is generally recognized. Of the four examples cited by Scopoli two are of Natica, as at present restricted, and it will prevent confusion if one of them be selected as the trpe.

The chief dirisions of the NATICIDE, being based for the most part on the character of the opereulum, can ouly be doubtfully recognized in fossil forms.

Type.-Nerita ritellus, Linnæus.

1 Cossmann, Ann. Soc. Roy. Malac. Belg. t. xxïi. 1888, p. 159; and Dall, Trans. Wagner Free In-t. Sci. Philad. vol. iii. pt. 2, 1892, p. 362.

2 I ćm. Soc. Hist. Nat. Paris, 1799, p. 77.

3 Ilist. Nat. Sćnégal (Coquillages), 1757, p. 172. 


\section{Natica hamiltonensis, Tate.}

1879. Natica wintlei var. hamittonensis, Tenison-Woods, Proc. Linn. Soc. N.S.W. vol. iii. p. 229 , pl. xxi. fig. 8 .

1893. Nutica hamiltonensis, Tate, Trans. Roy. Soc. South Aust. vol. xvii. pt. 2, p. 319, pl. x. fig. 6 .

Sliell globose; spire somewhat elevated, suture clear, accompanied by a depression; aperture broad, rounded in front, angulate behind; outer margin thin; inner margin cosered partially by enamel, but there is no posterior callosity; umbilicus semilunate, funiculus broad, the outer portion conterminons with the columellar border, slightly orerhanging, defined in front by a narrow sulcus.

Immature specimens resemble $N$. caillati, Deshayes, of the Enropean Eocene; but the aperture of the Australian species is broader, whilst the excavation behind the funiculus is characteristic, and the spire is not so much elevated.

Dimensions. - Length $20 \mathrm{~mm}$; breadth $18 \mathrm{~mm}$; length of aperture $15 \mathrm{~mm}$.

Form. and Loc.-Eocene: Muddy Creek, Victoria.

G. 9410. Series illustrating stages of growth.

Purchased.

\section{Natica subnoæ, Tate.}

1893. Natica subnor, Tate, Trans. Roy. Soc. South Aust. vol. xvii. pt. 2, p. 320 , pl. vi. fig. 1 .

1896. Natica subnoe, Pritchard, Proc. Roy. Soc. Vict. vol. viii. x.s. p. 112.

The shell of this species is flattened, and, in consequence, is not so globose as $N$. hamiltonensis; neither is the spire elevated. It is very closely allied to the European Eocene $N$. noce, D'Orbigny, but the spire of the latter is more salient, its funiculus is not so much dilated, and the suture is cut in, whereas in $N$. subnoe the suture is almost concealed.

Dimensions. - Length $12.5 \mathrm{~mm}$.; breadth $11 \mathrm{~mm}$.; length of aperture $9 \mathrm{~mm}$.

Form. and Loc.-Eocne: Table Cape, Tasmania.

G. 9413. Two examples with funiculus well developed. 


\section{Natica cunninghamensis, nom. mut.}

1893. Natica (Neverita) varians, Tate, Trans. Roy. Soc. South Aust. vol. xvii. pt. 2, p. 322, pl. vi. figs. 2, 9 (non Dujardiu).

Shell large, solid, narrow; spire very short, bods-whorl enveloping, few spiral striæ; aperture oblique; outer margin oblique; inner margin extremely callous posteriorly; umbilieus large, funieulus broad, terminating on the columella in a moderatesized callosity, bounded posteriorly by a deep, striated sulcus, anteriorly by an undulating groove.

The specific name given by Professor Tate is now ehanged, as it is preoccupied by Dujardin, $N$. varians being a common form in the Mioeene of the Touraine, and having nothing in eommon with the Australian species. The name here proposed is derived from Cunningham, in Gippsland, one of the localities where the species has been found.

The umbilicus in Neverita is practically filled, or is nearly covered over, by a funicular callosity, the outside portion of which is conterminous with the eolumellar border; the shell, also, is depressed. These characters are not possessed by $N$. cunninghamcnsis, as will be observer from what has already been said. The present species does not differ essentially from Natica, sensu stricto, except perhaps in having the posterior callosity, which does not seem to be of much systematic value; other species ineluded by Professor Tute in Neverita are here placed under Natica for similar reasons.

Dimensions. -- Length $36 \mathrm{~mm}$.; breadth $30 \mathrm{~mm}$.; length of aperture $25 \mathrm{~mm}$.

Form. and Loc.-Miocene: Muddy Creek, Victoria.

G. 4281, G. 5528. Examples of the adult.

Presented by John Dennant, Esq.

G. 9414. Examples of the neanic and ephebic stages of growth.

Purchased.

Natica wintlei, Tenisou-Woods.

1876. Natica wintlei, Tenison-Woods, Proc. Roy. Soc. Tas. 1875, p. 23, pl. i. fig. 3 .

1878. Natica vintlei, R. Ftheridge, jun., Cat. Aust. Foss. p. 166.

1888. Natiea wintlei, Johnston, Geol. Tasmania, pl. xxix. fig. 10. 
1893. Natica (Neverita) wintlei, Tate, Trans. Roy. Soc. South Aust. vol, xvii. pt. 2, p. 322 .

1895. Natica wintlei, Tate and Dennant, Trans. Roy. Soc. South Aust. vol. xix. pt. 1, p. 112.

1896. Natica wintlci, Pritchard, Proc. Roy. Soc. Vict. vol. viii. N.s. p. 112.

Shell narrower than in $N$. hamiltonensis, the spire is relatively more elevated, and the aperture is not so broad; suture clearly marked; posterior callosity of the aperture well dereloped; umbilicus small in adults, furnished with a funicle narrow in the early stages of growth and becoming relatively broader with age, bounded anteriorly by a deep sulcus.

Dimensions.-Length $25 \mathrm{~mm}$.; breadth $21.5 \mathrm{~mm}$.; length of aperture $17 \mathrm{~mm}$.

Form. and Loc.-Eocene: Tasmania and Victoria.

83982. Examples of the neanic stage of growth; from Table Cape.

Purchased.

G. 9411. Two specimens; from Table Cape.

Purchased.

G. 9412. Variation in which the funiculus is broad at its confluence with the inner margin of the aperture; from Spring Creek.

Purchased.

Natica conica, Lamarck.

1838. Natica conica, Lamarck, Deshayes, Hist. Nat. Anim. sans Vert. t. viii. p. 632.

1886. Natica (Mamma) conica, Tryon, Manual of Conchology, vol. viii. p. 44, pl. xviii. figs. 76-7.

Shell solid, spire conical; whorls compressed near the suture; aperture semilunate; umbilicus partly corered by a callous extension confluent with the inner margin of the aperture, and also by the spreading of the thick posterior callosity. Both in the young and the adult the umbilicus is frequently filled with these callous extensions.

Dimensions. -Length $31 \mathrm{~mm}$.; breadth $22.5 \mathrm{~mm}$.; length of aperture $20 \mathrm{~mm}$.

Form. and Loc.-Post-Pliocene: Western Australia and Victoria.

97721. Two specimens; (? locality), Western Australia. II. Y. L. Brown Coll.

G. 5567. Examples of the neanic and ephebic stages of growth; from Limestone Creek, Glenclg river.

Purchased. 


\section{Natica zelandica, Quoy and Gaimard.}

1832. Natica zclandica, Quoy aud Gaimard, Voy. de l'Astrolabe, Zool. t. ii. p. 237, pl. lxvi. figs. 11, 12.

1873. Nutica zelantica, Yon Martens, List. Moll. N.Z. p. 25.

1873, Natica zechendica, IIutton, Cat. Marine Moll. N.Z. p. 21.

1873. Vaticu zeclandica, Hutton, Cat. Tert. Moll. N.Z. p. 8.

1580. Nutica zealitendica, IIutton, Man. N.Z. Moll. p. 71.

1886. Nutica zealandica, Tryon, Manual of Conchology, vol. viii. p. 22, pl. iv. fig. 70 .

1893. Natica neozelanica, Hutton, Liun. Soc. N.S.W., Macleay Mem. Vol. p. 54 .

Shell globose; spire short, whorls ornamented by fire encireling bands on which, in the fossil specimens, are equidistant pale pink spottings; umbilicus funiculate, with a large entering callosity.

Dimensions. - Length $22.5 \mathrm{~mm}$.; breadth $20 \mathrm{~mm}$.; length of aperture $16.5 \mathrm{~mm}$.

Form. and Loc.-Pliocene: Shikespeare Cliff, New Zealand.

G. 9573. A series illustrating stages of growth.

Sir James Hector Coll.

\section{Natica ovata, Hutton.}

1873. Natica (Mamilla) ovata, Iutton, Cat. Tert. Moll. N.Z. p. 9.

1893. Natica (.Mamma) ovata, Iutton, Liun. Soc. N.S.W., Macleay Mem. Vol. p. 55 , pl, rii. fig. 40 .

"Shell pyriformly ovate, smooth, thick. Whorls five or six, the suture corered. Aperture semi-lunar; columellar callus large, but never completely covering the umbilicus."-IIutton.

It may possibly be referred to Polinices, Montfort; but is not here definitely relegated to that subgenus, as the umbilicus is not completely filled with callus.

Dimensions.-Length $38 \mathrm{~mm}$; breach $32 \mathrm{~mm}$; length of apcrture $28 \mathrm{~mm}$.

Form. and Loc.-Miocene and Pliocene: New Zealind.

G. 9560. Imperfect shells, imberded in argillaceous limestone, probably referuble to this species; from Molihinui.

Sir James Hector Coll.

G. 9614. Several examples of the adult; from Wangauni. 
G. 9561, G. 9613, G. 9615, G. 9616 . Many specimens associated with Dentalium, Axinca, etc., in blocks of argillaceous shelly limestone; from the Mangapakeha beds, Akuakua, Auckland.

Sir James Hector Coll.

G. 9702. Series illustrating stages of growth, showing that the umbilicus was largely covered in with callus even at an early age; from Parimoa. W. B. D. Mantell Coll.

\section{Subgenus LUNATIA, Gray.}

[Proc. Zool. Soc. 1847, p. 149.]

Vaticina, auctorum, non Guilding, 1834, nec Gray, 1842.

Shell more or less globose; umbilicus open, without funiculus.

The type of Natioina, Guilding, as specified by that author, ${ }^{1}$ is $N$. lactea, Guilding, and as this species falls within the earlier Polinices, Montfort, Naticina, Guilding, is synonymous with Polinices (Mamma), as pointed out by American authors. ${ }^{2}$ $N$. catena, Da Costa, regarded by some authors ${ }^{3}$ as the type of Naticina, does not fall within that subgenus. The Naticina of Gray refers to naticiform Sigareti, and is in no sense applicable to the mollusca falling under Naticina, as defined by Guilding. The majority of the fossil species usually iucluded under Naticina may be referred to Lunatia when that term is liberally interpreted.

Type.-Natica ampullaria, Lamarck.

Natica (Lunatia) substolida, Tate.

1893. Natica (Neverita) substolida, Tate, Trans. Roy. Soc. South Aust. vol. xvii. pt. 2, p. 323 , pl. vi. fig. 3 .

This species is closely allied to $N$. abducta, Deshayes, of the Lower Eocene of North-Western Europe, from which it differs, principally, in not having such a wide umbilicus, and in being

1 Traus. Linn. Soc. vol. xvii. 1834, p. 31.

* E.g. Dall, Trans. Wagner Free Inst. Sci. Philad. vol. iii, pt. 2, 1892, p. 36i; Tryon, Manual of Conchology, vol. viii. 1886, pp. 49, 89.

Cossmann, Ann. Soc. Roy. Malac. Belg. t. xxiii. 1888, p. 164. 
rather more eallous at the posterior of the inner margin; its outer margin is much drawn out in front, and the rounded anterior of the aperture is reflected.

Professor Tate compares it with $N$. repanda, Deshayes, to which it also bears some resemblance.

Dimensions. - Length $25 \mathrm{~mm}$.; breadth $22 \mathrm{~mm}$.; length of aperture $18.5 \mathrm{~mm}$.

Form. and Loc.--Eocene: Mruddy Creek, Victoria.

G. 4281. Two examples, in one of which the inner margin of the aperture is extremely callous. Presented by John Dennant, Esq.

G. 9407. Examples illustrating stages of growth. Purchased.

\section{Natica (Lunatia) polita, Tenison-Woods.}

1876. Natica polita, Tenison-Woods, Pap. Roy. Soc. Tas. 1875 , p. 23, pl. i. fig. 4 .

1893. Natica (Naticina) polita, Tate, Trans. Roy. Soc. South Aust. vol. xvii. pt. 2 , p. 325 .

1895. Natica polita, Pritchard, Proc. Roy. Soc. Vict. vol. viii. x.s. p. 112.

The spire of this small species is frequently more elevated than in $N$. perspectiva or $N$. substolida; the suture is canaliculate, growthlines rery oblique, and the whorls are faintly spirally striated; umbilicus almost circular, deep, and without a funiculus. It is not unlike the young of $N$. catena, $\mathrm{Da}$ Costa, though the suture of the latter is not cut in, and its shell is relatively broader.

Dimensions.-Length $9 \mathrm{~mm}$.; breadth $7.75 \mathrm{~mm}$.

Form. and Loc.-Eocene: Muddy Creek, Victoria.

G. 9409. Sercral examples of the adult.

Purchased.

\section{Natica (Lunatia) perspectiva, Tate.}

1893. Natica (Naticina) perspectiva, Tate, Trans. Roy. Soc. South Aust. vol. xvii. pt. 2, p. 326, pl. x. fig. 7 .

Shell globose; spire short, suture well defined; lines of growth prominent, oblique, whorls indistinctly spirally striated; umbilicus broad, decp, striated, defined in frout by an encircling keel, not funiculate.

It may be compared with $N$. limata, but its protoconch is not 
so much elevated as in the latter species; whilst the characteristic cuts bordering the suture, and the elearly-defined spiral striæ and lineatious in the brephic stage of $N$. limata, are missing in this species. It forms a connecting link between Lunatia and Stigmaulax.

Dimensions. - Length $13 \mathrm{~mm}$.; breadth $12 \mathrm{~mm}$.; length of aperture $9 \mathrm{~mm}$.

Form. and Loc.-Eocene: Muddy Creek, Victoria.

G. 4280. Three examples. Presented by John Dennant, Esq.

G. 9408. Examples of different stages of growth; one of which has an abnormally wide umbilicus.

Purchased.

\section{Subgenus STIGMAULAX, Mörch.}

[Cat. Yoldi, 1852, p. 133.]

The shell of this subgenus is of the same general character as Naticina, but the whorls are strougly spirally lineate, whilst the lines of growth are prominent, producing a rough species of cancellation; the umbilicus has no funiculus.

Type.-Natica sulcata, Born.

\section{Natica (Stigmaulax) limata, Tate.}

1893. Natica (Naticina) limata, Tate, Trans, Roy. Soc. South Aust. vol. xvii. pt. 2, p. 324, pl, x. fig. 4.

1895. Natica (Stigmaulax) (?) limata, Cossmann, Ann. Géol. Univ. t. x. p. 754 .

Shell thin, globose; protoconch (Plate VIII. Figs. $1 a-b$ ) smooth, depressed, suture canaliculate, composed of two turns, merging imperceptibly into the shell of the brephic stage where the suture is bordered by short longitudinal cuts, which must not be confounded with lines of growth; these cuts, as the neanic stage is approached, are modified into irregular small sulci exteuding right across the whorls; the spiral lineations, which are very irregular and much cut up by growth-lines in the body-whorl of the adult, commence as indistinct, regular lineations in the brephic stage; aperture ovate; outer margin oblique, thin; inner margin not 
callous; umbilicus not funiculate, deep, and bordered by a thin expansion on the inner margin.

Dimensions. - Length $21 \mathrm{~mm}$.; brealth $19 \mathrm{~mm}$.; length of aperture $16 \mathrm{~mm}$.

Form. and Loc.-Eocene: Muddy Creek, Victoria.

G. 4278. Examples of the adult.

Presented by John Dennant, Esq.

G. 5529. Specimen haring a narrow umbilicus and very thin inner margin.

Purchased.

G. 9406. Two specimens.

Purchased.

Subgenus SIGARETOPSIS, Cossmann.

[Ann. Soc. Roy. Malac. Belg. t. xxiii. 1888, p. 168.]

The chicf distinguishing features of this subgenus are the rery short spire, depressed form, immense umbilicus, and the absence of a funiculus, whilst in front of the latter the columellar border is thin and lamellose; inner margin callous posteriorly.

Type.-Natica infundibulum, Watelet.

Natica (Sigaretopsis) subinfundibulum, Tate.

1893. Natica (Sigaretopsis) subinfundibulum, Tate, Trans. Roy. Soc. South Aust. rol. xvii. pt. 2 , p. 327 , pl. x. fig. 11 ; pl. vi. fig. 6 .

Shell much depressed, spire very short, suture not cut in, body-whorl enveloping; lines of growth oblique, undulating; aperture orate; outer margiu thin; umbilicus rery large, striated, and open, displaying the spiral formed by successive whorls; posterior callosity of the inner margin not prominent.

It is rather more conical in form than $\lambda$. infundibulum, Watelet, the type of the subgenus, of the European Eocene, with which, howerer, it is closely allied.

Dimensions.-Length $15.5 \mathrm{~mm}$.; breadth $13 \mathrm{~mm}$.; length of aperture $11 \mathrm{~mm}$.

Form. and Loc.-Eocene: Muddy Creek, Victoria.

G. 9405. Examples illustrating stages of growth. Purchased. 


\section{Natica, sp.}

G. 9580. Imperfect examples of a species haviug a thick posterior callosity on the inner margin of the aperture, and the umbilicus filled with callus; allied to $N$. solida, Sowerby. From the Miocene, Upper Redeliffe beds, Red Cliff, Rakaia river, Canterbury, New Zealand.

Sir James Hector Coll.

G. 9607. Large species probably identical with the lastmentioned, the posterior callosity being enormous, filling the umbilicus and exteuding anteriorly. From the Eocene, Trelissick, New Zealand.

Sir James Hector Coll.

\section{Genus EUSPIRA, Desor and Agassiz.}

[Jas. Sowerby's Mineral-Conchologie Grossbrittaniens, 1837, pp. 14, 16; 1842, p. 320 (non Cossmann, etc.).]

"Ampulline" (Lamarck), Defrance, Dict. Sci. Nat. t. xx. 1821, p. 446.

(?) Ampullina, Deshayes, Ency. Meth. Vers. t. ii. 1830, p. 36 (non Blainville, Dict. Sci. Nat. t. xxxii. 1824, p. 235 ; nec H. and A. Adlams, Gen. Rec. Moll. vol, i. 1853, p. 208). Globulus, J. de C. Sowerby, Mineral Couchology, vol, vi. 1834, "System Index," p. 246 (non Schumacher).

Ampullina, Cossmann, Ann. Soc. Roy. Malac. Belg. t. xxiii. 1888, p. 170 ; et auctorum.

Shell naticiform; umbilicus without a funiculus, open or closed by callosity; aperture large; outer margin sinuous, produced at the middle; umbilical region limited by a spiral rib or limb more or less developed; columellar border curved, typically S-shaped.

The writer cannot find that the name Ampullina (so commonly applied to fossil naticiform shells of the Tertiary of North-Western Europe) was properly established before Desor and Agassiz had proposed the term Euspira. Defrance, who is generally credited with having introdnced Ampullina (op. supra cit.) does so in the vernacular as "Ampulline," and even if that could be admitted as proper establishment we are left in difficulty as to the meaning of the term. "Ampulline" is not diagnosed, nor is it stated in what way we are to distinguish it from Ampullaria as described by Defrance. 
Deshayes (op. supra cit.) mentions Ampullina as having been suggested by Lamarck, but never published by him; also, that the latter had subsequently abandoned the term. But Deshayes does not quote any species illustrating Lamarck's proposal, and we are thus left in doubt as to what Ampullina really was.

In 1822 Bowdich ${ }^{1}$ divided Ampullaria into two parts, one of which he çalled Ampullina. He gives a figure as representing it, ${ }^{2}$ but neither in the text nor in the explanation of the plate does he mention a single species in connection with it, and Ampullina is not there diagnosed nor established.

In 1830 Blainville (op. supra cit.) used the term Ampullina in another connection, so that after that date it was not arailable for the molluses indicated by Deshayes and as exemplified by $N$ atica sigaretina.

In 1837 Desor and Agassiz (op. supra cit.) suggested the term Euspira, comprising in it such species as Natica glaucinoides, Sowerby (non Deshayes), $N$. depressa, Sowerb5, Ampullaria patula, Lamarck, A. acuta, Lamarck, A. sigaretina, Lamarck, A. ambulacrum, Sowerby, etc., etc. French authors ${ }^{3}$ have interpreted Euspira through the medium of E. canaliculata, Morris and Lycett. That species canuot possibly be regarded as the type of the genus, howerer, as it was not mentioned by Desor and Agassiz when they founded Euspira-the species was not eren deuominated at that period. Euspira as delimited by the lastmentioned authors includes species of Natica; to prevent misconception the following well-known species is here selected as the type, from amongst those mentioned by the authors of the genus.

Type.-Ampullaria sigaretinu, Lamarck.

\section{Subgenus AMPULLOSPIRA, nom. mut.}

Euspira, Cossmann, etc. (non Desor and Agassiz).

Distinguished by its much elerated and canaliculate spire; columellar border thick, in part covering the umbilicus, which has no limb.

1 Elements of Conchology, pt. i. Univalves, 1822, p. 31.

2 Bowdich, op. cit. pl. ix. fig. 2.

${ }^{3}$ E.g. Cossmann, Ann. Soc. Roy. Malac. Belg. t. xxiii. 1888, p. 175.

- Moll. Great Oolite (l'al. Soc.), pt. i. 1850, p. 45. 
The reasons for changing the name of this subgenus are giren on pp. 26t-5.

Type-_Euspira canaliculata, Morris aud Lycett.

\section{Euspira (Ampullospira) effusa, Tate.}

1S93. Ampulline (Euspira) effusa, Tate, Trans. Roy. Soc. South Aust. vol. xvii. pt. 2 , p. 327 , pl. x. figs. $2,2 a$.

1894. Ampullina effusa, Tate, Journ. Roy. Soc. N.S.W. vol. xxvii. p. 181.

The specimeus in the Museum are not in good preservation, but Professor Tate, comparing $A$. effusa with the European Eocene A. acuminata, Lamarek, and A. levesquei, D'Orbiguy, states that "It agrees with them in the elerated and canaliculate spire, but is readily distinguished by its regular spire (not subulate), effusively dilated aperture, and elegant sculpture; from $A$. acuminata, it is further remored by being umbilicated, but resembles $A$. leresque $i$ in its simple umbilicus." The surface is ornamented by eloself-set spiral strix broken up by slightly eurred incised lines.

Dimensions (after Tate).-Length $35 \mathrm{~mm}$; breadth $24 \mathrm{~mm}$.; height of aperture $21 \mathrm{~mm}$; width of aperture $13 \mathrm{~mm}$.; width of umbilicus $2 \mathrm{~mm}$. (vix).

Form. and Loc.-Eocene: boring in Adelaide, South Australia.

G. 9432. Two specimens of the neanic stage of growth.

Purchased.

\section{Family SEGUENZIID E.}

\section{Genus SEGUENZIA, Jeffreys.}

[Proc. Roy. Soc. vol. xxv. 1876, p. 200.]

Shell small, trochiform, thinly nacreous; ornamented br spiral keels; "with an infra-sutural sinus resembling that of some Pleurotomidx, a sharp and shallow sinus at the periphery, and a third, more open, at the base; the columella is more or less twisted, with an interior tooth-like projection; the base is either deeply umbilicated or imperforate."-Tate. Professor Tate ${ }^{1}$ diseusses its affiuities at some length.

Type.-Seguenzia formosa, Jeffreys.

1 Trans. Roy. Soc. South Aust. rol. xiii. pt. 2, 1890, p. 192. 


\section{Seguenzia radialis, Tate.}

1890. Seguenzia radialis, Tate, Trans. Roy. Soc. South Aust. vol. xiii. pt. 2, p. 192.

1894. Seguenzia radialis, Tate, Journ. Roy. Soc. N.S.W. rol. xxvii. p. 185.

Shell broadly conical; "flat and sharply angulated at the base; perspectively umbilicated; ornamented by radial sigmoidal threads, latticed by spiral ones. . . . The umbilicus is wide . . . , margined by about sixteen stout granulations, from which proceed the radial threads in twos and threes. Aperture rhomboid, peristome completed by a thin nacreous growth. Outer lip roundly insinuated near the suture . . . . ; sharply and shortly notched at the posterior earina; at the exterior of the base roundly insinuated, separated by a similar sinus at the inner angle by a tuberele corresponding with umbilical carina."-Tate. The columella has a strong, twisted denticle at about two-thirds of its length.

The shell is rery rare.

Dimensions._-Length $3 \mathrm{~mm}$, ; breadth $3 \mathrm{~mm}$.

Form. and Loc.-Eocene: Muddy Creek, Victoria.

G. 9483. An example of the adult.

Purchased.

\section{Family SCALID E.}

Genus CIRSOTREMA, Mörch.

[Cat. Yoldi, 1852, p. 48.]

Caloscala, Tate, Southern Science Record, rol. i. s.s. 1885, p. 3.

Shell imperforate; lamellæ frequently erisped; spiral threads oecasionally very large; anterior portion of the body-whorl somewhat flattened and bounded by a concentric thread, which limits an expansion generally covering over the flattened edges of the lamella, or the area limited by that spiral thread may only be comparatirely smooth; the thread terminates in a dentiform projection on the outer margin.

The genus is here interpreted in the broad sense, none of the species to be allnded to being sufficiently well preserred to admit of their being satisfactorily assigned to subgenera.

Type-Scalaria raricosa, Lamarck. 


\section{Cirsotrema lyrata, Zittel (sp.).}

1865. Scalaria lyrata, Zittel, Reise der Norara, Paläontologie, Bd. i. Abth. ii. p. 41 , taf. ix. fig. 8.

1873. Scularia lyrata, Hutton, Cat. Tert. Moll. N.Z. p. 9.

Shell large, solid, imperforate; whorls convex, longitudinal, twelve in number, lamellæ distant from each other, thick, crenulated on the edge, each covering the suture by a flattened expansion which invades the precering whorl; spiral lineations bold, with smaller ones between; encircling thread on the anterior of the last whorl prominent, the area between that and the columella being comparatively smooth.

Dimensions.-Length cannot be stated from the specimens in the Museum, as they are incomplete; Hutton gives the length (axis) as 2 inches, breadth 0.95 inches.

Form. and Loc.-Pliocene (?): New Zealand.

G. 9696. Example of the adult, in which the spiral threads are very strong, varices accentuated; from Parimoa.

W. B. D. Mantell Coll.

G. 9720. Varices not so clearly marked; spiral threads smaller; from Takiroa. W. B. D. Mantell Coll.

G. 9721. Lamellæ much elevated; strongly crenulated at the edges; from Takiroa.

[Old Collection.]

G. 9722. Fragment of the adult, in fine sandstone; locality (?).

[Old Collection.]

\section{Cirsotrema browni, Zittel (sp.).}

1865. Scalaria browni, Zittel, Reise der Novara, Paläontologie, Bd. i. Abth. ii. p. 42 , taf. ix. fig. 9 .

1873. Scalaria browni, Hutton, Cat. Tert. Moll. N.Z. p. 9.

Shell elongate; whorls convex, strongly rariced, longitndinal lamellæ relatively smaller than in C. lyrata and closer together; strongly spirally lineate, causing subcancellation; last whorl keeled, the area enclosed between the keel and the columella being flattened and comparatively simple. The bad preservation of the shell docs not permit of the detail being satisfactorily made out. 
Dimensions. —"Axis 1.1; breadth $0 \cdot 35 . "$ - Ilutton. These measurements are in inches.

Form. and Loc.-Eocene: Brighton, New Zealand.

G. 9596. Fragment of the adult-three whorls, including the last whorl.

Sir James Hector Coll.

\section{Cirsotrema, sp.}

G. 9697. Fragment of a small species imbedded in soft sandstone, probably referable to Cirsotrema or Crisposcala; from Parimoa, New Zealand. W. B. D. Mantell Coll.

G. 9578. Crushed fragment of a large species, in which the ornament is simple and the last whorl rery broad. The generic position is doubtful; from the Miocene of Port Hills, Nelson, New Zealand.

Sir James Hector Coll.

\section{Genus CROSSEIA, A. Adams (em.).}

[Ann. Mag. Nat. Hist. 3rd ser. vol. xv. 1865, p. 323.]

Shell small, umbilicate, conical or turbinate; whorl convex, reticulated, simple or varicose; aperture rounded, prolonged anteriorly, where it is deeply notched and somewhat canaliculate; umbilicus bordered by a long, curved, raised rim, often crenulated.

Type.-Crossea miranda, A. Adams.

\section{Crosseia princeps, Tate.}

1890. Crossea princeps, Tate, Trans. Roy. Soc. South Aust. vol. xiii. pt. 2, p. 220 .

1892. Crossea princeps, Tate, id. supp. pl. viii. figs. $6,6 a$.

Shell depressed, eonoidal, solid, polished; whorls fire in number, strongly conrex, sharply sloping towards the suture; anterior noteh of the aperture slightly canaliculate; umbilical slit bordered by a long, raised, crenulated rim.

It has considerable analog 5 with the living $C$. concinna, Angas.

Dimensions.-Length $5 \mathrm{~mm}$.; breadth $4.75 \mathrm{~mm}$.

Furm. and Loc.-Eocene: Muddy Creek, Vietoria.

G. 9486. An example of the adult. 


\section{Genus EGLISIA, Gray.}

[Syu. Brit. Mus. 1840, p. 147 ; id. 1842, p. 61 (list names); Proc. Zool. Soc. 1847, p. 155.]

Shell imperforate, solid; whorls numerous, rounded, spirally grooved or lineated, frequently having scalariform longitudinal varices; aperture small, orbicular; columellar margin curver, thickened, flattened and angulate in front; umbilical region occupied by a twisted funiculus.

Type.-Turbo suturalis, Gray.

\section{Eglisia triplicata, Tate (sp.).}

1890. Scalaria (Eglisia) triplicata, Tate, Trans. Roy. Soc. South Aust. vol. xiii. pt. 2, p. 231.

1892. Scalaria triplicata, Tate, id. supp. pl. ix. fig. 2.

Shell solid, turreted; whorls to the number of fourteen or fifteen, spirally bicarinate in the earlier stages of growth, but becoming markedly tricarinate as the ephebic stage is approached; these carinæ are rounded and equidistant, and are interrupted by the crossing of longitudinal scalariform plates; the front of the body-whorl is flattened, spirally lineated, and crossed by lineations radiating from the pillar; aperture small, rounded, angulate anteriorly; inner margin reflected; columella slightly twisted.

The general aspect of this shell is rather that of Mathildia, Semper. Neither of the examples in the Museum collection have the protoconch preserved, but it would appear from Professor Tate's description (op. cit.) of the 'apex,' which he remarks is 'acute,' that the protoconch is not heterostroph, so that the species cannot be included in Mathildia.

Dimensions. - Length $38 \mathrm{~mm}$; breadth $10 \mathrm{~mm}$.; length of aperture $6 \mathrm{~mm}$.

Form. and Loc.-Miocene: Muddy Creek, Victoria.

G. 4228. Example of the adult.

Presented by John Dennant, Esq.

G. 5537. Specimen in which interstitial spiral lineations are very prouounced.

Purchased. 


\section{Family EULIMID E.}

\section{Genus EULIMA, Risso.}

[Hist. Nat. Eur. Mérid. t. iv. 1826, p. 123.]

Shell not umbilicate, subulate, composed of many whorls, polished, porcellanous; commonly the spire is slightly twisted to one sicie; rarices not well marked externally, but forming small ribs inside the whorls; aperture orate, entire, angulate posteriorly and rounded in front; eolumellar border reflected.

Type.-Eulima elegantissima, Montag.

\section{Eulima danæ, Tenison-Woods.}

1880. Eutima dane, Tenison-Woods, Proc. Linn. Soc. N.S.W. vol. iv. p. ', pl. i. fig. 1 .

1893. Eulima dane, Tate and Dennant, Trans. Roy. Soc. South Aust. vol. xvii. pt. 1, p. 222.

1895. Eulima dane, Tate and Dennant, id. vol. xix. pt. 1, p. 112.

Shell erect, spire in typical examples not curved, whorls very narrow, concare posteriorly, convex in front, suture but slightly oblique, polished, rarices iudented, eurved, not in line from whorl to whorl; last whorl large, rounded anteriorly; aperture oral; outer margin oblique with reference to the axis of the shell.

Dimensions. - Length $28.5 \mathrm{~mm}$.; breadth $8 \mathrm{~mm}$.; length of aperture $6 \mathrm{~mm}$.

Form. and Loc.-Eocene: Muddy Creek, Vietoria.

G. 4227. Two examples of the adult, both somewhat narrower than the type described by the author.

\section{Presented by John Dennant, Esq.}

G. 5540. Shell very narrow, spire curved, with rarices deeply inclented.

Purchased.

G. 9476. Series illustrating stages of growth.

Purchased. 


\section{Genus NISO, Risso.}

[IIist. Nat. Eur. Mérid. t. iv. 1826, p. 218.]

This genus is readily distinguished from Eulima by its large and deep umbilicus, angulated at the boundary; the whorls are almost flat, and the last whorl is commonly angulate at the periphery; aperture diamond-shaped, though rounded on the inner and outer margins.

Type.-Niso eburnea, Risso.

\section{Niso psila, Tenison-Woods.}

1880. Niso psila, Tenison-Woods, Proc. Linn. Soc. N.S.W. vol. iv. p. 18, pl. i. fig. 6.

1893. Niso psila, Tate and Dennant, Trans. Roy. Soc. South Aust. vol. xvii. pt. 1, p. 222.

This species bears considerable analogy to $N$. terebellata, Lamarck, of the Eocene of North-Western Europe, but is more rounded at the periphery of the whorl, and the aperture is markedly angulate in front. It is regularly, distantly, spirally striated, the striæ being almost microscopic in size; umbilicus sharply keeled at the border.

Dimensions. - Length $21.5 \mathrm{~mm}$.; breadth $8 \mathrm{~mm}$.; length of aperture $5.5 \mathrm{~mm}$.

Form. and Loc.-Eocene: Muddy Creek, Victoria.

G. 4227. An example of the adult, obtusely keeled at the periphery of the last whorl. Presented by John Dennant, Esq.

G. 9478. Series illustrating stages of growth. Purchased.

\section{Family TURBINID E.}

\section{Genns TURBO, Linnæus.}

[Syst. Nat. ed. 10, 1758, p. 761.]

Shell imperforate, or narrowly umbilicate, solid; spire short, whorls rounded, nacreous in the interior; aperture almost circular, entire; columella arehed, broad; outer margin simple, thin.

Type.-Turbo marmoratus, Liunæus. 


\section{Turbo smaragdus, Martyn.}

1784. Tuvbo smaragdus, Martyn, Univ. Conch. pls. lxxiii., lxxiv.

1790. Turbo smaragdus, Gmelin, Linn. Syst. Nat. ed. 13, p. 3595.

1873. Turbo smaragdus, Ton Martens, List Moll. N Z. p. 29.

1873. Turbo smaragdus, Hutton, Cat. Marine Moll. X.Z. p. 33.

1850. Turbo smaragdus, Hutton, Man. N.Z. Moll. p. 90.

188s. Turbo smaragdus, Pilsbry, Tryon's Manual of Conchology, rol. x. p. 217 , pl. lxii. fig. 13.

1893. Turbo smaragdus, Hutton, Linn. Soc. K.S.W., Macleay Mem. Vol. p. 67 .

Shell heliciform, depressed, solid; corcred with strong bluishblack euticle, beneath which (in living examples) it is green; usually eroded at the apex; whorls four or five in number, the earlier ones spirally sulcate; last whorl very large, flattened in the neighbourhood of the suture; lines of growth irregular, undulating and causing wrinkles, which feature is especially well marked in the older stages of growth; umbilical area excarated, concave.

Dimensions. - Length $39 \mathrm{~mm}$. ; breadth $38 \mathrm{~mm}$. ; length of aperture $24 \mathrm{~mm}$.

Furm. and Loc.-Post-Pliocene: New Zealand.

98049. An example of the adult; "from an old beach corered with lara," Lyttleton.

[Old Collection.]

G. 8280. Four specimens; from a raised beach at Opua, near Russell, from $60 \mathrm{ft}$. to $100 \mathrm{ft}$. abore sea-level.

Presented by F. A. Bather, Esq.

Turbo etheridgei, Tenison-Woods.

1877. Turbo etheridgei, Tenison-Woods, Pap. Roy. Soc. Tas. 1876, pp. $98,99$.

1896. Turbo etheridgei, Pritchard, Proc. Roy. Soc. Vict. rol. riii. s.s. p. 118.

Shell turbinately conical, solid, granular; spire elevated; whorls six or seren in number, courex, each furnished with from five to seren grauulate spiral carinx, interrupted by fine, oblique lines of growth; aperture circular, nacreous, entirc; outer margin thin, oblique; inner margin covered by a thin deposit of 
nacreous callus; eolumellar area smooth, broad, excarated, concare; imperforate.

This species, not haring been figured by the author, is now drawn on Plate VIII. Figs. $2 a-b$.

Dimensions.-Length $13 \mathrm{~mm}$; ; breadth $10.5 \mathrm{~mm}$.; length of aperture $7 \mathrm{~mm}$.

Form. and Loc.-Eocene: Table Cape, Tasmania.

83994. An example of the ephebic stage of growth. Purchased.

Turbo hamiltonensis, sp. nот.

[Plate VIIJ. Figs. $3 a-c$. ]

Shell turbinate-conical, imperforate; spire elevated, whorls five in number, convex; oruament consisting of subgranulate spiral carinæ causing angulations at the periphery, these are two in number on the spire-whorls and three on the last whorl; between them are dereloped minor spiral granulose lineations; the sloping area between the posterior carina and the deeply iucised suture has three rows of small spiral granulations, and a fourth, larger than the others, bordering the suture; the flattened base of the shell between the anterior of the three carinx and the columellar region bears a fourth carina with more distinct granulations than the others, and other rows of spiral granules, eight in number, in the type specimen; there is a spiral depression bordering the columella; aperture circular, entire; outer margiu thin; inner margin exeavated, slightly callous; columellar region broad, with two or three irregular, small granules in front.

This species differs from T. etheridgei, amongst other things, in having a much broader columellar area, by the spiral depression at the base, in having relatively broaler whorls, the deeply incised suture, the angulations of the periphery, and by the granulate ornament being differently disposed.

Dimensions.-Length $14 \mathrm{~mm}$.; breadth $13.5 \mathrm{~mm}$.; length of aperture $7 \mathrm{~mm}$.

Form. and Loc.-Eocene (?): Muddy Creek, Victoria.

G. 4299. The type specimen. Presented by John Dennant, Esq. 


\section{Turbo superbus, Zittel.}

1865. Turbo superbus, Zittel, Reise der Novara, Palïontologie, Bd. i. Abth. ii. p. 39, taf. xir. fig. 2.

1873. Turbo superbus, IIutton, Cat. Tert. Moll. N.Z. p. 15.

G. 9605. A large specimen, rery much crushed, that may probably be referred to this species; from the Miocene of Kawau, New Zealand.

Sir James IIector Coll.

\section{Turbo, sp.}

The following New Zealand specimens from the Sir James IIector Coll. are unrecognizable specifically :-

G. 9581. Mutilated example of a species allied to T. granosus, Lamarck; Pliocene, Wanganui.

G. 9582. Small species having closely-set spiral sulci; Eocene, Trelissick.

G. 9589. Cast of a large species with depressed spire; Eocene, Oamaru.

G. 9595. Cast of a large species with elerated spire and flat base, the whorls are but slightly convex, and the ornament exceedingly simple; Miocene, Lake Lyndon, West Coast Road, Canterbury.

\section{Genus PHASIANELLA, Lamarck.}

[Ann. du Musée, t. iv. 1804, p. 295.]

Shell imperforate, not nacreous, oval or oblong, polished; aperture entire, oral, longer than broad, angulate in front; columella smooth, compressed, attenuated at the basc; outer margin simple, sharp.

Type.-Phasianella turbinoides, Lamarck.

\section{Phasianella australis, Gmelin.}

1788. Buccinum australis, Gmelin, Linn. Syst. Nat. p. 3490.

18ss. Phasianclla australis, Pilsbry, 'Tryon's Manual of Conchology, vol. $x$. p. 164, pl. xxxvii. figs. $22-8$; pl. xxxriii. fig. 46 . 
G. 5571. Imperfect specimen, probably referable to this species; callus rather thick on the inner margin of the aperture. PostPliocene: Limestone Creek, Glenelg river, Victoria. Purchased.

\section{Genus COLLONIA, Gray.}

[Guide Syst. Dist. Moll. 1857, p. 143.]

Shell globose, solid, not nacreous, smooth or spirally striated, narrowly but decply umbilicated; spire depressed or short; aperture circular, peristome thick, thinnest where it reposes on the penultimate whorl; umbilicus typically erenulate at the border and having a ridge iuteriorly.

Type.-Delphinula marginata, Lamarek.

Collonia parvula, Tenison-Woods (sp.).

1880. Crossea parvula, Tenison-Woods, Proc. Linn. Soc. N.S.W. vol. iv. p. 4 , pl. i. fig. 7 .

1893. Collonia parvula, Tate and Dennant, Trans. Roy. Soc. South Aust. vol. xvii. pt. 1, p. 223.

Shell depressed, whorls faintly spirally striated, having a morlerately wide umbilicus, which is simple; aperture circular, solid.

Dimensions.-Length $2 \mathrm{~mm}$; ; breadth $3 \mathrm{~mm}$.

Form. and Loc._Eocene: Muddy Creek, Victoria.

G. 9462. Sereral examples of the adult.

Purchased.

Family TROCHID无.

Genus TROCHUS, Linnæus.

[Syst. Nat. ed. 10, 1758, p. 756.]

Shell conical, spire elevated, whorls but slightly conrex and frequently flat; last whorl keeled or angulate; base concare, broad; aperture rhomboidal; onter margin sharp, very oblique; with a more or less deep, false umbilicus; columella twisted, 
terminated by a dentiform projection or a small plication; anterior of the columella, or basal border, often plicate or deitate.

Type.-Trochus niloticus, Linnæus.

\section{Subgenus ANTHORA, Gray.}

[Guide Syst. Dist. Moll. 1857, p. 148.]

False umbilicus shallow, carrying two costæ on the inside; columella oblique, with a small fold or dentiform plication posteriorly, otherwise simple.

Type.-Polydonta tuberculata, Gray.

\section{Trochus (Anthora) viridis, Gmelin.}

1790. Trochus viridis, Gmelin, Linu. Syst. Nat. ed. 13, p. 3572.

1843. Polydonta tuberculata, Gray, Dieffenbach, Travels in New Zealand, p. 239.

1852. Trochus acinosus, Gould, U.S. Expl. Exped. p. 179.

1854. Trochus fulvolabris, Hombron and Jacquinot, Yoy. au Pole Sud, Zool. t. v. p. 56, pl, xiv. figs. 14-16.

1855. Polydonta tritonis, A. Adams, Proc. Zool. Soc. p. 132.

1873. Trochus (Polydonta) tuberculatus, Von Martens, List. Moll. N.Z. p. 32 .

1873. Polydonta tuberculata, Hutton, Cat. Marine MIoll. N.Z. p. 36.

1880. Anthora tubcrculata, Hutton, Man. N.Z. Moll. p. 93.

1889. Trochus (Anthora) viridis, l'ilsbry, Tryou's Mauual of Conchology, vol. xi. p. 43 , pl. iii. figs. $16,17$.

1893. Trochus viridis, Hutton, Liun. Soc. N.S.W., Macleay Mem. Vol. p. 68 .

Shell conical, solid; whorls having five or six elosely-set rows of bold spiral granulations, the one nearest the suture postcriorly being rather larger than the others, which are approximately equal in size; base flat, coneave, spirally striated; aperture quadrate, nacreous; onter margin very oblique, lirate within; inner margin tuberculose; false umbilicus shallow, furnished with spiral ribs.

Dimensions.—Length $23 \mathrm{~mm}$; ; breadth $20 \mathrm{~mm}$.

Form. and Loc.-Post-Pliocene: Turangauui, Porerty Bay, New Zealand.

G. 9569. Two examples of the adult. Sir James Hictor Coll. 


\title{
Subgenus CELOTROCHUS, Fischer.
}

\author{
[Coq. Yiv. 1880, p. 417.]
}

False umbilicus deep and narrow; the columella is inserted to one side instead of in the centre of the axis of the shell.

Type.-Trochus tiaratus, Quoy and Gaimard.

\section{Trochus (Cœlotrochus) tiaratus, Quoy and Gaimard.}

1834. Trochus tiaratus, Quoy and Gaimard, Voy. de l'Astrolabe, Zool. t. iii. p. 256, pl. lxiv. figs. 6-11.

1835. Polyodonta elegans, Gray, Yate's Account of New Zealand, p. 309.

1846. Trochus delicutulus, Philippi, Zeitschr. für Malac. p. 105.

1873. Trochus (Polydonta) tiaratus, Von Martens, List. Moll. N.Z. p. 32.

1873. Polydonta tiarata, Hutton, Cat. Marine Moll. N.Z. p. 36.

1873. Polydonta tiaratu, Hutton, Cat. Tert. Moll. N.Z. p. 15.

1880. Anthora tiarata, Hutton, Man. N.Z. Moll. p. 94.

1880. Colotrochus tiaratus, Fischer, Coq. Viv. p. 417.

1889. Trochus (Colotrochus) tiaratus, Pilsbry, Tryon's Mannal of Conchology, vol. xi. p. 42 , pl. xii. figs. $72-4$.

1893. Trochus tiaratus, Hntton, Linn. Soc. N.S.W., Macleay Mem. Vol. p. 68 .

This well-known species differs from $T$. viridis in being broader, less granose, by having a deeply-cut suture, the base is less concave, and by the absence of small tubercles on the inner margin of the aperture. It is specially characterized by the nature of the false umbilicus, which is plain and deep; by the possession of a broad simple surface on and near the columellar border; by a rim and tootl-like thickening on the posterior of the inner margin; and by the comparatively flat base, which is spirally granulate.

Dimensions._Length $14 \mathrm{~mm}$.; breadth $15 \mathrm{~mm}$.

Form. and Loc.-Pliocene: Wanganui, New Zealand.

G. 9568. An example of the adult. Sir James Hector Coll.

\section{Trochus, sp.}

G. 9572. Cast of a new species, too imperfect for detailed description. The spire is much elerated; whorls distantly tuberculose; last whorl keeled; base flat. Eocene: Trelissick, New Zealand. 
G. 9571. Cast of a smaller species, with rounded base and plain whorls. Eocene: Trelissick, New Zealand.

\section{Sir James Hector Coll.}

\section{Genus CLANCULUS, Montfort.}

[Conch. Syst. t. ii. 1810, p. 191.]

Shell conical or turbinate, usually spirally granose both on the whorls and base; last whorl keeled or subangulate at the periphery; falsely umbilicate; aperture oblique; outer margin dentate or lirate within; inner margin with a dentiform fold posteriorly, and a prominent tooth in front.

Type.-Trochus pharaonicus, Linnæus.

\section{Clanculus variegatus, A. Adams.}

1851. Clanculus variegatus, A. Adams, Proc. Zool. Soc. p. 160.

1s78. Clanculus variegatus, Tenison-Woods, Pap. Roy. Soc. Tas. 1877, p. 40.

1880. Clanculus variegatus, Hutton, Man. X.Z. Moll. p. 95.

Shell depressed, conical; whorls ornamented with spiral rows of graules, last whorl acutely keeled at the periphery; base almost flat, spirally granulate; columella twisted posteriorly where it enter's obliquely one, side of the false umbilicus, margin crenulated, furnished with a biplicate prominent denticle anteriorly.

Dimensions.—Length $12 \mathrm{~mm}$; breadth $16 \mathrm{~mm}$.

Form. and Loc.-Post-Pliocene: Limestone Creek, Glenelg river, Victorii.

G. 5568. Four specimens of the adnit.

Purchased.

\section{Genus 'THALOTIA, Gray.}

[Proc. Zool. Soc. 1847, p. 145.]

Shell imperforate, elerated, conical, whorls spirally granulate or lineate; periphery of last whorl subangular; aperture orate; outer margin crenulate within, columella truncate, carrying a small denticle in front.

Type.-Trochus pictus, Gray. 


\section{Thalotia exigua, Tenison-Woods.}

1879. Thalotia exigua, Tenison-Woods, Proc. Linn. Soc. N.S.W. vol. iii. p. 235 , pl. xx. fig. 11.

1889. Thalotia exigua, Dennant, Trans. Roy. Soc. South Aust. vol. xi. p. 48.

Shell small, spire much elevated; whorls nearly flat, furnished with four or five rows of elosely-set spiral granulations; suture not well marked; last whorl subangulate at the periphery; base having numerous, small spiral threads; aperture nacreous, quadrate, flat in front; outer margin obliıjue; columella with a single dentiform fold.

It is closely allied to the living $T$. conica, Gray.

Dimensions.-Length $8 \mathrm{~mm}$.; breadth $5.5 \mathrm{~mm}$.

Form. and Loc.-Eocene: Muddy Creek, Victoria.

G. 9485. Three examples of the adult.

Purchased.

\section{Genus BANKIVIA (Beck), Krauss.}

[Die Suidafrikanischen Moll. 1848, p. 105.]

Shell imperforate, elongate, multiwhorled, conical, slightly nacreous; aperture small; columella twisted, truncate anteriorly. Type.-Bankivia varians, Beck.

\section{Bankivia fasciata, Menke.}

1830. Phasianella fasciata, Menke, Synops. Meth. Moll. p. 141.

1830. Phasianella fulminata, Menke, id. p. 141.

1830. Phasianella undatella, Menke, id.p. 141.

1848. Bankivia varians (Beck), Krauss, Die Südafrikanischen Moll. p. 105, pl. vi. fig. 1 .

1851. Bankivia purpurascens, A. Adams, Proc. Zool. Soc. p. 171.

185̃1. Bankivia major, A. Adams, id. p. 171.

1851. Bankivia nitida, A. Adams, id. p. 172.

1886. Trochus (Bankivia) fasciatus, Watson, Voy. "Challenger," Zool. Gasteropoda, vol. xv. p. 64.

1889. Cantharidus (Bankivia) fasciatus, Pilsbry, Tryon's Manual of Conchology, vol. xi. p. 139, pl. xl. figs. 28-33.

A very variable speeies, as the synonymy above quoted indicates. The columella of the specimens in the Museum collection is more excavated and much more strongly twisted 
than in typical examples. Traces of coloration remain; they consist of zigzag pink lines longitudinally displayed. The last whorl near the columella is spirally striated.

Dimensions. - Length $21 \mathrm{~mm}$.; breadth $8 \mathrm{~mm}$.; length of aperture $5.5 \mathrm{~mm}$.

Form. and Loc.-Post-Pliocene : Limestone Creek, Glenelg river, Victoria.

G. 5577. Four examples of the adult.

Purchased.

Genus LIOPYRGA, H. and A. Adams.

[Ann. Nag. Nat. Hist. 3rd ser. vol. xi. 1863, p. 19.]

Shell similar to Phasianella, nacreous, umbilicate, thin; aperture semicireular, shorter than the spire; columella excavated, eurved, frequently raised near the umbilicus.

Type.-Liopyrga picturata, H. and A. Adams.

\section{Liopyrga quadricingulata, Tate.}

1891. Leiopyrga quadrieingulata, Tate, Trans. Roy. Soc. South Aust. vol. xiv. p. 266.

Shell elongate, spire elevated; protoconeh turbinate, eomposed of two and a half smooth turns, the anterior portion being spirally striated and dereloping a deep suleus near the suture posteriorly; whorls slightly convex, spirally carinate, the carinæ being four, five, or rarely six in number, three or four of them posteriorly situated being separated from the most anterior keel by a broad, flat space; last whorl subangulate at the periphery, base spirally lineate; growth-lines undulating, very fine; aperture ovate, contracted behind, round but slightly produced in frout; outer margin thin; columellia twisted, produciug a small fold in front, elevated near the umbilicus, which is curred and narrow.

Dimensions. - Length $11.5 \mathrm{~mm}$; breadth $6 \mathrm{~mm}$; length of aperture $4.5 \mathrm{~mm}$.

Form. and Loc.-Miocene: Muddy Creek, Victoria.

G. 4175. Four examples of the adult.

Presented by John Dennant, Esq.

G. 9489. Several specimens of dirers stages of growth. 


\section{Genus ETHALIA, Adams.}

[Proc. Zool. Soc. 18503, p. 189.]

"Shell orbicular, turbinately depressed; whorls conrex, smooth, or transversely striatel, the last rounded at the periphery; umbilicus partly [or almost entirely] closed by a callous deposit; columellar lip ending anteriorly in au obtuse dilated callus." Pilsbry.

The restriction of this genus, as proposed by Mr. Pilsbry, ${ }^{1}$ is here adopted.

Type.-Umbonium guamense, Quoy and Gaimard.

\section{Ethalia zelandica.}

1853. Timbonium zelandicum, A. Adams, Proc. Zool. Soc. p. 189.

1854. Rotella zelandica, Hombron and Jacquinot, Toy. au Pole Sud, Zool. t. т. p. 53, pl. xiv. figs. 5, 6 .

1873. Rotella zelandica, Von Martens, List Moll. N.Z. p. 34.

1873. Rotella zealandica, Hutton, Cat. Marine Moll. N.Z. p. 35.

1873. Rotella zkalandica, Hutton, Cat. Tert. Moll. N.Z. p. 35.

1880. Rotella zealandica, Hutton, Man. N.Z. Moll. p. 92.

1890. Ethalia zelandica, Pilsbry, Tryon's Mannal of Couchology, vol. xi. p. 459 , pl. lviii. figs. $9,32,33$; pl. lix. fig. 66 .

1895. Rotclla neozelanica, Hutton, Linn. Soc. N.S.W., Macleay Mem. Tol. p. 68 .

Shell nacreous, orbicular, depressed; last whorl subangulate at the periphery, suture linear, growth-lines conspicuous, spiral striæ obsolete in fossil examples, except ou the base; umbilicus surrounded by a free, undulating area circumscribed by au irregular lineation, almost entirely filled with callus; inner margin of the aperture profoundly excarated, callous.

Dimensions.-Length $13 \mathrm{~mm}$.; breadth $21 \mathrm{~mm}$.

Furm. and Loc.-Pliocene: Wanganui, New Zealand.

G. 9604. A large series illustrating stages of growth.

Sir James Hector Coll.

1 Tryou's Manual of Conchology, rol. xi. 1889, pp. 15, 457. 


\section{Genus SOLARIELLA, S. Wood.}

[Ann. Mag. Nat. Hist. vol. ix. 1842, p. 531.]

Shell thin, nacreous, commonly and typically widely umbilicate, the umbilicus being keeled and crenulate on the margin; ornamented by spiral threads which are sometimes grauulate; aperture subangular.

Type.-Solariella maculata, S. Wood.

\section{Solariella strigata, Tenison-Woods (sp.).}

1879. Minolia strigata, Tenison-Woods, Proc. Liun. Soc. N.S.W. vol. iii. p. 235 , pl. xxi. fig. 7 .

1893. Eumargarita strigata, Tate and Deunant, Trans. Roy. Soc. South Aust. vol. xrii. pt. 1, p. 223 .

1894. Eumargarita (Solariella) strigata, Tate, Journ. Roy. Soc. X.S.W. rol. xxrii. p. 185.

Shell turbinate, nacreous, spire elevated, composed of fire or six convex whorls, which are flattened near the suture posteriorly, the flut area being bounded by a crenulated spiral cariua; beyond this are two other peripheral carinæ, and the whole surface of the whorls has smaller spiral threads, includiug the conrex base of the last whorl; aperture entire, subquadrate; umbilicus rery wide, spirally and longitudinally lineate, bordered by a sharply crenulate keel.

Dimensions.-Length $5 \mathrm{~mm}$.; breadth $7 \mathrm{~mm}$.

Form. and Loc.-Eocene: Muddy Creek, Victoria.

G. 4173. A series including various stages of growth.

G. 9466. Sereral examples. Presented by John Dennant, Esq. Purchased.

\section{Family DELPHINULID E.}

\section{Genus LIOTIA, Gray.}

[Proc. Zool. Soc. 184i, p. 145.]

Shell umbilicate, solid, globose or discoidal; whorls convex, ornamented by trellised elerations, or merely longitudiual ribs; 
aperture circular, peristome continuous, thick, with broad marginal expansions; umbilicus deep.

Type.-Delphimula cancellata, Gray.

\title{
Liotia roblini, Johnston.
}

\author{
[Plate VIII. Figs. 4a-c.]
}

1880. Liotia roblini, Johnston, Pap. Roy. Soc. Tas. 1879, p. 39.

1885. Liotia roblini, Tate, id. 1884, p. 211.

1893. Liotia roblini, Tate and Dennant, Trans. Roy. Soc. South Aust. vol. xvii. pt. I, p. 223.

Shell small, with depressed spire; whorls rounded, trellised, there being seven spiral threads on the penultimate whorl, including those which border the suture and the umbilicus, the interspaces being finely longitudinally striated, points of intersection of the longitudinal and spiral threads nodose; aperture circular; peristome continuous, very thick, especially the basal portion of the outer margin; umbilicus deep, trellised.

The shell is not solid, nor are the longitudinal ribs so large as in L. gervillei, Defrance, of the Paris Basin, to which it bears some resemblance.

Dimensions. - Length $5.5 \mathrm{~mm}$.; breadth $6.5 \mathrm{~mm}$.; length of aperture $2 \cdot 75 \mathrm{~mm}$.

Form, and Loc.-Eocene: Muddy Creek, Victoria.

G. 4301. Three examples of the neanic stage of growth.

Presented by John Dennant, Esq.

G. 9465. Series illustrating stages of growth.

Purchased.

Family HALIOTID王.

Genus HALIOTIS, Linnæus.

[Syst. Nat. ed. 10, 1858, p. 779.]

Shell oval or oblong, nacreous; spire small, much depressed, suture well marked; aperture with continuous borders; columellar borler broad, compressed, and arched; outer margin very oblique; 
muscular impression on the interior, subcentral and frequently rugose; typically perforated near the periphery, the holes being numerous and in series.

Type.-Haliotis tuberculata, Linnæus.

\section{Haliotis iris, Martyn.}

1784. Haliotis iris, Martyn, Univ. Conch. rol. ii. pl. lxi. 1873. Haliotis iris, Von Martens, List Moll. X.Z. p. 34. 1873. Haliotis iris, Hutton, Cat. Tert. Moll. N.Z. p. 16. 1880. Haliotis iris, Hutton, Man. N.Z. Moll. p. 104.

G. 9549. Imperfect internal east of a large Haliotis, no doubt referable to this specics. Miocene: Cape Rodney, North Island, New Zealand. Sir James Hector Coll.

\section{Haliotis nævosoides, M'Coy.}

1876. Halootis nevosoides, $\mathrm{MI}^{\circ} \mathrm{Co5}$, Prod. Pal. Vict. dec. iii. p. 27, pl. xxri. figs. 1-2a.

1878. Haliotis navosoides, R. Etheridge, jun., Cat. Aust. Foss. p. 164.

Shell suborbicular, depressed; spire composed of two and a half molerately prominent whorls; upper surface with numerous short irregularly undulating ridges in radiating series, spirally striated; perforations close together near the periphery.

Its congener, $M$. ovinoides, $\mathrm{M}$ ' $\mathrm{Coy}$, has more prominent radiating ridges on the surfice, but they are not undulating, and are larger near the distal end than in the middle. It is very closely allied to $\Pi$. narosoides, however, and the differences are chiefly made out by meaus of casts of each species.

Dimensions.-Maxiunum diameter of surface $36 \mathrm{~mm}$; minimum. diameter $29 \mathrm{1nm}$.

Form. and Loc.-Pliocene: Flemington, near Melbourne.

48837. Internal casts of three specimens; from Mayne's Quarry. Presented by Dr. J. E. Gray.

G. 1935. Casts of two examples of the adult. Puichased.

G. 9686, G. 9687. Sereral casts.

Tiansferred from the Mruseum of Practical Goology. 


\section{Haliotis mooraboolensis, $\mathrm{II}^{\prime} \mathrm{Coy}$.}

1876. Haliotis moorabootensis, $\mathbf{I}^{\circ} \mathrm{C}$ Coy, Prod. Pal. Vict. dec. iii. p. 25, pl. xxv. figs. $3-3 b$.

1878. Haliotis mooraboolensis, R. Etheridge, jun., Cat. Aust. Foss. p. 164.

This species differs from $I T$. navosoides, principally in being less corrugated on the surface, the radiating ridges being absent, spiral sulci or ribs being more prominent, regular, and erenly disposed orer the whole surface; the shell is much larger, whilst the numerous apertures are placed nearer the periphery.

It is allied to $I$. scabricosta and $H$. roei, living in Australian waters.

Dimensions.-Maximum diameter of surface $58 \mathrm{~mm}$.; minimum diameter $45 \mathrm{~mm}$.

Form. and Loc.-Miocene: (? locality), Victoria.

G. 1934. Internal cast of specimen having much depressed spire, and the perforations are not so near the periphery as in the specimen figured by Sir F. M'Coy.

Purchased.

\section{Family PLEUROTOMARIID A.}

\section{Genus PLEUROTOMARIA, J. Sowerby.}

[Min. Conch. vol. iii. 1821, p. 139.]

Dr. Dall ${ }^{1}$ has shown that the name Pleurotomaria should be attributed to James Sowerby, and not to Defrance, to whom it is usually assigned by anthors.

Type.-Trochus gibsi, Sowerby.

\section{Pleurotomaria, sp.}

G. 9667. Example, 3 inches in length and $5 \frac{1}{4}$ inches in breadth, of a species that may be attributed to this genus. The greater part of it, however, is merely an internal cast, and the remains of the shell are too imperfect for detailed description. The comparatively uncrushed shell of the earliex whorls exhibits the characteristic filled sinus. From the Tertiary of Ardrossan, Yorke's Peninsula, South Australia. II. I. L. Brown Coll.

1 Bull. Museum Comp. Zool. Harvard, rol. xviii. 1889, p. 396.] 


\section{Family FISSURELLIDE.}

\section{Genus FISSURELLIDEA, D'Orbigny.}

[Toy. Amérique Méridionale, t. v. 1841, p. 477.]

Shell oral, somewhat depressed, surface not rugose; apical perforation immense, orate, subcentral, and haring a thickened border internally.

Type.-Fissurellidea megatrema, D'Orbigny.

Fissurellidea malleata, Tate.

[Plate VIII. Figs. 5a-c.]

1852. Fissurellidea malleata, Tate, Trans. Roy. Soe. South Aust. vol. v. p. 46.

1893. Fissurellidea malleata, Tate and Dennant, id. vol. xrii. pt. 1, p. 223.

Shell patelliform, ovate, contracted at one end; surface ornamented by conspicuous, concentric growth-lines and encircling punctures, these latter being rers small, close together, and regular, each one being almost square; border smooth; apical perforation oval, very large, thickly bordered internally; interior scored by encircling muscular attachments and roughened by ridges radiating from the apical perforation.

'This species does not appear to have been figured hitherto.

Dimensions.-Length $30 \mathrm{~mm}$.; breadth $19 \mathrm{~mm}$.; length of apical perforation $7 \mathrm{~mm}$.

Form, and Loc.-Eocene: Muddy Creek, Victoria.

G. 4225. Specimen in which the radiating ridges on the interior are obsolete, and the apical perforation is relatively broader than in the type. Presented by John Dennant, Esq.

G. 5539. Example of the adult, shell much thickened and corrugated internally.

Purchased.

G. 9468. Example of the neanic stage of growth. Purchased.

\section{Fissurellidea, sp.}

G. 4226. Example of a new species, much rolled and too imperfect for detailed description; it is narrower than $F$. malleata. From the Miocene (?) of Muddy Creek, Tictoria. 


\section{Genus EMARGINULA, Lamarek.}

[Syst. Anim. sans Vert. 1801, p. 69.]

Shell more or less conoidal, no septum in the interior; apex not absorbed; a slit or fissure in front, preceded by an elerated band, which differs in ornamentation from the other radiating longitudinal ribs.

Type.-Patella fissura, Linnæus.

Emarginula striatula, Quoy and Gaimard.

1834. Emarginula striatula, Quoy and Gaimard, Voy. de l'Astrolabe, Zool. t. iii. p. 332, pl. lxviii. figs. 21, 22 (non Sowerby).

1873. Emarginula striatula, Von Martens, List Moll. N.Z. p. 34.

1873. Emargimla striatula, Hutton, Cat. Tert. Moll. N.Z. p. 16.

1880. Emargimula striatula, Iutton, Man. N.Z. Moll. p. 106.

1893. Emarginula striatula, Hntton, Linn. Soc. N.S.W., Macleay Mem. Vol. p. 72 .

Shell conical, thin, apex oblique, recurved; radiating longitudinal ribs close together, granulate; spiral ridges of growth prominent, irregular, producing with the ribs subcancellation; margin crenulated; fissure broad and of medium length.

Dimensions. - Height $11.5 \mathrm{~mm}$.; maximum breadth of base $19 \mathrm{~mm}$.; minimum breadth $15 \mathrm{~mm}$.

Form. and Loc.-Pliocene: New Zealand.

G. 463. A specimen of the adult, having rather depressed spire; from Wanganui. Presented by Lieut.-Col. L. W. Wilmer.

G. 9593. Two examples, one of the gerontic stage; Shakespeare Cliff.

Sir James IIector Coll.

Emarginula wannonensis, sp. nov.

[Plate VIII. Figs. 6a-c.]

Shell conical, much elevated, apex oblique, recurved, marginal ; radiating longitudinal ribs in two series, one series being large, standing out well from the surface of the shell and haring 
closely-set compressed transrerse granulations; and the other scries being smaller, each rib alternating with those of the larger scries, these also are granulate, and are transversely scaly, the latter ornament being due to small transverse ribs crossing them; lines of growth lead to slight rugosities on the surface; margin crenulated, the anterior and posterior portions are produced, the middle slightly excavated; fissure very short, but broad.

It is of the same group as $E$. striatula, but the apex of the latter is not so near the margin, and the margins of the New Zealand shell are not so much excavated in the middle, whilst the surface ornamentation is different.

Dimensions. - Height $12 \mathrm{~mm}$. ; maximum brealth of base $16 \mathrm{~mm}$.; minimum breadth $12.5 \mathrm{~mm}$.; leugth of fissure $2 \mathrm{~mm}$.

Form. and Loc.-Eocene (?): Muddy Creek, Victoria.

G. 4167. The type specimen. Presented by John Dennant, Esq.

\section{Genus SUBEMARGINULA, Blainville.}

[Manuel de Malacologie, 1825, p. 501.]

Memitoma, Swainson, Malacology, 1840, p. 356.

Shell oral, conical, apex subcentral, directed posteriorly; surface radiately ribbed; anal fissure when present, short; continued upwards as a groove in the interior, the rib formed as the slit fills, with growth, is not differently ornamented to the other ribs; large muscle-scar in the interior, the ends of which are curred inwards towards the carity of the apex.

Type._Emarginula emarginata, Blainville.

\section{Subgenus TUGALIA, Gray.}

[Guide Syst. dist. Moll. 1557, p. 163.]

Sleell trpically elongate oblong, depressed, apex situated nearer the posterior margin; the anterior margin has no notch, fissure, nor slit, and there is no internal anal groore.

Type._Tiugalia elegans, Gray. 


\title{
Subemarginula (Tugalia) parmophoidea, Quoy and Gaimard.
}

1834. Emarginula parmophoidea, Quoy and Gaimard, Voy. de l'Astrolabe, Zool. t. iii. p. 325, pl. lxviii. figs. 15, 16.

1851. Tugalia parmophoroidea, A. Adams, Proc. Zool. Soc. p. 89.

1573. Tugali elegans, Hutton, Cat. Tert. Moll. N.Z. p. 16.

1880. Tugalia parmophoiden, Hutton, Man. N.Z. Moll. p. 106.

1891. Subemarginula (Tugatia) parmophoidea, Pilsbry, Tryon's Manual of Conchology, vol. xii. p. 285, pl. xlïi. figs. 78-80.

1593. Subemurginula parmophoida, Hutton, Linn. Soc. N.S.W., Macleay Mem. Vol. p. 72.

Shell oval, rounded at the ends, apex near the margin; close radiating and transverse ribbings of about equal size, though occasional smaller ones occur between, granulated and cancellated; margin arcuate, denticulate; "fissure" a mere sinuation of the margin, no internal sulcus.

Dimensions. - Height $6.5 \mathrm{~mm}$; maximum breadth of base $19 \mathrm{~mm}$.; minimum breadth $12 \mathrm{~mm}$.

Form. and Loc.-Pliocene: Shakespeare Cliff, New Zealand.

G. 9590. Two examples of the adult. Sir James Hlector Coll.

\section{Class SCAPHOPODA.}

\author{
Family DENTALIID \&.
}

\section{Genus DENTALIUM, Linnæus.}

[Syst. Nat. ed. 10, 1758, p. 785.]

Enlalis, Gray, Proc. Zool. Soc. 1847, p. 158; non Defrance, 1819 , nec G. B. Sowerby, 1839.

Entaliopsis, Newton and Harris, Proc. Malac. Soc. Lond. vol. i. 1894, p. 66.

It has been customary for many years past for authors to regard as genera and subgenera forms having the general characters of Dentulium (sensu strieto), but differing from it in possessing peculiar phenomena at the posterior orifice, and in the presence or abseuce of sculpture externally. Thus Entalis, Gray, was 
made to include those forms having a short, broad fissure at the posterior extremity in addition to being practically smooth. In Fistiaria, Stoliczka, the shell is also smooth, but the posterior extremity is furnished with a long linear slit. Lavidentalium, Cossmann, ${ }^{2}$ has a smooth surface, marked only by faint lines of growth; it has no posterior fissure, and is oval in section. In Schizodentalium, G. B. Sowerby, ${ }^{3}$ there are a number of small longitudinal slits in line with each other in the place usually occupied by the long posterior fissure, when that is present. In other words, the longitudinal slit is bridged over here and there. Lobantale, Cossmann, ${ }^{4}$ appears to be very different to other allies of Dentalium in being compressed, smooth, and carrying two lateral ribs in the interior of the shell.

Now, the type of the genus Dentalium is described by authors as having a truncated posterior orifice, without a noteh or slit. In a rerision of the British Eocene Scaphopoda, Mr. R. Bullen Newton, F.G.S., and the present writer ${ }^{5}$ agreed with those authors after examining typical specimens in the British Musenm, and allowed the absence of a notch to mark the difference between it and Entalis, Gray. The latter name being preoccupied, as will be noticed in the synonymy above given, we proposed a new one, Entaliopsis. Subsequently, howerer, we noted some undoubted specimens of the type species in the British Musem which were furnished with a small but well-marked notch. It became apparent that indiriduals of that species may or may not possess a notch. The question then arose as to whether the absence of a notch was due to mutilation of the shell, or was brought about by the repairs continually carried out by the animal. In this connection the observations of Professor Dall may be of service. He remarks ${ }^{6}$ that "species (of Dentalium) with very thin shells usually live buried in soft mud, which measurably protects them, but others with heary shells appear to be more rersatile; at all events, if the small end of the

1 Cretaceous Gastropoda, Mem. Geol. Surr. India, 1868, p. 439.

2 Aun. Soc. Roy. Malac. Belg. vol. xxiii. 1888, p. 7.

3 Proc. Malac. Sure. Loud. vol. i. 1894, p. 158.

+ Aun. Suc. Rog. Malac. Belg. rol, xxiii. 18s8, p. 7.

5 Proe. Malac. Soc. Lond. vol. i. 1894, p. 63.

6 Trans. Warner Free Iust. Ści. Philad, vol. iii. pt. 2, 1892, p. 436. 
shell is accidentally broken off, the animal can repair it, and in species which hare a simply tubular mantle and a thick shell the repairs take the shape of a small tube projecting from the blunt end of the large one, as it is impossible for the mantle to secrete a shell which is as large and thick as the original at the point of truncation." From this it is obvious that in such a thick shell as is possessed by the typical species of Dentalium, a small portion of the posterior orifice having been, by accident, broken off, it wonld not be within the animal's power to rehabilitate it in its entirety.

On the other hand, the possibility of the small notches on the typical specimens having been produced, not by any modification in the mantle of the animal, but by erosion, should be considered. It is well known that erosion, especially in specimens from reep water, modifies and sometimes imitates such slits. As Professor Dall observes," there "seems to be a peculiarity of some kind in the external prismatic layer of Dentalium, which lends itself to the propagation of erosion in longitudinal lines very much more effectirely than at right angles to such lines."

In regard to the systematic value to be attached to the notch, slit, or fissure, it may be remarked that these variations depend upon the shape of the edge of the mantle, which is an extremely contractile membrane, capable of secreting shelly matter. When the shell is quite perfect, the posterior end reflects the form of the membrane which secreted it. There ean be no doubt whatever that the leugth of the slit varies in individuals of the same species, apart from any appearance produced by erosion. It cannot, however, be asserted that a mere notch could by iuclividual peculiarity be elongated to such a length as obtains in typical specimens of Fustiaria. So that it may now be admitted that the presence or absence or length (within certain limits) of the slit is not of generic, nor even subgeneric importance, but it may with other characters be of specific value. In any case it seems desirable that Entaliopsis (=Entalis) shonld be regarded as a synonym of Dentalium; the sole difference between them, as now shown, being merely one of external ornament. In this Mr. R. Bullen Newton fully concurs with the present writer.

Type.-Dentalium elephantinum, Linnæus. 


\section{Dentalium aratum, Tate.}

1887. Dentalium aratum, Tate, Trans. Roy. Soc. Sonth Aust. vol. ix. p. 192, pl. xx. fig. 8 .

1893. Dentalium aratum, Tate and Deunant, id. vol. xvii. pt. 1, p. 223.

1895. Dentalium aratum, Tate and Dennant, id. vol. xix. pt. 1, p. 112.

Shell small, slightly curved, furnished with seven or eight bold longitudinal ribs, between which are several minute longitudinal strix crossed by conspicuous lines of growth.

This species was, apparently, withont a posterior fissure, and would be regarded as a typical Dentalium. Although small, the shell is solid, and forms no exception to the rule that solidarity is accompanied by frequent repairs to the shell. When broken, it will be seen that the hard internal layer tends to form a tube, which would probably lead some authors to classify it with the genus Antale; but, as previously remarked, such tube is of little or no systematic value.

Dimensions. - Length $22 \mathrm{~mm}$; width of anterior aperture $2.5 \mathrm{~mm}$. Form. and Loc.-Eocene: Muddy Creek, Victoria.

G. 9386 . Several specimens.

Purchased.

\section{Dentalium mantelli, Zittel.}

1850. Dentalium, sp. nov., Mantell, Quart. Journ. Geol. Soc. rol. vi. p. 331, pl. xxriii. fig. 15 .

1865. Dentalium mantelli, Zittel, Reise der Novara, Paläontologie, Bd. i. Abth. ii. p. 45 , taf. xiii. fig. 7.

1873. Dentalium mantelli, Hutton, Cat. Tert. Moll. N.Z. p. 1.

1873. Dentalium tenuis, Hutton, id. p. 1.

1873. Dentalium irregularis, IIntton, id. p. 1.

1876. Dentalium kicksii, Temison-Woods, Pap. Roy. Soc. Tas. 1875, p. 15 (non Nyst. 18t3).

1878. Dentalium kickii, R. Etheridge, jun., Cat. Anst. Foss. p. 162.

1887. Entalis mantelli, Tate, Trans. Roy. Soc. South Aust. vol. ix. p. 190.

1893. Entalis mantelli, Tate and Dennant, id. vol. xvii. pt. 1, p. 223.

1895. Entalis mantelli, Tate and Dennant, $i d$. vol. xix. pt. 1, p. 112.

1896. Entalis mantelli, Pritchard, Proc. Roy. Soc. Vict. vol. viii. x.s. p. 126.

This species differs from $D$. aratum in being larger, haring more numerous longitudinal costæ of variable size, crossed by frequent aud conspicnous lines of growth, and especially by the possession of a rather long and wide posterior fissure. This is a common species in the older Tertiary of Australasia. 
Dimensions.-Length $53 \mathrm{~mm}$.; width of anterior aperture $7 \mathrm{~mm}$. Form. and Loc. - Eocene and Miocene: Australia and New Zealand.

48052. Sereral examples; from Hobson's Bay. Purchased.

73219. A series of specimens showing variability of the external ornament; from Brighton, Victoria. Purchased.

G. 4283. Three examples of the adult; from Muddy Creek. Presented by John Dennant, Esq.

G. 9140. A rariation in which the longitudinal costæ are closer together than in typical specimens; from Rirer Murray cliffs.

Presented by $\Pi$ m. Evans, Esq.

G. 938\%. Four examples of the adult, exhibiting minor variations in external sculpture and in the proportional width of the anterior aperture; from Muddy Creek.

Purchased.

G. 10253. Haring lines of growth rather oblique, and producing slight granulation at the points of intersection with the longitudinal costæ; from the "Conus-beds," Mokihinui. Sir James Hector Coll.

G. 10254. Examples of the neanic stage of growth, in a block of shelly argillaceous limestone; from Duncan's, New Zealand.

Sir James Hector Coll.

G. 10258. Specimen having broad and prominent longitudinal costæ, probably the $D$. irregularis of Hutton; from Awamoa.

Sir James Hector Coll.

G. 10260. Sereral specimens of the adult; from Onekakara.

[Old Collection.]

Dentalium giganteum, G. B. Sowerby.

1846. Dentalium giganteum, G. B. Sowerby, in Darwin, Geol. Obs. etc,, South America, p. 263, pl. ii. fig. 1.

1873. Dentalium solidum, Hutton, Cat. Tert. Moll. X.Z. p. 2.

Shell large, nearly straight, solid, longitudinal sulci numerous, the interstices being rounded; in many specimens the annular striæ of growth are undulating, whilst encircling ridges are not infrequent; none of the specimens exhibit a posterior fissure.

D. solidum, Hutton, appears to differ from the present species in having more numerous longitudinal sulci, which, howerer, 
is hardly a specific characteristic. D. giganteum is closely related to D. mantelli, but the tessellated ornament of the latter, amongst other things, is highly distinctive.

Dimensions. - Length $109 \mathrm{~mm}$.; width of anterior aperture $12 \mathrm{~mm}$.

Form. and Loc.-Miocene and Pliocene: New Zealand.

G. 10251. Many examples imbedded in blocks of argillaceous shelly limestone; from Akuakua, east coast of Auckland.

Sir James Hector Coll.

G. 10256. Two fragments; from Kanieri, South Island.

Sir James Hector Coll.

G. 10257. Specimen constricted at irregular intervals; from Hick's Bay.

Sir James Hector Coll.

G. 10259. An example of the adult haring elosely-set longitudiual sulci and ridges; from Parimoa. W. B. D. Mantell Coll.

\section{Dentalium bifrons, Tate.}

1857. Dentalium bifrons, Tate, Trans. Roy. Soc. South Aust. vol. ix. p. 192, pl. xx. fig. $\tilde{\text { o. }}$

1S93. Dentalium bifrons, Tate and Dennant, id. vol. xrii. pt. 1, p. 223.

Shell large, but slightly eurved, longitudinally ribbed or striated at the posterior end, smooth at the anterior; the striæ are small and close together, and gradually die out at about one-third the length of the shell, where annular rings of growth become a marked feature, and obtain to the anterior aperture. The posterior fissure, which does not appear to hare been known to Professor Tate, is sereral millimetres in length and twisted, running obliquely with reference to the longitudinal costre alluded to.

The ornament of the striated portion is not tessellated as in D. mantelli; whilst the posterior end of $D$. annulatum, Tate, with which this species is related, is not costate, and the shell is narrower anteriorly.

Dimensions.-Length $74 \mathrm{~mm}$.; width of anterior aperture $8 \mathrm{~mm}$. Form. and Loc.-Miocene: Muddy Creek, Victoria.

G. 4282. Three examples, one having a nearly perfect apex, with clearly-marked fissure.

Presented by John Dennant, Esq. 


\section{Dentalium subfissura, Tate (sp.).}

1887. Entalis subfissura, Tate, Trans. Roy. Soc. South Aust. vol. ix. p. 191, pl. xx. figs. $4 a-b$.

1893. Entalis subfissura, Tate and Dennant, id. vol. xvii. pt. 1, p. 223.

1895. Entalis subfissura, Tate and Dennant, id. vol. xix. pt. 1, p. 112.

The shell of this species is smooth and polished, but possesses almost obsolete annular striæ with more prominent lines of growth. The posterior fissure is a triangular notch, the sides of which are slightly reflected outwardly. It may be easily differentiated from $D$. fissura, Lamarck, of the Paris Basin, with which the author compares it, in that the fissure in the European species is much longer.

Dimensions.-Length $45 \mathrm{~mm}$.; width of anterior aperture $4 \mathrm{~mm}$. Form. and Loc.-Eocene: Victoria.

48052. Two examples of the adult; from Hobson's Bay.

Purchased.

G. 9389. Two specimens, one of which is sharply curred near the posterior end; from Muddy Creek. Purchased.

\section{Dentalium acriculum, Tate (sp.).}

1887. Entalis acriculum, Tate, Trans. Roy. Soc. South Aust. vol. ix. p. 192, pl. $x x$. fig. 11 .

This species very closely approaches $D$. fissura, Lamarck, of the European Eocene, differing from it principally in not having such a long fissure, in the latter being slightly twisted and enlarged anteriorly, and in the shell being annularly constricted at irregular intervals. It is narrower and not so much curved as D. subfissura, whilst its fissure is not triangular, but linear; otherwise the two species are closely allied to each other.

Dimensions. - Length $33 \mathrm{~mm}$.; width of anterior aperture $2.5 \mathrm{~mm}$.

Form. and Loc.-Eocene: Muddy Creek, Victoria.

G. 9388. Series illustrating stages of growth.

Purchased. 


\section{Dentalium lævis, Hutton.}

1873. Dentalium levis, Hutton, Cat. Tert. Moll. N.Z. p. 2.

"Small; slightly curved, tapering slowly; smooth, with fine distant longitudinal lines."-IItton.

G. 10252. Fragment probably referable to this species, in micaceous, argillaceous, friable sandstone; Miocene, Port Hills, Nelson, New Zealand.

Sir James Ilector Coll.

G. 10255. Several fragments, too imperfect to enable the writer to figure and clescribe the species; Miocene, Kanieri, South Island, New Zealand.

Sir James Hector Coll.

\section{Genus CADULUS, Philippi.}

[Enum. Moll. Siciliæ, vol. ii. 1844, p. 209.]

The following species is referred to Cadulus with all reserve. It is practically inmossible to distinguish between that genus and Siphonodentalium with the shell alone. Authors have placed some reliance on the nature of the margin of the posterior orifice; but Dall has shown ${ }^{1}$ that the anal orifice of the shell may be wared or simple on its margin in different specimens of the same species; and Fischer has called attention ${ }^{2}$ to the fact that those which have the margin interrupted by several slits, or notches, exhibit considerable variation in the details. Howerer, if it is admitted that on the whole the shell of Cadulus should be short, inflated medially, and thickened internally towards the posterior orifice, which is crenulated, the Australian species about to be described may be assigned to that genus.

Type.-Cadulus orulum, Philippi.

\section{Cadulus mucronatus, Tate.}

1887. Cadulus mucronatus, Tate, Trans. Roy. Soc. South Aust. vol. ix. p. 193, pl. xx. fig. 10.

1893. Cadulus mucronatus, Tate and Dennant, id. vol. xvii. pt. 1, p. 223.

1 Trans. Wragner Free Inst. Sci. Philad. rol. iii. pt. 2, 1892, p. 443.

2 Manuel Conchyl. 1585, p. $\$ 95$. 
It is impossible to recognize this species from the caricature given on the plate above referred to; but Professor Tate describes it so minutely that the figure may almost be dispensed with. $\mathrm{He}$ remarks that the shell is "long, narrow, slightly bent; slightly swollen at a little nearer the anterior than the posterior end, more conspicuously so on the convex curve, which is a little nearer to the posterior end than is the bulging on the concare curve. Anterior to the inflation the tube is slightly laterally compressed. The month is slightly oblique, oval, with a thin and sharp edge; the posterior opening is round, thickened within, and bevelled to a sharp edge, inconspicuously mucronately produced on the convex side, corresponding with a faint internal rib, and slightly insinuated latcrally. Surface smooth, polished, microscopically concentrically striated, and with faint indications of opaque transverse bands."

Dimensions.-Length $7 \mathrm{~mm}$.; width of median inflation $1.75 \mathrm{~mm}$. Form. and Loc.-Eoccne: Nuddy Creek, Victoria.

G. 9390. Several examples of the aclult.

Purchased.

\section{Class LAMELLIBRANCHIATA.}

\section{Order TETRABRANCHIA.}

Family OSTREID E.

Genus OSTREA, Limnus.

[Syst. Nat. ed. 10, 1758, p. 696.]

Shell irregular in shape, attached by the left valve, which is the larger and the more convex; right valre usually flat or concave, often smooth, and minus the radiating ridges which are usually so conspicuous on the other ralve; lines or corrugations of growth prominent on botly valves; ligamental area triangular or elongate, symmetrical; structure laminated, subnacreous; musclescars large, well prononnecd, subcentral.

Type.-Ostrea edulis, Linnæus. 


\section{Ostrea hyotis, Linnæus.}

1758. Mytilus hyotis, Linnaxus, Syst. Nat. ed. 10, p. 704.

1870. Ostrea hyotis, Reeve, Conch. Icon. vol. xriii. pl. iv. fig. 7.

1886. Ostrea hyotis, Tate, Trans. Roy. Soc. South Aust. vol. viii. p. 96, pl. vi. fig. 5.

1889. Ostrea hyotis, Dennant, id. vol. xi. p. 49.

Shell subquadrate, solid, typical examples having tube-shaped spines upon large folds. As Professor Tute remarks, the fossil specimens rarely exhibit tubular spines; but the general contour of the shell (which, howerer, is extremely variable in regard to details) is that of the living O. hyotis, and it has the characteristic foliaceous sciles of that species.

Dimensions.-Height $112 \mathrm{~mm}$; ; length $97 \mathrm{~mm}$.

Form. and Loc.-Eocene: South Australia and Victoria.

48803. Left valre showing traces of tubules; River Murray clift's.

Presented by Commodore Goodenough, R.N.

L. 6581. Two left ralves, with foliaceous plates, which are not spiuose; from Muddy Creek. Purchased.

L. 10524. Two imperfect left valres, probably referable to this species; from Nullarbor Plains.

II. Y. L. Brown Coll.

I. 10525. Large left valve, not spinose, which is doubtfully referred to 0 . hyotis; from River Murray cliffs.

Transforred from the Museum of Practical Geology.

Ostrea sturtiana, Tate.

1S86. Ostrea sturtiana, Tate, Trans. Roy. Soe. South Aust. vol. viii. p. 97, pl. vi. fig. 1.

The only specimen in the Mnseum collection which approximates 0 . sturtiana is so very much larger than that indicated by Professor Tate, that the writer has some diffidence in assiguing it to that species. But in other respects it agrees so closely with the diagnosis given by the author, and the figure accompanying it, that for the present it may be regarded as a local rariation, characterized chiefly by the immense size of the shell. The specimen in question is moderately excarated interiorly, whilst ou the extcrior it is broadly and roughly rilged, and is scaly; the 
hinge is narrow for the size of the shell, and is deeply and broadly channelled in the middle; muscular impression large and deep.

'The author compares it with some varieties of the living o. edulis, Linnæus.

Dimensions.-Height $172 \mathrm{~mm}$.; length $125 \mathrm{~mm}$; thickness of left valve $47 \mathrm{~mm}$.

Form. and Loc.-Eocene (?): Bairnsdale, Gippsland, Victoria.

L. 5146. Left valve of the adult.

Purchased.

\section{Ostrea arenicola, Tate.}

18S6. Ostrea arenicola, Tate, Trans. Roy. Soc. South Aust. vol. viii. p. 97 , pl. x. fig. 6 .

Shell large, elongately ovate, slightly oblique, and produced anteriorly ; umbones depressed, bent forward. Left valve usually attached in the neighbourhood of the umbo ; radial ridges irregular, broad, and undulating throughout their length; lamellar plates frequent. Right valve flat or but slightly concave, except by contraction in senile individuals; growth-lines prominent.

It differs from the living $O$. angasi in having the umbones depressed and directed forward, whilst the left valve is more costate.

Dimensions.-Height $119 \mathrm{~mm}$. ; length $95 \mathrm{~mm}$.

Form. and Loc.-Eocene (?): South Australia.

42698. Double-valsed specimen, the scar of attachment being small; from near Adelaile. Presented by M. Marshall, Esq.

L. 10523. Examples of the senile stage, larger than that indicated by Professor Tate; from Willunga, near Adelaide. II. I. L. Brown Coll.

\section{Ostrea manubriata, Tate.}

1887. Ostrea manubriata, Tate, Trans. Roy. Soc. South Aust. vol. ix. p. 184, pl. six. fig. 10.

1889. Ostrea manubriata, Dennant, id. vol. xi. p. 49.

This species is more elongate than either of the preceding, and the left valve is a great deal larger than the right; binge frequently one-third the length of the shell in the left valre, 
broadly excarated in the middle, whilst it is so disposed as to bridge over a conical carity; muscle-marks elongate, excentric; external ornament consisting of irregular undulating ridges of growth.

The author compares it with 0 . undata of the European Tertiary, which it closely resembles.

Dimensions.-Height $52 \mathrm{~mm}$.; length $26 \mathrm{~mm}$.

Form. and Loc.-Miocene: Muddy Creek, Victoria.

L. 6582. Examples of both valves.

Purchased.

L. 9832. Sereral specimens of the adult, both ralres. Purchased.

\section{Ostrea nelsoniana(?), Zittel.}

1865. Ostrea nelsoniana, Zittel, Reise der Novara, Paläontologie, Bd. i. Abth. ii. p. 55 , taf. xi. fig. 7 .

1873. Ostrea nelsoniana, II utton, Cat. Tert. Moll. X.Z. p. 34.

Shell elongate, ovate, solid. Left valve convex, irregular, thickened, growth-lines laminated. Right valre flat, frequently thick, growth-lines rugose. Umbones oblique, hinge broad, furrowed; pit triangular ; muscular impression large, lunate.

None of the specimens in the Museum collection are exactly like that figured by Professor Zittel, but they possibly come within the permissible range of rariation. They appear to be more closely related to $O$. nclsoniana than to any other New Zealand Ostrea.

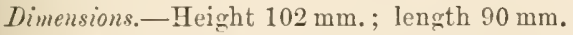

Form. and Loc.-Miocene: New Zealand.

L. 10517. Examples of both ralres, of a rather elongate rariation; from the upper end of Manawatu Gorge.

Sir James Hector Coll.

L. 10519. Complete specimen, left ralre rery conrex, orate; from IIassacre Bay.

Transferred from the Muserm of Practical Geology.

\section{Ostrea wullerstorfi, Zittel.}

1865. Ostrea wullestonfi, Zittel, Reise der Novara, Paläontologie, Bd. i. Abth. ii. p. 54, tat. xi. fig. 6 .

1873. Ostrea wullerstorfii, IIutton, Cat. Tert. MIoll. X.Z. p. 34.

Slell orbicular, flat, large. Left valre slightly convex, radially 
rugosely rilged, growth-lines distant, except near the ventral margin in the adult; hinge small, triangular, transversely striated. Right valve flat, almost the same size as the left; concentric growth-lines distant.

Dimensions.-Height $80 \mathrm{~mm}$.; length $82 \mathrm{~mm}$.

Form. and Loc.-Wiocene: Napier, New Zealand.

L. 10518. Several perfect, double-valred examples.

Sir James Hector Coll.

\section{Ostrea, sp.}

42682. Imperfect left valve of a new species, closely radially ricged on the exterior and interrupted by frequent irregular growthlines, anterior margin serrate; from the 'Tertiary of (locality ?) Sonth Australia. Presented by the Governors of Adelaide Muserm.

L. 348. Right and left valves of young Ostrea, indeterminable; from the Tertiary of Bairnsdale, Victoria.

Presented by $W$. H. Grigson, Esq.

L. 1052\%. Large specimen of Ostrea, allied to $O$. arenicola, Tute; Miocene (?), Parimoa, New Zealand. W. B. D. Mantell Coll.

\section{Genus GRYPH王A, Lamarck.}

[Syst. Anim. sans Vert. 1801, p. 398.]

Valves of unequal length, the left often free in the adult; umbo of left valve incurred, often oblique; right valve flat or concare, short.

Type.-Gryphea angulata, Lamarck.

\section{Gryphæa tarda, Hutton.}

1873. Giyphea tarda, Hutton, Cat. Tert. Moll. N.Z. p. 35.

1886. Gryphea tarda, Tate, Trans. Roy. Soc. South Aust. vol. viii. p. 98, pl. vi. figs, $2 a-b$.

Shell irregular in outline, general form ovate; umbo of left valve curved inwards and bent forward; right valve rather concave and much smaller than the other. Hutton says: "Area broad, triangular, distinctly transversely striated; musenlar impression 
sub-orbicular, rather flattened above, where it is deeply sunken, posterior plaeed high up."

It is not without some hesitation that the specimens in the Mruseum are assigned to this genus, their state of preservation being such that many of the essential eharacters eannot be satisfactorily made out. In the absence of more perfeet material these South Australian fossils may, however, be provisionally ideutified with $G$. tarda.

Dimensions (as given by Professor Tate, op. cit.).-—"Inferior ralre, height $45 \mathrm{~mm}$.; breadth $32 \mathrm{~mm}$.; thiekness $23 \mathrm{~mm} . "$

Form. and Loc.-Tertiary: Nullarbor Plains, Sonth Australia.

L. 10524. Several imperfect examples of the left valve. II. Y. L. Brown Coll.

L. 10526. Left valve of the adult. II. Y. L. Brown Coll.

Family ANOJIID E.

Genus PLACUNANOIMIA, Broderip.

[Proc. Zool. Soc. 1832, p. 28.]

One ralce earries two tangential museular impressions towards the eentre, the upper one appertaining to the musele of the byssus, the lower to the adduetor of the ralves; opposing valve perforated.

Type.-Placunanomia cumingii, Broderip.

\section{Placunanomia ione, Gray.}

1849. Placunanomia ione, Gray, Proc. Zool. Soc. p. 123.

1873. Placunanomia ione, Hutton, Cat. Marine Moll. N.Z. p. 84.

18s0. Placunanomia ione, Hutton, Mau. N.Z. Moll. p. I7t.

1856. Placunanomia ione, Tate, Trans. Roy. Soc. South Aust. rol. viii. p. 101 , pl. v. figs. $7 a-b$.

Shell orbicular, irregular, slightly convex, or rarely very eonvex, horny-pellueid. The speeimens in the Museum eollection are not well preserved, but Professor Tate remarks that the surfaee of the unattached ralve is "ornamented with imbrieating sealy lamellæ and radial threads or ridges; umbo sub-marginal, depressed, with a slight back eurvature. Ligamental sear within the umbonal carity transverse, oblong, cireumseribed by a raised border, radially 
striated, adjaeent to the anterior margin of which is a small conspicuous pedal sear." He refers this fossil to the reent $P$. ione with some hesitation.

Dimensions.-Height $40 \mathrm{~mm}$.; length $40 \mathrm{~mm}$.

Form. and Loc.-Miocene: Muddy Creek, Vietoria.

L. 6583 . Unattached valve, mueh worn.

Purchased.

L. 9831. Two examples of the unattached valve. Purchased.

\section{Placunanomia sella, Tate.}

1886. Placunanomia sella, Tate, Trans. Roy. Soc. South Aust. vol. viii. p. 102 , pl. v. figs. $1 a-c$.

1893. Placunanomia sclla, Tate and Dennant, id. vol. xrii. pt. 1, p. 223.

1896. Ilacunanomia sella, Pritchard, Proc. Roy. Soc. Vict. vol. viii. v.s. p. 127.

Shell ovate, thin, inequivalre, umbones depressed, marginal, orerhanging. Left valve bent, slightly eonrex, margin undulating; museular impressions large, two in number, towards the centre, comprised within a linear, eireumscribed, elongate area. Right valve irregularly coneave, perforation large, elongate, musclemarkings prominent. Exterior of both valves ornamented with numerous radial threads and lamelix of growth.

The surfaee ornament and the ovate or suborbieular shape of the shell serve to readily distinguish this speeies from $P$. ione.

Dimensions.-Height $27 \mathrm{~mm}$. ; length $25 \mathrm{~mm}$.

Form. and Loc.-Eocene: Muddy Creek, Victoria.

L. 4817. Two speeimens of the adult, both valves. Presented by John Dennant, Esq.

L. 9842. Examples of both valves. Purchased.

\section{Placunanomia elyros, Gray (sp.).}

1S49. Anomia elyros, Gray, Proc. Zool. Soc. p. 118, pl. iv. fig. 1.

1859. Anomia elyros, Reeve, Conch. Icon. rol. xi. pl. i. fig. 3 ; pl. ii. fig. 9.

The speeimens in the Museum colleetion now assigned to this speeies are more finely plicated exteriorly than are the Australian examples the writer has seen: the shell is so rariable that this New Zealand form might well be ineluded in $P$. clyros in preference to being relegated to a new species. The attached 
valve has two prominent muscle-markings in the "circumscribed area "; whilst the calcified, plugged perforation is narrow, elongate, and slightly oblique. The exterual ornament of both valves is more scaly and imbricated, and the irregular radiating plications are more prominent and much more numerous than in $P$. zealundica. Gray; whilst it differs also from $P$. ione, not only in the main features of the external ornament, but in having a relatively smaller byssal notch and in the shell not being rounded.

Dimensions.-Height $49 \mathrm{~mm}$.; length $47 \mathrm{~mm}$.

Form. and Loc.-Miocene (?): Parimoa, New Zealand.

L. 10520. Complete specimen of the adult, byssal notch calcified. Transferred from the Museum of Practical Geology.

L. 10521, L. 10528. Several examples of both valves.

W. B. D. Mantell Coll.

\section{Placunanomia, sp.}

L. 10516. Cast of the interior of the non-perforated valre of a species, showing well-marked radiating ridges; too imperfect for identification. Hiocene: Akuakua, east coast of Auckland, New Zealand.

Sir James Hector Coll.

\section{Family DIMYIDE.}

\section{Genus DIIMYA, Rouault.}

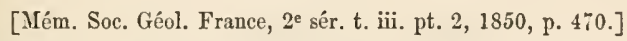

Shell inequivalve, suborbicular, equilateral, flat, adhering by one of the ralves; ligament internal, median, lodged in an elongated groore; no cardinal teeth; interior of the valres typically showing a linear row of denticles parallel to the margin of the shell.

After discussing the systematic position of the genus, Professor Tate remarks that the two new Australian species which he assigns to Dimya "have the general aspect of Plicatula rather than of Ostrea; whilst the two direrging cardinal rilges make an approach to Placune, though functionally different." That author is mistaken, however, in supposing that Dimya was founded on a shell from the Parisian Eocene; it came from Bos d'Arros, in the south of France.

Type.-Dimya deshayesiana, Rouault. 


\section{Dimya dissimilis, Tate.}

1886. Dimya dissimilis, Tate, Trans. Roy. Soc. South Aust. vol. viii. p. 100, pl. iii. figs. $9 a-c$.

1893. Dimya dissimilis, Tate and Dennant, id. vol. xvii. pt. 1, p. 224.

1895. Dimya dissimilis, Tate and Dennant, id. vol. xix. pt. 1, p. 112.

Attached ralve largely scarred by the broad area of attachment in the neighbourhood of the umbo, remainder of surface plicated, the ridges extending to the margin, they are scaly, undulating, and irregular; interior extensively occupied by the circumscribed white area in which the muscle-marks are situated, which is flanked on either side by a short row of elongate denticles; hinge-pit triangular and transversely striated. Unattached valve flat, haring a prominent umbo, from which the growth-lines gradually increase in vigour until they undulate and become plicated, forming radial, imbricating lamellæ, much as in common species of Chama; musclescars as in opposing ralve.

Dimensions (attached valve).-Height $21 \mathrm{~mm}$; length $17 \mathrm{~mm}$. Form. and Loc.-Eocene: Muddy Creek, Victoria.

L. 4806. Several examples of both valves.

Presented by Jolun Dennant, Esq.

L. 9838. A series of both valves showing stages of growth.

Purchased.

\section{Dimya sigillata, Tate.}

1886. Dimya sigillata, Tate, Trans. Roy. Soc. South Aust. vol. riii. p. 100, pl. viii. figs. $8 a-b$.

This differs principally from $D$. dissimilis in haring much finer ornament on the attached valve, which latter is usually more convex, and in having conspicuous ridges or riblets in the interior, radiating from the cireumscribed area to the pallial line.

Dimensions (attached valve).-Height $8.5 \mathrm{~mm}$.; length $6.5 \mathrm{~mm}$. Form. and Loc.-Eocene: Aldinga, South Australia.

L. 10030. Several examples of both ralres. Purchased. 


\section{Family SPONDYLID $A$.}

\section{Genus SPONDYLUS, Linnæus.}

[Syst. Nat. ed. 10, 1758, p. 690.]

Shell irregular, inequivalve, attached by the right ralve, auriculate, ornamented by radiating costæ which are typically spinose or sealy; right ralve more convex than the left, cardinal area triangular, haring in the centre a longitudinal groore; left valce smaller than the right, less convex; hinge of each ralve consisting of two large teeth, with corresponding pits on the opposing ralve; muscle impression near the centre of each ralve; pallial line entire.

Type.—Spondylus gaderopus, Linnæus.

\section{Spondylus gæderopoides, I'Coy.}

1576. Spondylus gaderopoides, $\mathbf{I I}^{\circ} \mathrm{Coy}$, Prod. Pal. Vict. dec. iv. p. 27, pl. xxxviii. figs. $1-1 d$.

1877. Spondylus gadcropoides, M'Coy, id. dec. v. p. 17, pl. xlv. figs, 1-3.

1856. Spondylus gederopoides, Tate, Trans. Roy. Soc. South Aust. vol. viii. p. 121.

1893. Spondylus gederopoides, Tate and Dennant, id. vol. srii. pt. 1, p. 224. 1896. Spondylus gaderopoides, Pritchard, Proc. Roy. Soc. Vict. vol. viii. x.s. p. 128.

"Obliquely orato-trigonal, gibbous, surface radiated with rery irregular, close, small ridges of very unequal sizes, often in groups of five, with middle one largest, occasionally alternate, roughened, with close, spinose, transverse scales, usually one to five rery small between each pair of larger strix, from one half to one line in width; from 4 to 10 thick ridges set with moderately close, rariable, long, arched spines, depressed near base, often compressed beycna, generally fewer on the upper than on the lower valve, but sometimes the lower ralre with no spinose ridges in the middle portion, but two or three on each side; the large valve ofteu with prominent concentric, scale-like laminæ near the beak and on the sides; arerage length of large valve from beak to front margin, 5 inches; proportional length from hinge-line (and length of 
smaller valve), $\frac{77}{100}$; greatest width, $\frac{75}{100}$; depth of larger valre, $\frac{27}{100}$; depth of small valre very variable."- $\boldsymbol{M}$ ' Coy.

The specific characters and dimensions are taken from Sir F. Ir'Coy's description, as none of the specimens in the Musenm collection are perfect, except two very small examples, which are not characteristic.

Form. and Loc.-Eocene: Victoria and South Australia.

L. 357. Right valve, costæ small, but principal ones bearing very long spines; from Bairnsdale. Presented by W. IT. Grigson, Esq.

L. 6586. Examples of both valves of the neanic stage of growth; from Muddy Creek.

Purchased.

L. 10600. Imperfect right valve, of large dimensions; from Willunga.

II. Y. L. Brown Coll.

Spondylus pseudoradula, MI'Coy.

1877. Spondylus psendoradula, M'Coy, Prod. Pal. Tict. dec. v. p. 17, pl. xlv. fig. 2 .

1886. Spondylus pseudoradula, Tate, Trans. Roy. Soc. South Aust. vol. viii. p. 121.

1893. Spondylus pseudoradula, Tate and Dennant, id. vol. svii. pt. 1, p. 224.

Shell thinner than S. gaderopoides, from which it may readily be distinguished in being less rentricose, and by the small spinose and granose ridges between the major spinose costæ, which are much reduced in size in many individuals; the auricles are nearly equal and are relatively larger than in that species.

Dimensions.-Height $39 \mathrm{~mm}$; ; length $35 \mathrm{~mm}$.

Form. and Loc.-Eocene: Muddy Creek, Victoria.

L. 4816. Three examples of the left valve.

Presented by John Dennant, Esq.

L. 9837. Examples of both valves, showing extreme variation in regard to external ornament.

Purchased.

\section{Spondylus, sp.}

L. 10601. Internal cast of a species allied to S.pseudoradula; from the Tertiary of Nullarbor Plains, South Australia. 


\section{Family LISID正.}

\section{Genus LIMA (Chemnitz), Lamarck.}

[Mém. Soc. Hist. Nat. Paris, 1799, p. 88.]

Shell equiralre, compressed, orate, oblique, slightly inflated; ornamented with radiating costæ, which may be simple or scaly; umbones prominent, auriculate, small lateral appendages unequal; cardinal area triangular, haring a central pit for the ligament; hinge without teeth; muscle impressions large. Bruguière figured but did not describe this genus. ${ }^{1}$

Type.-Ostrea lima, Linnæus.

\section{Lima colorata, Hutton.}

1873. Lima colorata, Hutton, Cat. Tert. Moll. N.Z. p. 33.

So far as the writer is able to judge from Hutton's brief description, the fossils here alluded to belong to his $L$. colorata, which appears to be closely related to $L$. zealandica, Sowerby. The shell is broad and solid; radiating costæ simple, or only ornamented by the crossing of growth-lines, distant, rounded at the sides and flat on top; triangular ligament pits large, risible from the exterior; anterior auricles slightly produced, posterior small, rilge-like; dorsal surface flattened and finely costated; umboncs acute, bent inwarls.

Dimensions.-Height $84 \mathrm{~mm}$.; length $66 \mathrm{~mm}$.

Furm. and Loc.-Pliocene (?) and Niocene: New Zealand.

34886. Man examples of both ralros, in various stages of growth; from Parimoa.

W. B. D. Mantell Coll.

L. 10597. Specimens of the adult, both valses; from Awamoa. Sir James Hector Coll.

1 Ency. Meth. Vers, etc. t. ii (plates), 1792, pl. ceri. 


\section{Lima bassi, Tenison-Woods.}

1877. Lima bassii, Tenison-Woods, Pap. Roy, Soc. Tas. 1876, p. 112.

1886. Lima bassii, Tate, Trans. Roy. Soc. South Aust. vol. viii. p. 117, pl. . fig. 8 ; pl. riii. fig. 1 .

1893. Lima bassii, Tate and Dennant, id. vol. xvii. pt. 1, p. 224.

1895. Lima bassii, Tate and Dennant, id. rol. xix. pt. 1, p. 112.

1896. Lima bassii, Pritchard, Proc. Roy. Soc. Vict. vol. viii. s.s. p. 128.

This common shell of the Australian and Tasmanian Tertiary is oblique, compressed, and rather thin; the radiating costæ are distaut, large, rounded, occasionally imbricated, scale-like expansions of the growth-lines, forming semilunate projections, which are usually more numerous at the sides than near the umbones and the middle of the shell; area short, broad; ligament pit triangular, large, shallow; auricles small; dorsal surface slightly concave. It is closely allied to $L$. colorata and $L$. zealandica, but is not so solid, whilst the scales on the radiating costæe are distinctive.

Dimensions.-Height $41 \mathrm{~mm}$.; length $31 \mathrm{~mm}$.

Form. and Loc.-Eocene: Muddy Creek, Victoria.

L. 4820. Specimen of the right valve, having very numerous radiating costæ, which possess but few scale-like projections.

Presented by John Dennant, Esq.

L. 6587. Two examples, in one of which the scales rise prominently into hollow, dome-shaped projections.

Purchased.

L. 9840. Series illustrating stages of growth, and the extreme variability in regard to number, size, and shape of costæ. Purchased.

\section{Lima linguliformis, Tate.}

1886. Lima linguliformis, Tate, Trans. Roy. Soc. South Aust. vol, viii. p. 118 , pl. iii. figs. $1 a-b$.

Shell fragile, much smaller than $L$. bassi, and having minute undulating costæ; these latter, as in L. scabra, Born, diverge from a median line extending from the umbo to the ventral margin, where they become somewhat granose; the frequent and closely-set lines of growth divide the costæ into short lengths. The valves are almost equilateral; anterior auricle prominent, posterior obsolete.

Dimensions.-Height $18 \mathrm{~mm}$; length $13 \mathrm{~mm}$. 
Form. and Loc.-Eocene: Muddy Creek, Victoria.

L. 6584. Examples of the adult.

Purchased.

L. 9841. Specimens of both valves.

Purchased.

\section{Subgenus LIMATULA, S. Wood.}

[Ann. Mag. Nat. Hist. vol. iii. 1839, p. 260.]

Shell erect, not so oblique as Lima, properly so called, subequilateral; ornamented with radiating striæ, which are most conspicuous towards the centre of the ralves.

Type.-Pecten subauriculatus, Montagu.

\section{Lima (Limatula) bullata, Born (sp.).}

1778. Ostrea bullata, Born, Mus. Cæs. Vindobon. pt. 1, p. 95.

1843. Lima bullata, Sowerby, Thes. Conch. vol. i. p. 84, pl. xxii. fig. 33 .

1873. Lima (Limatula) bullata, Hutton, Cat. Marine Moll. N.Z. p. 83.

1873. Lima bullata, Hutton, Cat. Tert. Moll. N.Z. p. 33.

1893. Lima (Limatula) bullata, Hutton, Linn. Soc. N.S.W., Macleay Mem. Tol. p. 88.

Shell elongate, rery slightly oblique; ornamented by numerous fine radiating costæ which become ousolete at the sides; hinge area straight, ligament pit broad, not deep; auricles small, slightly produced, nearly equal in size.

It is rather remarkable to find this Eocene species still living, but, on comparing examples of each, the differences observed are certainly not sufficiently important to warrant specific separation.

Dimensions.—Height $15 \mathrm{~mm}$; length $9 \mathrm{~mm}$.

Form. and Loc.-Eocene: Trelissick, New Zealand.

L. 10598. Example of the neanic stage of growth.

Sir James Hector Coll.

Lima (Limatula) jeffreysiana, Tate.

1877. Lima (Limatula) subauriculata, Tenison-Woods, Pap. Roy. Soc. Tas. 1876, p. 113 (non Montfort).

1885. Lima jeffreysiana, Tate, id. 1884, pp. 213, 230.

1886. Lima (Limatula) jeffreysiana, Tate, Trans. Ro5. Soc. South Aust. vol. viii. p. $119, \mathrm{pl}$. iv. fig. 8 .

1893. Limatula jeffreysiana, Tate and Dennant, id. vol. xrii. pt. 1, p. 224.

1896. Limatula jeffreysiana, Pritchard, Proc. Roy. Soc. Vict. vol. viii. x.s. p. 128. 
The radiating costæ in this species are very acute, interrupted by frequent, conspicuous growth-lines which produce minute granulations; the growth-lines are curved in the hollows between the costæ. The shell is more ventricose than in $L$. bullata, it is ovate, and instead of having approximately parallel sides they are arched; umbones acute; area broad; ligament pit shallow, broad, boldly transversely striated.

Dimensions - Height $24 \mathrm{~mm}$.; length $15 \mathrm{~mm}$.

Form. and Loc.-Eocene: Muddy Creek, Victoria.

L. 4821. Example of both valves of the neanic stage of growth. Presented by John Dennant, Esq.

L. 6585. Two specimens of the adult. Purchased.

I. 9844. A series illustrating stages of growth, from the brephic to the ephebic.

Purchased.

Lima, sp.

L. 10496. Example of a new species, $8 \frac{1}{2}$ inches in height and at least 8 inches in length. Judging from Hutton's description of L. lavigata, it appears to be allied to that species, as the shell is thin, equivalve, and compressed, but although it is smooth it is scored by very numerous, irregular undulating striæ, a feature not mentioned in Hutton's brief description alluded to. The auriculæ are broken off from the specimen, which is otherwise too imperfect to figure and describe in detail. From the Miocene, of Port Hills, Nelson, New Zealand.

Sir James Hector Coll.

\section{Genus LIMEA, Bronn.}

[Ital. Tert. 1831, p. 115.]

Limoarca, Münster, Leonh. and Bronn, Jahrb. 1832, p. 421.

The principal distinguishing features of this genus are the transverse ridges (as in Limopsis and Pectunculus) on the iuside of the auricles, and the small hinge area; impression of the adductor muscle of the valves subcentral.

Type.-Ostrea strigilata, Brocchi. 


\section{Limea transenna, Tate.}

1886. Limea transenna, Tate, Trans. Roy. Soc. South Aust. vol. viii. p. 119, pl. ix. figs. $6 a-b$.

Shell small, oblique, broad, ventricose; radiating costæ minute, numerous, the interstitial spaces with a median line, rendered granose by the passage of the frequent, regular, elerated growthlines; auricles small; hinge-line narrow, frequently overhanging and flanked on either side by four or five long ridges, which occupy the position of lateral teeth.

Dimensions.-Height $10 \mathrm{~mm}$; length $7 \mathrm{~mm}$.

Form. and Loc.-Eocene: Victoria.

L. 346. Right valre, larger than that indicated by the author of the species, and slightly more tumid-a local variation; from Bairnsdale.

Presented by $W$. II. Grigson, Esq.

L. 9839. Several examples of the adult; from Muddr Creek.

Purchased.

\section{Family PECTINID正.}

\section{Genus PECTEN, Müller.}

[Zool. Dan. Prodr. 1776, pp. xxxi.-248.]

Chlamys, auct. (See below.)

Shell suborbicular, auriculate, ornamented by radiating costæ; right valve typically convex, inflated and produced in the umbonal region, which curres inwards; left valve typically flat and smaller than the other, but in certain sections of the genus it is subequal and conrex; cardinal line straight; ligamental pit commonly triangular, internal.

This genus has been dividerl into a number of sections, the largest of which, Chlamys, included by anthors as a separate genus, certainly possesses some title to distinction, though the differences consist, principally, in its having the wing-like expansions of unequal size, and especially in that both the ralres are conrex. But the name is inadmissible: it was first proposed by Bolten in his Catalogue of the "Museum Boltcnianum," 1798, which work is not accepted by British malacologists, following the accepted rules of nomenclature. Before Bolten's name was adopted the term 
Chlamys was proposed for a genus of Coleoptera in 1801, and cannot therefore be used for the molluse.

There is no absolute synonym of Chlamys that could be employed, but the writer is not inclined to suggest a new term, believing that by a greater breadth of treatment than is now in rogue, one of the numerous sectional names already in existence will ultimately be applied to those Pecrinide that have hitherto been ealled Chlamys. The Australian forms here alluded to are therefore retained in Pecten, for the present.

Type.-Ostrea maxima, Linnæus.

\section{Pecten murrayanus, Tate.}

1886. Pecten murrayanus, Tate, Trans. Roy. Soc. South Aust. vol. viii. p. 105, pl. vii. figs. $5 a-b$.

1859. Pecten murrayanus, Dennant, id. vol. xi. p. 49.

1893. Pecten murrayensis, Tate and Dennant, id. vol. xvii. pt. 1, p. 224.

Shell orbicular, one valve convex, the other flat; radiating costæ from twenty to twenty-four in number, rounded, prominent, crossed by conspicuous, regular, closely-set, undulating lineations which are approximately coincident with the margin; interior ridged and furrowed, corresponding with the main features of the external ornament; auriculæ well dereloped, unequal in size, rayed and vertically striated on the exterior.

It may be distinguished from $P$. solarium, Lamarck, of the European Tertiary, by the Australian fossil having fewer costæ, and smaller auriculæ.

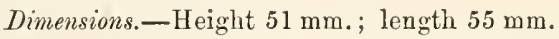

Form. and Loc.-Eocene: Victoria and South Australia.

L. 4812. Several examples of both ralves; from Muddy Creek. Presented by John Dennant, Esq.

L. 6578 , L. 9916 . Many specimens of the adult, both valves; from Muddy Creek.

Purchased.

L. 10531, L. 10532. Examples of both valves; from Fowler's Bay District.

II. Y. L. Brown Coll.

L. 10548. Flat valse; from the River Murray cliffs, near Adelaide.

Presented by William Evans, Esq.

L. 10549. Imperfect flat valres; from Nullarbor Plains.

II. Y. L. Brown Coll. 


\section{Pecten sturtianus, Tate.}

1886. Pecten sturtianus, Tate, Trans. Roy. Soc. South Aust. vol. viii. p. 109, pl. vii. figs, $2 a-c$.

1859. Pecten sturtiunus, Dennant, id. vol. xi. p. 49.

1893. Pccten sturtianus, Tate and Dennant, id. vol. xvii. pt. 1, p. 224.

Characterized by the regular radiating costre being scaly, the interspaces being transversely or obliquely lineated; auriculæ unequal, the posterior on the left valve being elongately produced, narrow, and deeply excarated by a byssal sinus.

Dimensions._Height $17 \mathrm{~mm}$.; length $16 \mathrm{~mm}$.

Form. and Loc. - Eocene (?): Victoria.

L. 340. Two examples; from Bairnsdale.

Presented by W. H. Grigson, Esq.

L. 4814. Left valre; from Muddy Creek.

Presented by John Dennant, Esq.

\section{Pecten asperrimus, Lamarck.}

1819. Pccten aspervimus, Lamarek, Hist. Nat. Anim. sans Yert. t. vi. p. 174. 1842. Pecten australis, Sowerby, Thes. Conch. vol. i. p. 76, pl. xix. figs. 219, 220 (non Philippi).

1853. Pecten asperrimus, Reeve, Conch. Icon. vol. riii. pl. xx. fig. 75.

1885. Pecten asperrimus, E. A. Smith, Toy. "Challenger," Zool. vol. xiii. Lamellibranchiata, p. 294.

In the adult the primary radiating costæ are flanked by two or three minor ribs on each side, the small ones being closely scaly, the interstices from summit to summit of the primary costæ being broadly $\mathrm{V}$-shaped.

Dimensions.-IHeight $83 \mathrm{~mm}$; length $78 \mathrm{~mm}$.

Form. and Loc.-Post-Pliocene : Limestone Creek, Glenelg river, Victoria.

L. 6567. Examples of the adult, both valres.

Purchased.

\section{Pecten antiaustralis, Tate.}

1882. Pecton asperrimus, var., Tate, Trans. Roy. Soc. South Aust. vol. ir. p. 34 .

1886. Pecten antiaustralis, Tate, $i d$. vol, viii. p. 106 , pl. ix. figs. $7 a-c$.

Distinguished by the ornamentation of the costæ, each of which consists of a large central rib flanked by one or two small lineations 
in the adult; the costæ are convex, crossed by erect lamellæ, the furrows being flattened and transversely striated; auriculæ rery unequal in size, the large projection on one side of the umbo being well-marked by fine costæ.

Dimensions.-Height $59 \mathrm{~mm}$.; length $56.5 \mathrm{~mm}$.

Form. and Loc.-Miocene: South Australia and Victoria.

33789. Example of the neanic stage of growth; (locality ?) South Australia.

Presented by J. D' Urban, Esq.

42698. Three specimens; from near Adelaide.

Presented by Mr. Mrarshall, Esq.

L. 6579 , L. 9918. Series illustrating stages of growth, both valves; from Muddy Creek.

Purchased.

L. 10533. Examples of the ephebic and neanic stages; from Willunga. II. Y. L. Brown Coll.

\section{Pecten polymorphoides, Zittel.}

1833. Pecten coarctatus, Sturt, Two Expeditions S. Aust. vol. ii. p. 254, pl. iii. fig. 13.

1862. Tecten coarctatus (?), J. E. Woods, Geol. Obs. S. Aust. p. 74, fig.

1865. Pecten polymorphoides, Zittel, Reise der Novara, Paläontologie, Bd. i. Abth. ii. p. 51, taf. xi. fig. 3.

1865. Pecton incertus, Tenison-Woods, Trans. Phil. Soc. Adelaide, pl. i. fig. 1.

1886. Pecten polymorphoides, Tate, Trans. Roy. Soc. South Aust. vol. viii. p. 113, pl. viii. fig. 2.

1889. Pecten polymorphoides, Dennant, id. rol. xi. p. 49.

1893. Pecten polymorphoides, Tate and Dennant, id. vol. xvii. pt. 1, p. 224.

Shell inequiralve, very inequilateral, irregularly convex, typically bent inwards along the rentral margin; ornamented by from five to seren broad undulating costæ, which, together with the interspaces, bear numerous minor radiatiug riblets; ridges commonly covered with imbricating scales; auriculæ very unequal in size, the smaller one is grooved in front from the umbo, and that leads to a general lateral inflection, which is highly characteristic, producing a distorted appearance in the shell. It is an exceedingly variable species. The synonymy is fully discussed by Professor Tate (op. cit. 1886, p. 113).

Dimensions.-Height $36 \mathrm{~mm}$.; length $37.5 \mathrm{~mm}$.

Form. and Loc.-Eocene: Victoria. 
L. 341. Specimens of both ralres in which the costre are much elevated; from Bairnsdale. Presented by $W$. II. Grigson, Esq.

L. 512. Three examples of the adult; (locality ?) New Zealand. Presented by Colonel L. W. Wilmer.

L. 4815. Example of the neanic stage of growth; from Muddy Creek. Presented by John Dennant, Esq.

L. 9917. Both valves, costæ not much imbricated; from MIuddy Creek.

Purchased.

\section{Pecten peroni, Tate.}

1586. Pecten peroni, Tate, Trans. Roy. Soc. South Aust. vol. viii. pl. $x$. figs. $1 a-b$.

1893. Pecten peroni (?), Tate and Dennant, id. vol. xvii. pt. 1, p. 224.

This may readily be distinguished by its elosely-set and fine scaly radiating costæ; the primary ribs, with the growth of the shell, become flanked by minor scaly costæ, which are rery minute at first, but rival in size their accompanying primary rib near the margin, in the adult; auriculæe well dereloped, unequal; shell longer thau broad.

Dimensions.-Height $44 \mathrm{~mm}$.; length $38 \mathrm{~mm}$.

Form. and Loc.-Eocene: Aldinga, South Australia.

L. 9914. Example of the adult, both valves.

Purchased.

\section{Pecten consobrinus, Tate.}

1886. Pecten consobrinus, Tate, Trans. Roy. Soc. South Aust. vol, viii. p. 104 , pl. iii. fig. 6 .

1893. Pecten eonsobrinus, Tate and Dennant, id. vol. xrii. pt. 1, p. 224.

Shell equilateral, slightly convex, the left valve rather flattened; there are eight primary, radial ridges, and altogether about 100 minor costx which are unequal in size, the interspaces being minutely granular; the last-mentioned feature is rery characteristic.

The author compares it with $P$. bifrons, with which it is closely allied.

Dimensions.-Height $42 \mathrm{~mm}$; length $41 \mathrm{~mm}$.

Form. and Loc.-Wiocene: South Australia. 
L. 9919. Examples of the neanic stage of growth, showing variation in regard to disposition of the radial costæ; from Aldinga.

Purchased.

L. 10533. Right valve of the neanic stage of growth; from Willunga.

II. Y. L. Brown Coll.

\section{Pecten palmipes, Tate.}

1886. Pecten palmipes, Tate, Trans. Roy. Soc. South Aust. vol. viii. p. 105, pl. v. fig. 4 ; pl. vii. figs. $4 a-b$.

Readily distinguished by its wide, undulating, distant, radiating costæ, which are faintly longitudinally lineated, and become fiatter as they approach the margin; and especially by the minutely granular structure of the spaces between the costæ, which also bear a few obscure longitudinal lineations; auricula well dereloped.

The author compares it with the living South Australian $P$. bifrons, Lamarek, from which it differs by the obliquity of its valves, and in being broader; the interior is plicated, but not costated as in P. bifrons.

Dimensions.-Height $40 \mathrm{~mm}$; length $38 \mathrm{~mm}$.

Form. and Loc.-Tertiary: Willunga, South Australia.

L. 10533. Right valve of the neanie stage of growth. II. Y. L. Brown Coll.

\section{Pecten eyrei, Tate.}

1886. Pccten eyrci, Tate, Trans. Roy. Soc. South Aust. rol. riii. p. 107, pl. viii. figs, $3 a-b, 6$.

Ornamented by closely-set, rounded, radiating costæ, bearing very numerous ereet scales decreasing in size and relative derelopment on being traced back from the margin until in the umbonal region the ribs are, practically, simple. The auriculæ are unequal, radially ridged, and transversely lamellated.

Dimensions.-Height $23 \mathrm{~mm}$. ; length $21 \mathrm{~mm}$.

Form. and Loc.-Tertiary: South Australia.

L. 10534. Right valve; from Willunga. II. Y. L. Brown Coll.

L. 10536, I. 10537. Specimens in limestone showing the 
intrior of the ralves, probably referable to this species; from Nullarbor Plains and Fowler's Bay District. II. Y. L. Brown Coll.

L. 10538. Trpical examples in soft limestone resembling chalk; from Nullarbor Plains. II. I. L. Brown Call.

\section{Pecten beethami, Hutton.}

1873. Pecten becthami, Hutton, Cat. Tert. Moll. N.Z. p. 31.

This species is not figured, but the specimens in the Museum collection, alluded to below, answer the description given by Hutton. They are suborbicular, the right valve is convex, and has numerous small radiating costæ, which become broader towards the rentral margin.

Dimensions. - None of the specimens are perfect; one has a length of $120 \mathrm{~mm}$.

Form. and Loc.-Eocene: New Zealand.

L. 10497, L. 10504. Large fragment imbedded in limestone; from Culverden, Nelson. Sir James Hector Coll.

L. 10509. An imperfect example of the adult; from Tata Island.

Sir James Hector Coll.

\section{Pecten semiplicatus, Hutton.}

1873. Pecten semiplicata, Hutton, Cat. Tert. Moll. N.Z. p. 30.

1593. Peten semiplicutus, Hutton, Linn. Soc. X.S.W., Macleay Mem. Tol. p. 89 .

Oruamented by five or six strong radiating plications near the umbones, which gradually disappear as the rentral margins, in the adult, are reached; between these are small ribs, commonly rounded at the summit.

Dimensions. - Height $55 \mathrm{~mm}$.; length $54 \mathrm{~mm}$.

Form. and Loc.-Wiocene: "Duncan's," East Coast, North Island, Nerr Zealand.

L. 10542. An imperfect example of the adult.

Sir James Hector Coll. 


\section{Pecten accrementa, Hutton.}

1873. Pecten accrementa, Hutton, Cat. Tert. Moll. N.Z. p. 31.

Distinguished by its broad, flat, rounded, radiating costæ, which are from twenty-three to twenty-five in number; these are simple near the umbo, but divide inta sereral small ones with growth; a smaller rib, extending nearly to the umbo, is placed in each space between the larger costx; it is inequivalve; the expansions are well developed.

Dimensions.--Height $62 \mathrm{~mm}$; ; length $55 \mathrm{~mm}$.

Form. and Loc. - Miocene: "Duncan's," East Coast, North Island, New Zealand.

L. 10501. Imperfect example, in which the larger costæ are medially sulcated.

Sir James Hector Coll.

L. 10502. Sereral impressions of the interior of both valves in friable, shelly, argillaceous sandstone, probably referable to this species.

Sir James Hector Coll.

L. 10543. Shell relatively broader than in typical examples; whilst the costæ are smaller and more numerous. It appears to be a local rariation.

Sir James Hector Coll.

\section{Pecten triphooki, Zittel.}

1865. Pecten triphooki, Zittel, Reise der Novara, Paläontologie, Bd. i. Abth. ii. p. 52, taf. xi. fig. 4 .

1873. Pecten triphooki, IIutton, Cat. Tert. Moll. N.Z. p. 31.

1893. Pecten triphooki, Hutton, Linn. Soc. N.S.W., Macleay Mem. Vol. p. 88.

Closely allied to $P$. accrementa, but the valves are slightly more convex and relatively broader, the radiating costæ are more distant from each other, and much raised; the costæ are sulcated and striated, and the interstices between them have each an elevated median lineation.

Dimensions.-Height $118 \mathrm{~mm}$; length $122 \mathrm{~mm}$.

Form. and Loe.-Miocene: Napier, New Zealand.

L. 10530. Example of the adult, both valies. [Old Collection.] 


\section{Pecten crawfordi, Hutton.}

18i3. Pecten craufordi, Hutton, Cat. Tert. Moll. N.Z. p. 32.

Shell slightly convex, haring fire or six principal radiating ridges, which are much elevated in the neighbourhood of the umbo, but become gradually depressed and eren obsolete on attaining the rentral margin, in the adult; these broad, flat costæ or ridges become dirided into several small rounded ribs on nearing the margin; the interstices have several minor costæ.

Dimensions. - Height $55 \mathrm{~mm}$. ; length $61 \mathrm{~mm}$.

Form. and Loc.-Eocene: Akuakua, east const of Auckland, New Zealand.

L 10541. Examples of both valves, apparently referable to this unfigured species.

Sir James Hector Coll.

\section{Pecten, sp.}

L. 10498. Internal cast and part of the shell of a species allied to P.crawfordi. Eocene: Akuakua, Auckland, New Zealand.

Sir James Hector Coll.

L. 10539. Part of the shell of a species haring distantly separated, rounded, and elevated radiating costæ, with a lineation in each of the interspaces. Eocene: Akuakua.

Sir James Hector Coll.

L. 10503, L. 10544. Casts and interior of an orbicular species, haring several broad radiating costæ, boldly lineated, as are also the interspaces. Eocene: Culverden, Nelson, New Zealand.

Sir James Hector Coll.

L. 10531. Imperfect specimen of a new species, allied to P. murrayanus; from Pidinga, Fowler's Bay District, South A ustralia.

H. Y. L. Brown Coll.

L. 10533-5. Sereral imperfect examples of a species allied to $P$. aldingensis, Tate; from Willunga, South Australia.

II. Y. L. Broon Coll.

L. 10549. Exterior of right ralre of a Pecten, aff. murrayanus; Nullarbor Plains, Sonth Australia. H. I. L. Brown Coll.

L. 10550. Cast of a species allied to, or identical with, $P$. antiaustralis. "Lower Tertiars": Arlrossan, Yorke's Peninsula, South Australia.

IT. Y. L. Brown Coll. 
Genus PSEUDAMUSSIUM (Klein), H. and A. Adams.

[Gen. Rec. Moll. vol. ii. 1858, p. 553.]

Distinguished from its near ally Amussium by not having radiating ribs on the interior of the shell; whilst the auriculæ are unequal in size.

Bruguière ${ }^{1}$ is generally credited with having been the first to adopt Klein's Pseudamussium (em.), but on reference to his work it will be seen that he is merely dealing with Klein's method of classification of the Mollusca, and that although he gives a brief description he does not quote any species in connection therewith so as to typify the genus. At a later date, in the same work, Deshayes $^{2}$ mentions Pseudamussium, but although he gives a diagnosis and illustrates it by quoting some species, he remarks that "this genus has not been adopted."

Messrs. H. and A. Adams appear to be the first to have actually adopted it, though they quote a number of species some of which are not typical of Pseudamussium as intended, apparently, by Klein. The type of the genus, as selected by Stoliczka ${ }^{3}$ and as given below, occurs in H. and A. Adams' list as a synonym, which, howerer, is easily recognized.

Type.-Pecten exoticus, Chemnitz.

\section{Pseudamussium yahlensis, Tenison-Woods (sp.).}

1865. Pecten yahlensis, Tenison-Woods, Trans. Phil. Soc. Adelaide, pl, i. fig. 4.

1876. Pecten yahlensis var. semilavis, $\mathrm{M}^{\circ} \mathrm{Coy}$, Prod. Pal. Vict. dec. iv. p. $13, \mathrm{pl}$. xxxiv.

1886. Pecten yahlensis, Tate, Trans. Roy. Soc. South Aust. vol. viii. p. 110.

1893. Pecten yahlensis, Tate and Dennant, $i d$. vol. xrii. pt. 1, p. 224.

1896. Pecten yahlensis, Pritchard, Proc. Roy. Soc. Vict. vol. viii. x.s. p. 127.

Shell suborbicular, thin; valves unequal, with dissimilar ornament. Right valve more convex than the left, surface having numerous

1 Ency. Meth. Vers. i. 1792, p. 536.

2 Ency. Meth. Vers. iii. 1832 , p. 854.

3 Mem. Geol. Surv. India, Cret. Fauna S. India, vol. iii. Pelecypoda, 1871, p. 426 . 
radiating, small, straight, rounded ridges flattened on top, crossed by distant concentric growth-lines; posterior auricle slightly larger than the anterior. Left valre nearly flat, with radiating ridges similar to the right valve, but not flattened on top, whilst they are crossed by closely-set concentric lamellæ; auriculæ nearly equal in size.

Dimensions.-Height $69 \mathrm{~mm}$; length $76 \mathrm{~mm}$.

Form. and Loc.-Eocene: Victoria.

L. 351. Example of the adult; from Bairnsdale.

Presented by W. II. Grigson, Esq.

L. 4811. Both valres; neanic stage of growth; from Muddy Creek.

Presented by Joln Dennant, Esq.

L. 6580. Examples of both valves; from Muddy Creek.

Purchased.

L. 9915. Large fragments of the adult; from Muddy Creek.

Purchased.

\section{Pseudamussium hochstetteri (?), Zittel (sp.).}

1865. Pecten hochstettcri, Zittel, Reise der Norara, Paläontologie, Bd. i. Abth. ii. p. 50, taf. xi. figs. $5 a-b$.

1873. Pecten hochstetteri, Hutton, Cat. Tert. Moll. N.Z. p. 30.

Shell suborbicular, thin, compressed; both valres smooth; auriculæ nearly equal in size, obtuse.

The specimens in the Museum collcction are rery small, and are referred to this species doubtfully. They somewhat resemble fig. $5 a$ in Zittel's work above quoted.

Dimensions.-Height $26 \mathrm{~mm}$. ; length $24 \mathrm{~mm}$.

Form. and Loc.-Miocene: New Zealand.

L. 10499. Cast of the interior of a valve; from Port Hills, Nelson. Sir James Tlector Coll.

L. 10505. Interior of ralre, attached to a block of argillaceous, micaceous sandstone; from Mokihinui.

Sir James IIector Coll. 
Genus AMUSSIUIM (Klein), Megerle von Mühlfeldt.

[Ges. Naturf. Fr. Berlin, Magazin, 1811, p. 59.]

Shell almost orbicular, depressed, auriculæ small, equal in size; ralves smooth on the exterior, but having radiating ribs in the interior, which is the principal differentiating feature of the genus; ventral border not plicated.

Of the two species mentioned by Megerle von Mühlfeldt the following is selected as the type of the genus.

Type.-Ostrea obliterata, Linnæus.

\section{Amussium zitteli, Hutton (sp.).}

1865. Pecten, sp., Zittel, Reise der Novara, Paläontologie, Bd. i. Abth. ii. p. 53, taf. ix. figs. 16 and 3.

1873. Pecten zitteli, Hutton, Cat. Tert. Moll. N.Z. p. 32.

18s0. Amussirm atkinsoni, Johnston, Pap. Roy. Soc. Tas. 1879, p. 41.

1886. Pecten zitteli, Tate, Trans. Roy. Soc. South Aust. vol. viii. p. 115, pl. vii. figs. $3 a-c$.

1893. Pecten zitteli, Tate and Dennant, id. vol. xvii. pt. 1, p. 224.

1895. Amussium zitteli, Tate and Dennant, id. vol. xix. pt. 1, p. 112.

Shell small, interior smooth, shining and furnished with from nine to eleven costæ which are truncated near the margin; left valre concentrically striated, auriculæ unequal ; right valve striatereticulate, or ridged, but the exterior ornament is very variable.

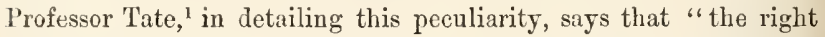
valve varies very much in respect of the number and thickness of the radial and concentric threads; usually the radial threads are stouter than the raised concentric lines, but this form merges on the one hand into a fenestrated ornament, and on the other to one in which the raclial ridges are very prominent and minutely scaly." The posterior auricle of the right valve is larger than the anterior; it is triangular and cancellate.

It is allied to $A$. squamula, Lamarck, of the Parisian Eocene, but the latter is devoid of conspicuous reticulate ornament on the exterior, and is relatively longer.

Dimensions.-Height $8 \mathrm{~mm}$.; length $9 \mathrm{~mm}$.

Form and Loc.-Eocene: Muddy Creek, Victoria.

L. $98 \% 6$. Several examples of both valves.

Purchased.

1 Trans. Roy. Soc. South Aust. vol. viii. 1886, p. 115. 


\section{Family AVICULIDA.}

\section{Genus MARGARITIFERA, P. Browne.}

[Nat. Hist. Jamaica, ed. 1789, p. 412.]

Unionium, Link, Besch. Rostock, Abth. iii. 1807, p. 155.

Margaritiphora, Megerle ron Mühlfeldt, Ges. Naturf. Fr. Berlin, Magazin, 1811, p. 66.

Margarita, Leach, Zool. Misc. vol. i. 1814, p. 107.

Perlamater, Schumacher, Essai Nouv. Syst. Habit. Testacés, 1817, p. 107.

Meleagrina, Lamarck (1812), Hist. Nat. Anim. saus Vert. t. vi. pt. 1,1819 , p. 150 .

Shell pearly, less oblique than in Avicula, whilst the valves are broader and almost equal in size; posterior auricle short, not separated by a siuus; hinge teeth visible in the joung, but not in the adult.

It is unfortunate that the well-known Meleagrina, Lamarck, should hare to disappear in symonymy, as abore indicated, but it cannot be helped if we are to be consistent in putting the law of priority in force. At least four names were suggested for this geuus before Lamarck's name of 1819 . If objection be taken to Patrick Browne's work, as he did not actually name a species in connection with Margaritifera, but referred to plates and figures in earlier works as iudicating what he meant, then Unionium, Link, is available, the type of which is, very clearly, Nytilus margaritiferus, Linnæus. But, seeing that Linwæus ${ }^{1}$ had interpreted the plates and figures alluded to, we are not left in doubt concerning the appellation of the shells represented, and the nane Margaritifera is, therefore, here adopted.

Type.-Mytilus margaritiferus, Linnæus.

\section{Margaritifera crassicardia, Tate (sp.).}

1886. Meleagrina crassicardia, Tate, Trans. Roy. Soc. South Aust. vol. viii. p. 121, pl. ix. figs. $9,10$.

1859. Mcleugrina crassicardia, Dennant, id. vol. xi. p. 49. 
Shell pearly, inequivalve, inequilateral, right valve flatter than the left; hinge-line loug, straight, with a cardinal tooth in the young; surface distantly, faintly striated.

Dimensions.-Height $18 \mathrm{~mm}$.; length $21 \mathrm{~mm}$.

Form. and Loc.-Eocene: Muldy Creek, Victoria.

L. 9843. Examples of both valves, of the neanic stage of growth.

Purchased.

\section{Genus VULSELLA, Lamarck.}

[Mém. Soc. Hist. Nat. Paris, 1799, p. 82.]

Shell subequivalve, not auricnlate, longer than broad; cardinal border not furnished with teeth; ligament similar to that in Ostrea and lodged in a triangular, oblique pit; structure of the test nacreous interiorly, prismatic externally.

Type.-Mya vulsella, Linnæus.

\section{Vulsella lævigata, Tate.}

1886. Trulsella levigata, Tate, Trans. Roy. Soc. South Aust. vol. viii. p. 122, pl. iii. figs. $3 a-b$.

In general form this shell resembles $V$. deperdita, of the Eocene of Europe, from which, however, it may be distinguished in being relatively narrower and in having less divergent umbones. The author remarks that its resemblance to $V$. angustata, Deshayes, of the Parisian Eocene, is very close, but that it differs by the large, straight ligamental pit.

Dimensions.-Height $26 \mathrm{~mm}$. ; length $14 \mathrm{~mm}$.

Form. and Loc.-Eocene: Aldinga, South Australia.

L. 10029. Two examples of the adult.

Purchased.

\section{Genus PINNA, Linnæus.}

[Syst. Nat. ed. 10,1758, p. 707.]

Shell equivalve, trigonal, umbones acute; posterior side truncate; ligament linear, long, lodged in a groove; cardinal border without teeth; nacreous, splitting into thin plates on decomposition, so that fossil examples are commonly fragile, and often prescnt the 
structure of the inside of the shell alone, as revealed by the surfaces of the layers, the outermost layers having been remored by decomposition, or shivered into minute fragments too imperfect for examination.

Type.-Pinna rudis, Linnæus.

\section{Pinna distans (?), Hutton.}

1873. Pinna distans, Hutton, Cat. Tert. Moll. N.Z. p. 26.

"Large, with distant plications, the ridges being much narrower than the furrows. Height 9 (inches); length $4 \cdot 5$ (inches); angle of apex $40^{\circ} . "-$ Illtton.

L. 10483, L. 10488. Casts of several specimens which may possibly be identified with this species; though the meagre description given by its author practically defies identification. Miocene: Akuakua, east coast of Auckland, New Zealand.

Sir Jumes Ileetor Coll.

\section{Pinna, sp.}

97721. Fragment of a species having semilunate undulating ridges; from (locality?) Western Australia. II. Y. L. Broun Coll.

L. 9583. Shell conglomerate, in which are several fragments of a large species of Pinna, too imperfect for specific identification; from the Post-Pliocene (?) of Flint Cliff, Shark's Bay, Western Australia. Presented by W. Saville-Kent, Esq., F.L.S.

Family MYTILID瓜.

\section{Genus MYTILUS, Linnæus.}

[Syst. Nat. ed. 10, 1758, p. 704.]

Shell equivalve, cuneiform, very inequilateral; umbones acute; posterior margin rounded; cardinal teeth small, or obsolete; ligament linear, marginal; interior of the valves commonly lined with nacreous matter; anterior adductor of the valves small, posterior very large.

Type.-Mytilus edulis, Linnæus. 


\section{Mytilus hamiltonensis, Tate.}

1887. Mytilus hamiltonensis, Tate, Trans. Roy. Soc. South Aust. vol. ix. p. 186 , pl. xviii. fig. 9 .

Distinguished by its external ornament, consisting of very numerous, frequently bifurcating, radial threads, crossed by closelyset strix of growth; the inner margin of the valves is denticulated all round; and there are two or three small teeth under the umbo in the right ralve.

The author compares it with the living $M$. hirsutus, Lamarck.

Dimensions.-Height $56 \mathrm{~mm}$. ; length $27.5 \mathrm{~mm}$.

Form. and Loc.-Miocene: Muddy Creek, Vietoria.

L. 4823. Specimen of the gerontic stage of growth.

Presented by John Dennant, Esq.

L. 9833. Two examples of the adult.

Purchased.

\section{Genus SEPTIFER, Récluz.}

[Rev. Zool. 1848, p. 275.]

Ventral border concave or sinuous for the passage of the byssus; surface of the valves radiately striated; umbones slightly inflected, having in the interior a thin plate on which is the impression of the anterior adductor of the valves; the cardinal border has a few dentiform erenulations.

Type.-Mytilus bilooularis, Linnæus.

\section{Septifer fenestratus, Tate.}

1886. Septifer fenestratus, Tate, Trans. Roy. Soc. South Aust. vol, viii. p. 124 , pl. ix. fig. 1 .

1887. Septifer fenestratus, Tate, id. vol. ix. p. 187.

1889. Septifer fenestratus, Dennant, id. vol. хi. p. 49.

Shell elongate, much flattened on one side; surface ornament consisting of elosely-set, divaricate lineations, much broken up by the platy ridges of growth; internal plate small, sinuous at the edge; margin of the valres elosely crenulated inside, dentate under the umbo; byssal sinus small. 
Dimensions. - Height $23 \mathrm{~mm}$; l length $10.5 \mathrm{~mm}$.

Form, and Loc.-Eocene: Muddy Creek, Victoria.

L. 9846. Three examples in which the growth ridges are very rugose.

Purchased.

\section{Genus MODIOLA, Lamarck (em.).}

[Mém. Soc. Hist. Nat. Paris, 1799, p. 87.]

Shell oblong, transverse, inequilateral, equivalve, tumid in front; umbones obtuse, not terminal; hinge either without teeth, or with merely a few crenulations anteriorly; ligament marginal, linear.

Type.-Mrytilus modiolus, Linnæus.

\section{Modiola, sp.}

L. 10484. Cast of a large species, aff. albicosta, Lamarck. Miocene: Trelissick, New Zealand.

Sir James Hector Coll.

L. 10485. Imperfect example of what may possibly be M. australis, Gray, though it is somewhat narrower than are typical specimens. Miocene: Napier, New Zealand.

Sir James Hector Coll.

\section{Genus CRENELLA, Brown.}

[Illust. Conch. Great Britain, 1827, pl. xxxi. figs. 12-14; 2nd ed. 1814, p. 75, pl. xxiii. figs. 12-14.]

IIyoparo, Lea, Contrib. to Geol. 1833, p. 73.

Shell oval, or rhomboidal, surface ornamented by longitudinal and concentric striæ; umbones incurved; cardinal border denticnlate, the denticles appearing to bo the continuation of the crenulations on the margin of the ralres; the single denticle present is also erenulated; interior of the ralres nacreous.

Type.-Irytilus decussatus, Montagu. 


\section{Crenella globularis, Tate.}

1886. Crenella globularis, Tate, Trans. Roy. Soc. South Aust. vol. viii. p. 126 , pl. x. figs. $3 a-b$.

1889. Crenella globularis, Dennant, id. rol. xi. p. 49.

1893. Crenella globularis, Tate and Dennant, id. vol. xrii. pt. 1, p. 224.

Shell subglobose, nacreous within, equivalve, inflated; inequilateral, the umbones being placed anteriorly, they are obtuse and incurved; ligamental groove internal, extending posteriorly; hingeline minutely transversely denticulated; a denticle terminates the groove under the umbo; margin of the valves faintly crenulated; the surface is regularly cancellated.

It is a close ally of $C$. elegans, Deshayes, of the Paris Basin.

Dimensions.-Height $5 \mathrm{~mm}$.; length $3.5 \mathrm{~mm}$.

Form. and Loc.-Eocene: Muddy Creek, Victoria.

L. 9874. Several examples of both valves.

Purchased.

Crenella elongata, Hutton.

1873. Crenella elongata, IIutton, Cat. Tert. Moll. N.Z. p. 25.

Dimensions.-Length $14 \mathrm{~mm}$.; breadth $8 \mathrm{~mm}$.

Form. and Loc.-Eocene: Trelissick, New Zealand.

I. 10486. Internal cast of the left valve.

Sir James Hector Coll.

Family ARCID正.

Genus ARCA, Linnæus.

[Syst. Nat. ed. 10, 1758, p. 693.]

Shell commonly equivalve, subrhomboidal, ventricose, costulate or canceliate; borders of the valves either smooth or dentate; hinge straight, horizontal, furnished with rery numerous, short teeth; umbones prominent, curred inwards, separated from each other by a more or less broad area, which carries several ligamental striæ or well-marked, narrow, linear groores commonly $\mathrm{V}$-shaped; impressions of the adductor muscles of the valves 
subequal, the anterior being rounded, the posterior divided; impression of the posterior adductor of the byssus elongate and situated near the cardinal line; that of the anterior adductor of the byssus small; pallial line simple.

The genus has been much subdirided according to the character of the external ornament, the shape of the shell, and the nature of the ligament area.

Type.-Area noce, Linnæus.

\section{Arca equidens, Tate.}

1886. Arca equidens, Tate, Trans, Roy. Soc. South Aust. rol. viii. p. 139, pl. xi. fig. 9.

In this small species the ralres gape rentrally; whilst the umbones are high and wide apart, and the few hinge teeth are oblique. There is a characteristic depression from the umbo to the rentral margin; surface ornament bold, consisting of concentric imbricating ridges and acute radial costre. The author remarks that the "ornament varies in respect to the relative strength of the radial ribs and concentric ridges, whilst in the other extreme it consists of radial ribs variously thickened at the intersections with the concentric lines." The inner margin of the ralres is not crenulated; hinge area broad, longitudinally lineated.

Judging from the obliquity of the hinge teeth and their increase in size laterally, this species forms a connecting link between Arca (sensu stricto) and the subgenus Barbatia.

Dimensions.-Height $3.5 \mathrm{~mm}$.; length $6 \mathrm{~mm}$.

Furm. and Loc.-Eocene: Aldinga, South Australia.

L. 9872. Several specimens of different stages of growth.

Purchased.

\section{Subgenus BARBATIA, Gray.}

[Syn. Brit. Mus. 1840, p. 151 (list uame); Proc. Zool. Soc. 1847, p. 197.]

Teeth numerous, those in the centre under the umbo small and increasing in size laterally, more or less oblique; ligament area narrow.

Type.-Arca barbata, Linnæus. 


\section{Arca (Barbatia) celleporacea, Tate (sp.).}

1886. Barbatia celleporacea, Tate, Trans. Roy. Soc. South Aust. vol. viii. p. 141, pl. x. fig. 10.

1593. Barbatia celleporacea, Tate and Demnant, id. vol. xvii. pt. 1, p. 224.

1896. Barbatia celleporacea, Pritchard, Proc. Roy. Soc. Vict. vol. viii. N.s. p. 147.

Shell elongate-oblong, inequilateral ; anterior side short; posterior side elongated, obtusely ancular, posterior slope carinated; ventral margin slightly sinuated; surface ornamented with concentric folds raised into frills which are most prominent posteriorly. The author remarks that the frills "in aged specimens pass into uncinate seales or hollow tubercles, the fimbriations within the interstitial spaces not infrequently perforated, the entire ornamentation simulating a polyzoal growth, as in Cellepora." Dimensions.-Height $12 \mathrm{~mm}$.; length $24 \mathrm{~mm}$.

Form. and Loc.-Eocene: Muddy Creek, Victoria.

L. 4797. Three specimens of the neanic stage of growth.

Presented by John Dennant, Esq.

I. 6595. Example of the adult, both valves. Purchased.

L. 9907. Series illustrating stages of growth.

Purchased.

\section{Arca (Barbatia) consutilis, Tate (sp.).}

1886. Barbatia consutilis, Tate, Trans. Roy. Soc. South Aust. vol. viii. p. 142, pl. ii. fig. 15 .

1893. Barbatia consutilis, Tate and Dennant, id. rol. xvii. pt. 1, p. 224.

Shell oblong, hinge area narrower than in $A$. celleporacea, whilst the posterior side is not so much prolonged; anterior side short, rounded, not angulate; external ornament consisting of crowded longitudinal lineations crossed by closely-set concentric lineations of about the same strength, slightly granulated at the points of intersection, the anterior and posterior extremities of the shell having this structure exaggerated.

Dimensions.-Height $15.5 \mathrm{~mm}$; length $31 \mathrm{~mm}$.

Form. and Loc.-Eocene: Muddy Creek, Victoria.

L. 4795. Examples of the adult, both ralves.

Prescnted by Jolin Dennant, Esq.

L. 6594. Two specimens. Purchased.

L. 9908. Series illustrating stages of growth. Purchased. 


\section{Arca (Barbatia) crustata, Tate (sp.).}

1886. Barbatia crustata, Tate, Trans. Roy. Soc. Sonth Aust. vol. viii. p. 140, pl. ii. fig. 16.

1889. Barbatia crustata, Dennant, id. vol. xi. p. 50.

1593. Barbatia crustata, Tate and Dennant, id. vol. xrii. pt. 1, p. 224.

Shell rhomboidal, though broader posteriorly, medially longitudinally depressed, ventral margin sinuated; hinge-line long, straight; external ornament consisting of bold, undulating concentric lineations, crossed by longitudinal lines, which become slightly swollen at the points of intersection, and have the appearance of being broken up into short lengths.

The median depression is characteristic, and serves to distinguish it from the young of $A$. celleporacea, to which it bears a superficial resemblance; another point of difference, on comparison with that species, is the relatively larger reticulated area between the obtuse keel and the superior border posteriorly in $A$. crustata.

Dimensions.-Height $5 \mathrm{~mm}$.; length $10 \mathrm{~mm}$.

Form. and Loc.-Eocene: Muddy Creek, Victoria.

L.9309. Several specimens of divers stages of growth. Purchased.

\section{Arca (Barbatia) simulans, Tate (sp.).}

1886. Barbatia simulans, Tate, Trans. Roy. Soc. South Aust. vol. viii. p. 142 , pl. xi. fig. 10 .

1889. Barbatia simulans, Dennant, id. vol. xi. p. 50 .

1893. Barbatia simulans, Tate and Dennant, id. vol. xvii. pt. 1, p. 224.

Differs from $A$. consutilis in being slightly less tumid and relatively longer; the hinge-line is straighter and longer, and is angulate at both ends. The ornament consists of closely-set radiating costr, each rib of the posterior half being longitudinally sulcated; growth-lines raised and prominent, causing granulation at the points of intersection with ribs.

Dimensions.-Height $15 \mathrm{~mm}$. ; length $27 \mathrm{~mm}$.

Form. and Loc.-Eocene: Muddy Creek, Victoria.

L. 6596. Examples of both ralres.

Purchased. 


\section{Arca (Barbatia) decussata, Sowerby.}

1833. Byssoarca decussata, Sowerby, Proc. Zool. Soc. p. 18.

1844. Arca dccussata, Reeve, Conch. Icon, vol. ii. pl. xii. fig. 81 .

? 1873. Barbatia sinuata, Hutton, Cat. Tert. Moll. N.Z. p. 27.

1880. Barbatia decussata, Hutton, Man. N.Z. Moll. p. 162.

1893. Area decussata, Hutton, Linn. Soc. N.S.W., Macleay Mem. Vol. p. 86.

The shell of this species closely resembles that of $B$. simulans, but that portion anterior to the umbones is relatively shorter, and the latter are very broad aud incurved; perhaps the most striking differences are the larger number of teeth on the hinge and the greater distance between the umbo and the beginning of the ridge which denotes the commencement of the anterior section of the hinge-line; the anterior margin is less rounded than in $B$. simulans, and the ventral margin is usually more deeply sinuated.

Dimensions.-Height $22 \mathrm{~mm}$; ; length $38 \mathrm{~mm}$.

Form. and Loc.-Pliocene: Shakespeare Cliff, New Zealand.

L. 10442. Examples of both valves of the adult.

Sir James Hector Coll.

\section{Arca (Barbatia) pumila, Tate (sp.).}

1886. Basbatia pumila, Tate, Trans. Roy. Soc. South Aust. vol. viii. p. 142, pl. x. fig. 7 .

1889. Bavbatia pumile, Dennant, id. vol. xi. p. 50.

1893. Barbatia pumila, Tate and Dennant, id. vol. xvii. pt. 1, p. 224.

Distinguished by the crenulations on the inside of the margin, which are very conspicuous on the posterior portion; dorsal and ventral margins straight; the radial ribs and concentric strix produce granular thickenings at the points of intersection, the ribs being much larger on the posterior slope than in the middle of the valve; umbones obtuse.

Dimensions.-Height $5.5 \mathrm{~mm}$.; length $9 \mathrm{~mm}$.

Form. and Loc.-Eocene: Muddy Creek, Victoria.

L. 4796. Right valve, of the neanic stage of growth.

Presented by John Dennant, Esq. 


\section{Subgenus PLAGIARCA, Conrad.}

[Geol. Surv. North Carolina, vol. i. 1875, App. A, p. 4.]

Shell transvorscly elongate; cardinal border straight, narrow, angulate at the extremities; teeth oblique; surface ornamented by radiating ribs and often punctate; ligamental area narrow.

Type.-Barbatia carolinensis, Conrad.

\section{Arca (Plagiarca) cainozoica, Tate (sp.).}

1886. Macyodon cainozoicus, Tate, Trans. Roy. Soc. South Aust. vol, viii. p. 143 , pl. x. fig. 4 .

1889. Macrodon cainozoicus, Dennant, $i d$. vol. xi. p. 50.

1893. Plagiarca cainozoica, Tate and Dennant, id. vol. xvii. pt. 1, p. 224.

The concentric ridges on the surface of the valres are more prominent than the broken radial lineations; umbones close to the anterior border; hinge area narrow, lineate; posterior border oblique, rounded and produced underneath; centre of the cardinal border edentulous.

Dimensions.-Height $10 \mathrm{~mm}$. ; length $22 \mathrm{~mm}$.

Form. and Loc.-Eocene: Muddy Creek, Victoria.

L. 4807. Two specimens of the neanic stage of growth.

Presented by John Dennant, Esq.

L. 6597. Examples of the adult. Purchased.

L. 9875. Series illustrating stages of growth. Purchased.

\section{Subgenus FOSSULARCA, Cossmann.}

[Ann. Soc. Roy. Malac. Belg. t. xxii. 1987, p. 138.]

Shell subquadrangular, inequiralre; surface trellised; ligamental area narrow, haring under the umbo a small triangular pit; teeth almost equal in size; more or less oblique.

Closely allied to Limopsis, but the eardinal pit is not so deep, the disposition of the teeth is different, and the form of the ralres is that of Arca.

Type.-Aroa quadrilatera, Lamarek. 


\section{Arca (Fossularca) dissimilis, Tate (sp.).}

1886. Barbatia dissimilis, Tate, Trans. Roy. Soc. South Aust. vol. viii. p. 140 , pl. xi. figs. $4,5$.

Shell rather tumid, rounded in front, truncated behind; ventral and dorsal margins nearly parallel; left ralve radially ribbed, crossed by concentric threarls, granulated at the points of intersection; right valve with equidistant concentric folds, pitted between.

Dimensions.—Height $5 \cdot 5 \mathrm{~mm}$.; length $8 \mathrm{~mm}$.

Form. and Loc.-Eocene: Aldinga, South Australia.

L. 9868. Several examples of both valves.

Purchased.

\section{Genus CUCULL王A, Lamarek.}

[Syst. Anim. sans Vert. 1801, p. 116.]

Shell rhomboidal, gibbose, almost completely equivalre; umbones far apart; area broad, large, having divergent ligament grooves; cardinal border narrow, anterior and posterior teeth large, oblique, almost horizontal, long, those in the centre short and vertical; posterior muscular impression large, usually bordered in front by a ridge.

Type-_Cucullea auriculifera, Lamarck.

\section{Cucullæa corioensis, $\mathrm{I}^{\top}{ }^{\circ} \mathrm{Coy}$.}

1876. Cucullea corioensis, M'Coy, Prod. Pal. Vict. dec. iii. p. 32, pl. xxrii. figs. $3-5 b$.

1886. Cucullaa corioensis, Tate, Trans. Roy. Soc. South Anst. vol. viii. p. 144.

18s8. Cucullea corioensis, R. M. Johnston, Geol. Tasmania, p. 235, pl. xxix. figs. $4-4 a$.

1893. Cucullea coriocnsis, Tate and Deunant, Trans. Roy. Soc. South Aust. vol. xrii. pt. 1, p. 224.

1896. Cucullea corioensis, Pritchard, Proc. Roy. Soc. Vict. vol. viii. x.s. p. 131 .

This species is allied to the European Eocene C. decussata, Parkinson, but the surface is not so highly sculptured. The shell is very gibbose, umbones prominent and incurred; area broad, almost flat, with numerous diverging, slightly undulating grooves; 
the teetb are very small and vertical in the ceutre, and large and horizontal at the extremities of the hinge-line; margin of the valves crennlated. The surface ornament consists of numerous, closely-set, radial ribs and lineations, crossed by transverse lines and ridges of growth.

Dimensions.-Height $49 \mathrm{~mm}$.; length $63 \mathrm{~mm}$.

Form. and Loc. - Eocene: Tasmania, Victoria, and South Australia.

42684. Cast of an adult; (locality ?) South Australia.

Presented by the Governors of Adelaide Museum.

42698. Cast of a left valve; from near Adelaide.

Presented by M. Marshall, Esq.

70399. Cast of both valves, in ferruginous sandstone; from Mordialloc, near Melbourne.

Purchased.

70411. Double-valved specimen ; from "Meribee river," Victoria.

Purchased.

83978. Right valre, neanic stage of growth; from Table Cape. Purchased.

98219. Left valve of an adult; from Flinders I. Purchased.

L. 4789. Examples of the neanic and ephebic stages of growth, both valres; from Muddy Creek. Presented by John Dennant, Esq.

L. 5644. Cast of both valres; from Gippslanil.

Presented by the Rev. J. S. II. Royce.

L. 6598. Right and left valves, in which the reutral margin is strongly plicated in the interior; from Mndlly Creek. Purchasel.

L. 9835 . Scries illustrating stages of growth, from the brephic to the ephobic. The smaller specimens indicate that at an early stage the interior of the shell is radially lineated, whilst the external ornament is very pronouneed. From MLuddy Creek.

Purchased.

L. 10568. Specimens of both ralves; from River Murray eliffs, near Adelaide. Presented by $\mathrm{Wm}$. Evans, Esq.

L. 10571. Cast of a rather elongate variation; from River Murray cliffs. Transferred from the Mheseum of Practical Geology.

L. 10572. Casts of left valves; from the Tertiary of Fowler's Bay District.

II. I. L. brown Coll. 


\section{Cucullæa alta, G. B. Sowerby.}

1846. Cucullea alta, G. B. Sowerby, in Darwin, Geol. Obs. South America, Appendix, p. 252, pl. ii. figs. 22, 23.

1873. Cucullea alta, Hutton, Cat. Tert. Moll. N.Z. p. 27.

None of the specimens in the Museum collection are well enough preserved to enable the writer to identify with certainty the New Zealand form with that from South America, and the determination is chiefly based on the authority of Professor Hutton. The shell is remarkable for its extreme tumidity, great breadth of the area, and immense internal ridge, on which are the scars of the posterior adductor of the valves.

Dimensions.-Height $67 \mathrm{~mm}$. ; length $77 \mathrm{~mm}$.

Form. and Loc._Eocene and Miocene: New Zealand.

83328. Right, valve; from the mouth of the Kakanti river, Oamaru.

Presented by Dr. W. L. Lindsay.

I. 10440. Two casts of the adult; from Akuakua (upper beds), east coast of Auckland. Sir James IIector Coll.

L. 10509. Portion of left valve; from Akuakua (lower beds). Sir James Hector Coll.

I. 10511. Left valve of the adult; from Taipos.

Sir James Hector Coll.

L. 10561. Both valves, in shelly argillaceous sandstone; from Akuakua (lower beds).

Sir James Hector Coll.

\section{Cucullæa attenuata, Hutton.}

1873. Cucullac attenuata, Hutton, Cat. Tert. Moll. N.Z. p. 28.

Shell not so tumid as in $C$. corioensis; it is much attenuated posteriorly; umbones very broad, distant; area broad, with a few divergent, deeply-cut sulci; external ornament consisting of closly-set radiating costæ, crossed by frequent minute transverse lineations and growth-lines.

Dimensions.-Height $80 \mathrm{~mm}$; ; length $109 \mathrm{~mm}$.

Form. and Loc.-Eocene and Miocene: New Zealand. 
L. 10506. Several casts, presumably of this species; from Akuakua (upper beds).

Sir James Hector Coll.

L. 10508. Casts of typical examples; from Akuakua (lowex beds).

Sir James Hector Coll.

L. 10510. Example of the right valve; from Taipos.

Sir James Hector Coll.

Cucullæa worthingtoni, Hutton.

1873. Cucullaa worthingtoni, Hutton, Cat. Tert. Moll. N.Z. p. 27.

"Ventricose, much larger than high; posterior side producel, rather dilated; umbones distant; hinge at right angles to the axis of the shell."-Hutton.

It is difficult to satisfactorily determine specimens from such a meagre description, but that alluded to below is probably referable to this species.

Dimensions.-Height $66 \mathrm{~mm}$; length $87 \mathrm{~mm}$.

Form. and Loc.-Pliocene (?): Parimoa, New Zealand.

L. 10445. Left valve of the adult. W. B. D. Mantell Coll.

Genus PECTUNCULUS, Lamarck.

[Mém. Soc. Hist. Nat. Paris, 1799, p. 87.]

This differs from Cucullea, in being orbicular, or suborbicular, equivalve and almost equilateral; the umbones are closer together, and the area is, in consequence, narrower and relatively smaller. The ligamental area, which is external, carries diverging grooves; cardinal border semicircular; teeth prominent, strong, becoming obliterated under the umbones as the gerontic stage is approached, by the invasion of the ligamental area; margins of the ralres crenulated.

Type.-Arca pectunculus, Linnæus. 


\section{Pectunculus cainozoicus, Tenison-Woods (sp.).}

1877. Cucullac cainozoica, Tenison-Woods, Pap. Roy. Soc. Tas. 1876, p. 111. 18S6. Pectuneulus cainozoicus, Tate, Trans. Roy. Soc. South Aust, vol. viii. p. 136, pl. x. figs. $8 a-b$.

1888. Pectunculus cainozoicus, Johnston, Geol. Tasmania, pl. xxxi. figs. 13a-b. 1893. Pectunculus cainozoicus, Tate and Denuant, id. vol. xrii. pt. 1, p. 224. 1896. Pectunculus cainozoicus, Pritchard, Proc. Roy. Soc. Vict. vol. viii. N.s. p. 130.

Shell roundly trigonal, oblique; surface faintly and closely marked with radiating ribs and concentric strix and ridges; umbones acute, incurred; area conspicuous, broad, traversed by divergent ligament grooves; teeth large, oblique; adductors of the valves large, shell on the inside of each depressed, the edges of the depressions bordering the scars and meeting the simple pallial line.

It is closely allied to $P$. cor, Lamarck, and young specimens of that are separated with difficulty from the present species. $P$. cainozoicus, however, has a relatively larger hinge, the umbones are more elevated and acute, and the depression on either side of the adductor scars is characteristic.

Dimensions. - Height $51 \mathrm{~mm}$.; length $52 \mathrm{~mm}$.

Form. and Loc.-Eocene and Miocene: Tasmania and Victoria.

83981. Two examples of the neauic stage of growth; from Table Cape.

Purchased.

L. 4825. Three specimens of the adult; from Muddy Creek. Presented by Jolu Dennant, Esq.

L. 6590. Left valve; from Muddy Creek. Purchased.

I. 6616. Right valve, abnormally thickened; from Muddy Creek.

Purchased.

L. 9896. Four examples; from Table Cape.

Purchased.

\section{Pectunculus subtrigonalis, Tate.}

1886. Pectunculus subtrigonalis, Tate, Trans. Roy. Soc. South Aust. vol. viii. p. 137, pl. xi. figs. $6 a-b$.

Shell solid, subtrigonal, subequilateral, oblique, slightly produced, convex; surface having about thirty conspicuous, broad, rounded, radiating costæ, separated by rather smaller, concave 
depressions, the whole being crossed by very closely-set lineations, and few ridges of growth; umbones small; area constricted, grooved; hinge-line very short; teeth few in number; inner margin of the valres broadly and strongly crenulate.

The surface ornament recalls the European Oligocene $P$. angusticosta, Lamarck, but the latter shell is orbicular, has a smallor ligament area, and more numerous teeth.

Dimensions.-Height $27 \mathrm{~mm}$. ; length $27 \mathrm{~mm}$.

Form. and Loc.-Eocene: South Australia and Victoria.

L. 4826. Two valres, much waterworn; from Muddy Creek.

Presented by John Dennant, Esq.

I. 9897. Several examples of the adult; from River Murray cliffs.

Purchased.

\section{Pectunculus laticostatus, Quoy and Gaimard.}

1834. Fectunculus laticostatus, Quoy and Gaimard, Voy. de l'Astrolabe, vol. iii. p. 466, pl. lxxvii. figs. 4-6.

1875. Pectunculus laticostatus, M['Coy, Prod. Pal. Vict. dec. ii. p. 26, pl. xix. figs. 10-14.

1884. Pectunculus maccoyi, Johnston, Pap. Roy. Soc. Tas. p. 199.

1886. Pectunculus laticostatus, Tate, Trans. Roy. Soc. South Aust. rol. viii. p. 137.

1886. Pcctunculus maccoyi, Tate, id. p. 137.

1858. Pectunculus maccoyi, Johuston, Geol. Tasmania, p. 235, pl. xxxi. figs. $1-1 d$.

1893. Pectunculus laticostatus, Tate aud Dennant, Trans. Roy. Soc. Sonth Aust. vol. xrii. pt. 1, p. 224.

1895. Pectunculus laticostatus, Tate and Dennant, id. vol. xix. pt. 1, p. 112.

1896. Pectunculus laticostatus, Pritchard, Proc. Roy. Soc. Vict. vol. viii. N.s. p. 130.

This species is closely allied to $P$. subtrigonalis, but it is thinner, suborbicular (instead of subtrigonal), much more depressed, and has a narrow hinge-line. Comparison of authenticated specimens of $P$. maccoyi, Johnston, with the living $P$. laticostatus, enables the writer to state, definitely, that they are synonymous.

Dimensions. - Height $72 \mathrm{~mm}$.; length $74 \mathrm{~mm}$.

Form. and Loc.-Eocene, Miocene, and Pliocene: Tasmania, Victoria, South Australia, and New Zealand.

83998. Left valve narrower than typical specimens; from Table Cape.

Purchased.

98220. Left ralse; from Table Cape. Purchased. 
L. 4828. Three specimens; from Muddy Creek.

Presented by John Dennant, Esq.

L. 5590. Example of the neanic stage of growth; from Mruddy Creck. Presented by Professor T. Rupert Jones, F.R.S.

L. 6591. Specimens of both valves; from Muddy Creek.

Purchased.

L. 9895. Series illustrating stages of growth; from Muddy Creek.

Purchased.

L. 10446. Right valve of the adult; from Parimoa.

W. B. D. Mantell Coll.

L. 10569. Many examples of both valves; from River Murray cliffs, near Adelaide.

Presented by IVilliam Evans, Esq.

L. 10564. Both valves of the adult; from Wanganui.

Sir James Hector Coll.

\section{Pectunculus convexus, Tate.}

1886. Pectunculus convexus, Tate, Trans. Roy. Soc. South Aust. vol. viii. p. 138 , pl. xi. figs. $7 a-b$.

1893. Pectunculus convexus, Tate and Dennant, id. vol. xvii. pt. 1, p. 224.

Nore tumid and more boldly sculptured than any other species of Pectunculus here mentioned; the ligamental area is very small, and the inner side of the margin strongly erenulated. The bold radiating costæ are about 24 in number and are crossed by fine growth-lines closely-set.

Dimensions._Height $28 \mathrm{~mm}$.; length $28 \mathrm{~mm}$.

Form. and Loc.-Miocene: Muddy Creek, Victoria.

L. 482\%. Left valve. Presented by John Dennant, Esq.

L. 6592. Examples of both valres. Purchased.

\section{Pectunculus flabellatus, Tenison-Woods.}

1878. Pectunculus fabellatus, Tenison-Woods, Trans. Roy. Soc. Vict. vol. xiv. p. 61 .

Shell more depressed than $P$. convexus, and the interspaces between the costæ are not as wide; the ligament area, also, is much smaller.

Dimensions.-Height $24 \mathrm{~mm}$. ; length $23 \mathrm{~mm}$.

Form. and Loc.-Post-Pliocene : Limestone Creek, Glenelg river, Victoria.

L. 6569. Two specimens, rather waterworn.

Purchased. 


\section{Pectunculus globosus, Hutton.}

1873. Pectunculus globosus, IIutton, Cat. Tert. Moll. N.Z. p. 28.

"Ventricose, subequilateral, as high as long; posterior end rounded, rather broader than the anterior; umbones rather distant, hinge at right angles to the axis of the shell, slightly curred, teeth oblique."-IIutton.

Dimensions.-Height $96 \mathrm{~mm}$. ; length $97 \mathrm{~mm}$.

Form. and Loc.-Miocene: New Zealand.

L. 10451. Example of the neanic stage of growth, in which the growth-lines are remarkably regular and distinct; locality (?).

[Old Collection.]

I. 10512. An immense double-valved specimen; from Hick's Bay.

Sir James Hector Coll.

L. 10513. Left valve; from Trelissick (upper beds).

Sir James Hector Coll.

L. 10515. Less tumid than typical specimens, both probably referable to this species.

Sir James Hector Coll.

\section{Pectunculus, sp.}

L. 5649. Casts of a large species allied to P. laticostatus; from Gippsland. Presented by the Rev. J. S. II. Royce.

L. 10514, L. 10540, L. 10562. Casts of a species resembling $P$. globosus; from the Eocene of Akuakua (lower beds).

Sir James Hector Coll.

Genus LIMARCA, Tate.

[Trans. Roy. Soc. South Aust. rol. viii. 1886, p. 135.]

"Very inequilateral; cartilage pit lanceolate, excarated on the hinge-line, directed backwards; hinge-line with anterior denticles and posterior elongated lougitudinal teeth. No area under the umbo."-Tute.

It is alliced to Limopsis, though the characters of the cardinal region recall Crenella. It agrees with Trinacria by the absence of an umbonal area, but differs in having fewer cardinal teeth.

Type.-Limarca angustifrons, Tate. 


\section{Limarca angustifrons, Tate.}

1886. Limarca angustifions, Tate, Trans. Roy. Soc. South Aust. vol. viii. p. 135 , pl. viii. figs. $5 a-b$.

Shell small; anterior margin rounded, posterior truncated; surface radially ribbed and concentrically lineated; ligamental pit excavated in the hinge-line, oblique, directed backwards; anterior to this pit are three prominent, almost horizontal denticles, and, posteriorly, are four longitudinal teeth; inner margin of the valves crenulated.

Dimensions.-Height $5.5 \mathrm{~mm}$; length $5 \mathrm{~mm}$.

Form. and Loc.-Eocene: Adelaide, South Australia.

L. 9873. Examples of both valves.

Purchased.

\section{Genus LIMOPSIS, Sasso.}

[Giornale Ligustico di Scienze, An. i. 1827, p. 476.]

Distinguished from Pectunculus, with which it is closely related, by the presence of a deep triangular pit underneath the umbo, by the less restricted but relatively broader cardinal border, and fewer teeth, which are oblique and best developed at the sides.

Type.-Arca aurita, Brocchi.

\section{Limopsis insolita, G. B. Sowerby (sp.).}

1846. Trigonocclia insolita, G. B. Sowerby, in Darwin, Geol. Obs. South America, p. 252, pl. ii. figs. 20, 21.

1865. Limopsis insolita, Zittel, Reise der Novara, Paläontologie, Bd. i. Abth. ii. p. 48 , pl, xiii. fig. 1.

1873. Limopsis insolita, Hutton, Cat. Tert. Moll. N.Z. p. 28.

1886. Limopsis insolita, Tate, Trans. Roy. Soc. South Aust. vol. viii. p. 134.

1893. Limopsis insolita, Tate and Dennant, id. rol. xrii. pt. 1, p. 224.

1895. Limopsis insolita, Tate and Dennant, id. rol. xix. pt. 1, p. 112.

Shell ovate, oblique; surface concentrically ridged, and faintly longitudinally striated, the strix being most pronounced towards the ventral margin; hinge-line curved, carrying a few conspicuous teeth almost rertical in the centre; under the umbo is a well- 
marked triangular pit. One of the adductors of the valres is situated close under the termination of the hinge; whilst the other is considerably removed therefrom, towards the oblique prolongation of the shell; pallial line simple, inside which is a number of radiating strix.

Dimensions.-Height $28 \mathrm{~mm}$.; length $31 \mathrm{~mm}$.

Form. and Loc.-Eocene, Miocene, and Pliocene (?): South Australia and New Zealaud.

L. 10444. Variation, in which the shells are abnormally high; from Parimoa.

W. B. D. Mantell Coll.

L. 10447. Several examples of both ralves, showing considerable variation in regard to tumidity; from Willunga.

H. Y. L. Brown Coll.

L. 10450. Series illustrating stages of growth; (locality?) New Zealand.

[ Old Collection.]

\section{Limopsis belcheri, Adams and Reere (sp.).}

1850. Pectuneulus belcheri, Adams and Reeve, Voy. Samarang, p. 76, pl. xxii. fig. 5 .

1875. Limopsis beleheri, M'Coy, Prod. Pal. Tict. dec. ii. p. 25, pl. xix. figs. $8,9$.

1886. Limopsis belcheri, Tate, Trans. Rov. Soc. South Aust. vol. viii. p. 134.

1893. Limopsis belcheri, Tate and Dennant, id. rol. xrii. pt. 1, p. 224.

Similar to $L$. insolita, but rather more produced and oblique; the hinge-line is arcuate, the teeth are rertical in the centre and become almost horizontal at the sides; the triangular pit is narrower; but the most conspicuous distinctions are the pronounced radiating lineations on the surface, and the subordination of the concentric growth-lines thereto, the rererse of which is the case in $L$. insolita.

Dimensions.-Height $22 \mathrm{~mm}$. ; length $24 \mathrm{~mm}$.

Form. and Loc.-Eocene and Miocene (?): Victoria and South Australia.

L. 350. Two examples of the neanic stage of growth; from Bairnstale. Presented by W. II. Grigson, Esq.

L. 4836. Specimens of both valves of the adult; from Muddy Creek. Presented by John Dennant, Esq. 
L. 6593. Both valves of the adult; from Muddy Creek.

Purchased.

L. 9860. Sereral specimens; from River Murray cliffs.

Purchased.

L. 105\%0. Many examples; from River Murray cliffs. Presented by $W m$. Evans, Esq.

\section{Limopsis multiradiata, Tate.}

1886. Limopsis multiradiata, Tate, Trans. Roy. Soc. South Aust. vol, viii. p. 135 , pl. xii. figs. $1 a-b$.

Readily distinguished from $L$. insolita and $L$. belcheri, by its orbicular shape, small size, Pectunculus-like tessellated surface sculpture, with bifurcate radial costæ, and crenulated inner margin. Triangular pit large, equilateral.

Dimensions.-Height $4 \mathrm{~mm}$. ; length $4 \mathrm{~mm}$.

Form. and Loc.-Eocene: Aldinga, South Australia.

L. 9859. Examples of both valves.

Purchased.

\section{Limopsis aurita, Brocchi (sp.).}

1814. Arca aurita, Brocchi, Conch. Foss. Subappenn. p. 485 , pl. xi. fig. 9. 1873. Limopsis zealandica, Hutton, Cat. Tert. Moll. N.Z. p. 28.

1875. Limopsis aurita, M'Coy, Prod. Pal. Vict. dec. ii. p. 23, pl. xix. figs. $5-7$.

1886. Limopsis aurita, Tate, Trans. Roy. Soc. South Aust. vol. viii. p. 134. 1893. Limopsis awita, Tate and Dennant, id. vol. xvii. pt. 1, p. 224.

There appears to be no conchological difference between the European and Australasian examples of this variable species. Typically, the shell is not so oblique as $L$. belcheri; radial lineations are barely perceptible (or absent) in many individuals. The writer agrees with Professor Tate (op. supra eit., 1886) that L. zealandica, Hutton, is a synonym.

Dimensions.-Height $21 \mathrm{~mm}$.; length $22.5 \mathrm{~mm}$.

Form. and Loc.-Wiocene: A wamoa, New Zealand.

L. 10566 . Examples of both valves.

Sir James Hector Coll. 


\section{Family NUCULID王.}

\section{Genus NUCULA, Lamarek.}

[Mém. Soc. Hist. Nat. Paris, 1799, p. 87.]

Shell oval, or elongate, cquivalve, inequilateral, posterior side very short; umbones incliued posteriorly; surface smooth or striated; hinge angulate; ligamental pit internal, triangular, and on each side are dereloped numerous compressed, sharp teeth; interior of the valres nacreous, adductor impressions subequal; pallial line simple.

\section{Type.-Arca nucleus, Linnæus.}

\section{Nucula tenisoni, Pritchard.}

1877. Nucula tumida, Tenison-Woods, Pap. Roy. Soc. Tas. 1876, p. 111 (non Hinds nee Philippi).

1878. Nuoula grayi, Tenison-Woods, id. 1877, p. 55 (non D'Orbigny).

1886. Nucula tumida, Tate, Trans. Roy. Soc. South Aust. vol. viii. p. 127, pl. vi. figs. $6 a-b$.

1893. Nucula tumida, Tate and Dennant, id. vol. xvii. pt. 1, p. 224.

1895. Nucula tumida, Tate and Denuant, id. vol. xis. pt. 1, p. 112.

1896. Nucula tenisoni, Pritchard, Proc. Roy. Soc. Vict. vol. viii. x.s. p. 128.

Shell solid, tumid, smooth; surface with sereral concentric growth-folds, lunule conspicuous; margin acute, not crenulated; "lhinge teeth diverging progressively in an increasing series, interrupted by a narrow, deep ligamental pit, which is obliquely produced" (Tate); the posterior row has about eight teeth, and the anterior thirty.

Mr. G. B. Pritchard (op. cit. supra, pp. 128-130), has treated of the synonymy at some length; the present writer has not the materials to enable him to express an opiuion as to whether $N$. tumida and $N$. grayi, Tenisou-Woods, are, or are not, identical.

Dimensions.-Height $17 \mathrm{~mm}$. ; length $22 \mathrm{~mm}$.

Form. and Loc.-Eocene: Tasmania and Victoria.

83995. Right valve; from Table Cape.

Purchased.

L. 4808. Sereral examples of both valres; from Muddy Creek. Prosented by John Dennant, Esq.

L. 9827. Serics illustrating stages of growth; from Mruddy Creek.

Purchased. 


\section{Nucula atkinsoni, Johnston (sp.).}

1881. Portlandia atkinsoni, Johnston, Pap. Roy. Soc. Tas. 1880, p. 39.

1886. Nucula atkinsoni, Tate, Trans. Roy. Soc. South Aust. vol. viii. p. 127, pl. iv. figs. $3 a-c$.

1893. Nucula atkinsoni, Tate and Dennant, id. vol. xvii. pt. 1, p. 224.

1896. Nucula atkinsoni, Pritehard, Proc. Roy. Soc. Vict. vol. viii. x.s. p. 147.

Nuch smaller than $N$. tenisoni, it may be distinguished from that species by the crenulated margin, and the tessellated sculpture of the exterior, in which the concentric lineations are the most prominent; ligament pit relatirely smaller.

Dimensions.-Height $6 \mathrm{~mm}$. ; length $7 \mathrm{~mm}$.

Form. and Loc.-Eocene: Muddy Creek, Victoria.

L. 9828. Examples of both ralves.

Purchased.

\section{Family NUCULANID无.}

\section{Genus NUCULANA, Link.}

[Besch. Rostock, Abth. iii. 1807, p. 155.]

Leda, Schumacher, Essai Nouv. Syst. Habit. Testacés, 1817, p. 173.

Differs principally from Nucula in being more or less produced and angulate in front, the surface is concentrically or obliquely ridged, and carries a well-defined keel curving from the umbo to the rostrate prolongation. The cardinal border is slightly angulate, hinge teeth numerous; pallial line sinuous.

Type.-Arca rostrata, Linnæus.

\section{Nuculana vagans, Tate (sp.).}

1880. Lcda lucida, Tenison-Woods, Proc. Linn. Soc. N.S.W. vol. iv. p. 3, pl. i. fig. 5 (non Lovén).

1886. Lcda lucida, Tate, Trans. Roy. Soc. South Aust. vol. riii. p. 131, pl. vi. figs. 7a-b (non Lovén).

1887. Leda vagans, Tate, id. vol. ix. p. 188.

1893. Leda vagans, Tate aud Dennant, id. vol. xvii. pt. 1, p. 224.

Shell solid, subventricose; umbones small, very slightly directed posteriorly; anterior side rounded, posterior rostrate; rentral 
margin straight, but sharply sloping upwards posteriorly; surface having concentric striæ and lines of growth; lunule elliptical, striated; ligament pit internal, directly under the umbo; cardinal teeth very numerous.

Professor Tate's interpretation of the immature shell figured by Tenison-Woods, in the memoirs above cited, is here accepted.

Dimensions.-Height $10.5 \mathrm{~mm}$. ; length $17 \mathrm{~mm}$.

Form. and Loc.-Eocene: River Murray cliffs, South Australia.

L. 9858. Sereral examples of both ralves.

Purchased.

Nuculana acinaciformis, Tate (sp.).

1886. Leda acinaciformis, Tate, Trans. Roy. Soc. South Aust. vol. viii. p. 130 , pl. v. figs. $6 a-b$.

Shell more elongate posteriorly than $N$. vagans, rentral margin gracefully curred, not so solid, hinge-line narrower; exterior of the shell equidistantly deeply striated, posterior keel conspicuous; lunule lanceolate, longitudinally ridged.

Dimensions.-Height $12 \mathrm{~mm}$.; length $23 \mathrm{~mm}$.

Form. and Loc.-Miocene: Muddy Creek, Victoria.

L. 4799. Right ralre.

Presented by John Dennant, Esq.

L. 6602. Examples of both ralres.

Purchased.

L. 9820. Specimens of the brephic and neanic stages of growth.

Purchased.

\section{Nuculana woodsi, Tate (sp.).}

1879. Leda inconspicua, Tenison-Woods, Proc. Linn. Soc. N.S.W. rol. iii. p. 139, pl. xxi. fig. 3 (non A. Adams).

1S56. Leda woodsii, Tate, Trans. Roy. Soc. South Aust. rol. riii. p. 133, pl. ix. fig. 8 .

1893. Leda woodsi, Tate and Dennant, id. rol. xrii. pt. 1, p. 224.

Allied to $N$. ragans, from which it differs in haring an arcuate (instead of a straight) ventral margin, a somewhat less elongate aud biangulate posterior rostrum, in being closely, evenly, concentrically striated on the surface, and in having a distinct posterior eurred keel commencing at the umbo, between which and the posterior 
dorsal margin the concentric striæ are commonly bolder than on any other part of the shell; lunule inconspicuous, elongate.

Dimensions.-Height $4.5 \mathrm{~mm}$; ; length $8 \mathrm{~mm}$.

Form. and Loc.-Eocene: MLuddy Creek, Victoria.

I. 9821. Sereral specimens of both valves.

Purchased.

\section{Nuculana apiculata, Tate (sp.).}

18S6. Leda apiculata, Tate, Trans. Roy. Soc. South Aust. vol. viii. p. 131, pl. ix, figs. $4 a-b$.

1893. Leda apiculata, Tate and Dennant, id. vol. xvii. pt. 1, p. 224.

1895. Leda apiculata, Tate and Denuant, id. vol. xix. pt. 1, p. 112.

Shell ovate-subtrigonal, ventricose; gradually acuminately rostrated; umbones moderately inflated; posterior dorsal area depressed, but slightly elevated at the extremity ; surface carrying numerous small concentric threads; lunule distinct.

Dimensions.-Height $5 \mathrm{~mm}$.; length $8 \mathrm{~mm}$.

Form. and Loc.-Eocene: Muddy Creek, Victoria.

L. 9826. Several examples of both valves.

Purchased.

\section{Nuculana leptorhyncha, Tate (sp.).}

1886. Leda leptorhyncha, Tate, Trans. Roy. Soc. South Aust. vol. viii. p. 131, pl. x. figs. $5 a-b$.

This species is not unlike the joung of $N$. apiculata, from which, however, it differs by the contraction and compression beneath the rostral prolongation, and by its irregular sculpturing.

Dimensions.-Height $3 \mathrm{~mm}$.; length $5 \mathrm{~mm}$.

Form. and Loc.-Eocene: Aldinga, South Australia.

L. 9824. Sereral examples.

Purchased.

\section{Nuculana crassa, Hinds (sp.).}

1843. Nucula crassa, Hinds, Proc. Zool. Soc. p. 99.

1871. Lada crassa, Sowerby, Conch. Icon. vol. xviii. pl. v. fig. 27.

1877. Leda erassa, Angas, id. p. 193.

1885. Leda crassa, E. A. Smith, Toy. "Challenger," Zool. vol. xiii. Lamellibranchiata, p. 237. 
Shell large, solid, hinge-line angulate, carrying a large number of $\mathrm{V}$-shaped teeth; ligament pit directly under the umbo, very deep; lunule large, striated; surface closely regularly lineate; kecl from the umbo to the rostrum prominent, curred; ventral margin arcuate.

Dimensions.-Height $22 \mathrm{~mm}$. ; length $35 \mathrm{~mm}$.

Form. and Loc.-Post-Pliocene: Limestone Creek, Glenelg river, Victoria.

L. 6574. Examples of both valves of the adult. Purchased.

\section{Nuculana huttoni, Tenison-Woods (sp.).}

1879. Leda huttoni, Tenison-Woods, Proc. Linn. Soc. N.S.W. vol. iii. p. 239, pl. xxi. fig. 2.

1886. Leda huttoni, Tate, Trans. Roy. Soc. South Aust. fol. riii. p. 130, pl. vi. fig. 4.

1893. Leda huttoni, Tate and Dennant, id. rol. xrii. pt. 1, p. 224.

Much more elongate than any other species of Auculana here described. The umbones are placed well forward; anterior side rounded; posterior elongate, truncate, and biangulate; surface concentrically irregularly striated and sulcate, and haring microscopic radiating striations.

Dimensions.—Height $4.5 \mathrm{~mm}$; length $11.5 \mathrm{~mm}$.

Form. and Loc.-Eocene: Muddy Creek, Victoria.

L. 9822. Many examples of both valves, illustrating stages of growth.

Purchased.

\section{Nuculana prælonga, Tate (sp.).}

1886. Leda prelonga, Tate, Trans. Roy. Soc. South Aust. rol. riii. p. 133, pl. xii. figs. $4 a-b$.

This shell is very small, transverscly ovate, the posterior side being the shorter-features which render it easily recognizable amongst its congeners. It is compressed, smooth, the umbones are inconspicuous; whilst it has a well-defined pallial sinus.

Dimensions. -Height $3 \mathrm{~mm}$.; length $4 \mathrm{~mm}$.

Form. and Loc.-Eocene: Muddy Creek, Victoria.

L. 9857. Several specimens of both valres.

Purchased. 


\section{Nuculana obolella, Tate (sp.).}

1886. Leda obolella, Tate, Trans. Roy. Soc. South Aust. vol. viii. p. 129, pl. v. figs. $3 a-b$.

1893. Leda obolella, Tate and Dennant, $i d$. vol. xvii. pt. 1, p. 224.

1895. Leda obolella, Tate and Dennant, id. vol. xix. pt. 1, p. 113.

This shell can be distinguished with facility, being oval and fragile; the hinge is narrow, much contracted, and the teeth are very small; in addition, it is not rostrated, and the surface is only very faintly striated concentrically. It is by no means a typical example of the genus.

Dimensions. - Height $9 \mathrm{~mm}$.; length $12.5 \mathrm{~mm}$.

Form. and Loc.-Eocene: Muddy Creek, Victoria.

L. 9825. Examples of the neanic and ephebic stages of growth.

Purchased.

\section{Family TRIGONIID E.}

\section{Genus TRIGONIA, Bruguière.}

[Ency. Meth. Vers. t. i. 1789, p. xiv.; Lamarck, Syst. Anim. sans Vert. 1801, p. 116.]

Shell thick, subtrigonal, oval, or subtrapezoidal, inequilateral; umbones directed posteriorly ; cardinal teeth divergent, transversely striated; impression of the anterior adductor of the valves smaller than that of the posterior, deeper, and placed on the cardinal border; ligament marginal, thick; surface of the valves commonly ornamented by radiating ribs, or tubercles; interior of the shell nacreous.

Type.-Trigonia nodulosa, Lamarck.

Trigonia subundulata ( $\mathrm{I}^{\prime} \mathrm{Coy}$ MS.), Jenkins.

1865. Trigonia subundulata (M`Coy MS.), H. M. Jenkins, Quart. Journ. Sci. vol. ii. p. 362 , pl. viii. fig. 6 .

1866. Trigonia semiundulata, H. M. Jenkins, Geol. Mag. vol. iii. p. 201.

1866. Trigonia semiundulata, M'Coy, id. vol. iii. p. 481.

1875. Trigonia semiundulata, M'Coy, Prod. Pal. Vict. dec. ii. p. 22, pl. xix. figs. 4-5.

1878. Trigonia semiundulata, R. Etheridge, jun., Cat. Aust. Foss. p. 158.

1886. Trigonia semiundulata, Tate, Trans. Roy. Soc. South Aust. vol, viii. p. 145 . 
1888. Trigonia semiundulata, Johnston, Geol. Tasmania, p. 235, pl. xxix. fig. 5 .

1893. Trigonia semiundulata, Tate and Dennant, Trans. Roy. Soc. South Aust. vol. xvii. pt. 1, p. 224.

1896. Trigonia semiundulata, Pritchard, Proc. Roy. Soc. Vict. vol. viii. x.s. p. 131.

Shell abruptly truncated and crenulated posteriorly; umbones near the anterior margin, which, in consequence, is short; external ornament consisting of prominent, curved, radiating, and occasionally granulate costæ, which occupy nearly one-half of the surface posteriorly, and abruptly terminate against a number of rather smaller curved ridges parallel to the rentral margin; these latter also bear some inconspicuous radiating costæ about the middle of the shell, which produce granulations at the points of intersection with the curved ridges alluded to.

Dimensions.-Height $88 \mathrm{~mm}$; length $46 \mathrm{~mm}$.

Furm. and Loc.-Eocene: Tasmania and Victoria.

83996. Portion of right valve; from Table Cape. Purchased.

L. 4838. Two right valves; from Muddy Creek.

Presented by John Dennant, Esq.

L. 6599. Examples of both valves, one of the neanic stage of growth, and the other of the ephebic; from Muddy Creek.

Purchased.

L. 9847. Specimen of the adult, both valres; from Muddr Creek.

Purchased.

\section{Trigonia tatei, Pritchard.}

1895. Trigonia tatei, Pritchard, Proc. Roy. Soc. Vict. N.s. rol. vii. p. 225, pl. xii. figs. 1-3.

Closely related to $T$. semiundulata, from which it differs in being more solid, regularly convex, not so elongate posteriorly, and consequently the shell is proportiunately higher; there are ferer posterior radial costæ on the surface, whilst the transrerse ridges are bolder.

Dimensions.-Height $37 \mathrm{~mm}$. ; leugth $40 \mathrm{~mm}$.

Form. and Loc.-Eocene: Maude, Victoria.

L. 10024. Right ralre of the adult.

Purchased. 


\section{Trigonia tubulifera, Tate.}

1885. Trigonia tubulifera, Tate, Southern Science Record, January, p. 3.

1886. Trigonia tubulifera, Tate, Trans. Roy. Soc. South Aust. vol. viii. p. 145 , pl. xi. figs. $13 a-b$.

1893. Trigonia tubulifera, Tate and Dennant, $i d$. vol. xvii. pt. 1, p. 224.

1895. Trigonia tubulifera, Tate and Dennant, id. vol xix. pt. 1, p. 113.

Shell very small; flat posterior area having sixteen radial costæ, remainder of surface with abont twenty concentric ridges, the whole of the costæ and ridges carrying numerous, equidistant, short tubular projections.

Dimensions.-Height $6 \mathrm{~mm}$.; length $6 \mathrm{~mm}$.

Form. and Loc.-Eocene: Muddy Creek, Victoria.

L. 9848. Examples of both valves.

Purchased.

\section{Trigonia howitti, M‘Coy.}

1876. Trigonia howitti, M`Coy, Prod. Pal. Vict. dec. iii. p. 31, pl. xxvii. figs. $1-2 c$.

1878. Trigonia howitti, R. Etheridge, jun., Cat. Aust. Foss. p. 158.

1886. Trigonic howitti, Tate, Trans. Roy. Soc. South Aust. vol. viii. p. 146.

Shell solid, transverse, posterior margin sloping; ornamented by about twenty granulated radial ribs, the largest being in the middle, the others decreasing in size as the posterior and anterior margins are approached, the granulations are largest on the anterior costro; ventral margiu undulating, broadly crenulated in the interior. It will be noticed that transverse ribs or ridges are absent in this species, the costæ all being radial.

Dimensions.-Height $44 \mathrm{~mm}$. ; length $50 \mathrm{~mm}$.

Form. and Loc.-Miocene: Victoria.

L. 4839. Examples of both ralves; from Muddy Creek.

Presented by John Dennant, Esq.

L. 5648. Fragment of right valve; from Jemmy's Point, Lake Tyers, Gippsland.

Presented by the Rev. J. S. H. Royce.

L. 6600 . Both valves of the adult; from Muddy Creek.

Purchased.

I. 9849. Two specimens; from Muddy Creek.

Purchased. 


\section{Trigonia acuticostata, $\mathrm{M}^{\prime} \mathrm{Coy}$.}

1866. Trigonia lamarckii, H. M. Jenkins, Geol. Mag. vol. iii. p. 201, pl. x. figs. 3-7 (non Math.).

1866. Trigonia acuticostata, M'Coy, Geol. Mag. vol. iii. p. 482, fig. I.

1875. Trigonia acuticostata, M.Coy, Prod. Pal. Vict. dec. ii. p. 21, pl. xix. figs. 1, 2.

1878. Trigonia acuticostata, R. Etheridge, jun., Cat. Aust. Foss. p. 157.

1886. Trigonia acuticostata, Tate, Trans. Roy. Soc. South Aust. vol. viii. p. 145.

Distinguished by the absence of transverse ridges, the ernament consisting of elerated radial costa, on which are numerous, equidistant, sharp denticles; the costæ are rather widely separated, the interstices exhibiting elesely-set lines of grewth.

Dimensions.-Height $24 \mathrm{~mm}$. ; length $28 \mathrm{~mm}$.

Form. and Loc.-Miocene: Victeria.

I. 353. Tro examples of a rariation in which the shell is rather less oblique than in typical specimens, whilst the denticles on the costæ are well elerated; from Bairnsckale.

Presented by W. H. Grigson, Esq.

L. 9850. Right valre; frem Muddy Creek.

Purchased.

\section{Trigonia, sp.}

L. 10558. Internal cast of right ralve, species indeterminable. Eocene (?): Waipara, New Zealand. Sir James Hector Coll.

\section{Family UNIONID E.}

\section{Genus UNIO, Retzius.}

[Diss. Nova Test. Genera, 1788, p. 16.]

Shell commenly equivalre; nacreous in the interier; umbones placed anteriorly, frequently corroded; surface smootl, plicatcl or tuberculose; ligament preminent, long; hinge of right valve carrying two anterior lateral teeth, and one long pesterier lateral teoth; hinge of left valve composed of one autcrier lateral tooth, one cardinal toeth placed under the umbe, and two long laterul posterier teeth; pallial line entire; surface ormament usually sinple.

Type.-Mya margaritifera, Limnæus. 


\section{Unio johnstoni, Etheridge, jun.}

1881. Unio johnstoni, R. Etheridge, jum., Pap. Roy. Soc. Tas. 1880, p. 20, plate, two upper figures.

1887. Unio johnstoni, Tate, Trans. Roy. Soc. South Aust. vol. ix. p. 153.

1888. Unio johnstoni, Johnston, Geol. Tasmania, pl. xxxiv. figs. 1-1a.

The anthor states that this does not resemble any of the living Australian species, but approaches nearest to $U$. mutabilis, Lea, found in the neighbourhood of Brisbane. The condition of the specimens, which are in the state of ironstone casts, renders it impossible to describe the features of the hinge-line or the surface characteristics, so that even the generic reference is a little doubtful.

Dimensions.-Height $51 \mathrm{~mm}$.; length $99 \mathrm{~mm}$.

Form. and Loc._-"Tertiary": Tasmania.

96928. Several double-valved specimens, including the type figured (op. supra cit.) by Mr. Robert Etheridge, jun.; from the Tamar river, between Whirlpool Reach and George Town.

Presented by Dr. J. Milligan.

98219. Six specimens; from Launceston.

Purchased.

I. 6099 . Two casts of the adult; locality (?).

Purchased.

\section{Genus ANODONTA, Lamarck.}

[Mém. Soc. Hist. Nat. Paris, 1799, p. 87.]

Shell inequilateral; umbones small ; cardinal border long, edentulous, but giving indications of a horizontal ridge which represents the posterior lateral tooth of Unio; ligament exterior; scars of the adductors of the valves not deep; impression of the anterior adductor of the foot small, near that of the valves; scar of the posterior adductor of the foot practically confluent with that of the adductor of the ralves in the same region; a muscle-scar also in the umbonal eavity; impression eaused by the attachment of the visceral mass well marked.

Type.-Mytilus cygneus, Linnæus.

Anodonta tamarensis, Etheridge, jun.

1581. Anodonte (?) tamarensis, R. Etheridgc, jun., Pap. Roy. Soc. Tas. 1880 , p. 22, plate, two lower figures.

1887. Unio tamarensis, Tate, Trans. Roy. Soc. South Aust. vol. ix. p. 153.

1888. Anodonta tasmanica, Johnston, Geol. Tasmunia, pl. xxxiv. figs. 2-2a. 
The specimens in the II useum collection are all ironstone casts, and, the hinge-line not being visible, the generic position of this species is doubtful also. In his diagnosis Mr. Etheridge, jun., remarks:- "Our fossil approaches some of the flat forms of Anodonta, and it is with these that it must be compared. The more or less compressed valves, strong posterior angnlation of the dorsal margin, obliquely truneated posterior margin, and obliquely rounded anterior margin, pending a knowledge of the dental characters of the hinge, all point in this direction."

Dimensions.-Height $57 \mathrm{~mm}$.; length $96 \mathrm{~mm}$.

Form. and Loc._"Tertiary": Tasmania.

96929. The type specimen, figured by Mr. Robert Etheridge, jun.; from the Tamar river, between Whirlpool Reach and George Town.

Presented by Dr. J. Milligan.

I. 6099. Two examples; locality (?).

Purchased.

\section{Family CARDITID玉.}

\section{Genus CARDITA, Bruguière.}

[Ency. Meth. Vers. t. i. 1792, p. 401.]

Shell oral, transverse, solid, inequilateral ; ornamented by salient and frequently scaly costæ; lunule more or less depressed; hinge oblique; right valre carrying one small anterior lateral tooth and two long posterior cardinal teeth; left ralve with a short anterior cardinal tooth, one long posterior cardinal tooth, and one small posterior lateral tooth ; muscle-scars large and conspicuous; pallial line simple.

As given by Brugnière, Cardita is a mixture of sereral genera; following the rule applicable in such cases we must accept the interpretation of Lamarck, ${ }^{1}$ who was the first to break up Cardita, and the type of the genus as given by that author is as here staterl.

It is impossible to satisfactorily separate Venericardia frou

1 Mém. Soc. Hist. Nat. Paris, 1779, p. 86. 
Cardita in the fossil state, as Stoliczka ${ }^{1}$ has pointed out, and the writer prefers to call the Australasian forms here described Cardita, for the present.

Type.-Chama calyculata, Linnæus. ${ }^{2}$

\section{Cardita scabrosa, Tate.}

1886. Cardita scalrosa, Tate, Trans. Roy. Soc. South Aust. vol. riii. p. 152, pl. ii. fig. 4 .

1893. Cardita scabrosa, Tate and Dennant, id. vol. svii. pt. 1, p. 224.

1896. Cardita scabrosa, Pritchard, Proc. Roy. Soc. Vict. vol. viii. v.s. p. 132.

Distinguished by the shell being oval-subquadrate, the radiating costæ being thirty in number, and by their bearing erect scales.

Dimensions.-Height $16 \mathrm{~mm}$; ; length $20 \mathrm{~mm}$.

Form. and Loc.-Eocene: Muddy Creek, Victoria.

L. 4802 , L. 4804 . Specimens of both valves.

Presented by John Dennant, Esq.

L. 9904. Examples of the right valve.

Purchased.

\section{Cardita polynema, Tate.}

1886. Cartita polynema, Tate, Trans. Roy. Soc. South Aust. vol. viii. p. 153 , pl. ii. fig. 7 .

1893. Cardita polynema, Tate and Dennant, id. rol. xvii. pt. 1, p. 224.

1895. Cardita polynema, Tate and Dennaut, $i d$. vol. xix. pt. 1, p. 113.

The chief differences between this and $C$. latissima, with which it is closely allied, are that the shell is narrower anteriorly, and there are a larger number of costæ. It is less produced anteriorly than is C. gracilicostata, Tenison-Woods.

Dimensions.-Height $34 \mathrm{~mm}$. ; length $40 \mathrm{~mm}$.

Form. and Loc.-Eocene: Spring Creek, Victoria.

L. 9902. Examples of both valves.

Purchased.

1 Palæont. Indica, Cret. Fauna S. India, vol. iii. Peleypoda, 1871, p. 282.

2 Cf. Fischer, Manuel de Conchyl. 1587, p. 1012. 


\section{Cardita latissima, Tate.}

1886. Cardita latissima, Tate, Trans. Roy. Soc. South Aust. vol. viii. p. 153, pl. ii. fig. 5 .

Shell roundly-oblong; surface ornamented with about thirty costæ having lamellar scales. It differs from $C$. polynema in being widened posteriorly, and in having fewer radial costr.

Dimensions.-Height $13 \mathrm{~mm}$.; length $14 \mathrm{~mm}$.

Form. and Loc.-Eocene: Aldinga, South Australia.

L. 9903. Specimens of both valves, of the neanic stage of growth.

Purchased.

\section{Cardita delicatula, Tate.}

1886. Cardita delicatula, Tate, Trans. Roy. Soc. South Aust. vol. viii. p. 154 , pl. ii. fig. 10 .

1893. Cardita delieatula, Tate and Dennant, id. vol. xrii. pt. 1, p. 224.

1895. Cardita delieatula, Tate and Dennant, id. vol. xix. pt. 1, p. 113.

Shell orate, depressed; umbones oblique, curved inwards; posterior margin roundly truncated; surface "with twenty-six compressed radial ribs, densely beset with granules passing into scales on the posterior slope; interspaces a little wider than the ribs ; inner margins of valres coarsely crenulated."-Tate.

Dimensions.-Height $10 \mathrm{~mm}$.; length $12 \mathrm{~mm}$.

Form. and Loc.-Eocene: Muddy Creek, Victoria.

I. 9905. Sereral examples of both valves.

Purchascl.

Cardita calva, Tate.

1887. Cardita calva, Tate, Trans. Roy. Soc. South Aust. vol. ix. p. 189, pl. xx. fig. 14.

Shell small, subtrigonal, depressed; umbones elerated, aente; umbonal area smooth, with distant sulei, from which proceed about twenty radial costr, elosely granulated; the intercostal spaces are widest anteriorly and posteriorly.

Dimensions.-Height $5 \mathrm{~mm}$.; length $5 \mathrm{~mm}$.

Form. and Loc.-Miocene: Muddy Creek, Victoria.

L. 9906. Examples of both valres.

Purchased. 
Cardita solida, Tate.

1887. Cardita solida, Tate, Trans. Roy. Soc. South Aust. vol. ix. p. 189, pl. xx. fig. 18 .

Shell readily distinguished from all other Australian species of Cardita here alluded to by its solidity, elevated umbonal region, with correspondingly large hinge area, but especially by its smooth, bold, radial costæ, to the number of about eighteen; margins strongly crenulated.

Dimensions.-Height $9 \mathrm{~mm}$.; length $9.5 \mathrm{~mm}$.

Form. and Loc._-Niocene: Muddy Creek, Victoria.

L. 9901. Series of both valves, illustrating stages of growth.

Purchased.

Cardita maudensis, Pritchard.

1895. Cardita maudensis, Pritchard, Proc. Roy. Soc. Vict. x.s. vol. vii. p. 229, pl. xii. figs. $6,7$.

In his diagnosis the author remarks that this shell resembles that of $C$. delicatula, Tate, but differs in not being so abruptly truncate posteriorly, the umbones are placed a little farther back from the anterior margin; it has fewer, broader, and much more coarsely ornamented costæ. It has also fewer and broader ribs than has C.tasmanica, Tate, whilst the interspaces are narrower, and the form of the two shells differs.

Dimensions.-Height $10.5 \mathrm{~mm}$. ; length $10 \mathrm{~mm}$.

Form. and Loc.-Eocene: Maude, Victoria.

I. 10027. Many examples of both valves of the adult. Purchased.

Cardita awamoensis, nom. mut.

1873. Tenericardia intermedia, Hutton, Cat. Tert. Moll. N.Z. p. 24 (non Lamarck, nec Basterot, nec Dubois).

Shell ovate, very inequilateral, truncated posteriorly; surface ornamented with about twenty-two radial costæe, typically nodose in the early growth of the shell, but becoming transversely striated on nearing the margin; lunule very small.

The species name is here changed, the appellation intermedia having been used for different kinds of Cardita, before Professor 
Hutton suggested its application to the New Zealand shell now described. Tho species name proposed refers to the locality A wamoa, where the shell is said to be common.

Dimensions.-Height $40 \mathrm{~mm}$; length $44 \mathrm{~mm}$.

Furm. and Loc.-Eocene and Miocene (?) : New Zealand.

L. 10553, L. 10554. Many examples of both ralves haring smooth ribs (var. $B$ of Hutton); from Parimoa.

W. B. D. Mantell Coll.

L. 10555. Two specimens ( $\operatorname{rar} . B$ of Hutton) from Parimoa, Transferred from the IIuseum of Practical Geology.

L. 10556. Cast in glauconitic sandstone; from Curiosity Shop, Canterbury. Sir James Hector coll.

\section{Cardita australis, Lamarck (sp.).}

1818. Venericardia australis, Lamarck, Hist. Nat. Anim. sans Vert. t. v. p. 610 .

1873. Cardita australis, Ton Martens, List Moll. N.Z. p. 47.

1873. Fenericardia australis, Hutton, Cat. Marine Moll. N.Z. p. 74.

1873. Venerieardia australis, IIutton, Cat. Tert. Moll. X.Z. p. 23.

1880. Cardita australis, Hutton, Man. N.Z. Moll. p. 158.

1893. Venericardia australis, Hutton, Linn. Soc. N.S.W. Macleay Mem. Vol. p. 85 .

Shell strongly radiately costated, each rib bearing a number of prominent, compressed tubercles, which frequently become subspinose towards the posterior end of the shell.

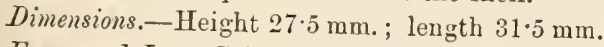

Form. and Loc.-Pliocene: Wanganui, New Zealand.

L. 10552. Three specimens.

IT. B. D. Irantell Coll.

L. 10557. Two examples of both ralres. Sir James Hector Coll.

\section{Cardita, sp.}

L. 5646. Cast of a species allied to Mytilicardia compta, Tate, but proportionately higher and more tumid, whilst the median radial costie are broader and flatter; from Gippsland, Victoria.

\section{Presented by the Rev. J. S. H. Royce.}

L. 10551 Cast of a large species; from the Tertiary of Nullarbor Pliins, South Australia. 


\section{Genus CARDITELLA, E. A. Smith.}

[Proc. Zool. Soc. 1881, pp. 42, 43.]

Shell trigonal, equilateral; carrying two cardinal teeth on the left valve and one on the right; each valve has two lateral teeth, one nearly marginal on the one side, the other on the opposite side being well within the outer edge, with a groove between it and the margin for the reception of the submarginal tooth of the other ralve; pallial line simple.

Type.-Carditella pallida, Smith. ${ }^{1}$

\section{Carditella lamellata, Tate (sp.).}

1886. Gouldia lamellata, Tate, Trans. Roy. Soc. Sonth Aust. vol. viii. p. 148, pl. ii. fig. 17.

1887. Carditella lamellata, Tate, id. vol. ix. p. 188.

Distinguished by its depressed, triangular form, with much prodiced acute umbo and rounded ventral margin ; surface ornamented by several conspicuous concentric lamellæ and growth-lines, in some individuals set elosely together, in others far apart.

Dimensions.-Height 4.5 mm.; length $4.5 \mathrm{~mm}$.

Form. and Loc.-Eocene: Aldinga, South Australia.

L. 9879. Sereral examples of the neanic and ephebic stages of growth.

Purchased.

\section{Carditella radiata, Tate (sp.).}

1886. Micromeris radiata, Tate, Trans. Roy. Soc. South Aust. vol. viii. p. 148, pl. x. fig. 12.

1887. Carditella rudiata, Tate, id. vol. ix. p. 188.

1893. Carditella radiata, Tate and Demant, id. vol. xrii. pt. 1, p. 225.

1895. Curditella radiata, Tate and Dennant, id. vol. xix. pt. 1, p. 113.

Shell trigonal, slightly convex; umbones produced; inner margin distantly crenulated; surface smooth, radially ribbed, concentrically ridged, or coarsely striated; there is a deep elliptical depression auterior and posterior to the umbones.

Dimensions.-Height $4.5 \mathrm{~mm}$. ; length $4.5 \mathrm{~mm}$.

Form. and Loc.-Eocene : Aldinga, South Australia.

L. 9878 . Specimens of the adult, both valves.

Purchased.

1 Voy. "Challenger," Zool. Lamellibranchiata, vol. xiii. p. 216. 


\section{Fumily CRASSATELLITIDA.}

\section{Genus CRASSATELLITES, Krüger.}

[Geschichte der Urwelt, Theil ii. 1823, p. 466.]

Crassatella, auctorum (non Lamarek, Mém. Soc. Hist. Nat. Paris, 1799 , pp. 85,86$)$.

American authors ${ }^{2}$ for some time past have recognized that the name Crassatellites, Krüger, must be applied to mollusca commonly known as Crassatella. In Lamarck's work abore cited the type of his Crassatella is given as Mactra cygnea, Chemnitz ( $=$ M. cyguus, Gmelin), which may, without hesitation, be referred to the Mactridx, and Crassatella must therefore be employed for certain members of that family, or fall in synonymy. Krüger's type, mentioned below, comes from the Bordeaux area.

Type-Crassatella sinuata, Lamarck.

\section{Crassatellites dennanti, Tate (sp.).}

1886. Crassatella dennanti, Tate, Trans. Roy. Soc. South Aust. rol. viii. p. 146, pl. xi. fig. 2 .

1893. Crassatella dennanti, Tate and Dennant, id. vol. xvii. pt. 1, p. 224.

Shell large, truncated posteriorly, rentral margin slightly crenulated in the adult; surface oruament consisting of concentric ridges, the last two or three dereloped posteriorly commonly run off the rentral margin as the anterior of the shell is reached; posterior ridge rounded, well developed.

Dimensions.-Height $37 \mathrm{~mm}$. ; length $54 \mathrm{~mm}$.

Form. and Loc.-Eocene: Muddy Creek, Victoria.

L. 4837. Right ralre of the adult; and examples of the brephie and neauic stages of growth. Presented by John Dennant, Esq.

L. 6588. Examples of both ralves.

Purchased.

L. 9852. Both valves of the adult. Purchased. 


\section{Crassatellites oblonga, Tenison-Woods (sp.).}

1876. Crassatella oblonga, Tenison-Woods, Pap. Roy. Soc. Tas. 1875, p. 25, pl. ii. fig. 11.

1886. Crassatella oblonga, Tate, Trans. Roy. Soc. South Aust. vol. viii. p. 146.

1888. Crassatella oblonga, Johnston, Geol. Tasmania, p. 234, pl. xxix. figs. 1-1a.

1896. Crassatella oblonga, Pritchard, Proc. Roy. Soc. Vict. vol, viii. v.s. p. 131.

Much more elongate posteriorly than $C$. dennanti, the concentric lines of growth are prominent, but are not accompanied by pronounced ridges, except in the umbonal region. The shells appear to vary considerably in regard to tumidity, but all are very solid. Mr. G. B. Pritchard remarks (op. supra cit.) that the Muddy Creek forms are separable from those at the typical locality, Table Cape, and he proposes to describe them as a new species. The only specimen from the last-mentioned place in the Museum collection is in such a bad state of preservation that the present writer is unable to control the matter.

Dimensions.-Height $47 \mathrm{~mm}$.; length $68 \mathrm{~mm}$.

Form. and Loc.-Eocene and Miocene: Table Cape and Victoria.

83999. Large fragment of right valve, much worn; from Table Cape. Purchased.

L. 4834. Examples of the adult, both valres; from Muddy Creek. Presented by John Dennant, Esq.

L. 6601. Specimens of both valves; from Nuddy Creek.

Purchased.

L. 9851. Specimens of the neanic and ephebic stages of growth ; from Muddy Creek.

Purchased.

Crassatellites communis, Tate (sp.).

1886. Crassatella astartiformis, Tate, Trans. Roy. Soc. South Aust. vol. viii. p. 147, pl. xi. figs. 12-15 (non Nyst.).

1893. Crassatella eommunis, Tate and Dennant, id. vol. xrii. pt. 1, p. 224.

Shell small, subquadrate, margins not crenulated; surface ornamented by fine concentric folis. The change of nomenclature 
ahore indicated is confirmed by a label attached to some specimens kindly sent by Professor Tate to the writer.

Dimensions.-Height 7.5 mm.; length $8 \mathrm{~mm}$.

Form. and Loc.-Eocene: Muddy Creek, Victoria.

L. 9853. Several examples of both valves.

Purchased.

\section{Crassatellites amplus, Zittel (sp.).}

1865. Crassatella ampla, Zittel, Reise der Novara, Paläontologie, Bd. i. Abth. ii. p. 46 , taf. xiv. figs. $3 a-b$.

1873. Crassatella ampla, Hutton, Cat. Tert. M[oll. N.Z. p. 24.

Shell trigonal, subequilateral, solid, irregularly concentrically striated; anterior end broad and obtuse, posterior slightly attenuated. The hinges in the Museum specimens are corered with hard matrix. Professor Hutton describes them as follows: "Hinge very broad and thick, cardinal tooth of the right ralre attenuated, and bificl at the base; cartilage pit large and deep; left valve with two teeth."

Dimensions.-Height $68 \mathrm{~mm}$; ; length $87 \mathrm{~mm}$.

Furm. and Loc.-Eocene and Miocene: New Zealand.

L. 10490. Examples of the right ralve, affixed to block of shelly argillaceous limestone; from Akuakua (lower beds).

Sir James Hector Coll.

L. 10492. Large fragment of right valve; from Kawau.

Sir James Ilector Coll.

Crassatellites attenuatus, Hutton (sp.).

1873. Crassatella attemuata, Hutton, Cat. Tert. Moll. N.Z. p. 24.

"Orate; inequilateral; broad and rounded in front, produced and tapering behind; posterior dorsal margin straight; hinge moderate; irregularly concentrically striated."-IIutton.

The following specimen appears to correspond to the abore brief descriptiou.

Dimensions.-Height $107 \mathrm{~mm}$; length $130 \mathrm{~mm}$.

Form. and Loc.-Eocene: Trelissick, New Zealand.

L. 10493. Left valve of the adult. Sir James IIector Coll. 


\section{Crassatellites traili, Hutton (sp.).}

1873. Crassatella traili, Hutton, Cat. Tert. Moll. N.Z. p. 24.

Allied to $C$. dennanti, from which it differs in having a produced (instead of truncated) posterior margiu; and by the fineness of its concentric lineations.

Dimensions.-Height $32 \mathrm{~mm}$; length $45 \mathrm{~mm}$.

Form. and Loc.-Miocene: Awamoa, New Zealand.

L. 10495. Left valve of the adult. Sir James Hector Coll.

\section{Crassatellites, sp.}

L. 9582. Block of shell conglomerate, containing many fragments of a species of Crassatellites. Post-Pliocene: Flint cliffs, Sharks' Bay, Western Australia. Presented by $W$. Saville-Kent, Esq.

L. 10494. Imperfect left valve of a species allied to $C$. attenuata, but strongly concentrically ridged. Eocene: Trelissick, New Zealand.

Family CARDIID无.

Genus CARDIUM, Linnæus.

[Syst. Nat. ed. 10, 1758, p. 678.]

Shell convex; umbones elevated, incurved and slightly inclined anteriorly; right valve having one or two cardinal teeth, two anterior lateral teeth, and one or two posterior lateral teeth; left valve, two cardinal teeth, one anterior lateral tooth, and one posterior lateral; ligament external; surface ornamented by more or less conspicuous radial costæ; pallial line entire.

Type.-Caräium edule, Linnæus. 


\section{Cardium victoriæ, Tate.}

1887. Cardium victorice, Tate, Trans. Roy. Soc. South Aust. vol. ix. p. 151, pl. xiv. figs. $1 a-b$.

Shell longitudinally orate, depressed, slightly oblique; eostre small, very numerous, several on the anterior slope eommonly granulated, and some near the posterior margin tubereulate.

Dimensions. - Height $21 \mathrm{~mm}$. ; length $19 \mathrm{~mm}$.

Form. and Loc.-Eocene: Muddy Creek, Victoria.

L. 10025. Left valve.

Purchased.

\section{Cardium spatiosum, Hutton.}

1873. Cardium spatiosum, IIutton, Cat. Tert. Moll. N.Z. p. 23.

Dimensions.-Height $115 \mathrm{~mm}$.; length $138 \mathrm{~mm}$.

Form. and Loc.-Wiocene; Taipos, Wellington, New Zealand.

L. 10574. Double-ralved example of this gigantie species, not, however, perfect enough for description. Sir James Ilector Coll.

\section{Cardium, sp.}

42688. Cast of left valve of a species allied to C. victoria ; from near Arlelaide, South Australia.

Presented by the Governors of Adelaide Muscum.

42698. Cast of right valve of a radially costate species; from near Adelaide.

Presented by M. Marshall, Esq.

L. 10575. Casts in, and impressions on, argillaceous limestone, of a small undescribed species. Miocene: Akuakua (upper beds), New Zealand.

Sir James Ilector Coll.

L. 10578, L. 10579. Casts of a species allied to $C$. victoria; from Nullarbor Plains, Sonth Australia. $\quad$ H. I. L. Broun Coll.

L. 10581, L. 10583 . Two cast’s; from Willunga, near Adelaide. II. Y. L. Brown Coll.

L. 10582. Casts of a species similar to L. 10578; from Fowler's Bay District, South Australia.

II. Y. L. Brown Coll.

L. 10584. Cast of the right ralve of a species in which the radiil costre are large, numerous, and regular; (locality ?) South Australia.

Transferred from the Museum of Practical Geology. 


\section{Genus PROTOCARDIUIM, Beyrich.}

[Menke's Zeitsch. Malakozoologie, 1845, pp. 17-20.]

Distinguished from Cardium in being more globose, but especially by the character of the surface ornament, which, typically, consists of radiating costæ posteriorly, and fine concentric lineations abutting against them on the remainder of the surface.

Type.-Cardium hillanum, Sowerby.

\section{Protocardium antisemigranulatum, $\mathrm{M}^{\prime} \mathrm{Coy}$ (sp.).}

1877. Cardium (Protocardium) antisemigranulatum, M'Coy, Prod. Pal. Vict. dec. v. p. 16, pl. xliv. figs. 2,3 .

1887. Cardium antisemigranulatum, Tate, Trans, Roy. Soc. South Aust. vol. ix. p. 152 .

1893. Cardium antisemigranulatum, Tate and Dennant, id. vol. xrii. pt. 1, p. 225 .

Posterior costæ partly tuberculate, remainder of surface smooth, but bearing minute concentric and radial striæ; margin crenulated. Dimensions.-Height $30 \mathrm{~mm}$.; length $32 \mathrm{~mm}$.

Form. and Loc.-Eocene: Muddy Creek, Victoria.

L. 10026. Right valve of the neanic stage of growth. Purchased.

\section{Protocardium hemimeris, Tate (sp.).}

1887. Cardium hemimeris, Tate, Trans. Roy. Soc. South Aust. vol. ix. p. 153, pl. xiv. figs. $2 a-c$.

Shell subglobose; umbones much elevated; "the anterior half of the surface of the valves is ornamented by numerous regular, equal, flat riblets, crossed by finer and closer concentric threads . . .; the intersection of the riblets and the liræ produce a tesselated ornament. The posterior half is ornamented with about fifty flat, narrow riblets, closely beset with small tubular, conical spines."-Tate.

Dimensions.-Height $8.5 \mathrm{~mm}$. ; length $8.5 \mathrm{~mm}$.

Form. and Loc.-Eocene: Aldinga, South Australia.

L. 9867. Several examples of both valves.

Purchased. 


\section{Protocardium serum, Hutton.}

1873. Protoeardium senum, Hutton, Cat. Tert. Moll. N.Z. p. 23.

L. 10577. Two large fragments probably referable to this species. Eocene : Trelissick, New Zealand. Sir James Hector Coll.

\section{Family CHAMID王.}

\section{Genus CHAMA, Linnæus.}

[Syst. Nat. ed. 10, 1758, p. 691.]

Shell irregular, inequivalve; umbones spiral or subspiral, that of the fixed valve always longer than the other; surface ornamented by lamellæ or spines, or both; upper valve operculiform, slightly convex; lower valve highly convex and much larger; ligament external; pallial line entire.

Type._Chama lazarus, Linnæus.

\section{Chama lamellifera, Tenison-Woods.}

1877. Chama lamellifera, Tenison-Woods, Pap. Roy. Soc. Tas. 1876, p. 114.

1887. Chama lamellifera, Tate, Trans. Roy. Soc. South Aust. vol. ix. p. 149, pl. xiv, figs, $5 a-b$.

1893. Chama lamellifera, Tate and Dennant, id. vol. xvii. pt. I, p. 225.

1896. Chama lamellifera, Pritchard, Proc. Roy. Soc. Vict. vol. viii. N.s. p. 133.

Both valves ornamented exteriorly with distant irregular lamellæ, occasionally elerated and subspinose; spaces between haring numerous minute concentrie strix.

Dimensions.—Height $17 \mathrm{~mm}$; length $21 \mathrm{~mm}$.

Form. and Loc.-Eocene: Tasmania and Victoria.

83985. Upper valve; from Table Cape.

Purchased.

L. 4790. Lower ralres, concentric lamellæ rery irregularly developed ; from Muddy Creek. Presented by John Dennant, Esq.

L. 6603. Both ralves of a typical example; from Muddy Creek. Purchased.

L. 9836. Examples of the adult; from Juddy Creek. Purchasel. 


\section{Family VENERID As.}

\section{Genus IMERETRIX, Lamarck.}

[Mém. Soc. Hist. Nat. Paris, 1799, p. 85.]

Cytherea, Lamarck, Ann. Mus. t. vii. 1806, p. 132.

Shell oval-subtrigonal, smooth or concentrically striated, lunule conspicuous; margin of the valves not erenulated; hinge carrying three cardinal tceth on each valie; ligament external; sinus deep.

Type.-Venus meretrix, Linnæus.

\section{Meretrix paucirugata, Tate (sp.).}

1887. Cytherea paucirugata, Tate, Trans. Roy. Soc. South Aust. rol. ix. p. 158, pl. xiv. fig. 14 .

Characterized by lamellate rugæ on the posterior slope, and by the acuminate posterior prolongation ; pallial sinus rery deep.

Dimensions.-Height $29 \mathrm{~mm}$. ; length $39 \mathrm{~mm}$.

Form. and Loc.-Miocene: Muddy Creek, Victoria.

L. 4831. Both valves of the adult.

Presented by Jokn Dennant, Esq.

L. 6607, L. 9894. Examples of both valves. Purchased.

\section{Meretrix submultistriata, Tate (sp.).}

1887. Cytherea submultistriata, Tate, Trans. Roy. Soc. South Aust. rol. ix. p. 160 , pl. xviii. figs, 6,8 .

Readily distinguished from $M$. paucirugata, Tate, by the absence of lamellate rugæ; the shell being elongate-ovate, smooth, the surface being irregularly lineated by growth-lines; anterior and posterior lateral teeth rery short.

Dimensions.-Height $28.5 \mathrm{~mm}$.; length $38 \mathrm{~mm}$.

Form. and Loc.-Miocene: Muddy Creek, Victoria.

L. 4832. Both ralves of the adult.

Presented by John Dennant, Esq.

L. 6608. Two specimens of the left ralre. Purchased. 


\section{Meretrix eburnea, Tate (sp.).}

18s7. Cytherea eburnea, Tate, Trans. Roy. Soc. South Aust. vol. ix. p. 160, pl. xviii. fig. 7 .

1893. Cytherea eburnea, Tate and Dennant, id. vol. xvii. pt. 1, p. 225.

Allied to $M$. submultistriata, but is more tumid, oral in form, rounded, and not acuminate posteriorly ; surface smooth, interrupted by irregnlar concentric lines of growth.

Dimensions.-Height $19 \mathrm{~mm}$. ; length $23 \mathrm{~mm}$.

Form. and Loc -Eocene: Muddy Creek, Victoria.

L. 9892. Series illustrating stages of growth.

Purchased.

\section{Meretrix tenuis, Tate (sp.).}

1887. Cytherea temis, Tate, Trans. Roy. Soc. South Aust. vol. ix. p. 159, pl. xiv. fig. 16.

1893. Cytherea tenuis, Tate and Dennant, id. vol. xrii. pt. 1, p. 225.

1895. Cytherea temis, Tate and Dennant, id. vol. xix. pt. 1, p. 113.

1896. Cytherea temuis, Pritchard, Proc. Roy. Soc. Vict. rol. viii. N.s. p. 135.

Shell thin, fragile, narrow anteriorly, produced, but truncated posteriorly; umbo incurred, situated at about one-fourth of the whole length from the anterior margin; rentral margin arcuate; surface shining, finely conceutrically striated; pallial sinus large, broad and deep.

Dimensions.-Height $15 \mathrm{~mm}$.; length $20 \mathrm{~mm}$.

Form. and Loc.-Eocene: Spring Creek, Victoria.

L. 9893. Examples of both valves.

Purchased.

\section{Meretrix, sp.}

L. 10586. Several casts of a species allied to $1 \boldsymbol{L}$. submultistriata, but much larger and more compressed; from Willunga, South Australia.

II. I. L. Brown Coll.

48803. Casts of a large species, too imperfect for determination specifically; from River Murray cliffs, South Australia.

Presented by Commodore Goodenough, R.X.

L. 5645. Several casts of a very tumid species; from Sile, Gippsland.

Presented by the Ret. J. S. II. lioyec.

L. 10589. Internal cast of lcft ralre; from the Lower Tertiary of Ardrossan, Yorke's Peninsula, South Australia. 


\section{Genus SUNETTA, Link.}

[Besch. Rostock, Abth. iii. 1807, p. 148.]

Meroe, Schumacher, Lssai Nouv. Syst. Habit. Testacés, 1817, p. 149.

Shell oval, trigonal, depressed, almost equilateral; posterior margin much shorter than the anterior; readily distinguished from Meretrix by the phenomena of the hinge, the position of the umbones, and by the sinus.

Type.-Chama sunet, Adanson.

\section{Sunetta gibberula, Tate (sp.).}

1887. Meroe gibberula, Tate, Trans. Roy. Soc. South Aust. vol. ix. p. 162, pl. xv. figs. $4 a-b$.

Posterior lateral area of the hinge large, broad, slightly convex; umbones acute; margin crenulated; surface smooth, shining, with inconspicuous lineations and undulating growth-lines, which are mostly dereloped near the ventral margin in the adult.

Dimensions. - Height $24 \mathrm{~mm}$.; length $29 \mathrm{~mm}$.

Form. and Loc.-Miocene: Muddy Creek, Victoria.

L. 4824. Examples of both valves.

Presented by John Dennant, Esq.

L. 6610 . Both valres of the adult. Purchased.

L. 9870. Specimens of the neanic stage of growth. Purchased.

Genus CHIONE, Megerle von Mühlfeldt.

[Ges. Naturf. Fr. Berlin, Magazin, 1811, p. 51.]

Shell oral, triangular, cardiual border narrow, having on each valve three divergent cardinal teeth, and, sometimes, on the left valve a rudimentary anterior lateral tooth; pallial sinus short, triangular, or obsolete; surface of the valres lamellose, cancellated, striated, or smooth.

Type.-Tenus dysera, Linnæus. 


\section{Chione dimorphophylla, Tate.}

1887. Chione dimorphophylla, Tate, Trans. Roy. Soc. South Aust. vol. ix. p. 155 , pl. xv. figs. $3 a-\dot{b}$.

1893. Chione dimorphophylla, Tate and Dennant, $i d$. vol. xvii. pt. 1, p. 225.

Shell large, ovate, regularly rounded anteriorly; umbones directed well forward, incurved; pallial sinus deep, augulate, reaching almost to the eentre of the shell; margin crenulated; surface of the exterior ornamented by prominent, elevated concentric lamellæ, between which are closely-set radial lineations; lunule well impressed, concave.

Dimensions.-Height $49 \mathrm{~mm}$.; length $60 \mathrm{~mm}$.

Form. and Loc.-Eocene : Victoria and South Australia.

L. 4833. Right valve of the adult; from Muddy Creek.

Presented by John Dennant, Esq.

L. 6604, L. 9870. Left valves; from Muddy Creek. Purchased.

L. 10591. Several examples of both valres; from the River Murray, near Adelaide. Presented by $W m$. Ecans, Esq.

\section{Chione dictua, Tate.}

1887. Chione dictua, Tate, Trans. Roy. Soc. South Aust. vol. ix. p. 158, pl. xvi. fig. 2.

Shell transversely-oblong, depressed, narrowed and obliquely truncate posteriorly; chiefly characterized by the surface being ornamented with suall radial costæ, decussated by concentric strix; lunule lanceolate, defined by a deep groove, withiu which are a few lamelle of growth.

Dimensions.-Height $9.5 \mathrm{~mm}$; leugth $12.5 \mathrm{~mm}$.

Form. and Loc.-Niocene: River $\mathbf{M}$ urray cliffs, South Australia.

L. 9889. Examples of both valves.

Purchased.

Chione cainozoica, Tenison-Woods (sp.).

1877. Fenus (Chione) cainozoica, Tenison- Woods, Pap. Roy. Soc. Tas. 1876, p. 113.

1887. Chione cainozoica, Tate, Trans. Roy. Soc. South Aust. vol. ix. p. 156, pl. xvi. figs. $3 a-b$.

1858. Chionc cainozoica, Joluston, Geol. Tasmania, p. 233, pl. xxxii. fìrs. 8-১u, 11-11a. 
1893. Chione cainozoica, Tate and Dennant, Trans. Roy. Soc. South Aust. vol. xrii. pt. 1, p. 225.

1895. Chione cainozoica, Tate aud Dennant, id. vol. xix. pt. 1, p. 113.

1896. Chione cainozoica, Pritchard, Proc. Roy. Soc. Vict. vol. viii. x.s. p. 135.

Shell suborbicular, highly conrex; surface with thin erect concentric lamellæ, which are much more closely-set than any other Australian Eocene Chione hitherto described; lunule broadly heart-shaped, defined by a groove which interrupts the regular course of the concentric lamellæ.

Dimensions.-Height $18 \mathrm{~mm}$.; length $20 \mathrm{~mm}$.

Form. and Loc.-Eocene: Victoria and South Anstralia.

L. 9888. Examples of different stages of growth; from MIuddy Creek.

Purchased.

L. 10587. Right valve, much crushed, probably referable to this species; from Willunga.

H. Y. L. Brown Coll.

\section{Chione subroborata, Tate.}

1887. Chione subrobonata, Tate, Trans. Roy. Soc. South Aust. vol. ix. p. 156, pl. xiv. fig. 17 .

Shell cordately trigonal, solid, broader anteriorly than posteriorly, umbones flattened, well forward; readily distinguished from C. cainozoica not only by its shape, but by the surface concentric lamellæ, which are very solid and distant from each other, there being only fifteen or sixteen on each valre in the adult; lunule small; pallial line some distance from the rentral margin.

The anthor compares it with the living $C$. raborata, Hanley.

Dimensions.-Height $22.5 \mathrm{~mm}$. ; length $25.5 \mathrm{~mm}$.

Form. and Loc.-Miocene: Victoria.

L. 355. Dwarfed specimens, a local variation of this species (?) from Bairnsdale. Presented by W. II. Grigson, Esq.

L. 4830 . Both valres; from Muddy Creek.

Presented by John Dennant, Esq.

L. 6605 , L. 9884 . Double-valved specimen, and separate right and left valves of the adult; from MIuddy Creek.

Purchased. 
Chione propinqua, Tenison-Woods.

1875. Ckione propinqua, Tenison-Woods, Pap. Roy. Soc. Tas. 1876, p. 113.

1857. Chione propinqua, Tate, Trans. Roy. Soc. South Aust. vol. ix. p. 157, pl. xiv. figs. 7,8 .

1893. Chione propinqua, Tate and Dennant, id. vol. svii. pt. 1, p. 225.

1896. Chione propinqua, Pritchard, Proc. Roy. Soc. Vict. vol. viii. N.s. p. $13 \tilde{5}$.

Shell transversely oral; surface with closely-set concentric ridges, lamellar at the extremities, which are finely radially lineated, the latter feature being most conspicuous between the ridges; pallial line near the margin, sinus rather shallow.

Mr. G. B. Pritchard (op. cit.) is of opinion that the Victorian fossils described by Professor Tate under this name are specifically distinct from the Table Cape shell on which Tenison-Woods founded $C$. propinqua. The materials at the writer's disposal are not such as to enable him to express an opinion on the subject.

Dimensions.-Height $18 \mathrm{~mm}$; ; length $23 \mathrm{~mm}$.

Form. and Loc.-Eocene and Miocene: Muddy Creek, Victoria.

L. 4829. Examples of both valres.

Presented by John Dennant, Esq.

L. 9883 , L. 9885 . Sereral specimens; from both horizons.

Purchased.

Family UNGULINID Æ.

Genus DIPLODONTA, Bronn.

[Ital. Tert. 1831, pp. ix.-xii.]

Shell inequilateral, suborbicular, sruooth, or concentrically striated; hinge having two cardinal teeth on each ralve; ligament external; pallial line simple; no lunule.

Type.-Venus lupinus, Brocchi.

\section{Diplodonta subquadrata, Tate.}

1887. Diplodonta subquadrata, Tate, Trans. Roy. Soc. South Aust. vol. ix. p. 147 , pl. xiv. figs. $10 a-b$.

1893. Diplodonta subquadrata, Tate and Dennant, id. vol. xvii. pt. 1, p. 225.

1896. Diplodonta subquadrata, Pritchard, Proc. Roy. Soc. Vict. vol. viii. s.s. p. 133. 
Shell quadrately-orbicular, thin, translucent, inequilateral, equivalve; posterior broad, with subtruncated margin; anterior narrower and rounded; surface has rather coarse concentric growth-lines; umbones small, acute. The author compares it with D. tasmanica, Tenison-Woods, from which it differs by its quadrate outline and regular sculpture, and in being less inequilateral. D. zealandica, Gray, has a rounded ventral margin and is more inflated, but otherwise resembles the present species.

Dimensions.-Height $22 \mathrm{~mm}$; l length $23.5 \mathrm{~mm}$.

Form. and Loc.--Eocene: Muddy Creek, Victoria.

L. 4805. Left valve of the neanic stage of growth.

L. 9854. Examples of both valves.

Presented by John Dennant, Esq.

\section{Diplodonta suborbicularis, Tate (sp.).}

1887. Sacchia suborbicularis, Tate, Trans. Roy. Soc. South Aust. vol. ix. p. 147 , pl. xviii. figs. $10 a-c$.

1894. Mysia (Felania) suborbicularis, Tate, Journ. Roy. Soc. N.S.W. vol. xxvii. p. 187.

Shell differs in shape on comparison with $D$. subquadrata, being triangularly (not quadrately) orbicular, depressed, posterior side rouuded, somewhat produced anteriorly; umbones smooth, remainder of surface marked with distant growth-folds; left ralve with two dirergent cardinal teeth; in the right valve the two cardinal teeth are separated by a triangular cardinal pit; no lateral teeth; cartilage pit broad; pallial line entire.

Dimensions.—Height $8 \mathrm{~mm}$.; length $7.5 \mathrm{~mm}$.

Form. and Loc.-Eocene: Muddy Creek, Victoria.

L. 9856. Specimens of both valves of the adult. Purchased.

Family DONACID无.

\section{Genus DONAX, Linnæus.}

[Syst. Nat. ed. 10, 1758, p. 682.]

Shell inequilateral, trigonal, oval, or cuneiform; umbones direeted backwards (as in Nucula, ete.); posterior side much shorter than the anterior; margin usually crenulated; right ralve 
with one anterior lateral tooth, two cardinal teeth the posterior of which is bifid, and one short posterior tooth; the left valve has an obsolete anterior lateral tooth, two dirergent cardinals (between which a smaller tooth occasionally occurs), and one posterior lateral tooth; pallial sinus rounded, very deep.

Type.-Donax truncules, Linnæus.

\section{Donax dixoni, Tate.}

1887. Donax dixoni, Tate, Trans. Roy. Soc. South Aust. vol. ix. p. 168, pl. xvi. fig. 15 .

Shell triangularly ovate, subequilateral; surface having broad, flatly rounded, radial costæ, interrupted by concentric striæ and grooves; ventral margin coarsely crenulated.

Dimensions.-Height $8 \mathrm{~mm}$; length $11 \mathrm{~mm}$.

Form. and Loc.-Eocene: Muddy Creek, Victoria.

L. 9877. Examples of both valres.

Purchased.

Family GARIIDA.

Genns GARI, Schumacher.

[Essai Nouv. Syst. Habit. Testacés, 1817, p. 131.]

Psammobia, Lamarck, Hist. Nat. Anim. sans Vert. t. v. 1818, p. 511.

Shell transversely elongated, subequilateral; anterior margin rounded; posterior margiu generally subtruncate and angulate; hinge of the riglit valve haviug two bifid tceth, the posterior being the larger; of the left, two teeth, of which the anterior is the largest, bifid, whilst the posterior is oblique; pallial sinus deep.

Type.-Tellina gari, Linuæus.

\section{Gari hamiltonensis, Tate (sp.).}

1885. Psammobia hamiltonensis, Tate, Southern Seience Record, January, p. 4. 1887. I'sammobia hamillonensis, Tate, Trans. Roy. Soc. Suuth Aust. rol. ix. p. 167, pl. xvi. fig. 13.

Shell narrowcr, more attenuated anteriorly and less abruptly truncated posteriorly than $G$. zonalis, Lamarek, from which it 
differs also in other particulars. It is sculptured externally with concentric linear incisions, which become roughened on the angulate posterior area.

Dimensions.—Height $15 \mathrm{~mm}$; ; length $30.5 \mathrm{~mm}$.

Furm. and Loc.-Miocene: Mudly Creek, Victoria.

I. 4818. Specimeus of both ralres.

Presented by John Dennant, Esq.

L. 9890. Examples of the neanic and ephebic stages of growth. Purchased.

\section{Gari æqualis, Tate (sp.).}

1885. Psammobia aqualis, Tate, Southern Scieuce Record, January, p. 4.

1887. Psammobia cequalis, Tate, Trans. Roy. Soc. South Aust. vol. ix. p. 168, pl. xvi. fig. 10 .

1893. Psammobia æqualis, Tate and Dennant, id. vol. xvii. pt. 1, p. 225.

The absence of a posterior keel serves to readily distinguish this species from $G$. hamiltonensis; surface with closely-set raised concentric lineations.

Dimensions.—Height 14.5 mm.; length $28 \mathrm{~mm}$.

Form. and Loc.-Eocene: Muddy Creek, Victoria.

L. 4819. Right valve, of the neanic stage of growth. Presented by John Dennant, Esq.

L. 9891. Series illustrating stages of growth. Purchased.

Family MESODESMATIDA.

Genus MESODESIMA, Deshayes.

[Ency. Meth. Ters. t. ii. 1831, p. 441.]

Shell subtrigonal, depressed; anterior side the longer; hinge thick, carrying a spoon-shaped depression for the ligament, in the centre, a small bifid or double cardinal tooth in front of the ligament pit; anterior and posterior lateral teeth double on the right valve, single on the left; pallial sinus more or less deep.

Type.-Mactra donacia, Lamarek. 


\section{Mesodesma, sp.}

L. 10473. Cast of leit ralves no doubt referable to this genus, not recognizable specifically; from the Upper Miocene of Red Cliff, Rakaia river, Canterbury, New Zealand. Sir James Hector Coll.

\section{Family MACTRID E.}

\section{Genus IM A C T R A, Linnæus.}

[Syst. Nat. ed. 12, 1767, p. 1125.]

Crassatella, Lamarck, Mém. Soc. Hist. Nat. Paris, 1799, p. 85.

Shell orate-trigonal; surface smooth or concentrically striated; hinge haring a deeply bifid cardinal tooth placed in front of the internal cartilage pit; the latter is triangular, large, and slightly oblique; lateral teeth strong, compressed, both anterior and posterior, double on the right valve and single on the left; pallial sinus round or angulate.

In reference to the synonym Crassatella, see p. 363.

Type.-Mactra stultorum, Linnæus.

\section{Mactra axiniformis, Tate.}

1887. Mactra axiniformis, Tate, Trans. Roy. Soc. South Aust. vol. ix. p. 170, pl. xrii. figs. $1 a-b$.

1893. Mactra axiniformis, Tate and Dennant, id. vol. xvii. pt. 1, p. 225.

Shell broadly ovately trigonal; somewhat acuminately produced posteriorly; surface almost smooth in the nmbonal region, remainder of valve having concentric slender growth-ridges and strix; ridges fewer, more pronounced and rugose on the characteristic anterior angulation, obliquely striated on the posterior carination.

Dimensions.-Heiglit $28 \mathrm{~mm}$. ; length $39.5 \mathrm{~mm}$.

Form. and Loc.-Miocene: Muddy Creek, Victoria.

L. 4840. Right valve of the adult.

Presented by John Dennant, Esq.

L. 6612 , L. 9881. Examples of both valres on which concentric colour bands are distinct.

Purchased. 
Mactra howchiniana, Tate.

1887. Mactra houchiniana, Tate, Trans. Roy. Soc. South Aust. vol. ix. p. 171, pl, xvii. figs. $3 a-b$.

1893. Mactra houchiniana, Tate and Dennant, $i d$. vol. xvii. pt. 1, p. 225.

Distinguished from the preceding species in being elongately orate, and attenuate at the extremities; surface finely concentrically ridged and striated; pallial sinus large.

Dimensions.-Height $21.5 \mathrm{~mm}$. ; length $36.5 \mathrm{~mm}$.

Form. and Loc.-Eocene: Muddy Creek, Victoria.

L. 9880 . Specimens of both valves.

Purchased.

\section{Mactra hamiltonensis, Tate.}

1887. Mactra hamiltonensis, Tate, Trans. Roy. Soc. South Aust. vol. ix. p. 171, pl. xvii. figs. $4 a-b$.

Shell shorter and broader than in M. axiniformis; posterior side straight; whilst the concentric striæ are simple at the sides instead of being exaggerated in thickness or obliquely striated. The author remarks that it differs from the living MI. polita, Chemnitz, of South Australian seas, in having flatter valves, in being less triangular in outline, proportionately larger, and the rentral margin is not so broadly curred.

Dimensions.-Height $15^{\circ} 5 \mathrm{~mm}$.; length $21 \mathrm{~mm}$.

Form. and Loc.-Miocene: Muddy Creek, Victoria.

L. 9882. Examples of the neanic stage of growth. Purchasel.

\section{Genus ZENATIOPSIS, Tate.}

[Trans. Phil. Soc. Adelaide, 1879, p. 129.]

"Shell equivalve, inæquilateral, oblong; umbo anterior, supported internally by a thick rib, extending, with a slightly backward inclination, half way across the valre; narrowly gaping at both ends; cartilage-plate prominent; cardinal teeth distinct, no lateral teeth ; pallial sinus deep, horizontal."-Tute.

The thick rib supporting the umbo internally is, perhaps, the 
most characteristic feature of this genus; the shell has the hinge characters of Zenatia.

Type.-Zenatiopsis angustata, Tate.

\section{Zenatiopsis angustata, Tate.}

1879. Zenatiopsis angustata, Tate, Trans. Phil. Soc. Adelaide, p. 129, pl. v. figs. $6 a-b$.

1887. Zenatiopsis angustata, Tate, Trans. Roy. Soc. South Aust. vol. ix. p. 172 .

Narrower, more attenuated posteriorly, and the anterior side not so abruptly arcnate as in the living Zenatia acinaces, Quoy and Gaimard; from which it is also distinguished, at sight, by the thick internal rib. Professor Tate quotes Table Cape as a locality for the fossil, but Mr. G. B. Pritchard ${ }^{1}$ is of opinion that the Tasmanian form is distinct, and calls it $Z$. fragilis.

Dimensions caunot be given as all the specimens in the collection are imperfect.

Form. and Loc.-Miocene: Mruddy Creek, Victoria.

L. 6613 , L. 9830 . Several fragments.

Purchased.

\section{Family MIYIDE.}

Genus CORBULA, Bruguière.

[Ency. Meth. Vers. Coq., etc. t. ii. 1797, p]. $\operatorname{ccxxx}{ }^{2}$ ]

Shell inequivalve, solid, gibbose, rostrate and obliquely angulate posteriorly; surface commonly concentrically ridged; right valve much larger and more convex than the left, and carrring a strong anterior cardinal tooth, followed by the internal cartilage pit, and one posterior cardinal tooth; left ralve with a large anterior cardinal pit, followed by a projecting, commonly spoon-shaped receptacle, for the cartilage, and one posterior cardiual tooth; pallial line slightly sinuous posteriorly.

Type.-Corbula sulcata, Lamarck.

1 Proc. Roy. Soc. Vict. rol. riii. x.s. pp. 139, 140.

${ }^{2}$ Cf. Deshayes, Ency. Meth. Vers. t. ii. pt. 2, 1S31, p. 8. 


\section{Corbula ephamilla, Tate.}

1865. Corbula sulcate, M'Coy, Ann. Mag. Nat. Hist. 3rd ser. vol. xvi. p. 114 (non Lamarek).

1876. Corbula sulcata, Tenison-Woods, Pap. Roy. Soc. Tas. 1875, p. 16.

1878. Corbula suleata, R. Etheridge, jun., Cat. Aust. Foss. p. 154.

1885. Corbula ephamilla, Tate, id. 1884, p. 229.

1887. Corbula ephamilla, Tate, Trans. Roy. Soc. South Aust. vol. ix. p. 176, pl. xvii. figs, $13 a-b$ and 14 .

1893. Corbula ephamilla, Tate and Deunant, id. vol. xvii. pt. 1, p. 225.

1896. Corbula ephamilla, Pritchard, Proc. Roy. Soc. Vict. vol. viii. N.s. p. 140 .

Shell of the same group as $C$. ficus, Solander, of the Upper Eocene of North-Western Europe; the right valve is very large as compared with the left, which has two or three irregular riblets rumning from the umbo to the ventral margin; the posterior margin of both valves is abruptly, obliquely truncated; surface of the right valve more strongl 5 , concentrically ridged than the left valve; a well-marked keel arising in the umbo and curving round to the extremity of the posterior ventral margin characterizes both ralves.

Dimensions.-Height $19 \mathrm{~mm}$; length $25 \mathrm{~mm}$.

Form. and Loc.-Eocene and Miocene: Tasmania, Victoria, and South Australia.

83984. Double-ralred specimen; from Table Cape. Purchased.

L. 4792. Many examples of both valves; from Muddy Creek. Presented by John Dennant, Esq.

L. 6614. Both valves of the adult; from Muddy Creek.

Purchased.

L. 9899. Series illustrating stages of growth; from Muddy Creek.

Purchased.

L. 10461, L. 10462. Several examples of the left valve; from the Murray river, near Adelaide. Presented by William Evans, Esq.

\section{Corbula pyxidata, Tate.}

1887. Corbula pixidata, Tate, Trans. Roy. Soc. South Aust. vol. ix. p. 177, pl. xvii. figs. $12 a-b$.

1893. Corbula pyxidata, Tate and Dennant, id. vol. xvii. pt. 1, p. 225.

1895. Corbula pyxidata, Tate and Dennant, id. vol. xix. pt. 1, p. 113.

Shell closely resembling the European Eocene C. lamarcki, Deshayes, which, howerer, has a concave post-dorsal surface, whilst that surface in the Australian species is slightly convex, 
and there are corresponding differences in the disposition of the concentric lineations, which in C.pyxidata are somewhat smaller. The author compares it with the soung of $C$. ephamilla, from which it may be distinguished in being less inequivalve, more convex, with larger umbones, and proportionately shorter. Kicel on the surface of the shell conspicuous; radial strix rery minute.

Dimensions.-Height $7 \mathrm{~mm}$; length $10 \mathrm{~mm}$.

Form. and Loc.-Eocene: Aldinga, South Australia.

L. 9898. Examples of the neanic and ephebic stages of growth.

Purchased.

\section{Family SAXICAVIDE.}

\section{Genus CAPISTROCARDIA, Tate.}

[Trans. Roy. Soc. South Aust. vol. ix. 1887, p. 179.]

The shell in this genus has the dentition of Glycymeris (Panopan, auct.), with an external resemblance to Saxicava; but it differs from both of those genera by haring closed valves; it has an umbonal rib confluent with the cardinal tooth, extending vertically across the interior to near the rentral margin; pallial line broken up, and there is, apparently, no sinus.

Type.-Capistrocardia fragilis, Tate.

\section{Capistrocardia fragilis, Tate.}

1857. Capistrocardia fragilis, Tate, Trans. Roy. Soc. South Aust. rol. ix. p. 180 , pl. xix. figs. $14 a-b$.

"Shell small, thin, translucent, trarersely elongate-oblong. Unbones depressed, approximate, near to the anterior margin. Anterior margin rounded; dorsal margin sloping backwards, forming an obtuse angle with the posterior margin, which is straight or slightly convex outwardly; rentral margin straight, sare for a broadish post-medial inflexion. The umbonal ridge, extending to the post-ventral margin, is moderately raised and roundly angulate. The exterior surface of the ralres is smooth and concentrically distantly striate; a few lamelli appear towards the margins." - Tate. The figures given by the author are not of much scrvice, but the following specimens agree with the description abore quoted. 
Dimensions.-Height $5.5 \mathrm{~mm}$; length $11.5 \mathrm{~mm}$. Form. and Loc.-Eocene: Muddy Creek, Victoria.

L. 9834. Examples of both ralves. Purchased.

Family PHOLADID㤅.

\section{Genus BARNEA, Leach.}

[In Risso, Hist. Nat. Eur. Mérid. t. iv. 1826, p. 376.]

Shell not gaping anteriorly, and having a single, lanceolate dorsal plate.

Type.-Barnea spinosa, Risso.

\section{Barnea tiara, Tate.}

1887. Barnea tiara, Tate, Trans. Roy. Soc. South Aust. vol. ix. p. 182, pl. xviii. figs. $l a-c$.

Shell narrowly elongate, inequilateral, attenuated at both ends; post-dorsal area very precipitous and concave behind the umbo; surface omamented with concentric ridges, which are angulate on the medial and anterior areas, where they are crossed by radiating threads, being subspinose at the points of intersection; interstitial spaces concentrically striated; the surface of the posterior half of the shell is granulated. The author remarks that the dorsal plate (which is fragmentary in the Museum specimens) is "narrowly oblong, rounded at the front, the very short posterior side is bent down at right angles, roundly truncated and medially insinnated at the end. The anterior portion of the plate has a wide, shallow median depression, bounded by an obtuse ridge on each, radiating from the umbo, the whole crossed by closely-set sharply-arched lamellæ; the narrow lanceolate depressed marginal areas exterior to the umbonal ridges are granulated."

Dimensions.-Height $15 \mathrm{~mm}$.; length $39 \mathrm{~mm}$.

Form. and Loc.-Niocene: Muddy Creek, Victoria.

L. 6615. Perfect examples of both valres, but the post-dorsal plate is missing.

Purchased.

L. 9829. Imperfect right valves, and large part of a postdorsal plate.

Purchased. 


\title{
Order DIBRANCHIA.
}

\author{
Family IUCINID E.
}

\section{Genus LUCINA, Bruguière.}

[Ency. Meth. Vers. Coq., etc. t. ii. 1798, pl. cclxxxiv.; Lamarck, Ném. Soc. Hist. Nat. Paris, 1799, p. 84.]

Shell suborbicular, or oral, slightly inequilateral, ornamented by stria or small concentric lamellæ, sometimes crossed by radiating ribs; lunule well defined; hinge very variable, but carrying normally two cardinal and one or two lateral teeth on eaeh valve; ligament marginal, long; interior of the valves punctate; pallial line large, simple.

Type.-Venus edentula, Linnæus.

\section{Lucina nuciformis, Tate.}

1886. Lucina muciformis, Tate, Trans. Roy. Soc. South Aust. vol. viii. p. 158 , pl. xii. figs, $10 a-b$.

1887. Lucina nuciformis, Tate, id. rol, ix. p. 144.

Shell globose, abruptly compressed in the post-dorsal area; surface ornamented by thick concentrie lamellie and radial lines; margin strongly crenulated; lumule small. It bears a superficial resemblance to $L$. (Linga) columbella, Lamarck, of the European Miocene.

Dimensions.-Height $8.5 \mathrm{~mm}$; ; length $9 \mathrm{~mm}$.

Form. and Loc.-Miocene: Aldinga, South Australia.

L. 9871. Several specimens of divers stages of growth.

Purchased.

\section{Lucina, sp.}

42689. Cast of a large flattened species, possibly referable to the subgenus Mittha; (locality?) South Australia.

Presented by the Governors of Adelaide Ifuseum.

L. 10435. Several casts of a large globose species; from Willunga, South Australia. II. I. L. Brown Coll. 
L. 10436. Three casts of a depressed orbicular species; from Fowler's Bay District, South Australia. II. Y. L. Brown Coll.

L. 10428. Casts in argillaceous limestone of a large depressed species. Miocene: Akuakua (upper beds), New Zealand.

Sir James IIector Coll.

L. 10431. Imperfect shell of a species referable to the subgenus Divaricella; (locality?) N'ew Zealand.

W. B. D. Mantell Coll.

Family TELLINID 玉.

\section{Genus TELLINA, Linnæus.}

[Syst. Nat. ed. 10, 1758, p. 674.]

Shell elongately oval, suborbicular, or transverse, compressed, attenuated and furnished posteriorly with a decurrent oblique plication; hinge having two cardinal teeth on each valre, and two lateral teeth (one anterior and one posterior) which are generally obsolete on the left valve; pallial sinus very deep.

Type.-Tellina virgata, Linnæus.

\section{Tellina albinelloides, Tate.}

1887. Tellina albinelloides, Tate, Trans. Roy. Soc. South Aust. vol. ix. p. 164 , pl. xvi. figs. $4 a-b$.

Shell oval, compressed, subangular, and slightly folded posteriorly ; umbones inconspicuous; exterior ornamented with fine, regular, concentric strix, which are raised on the posterior slope; siphonal inflection confounded with the pallial line. The author compares it, at some length, with $T$. albinella, inhabiting Southern Austrulian seas.

Dimensions.-Height $12.5 \mathrm{~mm}$. ; length $23 \mathrm{~mm}$. Form. and Loc.-Miocene: Muddy Creek, Victoria.

L. 9864. Left valre of the neanic stage of growth. Purchased. 


\section{Tellina masoni, Tate.}

1887. Tellina masoni, Tate, Trans. Roy. Soc. South Aust. vol. ix. p. 165, pl. xri. figs. $6 a-b$.

1893. Tellina masoni, Tate and Dennant, id. vol. xrii. pt. 1, p. 225.

In this species the umbones are situated about one-third the length of the shell from the posterior margin; the rentral margin is arehed; exterior ornamented by elosely-set, slightly elevated, concentrie lamellie; pallial sinus very large, reaching to near the anterior adductor sear.

Dimensions.-Height $14 \mathrm{~mm}$; l length $21 \mathrm{~mm}$.

Form. and Loc.-Eocene: Muddiy Creek, Victoria.

L. 9865. Examples of both valies.

Purchased.

\section{Tellina æquilatera, Tate.}

1887. Tellina equilatern, Tate, Trans. Roy. Soc. Sonth Aust. vol. ix. p. 166 , pl. xri. figs. $5 a-b, 9 a-b$, pl. xx. fig. 19 .

1893. Tellina cquilutera, Tate and Dennant, id. vol. xvii. pt. 1, p. 225.

Shell oval-oblong, nearly equilateral, smooth, and somewhat conrex; there is a slight radial depression near the post-dorsal margin, proceeding from the umbo; exterior ornamented with coucentrie striæ; siphonal inflection very deep, narrow, rounderi at the extremity, reaching to near the anterior adductor scar, and (contrary to what obtains in $T$. albinelloides and $T$. masoni) is quite detached from the pallial impression.

Dimensions.-Height $24 \mathrm{~mm}$.; length $35.5 \mathrm{~mm}$.

Form. and Loc.-Miocene: Muddy Creek, Victoria.

I. 9863 . Examples of both ralres.

Purchased.

\section{Tellina stirlingi, Tate.}

1887. Tellina stivlingi, Tate, Trans. Roy. Soc. South Aust. vol. ix. p. 166, pl. xri. figs. $i a-b$.

1593. Tellena stirlingi, Tate and Dennant, id. vol. xrii. pt. 1, p. 225.

Shell differs principally from T. aquilatera in being elongate-oval, 
inequilateral, and in being distinctly concentrically ridged. As in that species, howerer, the siphonal sinus is quite free from the pallial line; it is large, and ascends into the umbonal cavity.

Dimensions.-Weight $6.5 \mathrm{~mm}$; length $11 \mathrm{~mm}$.

Form. and Loc.-Eocene: Muddj Creek, Victoria.

L. 9866. Several specimens of different stages of growth.

Purchased.

\section{Family SCROBICULARIIDA.}

\section{Genus SEMELE, Schumacher.}

[Essai Nouv. Syst. Habit. Testacés, 1817, pp. 165, 166.]

Shell somewhat inflated, suborbicular, subequilateral; umbones small, turned anteriorly; slightly plicated posteriorly; two very small cardinal teeth on each valve, and two lateral, most distinct on the right valve; cartilage pit long, oblique, pallial sinus very deep.

Type.-Tellina reticulata, Spengler.

\section{Semele vesiculosa, Tate.}

1887. Semele vesiculosa, Tate, Trans. Roy. Soc. South Aust. vol. ix. p. 169, pl. xvi. tig. 12 .

1893. Semele vesiculosa, Tate and Dennant, id. vol. xrii. pt. 1, p. 225.

Shell transrersely ovate, inequilateral; the anterior side is the longer and is rounded, the posterior being obtuse-angled; right valve not so convex as the left, and not so conspicuously angulate at the umbonal slope; surface shining, few lines of growth; lunule broadly lanceulate; pallial sinus extending two-thirds across the interior, rounded at the apex.

Dimensions.-Height $7 \mathrm{~mm}$. ; length $9 \mathrm{~mm}$.

Form. and Loc.-Eocene: IInddy Creek, Victoria.

L. 9862. Specimens of both valves.

Purchased.

\section{Semele krauseana, Tate.}

1857. Semele krauseana, Tate, Trans. Roy. Soc. South Aust. rol. ix. p. 169, pl. xvi. figs. $18 n-b$.

1593. Semele krauseana, Tate and Dennant, id. vol. xvii. pt. 1, p. 225. 
Shell moderately convex; distinguished by the ralres being conspicuously turned to the right at the posterior extremity, where they are slightly gaping, and by the posterior portion of the shell being subrostrate, and haring a slight fold continued from the umbo to the post-ventral margin.

Dimensions.-Height $13 \mathrm{~mm}$.; length $21 \mathrm{~mm}$.

Form. and Loc.-Eocene: Mornington, Victoria.

L. 9861. Three examples of the right valve.

Purchased.

\section{Family CUSPIDARIIDA.}

\section{Genus CUSPIDARIA, Nardo.}

[Ann. Sci. Lombardo-Veneto, t. x. 1840, p. 49.]

Neara, J. E. Gray, in Griffith's "Animal Kingdom," rol xii. 1834, pl. xxii. fig. 5 (non Robineau-Desvoidy, 1830).

Shell piriform, right valve smaller and less conrex than the left; rounded and globose in front, rostrated and slightly gaping belind; hinge-teeth not constant, a small cardinal tooth sometimes occurs in front of the spoon-shaped depression of the cartilage which is internal, and whilst the posterior lateral tooth is generally well developed on the right valre, it is obsolete on the left; pallial sinus small.

Type.-Tellina cuspidata, Olivi.

\section{Cuspidaria subrostrata, Tate (sp.).}

1887 Necera subrostrata, Tate, Traus. Roy. Soc. South Aust. vol, ix. p. 177, pl. xv. figs. $2 a-b$.

Shell orate, moderately conrex, thin; much produced posteriorly; rentral margin sinuated in front of this rostral prolongation; umbo carinated, the keel being directly posteriorly, but it rapidly becomes obsolete; surface ornament consisting of coarse, concentric lines of growth, lamellose at the umbo and rostral insinuation.

Dimensions. - Height 10.5 mm.; length $21.5 \mathrm{~mm}$.

Furm, and Loc.-Eocene: Muddy Creek, Victoria.

L. 4810. Right ralre.

Presented by John Dinnant, Esq.

L. 9845. Specimens of both valres of the adult. I'urchased. 


\section{Family PANDORIDA.}

\section{Genus IMYADORA, Gray.}

[Ann. Nat. Hist. vol. iv. 1840, p. 306.]

Shell equilateral, trigonal, rounded anteriorly, truncated posteriorly, nacreous in the interior; left valve commonly flat, the right convex; cartilage pit narrow, median, internal, furnished with a falciform projection placed between two divergent teeth; pallial sinus small.

Type--Pandora brevis, Sowerby.

\section{Myadora tenuilirata, Tate.}

1887. Myodora tenuilirata, Tate, Trans. Roy. Soc. South Aust. vol. ix. p. 174 , pl. xvii. figs, $9 a-b$.

1893. Myadora tenuilirata, Tate aud Dennant, $i d$. vol. xvii. pt. 1, p. 225.

Right valve convex, oblong; left valve flat; finely concentrically rilged and radially striated, the last-mentioned feature being more conspicuous on the left valve.

Dimensions.-Height $9 \mathrm{~mm}$; l length $14.5 \mathrm{~mm}$.

Form, and Loc.-Eocene: Muddy Creek, Victoria.

L. 9910. Specimens of both valves.

Purchased.

\section{Myadora australis, Johnston.}

1880. Myodora australis, Johnston, Pap. Roy. Soc. Tas, 1879, p. 40.

1887. Myodora australis, Tate, Traus. Roy. Soc. South Aust. vol. ix. p. 174, pl. xvii. figs. $10 a-b$.

1896. Myodora australis, Pritchard, Proc. Roy. Soc. Vict. vol. viii. N.s. p. 140 .

Distinguished from $M$. tenuilirata by its shape, the right valve being ovately oblong, and moderately convex; whilst it is faintly ridged from the umbo to the post-rentral angle, and has numerous close concentric ridges; left valve almost flat, it has minute radial and fine concentric lineations.

Dimensions.-Height $12 \mathrm{~mm}$.; length $15 \mathrm{~mm}$.

Form. and Loc.-Eocene: Table Cape, Tasmania.

L. 9913. Examples of the adult, both valres.

Purchased. 


\section{Myadora corrugata, Tate.}

1887. Myodora corrugata, Tate, Trans. Roy. Soc. South Aust. vol. ix. p. 175, pl. xvii. tigs. $11 a-b$.

In this species the right valve is orate and convex; with but few, distant concentric ridges on the exterior; left valve flat.

Dimensions. - Height $14 \mathrm{~mm}$.; length $17 \mathrm{~mm}$.

Form. and Loc.-Miocene: Muddy Creek, Victoria.

L. 4809. Two examples of the left ralve.

Presented by Joln Dennant, Esq.

L. 9911. Specimens of both valves.

Purchased.

Myadora prælonga, Tate.

1887. Myodora prelonga, Tate, Trans. Roy. Soc. South Aust. vol. ix. p. 173 , pl. xix. figs. $12 a-d$.

Readily distinguished from other species of Mryadora here alluded to, in that the shell is subincquiralre and elongate. The author remarks that the anterior side is fire times as long as the posterior, and the shell as a whole is broad. In its congener 2 . angustior, Tate, the anterior side is not much longer than the posterior, and the shell is rery narrow.

Dimensions.-Height $6.5 \mathrm{~mm}$; ; length $11.5 \mathrm{~mm}$.

Form. and Loc.-Niocene: Muddy Creek, Victoria.

L. 9912. Series illustrating stages of growth. Purchased. 



\section{N D E X}

abbreviata, Harpa, 81 .

abducta, Natica, 260.

acanthostephes, Columbarium, 52.

Acardo, 23. Fusus, 52.

accedens, Newtoniella, 230.

accrementa, Pecten, 320 .

achatina, Cassis, 200.

aciformis, Fusus, 136. Latirofusus, 136.

acinaces, Zenatia, 381 .

acinaciformis, Leda, 349 .

Nuculana, 349.

acinosus, Trochus, 277.

acricula, Turritella, 238.

acrieulum, Dentalium, 297.

Actieon, 7 .

Entalis, 297.

aculeata, Crepidula, 247.

Patella, 247.

acuminata, Ampullina, 266.

acuta, Ampullaria, 265.

Turritella, 238.

acuticostata, Trigonia, 355 .

acutum, Solarium, 244.

additoides, Terebra, 25.

Adelactixon, 10.

Admete, 68 .

Admetula, 68 .

xqualis, Gari, 378.

Psammobia, 378.

xquilatera, Tellina, 387.

Ater, 144.

afer, Afer, 145 .

- Fusus, 144.

"Murex," 144.

Agaronia, 73 .

agglutinans, Xenophora, 254.

agnewi, Toluta, 111.

alba, Solidula, 8 .

Tornatella, 8.

albicosta, Mytilus, 329.

albinellat, 'I'elliua, 386 .

albinelloides, 'Tellina, 386 . albisulcata, Ancilla, 73 . Ancillaria, 76 .

album, Sistrum, 184.

albus, Buccinulus, 8 .

Alcithoe, 113.

aldingæe, Marginella, 90.

Turritella, 238.

aldingensis, Pecten, 321 .

algoensis, Cyprea, 206.

allporti, Yoluta, 103.

alokiza, Mitra, 119.

alta, Cuculliea, 338.

Pleurotoma, 45, 46.

aluco, MIurex, 224 .

alveolatus, Murex, 180 .

amblyceras, Мurex, 175 .

ambulacrum, Ampullaria, 265.

Amoria, 93, 108.

Amphibola, 5 .

Amphiperas, 210.

ampla, Crassatella, 365.

amplus, Crassatellites, 365 .

Ampullacera, 5.

Ampullaria, 5, 264.

ampullaria, Natica, 260.

Ampullina, 264.

Ampulliue, 264.

Ampullospira, 265.

Amussium, 322, 324.

Anaulax, 77 .

Aneilla, 72 .

Aneillaria, 72.

ancilloides, Scaphella, 112. Voluta, 112.

Aneistrosyrinx, 52.

angasi, Míurex, 178.

Ostrea, 300. Toluta, 109.

anguina, Serpula, 234.

angulata, Grypheca, 302.

angustata, Oliva, 71.

Olivella, 71 .

Vulsella, 326.

Zenatiopsis, 381. 
angusticosta, Pectunculus, 341 . angustifrons, Bathytoma, 49 . Dolichotoma, 49. Genotia, 49. - Limarea, 343, 344.

angustior, Myadora, 391.

annectans, Lotorium, 192. Triton, 192.

annulatum, Deutalium, 295.

Anodouta, 356.

Antale, 293.

antegressa, Uromitra, 125.

Anthora, 27\%.

antiaustralis, Pecten, 315.

anticingulata, Voluta, 98.

anticingulatus, Volutilithes, 94, 98.

antiquatus, Hipponys, 246.

antiscalaris, Voluta, 97, 98.

- Volutilithes, 94, 97.

antisenigrauulatum, Cardium, 368 .

— Protocardium, 368.

apheles, Cerithium, 224.

apiculata, Leda, 350 .

Nueulana, 350.

approximans, Latirus, 143.

Apollo, 195. Peristernia, 143.

Apollon, 186.

Aptyxis, 141.

Aquila, 186.

Aquillus, 186.

Aquilus, 186.

arachis, Bulla, 14.

Bullinella, 14

Cylichna, 14.

arachnoideus, Calyptræa, 251.

aratum, Dentalium, 293.

Area, 330.

arenaria, Ancilla, 74.

arenicola, Ostrea, 300 .

Argobuecinum, 186, 195.

Aricia, 208.

Aspella, 195.

asperrimus, Pecten, 315.

asperulus, Murex, 183. - Sipho, 155.

astartiformis, Crassatella, 364 .

Asthenotoma, 48.

athletus, Tolutilithes, 102.

atkinsoni, Nucula, 348 .

- Pecteu, 324. Portlaudia, 348.

atomatus, Bulimus, 3.

atractoides, Bathytoma, 50.

- Mitra, 123, 129.

Pleurotoma, 49.

attenuata, Crassatella, 365 .

Cucullæa, 338. attenuatus, Crassatellites, 365 .

Aulica, 93, $10 \mathrm{I}$.

aurantiacus, Latirus, 143.

auriculifera, Cucullæa, 336.

aurita, Area, 346.

Limopsis, 346.

australe, Umbraculum, 23.

australis, Amphibola, 5 .

Ancilla, 76.

Ancillaria, 76, 77 .

Buccinum, 275.

- Bulla, 13.

Cardita, 361.

- Cypræa, 214.

Erato, 215.

Murex, 219.

- Myadora, 390.

Myodora, 390.

Mytilus, 329.

Pecten, 315.

Phasianella, 275.

Pseudoliva, 167.

Struthiolaria, 220.

Trivia, $213,214$.

Venericardia, 361.

Zemira, 167.

austrina, Umbrella, 23.

Austrofusus, 157.

avellana, Amphibola, 5 .

Ampullacera, 5.

Ampullaria, 5.

Bulimus, 5.

Helix, 5.

Thallicera, 5 .

avellanoides, Cypræa, 213. Trivia, 213.

a vena, Marginella, 84 .

Avicula, 325 .

awamoensis, Cardita, 360 .

axiniformis, Mactra, 379 .

babylonius, Murex, 38 .

Balantium, 19.

Bankivia, 280.

barbata, Arca, 331.

Barbatia, 331 .

barclayi, Latirus, 149.

Barnea, 384.

bartonensis, Cypræa, 205.

bassi, lima, 310.

Bathytoma, 48.

Batillaria, 228.

bedualli, Voluta, 104.

beethami, Pecten, 319 .

Bela, 57, 60. 
belcberi, Limopsis, 345 . Pectunculus, 345 .

bella, Tormatellaca, 9 . beraulii, Drillia, 55.

Beruayia, 204.

bibalteata, Marginella, 84.

bicariuata, Clio, 20.

bicarinatus, Turbo, 233.

bieolor, Manrilia, 58 .

bideus, Clatliurella, 59 . Mangilia, 59.

bifusciata, Nargiuella, 87 .

bifrous, Deutalium, 295. Murex, 175. Pecten, 317 .

bilocularis, Mrtilus, 328 .

biplicata, Oliva, 71 .

bitubercularis, Ranella, 196.

Bivetia, 67 .

blainvillei, Murex, 179.

bovius, l'lacostylus, 4 .

brachyprga, Cyprea, 206.

brevis, Pिandora, 390.

brocchii, Couts, 30.

browui, Cirsotrema, 268.

Scalaria, 268.

bruguièrei, Bullinella, 14.

buccinoides, Ancilla, 73.

Buccinulus, 8.

Buccinum, 167.

buehanani, Pleurotoma, 47 .

Bulimus, 3.

Bulla, 12, 13, 14 .

bullata, Lima, 311.

Bullina, 13.

Ostrea, 311.

Bulliuella, 12, 13.

Cadulus, 297.

caillati, Natica, 256 .

cainozoica, Area, 335. Chione, 373. Cuculliei, 340. - Plagiarca, 335. - Venus, 373.

caiuozoicus, Macrodon, 335 .

Caloscala, 267. Pectunculus, 340 .

calva, Cardita, 359.

calvus, II urex, 174 .

calyculata, Clama, 358 .

Calyptrea, 246, 219 .

calyptratormis, Calyptraca, 252. Trochita, 250 .

Calyptropsis, 251.

Campanule, 2:28. camplytropis, Murex, 184 .

canaliculata, Euspira, 265, 266.

Caucellaria, 65.

cancellata, Delphinula, 284.

caucellatum, Cerithium, 227 .

Caucilla, 123, 129.

canreua, Natica, $25 \overline{5}$.

Cantharus, 161.

capillacea, Mangilia, 58 .

capillata, Cancellaria, 67 . - Naroua, 67.

Capistrocardia, 383.

Cardita, $35 \overline{7}$.

Carditella, 362.

Cardium, 366.

Caricella, 96.

carinifera, Turritella, 240.

carolinensis, Barbatia, 335.

Casmaria, 200.

Cassidaria, 201.

cassidarixeformis, Buccinun, 154.

Cassidea, 197.

eassidiformis, Marginella, 90.

Cassis, 197.

cataphracta, Bathytoma, 50.

cataphractus, II urex, 49 .

catena, Natica, 260.

catenifera, Terebra, 24.

cathedralis, Scaphella, 117. Voluta, 117.

catus, Conus, 35 .

cavershamensis, Turritella, 242.

cedonulli, Pleurotoma, 52 .

Cellepora, 332.

celleporacea, Arca, 332.

cellulifera, Mitra, 124 .

Cerithiella, 229.

Cerithiopsis, 229.

Cerithium, 223.

Cerostona, 172.

Chaua, 306, 369.

Chelyconus, 34 .

Chicoreus, 172, 178.

chiuensis, Patella, 249.

Chione, 372.

Unbella, 23.

Chlamrs, 313.

ciuct 1 , Struthiolaria, 221.

cingulata, Deuuantia, 163. Euthria, 163.

cingulifera, leucozouia, 145 . 'Terebra, 25.

Turbinella, 113 .

ciunamomea, Ancilla, 73 .

Cirsotrema, 267.

Clanculus, 279.

clarse, I'leurotoma, 43. 
clathrata, Trichotropis, 233.

Clathurella, 59.

clathurella, Mitra, 128.

Clavatula, 44. Uromitra, 128.

clavatula, Cancellaria, 67 .

Clavella, 137.

Cleodora, 19.

Clio, 18, 19.

coarctata, Mitra, 81.

coaretatus, Pecten, 316.

Cœlotrochus, 278.

Colina, 227.

Collonia, 276.

colon, Fusus, 135.

colorata, Lima, 309.

Colubraria, 194.

Columbarium, 51, 135.

columbella, Lucina, 385 .

colus, Murex, 52, 131.

communis, Crassatella, 364. Crassatellites, 364.

compacta, Nassa, 169.

complicatus, Conus, 31 .

compta, Mytilicardia, 361 .

conchyliophorus, Trochus, 253.

conciuna, Voluta, 115.

confusa, Helix, 2.

Xenophora, 254.

couica, Natica, 258.

Marginella, 88.

Thalotia, 280 .

coniformis, Voluta, 107.

conoidea, Voluta, 95, 107.

Conomitra, 129.

couquisita, Mitra, 125.

cousobrinus, Pecten, 317.

conspicabilis, Turritella, 237.

consutilis, Area, 332.

Barbatia, 332, Pleurotoma, 41.

contabulata, Marginella, S2.

contabulatus, Mfurex, 177.

coutorta, Crepidula, 246. - Crypta, 246.

contusa, Crypræa, 205.

Conulus, 92 .

Conus, 27.

convexus, Conus, 31.

Pectunculus, 342.

convolutum, Terebellum, 218.

cor, Pectunculus, 340.

Corbula, 381.

corioensis, Cucullæa, 336.

cornutum, Buccinum, 197.

coronata, Pelicaria, 222 .

L Tylospira, 222.

corrugata, Calyptraa, 250. corrugata, Myadora, 391.

costata, Crepidula, 247.

Crypta, 247.

Peristernia, 144.

Costellaria, 125.

costellatum, Diastoma, 232.

costulata, Mangelıa, 57, 61 .

craspedotus, Fusus, 54, 134.

crassa, Calyptræa, 250. Ĺeda, 350 .

- Nucula, 350.

Nuculana, 350.

Crassatella, 363, 379.

Crassatellites, 363 .

crassicardia, Margaritifera, 325. Meleagrina, 325.

crassigranosa, Nassa, 168.

erassilirata, Bela, 62 . Daphnella, 62.

crawfordi, Pecten, 321 .

crebrigranosus, Sipho, 153.

erenata, Helix, 5.

Tritonofusus, 153.

Crenella, 329 .

crenulata, Struthiolaria, 219.

Crepidula, 246.

Creseis, 18.

cribarivides, Cerithium, 230.

Newtouiella, 230.

Crisposcala, 269.

cristata, Fasciolaria, 138.

Crosseia, 269.

crustata, Arca, 333.

Crypta, 246, 247.

Cryptoconus, 48.

cryptoploca, Fasciolaria, 140.

Cryptospira. 90.

Cucullea, 336.

cumingii, Placunanomia, 303.

cunninghamensis, Natica, 237.

Cuspidaria, 389.

cuspidata, Tellina, 389.

cuspidatus, Conus, 32.

cygnea, Mactra, 363.

cygneus, Mytilus, 356 .

cygnus, Mactra, 363.

Cylichua, 13.

Crlindra, 64.

cylindracea, Bulla, 14.

Cymba, 96.

cyphus, Lotorium, 187. Triton, 187.

Cypræa, 213.

cypræola, Cypræa, 214.

Cythara, 58. 
Cytherea, 370 .

Dactylus, 8 .

danæ, Eulina, 271.

Daphnella, 60,64 .

decipiens, Fasciolaria, 141, 142. decomposita, Bathytoma, 50.

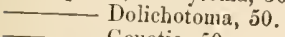

- Geuotia, 50 .

decussata, Arca, 334.

—_ Barbatia, 334. Byssoarca, 334.

delicatul Mytilus, 329. delicatul Cardita, 359 . delicatus, Trochus, 278. dennanti, Conomitra, 130. - Conus, 30, 33. Crassatella, 363. Crassatellites, 363 . Mitra, 130.

Dennantia, 162. II urex, 176.

Dentalium, 290.

denticostatus, Strombus, 217. denticulata, Ringicula, 15 . depanperatus, volutilithes, 97 . deperdita, Vulsella, 326 . deperditus, Conus, 28. depressa, Natica, 265. Vaginella, 21.

deshayesiana, Dimya, 305.

Diastoma, 231.

Dibaphus, 64 .

dictua, Chioue, 373.

dictyotis, Fusus, 132.

digna, Mitra, 120.

dimorphophylla, C'hione, 373.

Dimya, $3055^{\circ}$.

Dipludouta, 375.

dissinilis, Arca, 336. Barbatia, 336. Dinya, 306.
Pinna, 327 .

Divaricella, 386 .

dixoni, Donax, 377 .

Dolichotoma, 48.

Dolinm, 198.

donacia, Mactra, 378 .

Ionax, 376.

Drillia, 47,55 .

dysera, Vicuus, 372.

Eburna, 167.

cburnea, Cytherea, 371. II eretrix, 371. eburnea, Niso, 272.

echinatum, Buccinum, 184.

echinophorum, Buccinum, 201.

Echinora, 201.

edentula, Marginella, 216.

Venus, 385 .

dium, 366 .

edulis, Mytilus, 327 . Ostrea, 298.

effusa, Ampullina, 266.

Eglisia, 270. Euspira, 266. .

elegaus, Crenella, 330.

- Polyodonta, 278.

Tugali, 290.

'T'ugalia, 289.

elegantissima, Eulima, 27 I.

eleplautinum, Dentalium, 292.

eligmostoma, Vagiuella, 21 .

ellipsoidea, Voluta, 10.5.

elongata, Crenella, 330 .

elyros, Anomia, 304.

Placunanomia, $30 t$.

emarginata, Emarginula, 299.

Emargiuula, 288.

Embolus, 18.

Enæta, 94.

eugonia, Bathytoma, 51.

Entaliopsis, 290.

Eutalis, 290.

Eocithara, 78.

Eopsephia, 96, 114, 11 .

eplamilla, Corbula, 382 .

epidromiformis, Cancellaria, 70. Sreltia, 70 .

episcopalis, Voluta, 119.

equidens, Arca, 331.

Erato, 214.

erosa, Csprea, 208.

Erosaria, 20s.

Ethalia, 25\%.

etheridgei, Cancellaria, 68 .

- Narona, 68.

Euchilotheca, 20. Narona, 68.
Turbo, 273.

Eulina, 271.

Eumitra, 119.

europæa, Trivia, 213.

europea, Cyprea, 213.

Euryta, $2 i^{\circ}$

Euspira, 264, 265.

Euthria, 162.

evaricosus, Trphis, 171 .

erulsa, Cancellaria, 69.

erulsum, Buccinum, 68 .

exigua, Bullinella, it. Cassis, 197. Cyliclua, 14. 
exigua, Thalotia, 280.

exilis, Fasciolaria, 137.

Mitra, 126.

Streptochetus, 137.

Uromitra, 126.

eximia, Cyprea, 210. Cypreovula, 210.

exoleta, Turritella, 240.

exoticus, Pecten, 322.

extenuatus, Conus, 29.

eyrei, Murex, 181.

Pecten, 318.

fasciata, Bankivia, 280.

Phasianella, 280.

fasciatus, Cantharidus, 280. Trochus, 280.

Fasciolaria, 93, 138 .

Felania, 376.

fenestratus, Septifer, 328.

fibratus, Bulimus, 4. Placostylus, 4.

ficus, Corbula, 382.

fissura, Patella, 288. Dentalium, 296.

Fissurellidea, 287.

fistulosus, 'Typhis, 171.

flabellatus, Pectunculus, 342 .

flemingtonense, Cerithium, 226. flemiugtonensis, Cerithium, 226.

flesuosa, Triplex, 173.

flexuosus, Murex, 173.

florida, Mitra, 130 .

foliaceum, Columbarium, 53.

foliaceus, Fusus, 53.

fontinalis, Bathytoma, 51.

Dolichotoma, 51.

Genotia, 51.

formosa, Seguenzia, 266.

fornicata, Patella, 246.

Fossularca, 335.

fragilis, Capistrocardia, 383. Scaphander, 12.

Zenatiopsis, 381.

fraseri, Struthiolaria, 220.

frazeri, Struthiolaria, 220.

frondosus, Murex, 173.

Fulgoraria, 94, 100, 113.

fulminata, Phasianella, 280.

fulvolabris, Trochus, 277.

funiculosus, Fusus, 136.

fusiformis, Lotorium, 188.

Fusimitra, 124 . Seraphs, 218.

fusoides, Mitra, 129.

Fustiaria, 291.

Fusus, 51, 93, 131. fusus, Voluta, 114.

gæderopoides, Spondylus, 307. gxederopus, Spondylis, 307

galba, Bullinella, 14 .

Galeodea, 201.

Galerus, 249.

Gari, 377.

gari, Tellina, 377.

Gastroplax, 22.

geilstonensis, Helix, 2.

gemmulata, Turritella, 239.

geniculata, Terebra, 26.

Genotia, 48.

gervillei, Liotia, 284.

gibberula, Meroe, 372. Sunetta, 372 .

gibbsi, 'T rochus, 286.

gibbum, Lotorium, 189.

gibbus, Triton, 189.

gigantea, Fasciolaria, 139.

Turritella, 242.

giganteum, Dentalium, 294.

gigas, Cypræa, 208.

Gisortia, 208.

Glabella, 87.

glabella, Voluta, 82.

glabra, Mangilia, 58.

glaucinoides, Natica, 265.

globosus, Pectunculus, 343.

globularis, Crenella, 330 .

Globulus, 264. Cyprea, 207.

glycimeris, Arca, 339.

goodalli, Marginella, 89 .

gracilicostata, Cardita, 358 .

gracilis, Marginella, 84 . Scaphella, 114. Voluta, 114.

gracillima, Daphnella, 64, 65 . gracillimum, Teleochilus, 65 . gradata, Bivetia, 66.

Caucellaria, 66.

Cassidaria, 201.

Morio, 201.

grandis, Conus, 27.

granifer, Nassa, I68.

graniformis, Murex, 180.

grauulata, Colubraria, 194.

granulifera, Turritella, 240.

grayi, Nucula, 347.

gregsoni, Phos, 165.

Gryphæa, 302.

guamense, Umbonium, 282.

gunni, Liparus, 3.

Gyrina, 195.

gyrinus, Nurex, 195. 
Haliotis, 284.

hamiltoneusis, Gari, 377.

Mactra, 380 .

IIrtilus, 328 .

Natica, 256.

Psammobia, 377.

Turbo, 274.

hannatordi, Yoluta, 100.

Harpa, 78.

harpa, Buccinum, 78.

harpula, Lyria, 94, 99.

harpularia, Lyria, 99.

Haustator, $2 i 0$.

hebera, Ancilla, 74, 76. Ancillaria, 76 .

heberti, Solarium, 245 .

hebetatus, Typhis, 170 .

hectori, Cerithium, 227.

Heliacus, 245.

helicialis, Limacina, 19.

helicina, Clio, 19.

Heliconoides, 18.

Helicophora, 18.

Helix, I.

hemimeris, Cardium, 368.

Protocardium, 368.

Hemitoma, 289.

heterospira, Conus, 28, 35 .

hexagoualis, Fusus, 13 I. Latirofusus, 131.

hexagonus, Murex, I81.

hillanum, Cardium, 368.

Hima, 169.

Hindsia, 165.

Hippouyx, 246.

hirsutus, Mytilus, 328.

hochstetteri, Pecten, 323. Pseudamussium, 323.

horridus, 'Typhis, 171.

howchiniana, Mactra, 380.

howitti, Trigonia, 354.

huttom, Colina, 227.

Lerla, 351.

Nuculana, 351.

huxleyana, Helix, 2.

Hyalinia, 92.

hyotis, Ostrea, 299.

Ianacus, $2 \notin 8$.

imperialis, Voluta, 107.

incertus, Pccten, 316.

Streptochetus, 138.

inconspicua, Leda, 349 .

incurva, Crepidula, 248. - Crypta, 248.

indica, Xenophora, 254.

iuermis, Marginella, 86. inermis, Struthiolaria, 220.

inflata, Cyprea, 207.

Infundibulum, 249.

infundibulum, Murex, 152. Natica, 263.

ino, Denuantia, 162.

- Euthria, 162.

Fusus, 162.

inornata, Trichotropis, 233.

insolita, Limopsis, 344 . Trigonocœlia, 344 .

integra, Drillia, 56 .

interlineata. Peristernia, I 45 .

interlineatus, Latirus, 145 .

intermedia, Venericardia, 360 .

intortus, Fusus, 137.

ione, Placunanomia, 303.

iris, Haliotis, 285.

irregularis, Dentalium, 293. - Murex, 179.

isabella, Cyprea, 204.

islandicus, Fusus, 153.

jani, Surcula, 45.

japonica, Cassis, 198. Myonia, II.

jeffreysiana, Liwa, 3 II.

johnstoni, Fasciolaria, 142. Unio, 356.

johnstonii, Fnsus, 142.

junonia, Voluta, 111.

kanieriensis, Turritella, 241.

kickii, Dentalium, 293.

kicksii, Dentalium, 293.

kingi, Liparus, 3.

krauseana, Semele, 385.

labrosus, Sipho, 154. Tritonofusus, 154.

laciniatus, Trphis, I71.

lactea, Naticina, 260. - Ringicula, 15.

Lævidentalium, 291.

lærigata, Lima, 312. Tulsella, 326 .

Xenophora, 253.

levis, Dentalium, 297. Erato, 215.

Lagena, 150.

lamarcki, Corbula, 382.

lamarckii, Trigomia, 355.

lamellata, Carditella, 362.

Gouldia, 362 .

lamellifera, Chama, 369. 
lamellifera, Harpa, 79.

Lampania, 228.

lampas, Helix, 1.

Lampusia, 185.

lanceolata, Ancilla, 74.

Ancillaria, 74.

laticostatus, Pectuuculus, 341.

Latirofusus, 131, 135.

Latirolagena, 150 .

Latirus, 142 .

latissima, Cardita, 358, 359.

lazarus, Chama, 369.

Leda, 348.

leeuwinensis, Liparus, 3.

Jeiopyrga, 281.

leptalea, Mitra, 125.

Uromitra, 125.

Leptoconus, 27, 37 .

leptorhyncha, Cypræa, 207. Leda, 350. Nuculana, 350.

leucozonalis, Leucozonia, 151.

Leucozoma, 148.

levesquei, Ampulliua, 266.

ligata, Ancilla, 75.

- Ancillaria, 75.

Conomitra, 130.

Mitra, 130.

Tornatellæa, 9.

Triploca, 9.

ligatus, Conus, 28.

lignaria, Bulla, 12.

lignarius, Fusus, 162.

Lima, 309.

lima, Ostrea, 309.

Limacina, 18.

Limarea, 343.

limata, Natica, 261, 262.

Limatula, 311 .

Limea, 312.

Limnæa, 4.

Limoarea, 312.

Limopsis, 335, 344.

Linga, 385.

linguliformis, Lima, 310 .

Liopeplum, 93.

Liopyrga, 281.

Liotia, 283.

Liparus, 2.

lirrecostatus, Phos, 164.

lirata, Voluta, 103.

Lithoconns, 28, 30, 31 .

Lobantale, 291.

longirostris, Siphonalia, 154.

lophœssus, Murex, 178.

Lotorium, 185.

lotorium, Nurex, 186.

Lovenella, 229.
Loxotaphrus, 165.

lucida, Leda, 348.

Lucina, 385.

Lunatia, 260.

lupinus, Venus, 375.

Luponia, 205.

Luterinm, 185.

lymnæformis, Pleurotoma, 61.

lyræcostata, Cominella, 164.

lyrata, Cirsotrema, 268.

Scalaria, 268.

Lyria, 93, 98.

maccoyi, Pectunculus, 341 .

Typhis, 170.

Seaphella, 111.

macdonaldi, Voluta, 95, 106.

macroptera, Voluta, 100.

macrostoma, Cerithium, 227.

Mactra, 379.

maculata, Calyptræa, 252.

Crepidula, 252.

Solariella, 283.

Trochita, 252.

magellanica, Scaphella, 95 .

major, Bankivia, 280 .

malleata, Fissurellidea, 287.

Mamilla, 259.

mamillaris, Cassis, 197.

Мamma, 255, 260.

mandarina, Siphonalia, 157.

mandarinus, Fusus, 157.

Mangelia, 57 .

Neptunea, 157.

Nangilia, 57 .

mantelli, Dentalium, 293.

Entalis, 293.

manubriata, Ostrea, 300 .

mappa, Cyprea, 203.

Margarita, 325.

Margaritifera, 325.

Margaritiferus, Mytilus, 325.

Margaritiphora, 325.

marginata, Conomitra, 131.

Marginella, 82. Delphinula, 276.

mariesi, Terebra, 25.

marmoratus, Turbo, 272.

marmoreus, Conus, 27.

masoni, Tellina, 387 .

Voluta, 110.

Mathildia, 270.

maudensis, Cardita, 360.

maxima, Siphoualia, 155.

maximus, Ostrea, 314.

Nazzalina, 150 .

media, Cypræa, 204. 
meditteranea, Umbraculum, 24. megatrema, Fissurellidea, 2$\urcorner 7$. melaniana, Mitra, 120.

nelanoides, Diastoma, 232.

Meleagrina, 325.

mellingtoni," Mitra, 1:5.

Meretrix, 370 .

meretrix, Venus, 370 .

Meroe, 372 .

Mesudesma, 378.

metula, Cerithium, $2 \% 0$.

micula, Margivella, 89 .

millepunctatus, Conus, 31 .

Miltha, 355.

minima, Triria, 213.

minimum, Tritou, 191. Tritonium, 191.

minor, Erato, 215.

nirabilis, Pseudovaricia, 160.

miranda, Crossca, 269.

mississippiensis, Mitra, 125.

Mitra, 119.

mitrata, P'atella, 246.

mitreola, Olivella, 72 .

mitriformis, Nurex, 48.

Mitroidea, 64.

Modiola, 3ะ9.

modiolus, Mytilus, 329.

Monoplex, $18 \overline{.}$

monoxila, Crepidula, 246. Crypta, 246.

mooraboolensis, IIaliotis, 286.

Morio, 201.

mortoni, Voluta, 100.

morundianus, Latirus, 144 .

mucronata, Ancillaria, 76, 78 .

mucronatus, Cadulus, 297.

muelleri, Semicassis, 199.

multiradiata, Limopsis, 346 .

multisuleata, Nitra, 120 .

Murex, 172 .

Muricidea, 181.

muricina, Voluta, 116.

Muricopsis, 179.

murndaliana, Pleurotoma, 38, 39.

murraviana, Cypræa, 207.

murravianus, Couus, 30.

murrayana, Peristernia, 144. Torcula, 235.

Turritella, 235.

murrayanus, Latirus, 144 . Pecten, 314

murrayensis, Pecten, 314.

musearia, Marginella, 83.

musearioiles, MI arginella, 83 .

musica, Voluta, 79, 95, 99.

mutabile, Bnecinum, $16 \%$.

mutabilis, Unio, 356. mutica, Harpa, 78.

Terebra, 26.

Myadora, 390 .

Myodora, 390.

Myonia, 10 .

M yoparo, 329 .

N yosota, 7 .

Mytilus, 327 .

nievosoides, Ifaliotis, 285.

Narona, 67.

Nassa, 168.

nassa, Leucozonia, 148 .

Nassaria, 165 Murex, 148.

Natica, 255.

Naticina, 260.

Nerera, 389.

nebula, 11 urex, 60,61 .

nelsoniana, Ostrea, $30 \mathrm{I}$.

neozelanica, Natica, 259.

Rotella, 282.

neozelanicus, Murex, 182.

Nerita "nux avellana," 5.

neverita, 257 .

newtoui, Conus, 29.

Newtonia, 229.

Newtoniella, 229.

nigrirostratus, Fusus, $14 \mathrm{I}$.

niloticus, Trochus, 277.

Niso, 272.

nitida, Bankivia, 280 .

nitidula, Olivella, 71 .

nivea, Semicassis, 200.

now, Arca, 331.

nodosa, Neptunæa, 158. Siphonalia, 158.

nodosum, Buccinum, 158.

nodosus, Fusus, 158.

nodulosa, Struthiolaria, 218.

Trigonia, 3 ว2.

nodulosum, Cerithium, 227.

norie zealandire, Trochita, 252.

nove zeelandise, MIurex, 182.

nuciformis, Lucina, 385.

nucleus, $A$ rea, 347.

Nucula, 347 . Voluta, 99.

Nuculana, 348 .

uux-avellana, Amphibola, 6 .

nymphalis, Oliva, 72. - Olivella, 71, 72 .

obdita, Clathurella, 59.

olliterata, ()strea, 324 .

oblouga, Bulla, 13.

- Crassatella, 364 . 
oblonga, Crassatellites, 364. oblongula, Drillia, 56 . obolella, Leda, 352.

Nuculana, 352 .

obsoleta, Mangilia, 57.

occlusus, Tenagodes, 234 .

Ocinebra, 180.

Oligotoma, 48.

Oliva, 70 .

Olivancillaria, 73 .

Olivella, 70 .

olivellæformis, Actreopyramis, 11.

Olivina, 70 . Adelact:on, 11 .

olivula, Ancilla, 76.

Ombrella, 22.

"Onbrelle," 22.

Operculatum, 22.

optata, Pleurotoma, 44.

Ostrea, 298.

othone, Conomitra, 129. Mitra, 129.

otwayensis, Murex, 177. ovata, Marginella, 88. Natica, 259.

ovinoides, Haliotis, 285. ovulum, Cadulus, 297.

pacifica, Scaphella, 113. Toluta, 113.

pagoda, Columbarium, 53. Pleurotoma, 45.

pagodoides, Columbarium, 54 . Scaphella, 117. Toluta, 117.

pagodula, Turritella, 240.

pallida, Carditella, 362 .

palmipes, Pecten, 318.

papillaris, Struthiolaria, 219.

papillata, Ancilla, 75 .

Ancillaria, 75.

papillosa, Fasciolaria, 139

papulosa, Struthiolaria, 219.

papulosum, Buccinum, 219.

papyraceus, Actæon, 10.

parallela, Cypræa, 204.

parmophoidea, Emarginula, 290.

Subemarginula, 290.

Tugalia, 290.

parmophoroidea, Tugalia, 290.

parvula, Collonia, 276. Crossea, 276.

patula, Ampullaria, 265.

paucicostata, Mitra, 126. - Uromitra, 126.

paucirugata, Cytherea, 370 .

Pecten, 313.
Pectuneulus, 339.

Pelicaria, 218, 2.22.

pellucida, Calyptræa, 250.

Peristermia, 142.

Perlamater, 325.

peroui, Pecten, 317.

Persicula, 91.

perspectiva, Natica, 261.

perspectirus, Trochus, 243 .

pertusa, Terebra, 25.

pharnonicus, Trochus, 279.

Phasianella, 275.

Phorus, 253.

Phos, 164.

Phrontis, 168.

Phrllonotus, 181.

pieturata, Liopyrga, 281 .

pictus, Trochus, 279.

pinguis, Actæon, 7 .

Pinna, 326.

pinnatus, Murex, 173.

pirum, C'assis, 200.

Placostylus, 4 .

Placuna, 305.

Placunanomia, 303.

Plagiarea, 335.

plina, Crepidula, 248.

planata, Triforis, 231.

Plancus, 8.

platypyga, Cyprea, 209.

platyspira, Terebra, 25.

- Turritella, 236.

Pleurotoma, 37, 38.

Pleurotomaria, 286.

Pleurotomella, 60.

Plicatella, 150.

Plicatula, 305 .

plicatus, Triforis, 231.

Polinices, 259, 260.

polita, Mactra, 350.

Natica, 261.

Scaphella, 96, 112.

Voluta, 112.

Polydonta, 277, 278.

Polygona, 150.

polygonus, Fusus, 150.

polymorphoides, Pecten, 316.

polynema, Cardita, 358 .

" polyzona," 150.

pomahakensis, Batillaria, 229.

pomatia, Helix, 1.

porphrrostoma, Afer, 145 . "Tudicla," 144.

præcursoria, Zemira, 167.

prælonga, Leda, 351 .

Myadora, 391.

Mrodora, 391 .

Niculaua, 351 . 
pratti, Apollo, 196. Argobucciuum, 196.

prattii, Ranella, 196. Triton, 196.

precursoria, Zemira, 167.

princeps, Crossea, 269.

Crosseia, 269.

pritchardi, Cerithium, 225.

profunda, Crypta, $2 \pm 6$.

propinqua, Chione, 375.

Marginella, 85.

protensum, Lotorium, 191.

protensus, Triton, 191.

Protocardium, 368.

Protomedia, 18.

prorisi, Diastoma, 232.

Prumum, 86.

Psammobia, 377.

Pseplara, 115.

Pseudamussium, 322.

pseudaustralis, Ancilla, $73,75,77$. Ancillaria, 73 .

pseudolirata, Tolnta. 104.

pseudoradula, Spoudylus, 308.

Pseudotoma, 48.

Psendovaricia, 159.

psila, Niso, 272.

I'teronotus, 172, 173.

Pterospira, 93, 100.

ptychodermis, Comus, 34.

pugilis, Strombus, 216.

pulchra, Bela, 6*.

Daphuella, 62 .

pulligera, Ilarpa, su.

pullulescens, Conus, 30, 31, 32, 33, 34.

pumila, Area, 334 .

T'uncturella, 152 . Barbatia, 334.

pungeus, Typhis, 170.

purpurasceus, Bankivia, 280.

purpurea, Pleurotoma, 59.

purpuroides, Latirus, 185.

- Misania, 18.5.

Ricinula, 18.5.

Sistrum, 18 .

prramidata, Clio, 20.

pyrula, Mazzalina, 150.

pyrulata, Cyprea, 206.

- Frato, 216.

prrum, Cassi*, 200.

Sumicassis, 200.

pyxidat:1, Corbula, 3s:2.

quadricingulata, Liopyrga, 281.

quadrilatera, Area, 335.

quoyi, Lotorium, 193. '́ritou, 193. radiale, Lotorium, 187.

radialis, Seguenzia, 267. 1 riton, 187.

radiata, Carditella, 362 .

ralphi, Conus, 34 .

ramosus, Murex, 178.

Risnella, 156.

rangiaua, Clio, 20.

- Styliola, 20.

raphanus, Buccinum, 158.

Raphitona, 61.

rect:a, Styliola, 20.

repanda, Natica, 261.

reticulata, Tellina, $38 \mathrm{~s}$.

Rhytida, 2.

Ricinula, 184.

"Ricinule," 184.

ringens, Auricula, 15.

Ringicula, 15.

roblini, Liotia, 284.

roborata, Chione, 374 .

roei, Ilaliotis, 286.

rosea, Turritella, 240, 241.

rossiniana, Voluta, 107.

Rostellites, 94 .

rostrata, Area, 348.

Pisania, 161.

Rouaultia, 18 .

rubridentatus, Mures, $17 t$.

rudis, Pinma, 327.

"ruffina, Y.," si.

rugata, Fasciolaria, 139.

rugatum, Cerithium, 2:9.

rupestris, Voluta, 94.

saint-hilairei, Bullinella, 14.

salebrosa, l'leurotoma, 42.

samueli, P'leurutuma, 43 .

sarissa, Scaphella, 105, 116.

Saxicava, 383. Voluta, 116.

seabra, Limi, 310.

scabricosta, IIaliotis, 286.

scabrosa, Cardita, 3 šs.

siciva, 18.

scalaris, Volutilithes, $9 \mathfrak{1}, 97$.

scalena, Cyprica, 203.

Scapha, 1 if.

Scapllauder, 12.

Seaphella, 9.5, 109, 110.

Schrodentalium, 291.

serubieulati, Mitra, 119.

Tornatella, 7 .

scrobiculatus, Actieon, 7 .

sculptilis, Bela, 61, 6\%.

Daphnella, 61. 
scutulatum, Buccinum, 222.

Seguenzia, $2 n 6$.

sella, J'lacunanomia, 304 .

Semele, 388.

Semicassis, 198.

semicostata, Pisania, 161. Tritonidea, 161.

semicostatum, Potamides, 225 semicostatus, Cantharus, 161. semilævis, Ancilla, 74 .

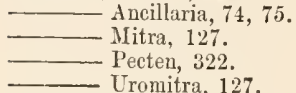

semiplicatus, Pecten, 319.

semiundulata, Trigonia, 352 . semperiana, Cancellaria, 66. senticosus, Fusus, 133, 164. septemlirata, Pleurotoma, 39. septemplicata, Marginella, 91. Septifer, 328 .

septifraga, Turritella, 236.

Seraphs, 218.

serratus, Fusus, 133.

serum, Protocardium, 369.

sieboldi, Conus, 29.

Sigapatella, 252.

sigaretina, Ampullaria, 265. Natica, 265.

Sigaretopsis, 263.

sigillata, Dimya, 306.

Silia, 78 .

Siliquaria, 233.

simulans, Area. 333.

Barbatia, 333.

simulatus, Actæon, 9.

sinclairi, Helix, 2.

sizuata, Barbatia, 334 .

Sipho, 152.

Crassitella, 363.

Siphoualia, 154.

Siphonodentalium, 297.

Sistrum, 184.

smaragdula, Leucozonia, 151.

smaragdulum, Buccinum, 151.

smaragdus, Turbo, 273.

Solariella, $2 \succ 3$.

Solarinm, 243.

solarium, Pecten, 314.

solida, Cardita, 360.

Solidula, 8 . Natica, 264.

solidula, Voluta, 8.

solidum, Dentalium, 294.

sopita, Bulla, 2 I8.

Sparclla, 72, 73.

spatiosum, Cardium, 367.

spengleri, Lotorinm, 193. spengleri, Murex, 193. Triton, 193.

Speo, 7. Tritonium, 193.

sphærodoma, Cypræa, 211.

spinicincta, Pleurotoma, 52. spiniferus, Fusus, 54.

spiniterum, Columbarium, 54 .

spinosa, Barnea, 384.

spinosus, Conus, 97 .

Strombus, 97.

Spiratella, 18.

Volutilithes, 94 .

Spirialis, 18.

Spondylus, 307.

squamula, Amussium, 324 .

staminea, Leucozomia, $15 \mathrm{I}$.

Stigmaulax, 262.

stirlingi, Telliua, 387.

stramineus, MIurex, 219.

Streptochetus, 137 .

Streptosiphon, 144.

striata, bela, 63 .

- Cylichna, 14

Cythara, 58.

Daphnella, 63.

striatula, Emarginula, 288.

striatus, Cassis, 200.

strigata, Eumargarita, 283.

Minolia, 283.

Solariella, 283.

Strigatella, 130.

strigilata, Ostrea, 312.

Strombus, 216.

strophodon, Voluta, 94, 95, 101.

Strutbiolaria, 218.

stultorum, Mactra, 379 .

sturtiana, Ostrea, 299.

sturtianus, Pecten, 315.

sturtii, Turritella, 239.

styliformis, Fusus, 156.

- Sipho, 156.

Styliola, 18, 20.

Siphonalia, 156.

subauriculata, Lima, 311.

subconcava, Pleurotoma, 11, 42.

Subemarginula, 289.

subfissura, Dentalium, 296.

—_ Lutalis, 296.

subgranosa, Semicassis, 201.

submultistriata, Cytherea, 370 . Meretrix, 370.

subnox, Natica, 256.

suborbicularis, Diplodonta, 376 . Mysia, 376.

Sacchia, 376 .

subquadrata, Diplodonta, 375 .

subroborata, Chione, 374 . 
subrostrata, Cuspidaria, 389. Leucozonia, 151. Nciera, 359.

subsiclua, Cyurea, 204. substolida, Natiea, 260. subtabulata Calyptras, 250. subtrigonalis, l'ectunculus, 340 . subula, Cleodori, 20.

subulatum, Buccinum, 24. subumlulata, Trigunia, 352. subundulosa, Peristeruia, 147. subundulosus, Latirus, 147. succincta, Ieristernia, 146. suecinctus, latirus, 146. Trophou, 146.

sufflata, Semicassis, 198. sufflatus, Cassis, 198. Semicassis, 198. sulcata, Corbula, 381, 382. - Mitra, 123.

suleosa, IIarpa, 79 .

Sunetta, 372.

sunetta, Chama, 372.

superbus, Turbo, 275.

Surcula, $37,42,43,44,45,47$.

sutiralis, Turbo, 270 .

Sveltia, 69.

swainsoni, Mitra, 124.

symmetricus, Tolutilithes, 102.

Sypho, 152.

tamarensis, Anodlouta, 356 . Unio, 356.

tarda, Gryphæa, 302.

tasmanica, Anodonta, 356 . Cardita, 360. Diplodonta, 376 .

tasmaniensis, Ilelix, 1. tatei, Latirus, 147. Nassa, 169. Siphonalia, 155. -Trigonia, 353. Xeuophora, 254.

Teleochilus, 64 .

Tellina, 386.

Tenargodes, 233.

teuisoui, Nucula. 317.

tenuicostati, Colubriria, 194. Pisania, 194.

tenuieostatus, Epidromns, 191. temuilirata, Myndora, 390. Myodora, 390 .

tcuus, Cytherea, 371. Dentalium, 293. - II arpa, so. tenuis, Meretrix, 371.

Scaphander, 12.

terebellata, Niso, 272.

Terebellum, 218.

Terebra, 24.

terebra, Turbo, 234.

terebriformis, Mitra, 128. Uromitra, 128.

tertiaria, Limacina, 19. Spiralis, 19.

testudinarius, Conus, 34 .

textile, Lotorium, 192. Triton, 192.

Thallicera, 5 .

Thalotia, 279.

tiara, Barnea, 384.

tiarata, Anthora, 278. Polydonta, 278.

tiaratus, Colotrochus, 278 .

Toriuia, 245.

Tornatelln, 7.

Toruatellica, 9 .

"Tornatclle," 7 .

tornatilis, Voluta, 7 .

tortirostris, Lotorium, 191. 'I'riton, 191.

truili, Crassatella, 366.

Crassatellites, 366.

trailli, Conus, 36.

transenua, Limea, 313. Semicassis, 198.

trevori, Drillia, 55.

'Trichotropis, 233.

trieincta, Marginella, 90.

Triforis, 231.

Trigonia, 352 .

trilirata, Pleurotoma, 40.

Trinacria, 543.

trinodosus, Murex, 178.

triphooki, P'ecten, 3:0.

Triplex, 172.

triplicata, Eglisia, 270 . Scalaria, 270 .

Turritella, 237, 241.

'Triploca, 9.

tripteris, Murex, 173.

tripteroides, Murex, 173, 174.

tricucter, Murex, 173.

tristira, Turritella, 237.

Tritoll, 185.

tritun, Buccinum, 158. Fistls, 158.

tritonis, Pulydouta, $27 \%$.

Tritonium, isj.

i ritomoiusus, 152 .

Trivia, 21:. 
Trochita, 249.

Trochus, 276.

trunculus, Douax, 377.

tuberculati, Authora, 277.

Haliotis, 285.

Polydonta, 277.

Strutlicolaria, 221.

tuberculatus, Trochus, 277 .

tubiter, Murex, 170. Typhis, 170.

tubulifera, Irigonia, 354.

Tugalia, 289.

Tuyurium, 254.

tulipa, Nurex, 138.

tunida, Nueula, 347.

tumulosum, Lotorium, 188.

tumulosus, Tritou, 188.

turbinata, Calyptraea, 251.

- Calyptropsis, $25 \mathrm{I}$. Trochita, 251.

Marginella, 87.

Turbinella, 93.

turbinoides, Phasianella, 275.

Turbo, 272.

turneri, Voluta, 108.

Turritella, 234.

Tylospira, 222.

Typhis, 170 .

Dinuella, 22.

Umbilia, 209.

umbilicata, Calyptræa, 252.

Calyptropsis, 252.

Crepidula, 252.

Cyprea, 210.

Drillia, 55.

Umbraculum, 22.

Umbrella, 22.

undata, Ostrea, 301.

undatella, Phasianella, 280.

undosum, Buccinum, 161.

undulata, Voluta, 104, 109.

unguiformis, Crepidula, 248.

Unio, 35.5 . Crrpta, $2+8$.

Unionium, 325.

uniplicata, Bullinella, 14.

- Mitra, 122.

Uromitra, 124.

Urosalpinx, 183.

ustulata, Terebra, 26.

vagans, Leda, 348 .

Nuculana, 348.

Vaginella, 17, 21.

rarians, Bankivia, 280.

Natica, 257.

varicifera, Cancellaria, 69 . variciferus, Phos, 166.

varicosa, Cancellaria, 69 . Sealaria, 267.

variegata, Heliacus, 245.

variegatus, Clanculus, 279.

velifieus, Murex, 173.

Venericardia, 357.

ventricosa, Marginella, 91. Nitra, 91.

rermis, Buccinum, 219.

Pelicaria, 218.

Struthiolaria, 219.

vernis, Pelicaria, 218.

vesiculosa, Semele, 388 .

Vespertilio, 95, 101.

riabrunnea, Bathytoma, 50 .

vibex, Bucciutm, 200.

- Nassa, 168.

victoriæ, Cardium, 367.

virgata, Telliua, 386 .

viridis, Trochus, 277.

vitellus, Nerita, 255.

vitrea, Narginella, 89.

vixumbilicata, Drillia, 56.

Voluta, 94, 99.

Tolutilithes, 93, 97.

Volutocomus, 93, 107.

Volvarina, 84 .

Vulgocerithium, 226.

Vulgusella, 203.

Vulsella, 326.

Jya, 326.

wandoensis, Mitra, 124.

wanganuiensis, Pleurotoma, 46.

wannonensis, Cancellaria, 66.

- Emarginula, 288.

Heliacus, 245.

Solarium, 245.

warburtoni, Turritella, 239.

weldi, Voluta, 94, 101, 102.

wentworthi, Marginella, s2.

wiuteri, Marginella, 84 .

wintlei, Natica, 256, 257.

woodsi, Cylichua. 14.

Leda, 349.

_ Lotorium, 190.

Nuculana, 349.

woodsii, Triton, 190.

worthingtoni, Cucullea, 339.

wrullerstorfi, Ostrea, 301.

Xenophora, 253.

yahlensis, Pecten, 322.

Pseudamussium, 322. 
Zaria, 241.

zealanclica, Diplodonta, 376 . Iima, 309. Limopsis, 346. Natiea, 259. Neptunea, 157. I'lacunauomia, 305. Rotella, 282.

zealandiens, Fusus, 157 . Murex, 182.

zebra, Voluta, 110.

zelaudica, Ethalia, 282. zelandica, Natica, 259. Rotella, 28:.

zelandicum, Umbonium, 282.

zelandieus, Murex, 182.

Zemira, 167.

Zenatia, 381.

Zenatiopsis, 380 .

zitteli, Anussium, 324. Peeten, 324 .

zonale, Cerithium, 228. zonalis, Gari, $37 \pi$. 



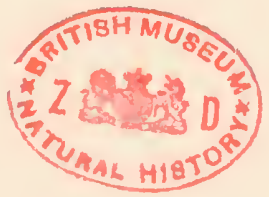




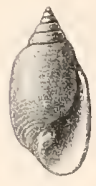

$1 a$.
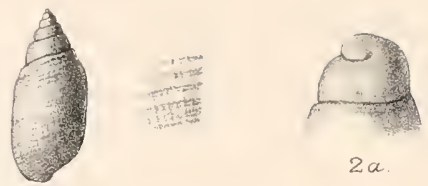

$2 \alpha$

$2 b$.
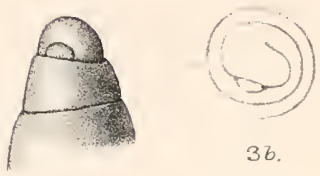

$3 a$

16.
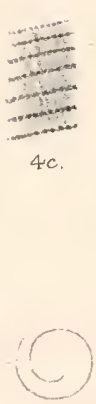

$5 \alpha$

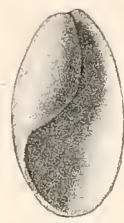

$4 a$

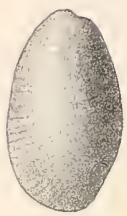

43.

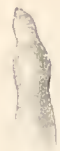

$6 b$.

$5 a$

56.
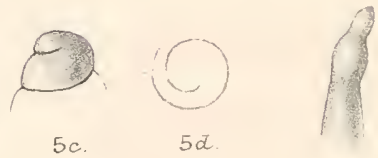

$6 a$.

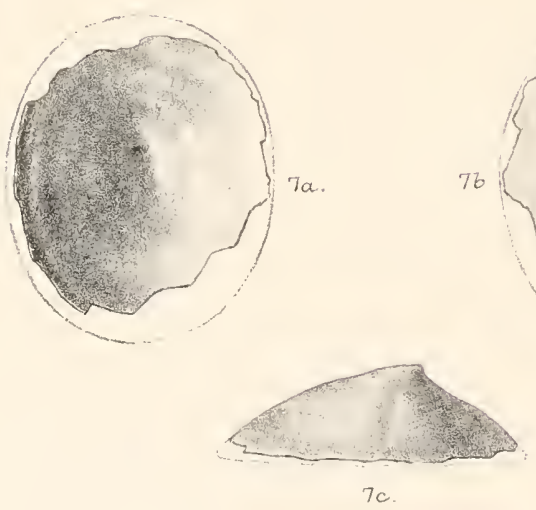

GMWoodward del et lith

West, Newman mp.

Opis tholoranchiata 


\section{EXPLANATION OF PLATES.}

Fio.

\section{PLATE I.}

1. Actcen scrobiculatus, Tenison-Woods. Eocene: Muddy Creek.

$a$, front; $b$, back of shell ( $\times 2$ diam.); and detail of sculpture.

[G. 4296.] T

2. Tomatelloca (Triploca) ligata, Tate (sp.). Eocene: Adelaide. Protoconch ( $\times 22$ diam. ): $a$, side view ; $b$, view from above.

[G. 9305.] 9

3. Adelactaon otivellaformis, Tate (sp.). Eocene: Muddy Creek. Protoconch $(\times 20$ diam. $): a$, side view ; $b$, view from above.

[G. 9307.]

PAQE T

4. Scaphander tenuis, sp. nov. Eocene: Muddy Creck. $a$, front; $b$, back ( $\times 1 \frac{1}{2}$ diam.); $c$, detail of sculpture. [G. 4171.] 12

5. Ringicula lactea, Johnston. Eocene: Muddy Creek. Shell

$(\times 5$ diam. $): a$, front; $b$, back. Protoconch (× 14 diam.)
c, side view ; $d$, view from above.
[G. 9304.]

$(\times 5$ diam. $): a$, front; $b$, back. Protoconch (× 14 diam.)
c, side view ; $d$, view from above.
[G. 9304.]

6. Clio (Styliola) rangiana, Tate (sp.). Eocene : Muddy Creek.
\[ a, b \text {, summit of shell, showing inflations ( } 12 \text { diam.). } \]
[G. 9306.]
7. Umbraculum australe, sp. nov. Eocene: Muddy Creek. a,

6. Clio (Styliola) rangiana, Tate (sp.). Eocene : Muddy Creek.
a, b, summit of shell, showing inflations ( $\times 12$ diam.).
[G. 9306.]
7. Umbraculum australe, sp. nov. Eocene : Muddy Creek. a, under surface ; $b$, upper surface ; $c$, side view (uat. size).

[G. 4183.] 



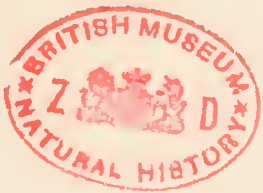



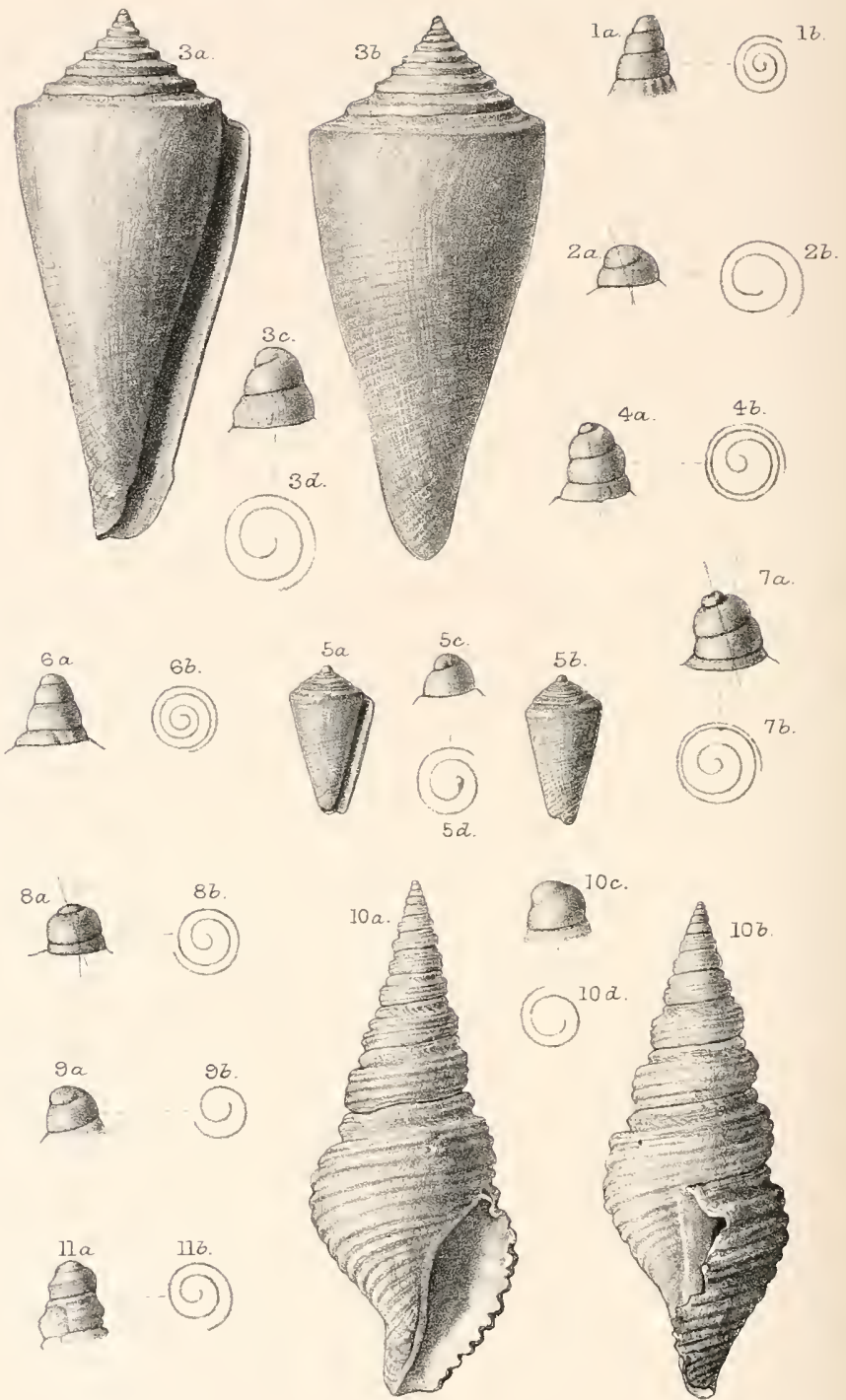


\section{PLATE II.}

Fio.

PAGE

1. Terebra geniculata, Tate. Miocene: Muddy Creek. Protoconch ( $\times 10$ diam.) : $a$, side view ; $b$, view from above.

[G. 9309.]

2. Conus (Leptoconus) ligatus, Tate. Eocene: Schnapper Point. Protoconch ( $\times 8$ diam.) : $\alpha$, side view ; $b$, viow from above.

[48052]

3. Conus (Leptoconus) newtoni, sp. nov. Eocene (?) : Muddy Creek. Shell $\left(\times 1 \frac{1}{6}\right.$ diam.): $a$, frout; $b$, back. Protoconch $(\times 9$ diam. $): c$, side view ; $d$, view from above.

[G. 4239.]

4. Conus (Leptoconus) murravianus, Tate. Eocene: River Iurray cliffs. Protoconch ( $\times 4$ diam.) : $a$, side view; $b$, view from above.

[G. 9136.]

5. Conus (Leptoconus) convexus, sp. nov. Eocene: "Meribee Plains," Victoria. Shell (nat. size) : $a$, front; $b$, back. Protoconch ( $\times 6$ diam.): $c$, side view; $d$, view from above.

[70424.]

6. Conus (Lithoconus) cuspidatus, Tate. Eocene: Muddy Creek. Protoconch ( $\times 10$ diam.) : $a$, side view; $b$, view from above.

[G. 5489.]

7. Conus (Lithoconus) pullulescens, Tenison-Woods, Eocene: Muddy Creek. Protoconch ( $\times 4$ diam.) : $a$, side view ; $b$, view from above.

[G. 5491.]

8. Conus (Lithoconus) dennanti, Tate. Eocene: Muddy Creek.

Protoconch ( $\times 3$ diam.) : $a$, side view ; $b$, view from above.

[G. 5493.]

9. Conus (Chelyconus) ralphi, Tenison-WToods. Eocene: Muddy Creek. Protoconch ( $\times 7$ diam.) : $a$, side view; $b$, 'view from abore.

[G. 5492.]

10. Pleurotoma septemlirata, sp. nov. Eocene: Muddy Creek. Shell (nat. size) : $u$, front; $b$, back. Protoconch ( $\times 7$ diam.): $c$, side riew ; $d$, view from above.

[G. 4231.]

11. Pleurotoma wanganuiensis, Hutton. Pliocene: Shakespeare Cliff. Protoconch ( $\times 8$ diam.) : $a$, side view; $b$, view from above.

[G. 9497.] 



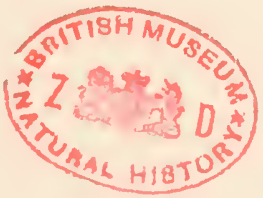



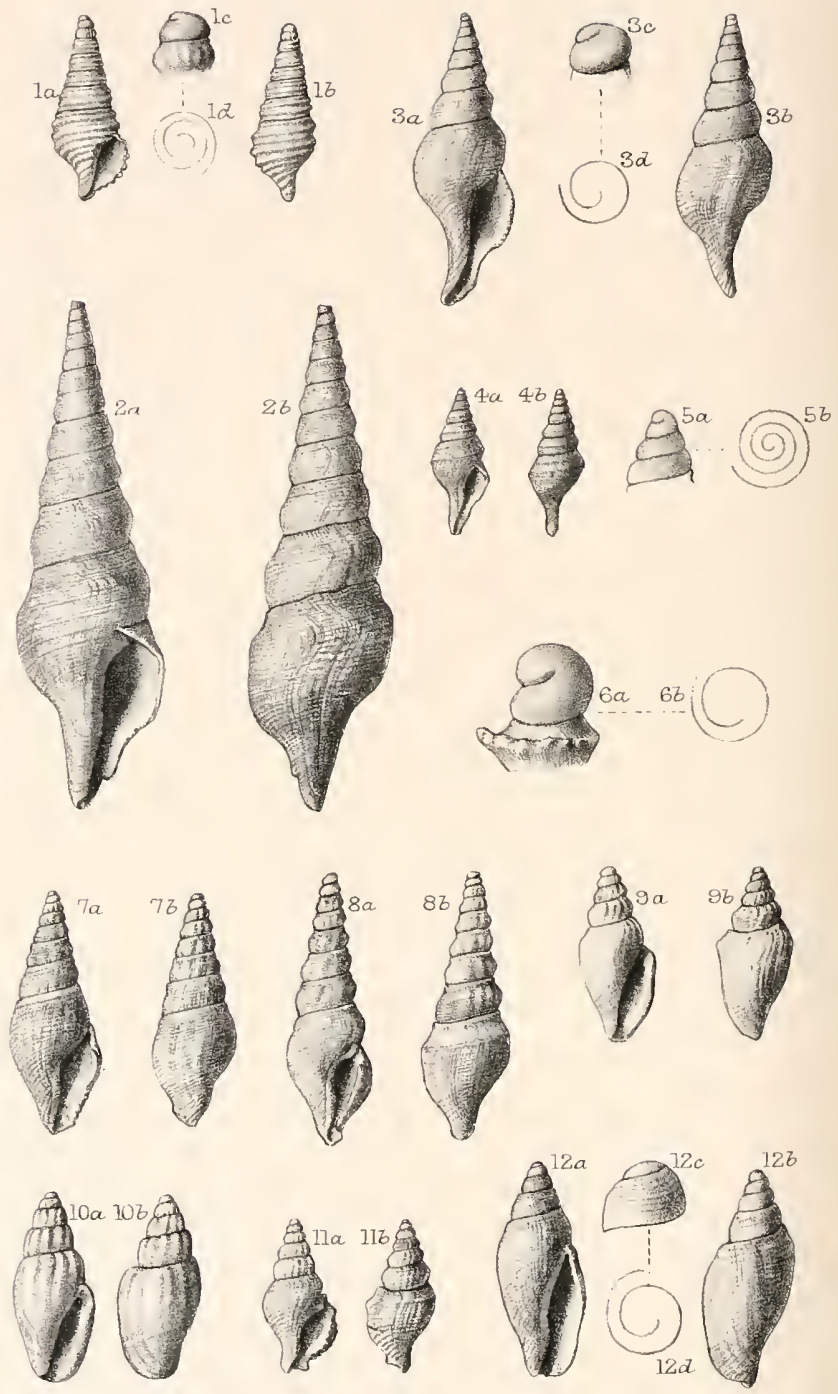

GM Woodward del ethth West, Newman imp. Pleurotomida. 


\section{PIATE III.}

Fig.

PAGE

1. Plenrotoma trilirata, sp. nov. Eocene: Hobson's Bay. Shell $(\times 2$ diam. $): a$, front ; $b$, back. Protoconch $(\times 7$ diam. $)$ : $c$, side vicw ; $d$, view from above.

2. Pleurotoma subconcava, sp. nov. Eocene : "Meribee river,"

Victoria. $a$, front; $b$, back of shell (nat. size). [70421.]

3. Pleurotoma salcbrosa, sp. nov. Eocene: Hobson's Bay.

Shell (nat.size): $a$, front; $b$, back. Protoconch ( $\times 6$ diam.):

$c$, side view ; $d$, view from above.

[48052.]

4. Pleurotoma optata, sp. nov. Eocene : Hobson's Bay. a, front;

$b$, back of shell (nat. size).

[48052.]

5. Menratoma samueli, Tenison-Woods. Eocene: Muddy

Creek. Protoconch ( $\times 15$ diam.) : $a$, side riew; $b$, view from above.

[G. 9329]

6. Columbarium acanthostephes, Tate (sp.). Eocene : Schmapper

Point. Protoconch ( $\times 7$ diam.): $c$, side view ; $b$, view from above.

7. Drilliu oblongula, sp. nov. Eocene: Muddy Creek. u, front; $b$, back of shell ( $\times 2$ diam.).

[G. 4219.]

8. Drillia vixumbiticata, sp. nov. Eocene: Muddy Creck. $a$, front ; $b$, back of shell $(\times 2$ diam. $)$.

[G. 4221.] 56

9. Mangilia obsolcta, sp. nor. Eocene (?): Muddy Creek. $a$, front ; $b$, back of $\operatorname{slıcll}(\times 2$ diam.). [G. 4222.]

10. Mangilia (Cythara) glabra, sp. nov. Miocene (?) : Muddy Creek. $a$, front ; $b$, back of shell ( $\times 2$ diam.). [G. 4201.]

11. Clathurella obdita, sp. nov. Eocene (?): Muddy Crcek. ", frout ; $b$, back of shell ( $\times 2$ diam.).

[G. 4204.]

12. Teleochilus grucillimum, Tenison-TToods (sp.). Eocene: Muddy Creek. Shell (nat. size) : $a$, front; $b$, back. Protoconch $(\times 6$ diam. $): c$, sidc view: $d$, view from abore. [G. 4162.] 



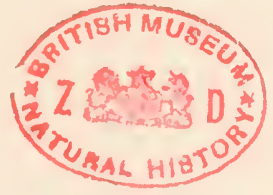



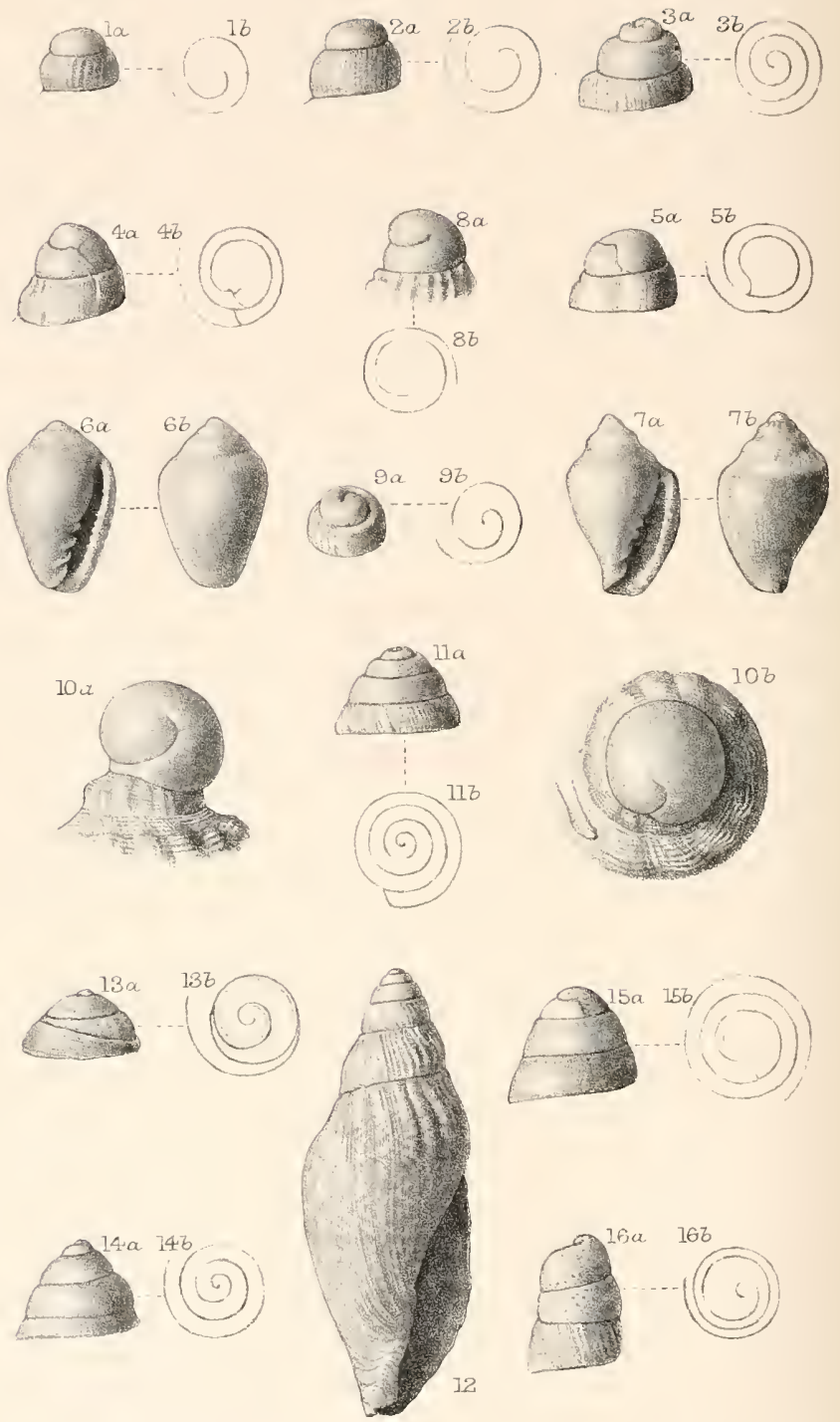

GM. Woodward del et Inth.

West, Newman imp

Pleurotomidæ, Harpidx, Marginellidæ. Volutidx. 


\section{PLATE IV.}

FIG.

1. Daphnella sculptilis, Tate (sp.). Eocene: Muddy Creek. Protoconch ( $\times 6$ diam.) : $a$, side riew ; $b$, vicw from above.

[G. 4194.]

PAGE

$6 I$

2. Daphnella crassilirata, Tate (sp.). Eocene: Muddy Creck. Protoconch ( $\times 6$ diam.) : $a$, side view ; $b$, view from abore.

[G. 5496.]

3. Harpa (Eocithara) lamellifera, Tate. Eocene: Muddy Creek. Protoconch ( $x \neq$ diam.): $a$, side view ; $b$, view from above.

[G. 4215.]

4. Harpa (Eocithara) tenuis, Tate. Eocene: Muddy Creek. Protoconch ( $\times 5$ diam.) : $a$, side view; $b$, view from above.

[G. 9335.]

5. Harpa (Eocithara) abbreviata, Tate. Eocene: MIuddy Creek. Protoconch ( $\times 5$ diam.): $a$, side view; $b$, riew from above.

[G. 4216.]

6. Marginella (Glabella) ovata, sp. nov. Miocene: Parimoa. $a$, front ; $b$, back of shell ( $\times 3$ diam.).

[G. 9522.]

7. Marginella (Gilabella) conica, sp. nov. Miocene: Parimoa. $a$, front ; $b$, back of shell ( $\times 3$ diam.).

[G. 9522.]

8. Volutilithes antiscalaris, M[ 'Coy (sp.). Eocene: Muddy Crcek. Protoconch ( $\times 6$ diam.) : $a$, side riew ; $b$, riew from above.

[G. 4276.]

9. Lyria harpularia, Tate. Eocene: Muddy Crcek. Protoconch $(x+$ diam. $): a$, side view ; $b$, view from above.

[G. 4174.]

10. Voluta (Pterospira) hannafordi, M'Coy. Eocene: MIuddy Creek. Protoconch (nat. size) : $a$, side riew ; $b$, view from above.

[G. 9351.]

11. Foluta (Aulica) strophodon, $\mathrm{I}^{\circ} \mathrm{Coy}$. Eoceue: MIudly Creek. Protoconch ( $\times 2 \frac{1}{2}$ diam.): $a$, side view; $b$, view from above.

[G. 4275.] 101

12. Voluta (Aulica) lirata, Johnston. Eocene: Muddy Creek. Side view of shell, showing disposition of colour-markings (nat. size).

[G. 5485.]

103

13. Voluta (Volutoconus) conoidea, Tate. Eocene: Muddy Crcek. Protoconch ( $\times 3 \frac{1}{2}$ diam.): $a$, side view ; $b$, view from above.

[G. 9353.] 107

14. Foluta (Amoria) masoni, Tatc. Miocene: Muddy Creek. Protoconch ( $x$ 2l diam.) : $a$, side view; $b$, vicw from above.

[G. 4258.]

15. Scaphclla polita, Tate (sp.). Eocene; Muddy Creck. Protoconch ( $\times 15$ diam.) : $a$, side view; $b$, vicw from above.

[G. 9355.]

16 Scaphella (Eopseplia) sarissa, Tate (sp.). Eocene: Muddy Creck. Protoconch $\left(\times 4 \frac{1}{2}\right.$ diam.): $a$, side vicw ; $b$, view from above.

[G. 9349 .] 



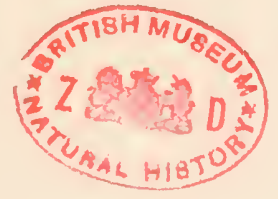



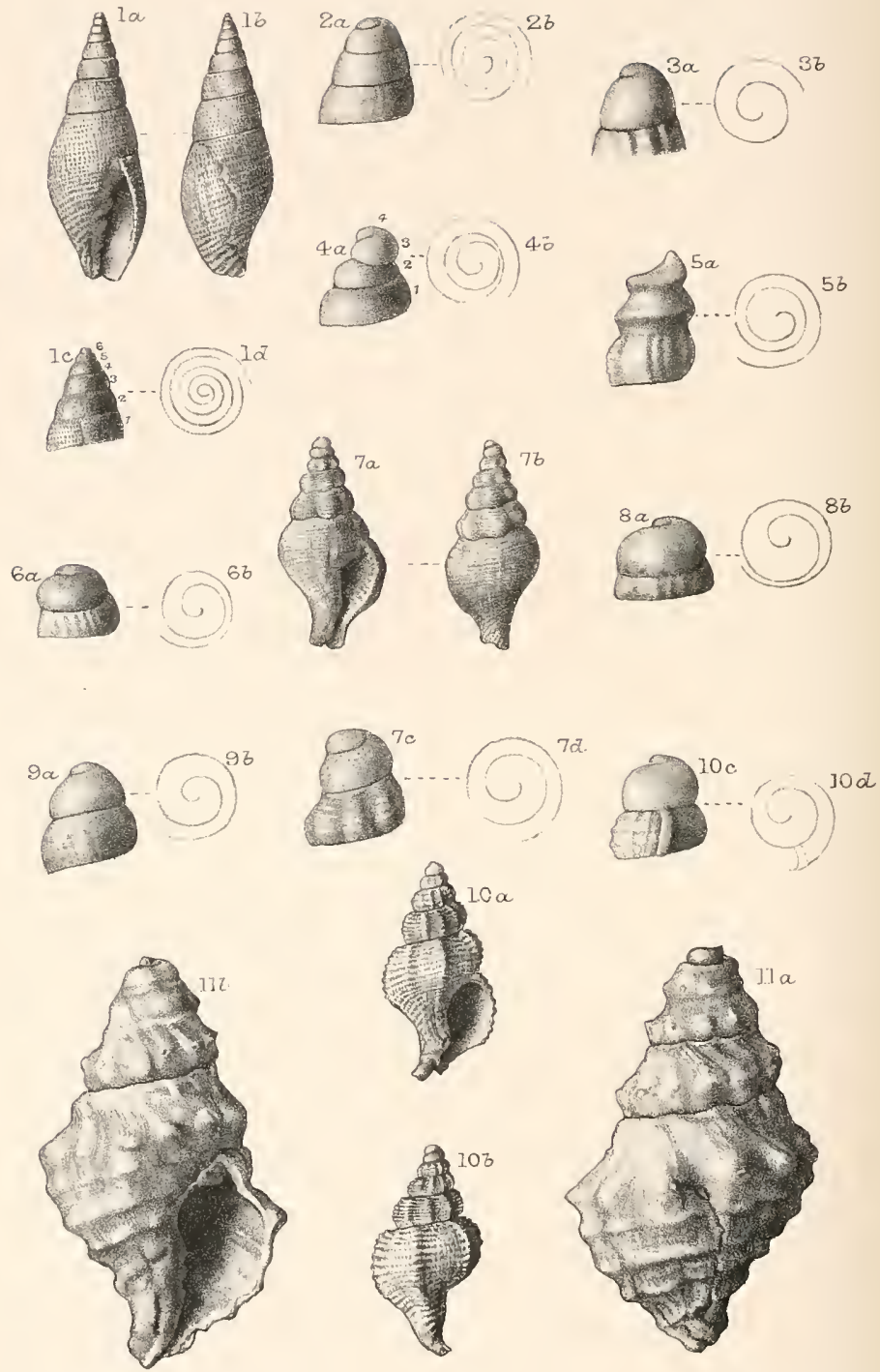

G.M Woodward del et lith

West, Newman mp. Mitridæ, Fasciolarida, Buccinıdæ, Muricidæ 


\section{PLATE V.}

Fig.

1. Nitra multisulcata, sp. nov. Eocene: Muddy Creek. Shell ( $\times 2$ diam. $): a$, front ; $b$, back. Protoconch ( $\times 10$ diam.) : $c$, side view ; $d$, view from above.

2. Nitra (Cancilla) atraetoides, Tate Focene M

Protoconch ( $\times 8$ diam ): $a$, side view ; $b$, view from above.

3. Cromitra leptalea, Tate (sp.). Eocene: Muddy Creek. Protoconch $(x 11$ diam. $): u$, side view; $b$, view from above.

[G. 9362.]

4. Conomitra dennanti, Tate (sp.). Eocene: Muddy Creek. Protoconch ( $\times 9$ diam.) : $a$, side view ; $b$, view from above.

5. Fusus hexagonalis, Tate. Eocene: Muddy Creek. Protoconch ( $\times 12$ diam.) : $a$, side view ; $b$, view from above.

[G. 9436.] I3!

6. Latimes mumayanus, Tate (sp.). Eocene: River Murray cliffis, ncar Morgan. Protoconch ( $\times 6$ diam.) : $a$, side view ; $b$, view from above.

7. Latirus tutei, sp. nov. Eocene: Spring Creek. Shell $(\times 2$ [G. 9460.$] \quad 144$ diam.): $a$, front; $b$, back. Protuconch ( $\times 11$ diam.): $c$, side view ; $d$, view from above.

8. Leucozonia (Latirolugena) staminea, Tate. Eocene: Gelli[G. 9860.] 14\% brand river. Protoconch ( $\times 8$ diam.): a, side view ; $b$, view from above. [G. 9490.]
9. Tritonofusus crebrigranosus, Tate (sp.). Eocene: Muddy Creck.
Protoconcl $(\times 12$ diam.) : $a$, side view ; $b$, view from above. Protocolich ( $\times 12$ diam.) : $a$, side view ; $b$, riew from above.

10. Murex (Muricidea) asperulus, Tate. Eocene: Muddy Creek. Shell $\left(\times 1 \frac{1}{2}\right.$ diam. $): a$, frout ; $b$, back. Protoconch $(\times 7$

diam.) : c, side riew ; $d$, view from above. [G. 10068.]
11. Leucozoniu nassu, Gnelin (s]).). Pliocenc: ('hatham I. $a$, back ; $b$, front of shell (nat. size).

[G. 9672.] 148 


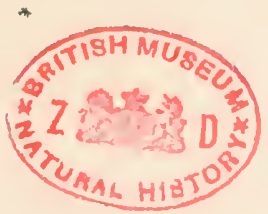

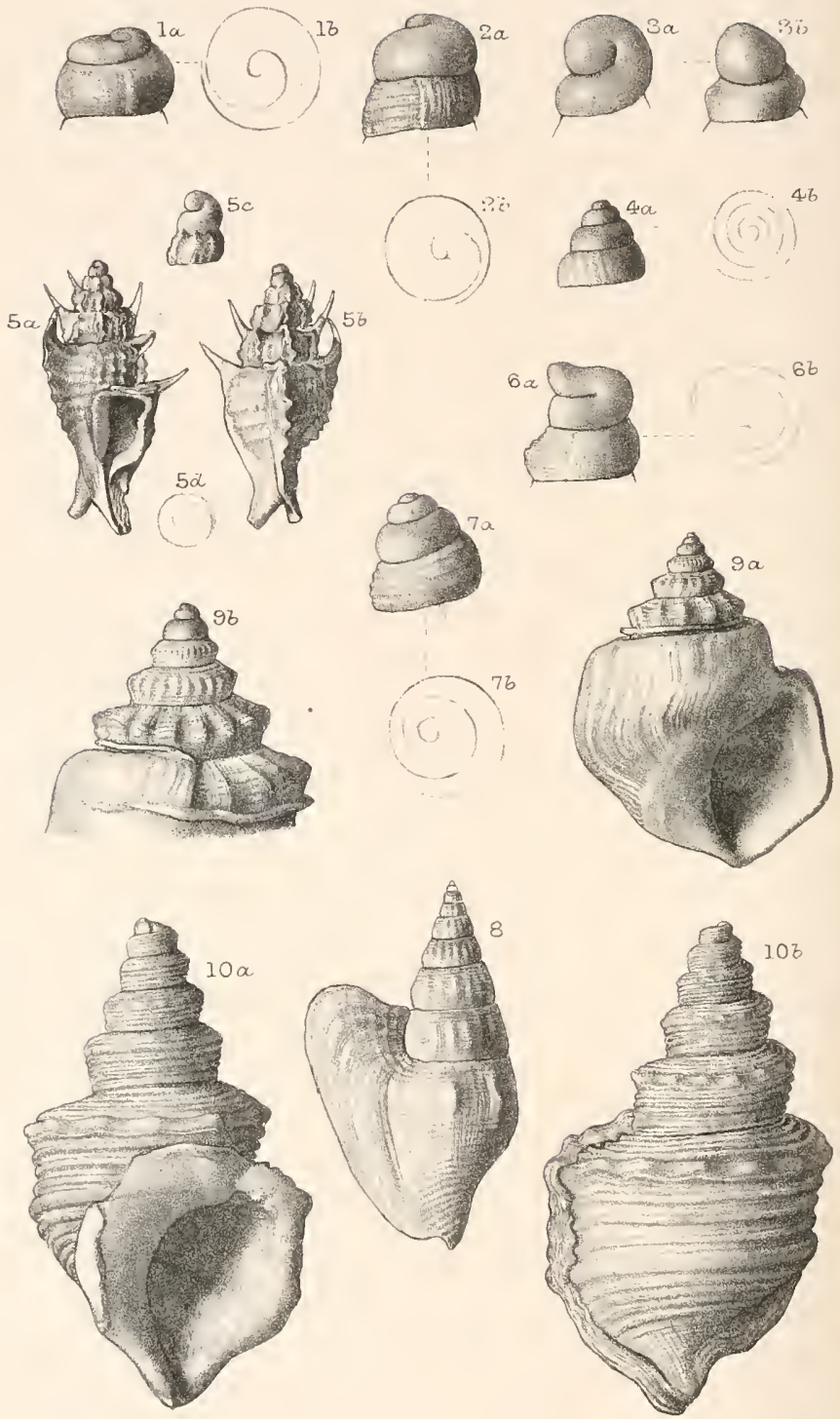

GMWoodward del et lith

West, Newman imp.

Buccinidæ, Nassidæ, Murıcidæ, Lotoridæ. Strombidæ, Struthiolamidæ 


\section{PLATE YI.}

Fig.

PAGE

1. Pseudoraricia mirabilis, Tate. Eocene: Muddy Creek. Protoconch $(\times 7$ diam. $): a$, side view ; $b$, view from above.

[G. 4169.] 160

2. Euthria (Dennantia) cingulata, Tate (sp.). Eocene : Schnapper Point. Protoconch ( $\times 9$ diam.) : $a$, side view ; $b$, view from abore.

3. Phos (Loxotaphrus) variciferus, Tate. Eocene: Muddy Creek. Protoconch ( $\times 12$ diam.) : $a$, side view ; $b$, view from above.

[G. 4160.] 166

4. Nassa tatei, Tenison-Wroods. Eocene: Muddy Creek. Protoconch ( 11 diam.) : $a$, side view ; $b$, view from above.

[G. 9470.] 169

5. Murex (Triplex) otwayensis, sp. nov. Eocene: Cape Otway. Shell ( $\times 3$ diam.) : $a$, front ; $b$, back. Protoconch $(\times 8$ diam.) : $c$, side vicw ; $d$, view from above.

[G. 9457.] $17 \%$

6. Lotorium rudiule, Tate (sp.). Eocene: River Murray cliffs. Protoconch ( $\times 8$ cliam.): $a$, side view ; $b$, view from abore. [G. 9400.] 167

7. Lotorium annectans, Tate (sp.). Eocene: Cape Otway. Protoconch ( $\times 8$ diam.): $a$, side vicw; $b$, view from above.

[G. 9403.] 192

8. Strombus denticostutus, sp. nov. Tertiary: Tallowan Well, Fowler's Bay District. Back view (nat. size). [G. 9654.]
[G.

9. Tylospirce coronatu, Tate (sp.). Miocene: Muddy Creck. $a$, front riew (nat. size) ; $b$, letails of the spire ( $\times 2$ diam.).

[G. 4293.] 222

10. Struthiolaria frazeri, Hutton. Pliocene : MacLean's station, Napier. $a$, front vicw of sliell ; $b$, back view ( $\frac{t}{5}$ nat. size). 



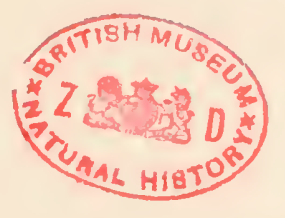




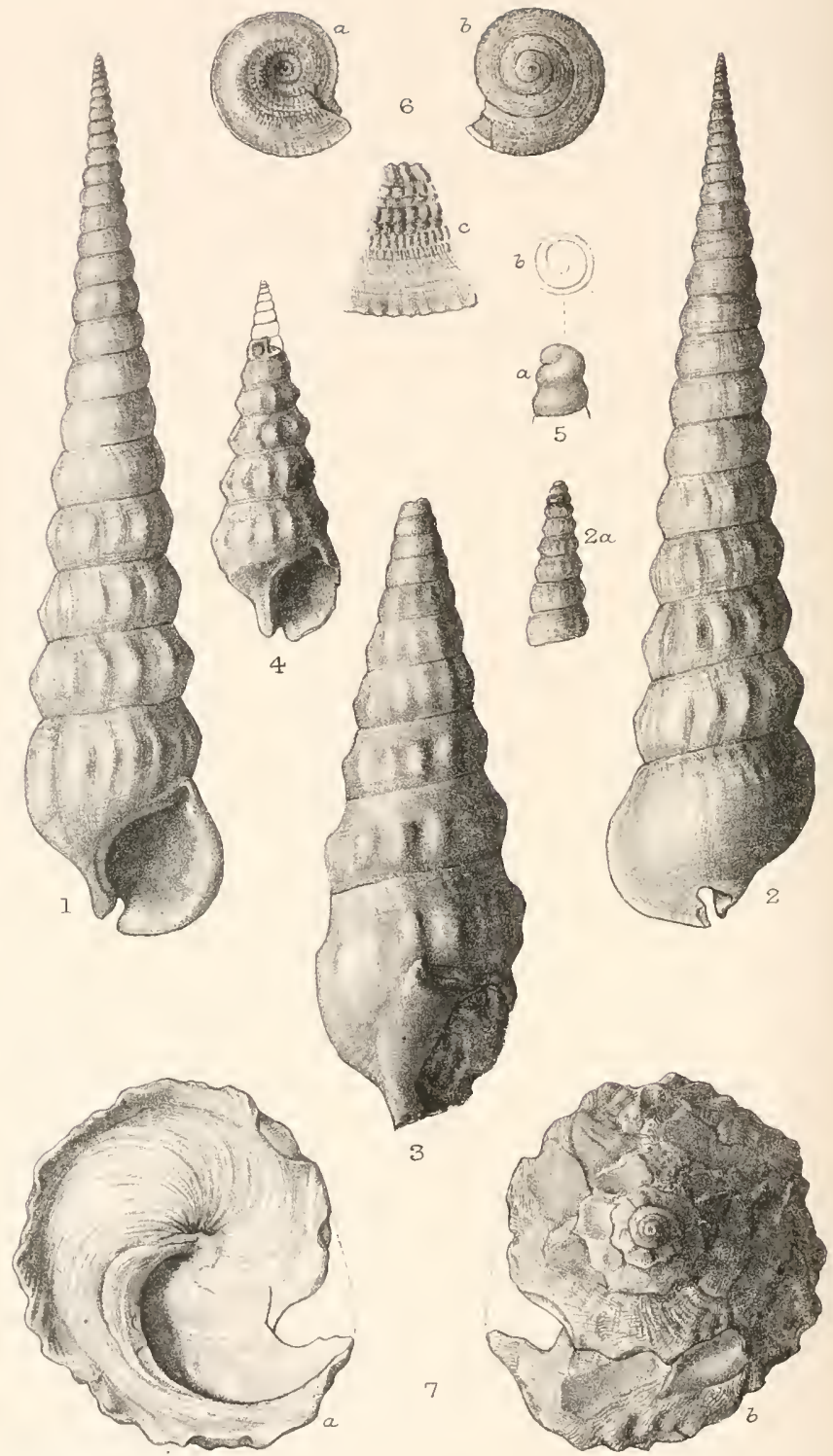

GIM.Woodward deletlith

West Newrnan imp Cerithildx, Tumrtellidx, Solarida, Xenowhoradx. 


\section{PLATE VII.}

FIG.

PAGE

1, 2. Cerithium upheles, Tenison-Woods. Eocene: Muddy Creek. 1 , frout; 2 , back (nat. size) ; $2 \alpha$, detail of early whorls showing longitudinal costæ $(\times 3$ diam.). [G. 4154.]

3. Cerithium pritchardi, nom. mut. Eocene: Table Cape. Front view of shell (nat. size).

[G. 9491.] 226

4. Batillaria pomahakensis, nom. mut. Miocene: Pomahaka, Otago. Front view of shell (nat. size).

[G. 9634.] 229

5. Turritella platyspira, Tenison-Woods. Eocene : Muddy Creek. Protoconch ( $\times 12$ diam.) : $a$, side riew; $b$, view from above.

[G. 4743.] 237

6. Solarium acutum, Tenison-Woods. Eocene: Muddy Creek.

Shell (nat. size) : $a$, base; $b$, view from above; $c$, detail ( $\times 3$ diam.).

[G. 9481.] 244

7. Xenophora (Tugurium) tatci, sp. nov. Eocene : Muddy Creek. $a$, base; $b$, view from above (nat. size).

[G. 5538.] 254 



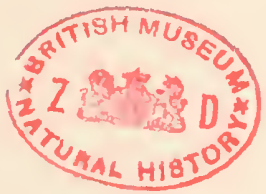



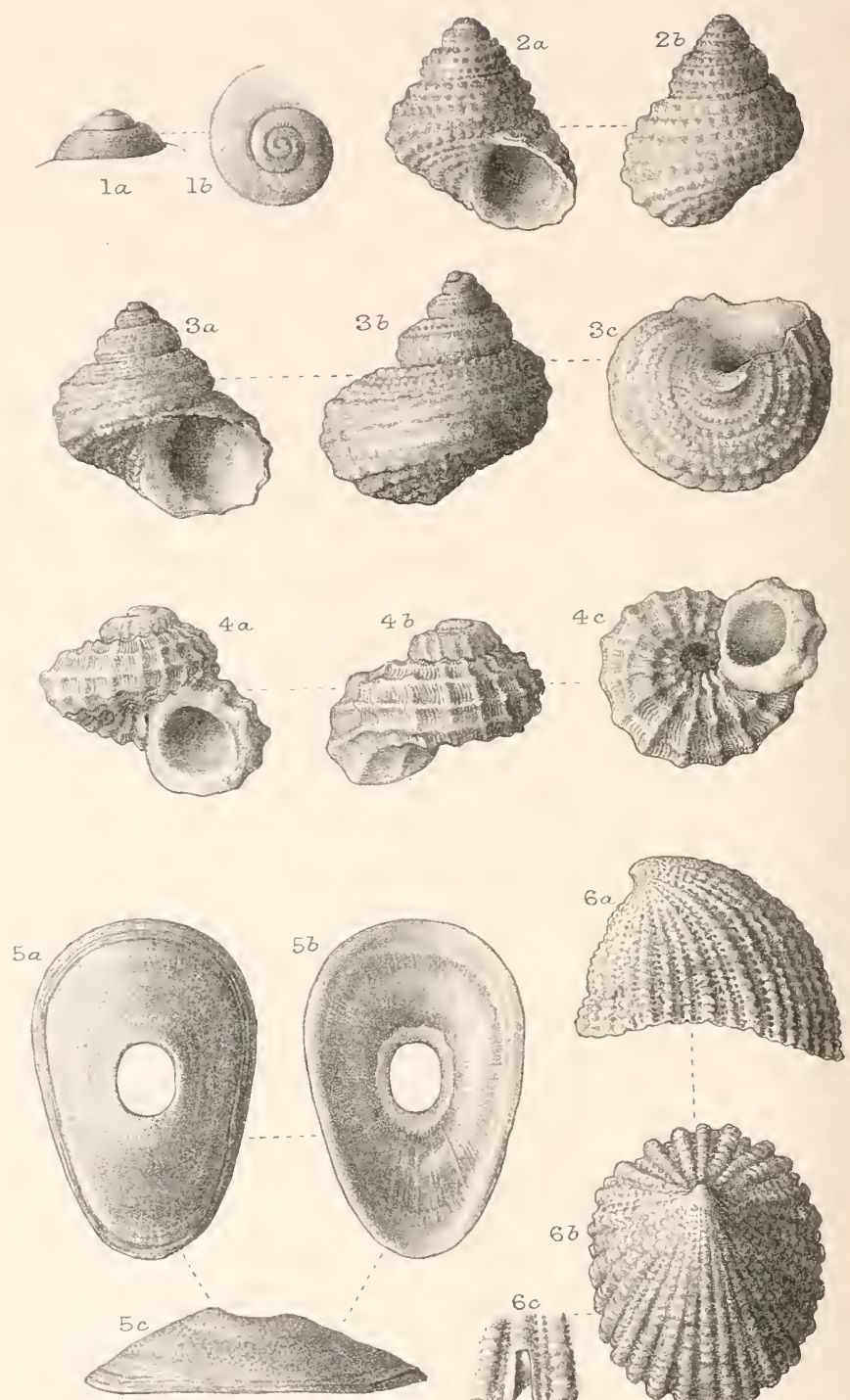

ill

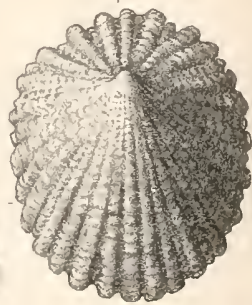

G.M.Woodward del.et lith

West, Newrnan imp Naticidæ, Turbinidxe Delphinulidæ, Fissurellidøe. 


\section{PLATE VIII.}

Fig.

1. Natica (Stigmaulax) limatu, Tate. Eocene: Muddy Creek. Protoconch ( $\times 5$ diam.) : $a$, side view ; $b$, view from above.

[G. 4278.] 262

2. Turbo etheridgei, Tenison-Woods. Eocene: Table Cape. $a$, front ; $b$, back of shell ( $\times 2$ diam.).

[83994.] 273

3. Turbo hamiltonensis, sp. nov. Eocene (?): Muddy Creek. $a$, front ; $b$, back ; $c$, base ( $\times 2$ diam.). [G. 4299.] 274

4. Liotia roblini, Johnston. Eocene: Muddy Creek. $a$, front ; $b$, back ; $c$, base ( $\times 3 \frac{1}{2}$ diam.).

5. Fissurellidea malleata, Tate. Eocene: Muddy Creek. $a$, view from above ; $b$, interior ; $c$, side view ( $\times 1 \frac{1}{4}$ diam.).

[G. 5539.] 287

6. Emarginula wannonensis, sp. nov. Eocene (?) : Muddy Creek. $a$, side view ; $b$, view from above ( $\times 2$ diam.) ; $c$, detail of fissure ( $\times 2$ diam.). 



\section{NATURAL HISTORY PUBLIGATIONS OH' TIIE 'TRUS'TEES OF' THE BRITISH MUSEUM.}

The following publications can be purchased through the $\Lambda$ greney of Messrs. Longimans \& Co., 39, Paternoster Row; Mr. Qgearírcu, 15, Picudilly: Messrs. Kegax Paul, Trencu, 'Trïnnere \& Co., Patemoster House, Charing Cross Road; and Messis. Dulad \& Co., 37, Soho Square; or at the Natulas. lisison Museun, Cromvell Road, London, S. $I V$.

Catalogue of the Specimens and Drawings of Mammals, Birds, Reptiles, and Fishes of Nepal and Tibet. Presented by B. H. Hodgson, Esq., to the British Musenm. 2nd edition. By John Edward Gray. Pp. xii., 90. [With an account of the Collection by $\mathrm{Mr}_{\mathrm{r}}$. Hodgson.] 1863, $12 \mathrm{mo} .2 s_{\mathrm{s}} 3 \mathrm{~d}$.

Report on the Zoological Collections made in the Indo-Pacific Ocean during the voyage of H.M.S. "Alert," lssl-2. Pp. xxv., 684. 5+ Plates. 1884, 8vo.

Summary of the Voynge - By Dr. R. W. Coppinger.

\begin{tabular}{|c|c|c|}
\hline Mammalia & 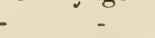 & O. Thomas. \\
\hline Aves - & - & "R. B. Sharpe. \\
\hline Reptilia, Batra & chia, Pisces & A. Günther. \\
\hline Mollusea & - & E. A. Smith. \\
\hline Echinodernata & a & F. J. Bell. \\
\hline Crustacea & - & " E. J. Miers. \\
\hline Coleoptera & - & C. O. Waterlonse. \\
\hline epicloptera & - & ", A. G. Butler. \\
\hline keyonaria :and & i & O. Riulley. \\
\hline
\end{tabular}

\section{MAMMLLS.}

List of the Specimens of Mammalia in the Collecton of the British Museum. By Dr. J. E. Gray, F.lR.s. Pp. xxviii,, 216. [With Systematic List of the Generat of Mammalia, Index of Donations, and Alphabetical Index.] 1843, $12 \mathrm{mo}$. 2s. $6 d$.

List of the Osteological Specimens in the Collection of the British Musemm. By John Edward Gray. Pp. xxy. 1.17. [With Systematic Index and Appendix.] 1847, 12 mo. $2 s$. 
Catalogue of the Bones of Mammalia in the Collection of the British Musenm. By Edward Gerrard. Pp. iv., 296. 1862, Sro. $5 s$.

Catalogue of Monkeys, Lemurs, and Fruit-eating Bats in the Collection of the British Musenm. By Dr. J.E.Gray, F.R.S., \&c. Pp. viii., 137. 21 Woodeuts. 1870, 8ro. $4 s$.

Catalogue of Carnivorous, Pachydermatous, and Edentate Mammalia in the British Museum. By John Edward Gray, F.R.S., \&c. Pp. vii., 398. 47 Woodcuts. 1869, 8vo. 6s. 6d.

Catalogue of Seals and Whales in the British Museum. By John Edward Gray, F.R.S., \&c. 2nd edition. Pp. vii., 402. 101 Woodcuts. 1866, 850. $8 s$.

- Supplement. By John Edward Gray, F.R.S., \&c. Pp. vi., 103. Il Woodcuts. 1871, 8ro. 2s. 6d.

List of the Specimens of Cetacen in the Zoological Department of the British Museum. By IVilliam Henry Flower, LI.D., F.R.S, \&c. [With Systematic and Alphabetical Indexes.] P'p. iv., 36. 1885, 8vo. $1 s .6 d$.

Catalogue of Ruminant Mammalia (Pecora, Linnæus) in the British Museum. By John Edward Gray, F.R.S., \&c. Pp. viii., 102. 4 Plates. 1872, 8vo. $3 s .6 d$.

Catalogue of the Marsupialia and Mouotremata in the Collection of the British Museum. By Oldfield Thomas. Pp. xiii., 401. 4 coloured and 24 plain Plates. [With Systematic and Alphabetical Indexes.] 1888, 8vo. 1l. 8 s.

\section{BIRDS.}

Catalogne of the Birds in the British Museum :-

Vol. VI. Catalogue of the Passeriformes, or Perching Birds in the Collection of the British Musuem. Cichlomorphe: Part III., containing the first portion of the family 'Timeliidx (Babbling Thrushes). By R. Bowdler Sharpe. Pp. xiii., 420. Woodcuts aud 18 coloured Plates. [With Systematic and Alphabetical Indexes.] 1881,8 ro. $1 l$.

Tol. VII. Catalogne of the Passeriformes, or Perching Birds, in thite Collection of the British Musenm. Cichlomorphe: Part IV., containing the concludiug portion of the family 'Timelidie (Babbling 'Thrushes). By $R$. Bowdler Sharpe. Pp. xvi, 698. Woolcuts and 15 coloured Plates. [With Systematic and Alphabetical Indexes.] 1883, 8ro. 1l.6s.

Vol. VIII. Catalogue of the Passeriformes or Perching Birds, in the Collection of the British Museum. Cichlomorpluce: Part V., containing the families Paride and Laniidie (Titmice and Shrikes); and Certhiomorpha (Creepers and Nuthatches). By Hans Garlow, M.A., Ph.D. P1. xiii., 386. Woodents and 9 colonred Plates. [Witl Systemaic and Alphabetical Indexes.] 1883, 8vo. 17s. 
Catalogue of the Birds in the British Museum-continued.

Vol. IX. Catalogue of the Passeriformes, or Perching Jirds, in the Collection of the British Museum. Cinnyrimorphe, containing the families Nectariniidæe and Meliphagidæ (Sun Birds and Honey-eaters). By Hans Gadow, M.A., Ph.D. Pp. xii., 310. Woodcuts and 7 coloured Plates. [With Systematic and Alphabetical Indexes.] 1884, 8 ro. $14 s$.

Vol. X. Catalogue of the Passeriformes, or Perching Birds, iu the Collection of the British Museum. Fringilliformes: Part I., containing the families Dicæidæe, Hirundinide, Ampelidæ, Mniotiltidæ, and Motacillide. By R. Bowdler Sharpe. Pp.xiii., 682. Woodcuts and 12 coloured Plates. [With Systematic and Alphabetical Indexes.] 1885, Sro. 1l.2s.

Vol. XI. C'atalogue of the Passeriformes, or Perching Birds, in the Collection of the British Musenm. Fringilliformes : l'art II., containing the families Cocrebidæ, 'Tanagridæ, and Icteridie. By Philip Lutley Sclater, M.A., F.R.S. Pp. xvii., 431. [With Systematic and Alplabetical Indexes.] Woodcuts and is coloured Plates. 1886, 8vo. $1 l$.

Vol. XII. Catalogue of the Passeriformes, or Perching Birds, in the Collection of the British Museum. Fringilliformes: Part III., containing the family Fringillidæ. By R. Bowdler Sharpe. Pp. xv., 871. Woodcuts and 1(; coloured Plates. [With Systematic and Alphabetical Indexes.] 1888, 8vo. 11.8s.

Vol. XIII. Catalogue of the Passeriformes, or Perehing Birds, in the Collection of the British Museum. Stumiformes, containing the families Artamida, Sturnidie, Ploceidx, and Alaudida. Also the families Atrichiida and Menurida. By R. Bowdler Sharpe. Pp. xri., 701. Woodeuts aud 15 coloured Plates. [With Systematic and $A$ phabetical Indexes.] $1890,8 v^{\circ}, 12.8 s$.

Fol. XIV. Catalogue of the l'asserilormes, or Perching Birds, in the Collection of the British Museum. Oligomyode, or the l'milies 'Tyranuide, Oxyrhamphide, Pipricla, Cotingidæe, l'hytotomidx, Philepittidæ, Pittidæ, Nenicidx, and Eurylemidx. By Plilip Lutley Sclater, M.A., F.R.S. Pp. xix., 494. Woodeuts and 26 coloured Plates. [With Systematic and Alphaberical Indexes.] 1888 , sro. 1 l. $4 s$.

Vol. XV, Catalogue of the Passeriformes, or P'erching Birls, in the Collection of the British Museum. Trachicophonce, or the families Dendrocolapticlx, Formicariidx, Conopophagidx, and Pteroptochida. By Philip Lutley Sclater, M.A., F.R.S. Pp. xvii., 371. Woodcuts and 20 coloured Plates. [With Systematic and Alphabetical Iullexes.] 1890, sro. $1 \%$. 
Catalogue of the Birds in the British Musenm-continued.

Vol. XV1. Catalogue of the P'icariæ in the Collection of the British Musenm. Upupe and Trochili, by Osbert Salvin. Coracice, of the families Cypselidæ, Caprimulgidæ, Podargida, and Steatornithidæ, by Ernst Hartert. Pp. xvi., 703. Woodeuts and 14 coloured Plates. [With Systematic and Aiphabetical Indexes.] $1892,8 \mathrm{vo} .1 \mathrm{l}, 16 \mathrm{~s}$.

Vol. XVII. Catalogue of the Picaria: in the Collection of the British Museum. Coracia (contin.) and Halcyones, with the families Leptusomatidæ, Coraciidæ, Meropida, Alcedinidæ, Momotidæ, Totidæ, and Coliidæ, by R. Bowdler Sharpe. Bucerotes and Trogones, by W. R. Ogilvie Grant. Pp. xi., 522. Woodeuts and 17 coloured Plates. [With Systematic and Alphabetical Indexes.] 1592, Svo. $1 l .10 s$.

Vol. XVIII. Catalogue of the Picaria in the Collection of the British Museum. Scansores, containing the family Picidæ. By Edward Hargitt. Pp. xv., 597. Woodcuts and 15 coloured Plates. [With Systematic and Alphabetical Indexes. $\quad 1890,8$ vo. $1 l .6 s$.

Vol. XIX. Catalogue of the Picarix in the Collection of the British Museum. Scansores and Coccyges: containing the families Rhamphastidx, Galbulidæ, and Bucconidx, by P. L. Selater ; and the families Indicatoridx, Capitonida, Suculidx, and Musophagidx, by G. E. Shelley. Pp. xii., 484 : 13 coloured Plates. [With Systematic and Alphahetical Indexes.] 1891, 8vo. 1l. $5 s$.

Vol. XX. Catalogue of the Psittaci, or Parrots, in the Collection of the British Museum. By 'T. Salvarlori. Pp. xvii., 658: woodeuts and 18 coloured Plates. [With Systematic and Alphabetical Indexes.] 1891, 8vo. 1l. $10 s$.

Vol. XXI. Catalogue of the Columbre, or Pigeons, in the Collection of the British Museum. By T. Salvadori. Pp. xvii., 676: 15 coloured Plates. [With Systematic and Alphabetical Indexes.] 1893, 8vo. 1l. $10 \mathrm{~s}$.

Vol. XXII. Catalogue of the Game Birds (Pterocletes, Galline, Opisthocomi, Hemipodii) in the Collection of the British Museum. By W. R. Ogilvie Grant. Pp. xvi., 585 : 8 colonred Plates. [With Systematic and Alphabetical Indexes.] 1893, 8vo. 1 ll.6s.

Vol. XXIII. Catalogne of the Fulicaria (Rallidæe and Heliornithidæ) and Alectorides (Aramidæ, Eurypygidæ, Mesitidæ, Rhinochetidæ, Gruidæ, Psophiidæ, and Otididæ) in the Collection of the British Museum. By R. Bowdler Sharpe. Pp. xiii, 353: 9 colonred Plates. [With Systematic and Alphabetical Indexes.] 1894. 8vo. 20s.

Vol, XXV. Catalogue of the Gavize and Turbinares in the Collection of the British Museum. Gaviæ (Terns, Gulls, ancl Skuas), by Howard Saunders. Turbinares (Petrels and Albatrosses), by Osbert Salvin. Pp. xv., 475: woodeuts and 8 coloured Plates. [With Systematic and Alphabetical Indexes.] $1896,8 v 0.1 l .1 s$. 
Ciulalosue of the Birds in the British Mnseum-continued.

Vol. XXVII. Catalogue of the Chenomorphe (Palamerlex, Phoenicopteri, Anseres), Crypturi, and Ritita: in the Collection of the British Museum. By T. Salvadori. P'1. xv., 636: 19 coloured Plates. [With systematic and Alphabetical Indexes.] 1895, 8vo. 17. 12s.

List of the Specimens of Birds in the Collection of the British Museum. By George Robert Gray :-

Part III., Section I. Ramphastirlæ. Pp. 16. [With Index.] 1855, $12 \mathrm{mo} .6 \boldsymbol{d}$.

Part III., Section II. Psittacidæ. Pp. 110. [With Index.] 1859,12 mo. $2 s$.

Part III., Seetions III. and IV. Capitonida and Picidæ. Pp. 137. [With Index.] 1868, 12mo. 1s. 6d.

Part IV. Columbæ. Pp.73. [With Index.] 1856, $12 \mathrm{mo.}$ 1 s. $9 d$.

Part V. Gallinæ. Pp. iv., 120. [With an Alphabetical Index.] 1867, 12mo. 1s. $6 d$.

Catalogue of the Birds of the Tropical Islands of the Pacifie Ocean in the Coilection of the British Museum. By George Robert Gray, F.L.S., \&e. Pp. 72. [With an Alphabetical Index.] 1859,8 vo. $1 s, 6 d$.

\section{REP'TILES.}

C'atalogue of the Tortoises, Crocodiles, and Amphisbruians in the Collection of the British Museum. By Dr. J. E. Gray, F.R.S., \&ce. P P. viii., 80. [With an Alphabetieal Index.] 1844, $12 \mathrm{mo} .1 \mathrm{~s}$.

Catalogue of Shield Reptiles in the Collection of the British Museum. By John Edward Gray, F.R.S., \&e. :-

Appendix. Pp. 28. 1872, 4to. 2s.6d.

Part II. Emydosaurians, Rhynchocephalia, and Amphisbænians. Pp. vi., 41. 25 Woodcuts. 1872, 4to. 3s. 6d.

Hand-List of the Specimens of Shield Reptiles in the British Museum. By Dr. J. E. Gray, F.R.S., F.L.S., \&e. Pp. iv, 124. [With an Alphabetical Index.] 1873, 8vo. 4s.

Catalogue of the Chelonians, Rhymehocephalians, and Crocodiles in the British Musenm (Naturul History). New Edition. By George Albert Bonlenger. Pp. x., 311. 73 Woodeuts and 6 Plates. [With Systematic and Alphahetical Indexes.] 1889, svo. $15 s$.

Catalogue of the Specimens of Lizards in the Collection of the British Mnsenm. By Dr. J. E. Gray, F.R.S., \&c. I'p. xxviii., 289. [With Geographic, Systematic, and Alphabetical Indexes.] $1845,12 \mathrm{mo} .3 s .6 d$.

Catalogue of the Lizards in the British Museum (Natural History). Second Edition. By George Albert Bonlenger" :-

Vol. I. Geckonidæ, Eublepniridx, Uroplatidx, Pygopodidar, Agamidre. Pp. xii., 436. 32 Plates. [With Systematic and Alphahetioal Indexes.] 188.5, 8ro. 20s. 
Catalogne of the Lizards in the British Museum-continued.

Vol. II. Ignanidæ, Xenosauridæ, Zonuridæ, Anguidæ, Anniellidæ, Helodermatidæ, Varanidæ, Xantusiidæ, Teiidæ, Amphisbrnidx. Pp. xiii., 497. 24 Plates. [With Systematic and Alphabetical Indexes.] 1885, 8vo. $20 \mathrm{~s}$.

Vol. III. Lacertidæ, Gerrlosanirilæ, Seincidæ, Anelytropidæ, Dibamidx, Chamæleontidx. Pp. xii., 575. 40 Plates. [With a Systematic Index aud an Alphabetical Index to the thrce volumes.] 1887, 8vo. 1l. 6s.

Catalogue of the Snakes in the British Museum (Natural History).

By George Albert Boulenger, F.R.S.:-

Vol. 1., containing the families Typhlopidx, Glauconiidx, Boillx, Ilysiidx, Uropeltile, Xenopeltidx, and Colubride aglyphix, part. Pp. xiii., 448: 26 Woodents and 28 Plates. [With Systematic and Alphabetical Indexes.] $1893,8$ го. $]$ \%. 1 s.

Vol. 11, containing the conclusion of the Colubride aglyphe. Pp. xi., 382: 25 Woodcuts and 20 Plates. [With Systematic and Alphabetical Indexes.] 1894, 8vo. 17s.6d.

Vol. III., containing the Colubride (Opisthoglyphre and Proter(glyphe), Amblycephalidæ, and Viperidæ. Pp.xiv., 727: 37 Woodcuts and 25 Plates. [With Systematic Index, and $A I_{p}$ liabetical Index to the 3 volumes.] 1896, Svo. Il. 6 s.

Catalogue of Colubrine Suakes in the Collection of the British Museum. By Dr. Albert Gïnther. Pp. xvi., 281. [With Geographic, Systematie, and Alphabetical Indexes.] 1858, $12 \mathrm{mo} .4 s$.

\section{BATRACHI ANS.}

Catalogue of the Batrachia Salientia in the Collection of the British Mnseum. By Dr. Albert Günther. Pp. xvi., 160. 12 Plates. [With Systematic, Geographic, and Alphabetical Iudexes.] 1858, 8ro. 6s.

Catalogne of the Batrachia Gradientia, s. Caudata, and Batrachia Apoda in the Collection of the British Museum. Second Edition. By George Albert Bonlenger. Pp. viii., 127. 9 Plates. [With Systematic and Alpliabetical Indexes.] 1882, 8vo. $9 s$.

\section{FISHES.}

Catalogne of the Fishes in the Collection of the British Museum. By Dr. Albert Güuther, F.R.S., Ic. :-

Vol. VII. Pliysostomi (Heterophygii, Cyprinida, Gonorinyichida, Hyorlontila, Osteoglossidæ, Clupeidæ, Chirocentridae, Alepocephalidie, Notopteridæ, Halosauridæ). P P. xx, 512. Woodents. [With Systematic and Alphabetical Indexes.] 1868, 8ro. \&s. 
Catalogue of Fishes in the British Mlnseum-continued.

Vol. VIII. Physostomi (Gymnotidx, Symbranchida, Muratnidx, Pegasidx), Lophobranchii, Plectognathi, Dipnoi, Ganoidei, Chondropterygii, Cyclostomata, Leptocardii. Pp. xxv., 549. [With Systematic and Alphabetical Indexes.] 1870, 8vo. 8s. $6 \mathrm{~d}$.

Citalogue of the Fishes in the British Musium. Second edition. Vol. I. Catalogue of the Perciform Fishes in the British Mnseum. Vol. I. containing the Centrarchidx, Percidæ, and Serranidae (part). By George Albert Boulenger, F.R.S. Pp. xix., 394. Woodcuts and 15 plates. [With Systematic and Alphabetical Indexes.] 1895, 8ro. $15 s$.

List of the Specimens of Fish in the Colleetion of the British Museum. Part I. Chondiopterygii. By J. E. Gray. Pp. x., 160. 2 Plates. [With Systematic and Alplubetical Indexes.] $1851,12 \mathrm{mo} .3 s$.

Catalogue of Fish collected and described by Laurence Theodore Gronow, now in the British Museum. Pp. vii., 196. [With a Systematic Index.] 185t, 12mo. $3 s .6 d$.

Catalogue of Lophobranchiate Fish in the Collection of the British Museum. Вy.J. J. Kaиp, Ph.D., \&c. Pp. ir., 80. 4 Plates. [Vith an Alphabetical Index.] 1856, 12mo. $2 s$.

\section{MOLLUSCA.}

Gnile to the Systematic Distribution of Mollusea in the Britisl Museum. Part I. By John Elward Gray, Plı.D., F.R.S., sic. Pp. xii., 230. 121 TVoodcuts. 1857, 8vo. 5s.

List of the Shells of the Canaries in the Collection of the British Museum, collected by MM. Wehb and Berthelot. Described and figured ly Prof. Alcide D'Orbigny in the "Histoire Naturelle des Iles Canaries." Pp. 32. 1854, 12mo. $1 s$.

List of the Shells of Cuba in the Collection of the British Museum, collected by M. Ramon de la Sagra. Descrilied by Prof. Alcide d'Orbigny in the "Historre de l'lle de Cuba." Pp.48. 185t, 12no. $1 s$.

List of the Shells of South America in the Collection of the British Musenm. Collected and described by M. Alcide D'Orbigny in the "Voyage dans l'Anérique Méridionale." I'p. 89.1854 , 12!1. $2 s$.

Catalogue of the Collection of Mazatlan Shells in the British Museum, collected by Frelerick Reigen. Described by Philip P. Carpenter. Pp. xvi., 552. 1857, $12 \mathrm{mo} .8 s$.

List of Mollusen and Shells in the Collection of the British Museum, collected and desuribed by MM. Eydonx and Souleyet. in the "Yoyage autour du Monke, exécuté pendant les années " 1836 et 1837 , sur lil Corvette "J Lil Bonite," and in the " Iistoire naturelle dies Mollisques Ptéropoules." Par MIL. P. C. A. L. Rang et Souleyet. 1'p. ir., 27. 1855, 12mo 8r. 
Catalogue of the Phaneropneumona, or Terrestrial Operculated Mollusca, in the Collection of the British Museun. By Dr. L. Yfeiffer. Pp. 324. [With an Alphabetical Index.] 185\%, $12 \mathrm{mo} .5 \mathrm{~s}$.

Nomenclature of Molluscous Animals and Shells in the Collection of the British Museum. Part I. Cyclophoridæ. Pp. 69. [With an Index.] 1850, $12 \mathrm{mo} .1 s, 6 d$.

Catalogue of Pulmonata, or Air Breathing Mollusca, in the Collection of the British Museum. Part I. By Dr. Louis Pfeiffer. Pp. iv., 192. Woodcuts. 1855, $12 \mathrm{mo} .2 s .6 \mathrm{~d}$.

Catalogue of the Auriculidx, Proserpinidx, and Truncatellidæe in the Collection of the British Museum. By Dr. Louis Pfeiffer. Pp. iv., 150. Woodeuts. 1857, 12mo. 1s.9d.

List of the Mollusca in the Collection of the British Museum. By John Edward Gray, Ph.D., F.R.S., \&c.

Part I. Volutida. Pp. 23. 1855, 12mo. 6d.

Part II. Olivida. Pp. 41. 1865, 12mo. $1 s$.

Catalogne of the Conchifera, or Bivalve Shells, in the Collection of the British Musenm. By M. Deshayes :-

Part I. Veneridæ, Cyprinidæ, Glaucouomidæ, and Petricoladx. Pp. iv., 216. 1853, J2mo. $3 s$.

Part II. Petricoladæ (concluded); Corbiculadax. Pp. 217-292. [With an Alphabetical Index to the two piats.] $1854,12 \mathrm{mo} .6 d$.

\section{BRACHIOPODA.}

Catalogue of Brachiopoda Ancylopoda or Jamp Shells in the Collection of the British Museum. [Issued as "Catalogue of the Mollusca, P'art IV."] Pp. iv., 128. 25 Woodeuts. [With in Alphabetical Index.] 1853, 12mo. $3 s$.

\section{POLYZOA.}

Uatalogue of Marine Polyzoa in the Collection of the British Mnseum. Part III. Cyclostomata. By George Busk, F.R.S. 1'p. viii., 39. 38 P'lates. [With a Systematic Index.] 1875, svo. 5s.

\section{CRUS'TACEA.}

Catalngue of Crustacea in the C'ollection of the British Musenm. Part I. Leucosiada. By Thomas Bell, V.P.R.S., Pres. L.S., \&c. Pp. iv., 24. 1855, 8vo. 6d.

Catalogue of the Specimens of Amphipodons Crustacea in the Collection of the British Museum. By C. Spence Bate, F.R.S., fre. Pr. iv.. 399. 58 Plates. [With an Alpbabetical Index.] 1862, 8ve. 1/. 5.. 


\section{ARACHNIDA.}

Descriptive Catalogue of the Spiders of Burnis, based upon the ('ollection mate hy Eugene $W$. Oates and preserved in the British Museum. By $T$. 'Thorell. Pp. xxxvi., 4()6. [Wit/ Systematic List and Alphabetical Index.] 1895, 8vo. 10s. 6id.

\section{MYRIOPODA.}

Cataloguc of the Myriapoda in the Collection of the British Musim. By George Newport, F.R.S., P.E.S., \&c. Palt I. Chilopoda. Pp. iv., 96. [With an Alphabetica! Index.] 1856, 12 mo. ls. $9 d$.

\section{INSEC'TS.}

\section{Coleopterous Insects.}

Nomenclature of Coleopterous Insects in the Collection of the Jritish Museum :-

Part IV. Clerida. By Adam White. Pp. 68. [With Index.] 1849, 12mo. $1 s .8 d$.

Part V. Cucujidx, \&c. By Frederick Smith. [Also issued a.s "List of the Coleopterous Insects. Part I."] Pp. 25. 1851, $12 \mathrm{mo} .6 d$.

Part VI. Passalide. By Frederick Smith. Pp. iv., 23. 1 Plate [With Index.] 1852, $12 \mathrm{mo} .8 d$.

Part VII. Longicornia, I. By Adam White. Pp. iv., 17. 4 Plates. $1853,12 \mathrm{mo} .2$ s. 6 d.

Part VIII. Longicornia, II. By Adam White. Pp. 237. 6 Plates. $1855,12 \mathrm{mo} .3 s .6 d$.

Part IX. Cassididx. By Charles H. Boheman, Professor of Natural History, Stockholm. Pp. 225. [With Index.] 1856, 12mo. 3s.

Illustrations of Typical Specimens of Coleoptera in the Collection of the British Museum. Part I. Lycidie. By Charles Owen Waterhouse. Pp. x., 83. 18 coloured Plates. [With Systematic and Alphabetical Iulexes.] 1879, 8vo. $16 s$.

Catalogne of the Coleopterous Insects of Madeira in the Collection of the British Museum. 'By 'T. Vernon Wollaston, M.A., F.L.S'. Pp. xvi., 234: 1 Plate. [With a Topographical Catalogue and an Alphabetical Index.] 1857,8 ro. $3 s$.

Catalogue of the Coleopterous Insects of the Canaries in the Collection of the British Museum. By T. Vernon Wollaston, M.A., F.L.S. Pp. xiri., 618. [With 'T'opographical and Alphabetical Indexes.] 1861, 8vo. 10s. 6d.

Catalogue of Halticidas in the Collection of the British Museum. By the Rev. Hamlet Clırk, M.A., F.L.s. Pliysapodes and (Edipodes. Part I. Pp. xii., 301. Frontispiece and 9 Plates. 1860, xvo. $7 s$. 
Catalogue of Hispide in the Collection of the British Museum. By Joscph S. Baly, M.E.S., \&c. Part I. Pp. x., 172. 9 l'lates. [With an Alphabetical Index.] 1858, 8vo. $6 s$.

\section{IIymenopterous Insects.}

List of the Specinens of Hymenopterous Insects in the Collection of the British Museum. By Francis Walker, F.L.S.:-

Part II. Chalcidites. Additional Species. Appendix. Pp.iv., 99-237. 1848, 12mo. 2s.

Catalogue of Hymenopterous Insects in the Collection of the British Museum. By Frederick Smith. 12mo.:-

Purt I. Andrenidie and Apida. Pp. 197. 6 Plates. 1853, $2 s .6 d$.

Part II. Apidæ. Pp. 199-465. 6 Plates. [With an Alphabetical Index.] 1854, $6 s$.

Part III. Mutillide and Pompilide. Pp. 206. 6 Plates. $1855,6 s$.

Part IV. Sphegidæ, Larridæ, and Crabronide. Pp. 207497. 6 Plates. [With an Alphabetical Index.] 1856, $6 s$.

Part V. Vespida. Pp. 147. 6 I'lates. [With an Alphabetical Index.] 1857, $6 s$.

Part VI. Formicidx. Pp. 216. 14 Plates. [With an Alphabetical Index.] 1858, $6 s$.

Part VII. Durylide and Thynnidx. $\mathrm{P}$ P. 76. 3 Plates. [With an Alphabetical Index.] 1859, $2 s$.

Deseriptions of New Species of Hymenoptera in the Collection of the British Museum. Fy Frederick Smith. Pl? xxi., 240. [With Systematic and Alphabetical Indexes.] 1879, 8vo. 10s.

List of Hymenoptera, with descriptions and figures of the Typical Specimens in the British Musenm. Vol. I., Tenthredinidx and Siricida. By IV. F. Kirby, Pp. xxviii., 450. 16 Coloured Plates. [W ith Systematic and Alphabetical Indexes.] 1882, 8ro. 17. $18 s$.

\section{Dipterous Insects.}

List of the Specimens of Dipterous Insects in the Collection of the British Museum. By Francis Walker, F.L.S. 12mo. :-

Part IV. Pp. 689-1172. [With an Index to the four parts, and an Index of Donor's. $1849.6 s$.

Part VII. Supplement III. Asilidx. Pp. ii., 507-775. 1855. 3s. 6d.

\section{Lepidopterous Insects.}

Illustrations of 'Typical Specimens of Lepidoptera Heterocera in the Collection of the British Museum :-

Part. III. By Arthur Gardiner Butler. Pp. xviii., 82. 41-60 Coloured Plates. [With a Systematic Inclex.] 1879, 4to. $2 l$. $10 s$. 
Illustrations of 'Typical Specimens of Lepidoptera Heterocera -continued.

Part V. By Arthur Gardiner Butler. Pp. xii., 74. 78-100 Coloured Plates. [With a Systematic Index.] 1881, 4to. $2 l .10 s$.

Purt VI. By Arthux Gardiner Butler. Pp. xv., 89. 101-120 Coloured Plates. [With a Systematic Index.] 1886, 4to. 2l. $4 s$.

Part VII. By Arthur Gardiner Bintler. Pp. iv., 124. 121-138 Colomed Plates. [With a Systematic List.] 1889,4 to. $2 l$.

l'art VIII. The Lepidoptera Hetereeera of the Nilgiri District. By George Francis Hampson. Pp. iv., 14.1. 139-156 Colonred Plates. [With il Systematic List.] 1891,4 to. $2 \%$

l'art IX. The Macrolepidoptera Heterocera of Ceylon. By George Francis Hampson. Pp. v., 182. 15\%-176. Coloured Plates. [With a General Systematic List of Speeies collected in, or recorded from, Cerlon.] 1893, 4to. $2 l .2 s$.

Catalogue of Diurnal Lepidoptera of the fumily Satyrida in the Collection of the British Museum. By Arthur Gardiner Butler, F.L.S., \&c. Pp. vi., 2I1. 5 Plates. [With : In Alphabetical Index.] 1868, 8vo. 5s. Gil.

Catalogue of Diurnal Lepidoptera described by Fabricius in the Collection of tìe British Musem. By Arthur Gardiner liutler, F.L.S., \&c. Y'p. iv., 303. 3 Plates. 1869, 8vo. 7s.6d.

Specimen of a Catalogue of Lycrenille in the British Muserm. By W. C. Hewitson. Pp. 15. \& Colonred Plates. 1862, 4to. 17. 1s.

List of Lepidopterous Insects in the Collection of the British Museum. I'art I. Papilionida. By G. R. Gray, F.L.S. Pp. 106. [With an Alphabetical Index.] 1856, 12mo. 2s.

List of the Specimens of Lepidopterous Insects in the Collection of the British Musemm. By Francis Walker. 12mo.:-

Part VI. Lepidoptera Heterocera. Pp. 1258-1507. 1855, $3 s .6 d$.

Part X. Noetuidx. 1'p. 253-191. 1856, 3s.6d.

Part XII. - Pp. 76.j-982. 1857, is. Gor.

Part XIII. - — — Pp. 983-1236. 1857, 3s. 6d.

Part XIV. — Pp. 123 - 1519 . 1858, 4s. 6d.

Part XV. Pl. 1520-1888. [With an Alphilbetical Index to Parts IX.-XV.] 18.58, 4s. 6rl.

Part XVI. Deltoiles. L'p. 253. 18,5, 3s. 6d.

l'art XIX. Pyralides. 1'p. 799-1036. [With in $\Lambda$ Ipha-

berical Index to Purts XVI.-XIX.] 1859, $3 s .6 d$.

l'art X.II. Geometrites. 1'p. 277-498. 1860, $3 s$.

Part XXII. — Pp. 499-755. 1861, 3s.6 6 .

Part XX111.— Pp. 756-1020. 1961, .s. 6el. 
List of Specimens of Lepidopterous Insects-continued.

I'art XXIV. - — P P. 1021-1280. 1862, 3s. 6rl.

Part XXV. Pp. 1281-1477. 1862, $3 s$.

Part XXVI. — Pp. 1478-1796. [With alı

Alphabetical Index to Parts XX.-XXVI.] 1862, 4s, 6rl.

Part XXVlI. Crambites aud Tortricites. Pp. 1-286. 1863, $4 s$.

Part XXVIII. 'Tortricites and Tineites. P.p. 287-561. $1863,4 s$.

Part XXIX. Tineites. Pp. 560-835. 1864, $t s$.

Part XXX. — Pp. 836-1096. [With an Alphabetical Index to Parts XXVII.-XXX.] 1864, $4 s$.

Part XXXI. Supplement. Pp. 1-321. 1864, 5s.

Part XXXII. Part 2. Pp. 322-706. 1865,

$5 s$.

Part XXXIII. — Part 3. Pp. 707-1120. 1865, $6 s$.

Part XXXIV. —_ Part 4. Ip. 1121-1533. 1865, 5s. $6 d$.

Part XXXV.

Part 5. Pp. 1534-2040. [With an Alphabetical Index to Parts XXXI.-XXXV.] 1866, $7 s$.

\section{Neuropterons Insects.}

Catalogue of the Specimens of Neuropterous Insects in the Colleetion of the British Museum. By Francis Walker. 12mo. :-

Part I. Phryganides-Perlides. Pp. iv., 192. 1852, 2s. $6 d$.

Part II. Sialidæ-Nemopterides. Pp. ii., 193-476. 1853, $3 s .6 d$.

Part III. 'Termitidæ-Ephemeridæ. I'p. ii., 477-585. 1853, 1s. $6 d$.

Catalogue of the Specimens of Neuropterous Insects in the Collection of the British Museum. By Dr. H. Hagen. Part I. Termitina. Pp. 34. 1858, 12mo. 6d.

\section{Orthopterous Insects.}

Catalogue of Orthopterons Insects in the Collection of the British Museum. Part 1. Phasmidæ. By John Obadial Westwood, F.I.S., \&e. Pp. 195. 48 Plates. [With an Alphabetical Index.] 1859, 4to. $3 l$.

Catalogne of the Specimens of Blattarix in the Collection of the British Museum. By Francis Walker, F.L.S., \&c. Pp. 239. [With an Alphabetical Index.] 1868, 8vo. 5s. $6 d$.

Catulogue of the specimens of Dermaptera Saltatoria [Part I.] and Supplement to the Blattaria in the Collection of the British Muscum. Gryllidx. Blatarix. Locustida: By Francis Walker, F.L.S., de. 1'p. 224. [With an Alphabetical Index.] 1869 , हैं 5. 
Catalogue of the Specinens of Dermaptera Saltatoriat in the Collection of the British Musemu. By Francis Walker, l'.T.S., \&c.-

Part II. Locustida (continued). Y'p. 225-423. [With an Alphabetical Index.] 1869,8 vo. $4 s .6 d$.

Part III. Locustidæe (continued).-Acrididæ. P'p. 425-604. [With an Alphabetical Index.] 1870, 8vo. 4s.

Part IV. Acrididae (continued). '’!. 60j-8(09. [With an Alphabetical Index.] 1870, 8vo. 6s.

Part $Y$. 'Tettigidæ.-Supplement to the Catalogue of Blattarix.-Supplement to the Catalogie of Dermaptera Saltutoria (with remarks on the Geographical Distribution of Dermaptera). Pp. 81]-850;43;116. [With Alphabetical Indexes.] $1870,8 \mathrm{vo} .6 s$.

\section{Hemipterous Insects.}

List of the Specimens of Hemipterous Insects in the Collection of the British Museum. By W. S. Dallas, F.L.S. Part II. Pp. 369-590. Plates 12-15. 1852, 12mo. 4s.

Catalogue of the Specimens of Heteropterous Hemiptera in the Collection of the British Mnseum. By Francis Walker, F.I.S., \&c. 8vo.:-

Part I. Sicutata. Pp. 240. 1867. 5s.

Part II. Scutata (continued). Pp. 241-417. 1867. 4s.

Part III. Pr. 418-599. [With au Alphabetical Index to

Parts I., II., III., and a Summary of Geographical

Distribution of the Species mentioned.] 1868. $4 \mathrm{~s}$. (irl.

Part IV. Pp. 211. [Alphabetical Index.] 187]. 6.s.

Part V. Pp. ¿02. — 1872. $5 \mathrm{~s}$.

Part VI. Pp. 210. — 1873. 5s.

Part VII. Pp. 213. —— 1873. 6s.

Part VIII. Pp. 220. —— 1873. 6s. Gd.

\section{Homopterous Insects.}

List of the Specimens of Homopterous Insects in the Collection of the Britisli Museum. By Francis Walker. Sinplement. Pp. ii., 369. [With an Alphabetical Index.] 1858, 12mo. 4s.6d.

\section{VERMES.}

Catalogue of the Species of Fntozoa, or Intestinal Worms, contained in the Collection of the British Musenm. By Dr. Baird, Pp. 1v., 132. 2 Plates. [With an Index of the Animals in whieh the Entozoa mentionerl in the Catalogue are foumd; and an Index of Genera and Species.] 1853, 12mo. $2 s$.

\section{AN'THOZOA.}

Catulogne of Sea-pens or Pennatulariicla in the Collection of thr British Muscum. By J. E. Gray, F.R.S., de. l'p. iv., 41). 2 Wooleuts. 1870,5 vo. 1.s. 6 \%. 
Catalogue of Lithophytes or Stony Corals in the Collection of the British Museum. By J. E. Gray, F.R.S., \&e. Pp. iv., 51. 14 Woorlents. 1870,8 vo. $3 s$.

Catalogue of the Madreporarian Corals in the British Museum (Natural History) :-

Vol. I. 'The Genus Madrepora. By George Brook. Pp. xi., 212. 35 Collotype Plates. [With Systematic and Alphabetical Indexes and Explanation of the Plates.] 1893, 4to. 1 $1.4 s$.

Vol. II. The Genus 'Turbinaria, the Genus Astræopora. By Henry M. Bernard, M.A. Cantab., F.L.S., F.Z.S. Pp. iv., 106. 30 Collotype and 3 Lithographic Plates. [With Index of Generis and Specific Names and Explanation of the Plates.] 1996, 4to. $18 s$.

\section{BRITISH ANIMALS.}

Catalogue of British Birds in the Collection of the British Museum. By George Robert Gray, F.L.S., F.Z.S., \&c. Pp. xii., 218. [With a List of Species.] 1363, 8vo. $3 s .6 d$.

Catalogue of British Hymenoptera in the Collection of the British Museum. Secenoi edition. Part I. Andrenidxe and Apidx. By Frederick Smith, M.E.S. New Issue. Pp. xi., 236. 11 Plates. [With Systematic and Alphabetical Indexes.] 1891, 8vo. $6 s$.

Catalogue of British Fossorial Hymenoptera, Formicidæ, and Vespida in the Collection of the British Museum. By Frederick Smith, V.P.E.S. Pp. 236. 6 Plates. [With an Alphabetical Index.] 18j8, 12mo. 6s.

A Catalogue of the British Non-parasitical Worms in the Collection of the British Musenm. By George Johnston, M.D., Edin., F.R.C.L. Ed., Lr.D. Marischal Coll. Aberdeen, \&c. Pp. 365. Woodents and 24 Plates. [With an Alphabetical Index.] 1865, 8vo. $7 s$.

Catalogue of the British Echinoderms in the British Museum (Natural History). By F. Jeffrey Bell, M.A. Pp. xvii., 202. Woodeuts and 16 Plates (2 coloured). [With Table of Contents, 'Tables of Distributiou, Alphabetical Index, Description of the Plates, \&e.j 1892, 8vo. 12s. 6d.

List of the Specimens of British Animals in the Collection of the British Museum; with Synonyma and References to fignres. $12 \mathrm{mo}$.

Part IV. Crustacea. By A. White. Pp. iv., 141. (With an Index.) $1850,2 s .6$.

Part V. Tepidoptera. By J. F. Stephens. 2nd Edition. Revised by H. T. Stainton and E. Shepherd. PY. iv., 224. $1856,1 s .9 d$.

Part VI. Hymenoptera. By F. Smith. Pp. 134. 1851, $2 s$. 
List of the Specimens of 13ritish Animals-continued.

I'art VII. Molluscia, Acephala, and Brachiopoda. By Dr J. E. Gray. Pp. iv., 167. 1851, 3s. 6rt.

Part VIII. Fish. By Adam White. Pp.xxii., 161.

(With Index and List of Donors.) 1851, 3s. 6rl.

Part IX. Eggs of British Birds. By George Robert Gray. Pp. 143. 1852, 2s. 6d.

Part XI. Anoplura or Parasitic Insects. By H. Denny. Pp. iv., 51. 1852, 1 s.

Part XII. Lepidoptera (continued.) By James F. Stephens. 'Pp. iv., 54. 1852, 9d.

Part XIII. Nomenclature of Hymenoptera. By Frederick Smith. Pp. iv., 74. 1853, 1s. $4 d$.

Part XIV. Nomenclature of Neuroptera. By Adam Whitc. Pp. iv., 16. 1853, 6d.

Part XV. Nomenclaturc of Diptera, I. By Adam White. Pp. iv., 42. 1853, $1 \mathrm{~s}$.

Part XVI. Lepidoptera (completed). By H. T. Stainton. Pp. 199. [With an Index.] 1854, 3s.

Part XVIT. Nomenclature of Anoplura, Euplexoptera, and Orthoptera. By Adam White. Pp. iv., 17. 1855, 6d.

\section{PLAN'TS.}

A Monograph of Lichens found in Britain: being a Descriptive Catalogne of the Species in the Herbarium of the British Musemm. By the Rev. James M. Crombie, M.A., F.L.S., F.G.S., \&c. Part I. Pp. viii., 519: 74 Woodents. [With Glossary, Synopsis, Tabuiar Conspectus, and Index.] 1894, 8vo. 16 s.

A Monograph of the Mycetozoa ; being a Deseriptive Catalogue of the Species in the Herbarium of the British Musenm. By Arthur Lister, F.L.S. Pp. 224. 78 Plates and 51 Woodcuts. [With Synopsis of Genera and List of Species, and Index.] 1894,8 ro. $15 s$ s.

List of British Diatomncea in the Collection of the British Museum. By the Rev. W.Smith, F.L.S., \&e. P P. iv., 55. 1859, 12mo. 1 s.

\section{FOSSILS.}

Catalogue of the Fussil Mammalia in the British Museum (Natnral History). By Richard Lydekker, J.A., F.G.S. :-

l'art I. Containing thic Orders l'rimates, Chiroptera, Insectivora, Carnivora, and liodentia. I'p. xxx., 268. 33 Woodeuts. [With Systematic and Alphabetical Indexes.] 188.5, 8vo. 5s.

Part II. Containing the Order Ungulata, Suborder Artiodactyla. Pl. xxii., 324. 39 Woodents. [With Systematic and Alphabetical Indexes.] 1855, svo. (is.

Purt III. Containing the Order ITngulata, Suborders Perissorlactyla, 'Toxodonti:l, Condylartbra, and Amblyporla. Pp. 
Catalogue of the Fossil Mammalia-continued.

xvi., 186. 30 Woodents. [With Systematic Index, and Alphabetical Index of Genera and Species, including Synonyuns.] 1886, 8vo. $4 s$.

Part IV. Containing the Order Ungulata, Suborder Proboscidea. Pp. xxiv., 235. 32 Woodcnts. [With Systematic Index, and Alphabetical Index of Genera and Species, including Synonyms.] 1886, 8 vo. $5 s$.

Part V. Containing the Group 'Tillodontia, the Orders Sirenia, Cetacea, Edentata, Marsupialia, Monotremata, and Supplement. Pp. xxxy., 345. 55 Woodeuts. EVith Systematic Index, and Alphabetical Index of Genera and Species, including Synonyms.] 1887, 8vo. $6 s$.

Catalogue of the Fossil Birds in the British Museum (Natural History). By Richard Lydekker, B.A.- Pp. xxvii., 368. 75 Woodents. [With Systematic Index, and Alphabetical Index of Genera and Species, including Synonyms.] 1891, 8vo. 10s.6 6l.

Catalogne of the Fossil Reptilia and Amphibia in the British Museum (Natural History). By Richard Lydekker, B.A., F.G.S.:-

Part I. Containing the Orders Ornithosauria, Crocodilia, Dinosauria, Squamata, Rhynchocephalia, and Proterosauria. Pp. xxviii., 309. 69 Woodents. [With Systematic Index, and Alphabetical Index of Genera and Species, inchuling Synonyms.] 1888,8 vo. $7 s .6 d$.

Part II. Containing the Orders Ichthyopterygia and Sauropterygia. Pp. xxi., 307. 85 Woodeuts. [With Systematic Index, and Alphabetical Index of Genera and Species, inchuding Synonyms.] 1889, 8vo. $7 s .6 d$.

Part III. Containing the Order Chelonia. Pp. xviii., 239. 53 Woodents. [With Systematic Index, and Alphabetical Index of Genera and Species, including Synonyms.] 1889, 8vo. $7 s .6 d$.

Part IV. Containing the Orders Anomodontia, Ecaudata, Caudata, and Labyrinthodontia; and Supplement. Pp. xxiii., 295. 66 Woodeuts. [With Systematic Index, Alphabetical Index of Genera and Species, including Synonyms, and Alphabetical Index of Genera and Species to the entire work.] 1890,8 vo. $7 s .6 d$.

Catalogue of the Fossil Fishes in the British Museum (Natural History). By Arthur Smith Woodward, F.G.S., F.Z.S. :-

Part I. Containing the Elasmobranchii. Pp. xlvii., 474. 13 Woodcuts and 17 Plates. [With Alphabetical Index, and Systematic Index of Genera and Species.] 1889, 8vo. $21 s$.

Part II. Containing the Elasmobranchii (Acanthodii), Holocephali, Ichthyodorulites, Ostracodermi, Dipnoi, and Teleostomi (Crossopterygii and Chondrostean Actinopterygii). Pp. xliv., 567. 58 Woodeuts and 16 Plates. [With Alphabetical Index, and Systematic Index of Genera aml Species.] 1891, 8vo. $21 s$. 
Catalogue of the Fossil Fishes-continued.

Part III. Containing the Actinopterygian Teleostomi of the Orders Chondrostei (concluded), Protospondyli, Aetheospondyli, and Isospondyli (in part). Pp. xlii., 544. 45 Woodcuts and 18 Plates. [With Alphabetical Index, and Systematic Inclex of Genera and Species.] 1895, 8ro $21 s$.

Systematic List of the Edwards Collection of Brinish Oligocene and Eocene Mullusen in the British Museum (Natural IIistory), with references to the type-specimens from similar horizons contained in other collections belonging to the Geological Department of the Museum. By Richard Bullen Newton, F.G.S. Pp. xxviii., 365. [With table of Families and Genera, Bibliography, Correlation-table, Appendix, and Alphabetical Index.] 1891, 8vo. 6s.

Catalogue of the Fossil Cephaloporla in the British Museum (Natural History). By Arthur H. Foord, F.G.S. :-

Part I. Containing part of the Suborder Nautiloidea, consisting of the families Orthoceratidx, Endoceratidx, Actinoceratidx, Gomphoceratidæ, Ascoceratidæ, Poterioceratidæ, Cyrtoceratidx, and Supplement. Pp. xxxi., 344. 51 Woodeuts. [With Systematic Index, and Alphabetical Index of Genera and Species, including Synonyms.] 1888, 8vo. 10s. $6 d$.

Part II. Containing the remainder of the Sulorder Nautiloidea, consisting of the families Lituitidre, Trochoceratidæ, Nautilidx, and Supplement. Pp. xxriii., 407. 86 Woodcnts. [With Systematic Index, and Alphabetical Index of Genera and Species, including Synonyms.] 1891, 8vo. 1 šs.

A Catalogue of British Fossil Crustacea, with their Synonyms and the Range in Time of each Genus and Order. By Henry Woodward, F.R.S. Pp. xii., 155. [With an Alphabetica] Index.] 1877,8 ro. $5 s$

Catalogue of the Blastoirlea in the Geological Department of the British Museum (Natural History), with an account of tho morphology and systematic position of the group, and a rerision of the genera and species. By Robert Etheridge, jun., of the Department of Geology, British Mruseum (Natural History), and P. Herbert Carpenter, D.Sc, F.R.S., F.L.S. (of Eton College). [With Preface by Dr. H. Woodward. Tabie of Contents, General Index, Explanations of the Plates, \&c.] Pp. xr., 322. 20 Plates. 1886,4 10. $25 s$.

Catalngue of the Fossil Sponges in the Geological Department of the British Musemn (Natural History). With descriptiuns of new and little knowu species. By George Jennings Hinde, Ph.D., F.G.S. Pp. viii., 248. 38 Plates. [With a Tabular List of Species, arranged in Zoological and Stritigraphical sequenec, and an Alphabetieal Inder.] 1883, 4to. 1l. 10s.

○ 92057 . 
Catalogue of the Fossil Foraminifera in the British Musem (Natural History). By Professor 'T. Rupert Jones, F.R.S., \&c. Pp. xxiv, 100. [With Geographical and A'phabetical Indexes.] 1882, Sro. 5 s.

Catalogue of the Palæozoic Plants in the Department of Geology and Palacontology, British Museum (Natural History). By Robert Kidston, F.G.S. Pp. viii., 288. [With a list of works quoted, and an Index.] 1886, 8vo. $5 s$.

Catalogue of the Mesozoic Plants in the Department of Geology, Britisl Musemm (Natural History). The Wealden Flora. By A. C. Seward, M.A., E.G.S., Uuiversity Lecturer in Botany, Cambridge:-

Part I. Thallophyta-Pteridophyta. Pp. xxxviii., 179: 17 Woodcuts and 11 Plates. [With Preface by Dr. Woodward, Alphabetical Index of Genera, Species, \&c.s Explanations of the Plates, \&c.] 1894, 8vo. $10 \mathrm{~s}$.

Part II. Gymnospermæ. Pp. viii., 259. 9 Woodeuts and 20 Plates. [With Alphabetical Index, Explanations of the Plates, \&e. 1895,8 vo. $15 s$.

\section{GUIDE-BOOKS.}

\section{(To be obtained only at the Museum.)}

A General Guide to the British Museum (Natural History), Cromwell Road, London, S.W. [By W. H. Flower.] With 2 Plans, 2 views of the building, and an illustrated cover. Pp. 80 . 1895,8 ro. $3 d$.

Guide to the Galleries of Mammalia (Marmmalian, Osteological, Cetacean) in the Department of Zoology of the British Museum (Natural History). [By A. Günther.] 5th Edition. Pp. 126. 57 Woodeuts and 2 Plans. Index. 1894, 8vo. 6d.

Gnice to the Galleries of Reptiles and Fishes in the Department of Zoology of the British Museum (Natural IIistory). [By A. Günther.] 3rd Edition. Pp. iv., 119. 101 Woodcuts and 1 Plan. Index. 1893, 8ro. 6d.

Guide to the Shell and Starfish Galleries (Mollusca, Echinodermata, Termes), in the Department of Zoology of the British Museum (Natural History). [By A. Güuther.] 2nd Edition. Yp. iv., 74. 51 Woodeuts and 1 Plan. 1888, 8ro. $4 d$.

A Guide to the Fossil Mammals and Birds in the Department of Geology and Palæontology in the British Museum (Natural History). Seventh Edition. [By Henry Wondward.] Pp. xii., 103. 116 Woodcuts. [With List of Illustrations, Table of Stratified Rocks, and Index.] 1896, 8vo. $6 d$.

A Guide to the Fossil Reptiles and Fishes in the Department of Geology and Palieontology in the British Musem (Natural History). PBy Henry Woodward.] Pp.xir., 129: 165 Woodcuts. [With List of Illustrations, 'Table of Stratified Rocks, and Index.] 1896, 8vo. lid. 
Guile to Sowerby's Models of British Fungi in the Department of Botany, British Museum (Natural History). By Worthington G. Smith, F.L.S. Pp. 82.93 Woodeuts. With 'Table of Diagnostic Characters and Index. 1893, 8ro. 4d.

Guide to the British Mycetozon exhihited in the Department of Botany, British Musenm (Natural History). By Arthur Lister, F.L.S. Pp. 42. 44 Woodents. Index. 1895, 8vo. $3 d$.

A Guide to the Mineral Gallery of the British Musenm (Natural History). [By L. Fletcher.] Pp 32. Plan. 1895, 8ro. 1d. The Student's Index to the Collection of Minerals, British Museum (Natural History). [New Edition.] Pp. 33. With a Plan of the Mineral Gallery. 1895,8 ro, $2 d$.

An Introduction to the Study of Minerals, with a Guide to the Mineral Gallery of the British Museum (Natural History), By L. Fletcher, M.A., F.R.S. Pp. 123. With numerous Diagrams, a Plan of the Mineral Gallery, and an Index.

An Introduction to the Study of Rocks. By L. Fletcher, M.A., F.R.S. Pp. 118. [With plan of the Miueral Gal!ery, table of Contents, and Index.] 1896, 8ro. 6d.

An Introduction to the Study of Meteorites, with a List of the Meteorites represented in the Collection. [By L. Fletcher.] Pp. 94. [With a Plan of the Mineral Gallery, and an Index to the Meteorites represented in the Collection.] 1364, 8ro. 6d.

Rritish Musenm

$$
\text { W. H. FLOWER, }
$$

(Nitural History),

Cromwell Road, Londou, S.W.

June Ist, 1896 , 
EONOV.19!4 

$x^{3} n^{2}$ 
